\title{
Evaluation of Dredged Material Proposed for Ocean Disposal from Red Hook / Bay Ridge Project Areas, New York
}

FERERTED

OCT $301 \% 3$

$0 \$ 11$

M. R. Pinza

E. S. Barrows

A. B. Borde

Battelle Marine Sciences Laboratory

Sequim, Washington

September 1996

Prepared for the

U.S. Army Corps of Engineers - New York District under a Related Services Agreement

with the U.S. Department of Energy

under Contract DE-AC06-76RLO 1830

Pacific Northwest National Laboratory

Operated for the U.S. Department of Energy

by Battelle Memorial Institute 


\section{DISCLAIMER}

This report was prepared as an account of work sponsored by an agency of the United States Government. Neither the United States Government nor any agency thereof, nor Battelle Memorial Institute, nor any of their employees, makes any warranty, express or implied, or assumes any legal liability or responsibility for the accuracy, completeness, or usefulness of any information, apparatus, product, or process disclosed, or represents that its use would not infringe privately owned rights. Reference herein to any specific commercial product, process, or service by trade name, trademark, manufacturer, or otherwise does not necessarily constitute or imply its endorsement, recommendation, or favoring by the United States Government or any agency thereof, or Battelle Memorial Institute. The views and opinions of authors expressed herein do not necessarily state or reflect those of the United States Government or any agency thereof.

\section{PACIFIC NORTHWEST NATIONAL LABORATORY operated by \\ BATTELLE MEMORIAL INSTITUTE \\ for the \\ UNITED STATES DEPARTMENT OF ENERGY \\ under Contract DE-AC06-76RLO 1830}

Printed in the United States of America

Available to DOE and DOE contractors from the

Office of Scientific and Technical Information, P.O. Box 62, Oak Ridge, TN 37831; prices available from (615) $576-8401$.

Available to the public from the National Technical Information Service, U.S. Department of Commerce, 5285 Port Royal Rd., Springfield, VA 22161 


\section{Evaluation of Dredged Material \\ Proposed for Ocean Disposal \\ from Red Hook / Bay Ridge \\ Project Areas, New York}

M. R. Pinza

E. S. Barrows

A. B. Borde

Battelle Marine Sciences Laboratory

Sequim, Washington

September 1996

Prepared for the

U.S. Army Corps of Engineers - New York District

under a Related Services Agreement

with the U.S. Department of Energy

under Contract DE-AC06-76RL.O 1830

Pacific Northwest National Laboratory

Operated for the U.S. Department of Energy

by Battelle Memorial Institute

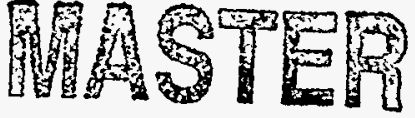

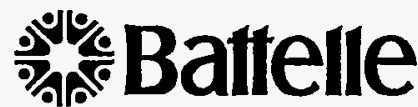

DISTABBUTON OF THIS DOCUnMET HA 


\section{DISCLAIMER}

Portions of this document may be illegible in electronic image products. Images are produced from the best available original document. 


\section{Summary}

The objective of the Red Hook/Bay Ridge project was to evaluate proposed dredged material from these two areas to determine its suitability for unconfined ocean disposal at the Mud Dump Site. Red Hook and Bay Ridge were two of four waterways that the U. S. Army Corps of Engineers-New York District (USACE-NYD) requested the Battelle/Marine Sciences Laboratory (MSL) to sample and evaluate for dredging and disposal in March 1995. Sediment samples were collected from the Red Hook/Bay Ridge project areas, as well as from Port Jersey and Claremont. Combining sample collection and evaluation of multiple dredged material projects was more cost-effective for the USACE-NYD, because the expense of reference site testing and quality control analyses could be shared among projects.

Tests and analyses were conducted according to the manual developed by the USACE and the U.S. Environmental Protection Agency (EPA), Evaluation of Dredged Material Proposed for Ocean Disposal (Testing Manual), commonly referred to as the "Green Book," and the regional manual developed by the USACE-NYD and EPA Region II, Guidance for Performing Tests on Dredged Material to be Disposed of in Ocean Waters.

The evaluation of proposed dredged material from the Red Hook/Bay Ridge project areas consisted of bulk sediment chemical analyses, chemical analyses of dredging site water and elutriate, water-column and benthic acute toxicity tests. Twenty-four individual sediment core samples were collected from these two areas and analyzed for grain size, moisture content, and total organic carbon (TOC). Three composite sediment samples, representing Red Hook Channel (RH COMP) and the two Bay Ridge Reaches ( BR-A COMP and BR-B COMP) to be dredged, were analyzed for bulk density, specific gravity, metals, chlorinated pesticides, polychlorinated biphenyl (PCB) congeners, polynuclear aromatic hydrocarbons (PAH), and 1,4dichlorobenzene. Dredging site water and elutriate water, which is prepared from the suspendedparticulate phase (SPP) of the three Red Hook/Bay Ridge sediment composites, were analyzed for metals, pesticides, and PCBs. Benthic acute toxicity tests were performed with the amphipod Ampelisca abdita and the mysid Mysidopsis bahia. The amphipod and mysid benthic toxicity test procedures followed EPA guidance for reduction of total ammonia concentrations in test systems prior to test initiation. Water-column or SPP toxicity tests were performed with three species, the mysid Mysidopsis bahia, the juvenile silverside Menidia beryllina, and lavae of the mussel Mytilus galloprovincialis. Bioaccumulation tests were conducted with the surface detritalfeeding, bent-nose clam Macoma nasuta and the burrowing polychaete worm Nereis virens.

Red Hook/Bay Ridge sediment core samples were generally black or gray-black, siltyclayey material. Eighteen of the 24 stations were predominantly silt and clay. The Red Hook/Bay Ridge sediment composite samples contained elevated levels of metals, pesticides 
(particularly the DDD/DDE/DDT group of compounds), PCBs, PAHs, and 1,4-dichlorobenzene.

Statistically significant acute toxicity and a greater than $20 \%$ increase in mortality over the reference sediment was found in the static-renewal test with $A$. abdita for test sediments from $\mathrm{RH}$ COMP and BR-B COMP. All three test sediment composites were acutely toxic and had greater than $10 \%$ mortality from the Mud Dump Reference Site for the $M$. bahia test. In water-column toxicity tests, all three test sediment composites were acutely toxic to all three species tested. The $\mathrm{LC}_{50} \mathrm{~s}$ for the $M$. beryllina test ranged from $19 \%$ to $60 \%$ of SP.P. The range of $\mathrm{LC}_{50} \mathrm{~s}$ for the M. bahia test were from $60 \%$ to $>100 \%$ of SPP. The $\mathrm{EC}_{50} \mathrm{~s}$ ( a more sensitive indicator of toxicity) for the M. galloprovincialis test were from $21 \%$ to $23 \%$ of SPP.

Following 28-day bioaccumulation tests, concentrations of contaminants were elevated in M. nasuta and $N$. virens tissues relative to levels in organisms exposed to the Mud Dump Reference Site. Tissues of both species exposed to each Red Hook/Bay Ridge sediment composite had tissue body burdens that were lower than the U.S. Food and Drug Administration (FDA) action levels for poisonous or deleterious substances in fish and shellfish for human consumption for selected pesticides, and FDA levels of concern for chronic shellfish consumption for selected metals. 
Hook/Bay Ridge sediment composite samples contained elevated levels of metals, pesticides (particularly the DDD/DDE/DDT group of compounds), PCBs, PAHs, and 1,4-dichlorobenzene.

Statistically significant acute toxicity and a greater than $20 \%$ increase in mortality over the reference sediment was found in the static-renewal test with $A$. abdita for test sediments from $\mathrm{RH}$ COMP and BR-B COMP. All three test sediment composites were acutely toxic and had greater than $10 \%$ mortality from the Mud Dump Reference Site for the $M$. bahia test. In water-column toxicity tests, all three test sediment composites were acutely toxic to all three species tested. The $L C_{50}$ s for the $M$. beryllina test ranged from $19 \%$ to $60 \%$ of SPP. The range of $L C_{50}$ for the M. bahia test were from $60 \%$ to $>100 \%$ of SPP. The $\mathrm{EC}_{50} \mathrm{~s}$ ( a more sensitive indicator of toxicity) for the M. galloprovincialis test were from $21 \%$ to $23 \%$ of SPP.

Following 28-day bioaccumulation tests, concentrations of contaminants were elevated in M. nasuta and $N$. virens tissues relative to levels in organisms exposed to the Mud Dump Reference Site. Tissues of both species exposed to each Red Hook/Bay Ridge sediment composite had tissue body burdens that were lower than the U.S. Food and Drug Administration (FDA) action levels for poisonous or deleterious substances in fish and shellfish for human consumption for selected pesticides, and FDA levels of concem for chronic shellfish consumption for selected metals. 


\section{Contents}

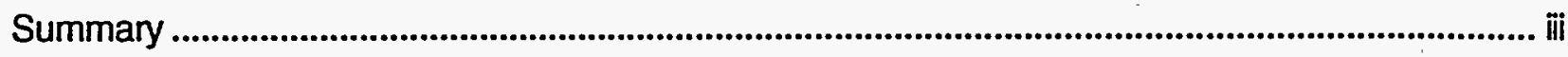

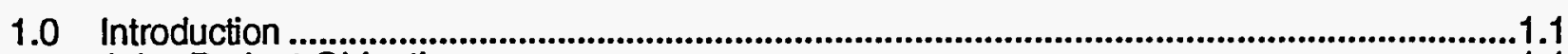

1.1 Project Objectives.....................................................................................................1.1

1.2 Project Background .......................................................................................................1.2

1.3 Organization of this Report .............................................................................................1.2

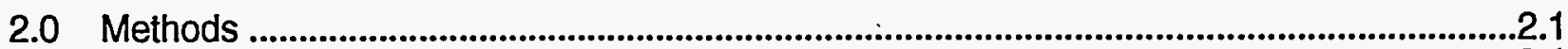

2.1 Sediment and Water Collection .........................................................................................

2.1.1 Test Sediment and Site Water Sampling ............................................................2.1

2.1.2 Reference and Control Sediment Sampling ........................................................2.2

2.2 Test Organism Collection .................................................................................................2.3

2.3 Sediment Sample Preparation ...............................................................................2.4

2.3.1 Laboratory Preparation and Safety Considerations ...........................................2.4

2.3.2 Preparation of Sediment for Benthic Testing and Bulk Sediment Analyses .....2.5

2.3.3 Preparation of Suspended-Particulate Phase and Elutriate...................................2.6

2.4 Physical and Chemical Analytical Procedures .................................................................2.7

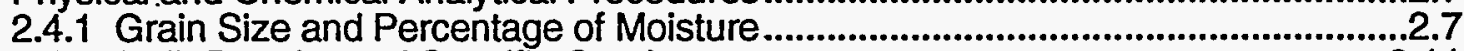

2.4.2 Bulk Density and Specific Gravity .......................................................................2.11

2.4.3 Total Organic Carbon ........................................................................................2.11

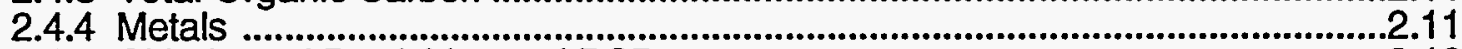

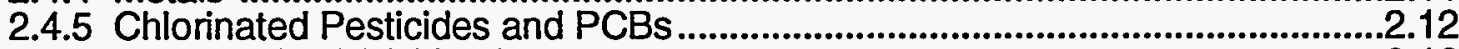

2.4.6 PAHs and 1,4-Dichlorobenzene ...........................................................................13

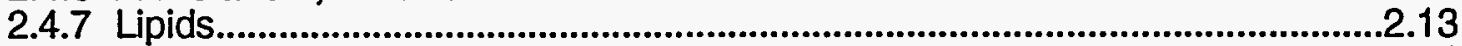

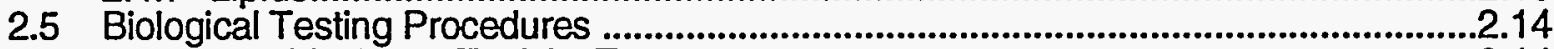

2.5.1 Benthic Acute Toxicity Tests ............................................................................2.14

2.5.1.1 Static Renewal Test with Ampelisca abdita............................................14

2.5.1.2 Static Test with Mysidopsis bahia ....................................................2.16

2.5.2 Water-Column Toxicity Tests .......................................................................2.18

2.5.2.1 Water-Column Toxicity Test with Menidia beryilina ..................................18

2.5.2.2 Water-Column Toxicity Test with Mysidopsis bahia ............................19

2.5.2.3 Water-Column Toxicity Test with Mytilus galloprovincialis

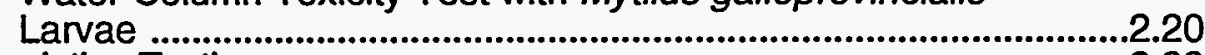

2.5.3 Bioaccumulation Testing ....................................................................................2.2.22

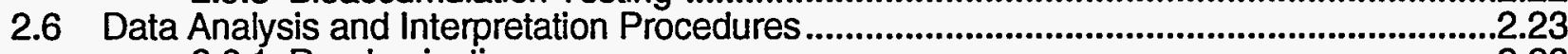

2.6.1 Randomization ..............................................................................................2.23

2.6.2 Statistical Analysis of Benthic Toxicity Tests ...................................................2.2.23

2.6.3 Statistical Analysis of Water-Column Tests ...........................................................2.24

2.6.4 Statistical Analysis of Bioaccumulation .................................................................2.2.24

2.7 Quality Assurance/Quality Control Procedures ...............................................................2.25

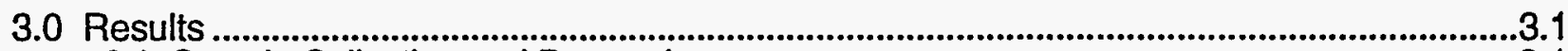

3.1 Sample Collection and Processing ...................................................................................1

3.2 Physical and Chemical Analyses ....................................................................................

3.2.1 Sediment Core Sample Description …………………................................................1

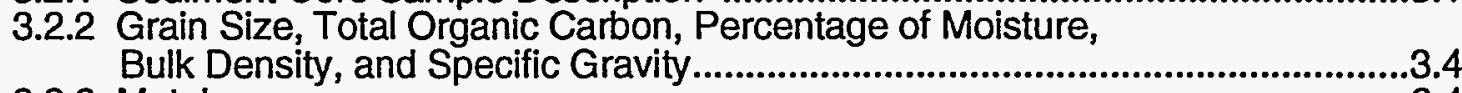

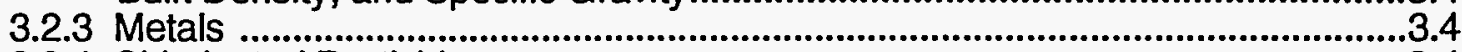

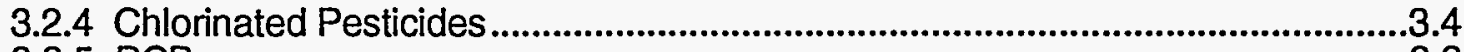

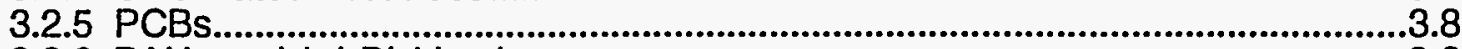

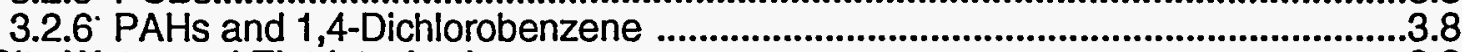

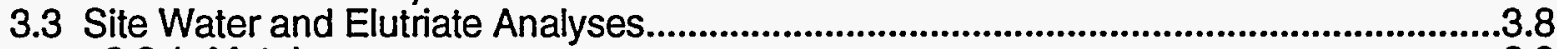

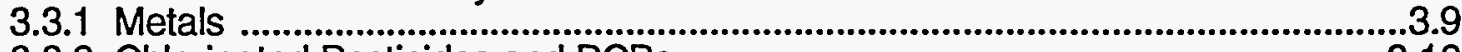

3.3.2 Chlorinated Pesticides and PCBs.......................................................................10 


\section{Contents (contd)}

3.4 Benthic Toxicity and Water-Column Testing...............................................................13

3.4.1 Ampelisca abdita Benthic Acute Toxicity Test .......................................................13

3.4.2 Mysidopsis bahia Benthic Acute Toxicity Test ..................................................3.13

3.4.3 Menidia beryllina Water-Column Toxicity Test ................................................14

3.4.4 Mysidopsis bahia Water-Column Toxicity Test .................................................15

3.4.5 Mytilus galloprovincialis Water-Column Toxicity Test ..........................................3.15

3.5 Bioaccumulation Tests with Macoma nasuta and Nereis virens ...................................3.16

3.5.1 Bioaccumulation of Metals in Macoma nasuta ...................................................3.17

3.5.2 Bioaccumulation of Chlorinated Pesticides in Macoma nasuta ............................1.

3.5.3 Bioaccumulation of PCBs in Macoma nasuta ..................................................17

3.5.4 Bioaccumulation of PAHs and 1,4-Dichlorobenzene in Macoma nasuta ..........3.18

3.5.5 Bioaccumulation of Metals in Nereis virens ....................................................3.18

3.5.6 Bioaccumulation of Chlorinated Pesticides in Nereis virens ..............................3.21

3.5.7 Bioaccumulation of PCBs in Nereis virens .......................................................21

3.5.8 Bioaccumulation of PAHs and 1,4-Dichlorobenzene in Nereis virens ...............3.23

3.5.9 Magnification factors of compounds in Macoma nasuta and Nereis virens ......3.24

4.0 Discussion and Conclusions

4.1

4.1 Sediment Physical and Chemical Characterization ..........................................................4.2

4.2 Site Water and Elutriate Chemical Characterization ........................................................2

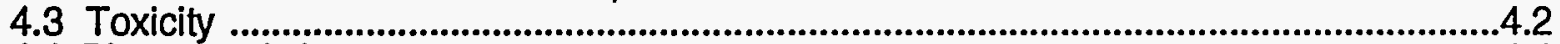

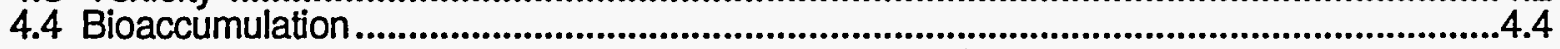

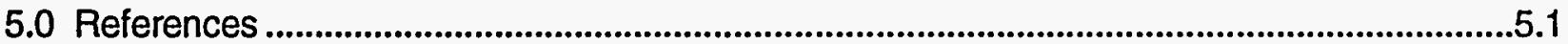

Appendix A. Quality Assurance/Quality Control Data for Sediment Physical Chemical Analyses, Red Hook and Bay Ridge Channels

Appendix B. Quality Assurance/Quality Control Data for Water and Elutriate Chemical Analyses, Red Hook and Bay Ridge Channels................................................ B.1

Appendix C. Benthic Acute Toxicity Test Data, Red Hook and Bay Ridge Channels ........... C.1

Appendix D. Water Column Toxicity Test Data, Red Hook and Bay Ridge Channels ......... D.1

Appendix E. Bioaccumulation Test Data, Red Hook and Bay Ridge Channels ..................... E.1

Appendix F. Quality Assurance/Quality Control Data for Chemical Analyses of Macoma nasuta Tissues, Red Hook and Bay Ridge Channels

Appendix G. Quality Assurance/Quality Control Data for Chemical Analyses of Nereis virens Tissues, Red Hook and Bay Ridge Channels

\section{Figures}

FIGURE 1.1 Location of Red Hook/Bay Ridge Project Area and Sample Collection Stations

FIGURE 2.1. Testing Containers for Amphipod Static Renewal Toxicity Tests .2 .15

FIGURE 4.1. Summary Matrix of Red Hook/Bay Ridge Sediment Toxicity and Bioaccumulation in Comparison with the Mud Dump Reference Site 


\section{Tables}

TABLE 2.1 List of Analytes, Methods, and Target Detection Limits .........................................2.8

TABLE 3.1 Summary of Sediment Sample Data for Red Hook/Bay Ridge Project Areas .....3.2

TABLE 3.2 Red Hook/Bay Ridge Sediment Core Descriptions ..............................................3.3

TABLE 3.3 Results of Analysis of Red Hook/Bay Ridge Sediment Samples for Grain Size, Total Organic Carbon and Percentage of Moisture ..........................................3.5

TABLE 3.4 Results of Analysis of Red Hook/Bay Ridge Sediment Composites For Bulk Density and Specific Gravity

TABLE 3.5 Results of Analysis of Red Hook/Bay Ridge Sediment Composites for Metals

TABLE 3.6 Results of Analysis of Red Hook/Bay Ridge Sediment Composites for Pesticides and PCBs

TABLE 3.7 Results of Analysis of Red Hook/Bay Ridge Sediment Composites for

PAHs, and 1,4-Dichlorobenzene

TABLE 3.8 Results of Analysis of Red Hook/Bay Ridge Site Water and Elutriates for Metals

TABLE 3.9 Results of Analysis of Red Hook/Bay Ridge Site Water for Pesticides and PCBs

TABLE 3.10 Results of Analysis of Red Hook/Bay Ridge Elutriate Preparations for Pesticides and PCBs

TABLE 3.11 Summary of Benthic Tests Performed with Red Hook/Bay Ridge Sediment Composites.

TABLE 3.12 Summary of Water-Column Toxicity Tests Performed with Red Hook Bay Ridge Sediment Composites.

TABLE 3.13 Mean Concentrations of Metals in Macoma nasuta Tissues Exposed to Red Hook/Bay Ridge Composites and Mud Dump Reference Site Composite

TABLE 3.14 Mean Concentrations of Pesticides and PCBs in Macoma nasuta Tissues Exposed to Red Hook/Bay Ridge Composites and Mud Dump Reference Site Composite

TABLE 3.15 Mean Concentrations of PAHs and 1,4-Dichlorobenzene in Macoma nasuta Tissues Exposed to Red Hook/Bay Ridge Composites and Mud Dump Reference Site Composite 


\section{Tables (contd)}

TABLE 3.16 Mean Concentrations of Metals in Nereis virens Tissues Exposed to Red Hook/Bay Ridge Composites and Mud Dump Reference Site Composite

TABLE 3.17 Mean Concentrations of Pesticides and PCBs in Nereis virens Tissues Exposed to Red Hook/Bay Ridge Composites and Mud Dump Reference Site Composite

TABLE 3.18 Mean Concentrations of PAHs and 1,4-Dichlorobenzene in Nereis virens Tissues Exposed to Red Hook/Bay Ridge Composites and Mud Dump Reference Site Composite

TABLE 3.19 Magnification Factors of All Analyzed Compounds in Macoma nasuta Tissues Exposed to Red Hook/Bay Ridge Composites Relative to Tissues Exposed to the Mud Dump Reference Site Composite

TABLE 3.20 Magnification Factors of All Analyzed Compounds in Nereis virens Tissues Exposed to Red Hook/Bay Ridge Composites Relative to Tissues Exposed to the Mud Dump Reference Site Composite

TABLE 4.1 Comparison of Contaminant Concentrations in Macoma nasuta and Nereis virens Tissues Exposed to Proposed Dredged Material from Red Hook/Bay Ridge Project Area with FDA Action Levels and Levels of Concem 


\subsection{Introduction}

\subsection{Project Objectives}

The objective of the Red Hook/Bay Ridge project was to evaluate proposed dredged material from the Red Hook Channel and the Bay Ridge Channel Reaches A and B to determine its suitability for unconfined ocean disposal at the Mud Dump Site. Tests and analyses for Mud Dump disposal were conducted on sediment core samples from these areas according to the manual developed by the U.S. Army Corps of Engineers (USACE) and the U.S. Environmental Protection Agency (EPA), Evaluation of Dredged Material Proposed for Ocean Disposal (Testing Manual) (EPA/USACE 1991), commonly referred to as the "Green Book," and the regional manual developed by the USACE-New York District (USACE-NYD) and EPA Region II, Guidance for Performing Tests on Dredged Material to be Disposed of in Ocean Waters (USACE-NYD/EPA Region II 1992), hereinafter referred to as the "Regional Guidance Manual." The Regional Guidance Manual provides specifications for the use of local or appropriate test species in biological tests and identifies chemical contaminants of concern.

As required by the Regional Guidance Manual, the evaluation of proposed dredged material from the Red Hook/Bay Ridge project areas consisted of bulk sediment chemical analyses, chemical analyses of dredging site water and elutriate, water-column and benthic acute toxicity tests, and benthic bioaccumulation studies. Individual sediment core samples collected from the Red Hook/Bay Ridge project area were analyzed for grain size, moisture content, and total organic carbon (TOC). One composite sediment sample from Red Hook, and two composite sediment samples from Bay Ridge representing each reach proposed for dredging, were analyzed for bulk density, specific gravity, metals, chlorinated pesticides, polychlorinated biphenyl (PCB) congeners, polynuclear aromatic hydrocarbons (PAHs), and 1,4-dichlorobenzene. Site water and elutriate water, which is prepared from the suspended-particulate phase (SPP) of the one Red Hook sediment composite and the two Bay Ridge sediment composites, were analyzed for metals, pesticides, and PCBs. Water-column or SPP toxicity tests were performed with three species, the mysid Mysidopsis bahia, the juvenile silverside Menidia beryllina, and larvae of the mussel Mytilus galloprovincialis. Benthic acute toxicity tests were performed with the amphipod, Ampelisca abdita and the mysid M. bahia. Bioaccumulation tests were conducted with the burrowing worm Nereis virens and the surface-detrital-feeding clam Macoma nasuta. 


\subsection{Project Background}

The Red Hook project area is located in Gowanus Bay (Figure 1.1) and requires dredging and disposal of an estimated 50,000 cu yd of sediment. The project depth of the channel is $40 \mathrm{ft}$ mean lower water (MLW) plus $2 \mathrm{ft}$ of overdepth. Stations $\mathrm{RH}-1$ through $\mathrm{RH}-6$ were combined to form the Red Hook composite. The Bay Ridge project area is also located in Gowanus Bay and adjacent to Brooklyn in New York. Stations BR-A-1 through BR-A-12 were combined to form BR-A COMP, and stations BR-B-13 through BR-B-18 were combined to form BR-B COMP. The Bay Ridge project requires dredging and disposal of an estimated $960,000 \mathrm{cu}$ yd of sediment. Project depth of the channel is $40 \mathrm{ft}$ MLW plus $2 \mathrm{ft}$ of overdepth. Red Hook and Bay Ridge Channels were two of four waterways that the USACE-NYD requested the Battelle/Marine Sciences Laboratory (MSL) to evaluate in a series of dredged material projects that became known as the New York/New Jersey Federal Projects 4 program. The other projects evaluated under the Federal Projects 4 program were the Port Jersey and Claremont Projects. Sediment samples from one reach in the Red Hook waterway and two reaches in Bay Ridge waterway were collected during a survey that took place from March 21, 1995 to March 30, 1995. Combining sample collection and evaluation of multiple dredged material projects was more cost-effective for the USACE-NYD, because the expense of reference site testing and quality control analyses could be shared among projects.

\subsection{Organization of this Report}

Following this introduction, Section 2 presents the methods and materials used for sample collection, sample processing, sediment sample analysis of physical and chemical parameters, and quality assurance. Results of all physical/chemical analyses and bioassays are presented in Section 3. A discussion of the results and conclusions is provided in Section 4 . Section 5 lists the literature cited in this report. Appendix A contains tabulated quality control data for all physical and chemical sediment analyses. Appendix $B$ contains results of replicate sample analyses and quality control data for site water and elutriate chemical parameters. Appendix $C$ contains raw data associated with benthic toxicity tests: water quality measurements, test animal survival data, and reference toxicant test results. Similar data for water-column acute toxicity tests are provided in Appendix D. Appendix E contains water quality measurements, test animal survival data, and reference toxicant test results for the bioaccumulation tests. Appendix $F$ contains replicate sample results and quality control data for chemical analyses of $M$. nasuta tissue samples generated from the bioaccumulation tests, and Appendix $G$ contains replicate sample results and quality control data for chemical analyses of $N$. virens tissue samples. 


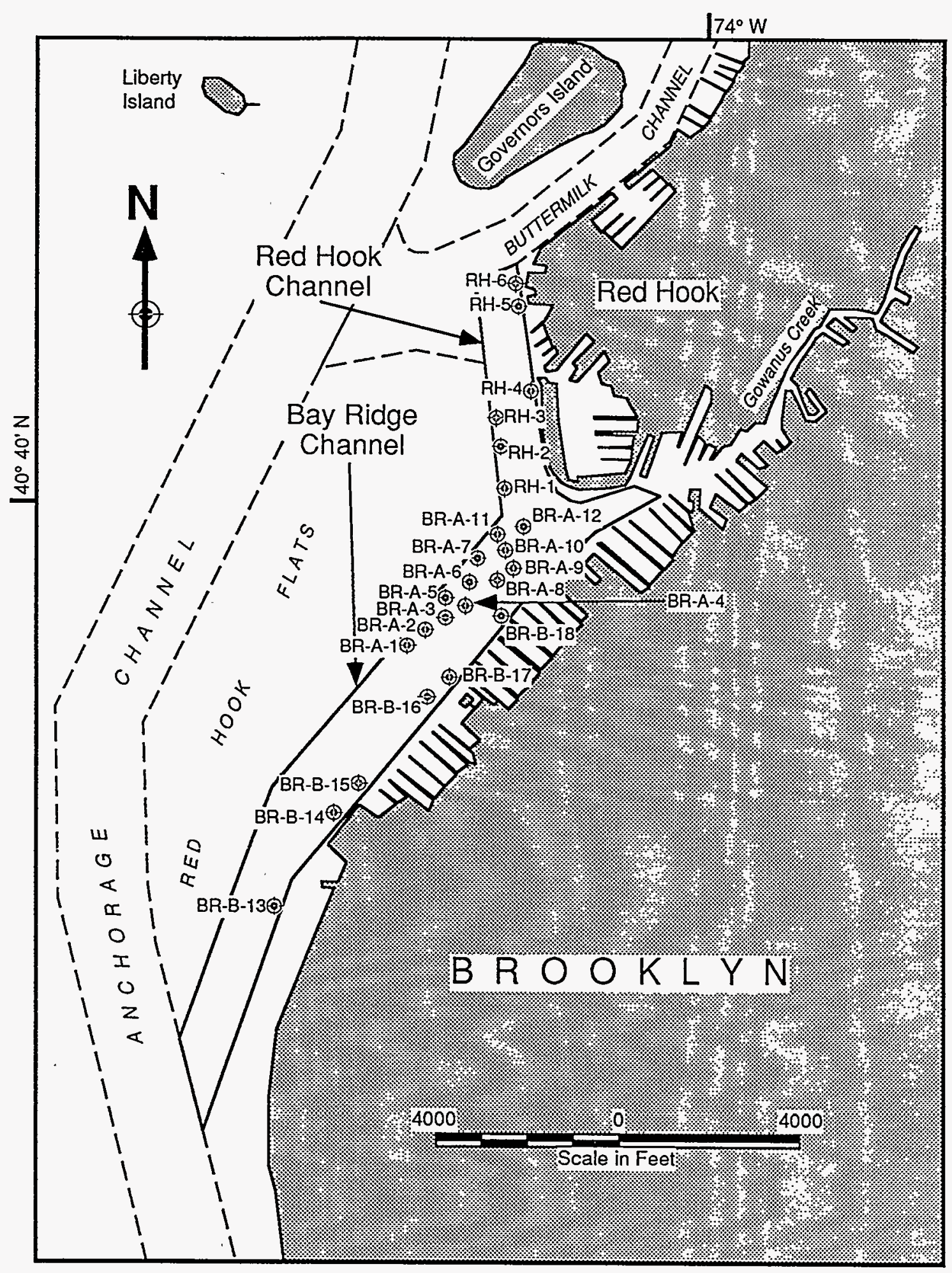

FIGURE 1.1. Location of Red Hook/Bay Ridge Project Area and Sample Collection Stations 


\subsection{Methods}

\subsection{Sediment and Water Collection}

Sediment samples were collected from 6 stations within the Red Hook project area and 18 stations within the Bay Ridge project area. Sampling locations were selected by the USACENYD based on recent bathymetric surveys. The locations, their coordinates, and water and core sampling depths are presented with the sampling results in Section 3.0. Water samples were collected at a representative location in Red Hook Channel and two locations in the Bay Ridge Channel, and in the Mud Dump Site. Reference sediment was collected from the Mud Dump Reference Site. All samples were collected aboard the MN Hayward, which is'owned and operated by USACE-NYD at Caven Point, New Jersey.

\subsubsection{Test Sediment and Site Water Sampling}

The approximate core sampling locations were first determined with the aid of reference to landmarks, such as shoreline features or buoys, as well as by water depth. Then, a hand-held Magellan differential Global Positioning System (dGPS) was used to identify and record (within $30 \mathrm{~m}$ ) the approximate location of each sampling station. The vessel's dGPS was used to establish the final location. Water depth at the time of sampling was measured by a fathometer on the ship. The actual water depth was corrected to MLW depth by correcting to the tide height at the time the depth was recorded. The difference between the MLW depth and the project depth, plus $2 \mathrm{ft}$ overdepth, yields the amount of core required. At some sites, more than one core replicate was required to collect a sufficient volume of sediment for conducting all tests.

Core samples were collected aboard the Hayward using a vibracore sampler owned and operated by Alpine Ocean Seismic Survey, Inc, Norwood, New Jersey. The vibracore sampler consisted of a 4-in. outer diameter (OD), steel core barrel attached to a pneumatic vibratory hammer. The vibratory hammer could be fitted to steel core barrels of various lengths, depending on the length of core needed. To collect a core sample, the core barrel was fitted with a 3.125-in. interior diameter (ID), steam-cleaned, Lexan polycarbonate tube. The vibracore was then suspended by the ship's crane. Once the coring apparatus was directly above the sampling station, the core was lowered through the water to the sediment surface. At this point, the station coordinates were recorded from the vessels dGPS, and water depth was recorded from the ship's fathometer. The vibratory hammer was switched on until the corer penetrated through the sediment to the desired project depth. Adequate penetration was determined relative to marks on the outside of the core barrel and on the cable suspending the vibracore from the crane. The vibracore apparatus was then pulled out of the sediment and lowered onto the ship's deck. A 
cutter-head and core-catcher assembly prevented loss of the sediment through the bottom of the core liner. After each core was brought on board, the liner was pulled from the barrel and the length of cored sediment was measured from the mudline to determine whether the project depth plus $2 \mathrm{ft}$ overdepth had been reached. If not, the liner was replaced and a second core sample was attempted. If the sediment core length was at least project depth plus $2 \mathrm{ft}$ overdepth, it was capped, sealed with tape, and labeled. While on board the sampling vessel, cores were kept $\mathrm{cool}\left(\sim 4^{\circ} \mathrm{C}\right)$ in a walk-in freezer on the deck of the ship.

Surface-water samples for dredging site water chemical analysis were collected at one station (RH-3) in the Red Hook project area, and two stations(BR-A-8 and BR-B-15) in the Bay Ridge project area. Site water was also collected from the Mud Dump Site for chemical analysis and used as dilution water in water-column toxicity tests. Water samples were collected using a peristaltic pump, which collected water several feet below the surface. Water was then transferred to precleaned, 20-L polypropylene carboys which were previously rinsed with site water three times before filling. Water samples were labeled and stored in the walk-in freezer while on board the ship. (Prior to the sampling survey, carboys were washed with hot water and detergent, acid-rinsed with dilute hydrochloric acid, then rinsed with distilled water, followed by acetone).

A log book was maintained containing records of each sample collected, including station designation, coordinates, replicate number, date, sampling time, water depth, core length, and number of core sections per core. At the end of each sampling day, when the Hayward returned to Caven Point, all sediment cores and water samples were loaded into a refrigerated van, thermostatically controlled to maintain temperature at approximately $4^{\circ} \mathrm{C}$. Sample identification numbers were logged on chain-of-custody forms daily.

At the conclusion of the sample collection survey, sediment cores and water samples were shipped by refrigerated van from Caven Point, New Jersey, to the MSL in Sequim, Washington. The shipment departed from Caven Point on March 30,1995, and arrived at the MSL on April 6, 1995.

\subsubsection{Reference and Control Sediment Sampling}

Reference sediments for toxicity and bioaccumulation tests were collected from the Mud Dump Reference Site. Four 5-gal containers of surficial sediment were collected using a modified van Veen grab sampler. After recovery, water was drained from the sampler, and the sediments were transferred to epoxy-coated steel buckets. The buckets were covered, labeled, and stored in the walk-in freezer $\left(4^{\circ} \mathrm{C}\right)$ while aboard the ship. Records of reference sediment collection included navigational coordinates, replicate number, date, sampling time, and water depth. 
Reference sediment samples were loaded into the refrigerated van at the staging area upon return to port, and sample identification numbers were logged on chain-of-custody forms.

Control sediments were used in each toxicity and bioaccumulation test to validate test procedures. Control sediment used in $M$. nasuta and $M$. bahia tests was collected from Sequim Bay, Washington, using a van Veen sampler deployed from an MSL research vessel. Native control sediment for $A$. abdita and $N$. virens were supplied with the test organisms by their respective suppliers.

\subsection{Test Organism Collection}

Seven species of test organisms were used to evaluate sediment samples from the Red Hook/Bay Ridge project area:

- $\quad$ Ampelisca abdita, a tube-dwelling, surface detrital-feeding amphipod

- $\quad$ Mysidopsis bahia, a juvenile mysid shrimp

- Menidia beryllina, a juvenile silverside fish

- Mytilus galloprovincialis, the larval zooplankton stage of the mussel

- Macoma nasuta, the bent-nose clam, a burrowing, surface detrital-feeder

- $\quad$ Nereis virens, a burrowing, deposit-feeding polychaete.

All test organisms except mysids, and silversides were wild-captured animals, collected either by a commercial supplier or by MSL personnel. Silversides were supplied by Aquatic Research Organisms in Hampton, New Hampshire, and were shipped via overnight delivery in plastic bags containing oxygen-supersaturated seawater maintained at approximately $22^{\circ} \mathrm{C}$ with gel refrigerant packs. Mussels used for obtaining $M$. galloprovincialis larvae were purchased from the commercial supplier Marinus Inc., Long Beach, California. Mussels were wrapped in moist paper towels and transported in a Styrofoam cooler packed with gel refrigerant packs to maintain an ambient temperature of approximately $15^{\circ} \mathrm{C}$. The amphipod $A$. abdita was supplied by East Coast Amphipod, Kingston, Rhode Island. A. abdita and its native sediment were collected from Narragansett Bay, Rhode Island, by dragging a large dipnet along the sediment surface. Test organisms were carefully removed from their tubes for counting, and then placed in clean, native sediment for overnight transport to the MSL. Mysids were purchased from Aquatic Biosystems, Fort Collins, Colorado. Mysids that were less than 24-h old were shipped via overnight delivery in plastic bags containing oxygen-supersaturated seawater maintained at approximately $15^{\circ} \mathrm{C}$ with gel refrigerant packs. Clams ( $M$. nasuta) were collected from intertidal zones in Discovery Bay, Washington, by Johnson and Gunstone. The clams were kept in large containers filled with sediment and seawater obtained from the collection site and transported to the MSL. Worms ( $N$. virens) were purchased through Envirosystems, Inc., and were collected from an intertidal 
region in Newcastle, Maine. The worms were packed in insulated boxes with mats of moist seaweed and shipped at ambient temperature to the MSL via overnight delivery.

All organisms were shipped or transported in native sediment or under conditions designed to ensure their viability. After arrival at the MSL, the test organisms were gradually acclimated to test conditions. Animals with abnomal behavior or appearance were not used in toxicological tests. All acclimation and animal care records are part of the raw data files for these projects.

\subsection{Sediment Sample Preparation}

Sediment sample preparation consists of all steps performed in the laboratory between receipt of the samples at the MSL and the preparation of samples for biological testing and physical/chemical analyses. Sediment samples for physical, chemical, and biological analysis were prepared from individual core samples, composites of a number of core samples, reference sediment, and control sediment. All sediment samples were assigned random, unique code numbers to ensure that samples are handled without bias by staff in the biology or chemistry laboratories.

Sediment for biological testing was used within the 6-week holding period specified in the Green Book. During this holding time, the sediment samples were received at the MSL; inventoried against chain-of-custody forms; processed and used for benthic toxicity and watercolumn tests, elutriate analysis, and bioaccumulation tests; and subsampled for sediment physical/chemical analyses. This section describes procedures followed for equipment preparation, compositing strategy, and preparation of sediments for biological testing and chemical analyses.

\subsubsection{Laboratory Preparation and Safety Considerations}

All glassware, stainless-steel or titanium utensils, Nalgene, Teflon, and other laboratory containers and equipment underwent stringent cleaning procedures to avoid contamination of samples. Glassware (e.g., test containers, aquaria, sediment transfer dishes) was washed with hot water and detergent, rinsed with deionized water, then soaked in a $10 \%$ solution of reagent grade nitric acid for a minimum of $4 \mathrm{~h}$ and rinsed again with deionized water before it was allowed to air dry. Glassware was then rinsed with methylene chloride and allowed to dry under a fume hood. Polyvinyl chloride (PVC), Nalgene, and Teflon tools were treated in the same manner as glassware. Stainless-steel bowls, spoons, spatulas, and other utensils were washed with hot water and detergent, rinsed with deionized water, and allowed to air dry. They were then solvent-rinsed with methylene chloride and allowed to dry under a fume hood. 
Neoprene stoppers and polyethylene sheets or other porous materials were washed with hot water and detergent and rinsed with deionized water. These items were then "seasoned" by continuous soaking in $0.45-\mu \mathrm{m}$ filtered seawater for at least 2 days prior to use. Large pieces of laboratory equipment, such as the epoxy-coated sediment mixer, were washed with a dilute solution of detergent, and thoroughly rinsed with tap water followed by deionized water.

Equipment used for determining water quality, including the meters for $\mathrm{pH}$, dissolved oxygen (DO), temperature, ammonia and salinity, were calibrated according to the manufacturers' specifications and intemal MSL standard operating procedures (SOPS).

Because the potential toxicity of the Red Hook/Bay Ridge sediment was unknown, sediment processing and testing were segregated from other laboratory activities. Specific areas at the MSL were established for sample storage and for core-cutting, sediment mixing, and sediment sieving. Work areas were covered with plastic sheeting to contain any waste sediment. Wastewater generated during all operations was retained in 55-gal barrels and periodically pumped through activated charcoal filters and into the MSL's wastewater treatment system. These procedures minimized any potential for cross-contamination of sediment samples and any potential accidental release to the environment.

Laboratory staff members were protected by personal safety equipment such as eyewear, Tyvek suits, plastic aprons, and rubber gloves. Those who were likely to have the most exposure to the potential volatile compounds in the bulk sediment (i.e., those responsible for opening, homogenizing, and compositing core samples) were also provided with half-mask respirators.

\subsubsection{Preparation of Sediment for Benthic Testing and Bulk Sediment Analyses}

Each core was opened by scoring the Lexan core liner longitudinally with a circular saw and splitting the liner with a clean linoleum knife to expose the sediment. As each sediment core sample was opened, it was examined for physical characteristics (e.g., sediment type and consistency, color, odor). In particular, the presence of any strata in the cores was noted. All core observations were recorded in the sediment preparation log book. The sediment between the mudline and project depth was then transferred from the core liner to a clean, stainless-steel bowl by scooping the sediment from the core liner with a spoon or spatula. The sediment was mixed by hand with stainless-steel utensils until the color and consistency appeared homogenous, creating a sample representative of the individual sampling station. Sieving was not necessary because organisms that might interfere with the benthic toxicity tests were not present in the sediment samples. 
Aliquots of the homogenized sediment were then transferred to the appropriate sample jar(s) for physical or chemical analyses required on individual core samples. A portion of each homogenized core sample was also retained as an archive sample. The remainder of the homogenized sediment from the individual core stations was combined to create one composite sample representing the Red Hook project area, designated RH COMP and two composite samples representing the Reach $A$ and Reach $B$ of the Bay Ridge project area, designated BR-A COMP and BR-B COMP, respectively. The Red Hook composite contained sediments from $\mathrm{RH}-1$ through RH-6. The Reach A composite contained sediments from Stations BR-1 through BR-12. The Reach B composite contained sediments from Stations BR-13 through BR-18. Additional composites were created for chemical analysis, solid-phase toxicity, water column toxicity, and bioaccumulation testing, as required for USACE-NED. The compositing scheme for these samples is provided in Section 3. Each sediment composite was homogenized in an epoxy-coated mixer. Aliquots of homogenized composite sediment were transferred to the appropriate sample jar(s) for physical or chemical analyses required on the composite sample. A portion of the homogenized composited sediment was also retained as an archive sample. The remainder was stored in labeled epoxy-coated pails, tightly covered, at $4^{\circ} \mathrm{C} \pm 2^{\circ} \mathrm{C}$ until use for SPP/elutriate preparation or benthic toxicity and bioaccumulation tests.

The Mud Dump Reference Site sediment, $M$. nasuta native control sediment, and $N$. virens native control sediment were also homogenized in the large, epoxy-coated mixer, but prior to mixing, these sediments were pressed through a 1-mm mesh to remove live organisms that might affect the outcome of toxicity tests. After mixing, aliquots for physical and chemical analyses were removed. Native control sediment for $A$. abdita was sieved through a $0.5-\mathrm{mm}$ mesh to remove live organisms and mixed in stainless-steel bowls after sieving. All reference and control sediments were stored at $4^{\circ} \mathrm{C} \pm 2^{\circ} \mathrm{C}$ until use in benthic toxicity and bioaccumulation tests.

\subsubsection{Preparation of Suspended-Particulate Phase and Elutriate}

Toxicological effects of dredged sediments dissolved and suspended in the water-column at an open-water disposal site were simulated in the laboratory by preparation of the SPP. To prepare the SPP, a sediment-water slurry was created and centrifuged at low speed. The centrifugation procedure replaced the $1-\mathrm{h}$ settling procedure described for elutriate preparation in the Green Book. Low speed centrifugation provided a more timely SPP preparation and maintained consistency between projects. The supematant was decanted and reserved for testing with water-column organisms. The elutriate phase was prepared by centrifuging the SPP at a higher speed and collecting the decanted supernatant. This liquid was analyzed for chemical constituents to identify potential water-soluble contaminants that could remain in the water-column after dredge and disposal operations. 
The SPP was prepared by creating a 4:1 (volume:volume) water-to-sediment slurry in 1-L glass jars with Teflon-lined lids. The jars were marked at $200 \mathrm{~mL}$ and $400 \mathrm{~mL}$ and filled to the 200-mL mark with 0.45- $\mu$ m-filtered Sequim Bay seawater. Homogenized sediment was added until the water was displaced to the 400-mL mark. Each jar was then filled to $1 \mathrm{~L}$ with filtered seawater, placed on a shaker table, and agitated for $30 \mathrm{~min}$ at 120 to $150 \mathrm{cycles} / \mathrm{min}$. The slurry was then transferred to 500-mL Teflon jars, tightly sealed, and centrifuged at approximately 1750 rpm for $10 \mathrm{~min}$, at a relative centrifugal force of approximately $1000 \mathrm{~g}$. Following centrifugation, the supernatant was poured into $4-\mathrm{L}$ glass jars. The Teflon jars were rinsed after each use and the above process continued until an adequate amount of SPP was produced from each composite. Between SPP preparations, all glass and Teflon containers were cleaned according to procedures described in Section 2.3.1. When all SPP for a treatment was prepared, portions were taken for elutriate preparation. The remaining SPP was either used immediately for biological tests or stored at $4^{\circ} \mathrm{C} \pm 2^{\circ} \mathrm{C}$ and used within $24 \mathrm{~h}$ for testing. The $100 \%$ SPP was mixed with Mud Dump Site water to yield three dilutions: $0 \%, 10 \%$, and $50 \%$ SPP, for a total of four concentrations for each sediment composite.

To prepare elutriate for chemistry analyses, a 1-L aliquot of the SPP was collected in an acid-washed Teflon bottle for trace metals analysis, and three 1- $L$ aliquots were collected in EPAcertified amber glass bottles for analysis of organic compounds. The SPP for metals analysis was transferred to acid-washed polycarbonate centrifuge jars, and the SPP for analysis of organic compounds was transferred to Teflon centrifuge jars. Both were centrifuged at $2000 \mathrm{rpm}$ for $30 \mathrm{~min}$ at a relative centrifugal force of approximately $1200 \mathrm{~g}$. The decanted supernatant liquid was the elutriate phase. One liter of elutriate was submitted for triplicate trace metals analysis and three $1-L$ portions were submitted for analysis of organic compounds.

\subsection{Physical and Chemical Analytical Procedures}

Individual sediment cores, composited bulk sediment, water, elutriate, and tissue samples were analyzed for selected physical and chemical parameters. Table 2.1 lists the parameters measured in each sample type, the method used for each analysis, and the target analytical detection limits. The following sections briefly describe the procedures used for physical and chemical analyses. Procedures followed those required by the Regional Guidance Manual unless otherwise noted.

\subsubsection{Grain Size and Percentage of Moisture}

Grain size was measured following two methods described by Plumb (1981). The wet sieve method was used to determine the size distribution of sand or coarser-grained particles 
TABLE 2.1. List of Analytes, Methods, and Target Detection Limits

\begin{tabular}{|c|c|c|c|c|}
\hline Analyte & Methods & $\begin{array}{c}\text { Sediment } \\
\text { Detection } \\
\text { Limit (a) } \\
\end{array}$ & $\begin{array}{c}\text { Tissue } \\
\text { Detection } \\
\text { Limit (b) }\end{array}$ & $\begin{array}{c}\text { Water } \\
\text { Detection } \\
\text { Limit }\end{array}$ \\
\hline \multicolumn{5}{|c|}{ PHYSICALPABAMETERS } \\
\hline Grain Size & Plumb (1981) & $1.0 \%$ & & \\
\hline Specific Gravity & ASTM D-854 & & & \\
\hline Bulk Density & EM 1110-2-1906 (USACE 1970) & & & \\
\hline Percent Moisture & $\begin{array}{l}\text { Sediment: Plumb (1981) } \\
\text { Tissue: Freeze-dry }\end{array}$ & $1.0 \%$ & $1.0 \%$ & \\
\hline Total organic carbon & EPA (1986) & $0.1 \%$ & & \\
\hline \multicolumn{5}{|l|}{ METALS } \\
\hline Arsenic & EPA 200.2, -..3, -.8 (c) & $0.1 \mathrm{mg} / \mathrm{kg}$ & $1.0 \mathrm{mg} / \mathrm{kg}$ & \\
\hline Cadmium & EPA 200.2, -.3, -.8 (c) & $0.01 \mathrm{mg} / \mathrm{kg}$ & $0.1 \mathrm{mg} / \mathrm{kg}$ & $0.025 \mu \mathrm{g} / \mathrm{L}$ \\
\hline Chromium & EPA 200.2, -.3, -.8(c) & $0.02 \mathrm{mg} / \mathrm{kg}$ & $0.2 \mathrm{mg} / \mathrm{kg}$ & $1.0 \mu g / L$ \\
\hline Copper & EPA 200.2, -.3, -.8(c) & $0.1 \mathrm{mg} / \mathrm{kg}$ & $1.0 \mathrm{mg} / \mathrm{kg}$ & $0.35 \mu g / L$ \\
\hline Lead & EPA 200.2, -.3, -.8(c) & $0.1 \mathrm{mg} / \mathrm{kg}$ & $0.1 \mathrm{mg} / \mathrm{kg}$ & $0.35 \mu \mathrm{g} / \mathrm{L}$ \\
\hline Mercury & $\begin{array}{l}\text { EPA } 245.5 \text { (sed.); } 245.6 \text { (tiss.) (c) } \\
\text { Bloom and Crecelius (1983) (water) }\end{array}$ & $0.02 \mathrm{mg} / \mathrm{kg}$ & $0.02 \mathrm{mg} / \mathrm{kg}$ & $0.002 \mu \mathrm{g} / \mathrm{L}$ \\
\hline Nickel & EPA 200.2, -.3, 8 (c) & $0.1 \mathrm{mg} / \mathrm{kg}$ & $0.1 \mathrm{mg} / \mathrm{kg}$ & $0.30 \mu \mathrm{g} / \mathrm{L}$ \\
\hline Silver & EPA 200.2, -.3, -.9 (c) & $0.1 \mathrm{mg} / \mathrm{kg}$ & $0.1 \mathrm{mg} / \mathrm{kg}$ & $0.25 \mu \mathrm{g} / \mathrm{L}$ \\
\hline Zinc & EPA 200.2, -.3, -.8(c) & $0.1 \mathrm{mg} / \mathrm{kg}$ & $1.0 \mathrm{mg} / \mathrm{kg}$ & $0.15 \mu \mathrm{g} / \mathrm{L}$ \\
\hline \multicolumn{5}{|c|}{ ORGANIC COMPOUNDS } \\
\hline \multicolumn{5}{|l|}{ Pesticides } \\
\hline Aldrin & $\begin{array}{l}\text { EPA } 8080 \text { (sediment, tissue) } \\
\text { EPA } 608 \text { (water) (c) }\end{array}$ & $1.0 \mu \mathrm{g} / \mathrm{kg}$ & $0.4 \mu \mathrm{g} / \mathrm{kg}$ & $0.004 \mu \mathrm{g} / \mathrm{L}$ \\
\hline$\alpha$-Chlordane & $\begin{array}{l}\text { EPA } 8080 \text { (sediment, tissue) } \\
\text { EPA } 608 \text { (water) (c) }\end{array}$ & $1.0 \mu \mathrm{g} / \mathrm{kg}$ & $0.4 \mu \mathrm{g} / \mathrm{kg}$ & $0.014 \mu \mathrm{g} / \mathrm{L}$ \\
\hline trans-Nonachlor & $\begin{array}{l}\text { EPA } 8080 \text { (sediment, tissue) } \\
\text { EPA } 608 \text { (water) (c) }\end{array}$ & $1.0 \mu \mathrm{g} / \mathrm{kg}$ & $0.4 \mu \mathrm{g} / \mathrm{kg}$ & $0.014 \mu \mathrm{g} / \mathrm{L}$ \\
\hline Dieldrin & $\begin{array}{l}\text { EPA } 8080 \text { (sediment, tissue) } \\
\text { EPA } 608 \text { (water) (c) }\end{array}$ & $1.0 \mu \mathrm{g} / \mathrm{kg}$ & $0.4 \mu \mathrm{g} / \mathrm{kg}$ & $0.002 \mu \mathrm{g} / \mathrm{L}$ \\
\hline $4,4^{\prime}-\mathrm{DDT}$ & $\begin{array}{l}\text { EPA } 8080 \text { (sediment, tissue) } \\
\text { EPA } 608 \text { (water) (c) }\end{array}$ & $1.0 \mu \mathrm{g} / \mathrm{kg}$ & $0.4 \mu \mathrm{g} / \mathrm{kg}$ & $0.012 \mu \mathrm{g} / \mathrm{L}$ \\
\hline 2,4'-DDT & $\begin{array}{l}\text { EPA } 8080 \text { (sediment, tissue) } \\
\text { EPA } 608 \text { (water) (c) }\end{array}$ & $1.0 \mu \mathrm{g} / \mathrm{kg}$ & $0.4 \mu \mathrm{g} / \mathrm{kg}$ & $0.020 \mu \mathrm{g} / \mathrm{L}$ \\
\hline 4,4'-DDD & $\begin{array}{l}\text { EPA } 8080 \text { (sediment, tissue) } \\
\text { EPA } 608 \text { (water) (c) }\end{array}$ & $1.0 \mu \mathrm{g} / \mathrm{kg}$ & $0.4 \mu \mathrm{g} / \mathrm{kg}$ & $0.011 \mu \mathrm{g} / \mathrm{L}$ \\
\hline 2,4'-DDD & $\begin{array}{l}\text { EPA } 8080 \text { (sediment, tissue) } \\
\text { EPA } 608 \text { (water) (c) }\end{array}$ & $1.0 \mu \mathrm{g} / \mathrm{kg}$ & $0.4 \mu \mathrm{g} / \mathrm{kg}$ & $0.020 \mu g^{\prime} L$ \\
\hline 4,4'-DDE & $\begin{array}{l}\text { EPA } 8080 \text { (sediment, tissue) } \\
\text { EPA } 608 \text { (water) (c) }\end{array}$ & $1.0 \mu \mathrm{g} / \mathrm{kg}$ & $0.4 \mu \mathrm{g} / \mathrm{kg}$ & $0.004 \mu g / L$ \\
\hline $2,4^{\prime}-\mathrm{DDE}$ & $\begin{array}{l}\text { EPA } 8080 \text { (sediment, tissue) } \\
\text { EPA } 608 \text { (water) (c) }\end{array}$ & $1.0 \mu \mathrm{g} / \mathrm{kg}$ & $0.4 \mu \mathrm{g} / \mathrm{kg}$ & $0.020 \mu g^{\prime} L$ \\
\hline
\end{tabular}


TABLE 2.1. (contd)

\begin{tabular}{|c|c|c|c|c|}
\hline Analyte & Method(s) & $\begin{array}{c}\text { Sediment } \\
\text { Detection } \\
\text { Limit }\end{array}$ & $\begin{array}{c}\text { Tissue } \\
\text { Detection } \\
\text { Limit }\end{array}$ & $\begin{array}{c}\text { Water } \\
\text { Detection } \\
\text { Limi }\end{array}$ \\
\hline Endosulfan I & $\begin{array}{l}\text { EPA } 8080 \text { (sediment, tissue) } \\
\text { EPA } 608 \text { (water) (c) }\end{array}$ & $1.0 \mu \mathrm{g} / \mathrm{kg}$ & $0.4 \mu \mathrm{g} / \mathrm{kg}$ & $0.014 \mu \mathrm{g} / \mathrm{L}$ \\
\hline Endosulfan $\|$ & $\begin{array}{l}\text { EPA } 8080 \text { (sediment, tissue) } \\
\text { EPA } 608 \text { (water) (c) }\end{array}$ & $1.0 \mu \mathrm{g} / \mathrm{kg}$ & $0.4 \mu g / \mathrm{kg}$ & $0.004 \mu \mathrm{g} / \mathrm{L}$ \\
\hline Endosulfan sulfate & $\begin{array}{l}\text { EPA } 8080 \text { (sediment, tissue) } \\
\text { EPA } 608 \text { (water) (c) }\end{array}$ & $1.0 \mu \mathrm{g} / \mathrm{kg}$ & $0.4 \mu \mathrm{g} / \mathrm{kg}$ & $0.010 \mu \mathrm{g} / \mathrm{L}$ \\
\hline Heptachlor & $\begin{array}{l}\text { EPA } 8080 \text { (sediment, tissue) } \\
\text { EPA } 608 \text { (water) (c) }\end{array}$ & $1.0 \mu \mathrm{g} / \mathrm{kg}$ & $0.4 \mu \mathrm{g} / \mathrm{kg}$ & $0.003 \mu \mathrm{g} / \mathrm{L}$ \\
\hline Heptachlor epoxide & $\begin{array}{l}\text { EPA } 8080 \text { (sediment, tissue) } \\
\text { EPA } 608 \text { (water) (c) }\end{array}$ & $1.0 \mu \mathrm{g} / \mathrm{kg}$ & $0.4 \mu \mathrm{g} / \mathrm{kg}$ & $0.100 \mu g / L$ \\
\hline \multicolumn{5}{|l|}{$\mathrm{PCBs}$} \\
\hline $8\left(2,4^{\prime}\right)$ & NYSDEC (1992) (c) & $1.0 \mu \mathrm{g} / \mathrm{kg}$ & $0.4 \mu \mathrm{g} / \mathrm{kg}$ & $0.0005 \mu \mathrm{g} / \mathrm{L}$ \\
\hline $18\left(2,2^{\prime}, 5\right)$ & NYSDEC (1992) (c) & $1.0 \mu \mathrm{g} / \mathrm{kg}$ & $0.4 \mu \mathrm{g} / \mathrm{kg}$ & $0.0005 \mu \mathrm{g} / \mathrm{L}$ \\
\hline $28\left(2,4,4^{\prime}\right)$ & NYSDEC (1992) (c) & $1.0 \mu \mathrm{g} / \mathrm{kg}$ & $0.4 \mu \mathrm{g} / \mathrm{kg}$ & $0.0005 \mu \mathrm{g} / \mathrm{L}$ \\
\hline $44\left(2,2^{\prime}, 3,5^{\prime}\right)$ & NYSDEC (1992) (c) & $1.0 \mu \mathrm{g} / \mathrm{kg}$ & $0.4 \mu \mathrm{g} / \mathrm{kg}$ & $0.0005 \mu \mathrm{g} / \mathrm{L}$ \\
\hline $49\left(2,2^{\prime}, 4,5^{\prime}\right)$ & NYSDEC (1992) (c) & $1.0 \mu \mathrm{g} / \mathrm{kg}$ & $0.4 \mu \mathrm{g} / \mathrm{kg}$ & $0.0005 \mu \mathrm{g} / \mathrm{L}$ \\
\hline $52\left(2,2^{\prime}, 5,5^{\prime}\right)$ & NYSDEC (1992) (c) & $1.0 \mu \mathrm{g} / \mathrm{kg}$ & $0.4 \mu \mathrm{g} / \mathrm{kg}$ & $0.0005 \mu \mathrm{g} / \mathrm{L}$ \\
\hline $66\left(2,3^{\prime}, 4,4^{\prime}\right)$ & NYSDEC (1992) (c) & $1.0 \mu \mathrm{g} / \mathrm{kg}$ & $0.4 \mu g / \mathrm{kg}$ & $0.0005 \mu \mathrm{g} / \mathrm{L}$ \\
\hline $87\left(2,2^{\prime}, 3,4,5^{\prime}\right)$ & NYSDEC (1992) (c) & $1.0 \mu \mathrm{g} / \mathrm{kg}$ & $0.4 \mu \mathrm{g} / \mathrm{kg}$ & $0.0005 \mu \mathrm{g} / \mathrm{L}$ \\
\hline $101\left(2,2^{\prime}, 3,5,5^{\prime}\right)$ & NYSDEC (1992) (c) & $1.0 \mu \mathrm{g} / \mathrm{kg}$ & $0.4 \mu \mathrm{g} / \mathrm{kg}$ & $0.0005 \mu \mathrm{g} / \mathrm{L}$ \\
\hline $105\left(2,3,3^{\prime}, 4,4^{\prime}\right)$ & NYSDEC (1992) (c) & $1.0 \mu \mathrm{g} / \mathrm{kg}$ & $0.4 \mu \mathrm{g} / \mathrm{kg}$ & $0.0005 \mu \mathrm{g} / \mathrm{L}$ \\
\hline $118\left(2,3^{\prime}, 4,4^{\prime}, 5\right)$ & NYSDEC (1992) (c) & $1.0 \mu \mathrm{g} / \mathrm{kg}$ & $0.4 \mu \mathrm{g} / \mathrm{kg}$ & $0.0005 \mu \mathrm{g} / \mathrm{L}$ \\
\hline $128\left(2,2^{\prime}, 3,3^{\prime}, 4,4^{\prime}\right)$ & NYSDEC (1992) (c) & $1.0 \mu \mathrm{g} / \mathrm{kg}$ & $0.4 \mu \mathrm{g} / \mathrm{kg}$ & $0.0005 \mu \mathrm{g} / \mathrm{L}$ \\
\hline $138\left(2,2^{\prime}, 4,4^{\prime}, 5,5^{\prime}\right)$ & NYSDEC (1992) (c) & $1.0 \mu \mathrm{g} / \mathrm{kg}$ & $0.4 \mu \mathrm{g} / \mathrm{kg}$ & $0.0005 \mu \mathrm{g} / \mathrm{L}$ \\
\hline $153\left(2,2^{\prime}, 4,4^{\prime}, 5,5^{\prime}\right)$ & NYSDEC (1992) (c) & $1.0 \mu \mathrm{g} / \mathrm{kg}$ & $0.4 \mu \mathrm{g} / \mathrm{kg}$ & $0.0005 \mu \mathrm{g} / \mathrm{L}$ \\
\hline $170\left(2,2^{\prime}, 3,3^{\prime}, 4,4^{\prime}, 5\right)$ & NYSDEC (1992) (c) & $1.0 \mu \mathrm{g} / \mathrm{kg}$ & $0.4 \mu \mathrm{g} / \mathrm{kg}$ & $0.0005 \mu \mathrm{g} / \mathrm{L}$ \\
\hline $180\left(2,2^{\prime}, 3,4^{\prime}, 5,5^{\prime}, 6\right)$ & NYSDEC (1992) (c) & $1.0 \mu \mathrm{g} / \mathrm{kg}$ & $0.4 \mu \mathrm{g} / \mathrm{kg}$ & $0.0005 \mu \mathrm{g} / \mathrm{L}$ \\
\hline $183\left(2,2^{\prime}, 3,4,4^{\prime}, 5^{\prime}, 6\right)$ & NYSDEC (1992) (c) & $1.0 \mu \mathrm{g} / \mathrm{kg}$ & $0.4 \mu g / k g$ & $0.0005 \mu \mathrm{g} / \mathrm{L}$ \\
\hline $184\left(2,2^{\prime}, 3,4,4^{\prime}, 6,6^{\prime}\right)$ & NYSDEC (1992) (c) & $1.0 \mu \mathrm{g} / \mathrm{kg}$ & $0.4 \mu \mathrm{g} / \mathrm{kg}$ & $0.0005 \mu \mathrm{g} / \mathrm{L}$ \\
\hline $187\left(2,2^{\prime}, 3,4^{\prime}, 5,5^{\prime}, 6\right)$ & NYSDEC (1992) (c) & $1.0 \mu \mathrm{g} / \mathrm{kg}$ & $0.4 \mu \mathrm{g} / \mathrm{kg}$ & $0.0005 \mu \mathrm{g} / \mathrm{L}$ \\
\hline $195\left(2,2^{\prime}, 3,3^{\prime}, 4,4^{\prime}, 5,6\right)$ & NYSDEC (1992) (c) & $1.0 \mu \mathrm{g} / \mathrm{kg}$ & $0.4 \mu \mathrm{g} / \mathrm{kg}$ & $0.0005 \mu \mathrm{g} / \mathrm{L}$ \\
\hline $206\left(2,2^{\prime}, 3,3^{\prime}, 4,4^{\prime}, 5,5^{\prime}, 6\right)$ & NYSDEC (1992) (c) & $1.0 \mu \mathrm{g} / \mathrm{kg}$ & $0.4 \mu \mathrm{g} / \mathrm{kg}$ & $0.0005 \mu \mathrm{g} / \mathrm{L}$ \\
\hline $209\left(2,2^{\prime}, 3,3^{\prime}, 4,4^{\prime}, 5,5^{\prime}, 6,6^{\prime}\right)$ & NYSDEC (1992) (c) & $1.0 \mu \mathrm{g} / \mathrm{kg}$ & $0.4 \mu \mathrm{g} / \mathrm{kg}$ & $0.0005 \mu \mathrm{g} / \mathrm{L}$ \\
\hline
\end{tabular}


TABLE 2.1. (contd)

\begin{tabular}{|c|c|c|c|c|}
\hline Analyte & Method(s) & $\begin{array}{c}\text { Sediment } \\
\text { Detection } \\
\text { Limit } \\
\end{array}$ & $\begin{array}{c}\text { Tissue } \\
\text { Detection } \\
\text { Limit } \\
\end{array}$ & $\begin{array}{c}\text { Water } \\
\text { Detection } \\
\text { Limi }\end{array}$ \\
\hline \multicolumn{5}{|l|}{$\mathrm{PAHs}$} \\
\hline Acenaphthene & EPA 8270 (c) & $10 \mu \mathrm{g} / \mathrm{kg}$ & $4 \mu g / k g$ & \\
\hline Acenaphthylene & EPA 8270 (c) & $10 \mu g / k g$ & $4 \mu \mathrm{g} / \mathrm{kg}$ & \\
\hline Anthracene & EPA 8270 (c) & $10 \mu g / k g$ & $4 \mu \mathrm{g} / \mathrm{kg}$ & \\
\hline Fluorene & EPA 8270 (c) & $10 \mu \mathrm{g} / \mathrm{kg}$ & $4 \mu \mathrm{g} / \mathrm{kg}$ & \\
\hline Naphthalene & EPA $8270(c)$ & $10 \mu \mathrm{g} / \mathrm{kg}$ & $4 \mu \mathrm{g} / \mathrm{kg}$ & \\
\hline Phenanthrene & EPA 8270 (c) & $10 \mu \mathrm{g} / \mathrm{kg}$ & $4 \mu \mathrm{g} / \mathrm{kg}$ & \\
\hline Benzo[a]anthracene & EPA 8270 (c) & $10 \mu \mathrm{g} / \mathrm{kg}$ & $4 \mu g / k g$ & \\
\hline Benzo[a]pyrene & EPA 8270 (c) & $10 \mu \mathrm{g} / \mathrm{kg}$ & $4 \mu \mathrm{g} / \mathrm{kg}$ & \\
\hline Benzo[b]fluoranthene & EPA 8270 (c) & $10 \mu \mathrm{g} / \mathrm{kg}$ & $4 \mu \mathrm{g} / \mathrm{kg}$ & \\
\hline Benzo[ghi]perylene & EPA 8270 (c) & $10 \mu g / \mathrm{kg}$ & $4 \mu \mathrm{g} / \mathrm{kg}$ & \\
\hline Benzo[k]fluoranthene & EPA 8270 (c) & $10 \mu \mathrm{g} / \mathrm{kg}$ & $4 \mu \mathrm{g} / \mathrm{kg}$ & \\
\hline Chrysene & EPA 8270 (c) & $10 \mu \mathrm{g} / \mathrm{kg}$ & $4 \mu \mathrm{g} / \mathrm{kg}$ & \\
\hline Dibenzo[a,h]anthracene & EPA 8270 (c) & $10 \mu \mathrm{g} / \mathrm{kg}$ & $4 \mu \mathrm{g} / \mathrm{kg}$ & \\
\hline Fluoranthene & EPA 8270 (c) & $10 \mu \mathrm{g} / \mathrm{kg}$ & $4 \mu \mathrm{g} / \mathrm{kg}$ & \\
\hline Indeno[1,2,3-cd]pyrene & EPA 8270 (c) & $10 \mu \mathrm{g} / \mathrm{kg}$ & $4 \mu \mathrm{g} / \mathrm{kg}$ & \\
\hline Pyrene & EPA 8270 (c) & $10 \mu \mathrm{g} / \mathrm{kg}$ & $4 \mu \mathrm{g} / \mathrm{kg}$ & \\
\hline 1,4-Dichlorobenzene & EPA 8270 (c) & $1.0 \mu \mathrm{g} / \mathrm{kg}$ & $\dot{0} .4 \mu \mathrm{g} / \mathrm{kg}$ & \\
\hline \multicolumn{5}{|c|}{ OTHER MEASUREMENTS } \\
\hline Total Lipids & $\begin{array}{l}\text { Bligh and Dyer (1959)/ } \\
\text { Randall (1988) }\end{array}$ & & $0.1 \%$ & \\
\hline
\end{tabular}

(a) Detection limits are in dry weight for all sediment parameters except $\mathrm{Hg}$.

(b) Detection limits are in wet weight for all organic and inorganic tissue parameters.

(c) Equivalent MSL standard operating procedures were substituted for the methods cited. 
larger than a U.S. No. 230 standard sieve (62.5- $\mu \mathrm{m}$ mesh). The size distribution of particles smaller than a U.S. No. 230 sieve was determined using the pipet method. Grain size was reported as percentages within four general size classes:

$\begin{array}{ll}\text { gravel } & >2000-\mu \mathrm{m} \text { diameter } \\ \text { sand } & \geq 62.5-\mu \mathrm{m} \text { diameter and }<2000-\mu \mathrm{m} \text { diameter } \\ \text { silt } & \geq 3.9-\mu \mathrm{m} \text { diameter and }<62.5-\mu \mathrm{m} \text { diameter } \\ \text { clay } & <3.9-\mu \mathrm{m} \text { diameter. }\end{array}$

Percentage of moisture was obtained using the Plumb (1981) method for determining total solids. The procedure involves drying a sediment sample at $100^{\circ} \mathrm{C}$ until a constant weight is obtained. Percentage of moisture was calculated by subtracting the percentage of total solids from $100 \%$.

\subsubsection{Bulk Density and Specific Gravity}

Bulk density, or unit weight, was determined according to EM 111-2-1906 (USACE 1970). Specific gravity, the ratio of the mass of a given volume of material to an equal volume of water at the same temperature, was measured according to ASTM D-854.

\subsubsection{Total Organic Carbon}

Samples were analyzed according to the EPA Edison, New Jersey, Laboratory Procedure (EPA 1986). Inorganic carbon was removed from the sample by acidification. The sample was combusted and the evolved carbon dioxide was quantitated using a carbon-hydrogen-nitrogen (CHN) analyzer. TOC was reported as a percentage of the dry weight of the unacidified sample.

\subsubsection{Metals}

Preparation and analysis of water samples for $\mathrm{Cd}, \mathrm{Cr}, \mathrm{Cu}, \mathrm{Pb}, \mathrm{Ni}, \mathrm{Ag}$, and $\mathrm{Zn}$ were conducted according to MSL SOPs equivalent to EPA Methods 200.2 and 200.9 (EPA 1991). Samples were chelated with $2 \%$ ammonium pyrrolidinedithiocarbamate (APDC), precipitated out of solution, and filtered. The filter was digested in concentrated nitric acid, and the digestate was analyzed by graphite fumace atomic absorption (GFAA) spectroscopy for $\mathrm{Cr}$ and $\mathrm{Zn}$, or by inductively coupled plasma/mass spectrometry (ICP/MS) for $\mathrm{Cd}, \mathrm{Cu}, \mathrm{Pb}, \mathrm{Ni}$, and $\mathrm{Ag}$. Water samples were analyzed for $\mathrm{Hg}$ directly by cold vapor atomic fluorescence (CVAF) according to the method of Bloom and Crecelius (1983). This CVAF technique is based on emission of 254 $\mathrm{nm}$ radiation by excited elemental $\mathrm{Hg}$ atoms in an inert gas stream. Mercuric ions in an oxidized sample were reduced to elemental $\mathrm{Hg}$ with tin chloride $\left(\mathrm{SnCl}_{2}\right)$, then purged onto gold-coated sand traps to pre-concentrate the $\mathrm{Hg}$ and remove interferences. Mercury vapor was thermally 
desorbed to a second "analytical" gold trap, and from that into the fluorescence cell. Fluorescence (indicated by peak area) is proportional to the quantity of $\mathrm{Hg}$ collected, and was quantified using a standard curve as a function of the quantity of the sample purged.

Sediment samples for analysis of $\mathrm{As}, \mathrm{Cd}, \mathrm{Cr}, \mathrm{Cu}, \mathrm{Pb}, \mathrm{Ni}$, and $\mathrm{Zn}$ were prepared according to an MSL SOP equivalent to EPA Method 200.2 (EPA 1991). Solid samples were first freeze-dried and blended in a Spex mixer mill. A 0.2- to 0.5-g aliquot of dried homogeneous sample was then digested using peroxide and nitric acid. Samples were heated in sealed Teflon bombs overnight at approximately $130^{\circ} \mathrm{C}$. Sediment samples were analyzed for $\mathrm{Ag}, \mathrm{As}, \mathrm{Cd}, \mathrm{Cr}$, $\mathrm{Cu}, \mathrm{Pb}, \mathrm{Ni}$, and $\mathrm{Zn}$ using ICP/MS, following an MSL SOP based on EPA Method 200.8 (EPA 1991). Sediments were analyzed for $\mathrm{Hg}$ by CVAA according to an MSL procedure for total $\mathrm{Hg}$ determination equivalent to EPA Method 245.5 (EPA 1991).

Tissue samples were prepared for analysis of metals according to an MSL SOP based on EPA Method 200.3 (EPA 1991). Solid samples were first freeze-dried and blended, and a 0.2to $0.5 \mathrm{~g}$ aliquot of dried homogeneous sample was then digested in a microwave using nitric acid, hydrogen peroxide, and hydrochloric acid. Tissue samples were analyzed for $\mathrm{As}, \mathrm{Cd}, \mathrm{Cr}, \mathrm{Cu}$, $\mathrm{Pb}, \mathrm{Ni}, \mathrm{Ag}$, and $\mathrm{Zn}$ using the ICP/MS method (EPA Method 200.8 [EPA 1991]). Tissue samples were analyzed for $\mathrm{Hg}$ by CVAA following an MSL procedure equivalent to EPA Method 245.6 (EPA 1991).

\subsubsection{Chlorinated Pesticides and PCBs}

Water samples were prepared and analyzed for chlorinated pesticides and PCBs according to a Battelle Ocean Sciences procedure equivalent to EPA Method 8080 (EPA 1990), and incorporating techniques developed by the National Oceanic and Atmospheric Administration (NOAA) National Status and Trends "Mussel Watch" Program (NOAA 1993). Samples were extracted with methylene chloride. Extract volumes were reduced and solvent-exchanged to hexane. The sample extracts underwent cleanup by alumina and silica column chromatography; further interferences were removed by an additional cleanup treatment using high-performance liquid chromatography (HPLC). Sample extracts were concentrated and analyzed using gas chromatography with electron capture detection (GC-ECD) by the intemal standard technique.

Sediment and tissue samples for pesticide and PCB analysis were extracted and analyzed according to an MSL procedure similar to EPA Method 8080 for pesticides and the New York State Department of Environmental Conservation (NYSDEC) Congener-Specific Method 91-11 (NYSDEC 1992). The method also uses techniques from the NOAA Mussel Watch procedure. A 20- to 50-g sample of homogenized sediment or macerated tissue was first combined with sodium sulfate in a sample jar to remove water. Samples were extracted by adding successive portions of methylene chloride and agitating sample jars at ambient 
temperature using a roller technique. Extract volumes were reduced and solvent-exchanged to hexane, followed by Florisil column chromatography cleanup. Interferences were removed using HPLC cleanup; tissue sample extracts underwent an additional cleanup by gel permeation chromatography (GPC). Sample extracts were concentrated and analyzed using GC-ECD by the intemal standard technique.

The concentration of total PCB in each matrix was estimated by taking the sum of the 22 congeners $(x)$ and multiplying by two. The procedure for calculation of total PCBs was established in 1996 (Mario Del Vicario, Chief of the Marine and Wetlands Protection Branch, U.S. Environmental Protection Agency Region 2, Feb 14, 1996, letter to John F. Tavolaro, Chief Operations Support Branch, U.S. Army Corps of Engineers, New York District). One-half of the detection limit was used in summation when an analyte was undetected.

\subsubsection{PAHs and 1,4-Dichlorobenzene}

Sediment samples were prepared for the analysis of 16 PAHs and 1,4-dichlorobenzene (see Table 2.1) according to a Battelle Ocean Sciences method based on the NOAA Mussel Watch procedure (NOAA 1993). A 20- to 50-g sample of homogenized sediment or macerated tissue was first combined with sodium sulfate in a sample jar to remove water. Samples were extracted by adding successive portions of methylene chloride and agitating sample jars at ambient temperature using an ambient shaker technique. Extract volumes were reduced and solvent-exchanged to hexane, followed by column chromatography cleanup. Interferences were removed using HPLC cleanup; tissue sample extracts underwent an additional cleanup by GPC. Sample extracts were concentrated and analyzed using gas chromatography with mass spectrometry (GC/MS) in the selective ion monitoring (SIM) mode.

\subsubsection{Lipids}

The lipid content of $M$. nasuta and $N$. virens was determined by the analysis of unexposed background tissue samples of each species. The lipid analysis procedure is a modification of the Bligh and Dyer (1959) methods, which involves a chloroform extraction followed by gravimetric measurement of lipids. Randall (1988) modified the original Bligh and Dyer method to accommodate a smaller tissue sample size. Lipid analysis was performed in triplicate, once for each species. Lipid concentration was reported as a percentage on both a wet and dry weight basis. 


\subsection{Biological Testing Procedures}

\subsubsection{Benthic Acute Toxicity Tests}

Deposited sediment effects of open-water dredged material disposal were evaluated by benthic acute toxicity tests with the marine amphipod species, $A$. abdita and the mysid $M$. bahia.

\subsubsection{Static Renewal Test with Ampelisca abdita}

Upon receipt, the $A$. abdita were placed in a tub of clean sand from their collection area and gradually acclimated to laboratory conditions with unfitered flowing Sequim Bay seawater.

A. abdita were received at approximately $12^{\circ} \mathrm{C}$ and acclimated to $20^{\circ} \mathrm{C} \pm 2^{\circ} \mathrm{C}$ over a period of 5 days. The test organisms were not fed prior to testing.

All amphipod static renewal tests were performed in 1-L glass jars modified for use as flow-through test chambers. The test chambers were fitted with funneled lids and screens and overflow ports (Figure 2.1). Five replicates of each Red Hook/Bay Ridge composite sediment, Mud Dump Reference Site sediment, and native animal control treatments were tested.

Concentrations of ammonia have been encountered in the pore water of sediment core samples from New York/New Jersey waterways at concentrations high enough to affect survival of amphipods in benthic toxicity tests (Barrows et al. 1996). Therefore, the amphipod tests were conducted according to the ammonia reduction methods recommended in the correction (errata) to the EPA standard methods document for conduct of benthic acute toxicity tests (EPA 1994a). This guidance requires postponing test initiation (exposure of test animals) until pore water total ammonia concentrations are below levels where a toxic effect can be noted (i.e., the noobservable-effects-concentration or NOEC). During this "purging" period, test chambers were set up and maintained under test conditions, and the overying water was exchanged twice daily until the pore water ammonia concentrations reached the level appropriate for the particular amphipod. The water-system was tumed on daily to deliver a volume of seawater equivalent to two chamber exchanges per day (approximately $10 \mathrm{~min}$, two times per day). Pore water ammonia measurements were made on "dummy" containers that were set up and maintained in the same manner as the actual test containers but without animals added to them. The pore water was obtained by siphoning off the overtying water in the dummy jar and centrifuging the sediment in a Teflon jar for at least $20 \mathrm{~min}$ at approximately $3000 \mathrm{~mm}$. Salinity, temperature, and $\mathrm{pH}$ were also determined in the pore water samples. Once the test was initiated, overlying water was renewed at a rate of two chamber exchanges per day throughout the 10-day tests.

The amphipod benthic toxicity tests were initiated by the addition of 20 organisms to each test chamber for a test population of 100 amphipods per sediment treatment. Amphipods were gently sieved from their native sediment in holding tanks and transferred to shallow baking dishes. 




FlGURE 2.1. Testing Containers for Amphipod Static Renewal Toxicity Tests 
For each test chamber, five animals were counted and transferred by pipet into each of four small, plastic cups. The animals in each transfer cup were recounted by a second analyst. The animals were placed in the test chamber by dipping the cup below the surface of the water to release the amphipods.

Salinity, temperature, DO, and pH were measured in all replicates prior to test initiation, in at least one replicate per treatment daily, and in all replicates at test termination. Measurements of total ammonia levels in the overtying water and pore water also continued during testing. Overying water ammonia was measured in all replicates prior to test initiation (Day 0), in at least one replicate per treatment daily, and in all replicates at test termination (Day 10). Pore water ammonia was measured "dummy containers on Day 0 and Day 10. The following were the acceptable ranges for water quality parameters during the $A$. abdita tests:

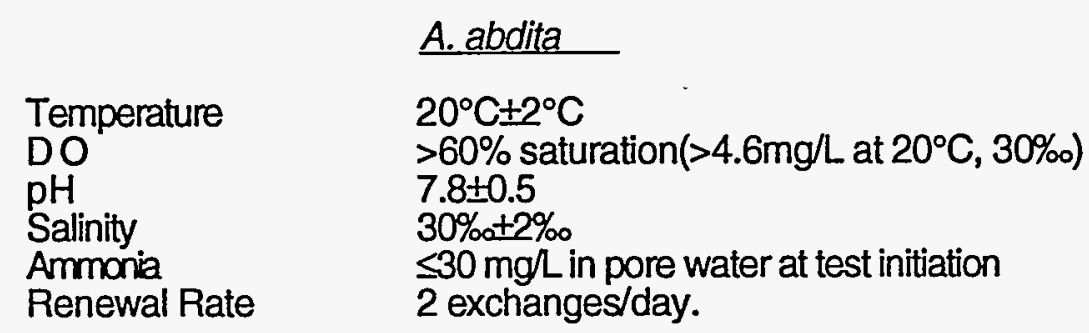

The ammonia pore water maximum limit is based on a directive from the USACE-NYD (personal communication, M. Greges, USACE, April 1995).

Gentle aeration was provided throughout the test, and the amphipods were not fed during testing. At the end of the 10-day period, the contents of each chamber were gently sieved through 0.5-mm mesh, and the number of live, dead, and missing amphipods was recorded on termination forms. An animal was considered dead if it did not respond to gentle probing. As a quality control check, a second observer confimed surviving test organisms on at least $10 \%$ of the temination counts.

Reference toxicant tests with cadmium chloride were performed concurrently with each species. The reference toxicant tests were $96-h$, water-only exposures that were otherwise conducted following the same procedures as for the static tests with sediment. $A$. abdita were exposed to nominal concentrations of $0,0.19,0.38,0.75$, and $1.5 \mathrm{mg} / \mathrm{L} \mathrm{Cd}$.

\subsubsection{Static Test with Mysidopsis bahia}

Upon receipt at the laboratory, M. bahia were placed in 10-gal aquaria and gradually acclimated from $25 \%$ seawater to $30 \%$ and $20^{\circ} \mathrm{C} \pm 2{ }^{\circ} \mathrm{C}$ with Sequim Bay seawater over a period of 3 days. Mysids were fed concentrated brine shrimp nauplii twice daily prior to testing. Mortality of the M. bahia during holding was less than $1 \%$. 
The 10-day static benthic acute toxicity test with $M$. bahia was performed in $1-L$ glass jars. To prepare each test container, $200 \mathrm{~mL}$ of clean seawater was placed in each jar. Sediment was added until water was displaced up to the 400-mL mark, then seawater was added up to the 750-mL mark. Five replicates of each Red Hook/Bay Ridge sediment composite and the Mud Dump Reference Site sediment were tested. Static jars were renewed twice daily for 10 days. At the start of the test the porewater ammonia concentrations ranged from 1.44 to $39.4 \mathrm{mg} / \mathrm{L}$ and overlying water ammonia concentrations were all less than $1.0 \mathrm{mg} / \mathrm{L}$.

The mysid benthic toxicity test was initiated by the addition of 20 organisms to each test chamber for a test population of 100 mysids per sediment treatment. Mysids were transferred from holding tanks to shallow glass dishes. For each test chamber, five animals were counted and transferred by pipet into each of four small, plastic cups. The animals in each transfer cup were recounted by a second analyst. The animals were placed in the test chamber by dipping the cup below the surface of the water to release the mysids.

Salinity, temperature, $\mathrm{DO}, \mathrm{pH}$, and total ammonia in overlying water were measured in all replicates prior to test initiation, in at least one replicate per treatment daily, and in all replicates at test termination. The following were the acceptable ranges for water quality parameters during the M. bahia benthic test:

\section{M. bahia}

Temperature
DO
pH
Salinity
Ammonia

$20^{\circ} \mathrm{C} \pm 2^{\circ} \mathrm{C}$ $>40 \%$ saturation $\left(>3.0 \mathrm{mg} / \mathrm{L}\right.$ at $20^{\circ} \mathrm{C}, 30 \%$ ) $7.8+0.5$ $30 \% \pm 2 \%$ $\leq 15 \mathrm{mg} / \mathrm{L}$ in overlying water at test initiation.

The ammonia overlying water maximum limit is based on EPA guidance (EPA 1994b) that provided criteria of $0.6 \mathrm{mg} / \mathrm{L}$ unionized ammonia at $\mathrm{pH}$ of $7.9-8.0$ and $0.3 \mathrm{mg} / \mathrm{L}$ unionized ammonia at $\mathrm{pH}$ of 7.5 (at $26^{\circ} \mathrm{C}$ and $31 \%$ salinity). When converted to test temperature, $\mathrm{pH}$, and salinity used at the MSL, these values equal approximately $15 \mathrm{mg} / \mathrm{L}$ total ammonia.

Gentle aeration was provided to all test chambers during the test to maintain consistency in DO concentration among test containers. At the end of the 10-day period, the contents of each chamber were gently sieved through $0.5-\mathrm{mm}$ mesh, and the number of live and dead or missing mysids was recorded on termination forms. An animal was considered dead if it did not respond to gentle prodding. As a quality control check, a second observer confirmed surviving test organisms on at least $10 \%$ of the termination counts.

Because the same mysid population was used for the benthic test and the water-column test, one 96-h, water-only reference toxicant test with copper sulfate $(0,100,150,200$ and $300 \mu \mathrm{g} / \mathrm{L}$ copper) was performed concurrently with these tests (Refer to Section 2.5.1.2.). 


\subsubsection{Water-Column Toxicity Tests}

Water-column effects of open-water dredged-material disposal were evaluated by exposing three species of water-column organisms to the SPP of the Red Hook/Bay Ridge sediment composites. The three test species were juvenile M. beryllina (silverside) and M. bahia (mysid), and larval M. galloprovincialis (mussel). Total ammonia monitoring was not performed during water-column toxicity tests, but prior to test initiation total ammonia concentrations were measured for the $100 \%$ SPP concentration and is presented in Section 3.4 .

\subsubsection{Water-Column Toxicity Test with Menidia beryllina}

Upon receipt, the $M$. beryllina were placed in a 10-gal glass aquarium and acclimated from $20.5 \%$ seawater to $30.0 \%$ Sequim Bay seawater over a 3-day period. M. beryllina were received and held at $20^{\circ} \mathrm{C} \pm 2{ }^{\circ} \mathrm{C}$ prior to testing and were fed concentrated brine shrimp nauplii daily. During acclimation and holding, $2 \%$ to $3 \%$ mortality of the sitversides was observed.

Test containers for the water-column toxicity test with silversides were 500 -mL glass jars, labeled with sediment treatment code, concentration, position number, and replicate number. Five replicates of each concentration (0\%, 10\%, 50\%, and 100\% SPP) were tested, with a $300-\mathrm{mL}$ test volume per replicate. Each test chamber was then placed in a randomly assigned position on a water table at $20^{\circ} \mathrm{C} \pm 2^{\circ} \mathrm{C}$ and allowed to equilibrate to test temperature for several hours. After the SPP concentrations reached test temperature, water quality parameters were measured and recorded for all replicates of all concentrations for eact sediment treatment.

To initiate the test, $M$. beryllina were transferred from the holding tank to test chambers with a wide-bore pipet via small transfer cups. Ten individuals were introduced to each test chamber, creating a test population of 50 silversides per concentration for each treatment. Ten animals per test chamber were used, rather than the 20 animals per chamber as described in the Regional Guidance Manual, because it is not possible to make accurate daily observations of M. beryllina behavior when using 20 animals. Test initiation time and date were recorded.

Following test initiation, water quality parameters were recorded in one replicate of each concentration daily. Because several treatments had DO levels lower than $40 \%$ saturation prior to test initiation, all test chambers were aerated to maintain consistency in DO concentration among test containers. Acceptable parameters for this test were as follows:

\section{M. beryllina}

Temperature

DO

$\mathrm{pH}$

Salinity $20^{\circ} \mathrm{C}+2^{\circ} \mathrm{C}$ $>40 \%$ saturation ( $>3.0 \mathrm{mg} / \mathrm{L}$ at $20^{\circ} \mathrm{C}, 30 \%$ )

$7.8 \pm 0.5$

$30.0 \%$ o+2.0\% 
The test was run under a 16-h light/8-h dark photoperiod, and siversides were fed brine shrimp nauplii daily during the test. Observations of the animals were performed at $2 h, 24 h$, $48 \mathrm{~h}$, and $72 \mathrm{~h}$, and the number of live, dead, and missing was recorded. At the end of the $96-\mathrm{h}$ test period, water quality parameters were measured for all test chambers, and the number of live, dead, and missing silversides was recorded on termination forms. As a quality control check, a second observer confirmed surviving test organisms on at least $10 \%$ of the termination counts.

A 96-h, water-only, reference toxicant test was performed concurrently with the toxicity test with each population of $M$. beryllina to establish the health and expected response of the test organisms. The reference toxicant test was conducted in the same manner as the watercolumn toxicity test. $M$. beryllina were exposed to a seawater control plus four concentrations of copper sulfate: $16,64,160$, and $400 \mu g / L$ copper, using three replicates of each concentration.

\subsubsection{Water-Column Toxicity Test with Mysidopsis bahia}

Upon receipt, the $M$. bahia were placed in a 10-gal aquarium and gradually acclimated from $28.0 \%$ seawater to $30 \%$ Sequim Bay seawater over a 4 day period. Mysids were received and held at $20^{\circ} \mathrm{C} \pm 2^{\circ} \mathrm{C}$ until testing and were fed concentrated brine shrimp naupli twice daily prior to testing. Mortality of the $M$. bahia during holding was less than $1 \%$.

The water-column toxicity test with the mysid was performed in $200 \mathrm{~mL}$ of test solution in 400-mL jars, labeled with sediment treatment code, concentration, position number, and replicate number. Five replicates of each concentration were tested. Each of the test chambers received $200 \mathrm{~mL}$ of test solution, then was placed randomly in a recirculating water bath and allowed to equilibrate to test temperature for several hours. Prior to test initiation, water quality parameters were measured in each replicate of each sediment treatment concentration. Acceptable water quality parameters for this test were as follows:

\section{M. bahia}

Temperature
DO
pH
Salinity

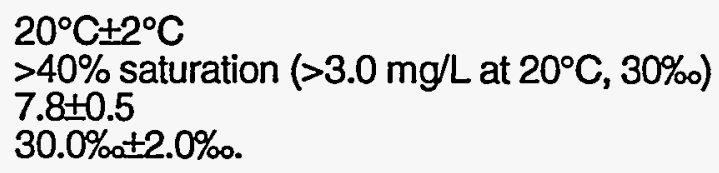

To initiate the test, $M$. bahia were transferred from the holding tank to test chambers with a wide-bore pipet via small transfer cups. Ten individuals were introduced to each test chamber, creating a test population of 50 mysids per concentration ( 200 mysids per treatment). Ten animals per test chamber were used, rather than the 20 animals per chamber as described in the Regional Guidance Manual, because it is not possible to make accurate daily observations of M. bahia behavior when using 20 animals. Test initiation time and date were documented on data forms. Observations of test organisms were performed at $4 \mathrm{~h}, 24 \mathrm{~h}, 48 \mathrm{~h}$, and $72 \mathrm{~h}$, using a

\section{BED HOOKJBAY BIDGE REPORT $\quad 2.19$}


fluorescent light table to enhance visibility of the M. bahia. After test initiation, water quality parameters were measured daily in one replicate concentration of all concentrations for each sediment treatment. During the 96-h exposure, M. bahia were fed <24-h-old brine shrimp daily. Excess food was removed daily with a small pipet, taking care not to disturb test animals. Molted exoskeletons and any particulates from the SPP solutions were also removed.

Prior to test termination, water quality parameters were measured in all replicates. At $96 \mathrm{~h}$, the number of live versus dead animals was recorded for each test container. An animal was considered dead if it did not respond to gentle probing. As a quality control check, a second observer confirmed surviving test organisms on at least $10 \%$ of the termination counts.

A 96-h, water-only, reference toxicant test was performed concurrently with the toxicity test with each batch of $M$. bahia to establish the health and expected response of the test organisms. The reference toxicant test was conducted in the same manner as the water-column toxicity test. $M$. bahia were exposed to a seawater control plus four concentrations of copper sulfate: $100,150,200$, and $300 \mu \mathrm{g} / \mathrm{L}$ copper, using three replicates of each concentration.

\subsubsection{Water-Column Toxicity Test with Mytilus galloprovincialis Larvae}

Prior to testing, adult M. galloprovincialis were held in flowing, unfiltered Sequim Bay seawater at ambient temperatures for approximately 5 days.

Chambers for the bivalve larvae test were 500-mL glass jars labeled with sediment treatment code, concentration, position number, and replicate number. Dilutions of SPP from sediment composites $(0 \%, 10 \%, 50 \%$, and $100 \%)$ were prepared with Mud Dump Site water in a 2000-mL graduated cylinder, then $300 \mathrm{~mL}$ of test solution was transferred into each test chamber. Test chambers were placed in random positions on a water table and allowed to equilibrate to test temperature for several hours. Initial water quality parameters were measured in all replicates once test chambers reached testing temperatures $\left(16^{\circ} \mathrm{C} \pm 2^{\circ} \mathrm{C}\right)$.

Spawning was induced by placing $M$. galloprovincialis into $15^{\circ} \mathrm{C}$, filtered Sequim Bay seawater and rapidly raising the holding water temperature to $20^{\circ} \mathrm{C}$. Spawning generally occurs within $1 \mathrm{~h}$ of temperature elevation; however, on the first day of spawning, gametes were shed after $3 \mathrm{~h}$ to $4 \mathrm{~h}$. For this group of mussels, the water bath was changed when DO levels fell below $3.0 \mathrm{mg} / \mathrm{L}$. When spawning began, males and females were identified and isolated in individual jars containing filtered Sequim Bay seawater and allowed to shed gametes for approximately $45 \mathrm{~min}$. Eggs from each female were filtered through a $75-\mu \mathrm{m}$ Nytex screen into separate jars to remove feces, detritus, and byssal fibers. Sperm from at least three males were pooled, and $10 \mathrm{~mL}$ of sperm solution was then added to each of the egg stocks. Egg-sperm solutions were gently mixed every $10 \mathrm{~min}$ with a perforated plunger. Fertilization proceeded for $1 \mathrm{~h}$, then fertilization rate (percentage of fertilized eggs) was determined by removing a 
subsample and observing the number of multicell-stage embryos. Fertilization was considered successful if greater than $90 \%$ of the embryos were in the multicell stage. Egg stocks with greater than $90 \%$ feritization were combinéd and rinsed on a $20-\mu \mathrm{m}$ Nytex screen to remove excess sperm. Stock embryo solution density was estimated by removing a $0.1-\mathrm{mL}$ subsample and counting all multicell embryos, then multiplying by 10 to yield embryo density (embryos $/ \mathrm{mL}$ ). Stock solution was diluted or concentrated to yield 7500 to $9000 \mathrm{embryos} / \mathrm{mL}$. The test was initiated by introducing $1 \mathrm{~mL}$ of stock solution into each test chamber, to produce embryo densities of 25 to $30 \mathrm{embryos} / \mathrm{mL}$. Test initiation date and time were recorded on data sheets. Following initiation, $10 \mathrm{~mL}$ stocking-density subsamples were removed from each container and preserved in $5 \%$ formaldehyde to determine actual stocking density later.

Water quality parameters were measured in one replicate of each concentration per treatment daily throughout the test. Acceptable ranges for water quality parameters were as follows:

\section{M. galloprovincialis}

Temperature
DO
pH
Salinity

$16^{\circ} \mathrm{C} \pm 2^{\circ} \mathrm{C}$ $>40 \%$ saturation $\left(>4.9 \mathrm{mg} / \mathrm{L}\right.$ at $16^{\circ} \mathrm{C}, 30 \%$ ) $7.8 \pm 0.5$ $30.0 \%+2.0 \%$.

Because several treatments had DO levels below the acceptable level of $40 \%$ saturation, each chamber was provided with gentle aeration to maintain consistency in DO concentration among test containers: The bivalve test was terminated after $48 \mathrm{~h}$ when greater than $80 \%$ of the larvae in the controls had reached the-D-cell stage. Final water quality parameters were recorded for all replicates. The contents of each chamber were then homogenized with a perforated plunger, and a $10-\mathrm{mL}$ subsample was removed and placed into a 20-mL scintillation vial. The subsample was then fixed with $1 \mathrm{~mL}$ of $50 \%$ solution of formaldehyde in seawater. Samples were scored for the appearance of normal and abnormal Dshaped larvae, blastula larvae, and total number of larvae. At least $10 \%$ of the counts were confirmed by a second observer.

A 72-h reference toxicant test was conducted to verify the health and expected response of the test organisms. The reference toxicant test was set up and conducted in the same manner as the liquid-phase tests. M. galloprovincialis larvae were exposed to a filtered Sequim Bay seawater control plus copper sulfate concentrations of $1,4,16$, and $64 \mu \mathrm{g} / \mathrm{L}$ copper, with three replicates per concentration. 


\subsubsection{Bioaccumulation Testing}

The bivalve $M$. nasuta and the polychaete $N$. virens were used to evaluate the potential bioaccumulation of contaminants from dredged material. The bioaccumulation tests were 28-day flow-through exposures to sediment, followed by a.24-h depuration period that allowed the organisms to void their digestive tracts of sediment. M. nasuta and $N$. virens were tested in separate 10-gal flow-through aquaria. Animals were exposed to five replicates of each Red Hook/Bay Ridge sediment composite, Mud Dump Reference Site sediment, and native control sediment. Each chamber contained $25 \mathrm{M}$. nasuta or $20 \mathrm{~N}$. virens. Water quality parameters (temperature, $\mathrm{DO}, \mathrm{pH}$, and salinity) were measured in all replicates at test initiation, in at least one replicate per treatment daily, and in all replicates at test termination. Flow rates were measured daily in all chambers.

Upon receipt at the laboratory, $M$. nasuta were received damp and held in control sediment with flowing Sequim Bay seawater for 4 days at $15^{\circ} \mathrm{C} \pm 2^{\circ} \mathrm{C}$ until testing and were not fed. $N$. virens were placed in holding trays of control sediment with heated Sequim Bay seawater flowing into the trays. $N$. virens were received at $17^{\circ} \mathrm{C}$ and gradually acclimated to $20^{\circ} \mathrm{C} \pm 2^{\circ} \mathrm{C}$ over a 9-day period. $N$. virens were not fed prior to testing. Mortality of $M$. nasuta and $N$. virens during holding was less than $1 \%$.

The Regional Guidance Manual provides an acceptable temperature range of $13^{\circ} \mathrm{C} \pm 1^{\circ} \mathrm{C}$ for $M$. nasuta; however, laboratory logistics required that $M$. nasuta be conducted at $15^{\circ} \mathrm{C}$ under flow-through conditions. This alteration of test temperature was not expected to affect the outcome of the test; bioaccumulation tests with $M$. nasuta have been successfully conducted at $15^{\circ} \mathrm{C} \pm 2^{\circ} \mathrm{C}$. After discussion with the USACE-NYD project manager, the following ranges for water quality parameters were established as acceptable for the $M$. nasuta and $N$. virens tests:

\begin{tabular}{llll} 
& \multicolumn{1}{c}{$M$. nasuta } & & \multicolumn{1}{c}{$N$. virens } \\
Temperature & $15^{\circ} \mathrm{C} \pm 2^{\circ} \mathrm{C}$ & & $20^{\circ} \mathrm{C}+2^{\circ} \mathrm{C}$ \\
DO & $>60 \%$ saturation & & $>60 \%$ saturation \\
pH & $7.8 \pm 0.5$ & & $7.8 \pm 0.5$ \\
Salinity & $30 \%$ a $+2 \%$ & $30 \%+2 \%$ \\
Flow Rate & $125 \pm 10 \mathrm{~mL} / \mathrm{min}$ & & $125 \pm 10 \mathrm{~mL} / \mathrm{min}$.
\end{tabular}

Aeration was provided to all test chambers to maintain consistency in DO concentrations among test chambers. Water quality, organism behavior (e.g., burrowing activity, feeding), and organism mortality were recorded daily. Ammonia reduction procedures were not performed on sediments used for bioaccumulation tests. Dead organisms were removed daily. At the end of the 28-day testing period, $M$. nasuta and $N$. virens were placed in clean, flowing seawater for 24 $h$, after which the tissues were transferred into the appropriate chemistry jars for metals, 
pesticide/PCB, and $\mathrm{PAH}$ analyses. All tissue samples were frozen immediately and stored at less than $-20^{\circ} \mathrm{C}$ until analysis.

Water-only reference toxicant tests (96-h) were also performed using copper sulfate in six geometrically increasing concentrations. The exposures were conducted using a test volume of $5 \mathrm{~L}$ in static 9.5-L (2.5-gal) aquaria. Three replicates of each concentration were tested, each containing 10 organisms. Water quality parameters were monitored at the same frequency and maintained within the same limits as the 28-day test, except that there were no flow rates. The M. nasuta reference toxicant test was conducted with treatments of $0,0.25,0.50,0.75,1.0,1.5$ and $2.5 \mathrm{mg} / \mathrm{L} \mathrm{Cu}$; the $N$. virens test was conducted with treatments of $0,0.05,0.075,0.15$, $0.20,0.25$, and $0.30 \mathrm{mg} / \mathrm{L} \mathrm{Cu}$.

\subsection{Data Analysis and Interpretation Procedures}

Statistical analyses were conducted to determine the magnitude and significance of toxicity and bioaccumulation in test treatments relative to the reference treatment. Each statistical test was based on a completely random design that allowed unbiased comparison between treatments.

\subsubsection{Randomization}

All water-column and-benthic toxicity tests were designed as completely randomi tests. Organisms were randomly: allocated to treatments;-and treatments were randomly positioned on water tables. To determine randomization, a-random-number table was generated for each test using the discrete random-number generator in Microsoft Excel spreadsheet software.

\subsubsection{Statistical Analysis of Benthic Toxicity Tests}

Benthic toxicity of all sediment treatments was compared to a single reference treatment using Dunnett's test (Dunnett 1964). The arcsine square root of the proportion of organisms surviving the test was used to stabilize the within-class variances. As recommended by the Green Book an experiment-wise error $\alpha=0.05$ was used. Acute toxicity for the amphipod test indicates that the test treatment was statistically significant relative to the reference treatment and had a greater than $20 \%$ difference in survival from the reference treatment. Acute toxicity for the mysid test indicates that the test treatment was statistically significant relative to the reference treatment and had a greater than $10 \%$ difference in survival from the reference treatment. 


\subsubsection{Statistical Analysis of Water-Column Tests}

Two statistical analyses are presented in the Green Book for the interpretation of SPP (water-column) tests. The first is a one-sided $t$-test between survival in control test replicates and survival in the 100\% SPP test replicates. A significant difference indicates acute toxicity in the $100 \%$ SPP treatment. This analyses was performed only when survival in the $100 \%$ SPP is less than the control ( $0 \%$ SPP) survival, and when control survival is $>90 \%$ for nonlarval tests and $>70 \%$ for larval tests. Prior to conducting the t-test, angular transformation (arcsine of the square root) of the proportion surviving in test replicates was performed to reduce possible heterogeneity of variance between mean survival of test organisms in the control and in the $100 \%$ SPP. The second analysis required by the Green Book is estimation of the medium lethal concentration $\left(\mathrm{LC}_{50}\right)$ or median effective concentration $\left(\mathrm{EC}_{50}\right)$. The $\mathrm{LC}_{50}$ or $E \mathrm{C}_{50}$ values for these tests were estimated using the trimmed Spearman-Karber method (Finney 1971) and are expressed in percentage of SPP. The Spearman-Karber estimator is appropriate only if there was increasing mortality (or effect) with increasing concentration, and if $\geq 50 \%$ mortality (or effect) was observed in at least one test concentration when normalized to control survival. If $50 \%$ mortality (or effect) did not occur in the $100 \%$ SPP concentrations for any treatments, then $\mathrm{LC}_{50}$ or $\mathrm{EC}_{50}$ values were reported as $>100 \% \mathrm{SPP}$.

\subsubsection{Statistical Analysis of Bioaccumulation}

The results of the chemical analyses of test organism tissues exposed to the dredged sediment treatments was statistically compared with those tissues similarly exposed to the Mud Dump Reference Site treatment using Dunnett's test with an experiment-wise error of $\alpha=0.05$. The Dunnett's tests determined whether or not the concentrations of contaminants of concem in the organisms exposed to the dredged sediments statistically exceeded those of organisms exposed to the reference sediment

Statistical analyses were performed on the dry weight concentrations. When a compound (metals, pesticides, PCBs, and PAHs) was undetected (indicated by a " $Q$ " flag in the report tables and a " $U$ " flag in the appendix tables), one-half the detection limit of a compound was used in numerical calculations. If the compound was undetected in all five replicates of a test treatment, or if the mean concentration of a compound was greater in tissue samples from the reference treatment than in tissue samples from the test treatments, no further analysis was necessary. If a compound was undetected in all five replicates of the reference treatment, a one-sided, onesample t-test $(\alpha=0.05)$ was used to determine if the tissue concentrations from organisms exposed to dredged sediment treatments were statistically greater than the mean detection limit for that compound from the reference tissue. Results of background and control tissues were not statistically compared with the reference. 
Magnification factors were calculated for each compound as the dry weight ratio of the mean tissue concentration from organisms exposed to dredged sediment treatments to the mean tissue concentration from organisms exposed to the Mud Dump Reference Site sediment. Whole detection limits were used for non-detects in this calculation.

\subsection{Quality Assurance/Quality Control Procedures}

The quality assurance/quality control (QAVC) procedures for the Red Hook/Bay Ridge project were consistent with the Regional Guidance Manual and the Green Book, and were documented in the Work/Quality Assurance Project Plan, Evaluation of Dredged Material Proposed for Ocean Disposal from Federal Projects in New York (Parts 4,5, and 6), prepared by the MSL and submitted to the USACE-NYD for this program. This document describes all QAVQC procedures that were followed for sample collection, sample tracking and storage, and physical/chemical analyses. A member of Pacific Northwest National Laboratory's quality engineering staff was present throughout all phases of this program to observe procedures, review and audit data, and ensure that accepted protocols were followed. Data accumulation notebooks were assigned to each portion of these studies and served as records of day-to-day project activities. 


\subsection{Results}

This section presents results of sample collection and processing, and physical and chemical analyses conducted on sediment collected from the Red Hook/Bay Ridge dredging area.

\subsection{Sample Collection and Processing}

Sediment core samples were collected from the Red Hook/Bay Ridge project areas on March 21 through March 30, 1995 (Figure 1.1). Table 3.1 lists each sampling station within the Red Hook/Bay Ridge project areas, sampling coordinates, collection date, length of core required for testing (including $2 \mathrm{ft}$ of overdepth), and length of core actually collected. Twenty-four core samples were collected aboard the Hayward. Eighteen of the Bay Ridge core samples were collected to the project depth of $-40 \mathrm{ft} \mathrm{MLW}$.plus $2 \mathrm{ft}$ of-overdepth;-three core-samples were short of project depth by $0.2 \mathrm{ft}$ to $0.4 \mathrm{ft}$. Project depth was not reached at those stations because the vibratory core sampler met the point of resistance prior to reaching it:- It was decided by the NYD-project manager that the shorter cores would be used in the chemical-and toxicological evaluations. Two of the six Red Hook core samples were collected to the project depth of $-40 \mathrm{ft}^{--}$ plus-2 $\mathrm{ft}$-of overdepth. The other Red Hook core samples were from 0:35 $\mathrm{ft}$ to-7:8: $\mathrm{ft}$ short of reaching project depth.

Upon delivery of the sediment core samples to the MSL on April,-1994, samples were . . prepared for the physical and chemical analyses according to the procedures described in Section 2. Individual sediment core samples were analyzed for grain size; moisture content, and TOC. One.composite sample representing the Red Hook project area (RH GOMP) and two composite sediment composites representing Reaches $A$ and $B$ of the Red Hook/Bay Ridge project area (COMP BR-A and COMP BR-B) were analyzed for bulk density, specific gravity, metals, chlorinated pesticides, PCBs, PAHs, and 1,4-dichlorobenzene. The Red Hook composite contained stations $\mathrm{RH}-1$ through $\mathrm{RH}-6$. Reach $A$ consisted of stations $B R-A-1$ through $B R-A-12$. Reach $B$ consisted of stations BR-B-13 through BR-B-18.

\subsection{Physical and Chemical Analyses}

\subsubsection{Sediment Core Sample Description}

Table 3.2 lists physical characteristics of each sediment core sample that was examined. Red Hook/Bay Ridge sediment samples were generally black or gray-black, silty-clayey material. 
TABLE 3.1. Summary of Sediment Sample Data for Red Hook/Bay Ridge Project Areas

\begin{tabular}{|c|c|c|c|c|}
\hline & Collection & Station Coord & Length & Core Length \\
\hline ation & Date & Longitude & Required (ft) & Collected (ft) \\
\hline
\end{tabular}

Red Hook

$\begin{array}{lrllrrr}\text { RH-1 } & 3 / 21 / 95 & 40^{\circ} 39.95^{\prime} & 74^{\circ} 01.37^{\prime} & 11.9 & 12.0 & 30.1 \\ \text { RH-2 } & 3 / 21 / 95 & 40^{\circ} 39.98^{\prime} & 74^{\circ} 01.33^{\prime} & 7.5 & 7.8 & 34.5 \\ \text { RH-3(a) } & 3 / 21 / 95 & 40^{\circ} 40.07^{\prime} & 74^{\circ} 01.37^{\prime} & 5.1 & 4.8 & 36.9 \\ \text { RH-4 } & 3 / 21 / 95 & 40^{\circ} 40.25^{\prime} & 74^{\circ} 01.15^{\prime} & 9.4 & 7.2 & 32.6 \\ \text { RH-5 } & 3 / 21 / 95 & 40^{\circ} 40.57^{\prime} & 74^{\circ} 01.22^{\prime} & 10.7 & 2.9 & 31.3 \\ \text { RH-6 } & 3 / 23 / 95 & 40^{\circ} 40.70^{\prime} & 74^{\circ} 01.23^{\prime} & 5.9 & 4.0 & 36.1\end{array}$

Bay Ridge Reach A

$\begin{array}{lrlrrrr}\text { BR-A-1 } & 3 / 22 / 95 & 40^{\circ} 39.23^{\prime} & 74^{\circ} 01.88^{\prime} & 4.2 & 4.7 & 37.8 \\ \text { BR-A-2 } & 3 / 22 / 95 & 40^{\circ} 39.32^{\prime} & 74^{\circ} 01.73^{\prime} & 3.5 & 4.0 & 38.5 \\ \text { BR-A-3 } & 3 / 22 / 95 & 40^{\circ} 39.40^{\prime} & 74^{\circ} 01.62^{\prime} & 4.3 & 5.0 & 37.7 \\ \text { BR-A-4 } & 3 / 22 / 95 & 40^{\circ} 39.45^{\prime} & 74^{\circ} 01.53^{\prime} & 4.6 & 5.2 & 37.4 \\ \text { BR-A-5 } & 3 / 22 / 95 & 40^{\circ} 39.53^{\prime} & 74^{\circ} 01.62^{\prime} & 11.9 & 13.0 & 30.1 \\ \text { BR-A-6 } & 3 / 22 / 96 & 40^{\circ} 39.57^{\prime} & 74^{\circ} 01.52^{\prime} & 7.9 & 8.8 & 34.1 \\ \text { BR-A-7 } & 3 / 23 / 95 & 40^{\circ} 39.10^{\prime} & 74^{\circ} 01.62^{\prime} & 11.4 & 5.13 .0 & 30.6 \\ \text { BR-A-8(a) } & 3 / 22 / 95 & 40^{\circ} 39.53^{\prime} & 74^{\circ} 01.40^{\prime} & 3.0 & 3.0 & 39.0 \\ \text { BR-A-9 } & 3 / 22 / 95 & 40^{\circ} 39.53^{\prime} & 74^{\circ} 01.30^{\prime} & 3.9 & 4.0 & 38.1 \\ \text { BR-A-10 } & 3 / 22 / 95 & 40^{\circ} 39.62^{\prime} & 74^{\circ} 01.32^{\prime} & 5.4 & 5.0 & 36.6 \\ \text { BR-A-11 } & 3 / 22 / 95 & 40^{\circ} 39.72^{\prime} & 74^{\circ} 01.38^{\prime} & 4.0 & 5.0 & 38.0 \\ \text { BR-A-12 } & 3 / 21 / 95 & 40^{\circ} 39.77^{\prime} & 74^{\circ} 01.27^{\prime} & 2.9 & 3.0 & 39.1\end{array}$

Bay Ridge Reach B

$\begin{array}{lrllrrr}\text { BR-B-13 } & 3 / 23 / 95 & 40^{\circ} 38.23^{\prime} & 7^{\prime} 02.44^{\prime} & 7.2 & 7.3 & 34.8 \\ \text { BR-B-14 } & 3 / 23 / 95 & 40^{\circ} 38.58^{\prime} & 74^{\circ} 02.17^{\prime} & 8.3 & 8.6 & 33.7 \\ \text { BR-B-15(a) } & 3 / 23 / 95 & 40^{\circ} 38.67^{\prime} & 74^{\circ} 02.03^{\prime} & 6.2 & 6.0 & 35.8 \\ \text { BR-B-16 } & 3 / 23 / 95 & 40^{\circ} 39.02^{\prime} & 74^{\circ} 01.72^{\prime} & 5.5 & 6.0 & 36.5 \\ \text { BR-B-17 } & 3 / 23 / 95 & 40^{\circ} 39.08^{\prime} & 74^{\circ} 01.62^{\prime} & 11.9 & 12.5 & 30.1 \\ \text { BR-B-18 } & 3 / 22 / 95 & 40^{\circ} 39.32^{\prime} & 7^{\circ} 01.38^{\prime} & 7.0 & 6.8 & 35.0\end{array}$

Grab Samples

$\begin{array}{lllllll}\text { MDRS(b) } & 3 / 28 / 95 & 40^{\circ} 20.20^{\prime} & 74^{\circ} 52.18^{\prime} & -- \text { (c) } & - & 67-68\end{array}$

(a) Site water sample collected at this station.

(b) MDRS Mud Dump Reference Site.

(c) - Not applicable. 


\section{TABLE 3.2. Red Hook/Bay Ridge Sediment Core Descriptions}



(a) Project depth plus $2 \mathrm{ft}$ overdepth. 


\subsubsection{Grain Size, Total Organic Carbon, Percentage of Moisture, Bulk Density, and Specific Gravity}

Table 3.3 shows the results of the analysis of individual Red Hook/Bay Ridge core samples for grain size, TOC, and percentage of moisture. Table 3.4 shows the results of the bulk density and specific gravity analysis of each composite. A quality control summary and quality control data for grain size and TOC measurements are provided in Appendix A.

The physical characteristics of Red Hook/Bay Ridge sediments were variable; eight stations were predominantly sand and gravel (RH-2, $\mathrm{RH}-3, \mathrm{RH}-4, \mathrm{RH}-5, \mathrm{RH}-6, \mathrm{BR}-\mathrm{B}-15$, BR-B$16, \mathrm{BR}-\mathrm{B}-17)$, whereas the remaining 16 test sediments and the three control sediment were predominantly silt and clay. Percentages of gravel ranged from $0 \%$ to $36 \%$; sand ranged from $10 \%$ to $84 \%$; silt ranged from $5 \%$ to $52 \%$; and clay ranged from $2 \%$ to $49 \%$. Each sediment sample (station) was represented by at least three grain-size fractions. The Mud Dump Reference Site sediment was composed of $96 \%$ sand.

The TOC values for.the individual test-stations ranged from $0: 28 \%$ to $3.59 \%$ with 17 of the 24 test stations with TOC values above $2.0 \%$ : The Múd Dump Reference site had a TOC concentration of $0.02 \%$. The percentage of moisture of the 24 individual stations ranged from $16 \%$ to $63 \%$. The Mud Dump-Reference Site sediment-had a:percentage of moisture of $13 \%$.

Bulk density. and specific gravity were also measured on the Red Hook/Bay Ridge composites and the Mud Dump Reference Site. The results are-shown in=Fable 3.4. Bulk density values (dry weight) ranged from $35 \mathrm{lb} / \mathrm{cu} \mathrm{ft}$ to $96 \mathrm{lb} / \mathrm{cu} \mathrm{ft}$. The:specific-gravity values ranged from 2.63 to 2.68 .

\subsubsection{Metals}

Table 3.5 shows the results of the metals analysis for the three test sediment composites (RH COMP, BR-A COMP, and BR-B COMP). A quality control sample summary and quality control data associated with the metals analysis are provided in Appendix $A$.

Concentrations of all nine metals analyzed for this project were detected in the Red Hook/Bay Ridge sediment composites. The sediment from BR-A COMP had the highest levels of six of the nine metals analyzed when compared with the other composites. Levels of metals between RH-COMP and BR-B COMP were similar.

\subsubsection{Chlorinated Pesticides}

Table 3.6 shows the results of the analysis of Red Hook/Bay Ridge composites for chlorinated pesticides. A quality control summary and associated quality control data are provided in Appendix A. 
IABLE 3.3. Results of Analysis of Red Hook/Bay Ridge Sediment Samples for Grain Size, Total Organic Carbon, and Percentage of Moisture

Total Percent (dny weight)

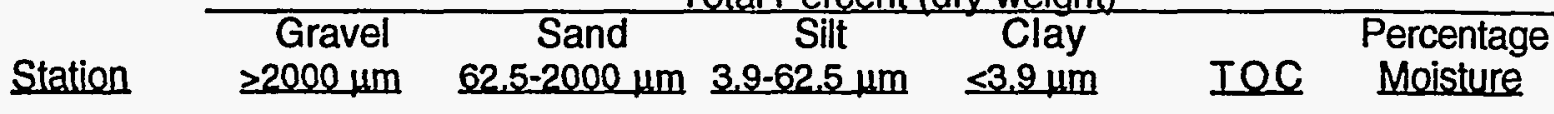

Bed Hook

$\begin{array}{lrrrrll}\mathrm{RH}-1 & 2 & 29 & 35 & 34 & 3.59 & 51 \\ \mathrm{RH}-2 & 7 & 63 & 16 & 14 & 1.56(\mathrm{a}) & 37 \\ \mathrm{RH}-3 & 7 & 54 & 22 & 17 & 1.93 & 41 \\ \mathrm{RH}-4 & 6 & 67 & 15 & 12 & 0.74 & 34 \\ \mathrm{RH}-5 & 36 & 47 & 10 & 7 & 2.99 & 23 \\ \mathrm{RH}-6 & 3 & 75 & 16 & 6 & 0.28 & 18\end{array}$

Bay Ridge Reach A

BR-A-1

BR-A-2

BR-A-3

$B R-A-4$

BR-A-5

BR-A-6

BR-A-7

BR-A-8

BR-A-9

BR-A-10

BR-A-11

BR-A-12

$\begin{array}{ll}0 & 21 \\ 1 & 24 \\ 2 & 18 \\ 0 & 16 \\ 0 & 15 \\ 0 & 10 \\ 0 & 10 \\ 0 & 18 \\ 0 & 16 \\ 0 & 11 \\ 1 & 13 \\ 2 & 19\end{array}$

43

43

45

52

43

41

44

47

47

44

36

2.70

2.66

2.80

2.82

3.19

3.02

3.17

2.80

2.77

2.95

3.02

2.82

58

57

59

58

61

58

59

63

42

57

60

62

Bay Ridge Reach B

BR-B-13

BR-B-14

BR-B-15

BR-B-16

BR-B-17

BR-B-18

$\begin{array}{ll}0 & 29 \\ 0 & 29 \\ 1 & 69 \\ 5 & 55 \\ 9 & 84 \\ 0(a) & 27(a)\end{array}$

43

40

17

22

$42(a)$

32

59

MDRS(b)

Sequim Bay Control

Nereis Control

$3 \quad 96$

Ampelisca Control

96
21
13
11

0
52
60
67

28
31
13
18
2
$31(a)$

3.56

3.39

48

0.66

1.02

0.36
2.90

51

33

43

16

51 (a)

(a) Mean of replicates.

(b) MDRS Mud Dump Reference Site.

$0.02 \quad 13$

$\begin{array}{rlr}1 & 0.02 & 13 \\ 27 & 2.00 & 75 \\ 27 & 2.11 & 54 \\ 22 & 2.95 \text { (a) } & 69\end{array}$


TABLE 3.4. Results of Analysis of Red Hook/Bay Ridge Sediment Composites for Bulk Density and Specific Gravity

Sediment Treatment

RH COMP

BR-A COMP

BR-B COMP

MDRS(a)

\begin{tabular}{lc}
\multicolumn{2}{c}{ Bulk Density } \\
$\begin{array}{l}\text { Wet } \\
\text { lbs/ff3 }\end{array}$ & Dry \\
lbs/ft3
\end{tabular}

104

85

106

110
64

35

69

96
Specific

Gravity

2.68

2.63

2.66

2.68

(a) MDRS Mud Dump Reference Site.

TABLE 3.5. Results of Analysis of Red Hook/Bay Ridge Sediment Composites for Metals

Sediment

Treatment

\begin{tabular}{lllll}
\multicolumn{8}{c}{ Concentrations in $\mathrm{mg} / \mathrm{kg}$ dry weight } \\
$\mathrm{Ag} \quad \underline{\mathrm{As}} \quad \underline{\mathrm{Cd}} \underline{\mathrm{Cr}} \underline{\mathrm{Bg}} \underline{\mathrm{Zn}}$
\end{tabular}

RH COMP(a)

$3.47 \quad 14.9 \quad 1.64$

$64.8 \quad 82.4$

1.87

$43.8 \quad 178$

132

BR-A COMP

$\begin{array}{lll}7.06 & 12.0 & 2.43\end{array}$

$\begin{array}{lll}4.32 & 10.3 & 2.02\end{array}$

$110 \quad 122$

$78.2 \quad 89.2$

1.95

$31.5 \quad 172$

177

BR-B COMP

(a) Mean of replicates. 
TABLE 3.6. Results of Analysis of Red Hook/Bay Ridge Sediment Composites for Pesticides and PCBs

Sediment

Treatment

$2,4^{\prime}-\mathrm{DDD}$

$2,4^{\prime}-\mathrm{DDE}$

2,4'-DDT

4,4'-DDD

$4,4^{\prime}-\mathrm{DDE}$

4,4'-DDT

Total DDTs(b)

Aldrin

$\alpha$-Chlordane

Dieldrin

Endosulfan I

Endosulfan II

Endosulfan Sulfate

Heptachlor

Heptachlor Epoxide

trans-Nonachlor

se-

PCB 8

PCB 18

PCB 28

PCB 44-

PCB 49

PCB 52

PCB 66

PCB 87

PCB 101

PCB 105

PCB 118

PCB 128

PCB 138

PCB 153

PCB 170

PCB 180

PCB 183

PCB 184

PCB 187

PCB 195

PCB 206

PCB 209

Total PCBs(d)

\begin{tabular}{c}
\hline RH COMP \\
\hline 4.34 \\
$0.69 \mathrm{U}(\mathrm{a})$ \\
$0.24 \mathrm{U}$ \\
12.9 \\
12.1 \\
8.55
\end{tabular}

38.4

5.81

3.45

1.79

4.75

$0.32 \mathrm{U}$

0.99

$0.07 \mathrm{U}$

$0.32 \mathrm{U}$

$0.24 U$

\subsection{5}

34.6

34.4

18.5

15.0

21.8

27.5

5.52

14.7

9.85

16.0

2.55

13.5

18.2

4.27

8.52

3.77

$0.07 \mathrm{U}$

8.11

$0.02 \mathrm{U}$

$0.03 \mathrm{U}$

1.14
Concentrations in $\mu \mathrm{g} / \mathrm{kg}$ dry weight BR-A COMP

7.30
$0.96 \mathrm{U}$
$0.34 \mathrm{U}$
21.5
27.4
13.8

70.7

10.6

5.56

5.38

$0.45 \mathrm{U}$

$0.45 \mathrm{U}$

0.44

$0.09 \mathrm{U}$

$0.44 \mathrm{U}$

2.98

15.7

$43.2 \mathrm{D}(\mathrm{c})$

71.0

27.6

25.6

33.1

50.2. D

7.39

26.3

16.3

36.1

5.64

29.7

34.8

9.85

19.3

6.63

$0.10 \mathrm{U}$

14.7

1.41

0.89

$0.03 \mathrm{U}$
12.3

$0.64 \mathrm{U}$

$0.22 \mathrm{U}$

48.5

42.3

19.9

123

6.86

4.66

2.66

$0.30 \mathrm{U}$

$0.30 \mathrm{U}$

0.70

$0.06 \mathrm{U}$

$0.29 \mathrm{U}$

$0.22 \mathrm{U}$

528

951
7.18

$51.4 \mathrm{D}$

$37.7 \mathrm{D}$

$-22.7 \ldots$

17.1.

33.6 -D

7.62

$23.0^{\circ}$

16.9

31.7

5.69

26.7

30.1

7.15

16.0

13.4

$0.07 \mathrm{U}$

12.4

1.56

1.14

1.84

(a) Undetected at or above given concentration.

(b) Sum of 2,4'-DDD, 2,'4-DDE, 2,4'-DDT, 4,4'-DDD, 4,4'-DDE, and 4,4'-DDT; one-half of the detection limit used in summation when analyte was undetected.

(c) D Determined from diluted sample (1:5).

(d) Total PCBs $=2.0(x)$, where $x$ is the sum of all PCB congeners detected; one-half of the detection limit used in summation when analyte was undetected. 
The dominant pesticides found in the three sediment composites were DDT family of compounds, followed by aldrin, $\alpha$-chlordane, and dieldrin. In general, BR-A COMP and BR-B COMP had higher concentrations of chlorinated pesticides than RH-COMP. Total sum of DDTs were $123 \mu \mathrm{g} / \mathrm{kg}$ for BR-B COMP, $70.7 \mu \mathrm{g} / \mathrm{kg}$ for BR-A COMP, and $38.4 \mu \mathrm{g} / \mathrm{kg}$ for RH COMP.

\subsubsection{PCBs}

Table 3.6 shows the results of the analysis of the Red Hook/Bay Ridge composites for PCBs. A quality control sample summary and associated quality control data are provided in Appendix A.

All of the $22 \mathrm{PCB}$ congeners analyzed for this project were detected in the three test sediment composites, except for four congeners (PCBs 184, 195, 206, and 209), which were undetected in one or more of the composites. Total PCB concentrations calculated were $951 \mu \mathrm{g} / \mathrm{kg}$ for BR-A COMP, $784 \mu \mathrm{g} / \mathrm{kg}$ for BR-B COMP, and $528 \mu \mathrm{g} / \mathrm{kg}$ for RH-COMP.

\subsubsection{PAHs and 1,4-Dichlorobenzene}

Table 3.7 shows the results of the analysis of-the.Red Hook/Bay Ridge sediments for PAHs and 1;4-dichlorobenzene. A quality control samplesummary and associated quality control data are provided in Appendix $A$.

All 16 PAHs analyzedffor this project were detected in the three test sediment composites. The distribution of PAHs in sediment:from:the:RH=COMP-showed that the low-molecular-weight PAH (LPAH) made up_approximately $43 \%$ of the totatPAH_concentration, whereas highmolecular-weight PAH (HPAH) made up 57\% of the total. -The:distribution of PAHs in BR-A COMP was $18 \%$ LPAHs and $82 \%$ HPAHs. The PAH distribution for BR-B COMP was $60 \%$ LPAHs and 40\% HPAHs. Sediments from both RH-COMP and BR-B COMP contained approximately three times morre total PAHs than sediments from BR-A COMP.

Concentrations of 1,4-dichlorobenzene in the three test sediment composites were $74.5 \mu \mathrm{g} / \mathrm{kg}, 145 \mu \mathrm{g} / \mathrm{kg}$ and $120 \mu \mathrm{g} / \mathrm{kg}$ for RH-COMP, BR-A COMP, and BR-B COMP respectively.

\subsection{Site Water and Elutriate Analyses}

Metals, chlorinated pesticides, and PCBs were analyzed in dredging site water collected from the Red Hook/Bay Ridge project areas, and in elutriate samples prepared with clean seawater (Sequim Bay) and the Red Hook/Bay Ridge test sediment composites. Mud Dump Site water and Sequim Bay control water were also analyzed. All water and elutriate samples were analyzed in triplicate. Mean results of the triplicate analyses are presented and discussed 
IABLE 3.7. Results of Analysis of Red Hook/Bay Ridge Sediment Composites for PAHs and 1,4-Dichlorobenzene

Sediment

Treatment

Naphthalene

Acenaphthylene

Acenaphthene

Fluorene

Phenanthrene

Anthracene

LPAHs

Fluoranthene

Pyrene

Benzo[a]anthracene

Chrysene

Benzo[b]fluoranthene

Benzo[k]fluoranthene

Benzo[a]pyrene

Indeno[123-cd]pyrene

Dibenzo[a,h]anthracene

$\therefore$ B... Benzo[g,h,i]perylene

HPAHS

Total PAHs.

\begin{tabular}{c}
\hline RH COM \\
\hline 3360 \\
416 \\
2530 \\
2020 \\
8470 \\
3400
\end{tabular}

20,200

4670

6420

3230

3680

2520

885

2720

1290

417

1340

27,200

47,400

74.5
Concentrations in $\mu \mathrm{a} / \mathrm{kg}$ dry weight BR-A COMP BR-B COMP

517
231
172
226
1060
656

11100

437

4370

2280

6330

2450

2,860

1970

2280

1370

1300

1700

579

1460

948

277

958

27,000

3110

4130

1920

1960

1810

651

1820

982

308

1000

12,800

17,700

15,700

44,700

.145

120

74.5

.145

120

in the following sections. Complete results of all site water and elutriate samples, as well as a quality control summary and associated quality control data, are provided in Appendix B.

\subsubsection{Metals}

Results of analysis of Sequim Bay control water, Mud Dump Site water, Red Hook/Bay Ridge Site waters, and Red Hook/Bay Ridge elutriates are shown in Table 3.8. Site water from Red Hook station RH-3, had the highest concentration of metals. The concentration of metals were similar for the two Bay Ridge stations, BR-A-6 and BR-B-15. All metals analyzed except for $\mathrm{Cd}$ and $\mathrm{Zn}$ were at least three times higher in Red Hook/Bay Ridge Site waters than in Mud Dump Site water or the Sequim Bay Site water.

Concentrations of $\mathrm{Ag}, \mathrm{Cd}$, and Ni were similar between the Sequim Bay control water and Mud Dump Site water, whereas concentrations of $\mathrm{Cu}, \mathrm{Hg}, \mathrm{Pb}$, and $\mathrm{Zn}$ were at least one and a half times higher in the Mud Dump Site water than in the control water. In particular, $\mathrm{Hg}$ and $\mathrm{Pb}$ were about an order of magnitude higher in the Mud Dump Site water than in the control water. 
TABLE 3.8. Results of Analysis of Red Hook/Bay Ridge Site Water and Elutriates for Metals

Sediment

Treatment

$\mathrm{Ag} \quad \mathrm{Gd} \quad \mathrm{Gr} \quad$ Concentrations in $\mu \mathrm{g} / \mathrm{L}$ (a)

$\underline{\mathrm{Cu}} \underline{\mathrm{Hg}} \underline{\mathrm{Ni}} \underline{\mathrm{Pb}} \underline{\mathrm{Zn}}$

Site Water

$\mathrm{RH}-3$

BR-A-6

BR-B-15

0.116

0.081

0.073

0.070

1.83

1.14

3.59

2.79

0.0208

0.0105

1.35

0.0091

1.33

1.83

1.11

25.7

0.081

$0.072 \quad 1.22$

2.90

1.21

1.06

12.1

Mud Dump

Site Water

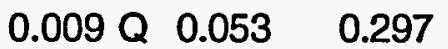

0.963

0.0013

0.409

0.231

25.4

Sequim Bay

Control Water

$\begin{array}{lll}0.009 \text { Q } & 0.067 & 0.430\end{array}$

0.576

0.0002

0.466

0.014

16.0

Elutriate

RH COMP BR-A COMP

0.025

0.044

0.211

0.015

0.853

0.022

1.69

0.904

1.81

0.963

$0.0174,1.90$

$0.0107,1.44$

0.824

$0.0233 ;: 0.900$

0.245

2.35

1.26

0.534 .

2.25

3.10

(a) Value shown is the mean of triplicate analyses; one-half the detection limit used when analyte was undetected.

(b) Q Undetected at or above twice the given concentration.

$\because \quad$ Elutriate metal concentrations. were similar between Red Hookand.Bay Ridge samples for $\mathrm{Ag}, \mathrm{Cu}$, and $\mathrm{Zn}$. For the remaining metals, the difference among.Red Hook and Bay Ridge elutriate preparations ranged from 1.3 to 10 times-between-the.lowest.and highest-concentration. of each analyte, The elutriates prepared from the sediment composites:and site water hadtlowe metals concentrations than the original site water in all but 6 of the 24 possible comparisons.

\subsubsection{Chlorinated Pesticides and PCBs}

Results of analysis of Bay Ridge Reach A and Reach B site. waters, Red Hook site water and the Mud Dump Site water are shown in Table 3.9. The results of the elutriate analysis on sediments from these same reaches are shown in Table 3.10. With few exceptions, pesticides and PCB congeners were not detected in the site water samples.

Elutriate samples generally had higher pesticide concentrations than the site water samples. Pesticides were highest in elutriate preparations from BR-B COMP, followed by RH COMP and then BR-A COMP. The DDT family of compounds was found at the highest concentrations in the elutriate samples, followed by aldrin and dieldrin.

Nineteen PCBs were detected in the elutriates from the three test sediment composites. The PCB concentrations were much higher in the elutriate preparation from BR-B COMP than in either the RH or BR-A COMP elutriates. Total PCBs were $553 \mathrm{ng} / \mathrm{L}$ for BR-B COMP, $60.9 \mathrm{ng} / \mathrm{L}$ for RH COMP, and $22.9 \mathrm{ng} / \mathrm{L}$ for BR-A COMP. 
TABLE 3.9. Results of Analysis of Red Hook/Bay Ridge Site Water for Pesticides and PCBs

Sediment

Treatment

$2,4^{\prime}-\mathrm{DDD}$

2,4'-DDE

2,4'-DDT

4,4'-DDD

4,4'-DDE

4,4'-DDT

Total DDT(c)

Aldrin

$\alpha$-Chlordane

Dieldrin

Endosulfan I

Endosulfan II

Endosulfan Sulfate

Heptachlor

Heptachlor Epoxide

trans-Nonachlor

PCB 8

PCB 18

PCB 28

PCB 44

PCB 49

PCB 52

PCB 66

PCB 87

PCB 101

PCB 105

PCB 118

PCB 128

PCB 138

PCB 153

PCB 170

PCB 180

PCB 183

PCB 184

PCB 187

PCB 195

РCB 206

PCB 209

Total PCBs(d)
Concentrations in ng/L(a)

\begin{tabular}{ll}
\hline $\mathrm{RH}-3$ & \multicolumn{1}{c}{ BR-A-6 } \\
$0.47 \mathrm{Q}(\mathrm{b})$ & $0.47 \mathrm{Q}$ \\
$0.12 \mathrm{Q}$ & $0.12 \mathrm{Q}$ \\
0.88 & $0.22 \mathrm{Q}$ \\
$0.23 \mathrm{Q}$ & $0.23 \mathrm{Q}$ \\
4.37 & $0.14 \mathrm{Q}$ \\
$0.20 \mathrm{Q}$ & $0.20 \mathrm{Q}$
\end{tabular}

1.38

1.00

$0.42 \mathrm{Q}$

$0.06 \mathrm{Q}$

$0.23 \mathrm{Q}$

$0.23 \mathrm{Q}$

$0.23 \mathrm{Q}$

$0.24 \mathrm{Q}$

$0.06 \mathrm{Q}$

$0.06 \mathrm{Q}$

$0.56 \mathrm{Q}$

$0.50 \mathrm{Q}$

$0.53 \mathrm{Q}$

$0.36 \mathrm{Q}$

$0.16 \mathrm{Q}$

0.45

$0.18 \mathrm{O}$

$0.19 \mathrm{O}$

$0.18 \mathrm{Q}$

$0.24 \mathrm{Q}$

$0.15 \mathrm{Q}$

$0.24 \mathrm{Q}$

$0.12 \mathrm{Q}$

$0.17 \mathrm{Q}$

$0.20 \mathrm{Q}$

$0.10 \mathrm{Q}$

$0.14 \mathrm{Q}$

$0.27 \mathrm{Q}$

$0.27 \mathrm{Q}$

$0.20 \mathrm{Q}$

$0.14 \mathrm{Q}$

$0.20 \mathrm{Q}$

$0.14 \mathrm{Q}$

10.3

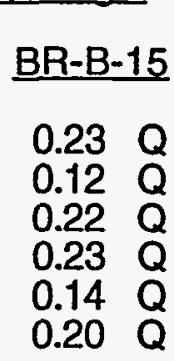

1.14

$0.20 \mathrm{Q}$

$0.42 \mathrm{Q}$

$0.06 \mathrm{Q}$

$0.23 \mathrm{Q}$

$0.23 \mathrm{Q}$

$0.23 \mathrm{Q}$

$0.24 \mathrm{Q}$

$\begin{array}{ll}0.06 & Q \\ 0.56 & Q\end{array}$

$0.50 \mathrm{Q}$

$0.53 Q$

$0.36^{\circ} \mathrm{Q}$

$0.16 \mathrm{Q}$

$0.27 \mathrm{Q}$

$0.18 \mathrm{Q}$

$0.19 \mathrm{Q}$

$0.18 \mathrm{Q}$

$0.24 \mathrm{Q}$

$0.15 Q$

$0.24 \mathrm{Q}$

$0.17 \mathrm{Q}$

0.20

$0.10 \mathrm{Q}$

$0.14 \mathrm{Q}$

0.27

$0.27 \mathrm{Q}$

$0.20 \mathrm{Q}$

$0.14 \mathrm{Q}$

0.20

$0.14 Q$

9.90
Mud Dump

Site Water

$0.47 \mathrm{Q}$

$0.12 \mathrm{Q}$

$0.22 \mathrm{Q}$

$0.23 \mathrm{Q}$

$0.14 \mathrm{Q}$

$0.20 \mathrm{Q}$

1.38

$0.20 \mathrm{Q}$

$0.42 \mathrm{Q}$

$0.06 \mathrm{Q}$

$0.23 \mathrm{Q}$

$0.23 \mathrm{Q}$

$0.23 \mathrm{Q}$

$0.24 \mathrm{Q}$

$0.06 \mathrm{Q}$

$0.56 \mathrm{Q}$

$0: 50 \mathrm{Q}$

$0.53 \mathrm{Q}$

$0.36 \mathrm{Q}$

$0.16 \mathrm{Q}$

$0.27 \mathrm{Q}$

$0: 18 Q$

$0.19 \mathrm{Q}$

$0.18 \mathrm{Q}$

$0.24 \mathrm{Q}$

$0.15 \mathrm{Q}$

$0.24 \mathrm{Q}$

$0.12 \mathrm{Q}$

$0.17 \mathrm{Q}$

$0.20 \mathrm{Q}$

$0.10 \mathrm{Q}$

$0.14 \mathrm{Q}$

$0.27 \mathrm{Q}$

$0.27 \mathrm{Q}$

$0.20 \mathrm{Q}$

$0.14 \mathrm{Q}$

$0.20 \mathrm{Q}$

$0.14 Q$

9.90

(a) Value shown is the mean of triplicate analyses; one-half the detection limit used when analyte was undetected.

(b) $Q$ Undetected at or above twice the given concentration.

(c) Sum of 2,4'-DDD, 2,4'-DDE, 2,4'-DDT, 4,4'-DDD, 4,4'-DDE, and 4,4'-DDT; one-half of the detection limit used in summation when analyte was undetected.

(d) Total $P C B=2.0(x)$, where $x=$ sum of all $P C B$ congeners; one-half of the detection limit used in summation when analyte was undetected. 
TABLE 3.10. Results of Analysis of Red Hook/Bay Ridge Elutriate Preparations for Pesticides and PCBs

Sediment

Treatment

\begin{tabular}{cl}
\hline RH COMP \\
0.48 & $Q^{(b)}$ \\
0.12 & $Q$ \\
0.22 & $Q$ \\
0.23 & $Q$ \\
7.33 & \\
7.96 &
\end{tabular}

Concentrations in ng/L(a)

2,4'-DDD

2,4'-DDE

2,4'-DDT

4,4'-DDD

4,4'-DDE

4,4'-DDT

16.3

BR-A COMP

BR-B COMP

Total DDT(c)

$\begin{array}{ll}0.47 & Q \\ 0.12 & Q \\ 0.22 & Q \\ 0.23 & Q \\ 6.82 & \\ 7.98 & \end{array}$

6.67

$0.12 \mathrm{Q}$

$0.22 \mathrm{Q}$

13.6

29.4

15.6

Aldrin
$\alpha$-Chlordane
Dieldrin
Endosulfan I
Endosulfan II
Endosulfan Sulfate
Heptachlor
Heptachlor Epoxide
trans-Nonachlor



65.6

PCB 8

PCB 18

PCB 28

PCB 44

PCB 49

PCB 52

PCB 66

PCB 87

PCB 101

PCB 105

PCB 118

PCB 128

PCB 138

PCB 153

PCB 170

PCB 180

PCB 183

PCB 184

PCB 187

PCB 195

PCB 206

PCB 209

Total PCBs(d)

60.9

15.8

8.00

$0.42 \mathrm{Q}$

6.58

$0.23 \mathrm{Q}$

0.53

$0.23 \mathrm{Q}$

$0.24 \mathrm{Q}$

$0.06 \mathrm{Q}$

$0.56 \mathrm{Q}$

(a) Value shown is the mean of triplicate analyses; one-half the detection limit used when analyte was undetected.

(b) $\mathrm{Q}$ Undetected at or above twice the given concentration.

(c) Sum of 2,4'-DDD, 2,4'-DDE, 2,4'-DDT', 4,4'-DDD, 4,4'-DDE, and 4,4'-DDT; one-half of the detection limit used in summation when analyte was undetected.

(d) Total $P C B=2.0(x)$, where $x=$ sum of all $P C B$ congeners; one-half of the detection limit used in summation when analyte was undetected. 


\subsection{Benthic Toxicity and Water-Column Testing}

Both benthic and water-column tests were performed on the Red Hook/Bay Ridge sediment composites. Benthic acute toxicity tests were performed with the infaunal amphipod A. abdita and the mysid M. bahia. Suspended-particulate-phase tests were conducted with the silverside M. beryllina, the mysid M. bahia, and larvae of the bivalve M. galloprovincialis. Complete test results, water quality measurements, and the results of the reference-toxicant tests are presented in Appendix $C$ for water-column tests, and Appendix $D$ for benthic test results. Throughout this section the term "acutely toxic" is used to express statistically significant differences and at least 10\% (mysid) or 20\% (amphipod) decreases in survival from the reference sediment. Tests for statistical significance between test treatments and reference treatments were performed following methods outlined in Section 2.6.

\subsubsection{Ampelisca abdita Benthic Acute Toxicity Test}

Results of the benthic acute toxicity test with $A$. abdita are summarized in Table 3.11.

- Complete test results and water quality data-are presented in Appendix:C, Tables C.1 through . the test sediment composites RH COMP, BR-A COMP, and BR=B=COMP.were $65 \%$, $91 \%$; - and $35 \%$. Sediments from BR-B COMP and RH COMP were-acutêly.toxic comparedwith

$\therefore$ sediments from the Mud Dump Reference Site (94\%.survival).

Water quality parameters were within acceptable ranges throughout the test; except for. minor deviations in $\mathrm{pH}$ measurements (see Table C.2). The Cd-reference-toxicant test produced an LC50 of $0.55 \mathrm{mg} / \mathrm{L} \mathrm{Cd}$, which is within the control range established by other scientists and at

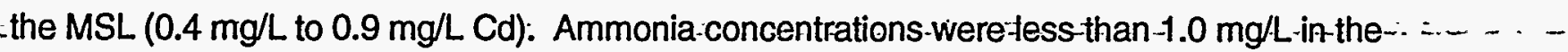
overlying water and less than $8.2 \mathrm{mg} / \mathrm{L}$ in the pore water of the Red Hook and Bay Ridge composites.

\subsubsection{Mysidopsis bahia Benthic Acute Toxicity Test}

Results of the benthic acute toxicity test with M. bahia are summarized in Table 3.11. Complete results and water quality data are presented in Appendix C, Tables C.5 through C.8. Survival in the Sequim Bay control sediment was $97 \%$, validating this test. Survival in the three test sediment composites, RH COMP, BR-A COMP, and BR-B COMP were $77 \%, 76 \%$, and $74 \%$. All three composites were acutely toxic to $M$. bahia when compared with the survival of M. bahia in the sediment from the Mud Dump Reference Site (95\% survival).

All water quality parameters were within acceptable ranges throughout the test except for $\mathrm{pH}$ values for BR-A COMP and the Sequim Bay control which were slightly above the acceptable range throughout testing. The $\mathrm{Cu}$ reference toxicant test produced an $\mathrm{LC}_{50}$ of 
TABLE 3.11. Summary of Benthic Tests Performed with Red Hook/Bay Ridge Sediment Composites

\begin{tabular}{|c|c|c|c|}
\hline Sediment Treatment & $\begin{array}{l}\text { Mean \% } \\
\text { Survival }\end{array}$ & $\begin{array}{l}\text { Statistically } \\
\text { Significant }\end{array}$ & $\begin{array}{l}\geq 10 \% \mathrm{My} \\
\text { Differencs }\end{array}$ \\
\hline $\begin{array}{l}\text { A. abdita } \\
\text { RH COMP } \\
\text { BR-A COMP } \\
\text { BR-B COMP } \\
\text { MDRS }\end{array}$ & $\begin{array}{l}65 \\
91 \\
35 \\
94\end{array}$ & $\begin{array}{l}\text { Yes } \\
\text { No } \\
\text { Yes } \\
\text { NA }\end{array}$ & $\begin{array}{l}\text { Yes } \\
\text { No } \\
\text { Yes } \\
\text { NA }\end{array}$ \\
\hline $\begin{array}{l}\text { M. bahia } \\
\text { RH COMP } \\
\text { BR-A COMP } \\
\text { BR-B COMP } \\
\text { MDRS }\end{array}$ & $\begin{array}{l}77 \\
76 \\
74 \\
95\end{array}$ & $\begin{array}{l}\text { Yes } \\
\text { Yes } \\
\text { Yes } \\
\text { NA }\end{array}$ & $\begin{array}{l}\text { Yes } \\
\text { Yes } \\
\text { Yes } \\
\text { NA }\end{array}$ \\
\hline
\end{tabular}

$225 \mu \mathrm{g} / \mathrm{L} \mathrm{Cu}$, which is within the control range established at the MSL (154 $\mu \mathrm{g} / \mathrm{L}$ to $303 \mu \mathrm{g} / \mathrm{L} \mathrm{Cu}$ ). Overlying-water ammonia concentrations were less than $1.0 \mathrm{mg} / \mathrm{L}$ at test initiation.

\subsubsection{Menidia beryllina Water-Column: Toxicity= Test}

Results of the M:-beryllina-water-column toxicity test-are-summarized in Table 3.12. Complete test results, as well as water quality data; are:presented:in:Appendix D, Tables D.1 through D.4. The control-filtered Sequim Bay:seawater-from-the-coneurrent reference-toxicant test using the same population of $M$. beryllina) survival was $90 \%$; validating the SPP results associated with all three composites. The survival of the $0 \%$ SPP (Mud Dump site water) from RH COMP, BR-A COMP, and BR-B COMP were $94 \%, 82 \%$, and $88 \%$ respectively. The $0 \%$ SPP were significantly different from the $100 \%$ SPPpreparations forall thiree composites. Survival in the $100 \%$ SPP preparations was $6 \%$ for RH COMP., and $0 \%$ for both BR-A and BRB COMPs. The calculated $L C_{50}$ for RH-COMP, BR-A COMP and BR-B COMP were $60 \%$, $30 \%$, and $19 \%$ of SPP, respectively.

All water quality parameters were within acceptable ranges throughout the test, except for a minor elevation in $\mathrm{pH}$ in some of the $50 \%$ and $100 \%$ SPP preparations. The copper reference toxicant test produced an $\mathrm{LC}_{50}$ of $85.1 \mathrm{\mu g} / \mathrm{L} \mathrm{Cu}$, within the control range (mean \pm 2 standard deviations) established at the MSL $(79 \mu \mathrm{g} / \mathrm{L}$ to $123 \mu \mathrm{g} / \mathrm{L} \mathrm{Cu})$. Ammonia was measured in the $100 \%$ SPP of each test composite immediately after preparation. The ammonia values at that time were $20.0 \mathrm{mg} / \mathrm{L}, 34.8 \mathrm{mg} / \mathrm{L}$, and $30.9 \mathrm{mg} / \mathrm{L}$ for RH COMP, BR-A COMP, and BR-B COMP. 


\subsubsection{Mysidopsis bahia Water-Column Toxicity Test}

Results of the M. bahia water-column toxicity test are summarized in Table 3.12. Complete test results, as well as water quality data, are presented in Appendix D, Tables D.5 through D.8. This test was validated by a control survival (taken from the results of the concurrent reference toxicant test) of $100 \%$ for all three composites. Survival in the $100 \%$ SPP preparations were $76 \%$ in RH COMP, $0 \%$ in the BR-A COMP and $6 \%$ in the BR-B COMP. The survival of $M$. bahia in the $100 \%$ SPP preparations of all three composites were significantly lower than the control preparations. The M. bahia $L_{50}$ s for the RH COMP, BR-A COMP, and BR-B COMP were $>100 \%, 60 \%$, and $70 \%$ of SPP.

All water quality parameters were within acceptable ranges throughout the test, with the exception of $\mathrm{pH}$, which rose to 8.7 in some of the $50 \%$ and $100 \%$ SPP preparations. The copper reference toxicant test revealed an $\mathrm{LC}_{50}$ of $238 \mu \mathrm{g} / \mathrm{L} \mathrm{Cu}$, which is within the control range established at the MSL (154 $\mu \mathrm{g} / \mathrm{L}$ to $303 \mu \mathrm{g} / \mathrm{L} \mathrm{Cu})$. Ammonia was measured in the $100 \%$ SPP of each test composite right after preparation:-The ammonia values at that time were $20.0 \mathrm{mg} / \mathrm{L}$, $34.8 \mathrm{mg} / \mathrm{L}$; and $30.9 \mathrm{mg} / \mathrm{L}$ for RH COMP, BR-A COMP; and BR-B COMP.

\subsubsection{Mytilus galloprovincialis Watè-Column Toxicity-Test}

Results of the M. galloprovincialis water-column:toxicity test are:summarized in Table 3.12. Complete test results and water quality data are presented in:Appendix D, Tables D.9 through D.12. This test was validated by $96 \%$ survival and nomal development in the controls (results taken from concurrent reference toxicant test). Survival in the $0 \%$ SPP (Dredging site water) preparation was $85 \%$ for RH COMP, $97 \%$ for BR-A COMP, and $100 \%$ for BR-B COMP. Significantly reduced survival; relative to the-controls,-was:observedia-the $100 \%$ SPP treatment of all three composites. Survival in the 100\% SPP preparations were $41 \%$ for RH COMP, $19 \%$ for BR-A COMP, and $14 \%$ for BR-B COMP. The LC $_{50 \text { s }}$ were $58 \%$ of SPP for RH COMP, of $65 \%$ SPP for BR-A COMP and $71 \%$ of SPP for BR-B COMP. Normal development, which is considered a more sensitive indicator of toxicity, was significantly reduced for all three composites with $\mathrm{EC}_{50} \mathrm{~s}$ of $23 \%$ SPP for RH COMP and $21 \%$ SPP for BR-A COMP and BR-B COMP.

All water quality parameters were within acceptable ranges throughout the test, with the exception of $\mathrm{pH}$, which rose to 8.6 in some of the $50 \%$ and $100 \%$ SPP preparations of all three test composites. The $\mathrm{Cu}$ reference toxicant test produced an $\mathrm{EC}_{50}$ of $7.3 \mu \mathrm{g} / \mathrm{L} \mathrm{Cu}$, which is within the control range established for copper at the $\mathrm{MSL}\left(\mathrm{EC}_{50}: 4.6 \mu \mathrm{g} / \mathrm{L}\right.$ to $9.2 \mu \mathrm{g} / \mathrm{L} \mathrm{Cu}$ ). Ammonia was measured in the $100 \%$ SPP of each test composite immediately after preparation. The ammonia values were $20.0 \mathrm{mg} / \mathrm{L}, 34.8 \mathrm{mg} / \mathrm{L}$, and $30.9 \mathrm{mg} / \mathrm{L}$ for RH COMP, BR-A COMP, and BR-B COMP. 
TABLE 3.12. Summary of Water-Column Toxicity Tests Performed with Red Hook/Bay Ridge Sediment Composites

Sediment

Treatment

RH COMP

BR-A COMP

BR-B COMP

RH COMP

BR-A COMP

BR-B COMP

Test Organism
Menidia beryllina
Menidia beryllina
Menidia beryllina

Survival in

$0 \%$ SPP

Survival in

$0 \%$ and $100 \%$

Significantly

Different

$L_{50}(\% S P P)$

Mysidopsis bahia

Mysidopsis bahia

Mysidopsis bahia

$94 \%$
$82 \%$
$88 \%$

$6 \%$

$0 \%$

$0 \%$

Yes

Yes

60

30

$98 \% \quad 76 \% \quad$ Yes

$100 \%$

$0 \%$

$6 \%$

Yes

$98 \%$

Yes

70

Survival Results

RH COMP

BR-A COMP

BR-B COMP
M. galloprovincialis

M. galloprovincialis

M. galloprovincialis
$85 \%$

$94 \%$

$96 \%$
$41 \%$

$19 \%$

$14 \%$
Yes

Yes

Yes
58

65

71

Proportion Normal Results

$\begin{array}{llllllll}\text { RH COMP } & \text { M. galloprovincialis } & 80 \% & \ldots & 0 \% & \text { Yes } & 23(\text { a) } \\ \text { BR-A COMP } & \text { M. galloprovincialis } & 93 \% & \cdots & 0 \% & \text { Yes } & 21 \\ \text { BR-B COMP } & \text { M. galloprovincialis } & 99 \% & \ddots & 0 \% & 0 . \cdots & \text { Yes } & 21\end{array}$

(a) Median effective concentration $\left(E C_{50}\right)$ based=on normal development to the $D$-cell, prodissoconch.I stage.

\subsection{Bioaccumulation Tests with Macoma nasuta and Nereis virens}

Bioaccumulation tests with $M$. nasuta and $N$. virens were conducted using the composite from Red Hook ( $\breve{H}$ C COMP), the two composites from Bay Ridge (BR-A COMP and BR-B COMP), the Mud Dump Reference Site, and the native control sediments. Both M. nasuta and $N$. virens were exposed for 28 days under flow-through conditions. Survival was $90 \%$ in the $M$. nasuta control exposure, and $62 \%$ in the $N$. virens control exposure. Causes for the lower survival of $N$. virens exposed to the control sediment are unknown. Complete test results and water quality data are presented in Appendix $\mathrm{E}$. The tissues of the exposed organisms were analyzed for metals and selected organic contaminants (pesticides, PCBs, and PAHs), the results of which are summarized in this section. Complete test results and water quality data are tabulated in Appendix $E$ for both species. Analytical results, including a quality control summary and associated quality control data, are presented in Appendix $F$ for $M$. nasuta and in Appendix $\mathrm{G}$ for $\mathrm{N}$. virens. The statistical analysis of tissue data was performed using sample dry weight concentrations to remove any variance associated with water content in each sample. Statistical 
difference between reference site and test sediment exposures is shown in the following tables with the results of sample analysis on a wet weight basis. Reporting data in this manner allows for comparison of wet weight concentrations obtained from this study with regulatory levels such as the FDA action levels reported in section 4.0 of this report. Lipids were analyzed on the background samples of the M. nasuta and $N$. virens tissues. These samples were triplicated and the average lipid contents in wet weight for $M$. nasuta and $N$. virens were $1.79 \%$ and $0.71 \%$, respectively. The average dry weight lipid concentrations for these two species were $12.8 \%$ and $4.67 \%$, respectively.

\subsubsection{Bioaccumulation of Metals in Macoma nasuta}

Results of analysis of M. nasuta tissues exposed to Red Hook/Bay Ridge composites and the Mud Dump Reference Site are shown in Table 3.13. All nine metals were detected in tissues exposed to the Red Hook/Bay Ridge composites. The RH COMP had statistically significant and elevated concentrations of $\mathrm{Ni}$ and $\mathrm{Pb}$ relative to the Mud Dump Reference Site. The BR-A COMP and BR-B COMP had significantly elevated concentrations. of $\mathrm{Cr}$, $\mathrm{Ni}$, and $\mathrm{Pb}$ relative to the Mud Dump Reference. Site. The magnification factor; the magnitudeby which a contaminant concentration in the test composite tissues exceeds that from the reference composite tissues, was less than three for all metals.

\subsubsection{Bioaccumulation of Chlorinated Pesticides in-Macoma nasuta}

Results of chlorinated pesticide analysis of $M$. nasuta tissues exposed to the Red Hook/Bay Ridge composites and the Mud Dump Reference Site are shown in Table 3.14. In companison with tissues exposed to the Mud Dump Reference Site sediment, the RH COMP tissues were statistically significant and elevated for most of the DDT family of compounds. These compounds exceeded those of the Mud Dump Reference Site by 1.2 to 11.2 times. In BR-A COMP and BR-B COMP exposed tissues, significant elevations relative to the Mud Dump Reference Site were found for 4,4'-DDD, 4,4'-DDE, 4,4'-DDT, $\alpha$-chlordane, and aldrin. These compounds were detected at concentrations at least three times higher in tissues from both composites relative to tissues exposed to sediments from the Mud Dump Reference Site.

\subsubsection{Bioaccumulation of PCBs in Macoma nasuta}

Results of analysis of $M$. nasuta tissues exposed to the Red Hook/Bay Ridge composites and the Mud Dump Reference Site are shown in Table 3.14. At least 12 of 22 PCBs analyzed were detected in $M$. nasuta tissues exposed to the Red Hook/Bay Ridge test sediment 
TABLE 3.13. Mean Concentrations of Metals in Macoma nasuta Tissues Exposed to Red Hook/Bay Ridge Composites and the Mud Dump Reference Site Composite

\begin{tabular}{|c|c|c|c|c|c|c|c|}
\hline \multirow[b]{3}{*}{ Analyte } & \multicolumn{7}{|c|}{ Concentrations in makg wet weight(a) } \\
\hline & $\mathrm{RH}$ & & BR-A & & BR-B & & \\
\hline & COMP & $\underline{S O}(b)$ & COMP & $\underline{S D}$ & COMP & $\mathrm{SD}$ & MDRS(C) \\
\hline Silver & 0.041 & $\overline{\text { No }}$ & 0.065 & No & 0.072 & $\overline{\text { No }}$ & $\overline{0.046}$ \\
\hline Arsenic & 3.93 & No & 3.44 & No & 3.54 & No & 3.13 \\
\hline Cadmium & 0.030 & No & 0.034 & No & 0.035 & No & 0.027 \\
\hline Chromium & 0.33 & No & 0.570 & Yes & 0.480 & Yes & 0.225 \\
\hline Copper & 2.79 & No & 3.00 & No & 3.18 & No & 2.78 \\
\hline Mercury & 0.020 & No & 0.019 & No & 0.018 & No & 0.017 \\
\hline Nickel & 0.520 & Yes & 0.580 & Yes & 0.480 & Yes & 0.300 \\
\hline Lead & 0.700 & Yes & 0.785 & Yes & 0.715 & Yes & 0.335 \\
\hline Zinc & 12.3 & No & 13.8 & No & 13.4 & No & 13.0 \\
\hline
\end{tabular}

(a) Value shown is the mean of triplicate analyses; one-half the detection limit used when analyte was undetected.

(b) SD Dry weight concentrations significantly different.

(c) MDRS - Mud Dump Reference Site.

composites. At least eleven PCBs were observed at concentrations that were significantly elevated in either RH.COMP, BR-A COMP, or BR-B COMP tissues relative to those in tissues exposed to the Mud:Dump-Reference Site sediment: -The total sum. of PCB congeners for the Red Hook/Bay. Ridge-M.nasuta:tissues-ranged-from 62.6 to $113 \mu \mathrm{g} / \mathrm{kg}$. The magnification factors for five PCB congeners'were greater than 10:times-higher for all three test treatment tissue samples relative to Mud Dump Reference Site:tissue-samples.

\subsubsection{Bioaccumulation of PAHs $\&=1,4=$ Dichlorobenzene in-Macoma nasuta}

Results of analysis of $M$. nasuta tissues exposed to the Red Hook/Bay Ridge composites and the Mud Dump Reference Site sediments for PAHs and 1,4-dichlorobenzene are shown in Table 3.15. All sixteen PAHs analyzed were detected in $M$. nasuta tissues exposed to the three test composites at statistically significant and elevated concentrations, relative to tissues exposed to the Mud Dump Reference Site. Magnification factors were greatest for RH COMP, ranging from 3.3 to 345 times concentrations found in the Mud Dump Reference Site tissues and were the lowest for BR-A COMP, ranging from 1.7 to 32.2 times higher than Mud Dump Reference Site tissues.

\subsubsection{Bioaccumulation of Metals in Nereis virens}

Results of $N$. virens tissues exposed to the Red Hook/Bay Ridge composites and the Mud Dump Reference Site composite for metals are shown in Table 3.16. All metals analyzed except Ag for the RH COMP were detected in N. virens tissues exposed to the Red Hook/Bay Ridge composites. The compound Ni was significantly higher in tissues from RH COMP, BR-A COMP and BR-B COMP than in Mud Dump Reference Site-exposed tissues. Magnification factors were less than two for all metals. 
TABLE 3.14. Mean Concentrations of Pesticides and PCBs in Macoma nasuta Tissues Exposed to Red Hook/Bay Ridge Composites and the Mud Dump Reference Site Composite

\begin{tabular}{|c|c|c|c|c|c|c|c|c|}
\hline & & & & & Conce & rations in uc & wet weig & \\
\hline $\begin{array}{l}\text { Analyte } \\
\text { (ug/kg) }\end{array}$ & $\begin{array}{l}\mathrm{RH} \\
\text { COMP }\end{array}$ & $S D(b)$ & $\begin{array}{l}\text { BR-A } \\
\text { COMP }\end{array}$ & & SD & $\begin{array}{l}\text { BR-B } \\
\text { COMP }\end{array}$ & SD & MDRS(c) \\
\hline $2,4^{\prime}-D D D$ & 1.07 & Yes & 0.34 & & No & 1.07 & Yes & $0.13 Q^{(d)}$ \\
\hline 2,4'-DDE & $0.29 \mathrm{Q}$ & No & $0.15 \mathrm{Q}$ & & $\mathrm{No}$ & $0.13 Q$ & $\mathrm{No}$ & $0.13 Q$ \\
\hline 2,4'-DDT & $0.20 \mathrm{Q}$ & No & $0.10 Q$ & & No & $0.09 Q$ & No & $0.09 \mathrm{Q}$ \\
\hline 4,4'-DDD & 2.49 & Yes & 2.05 & & Yes & 3.53 & Yes & $0.13 Q$ \\
\hline $4,4^{\prime}-D D E$ & 3.98 & Yes & 4.66 & & Yes & 7.32 & Yes & 0.79 \\
\hline 4,4'-DDT & 1.83 & Yes & 1.28 & & Yes & 0.98 & Yes & $0.08 \mathrm{Q}$ \\
\hline Total DDT(e) & 9.86 & Yes & 8.58 & & Yes & 13.1 & Yes & 1.35 \\
\hline$\alpha$-Chlordane & 0.53 & No & 0.75 & & Yes & 0.89 & Yes & 0.20 \\
\hline Aldrin & 1.02 & No & 2.00 & & Yes & 1.88 & Yes & 0.33 \\
\hline Dieldrin & 1.26 & No & 1.19 & & No & 1.77 & Yes & 0.65 \\
\hline Endosulfan I & 0.30 & No & $0.10 \mathrm{Q}$ & & No & $0.09 Q$ & No & $0.09 Q$ \\
\hline $\begin{array}{l}\text { Endosulfan II } \\
\text { Endosulfan }\end{array}$ & $0.20 \mathrm{Q}$ & No & $0.10 \mathrm{Q}$ & & No & 0.22 & No & $0.09 Q$ \\
\hline Sulfate & $0.28 \mathrm{Q}$ & No & $.0 .14 \mathrm{Q}$ & & No & $0.13 \mathrm{Q}$ & No & $0.13 \mathrm{Q}$ \\
\hline $\begin{array}{l}\text { Heptachlor } \\
\text { Heptachlor }\end{array}$ & $0.21 Q$ & - No & 0.17 & & No & $0.09 \mathrm{Q}$ & No & 0.12 \\
\hline Epoxide & $0.15 Q$ & $=\mathrm{No}$ & $0.07 Q$ & - & No & $0.07 \mathrm{Q}$ & No & $0.07 \mathrm{Q}$ \\
\hline trans-Nonachlor & $0.16 \mathrm{Q}$ & No & 0.15 & & No & $0.07 \mathrm{Q}$ & No & $0.07 \mathrm{Q}$ \\
\hline PCB 8 & $0.30 \mathrm{Q}$ & No & 0.35 & & No & 0.32 & No & 0.39 \\
\hline РCB 18 & 3.49 & $\therefore$ Yes & $\because 2.55$ & $=$ & Yes & 5.93 & Yes & $0.05 \mathrm{Q}$ \\
\hline РCB 28 & 6.22 & Yes & 5.85 & & Yes & 7.48 & Yes & 0.22 \\
\hline PCB 44 & $0.08 \mathrm{Q}$ & No & 1.92 & & Yes & 3.95 & Yes & $0.04 \mathrm{Q}$ \\
\hline РСВ 49 & 2.49 & Yes & 4.25 & & Yes & 4.37 & Yes & $0.09 \mathrm{Q}$ \\
\hline PCB 52 & 4.39 & Yes & 5.89 & & Yes & 7.93 & Yes & 0.39 \\
\hline РCB 66 & 3.83 & Yes & 6.29 & & Yes & 7.61 & Yes & $0.08 \mathrm{Q}$ \\
\hline PCB 87 & 0.90 & Yes & 1.07 & & Yes & 1.65 & Yes & $0.13 Q$ \\
\hline PCB 101 & 2.70 & Yes & 4.44 & & Yes & 5.00 & Yes & 0.17 \\
\hline PCB 105 & $=0.98$ & Yes & 0.71 & . & Yes & -1.09 & Yes & $0.09 . Q$ \\
\hline PCB 118 & 1.68 & Yes & 3.17 & & Yes & 3.63 & Yes & 0.12 \\
\hline PCB 128 & 0.18 & No & 0.32 & & Yes & 0.46 . & Yes & $0.05 \mathrm{Q}$ \\
\hline PCB 138 & 0.92 & Yes & 2.28 & & Yes & 2.30 & Yes & 0.17 \\
\hline PCB 153 & 1.30 & Yes & 3.13 & & Yes & 2.76 & Yes & $0.22 Q$ \\
\hline PCB 170 & $0.20 \mathrm{Q}$ & No & 0.24 & & No & 0.19 & No & $0.09 Q$ \\
\hline PCB 180 & $0.42 \mathrm{Q}$ & No & 0.68 & & Yes & 0.58 & No & $0.19 Q$ \\
\hline PCB 183 & $0.21 Q$ & No & 0.22 & & No & 0.19 & No & $0.09 Q$ \\
\hline PCB 184 & $0.21 Q$ & No & $0.10 Q$ & & No & $0.09 \mathrm{Q}$ & No & $0.09 Q$ \\
\hline PCB 187 & $0.23 \mathrm{Q}$ & No & 0.61 & & Yes & 0.51 & - Yes & $0.11 Q$ \\
\hline PCB 195 & $0.14 Q$ & No & $0.07 \mathrm{Q}$ & & No & $0.06 \mathrm{Q}$ & No & $0.06 Q$ \\
\hline PCB 206 & $0.23 \mathrm{Q}$ & No & $0.11 Q$ & & No & $0.11 \mathrm{Q}$ & No & $0.11 \mathrm{Q}$ \\
\hline PCB 209 & $0.21 \mathrm{Q}$ & No & $0.10 \mathrm{Q}$ & & No & $0.10 \mathrm{Q}$ & No & $0.10 \mathrm{Q}$ \\
\hline Total $\mathrm{PCB}(\mathfrak{f})$ & 62.6 & & 88.7 & & & 113 & & 6.1 \\
\hline
\end{tabular}

(a) Value shown is the mean of triplicate analyses; one-half the detection limit used when analyte was undetected.

(b) SD Dry weight concentrations significantly different.

(c) MDRS - Mud Dump Reference Site.

(d) $\mathrm{Q}$ Undetected at or above twice the given concentration

(e) Sum of 2,4'-DDD, 2,4'-DDE, 2,4'-DDT, 4,4'-DDD, 4,4'-DDE, and 4,4'-DDT; one -half of the detection limit used in summation when analyte was undetected.

(f) Total $P C B=2(x)$, where $x=$ sum of all $P C B$ congeners; one-half of the detection limit used in summation when analyte was undetected. 
TABLE 3.15. Mean Concentrations of PAHs and 1,4-Dichlorobenzene in Macoma nasuta Tissues Exposed to Red Hook/Bay Ridge Composites and Mud Dump Reference Site Composite

\begin{tabular}{|c|c|c|c|c|c|c|c|}
\hline \multirow[b]{3}{*}{ Analyte } & \multicolumn{7}{|c|}{ Concentrations in $\mu \mathrm{g} / \mathrm{kg}$ wet weight(a) } \\
\hline & $\mathrm{RH}$ & & BR-A & & $\mathrm{BR}-\mathrm{B}$ & & \\
\hline & COMP & $\underline{S D(b)}$ & COMP & $\underline{S D}$ & COMP & $\underline{S D}$ & MDRS(c) \\
\hline Naphthalene & 8.69 & Yes & 4.24 & No & 7.86 & Yes & 2.44 \\
\hline Acenaphthylene & 4.00 & Yes & 2.02 & Yes & 4.12 & Yes & $0.37 Q(0)$ \\
\hline Acenaphthene & 24.8 & Yes & 2.26 & Yes & 55.5 & Yes & $0.66 \mathrm{Q}$ \\
\hline Fluorene & 32.9 & Yes & 2.39 & Yes & 46.5 & Yes & $0.62 \mathrm{Q}$ \\
\hline Phenanthrene & 440 & Yes & 12.6 & Yes & 368 & Yes & 1.69 \\
\hline Anthracene & 219 & Yes & 9.26 & Yes & 154 & Yes & 1.46 \\
\hline LPAH & 729 & NA(e) & 32.8 & NA & 636 & NA & 7.24 \\
\hline Fluoranthene & 716 & Yes & 68.5 & Yes & 404 & Yes & $2.70 \mathrm{Q}$ \\
\hline $\begin{array}{l}\text { Pyrene } \\
\text { Benz[a] }\end{array}$ & 916 & Yes & 106 & Yes & 534 & Yes & $2.30 \mathrm{Q}$ \\
\hline anthracene & 577 & Yes & 53.0 & Yes & 238 & Yes & 1.57 \\
\hline $\begin{array}{l}\text { Chrysene } \\
\text { Benz[b+k] }\end{array}$ & 631 & Yes & 65.6 & Yes & 273 & Yes & $1.11 \mathrm{Q}$ \\
\hline fluoranthene & 306 & - Yes & 75.7 & Yes & 149 & Yes & 3.07 \\
\hline Benzo[e]pyrene & 175 & Yes & 41.7 & Yes & 82.8 & Yes & $0.76 \mathrm{Q}$ \\
\hline Benzo[a]pyrene & 242 & Yes & 42.4 & ¿rYes. & 111 & Yes & 1.41 \\
\hline $\begin{array}{l}\text { Perylene } \\
\text { Indeno[123-cd] }\end{array}$ & 29.1 & Yes & 13.2 & Yes & 18.7 & Yes & $0.71 \mathrm{Q}$ \\
\hline $\begin{array}{c}\text { pyrene } \\
\text { Dibenz[a,h] }\end{array}$ & 43.1 & Yes & 11.3 & $\therefore \ldots$ Yes & 15.8 & Yés & 1.60 \\
\hline $\begin{array}{l}\text { anthracene } \\
\text { Benzo[g,h,i] }\end{array}$ & 13.6 & - Yes & 4.11 & $=y$ yes & 4.97 & Yes & $0.64 Q$ \\
\hline perylene & 53.6 & Yes & 14.2 & Yes & 19.5 & Yes & 1.13 \\
\hline НРАН & 3700 & NA & 497 & NA & 1850 & NA & 17.0 \\
\hline TPAH & 4430 & NA & 530 & NA & 2490 & NA & 24.2 \\
\hline 1,4-Dichlorobenzene & 2.35 & No & $1.04 \mathrm{Q}$ & $=$ No & $0.94 \mathrm{Q}$ & No & $0.94 \mathrm{Q}$ \\
\hline
\end{tabular}

(a) Value shown is the mean of triplicate analyses; one-half the detection limit used when analyte was undetected.

(b) SD Dry weight concentrations significantly different.

(c) MDRS - Mud Dump Reference Site.

(d) $Q$ Undetected at or above twice the given concentration.

(e) Not applicable; statistical analysis not performed on LPAH, HPAH, or TPAH results. 
TABLE 3.16. Mean Concentrations of Metals in Nereis virens Tissues Exposed to Red Hook/Bay Ridge Composites and Mud Dump Reference Site Composite

\begin{tabular}{|c|c|c|c|c|c|c|c|}
\hline \multirow[b]{3}{*}{ Analyte } & \multicolumn{7}{|c|}{ Concentrations in mg/kg wet weight(a) } \\
\hline & $\mathrm{RH}$ & & BR-A & & BR-B & & \\
\hline & COMP & $\underline{\mathrm{SD}(b)}$ & COMP & $\underline{S D}$ & COMP & $\underline{\mathrm{SD}}$ & MDRS(c) \\
\hline Silver & $0.016 \mathrm{Q}(\mathrm{d})$ & No & 0.225 & No & 0.0205 & No & 0.0190 \\
\hline Arsenic & 2.16 & No & 2.09 & No & 1.93 & No & 2.36 \\
\hline Cadmium & 0.039 & No & 0.355 & No & 0.0375 & No & 0.0370 \\
\hline Chromium & 0.182 & No & 0.171 & No & 0.180 & No & 0.166 \\
\hline Copper & 1.44 & No & 1.32 & No & 1.45 & No & 1.31 \\
\hline Mercury & 0.0194 & No & 0.0127 & No & 0.0160 & No & 0.0187 \\
\hline Nickel & 0.194 & Yes & 0.174 & Yes & 0.197 & Yes & 0.104 \\
\hline Lead & 0.208 & No & 0.221 & No & 0.188 & No & 0.147 \\
\hline Zinc & 29.3 & No & 18.9 & No & 20.2 & No & 15.3 \\
\hline
\end{tabular}

(a) Value shown is the mean of triplicate analyses; one-half the detection limit used when analyte was undetected.

(b) SD Dry weight concentrations significantly different.

(c) MDRS - Mud Dump Reference Site.

(d) Q Undetected at or above twice the given concentration.

\subsubsection{Bioaccumulation of Chlorinated Pesticides in Nereis virens}

Results of analysis of $N$. virens tissues exposed to the Red Hook/Bay Ridge composites and the Mud Dump Reference Site sediments for chlorinăted pesticides are shown in Table 3.17. Some of the DDT-family of compounds (2,4'-DDD, 4,4'-DDD, and 4,4'-DDE) as well as $\alpha-$ chlordane, aldrin, and dieldrin were statistically significantly elevated in the RH COMP composite tissues when compared with the Mud Dump Reference Site tissues. In BR-A COMP and BR-B COMP tissues, in addition to the same family DDT compounds, $\alpha$-chlordane, aldrin, and transnonaclor was also significantly elevated above the reference. Dieldrin was also significantly elevated in BR-B.COMP-exposed tissues relative the Mud Dump Reference Site-exposed tissues. Aldrin in tissues from all three test sediment composites exceeded reference tissue concentrations by at least 10 times.

\subsubsection{Bioaccumulation of PCBs in Nereis virens}

Results of analysis of $N$. virens tissues exposed to the Red Hook/Bay Ridge composites and the Mud Dump Reference Site sediments for PCBs are shown in Table 3.17. At least 19 of the 22 PCBs congeners analyzed were detected in $N$. virens tissues exposed to Red Hook/Bay Ridge composites. Sixteen of these congeners were detected at concentrations that were significantly elevated relative to those in tissues exposed to the Mud.Dump Reference sediment. Concentrations of six PCBs in tissues exposed to all three test sediment composites were significantly elevated by at least a factor of 10 times those of the tissues exposed to the Mud Dump Reference composite. The sum of total PCBs in $N$. virens tissues for the RH COMP, BRA COMP, and BR-B COMP, were 141, 102, and $214 \mu \mathrm{g} / \mathrm{kg}$, respectively. 
TABLE 3.17. Mean Concentrations of Pesticides and PCBs in Nereis virens Tissues Exposed to Red Hook/Bay Ridge Composites and the Mud Dump Reference Site Composite

\begin{tabular}{|c|c|c|c|c|c|c|c|}
\hline Anatyte & $\begin{array}{l}\text { PH } \\
\text { OOMP }\end{array}$ & SD(b) & $\begin{array}{l}\text { BR-A } \\
\text { COMP }\end{array}$ & SD & $\begin{array}{l}\text { BRB } \\
\text { CQMP }\end{array}$ & SD & MDRS(c) \\
\hline $2,4^{\prime}-\mathrm{DDD}$ & 1.26 & Yes. & 0.93 & Yes & 2.41 & $\overline{\text { Yes }}$ & 0.26 \\
\hline 2,4'-DDE & $0.15 Q(0)$ & No & $0.13 Q$ & No & $0.13 Q$ & $\mathrm{No}$ & $0.13 Q$ \\
\hline 2,4'-DDT & $0.11 Q$ & No & $0.09 \mathrm{Q}$ & $\mathrm{No}$ & $0.09 \mathrm{Q}$ & No & $0.09 \mathrm{Q}$ \\
\hline 4,4'-DDD & 3.02 & Yes & 2.27 & Yes & 7.92 & Yes & 0.71 \\
\hline 4,4'-DDE & 3.22 & Yes & 2.20 & Yes & 8.22 & Yes & $0.09 \mathrm{Q}$ \\
\hline 4,4'-DDT & 2.57 & No & 2.25 & $\mathrm{Nb}$ & 4.10 & No & 1.50 \\
\hline Total DDT(o) & 10.3 & Yes & 7.87 & Yes & 22.9 & Yes & 2.78 \\
\hline$\alpha$-Chlordane & 0.77 & Yes & 0.84 & Yes & 1.31 & Yes & 0.12 \\
\hline Aldrin & 2.47 & Yes & 1.82 & Yes & 3.25 & Yes & $0.07 \mathrm{Q}$ \\
\hline Dieldrin & 1.44 & Yes & 0.96 & No & 2.58 & Yes & 0.71 \\
\hline Endosulfan I & 0.11 & No & $0.09 Q$ & No & $0.09 Q$ & No & 0.19 \\
\hline $\begin{array}{l}\text { Endosulfan II } \\
\text { Endosulfan }\end{array}$ & $0.11 Q$ & No & $0.09 Q$ & $\mathrm{No}$ & $0.09 Q$ & No & $0.09 \mathrm{Q}$ \\
\hline Sulfate & $0.15 Q$ & No & $0.13 \mathrm{Q}$ & No & $0.13 \mathrm{Q}$ & No & $0.13 Q$ \\
\hline Heptachlor & 0.17 & No & $0.09 \mathrm{Q}$ & No & $0.10 \mathrm{Q}$ & No & $0.10 \mathrm{Q}$ \\
\hline Heptachlor & & & & & & & \\
\hline Epoxide & $0.08 Q$ & - No & $0.07 Q$ & No & $0.07 Q$ & No & 0.35 \\
\hline trans-Nonachlor & 0.31 & No & 0.58 & Yes & 0.89 & Yes & 0.17 \\
\hline РCB 8 & $0.21 Q$ & $\therefore$ No & $-0: 17 Q$ & No & $0.18 Q$ & No & $0.18 \mathrm{Q}$ \\
\hline PCB 18 & 11.3 & Yes & $=7: 22$ & Yes & 10.7 & Yes & $0.05 \mathrm{Q}$ \\
\hline PCB 28 & 7.06 & Yes & $\because 4: 34$ & Yes & 9.36 & Yes & $0.06 \mathrm{Q}$ \\
\hline PCB 44 & 6.91 & Yes & $\therefore 3.82$ & Yes & 7.08 & Yes & $0.04 \mathrm{Q}$ \\
\hline PCB 49 & 4.17 & Yes & $2: 70$ & Yes & 6.10 & Yes & $=0.09 \mathrm{Q}$ \\
\hline PCB 52 & 9.52 & Yes & 5.88 & Yes & 13.6 & Yes & $0.16 \mathrm{Q}$ \\
\hline PCB 66 & 6.45 & Yes & 5.10 & Yes & 11.3 & Yes & $0.08 \mathrm{Q}$ \\
\hline PCB 87 & 0.53 & Yes & 0.20 & No & 1.14 & Yes & $0.13 Q$ \\
\hline РCB 101 & 4.78 & Yes & 3.85 & Yes & 8.89 & Yes & 0.40 \\
\hline PCB 105 & 1.26 & Yes & 1.16 & Yes & 2.89 & Yes & 0.25 \\
\hline PCB 118 & 3.24 & Yes & 2.31 & Yes & 6.00 & Yes & 0.23 \\
\hline PCB 128 & 0.24 & No & 0.38 & Yes & 1.03 & Yes & 0.11 \\
\hline PCB 138 & 3.51 & Yes & 3.30 & Yes & 6.84 & Yes & 1.40 \\
\hline РCB 153 & 5.19 & Yes & 4.94 & Yes & 9.25 & Yes & 2.50 \\
\hline PCB 170 & 0.72 & Yes & 0.77 & Yes & 1.63 & Yes & 0.29 \\
\hline PCB 180 & 1.86 & Yes & 1.85 & Yes & 4.01 & Yes & 0.74 \\
\hline РСB 183 & 0.65 & Yes & 0.62 & No & 1.60 & Yes & 0.25 \\
\hline PCB 184 & $0.11 Q$ & No & $0.09 Q$ & No & $0.09 Q$ & No & $0.09 \mathrm{Q}$ \\
\hline PCB 187 & 1.79 & Yes & 1.76 & Yes & 3.31 & Yes & 0.85 \\
\hline PCB 195 & 0.11 & No & 0.08 & No & 0.18 & No & $0.07 \mathrm{Q}$ \\
\hline PCB 206 & 0.54 & Yes & 0.33 & Yes & 1.01 & Yes & 0.13 \\
\hline РCB 209 & 0.24 & No & $0.10 \mathrm{Q}$ & No & 0.57 & Yes & $0.10 \mathrm{Q}$ \\
\hline Total PCB(f) & 141 & & 102 & & 214 & & 16.4 \\
\hline
\end{tabular}

(a) Value shown is the mean of triplicate analyses; one-half the detection limit used when analyte was undetected.

(b) SD Dry weight concentrations significantly different.

(c) MDRS - Mud Dump Reference Site.

(d) $Q$ Undetected at or above twice the given concentration.

(e) Sum of 2,4'-DDD, 2,4'-DDE, 2,4'-DDT, 4,4'-DDD, 4,4'-DDE, and 4,4'-DDT; one -half of the detection limit used in summation when analyte was undetected.

(f) Total PCB $=2.0(x)$, where $x=$ sum of all PCB congeners; one-half of the detection limit used in summation when analyte was undetected. 


\subsubsection{Bioaccumulation of PAHs and 1,4-Dichlorobenzene in Nereis virens}

Results of analysis of $N$. virens tissues exposed to the Red Hook/Bay Ridge composites and the Mud Dump Reference Site for PAHs and 1,4-dichlorobenzene are shown in Table 3.18. All PAHs analyzed (with the exception of perylene for BR-A COMP) were detected in tissues exposed to all three Red Hook/Bay Ridge composites. Concentrations of nine PAHs in tissues exposed to RH COMP and BR-B COMP were significantly elevated by at least a factor of 10 over tissues exposed to the Mud Dump Reference Site. The compound 1,4-dichlorobenzene was not detected in any of the test composite tissues.

TABLE 3.18. Mean Concentrations of PAHs and 1,4-Dichlorobenzene in Nereis virens Tissues Exposed to Red Hook/Bay Ridge Composites and Mud Dump Reference Site Composite

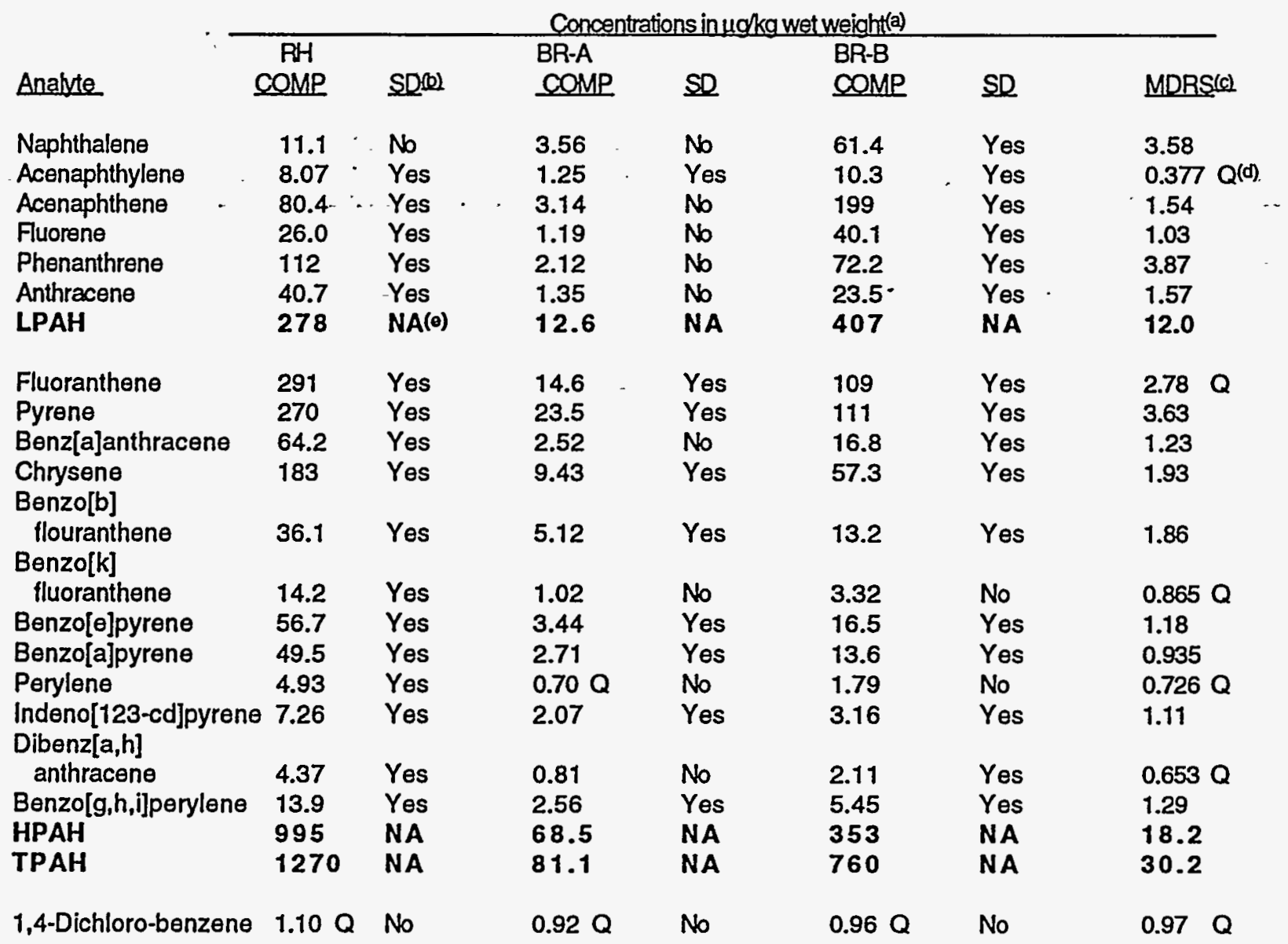

(a) Value shown is the mean of triplicate analyses; one-half the detection limit used when analyte was undetected.

(b) SD Dry weight concentration significantly different.

(c) MDRS - Mud Dump Reference Site.

(d) Q Undetected at or above twice the given concentration.

(e) Not applicable; statistical analysis not performed on LPAH, HPAH, or TPAH results. 


\subsubsection{Magnification Factors of Compounds in Macoma nasuta and Nereis virens}

Tables 3.19 and 3.20 show the calculated magnification factors of all compounds analyzed in tissues of $M$. nasuta and $N$. virens. Magnification factors were calculated with the dry weight concentrations of the compounds in the tissues of the test organism. These factors show the magnification of the Red Hook/Bay Ridge-exposed tissues over the Mud Dump Reference Siteexposed tissues. When all replicate analysis of a compound showed that the compound was undetected, the magnification factor displays the magnification of the Red Hook/Bay Ridgeexposed tissues above the detection limit of the Mud Dump Reference Site-exposed tissues. 
TABLE 3.19. Magnification Factors of All Analyzed Compounds in Macoma nasuta Tissues Exposed to Red Hook'Bay Ridge Composites Relative to Tissues Exposed to the Mud Dump Reference Site Composite

Analyte

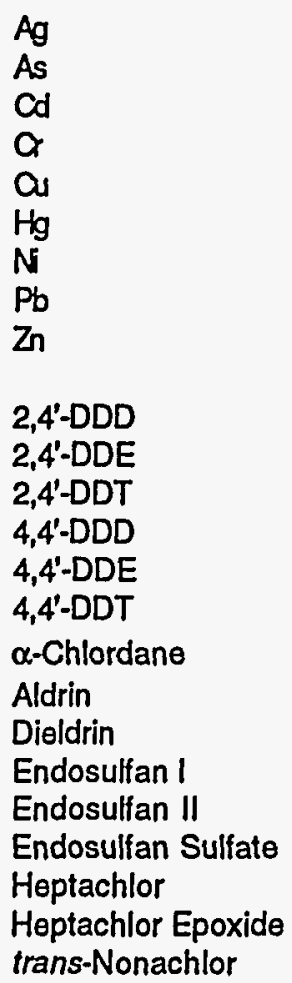

PCB 8

PCB 18

PCB 28

PCB 44

PCB 49

PCB 52

PCB 66

PCB 87

PCB 101

PCB 105

PCB 118

PCB 128

PCB 138

PCB 153

PCB 170

PCB 180

PCB 183

PCB 184

PCB 187

PCB 195

PCB 206

PCB 209

\begin{tabular}{lll}
\multicolumn{3}{c}{ Magnification Factors(a) } \\
\hline BHCOMP & BR-ACOMP & BR-B COMP
\end{tabular}

0.815
1.16
1.00
1.34
0.92
1.11
1.58
1.91
0.88

1.24

1.04

1.16

2.40

1.00

1.09

1.82

2.21

1.44

1.13

1.28

2.10

1.12

1.09

1.58

2.10

1.01

1.02

4.51

1.17

2.03

$\frac{8.81}{4.65}$

11.2

2.14

2.88

2.03

2.43

2.05

2.05

2.00

2.09

2.04

1.60

32.3

24.8

2.11

13.4

9.52

24.4

3.82

13.2

5.53

8.14

2.39

3.69

3.26

2.03

2.04

2.09

2.09

2.04

2.07

2.03

1.96
1.72

0.60

1.06

7.38

$\underline{5.55}$

8.01

3.12

5.25

1.52

1.06

1.06

1.06

1.25

1.06

1.32

1.01

23.7

23.5

26.2

22.2

12.4

39.4

3.99

21.9

4.20

15.4

2.96

7.98

6.74

1.39

1.75

1.41

1.06

2.89

1.05

0.95

0.95
4.25

0.56

1.00

13.3

9.13

6.76

3.87

5.17

2.33

1.00

1.42

1.00

0.96

1.00

0.98

1.00

57.8

31.5

56.0

23.9

17.5

49.8

6.46

25.8

6.39

18.4

4.23

8.40

6.21

1.17

1.59

1.36

1.01

2.48

0.98

1.00

1.00 
TABLE 3.19. (contd)

Analyte

Naphthalene

Acenaphthylene

Acenaphthene

Fluorene

Phenanthrene

Anthracene

Fluoranthene

Pyrene

Benz[a]anthracene

Chrysene

Benzo[b]fluoranthene

Benzo[k]flouranthene

Benzo[b+k]flouranthene

Benzo[e]pyrene

Benzo[a]pyrene

Perylene

Indeno[123-c]pyrene

Dibenz $[a, h] a n t h r a c e n e$

Benzo[g,h,i]perylene

\section{RHCOMP}

3.34

$\underline{5.11}$

17.8

24.7

152

86.6

125

187

345

242

65.2

32.4

67.8

77.0

133

19.4

20.7

$\underline{9.97}$

29.7

2.06

Magnification Factors(a)

1,4-dichlorobenzene

\section{BR-A COMP}

1.66

2.61

1.74

1.96

4.42

3.72

12.1

21.8

32.2

25.3

17.3

12.0

16.8

18.4

23.5

$\underline{8.88}$

$\underline{5.50}$

3.07

$\underline{8.01}$

1.05
BR-B COMP

3.20

5.57

41.9

36.9

135

64.7

74.4

115

151

110

34.7

17.1

34.6

38.2

64.3

13.1

$\underline{8.10}$

3.89

3.89

1.00

(a) Magnification factors are the number of times the test treatment concentration is greater-than-the reference treatment concentration. When the analyte is undetected in one-or-more replicates, the achieved detection limit value is used in the calculation. Calculations-are based on dry 'weight * concentrations.- Underlined values are between 5 and $<10$ times referénce site values, values shown in bold are $\geq 10$ times reference site values. 
TABLE 3.20. Magnification Factors of All Analyzed Compounds in Nereis virens Tissues Exposed to Red Hook/Bay Ridge Composites Relative to Tissue Exposed to the Mud Dump Reference Site

Analyte

$\mathrm{Ag}$

As

Cd

$\mathrm{Cr}$

$\mathrm{Cu}$

$\mathrm{Hg}$

$\mathrm{Ni}$

$\mathrm{Pb}$

$\mathrm{Zn}$

2,4'-DDD

2,4'-DDE

2,4'-DDT

4,4'-DDD

4,4'-DDE

4,4'-DDT

$\alpha$-Chlordane

Aldrin

Dieldrin

Endosulfan I

Endosulfan II

Endosulfan Sulfate

Heptachlor

Heptachlor Epoxide

trans-Nonachlor

PCB 8

PCB 18

PCB 28

PCB 44

PCB 49

PCB 52

PCB 66

PCB 87

PCB 101

PCB 105

PCB 118

PCB 128

PCB 138

PCB 153

PCB 170

PCB 180

PCB 183

PCB 184

PCB 187

PCB 195

PCB 206

PCB 209

\begin{tabular}{l} 
Magnification Factors (a) \\
\hline BH COMP
\end{tabular}

0.98

0.85

0.98

1.03

1.03

0.97

1.80

1.33

1.82

3.57

1.15

1.15

4.08

8.65

1.73

5.07

19.1

2.03

0.81

1.15

1.16

1.43

0.39

1.55

1.16

111

63.2

96.7

22.5

29.1

42.0

2.09

11.3

4.07

12.1

1.98

2.52

2.09

2.51

2.51

2.59

1.15

2.13

1.22

2.51

1.38
1.04

0.80

0.89

0.95

0.92

0.62

1.57

1.25

1.15

2.58

0.96

0.96

2.97

5.74

1.46

5.30

13.7

1.31

0.67

.0 .96

0.95

0.95

0.32

2.50

0.96

68.2

37.9

51.7

15.9

17.5

32.3

1.03

8.81

3.63

8.36

2.77

2.29

1.92

2.61

2.43

2.39

0.95

2.02

0.99

1.55

0.96
1.01

0.77

0.97

1.04

1.04

0.82

1.84

1.23

1.28

6.88

1.02

1.02

10.9

22.5

2.78

8.72

25.4

3.70

0.72

1.02

1.02

1.00

0.34

4.03

1.02

106

85.1

99.9

33.3

42.1

74.1

4.51

21.2

9.43

22.6

7.74

4.93

3.74

5.75

$\underline{5,45}$

$\underline{6.42}$

1.01

3.94

1.57

4.72

2.85 
TABLE 3.20. (contd)

Analyte

Naphthalene

Acenaphthylene

Acenaphthene

Fluorene

Phenanthrene

Anthracene

Fluoranthene

Pyrene

Benz[a]anthracene

Chrysene

Benzo[b]fluoranthene

Benzo[k]flouranthene

Benzo[e]pyrene

Benzo[a]pyrene

Perylene

Indeno[123-cd]pyrene

Dibenz[a,h]anthracene

Benzo[g,h,i]perylene
RHCOMP

3.14

10.8

48.9

18.4

23.3

16.4

52.5

49.0

44.4

64.3

16.7

$\underline{8.33}$

31.1

31.8

3.40

3.94

3.35

7.49

1.15
Magnification Factors (a)

BR-A COMP

BR-B COMP

17.8

14.1

124

29.2

15.4

9.73

20.1

20.8

11.9

20.4

$\underline{6.25}$

2.11

$\underline{9.18}$

$\underline{8.87}$

1.45

1.72

1.63

2.95

1.01

0.94

1,4-Dichlorobenzene

$\therefore \therefore-\therefore=($ a) Magnification factors are the number of times the test treatment concentration is greater than the reference treatment concentration. When the analyte is undetected-in-one or-more replicates; the achieved detection limit value is used in the calculation. Calculations are based on dry weight-:-: concentrations. Underlined values are between 5 and $<10$ times reference site values, values shown in bold are $\geq 10$ times reference site values. 


\subsection{Discussion and Conclusions}

In this section, physical and chemical analyses, and bioassays performed on the Red Hook/Bay Ridge test sediment composites are evaluated relative to the Mud Dump Reference Site composite by Green Book Tier III guidelines and by additional guidelines provided by USACE-NYD. Tier III evaluations include water-column toxicity tests, benthic toxicity tests, and whole-sediment bioaccumulation studies. Tier III evaluations assess the impact of contaminants in the dredged material on marine organisms to determine whether there is potential for the material to have an unacceptable environmental effect during ocean disposal. The Green Book and USACE-NYD provide the following guidance for determining whether the proposed dredged material is unacceptable for ocean disposal based on the Tier III test:

- Water-Column Toxicity. The limiting permissible concentration (LPC) of dissolved plus suspended contaminants cannot exceed 0.01 of the acutely toxic concentration at the boundaries of the disposal site within the first $4 \cdot h$-after disposal, or at any point in the marine environment after the first $4 \mathrm{~h}$. The acutely toxic concentration in this-case is taken to be the median lethal concentration $\left(\mathrm{LC}_{50}\right)$; therefore, acuite toxicity in SPP tests would require at least $50 \%$ mortality in an SPP treatment to be evaluatedaccording to the Green Book. A numerical mixing model should be used to predict whether concentrations greater than 0.01 of the acutely toxic SPP concentrations are likely:to:occur beyond the boundaries of the disposal site within the first $4 \mathrm{~h}$ after disposal:

- - Benthic Acute Toxicity. The proposed dredged material does not meet the LPC for - benthic toxicity when organism survival in the-test sediment and the reference site sediment is statistically significant, and the survival in the test sediment is at least $20 \%$ lower than survival in the reference treatment for $A$ : abdita; or $10 \%$ for $M$ : bahia

- Bioaccumulation. The proposed dredged material does not meet the LPC for bioaccumulation if tissue concentrations of one or more-contaminants of-concem are-greaterthan the applicable FDA levels. Regional guidance (USACE 1981) for interpretation of bioaccumulation was also considered. When the bioaccumulation of contaminants in the dredged material exceeds that in the reference material exposures, further case-specific evaluation criteria listed in the Green Book should be consulted to determine LPC and benthic effects compliance.

Sections 4.1 through 4.4 discuss the proposed Red Hook/Bay Ridge dredged material in terms of sediment characterization and Tier III evaluations. The contribution of the Red Hook and Bay Ridge composites to water-column or benthic acute toxicity and potential for bioaccumulation relative to the Mud Dump Reference Site is also presented. 


\subsection{Sediment Physical and Chemical Characterizations}

Red Hook/Bay Ridge sediment core samples were generally black or gray-black, siltyclayey material. Five of the six stations from the Red Hook composite were predominantly sand and gravel (RH-2, $\mathrm{RH}-3, \mathrm{RH}-4, \mathrm{RH}-5$, and $\mathrm{RH}-6$ ), whereas sediment from station $\mathrm{RH}-1$ was predominantly silt and clay. The individual stations from Bay Ridge Reaches $A$ and $B$ were predominantly silts and clays with the exception of sediments from BR-B-15, 16, and 17 which were mainly sand. Sediment moisture contents ranged from $16 \%$ to $63 \%$ in individual cores from the Red Hook/Bay Ridge project areas. The dominant pesticides found in all three test sediment composites were the DDT family of compounds $(38.4 \mu \mathrm{g} / \mathrm{kg}, 70.7 \mu \mathrm{g} / \mathrm{kg}$ and $123 \mu \mathrm{g} / \mathrm{kg}$ total DDTs, respectively), followed by aldrin. At least 19 of the 22 PCB congeners analyzed were detected in the three test sediment composites, with total PCB concentrations of $528 \mu \mathrm{g} / \mathrm{kg}$ for $\mathrm{RH}$ COMP, $951 \mu \mathrm{g} / \mathrm{kg}$ for BR-A COMP and $784 \mu \mathrm{g} / \mathrm{kg}$ for BR-B COMP. All 16 PAHs analyzed were detected in Red Hook/Bay Ridge test sediment composites. Concentrations of total PAHs were similar between RH COMP and BR-B COMP, with values of $47,400 \mu \mathrm{g} / \mathrm{kg}$ and 44,700 $\mu \mathrm{g} / \mathrm{kg}$ respectively. Concentrations of total PAHs were müch lowē̄för $B R=A-C O M P$, with a value of $15,700 \mu \mathrm{g} / \mathrm{kg}$. The concentrations of 1,4-dichlorobenzeñe were $74.5 \mu \mathrm{g} / \mathrm{kg}, 145 \mu \mathrm{g} / \mathrm{kg}$, and $120 \mu \mathrm{g} / \mathrm{kg}$ (dry weight) in RH COMP, BR-A COMP and BR=B COMP, respectively:-

\subsection{Site Water and Elutriate Chemical Characterization}

Concentrations of metals were variable among the Sequim Bay.control water, the Mud . - .

-Dump Site water and the Red Hook/Bay Ridge Site water samples. The-highest metals concentrations were found in the sample from station $\mathrm{RH}-3$; whereas elutriate concentrations of metals were similar among the Red Hook/Bay Ridge samples: Chromium; $\mathrm{Cu}$, and $\mathrm{Zn}$ were the three metals found in the highest concentrations for both the site water and elutriate samples. In most cases the concentration of metals in the elutriate preparation are less than the metals values in the site water. The majority of pesticides and PCB congeners were not detected in the site water samples. The elutriate sample from BR-B COMP had the highest concentrations of pesticides and PCB congeners. The most elevated concentrations of compounds included the DDT family of compounds, aldrin, dieldrin, PCB congeners 18, 44, 66, 52, and 101.

\subsection{Toxicity}

The contribution of the Red Hook and Bay Ridge composites to benthic acute toxicity relative to the Mud Dump Reference Site is presented in Figure 4.1. Acute toxicity and at least a $20 \%$ increase in mortality relative to the Mud Dump Reference Site sediment was found in 


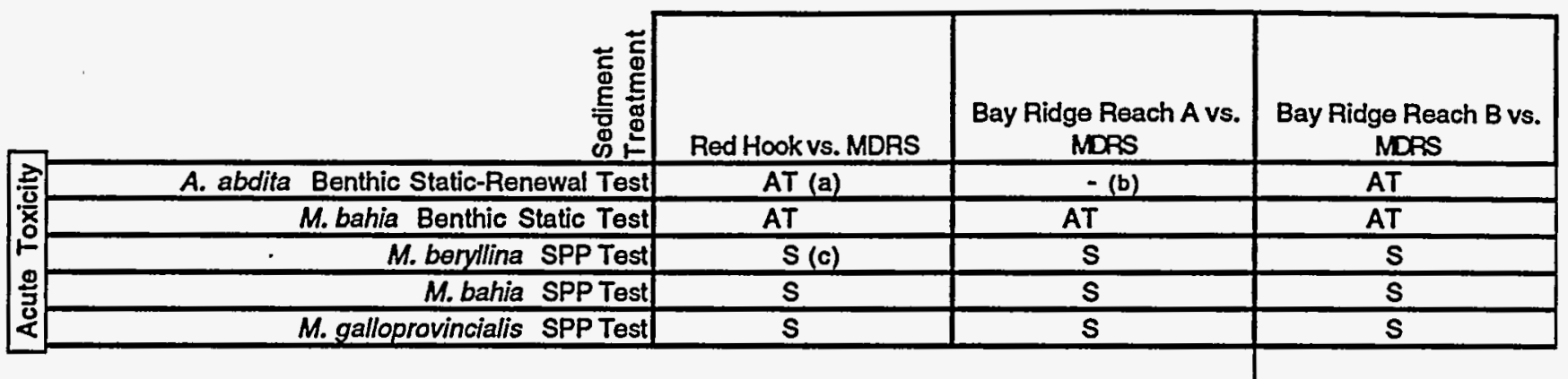



\begin{tabular}{|c|c|c|c|c|c|c|c|}
\hline \multirow{5}{*}{ 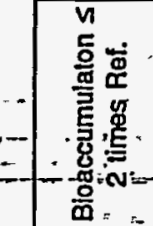 } & \# of Metals (9 total) & 2 & .1 & 1 & 1 & 1 & 1 \\
\hline & \# of Pesticide compounds (15 total) & $\because$ & - & $z \ldots=\ldots$ & $\therefore$ & $\therefore$ & - \\
\hline & \# of PCB congeners (22 total) & $\because$ & - & 9 & $\therefore 2$ & $=$ & - \\
\hline & $\#$ of PAH compounds ( 17 or 18 total) & - & - & $2-2$ & $\cdots 5-$ & -- & 2 \\
\hline & 1,4-dichlorobenzene & $\therefore$ & - & - & - & $\ldots$ & - \\
\hline
\end{tabular}

\begin{tabular}{|c|c|c|c|c|c|c|c|}
\hline 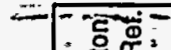 & \# of Metals $(9$ total) & - & - & 2 & $\because$ & 2 & - \\
\hline$-1=\frac{5}{3} n$ & \# of Pesticide compounds (15 total) & $\overline{2}$ & $3-$ & $\ldots 1-\cdots$ & $=-3$ & $=3$ & 2 \\
\hline$E=$ & \# of PCB congeners (22 total) & -3 & 9 & $\because 4=0$ & $x=6$ & 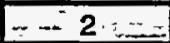 & 6 \\
\hline-6 & \# of PAH compounds ( 17 or 18 total) & 1 & 3 & 4 & 4 & 3 & 1 \\
\hline 品 & 1,4-dichlorobenzene & $\because$ & - & - & - & - & - \\
\hline \multirow{5}{*}{$=$} & \# of Metals $(9$ total) & - & - & - & - & $\overline{-}$ & - \\
\hline & \# of Pesticide compounds (15 total) & 1 & 2 & 4 & 2 & 3 & 2 \\
\hline & \# of PCB congeners (22 total) & 3 & - & 2 & 2 & 4 & 5 \\
\hline & \# of PAH compounds ( 17 or 18 total) & 2 & 2 & 3 & $=$ & 2 & 4 \\
\hline & 1,4-dichlorobenzene & - & - & - & - & - & - \\
\hline
\end{tabular}

\begin{tabular}{|c|c|c|c|c|c|c|c|}
\hline \multirow{5}{*}{ 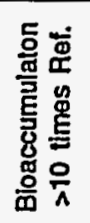 } & \# of Metals (9 total) & - & - & - & - & - & - \\
\hline & \# of Pesticide compounds (15 total) & 1 & 1 & - & 1 & 1 & 3 \\
\hline & \# of PCB congeners (22 total) & 5 & 8 & 8 & 6 & 8 & 8 \\
\hline & \# of PAH compounds (17 or 18 total) & 14 & 12 & 7 & $=$ & 12 & 9 \\
\hline & 1,4-dichlorobenzene & - & - & - & - & . & - \\
\hline
\end{tabular}

(a) AT Acutely toxic; significantly different from reference and mortality greater than $20 \%$ difference (10\%) mysids greater than reference.

(b) - No significant difference/no significant bioaccumulation at this level.

(c) S Significantly different mortality between $0 \%$ and $100 \%$ SPP.

(d) Number of compounds bloaccumulating in tissues of test species.

FIGURE 4.1. Summary Matrix of Red Hook/Bay Ridge Sediment Toxicity and Bioaccumulation in Comparison with the Mud Dump Reference Site 
A. abdita test for both RH COMP and BR-B COMP. Acute toxicity and a at least $10 \%$ increase in mortality relative to the Mud Dump Reference Site sediment was found in the M. bahia test for all three Red Hook/Bay Ridge test sediment composites. Therefore, both the Red Hook composite and the two Bay Ridge sediment composites did not meet the LPC for benthic toxicity to these test organisms at the Mud Dump Site, if the observed effects were due to persistent contaminants.

The water-column toxicity of each composite is also presented in Figure 4.1. In water-column toxicity tests, acute toxicity was found for all three test sediment composites and for the three species tested. For RH COMP, the $\mathrm{LC}_{50}$ s were $60 \%$ SPP for $M$. beryllina, $>100 \%$ SPP for $M$. bahia and $58 \%$ for M. galloprovincialis. The $\mathrm{EC}_{50}$ for M. galloprovincialis normal development, a more sensitive measure than survival, was $23.0 \%$ for the Red Hook composite. Based on acute mortality results for RH COMP $\left(\mathrm{LC}_{50} \mathrm{~s}\right)$, the LPCs for water-column effects outside of the disposal site boundaries after $4 \mathrm{~h}$ is $0.60 \%$ SPP for M. beryllina, $>1.0 \%$ SPP for $M$. bahia and $0.58 \%$ for M. galloprovincialis. A projection of SPP concentrations exceeding this value after $4 \mathrm{~h}$ at the Mud Dump Site would be unacceptable. The $\mathrm{LC}_{50}$ results for:BR-A COMP were $30 \%$ for $M$. beryllina, $60 \%$ for $M$. bahia, and $65 \%$ for M. galloprovincialis. The $\mathrm{EC}_{50}$ for this composite was $21 \%$ SPP. Based on acute mortality results for BR-A COMP $\left(L_{50} s\right)$, the $L \mathrm{LES}$ for water-column effects outside of the disposal site-boundaries after $4 \mathrm{~h}$ is:0:30\%:SP:for $M-b$ SPP for M. bahia and $0.65 \%$ for M. galloprovincialis. Water-column-tóxicity results for BR-B COMP, expressed as $L_{50}$ results, were $19 \%$ SPP for $M=$-beryllina $70 \%$ SPP for $M$. bahia; and $7.1 \%$ for $M$. galloprovincialis.- The calculated $E \epsilon_{50}$-for-the $M$-galloprovincialis-test was $21 \%$ SPP.

- The LPCs for BR-B COMP are $0.19 \%$ SPP, $0.70 \%$ SPP, and $0.71 \%$ SPP-for the-M. beryllina, the M. bahia, and the M. galloprovincialis tests, respectively.

\subsection{Bioaccumulation}

Results of $N$. virens and $M$. nasuta tissue analyses from test sediment bioaccumulation studies were compared with action levels for poisonous or deleterious substances in fish and shellfish for human consumption published by the FDA and with USACE-NYD (1981) bioaccumulation matrix tables. Concentrations of $\mathrm{As}, \mathrm{Cd}, \mathrm{Cr}, \mathrm{Ni}$, and $\mathrm{Pb}$ were also compared with the FDA level of concern for chronic shellish consumption (FDA 1993a, 1993b, 1993c, 1993d, 1993e) for each of these metals. Results of tissue analyses from test sediment bioaccumulation studies were also compared with contaminant concentrations in tissues of organisms similarly exposed to Mud Dump Reference Site sediment. 
When M. nasuta and N. virens were exposed to Red Hook/Bay Ridge test sediment composites in 28-day bioaccumulation tests, concentrations of some contaminants were elevated in tissues of both species relative to levels in organisms exposed to the Mud Dump Reference Site. Concentrations of all metals (except $\mathrm{Cd}$ and $\mathrm{Zn}$ ) were higher in $M$. nasuta than in $N$. virens. Pesticide and PCB concentrations were similar in the two species, with some analytes higher in the $N$. virens, and others higher in the M. nasuta. Sediments from BR-B COMP had overall higher concentrations of pesticides and PCBs in $N$. virens tissues relative to $M$. nasuta tissues. Concentrations of most PAHs were higher in $M$. nasuta tissues, many compounds by factors of 4 to 10 or more times, than in $N$. virens. Table 4.1 compares the NYD bioaccumulation matrix guidance levels (USACE 1981), FDA action levels for poisonous or deleterious substances in fish and shellfish for human consumption for selected pesticides, and FDA levels of concern for chronic shellfish consumption for selected metals with the mean concentration of these contaminants found in tissues of each test species. The $M$. nasuta and $N$. virens tissues exposed to Red Hook/Bay Ridge test sediments had tissue body burdens that were lower than the FDA levels for each of these selected contaminants. .

When tissue burdens of organisms exposed to Red Hook/Bay Ridge test sediment composites were compared with those exposed to the-Mud-Dump Referrence-Site, the tissue burdens were statistically significant and higher for metals, pesticides,-RCBs;-and-PAHs: Therefore, Red Hook/Bay Ridge sediment requires further-evaluation to determine LPC and benthic effects compliance. Figure 4.1 shows bioaccumulation potential as the:number of contaminants that were elevated in the tissues of $M$. nasuta and $N$. virens at certain magnitudes (i.e., 2, 5, or 10 times) above tissues of each species exposed to the reference sediment. This format clearly indicates where and to what degree similar classes of contaminants were accumulated in both species. 
Table 4.1. Comparison of Contaminant Concentrations in M. Nasuta and N. virens Tissues Exposed to Proposed Dredged Material for Red Hook/Bay Ridge Project Area with FDA Action Levels and Levels of Concern

\begin{tabular}{|c|c|c|c|c|c|c|c|}
\hline \multirow[b]{2}{*}{ Substance } & \multirow[b]{2}{*}{$\begin{array}{l}\text { Guidance Level } \\
\text { (mg/kg wet wt) }\end{array}$} & \multicolumn{3}{|c|}{$\begin{array}{c}\text { Concentrations(a) } \\
\text { in } M \text {. nasuta Tissues } \\
\text { (ma/kg wet wt) }\end{array}$} & \multicolumn{3}{|c|}{$\begin{array}{l}\text { Concentrations(a) } \\
\text { in } N \text {. virens Tissues } \\
\text { (ma/kg wet wt) }\end{array}$} \\
\hline & & $\begin{array}{l}\overline{\mathrm{RH}} \\
\text { COMP }\end{array}$ & $\begin{array}{l}\text { BR-A } \\
\text { COMP }\end{array}$ & $\begin{array}{l}\text { BR-B } \\
\text { COMP } \\
\end{array}$ & $\begin{array}{l}\text { RH } \\
\text { COMP }\end{array}$ & $\begin{array}{l}\text { BR-A } \\
\text { COMP } \\
\end{array}$ & $\begin{array}{r}\text { BR-B } \\
\text { CQMP } \\
\end{array}$ \\
\hline $\begin{array}{l}\text { Chlordane(b) } \\
\text { Total DDT(d) } \\
\text { Dieldrin + Aldrin } \\
\text { Heptachlor }\end{array}$ & $\begin{array}{l}0.3(c) \\
5.0(c) \\
0.3(c)\end{array}$ & $\begin{array}{l}0.0005 \\
0.010 \\
0.002\end{array}$ & $\begin{array}{l}0.0008 \\
0.009 \\
0.003\end{array}$ & $\begin{array}{l}0.0 \\
0.0 \\
0.0\end{array}$ & $\begin{array}{l}0.0008 \\
0.010 \\
0.004\end{array}$ & $\begin{array}{l}008 \\
08 \\
03\end{array}$ & $\begin{array}{l}0.0013 \\
0.023 \\
0.006\end{array}$ \\
\hline $\begin{array}{l}\text { Heptachlor epoxide } \\
\text { Total PCBs(e) }\end{array}$ & $\begin{array}{l}0.3(c) \\
2.0(c)\end{array}$ & $\begin{array}{l}0.0004 \\
0.063\end{array}$ & & $\begin{array}{l}0.0002 \\
0.113\end{array}$ & $\begin{array}{l}0.0 \\
0.1\end{array}$ & & $\begin{array}{l}0.0002 \\
0.214\end{array}$ \\
\hline $\begin{array}{l}\text { Arsenic } \\
\text { Cadmium } \\
\text { Chromium } \\
\text { Lead } \\
\text { Nickel } \\
\text { Methyl Mercury }\end{array}$ & $\begin{array}{c}86(f) \\
3.7(f) \\
13(f) \\
1.7(f) \\
80(f) \\
1.0(f)\end{array}$ & $\begin{array}{l}7.85 \\
0.059 \\
0.656 \\
1.40 \\
1.04 \\
0.039(\mathrm{~g})\end{array}$ & $\begin{array}{l}6.88 \\
0.067 \\
-1.14 \\
1.57 \\
.1 .16 \\
0.037(\mathrm{~g})\end{array}$ & $\begin{array}{l}7.08 \\
0.070 \\
0.96 \\
1.43 \\
0.96 \\
0.036(\mathrm{~g})\end{array}$ & $\begin{array}{l}4.32 \\
0.077 \\
0.364 \\
0.415 \\
0.388 \\
0.039 \text { (g) }\end{array}$ & $\begin{array}{l}8 \\
71 \\
41 \\
01 \\
48 \\
25(g)\end{array}$ & $\begin{array}{l}3.85 \\
0.075 \\
0.360 \\
0.375 \\
0.393 \\
0.032(\mathrm{~g})\end{array}$ \\
\hline $\begin{array}{l}\text { Total DDT(d) } \\
\text { Total PCBs( }(\theta) \\
\text { Total PCBs( }(\theta) \\
\text { - Mercury (total) } \\
\text { Cadmium }\end{array}$ & $\begin{array}{l}0.04(h) \\
0.40(h) \\
0.10(h) \\
0.20(h) \\
0.30(h)\end{array}$ & $\begin{array}{l}0.010 \\
\text { NA(i) } \\
0.063 \\
0.0390 \\
0.059\end{array}$ & $\begin{aligned} & =0.00 \overline{9} \\
& N A \\
& 0.089 \\
= & 0.037 \\
= & 0.067\end{aligned}$ & $\begin{aligned} & 0.013= \\
& \therefore N A \\
& \therefore= 0.113 \\
&= 0.036 \\
& 0.070\end{aligned}$ & $\begin{array}{c}0.010 \\
0.141 \\
N A \\
0.039 \\
0.077\end{array}$ & $\begin{array}{l}0.102 . \\
N A \\
0.025 \\
0.071 .\end{array}$ & $\begin{array}{l}0.214 \\
N A \\
0.032 \\
0.075\end{array}$ \\
\hline
\end{tabular}

(a) Concentration shown is the mean of five replicate tissue analysis: If any constituents were

- undetected, one-half of the detection limit was used in calculation of the mean concentration.

(b) Sum of $\alpha$-chlordane and trans-nonachlor only, whereas FDA action level is a sum of nine chlordane analytes.

(c) FDA Action Levels for Poisonous and Deleterious Substances in Fish and Shellfish for Human Food.

(d) Sum of mean values for 2,4'-DDT, 4,4'-DDT, 2,4'-DDE, and 4,4'-DDE, 2,4'-DDD, and 4,4'-DDD. One-half of the detection limit was used in the summation when miean values were undetected in a replicate.

(e) Total PCBs $=2.0(x)$, where $x$ equals the sum of the 22 congeners. One-half of the detection limit was used in summation when mean values were undetected in a replicate.

(f) FDA Level of concem for chronic shellfish consumption.

(g) Value reported here is for total mercury.

(h) NYD bioaccumulation matrix value designated in 1981 (USACE 1981).

(i) Not applicable. 


\subsection{References}

Barrows, E.S., M.R. Pinza, W.W. Gardiner, N.P. Kohn, B.D. Gruendell, H.L. Mayhew, J.Q. Word, and L.B. Rosman. 1996. Evaluation of Dredged Material Proposed for Ocean Disposal from Federal Projects in New York and New Jersey and the Military Ocean Terminal (MOTBY). Prepared for Department of the Army, U.S. Army Corps of Engineers, New York District, Water Quality Branch, by Battelle/Marine Sciences Laboratory, Pacific Northwest National Laboratory, Richland, Washington. (In preparation.)

Bligh, E.G., and W.J. Dyer. 1959. "A Rapid Method of Total Lipid Extraction and Purification." Canadian Journal of Biochemistry and Physiology. 37:8 911-917.

Bloom, N.S., and E.A. Crecelius. 1983. "Determination of Mercury in Seawater at Sub-Nanogram per Liter Levels." Mar. Chem. 14:49-59.

Dunnett, C.W. 1964. "New Tables for Multiple Comparisons with a Control." Biometrics 20:482-491.

EPA (U.S. Environmental Protection Agency). 1986. Determination of Total Organic Carbon in Sediment. U.S. Environmental Protection Agency, Region II, Environmental Services Division, Monitoring Management Branch, Edison, New-Jersey.

EPA (U.S. Environmental Protection Agency). 1990: Test Methods för Evaluating Solid Waste, Physical/Chemical Methods, SW-846: 3rd Ed. U.S. Environmental Protection Agency. Washington, D.C.

EPA (U.S. Environmental Protection Agency). 1991. Methods for the Determination of Metals in Environmental Samples.- EPA/600/4-91-010. U.S. Environmental Protectión Agency, Office of Research and Development; Washington, D.C.

EPA/USACE (U.S. Environmental Protection Agency/U.S.-Army Corps of-Engineers). 1991. Evaluation of Dredged Material Proposed for Ocean Disposal (Testing Manual). EPA-503/891/001. U.S. Environmental Protection Agency, Office of Marine and Estuarine Protection, Washington, D.C.

EPA (U.S. Environmental Protection Agency). 1994a. Methods for Assessing the Toxicity of Sediment-associated Contaminants with Estuarine and Marine Amphipods. EPA/600/R-94-025. U.S. Environmental Protection Agency, Office of Research and Development, Washington, D.C.

EPA (U.S. Environmental Protection Agency). 1994b. Memorandum: Recommendations for Conducting Sediment Toxicity Tests with Mysidopsis bahia when Ammonia may be present at Toxic Levels. June 14, 1994. U.S. Environmental Protection Agency, Office of Science and Technology, Washington, D.C.

FDA (U.S. Food and Drug Administration). 1993a. Guidance Document for Arsenic in Shellfish. U.S. Food and Drug Administration, Center for Food Safety and Applied Nutrition, Washington, D.C.

FDA (U.S. Food and Drug Administration). 1993b. Guidance Document for Cadmium in Shellfish. U.S. Food and Drug Administration, Center for Food Safety and Applied Nutrition, Washington, D.C. 
FDA (U.S. Food and Drug Administration). 1993c. Guidance Document for Chromium in Shellfish. U.S. Food and Drug Administration, Center for Food Safety and Applied Nutrition, Washington, D.C.

FDA (U.S. Food and Drug Administration). 1993d. Guidance Document for Nickel in Shellfish. U.S. Food and Drug Administration, Center for Food Safety and Applied Nutrition, Washington, D.C.

FDA (U.S. Food and Drug Administration). 1993e. Guidance Document for Lead in Shellfish. U.S. Food and Drug Administration, Center for Food Safety and Applied Nutrition, Washington, D.C.

Finney, D. J. 1971. Probit Analysis. 3rd Ed. Cambridge University Press, Boston, Massachusetts.

NOAA (National Oceanic and Atmospheric Administration). 1993. Sampling and Analytical Methods of the National Status and Trends Program National Benthic Surveillance and Mussel Watch Projects 1984-1992. Volume IV. Comprehensive Descriptions of Trace Organic Analytical Methods. G. G. Lauenstein and A.Y. Cantillo, eds. NOAA Technical Memorandum NOS ORCA 71. National Oceanic and Atmospheric Administration, Coastal Monitoring and Bioeffects Assessment Division, Office of Ocean Resources Conservation and Assessment, Silver Spring, Maryland.

NYSDEC (New York State Department of Environmental Conservation). 1992. Analytical Method for the Determination of PCB congeners by Fused Silica Capillary Column Gas Chromatography with Electron Capture Detector: NYSDEC Method 91-11. New York State Department of Environmental Conservation;; Albany; New York. .

Plumb, R: H., Jr.- 1981:- -Procedure for Handling and Chemical Analysis of Sediment and Water Samples. Tech.-Rep.:EPAVCE-81-1:- Prepared by-GreattEakes Laboratory, State University College at Buffalo; New York, for the U.S. Eñvironmentäl:Protection Agency/U.S. Army Corps of Engineers. Technical Committee on. Criteria for Dredged and.Fill Material. U.S. Amy Engineer . Waterways Experiment Station, Vicksburg, Mississippi.

Randall, R. C. 1988. Lipid Standard Operating Procedure, Modified Bligh/Dyer. U.S. Environmental Protection. Agency Office of Research and Development, Environmental Research, Washington D.C.

USACE (U.S. Army Corps of Engineers). 1970 (Revised 1980). Engineer Manual, Engineering and Design, Laboratory Soils Testing. EM 110-2-1906. Headquarters, Department of the Army, Office of the Chief of Engineers, Washington, D.C.

USACE (U.S. Army Corps of.Engineers). 1981. Memorandum: Final Interpretive Guidance for Bioaccumulation of Petroleum Hydrocarbons, DDT, Cadmium, and Mercury in the New York Bight. USACE Office of the Chief of Engineers. April 7, 1981.

USACE-NYD/EPA Region II (U.S. Army Corps of Engineers, New York District/U.S.

Environmental Protection Agency, Region II). 1992. Guidance for Performing Tests on Dredged Material Proposed for Ocean Disposal. 18 December 1992 Draft. U.S. Amy Corps of Engineers, New York District and U.S. Environmental Protection Agency, Region II. New York, New York. 


\section{Appendix A.}

Quality Assurance/Quality Control Data for Sediment Physical/Chemical Analyses, Red Hook and Bay Ridge Channels 

PROGRAM: $\quad$ New York/New Jersey Red Hook/Bay Ridge Projects

PARAMETER: $\quad$ Grain Size, Bulk Density, Specific Gravity, and Total Solids

LABORATORY: $\quad$ Soil Technology, Bainbridge island, Washington

MATRIX: Sediment

\section{QA/QC DATA QUALITY OBJECTIVES}

$\begin{array}{lccc}\text { Grain Size } & \begin{array}{c}\text { Reference } \\ \text { Method }\end{array} & \begin{array}{c}\text { Target } \\ \text { Relative } \\ \text { Precision }\end{array} & \begin{array}{c}\text { Detection } \\ \text { Limit }\end{array} \\ \text { Bulk Density } & \text { \&D-422 } & & 520 \% \\ \text { Specific Gravity } & \text { ASTM-D854 } & \leq 20 \% & 1.0 \% \\ \text { Total Solids } & \text { EM-1110-2-1906 } & \leq 20 \% & \text { NA } \\ & \text { Plumb 1981 } & \text { NA } & \text { NA }\end{array}$

METHOD Grain size was measured for four fractions using a combination of sieve and pipet techniques, following ASTM method D-2217 and D-422 for wet sieving. Bulk density. was measured in accordance with ASTM method D-854. Specific gravity was measured in accordance with Method EM 1110-2-1906 (USACE 1970).

Total solids was measured gravimetrically following Plumb (1981).

HOLDING TIMES Samples were analyzed within the 6-month holding time.

DETECTION LIMITS Target detection limits of $1.0 \%$ were met for each sample.

METHOD BLANKS Not applicable.

MATRIX SPIKES Not applicable.

REPLICATES Four samples were analyzed in triplicate for grain size and total solids. Precision was measured by calculating the relative standard deviation (RSD) among triplicate results. The RSDs ranged from $0 \%$ to $9 \%$ for grain size and from $0 \%$ to $2 \%$ for total solids, indicating acceptable precision. One sample was analyzed in triplicate for bulk density and specific gravity. The RSDs for this sample ranged from $0 \%$ to $1 \%$, again indicating acceptable precision.

SRM Not applicable.

A. iii 
QAIQC SUMMARY GRAIN SIZE (contd)

\section{REFERENCES}

ASTM D-2217. Standard Method for Wet Preparation of Soil Samples for Particle-size Analysis and Determination of Soil Constants.

ASTM D-422. Standard Method for Particle-size Analysis of Soils

ASTM D-854. Standard Method for Specific Gravity

USACE (U.S. Army Corps of Engineers). 1970. Engineering and Design Laboratory Soils Testing. EM1110-2-1906, Vicksburg, Mississippi.

Plumb, R. H., Jr. 1981. Procedure for Handling and Chemical Analysis of Sediment and Water Samples. Tech. Rep. EPAUUSACE-81-1. Prepared by Great Lakes Laboratory, State University College at Buffalo, New York, for the U.S. Environmental Protection Agency/U.S. Army Corps of Engineers Technical

Committee on Criteria for Dredged and Fill Material. U.S. Army Engineer Waterways Experiment Station, Vicksburg, Mississippi. 
PROGRAM: $\quad$ New York/New Jersey Red Hook/Bay Ridge Projects

PARAMETER: Total Organic Carbon

LABORATORY: $\quad$ Applied Marine Sciences, Inc., College Station, Texas

MATRIX: $\quad$ Sediment

\section{QA/QC DATA QUALITY OBJECTIVES}

$\begin{array}{lccc}\begin{array}{c}\text { Reference } \\ \text { Method }\end{array} & \begin{array}{c}\text { Target } \\ \text { Range of } \\ \text { Recovery }\end{array} & \begin{array}{c}\text { Relative } \\ \text { Precision }\end{array} & \begin{array}{c}\text { Detection } \\ \text { Limit (\%) }\end{array} \\ 1986 & \leq 20 \% & \text { s10\% } & 0.1\end{array}$

-. METHOD - . Total organic carbon is the amount of non-volatile, partially volatile, volatile; and particulate organic carbon compounds in a sample. Each sample was dried and ball:milled to a fine powder. Before combustion; inorganic carbon in the sample : was removed by acidification. The TOC was then determined by-measuring the carbon dioxide released during combustion of the sample.

HQLDING TIMES . The họlding time of 6 months was met for all TOC analyses.

DETECTION LIMITS - Target detection limits of $0.1 \%$ were met for all samples.

METHOD BLANKS Not applicable.

MATRIX SPIKES Not applicable.

REPLICATES Five samples were analyzed in triplicate. Precision was measured by calculating the relative standard deviation (RSD) among the triplicate results. All RSDs were between $1 \%$ and $4 \%$, indicating acceptable precision.

SRMs The standard reference material 1941a was analyzed with each batch of analytical samples. The non-certified value for this SRM is $4.8 \pm 1.2$. The SRM values obtained in each analytical batch were within this non-certified range.

\section{REFERENCES}

U.S. Environmental Protection Agency (EPA). 1986. Determination of Total Organic Carbon in Sediment. U.S. EPA Region II, Environmental Services Division, Monitoring Management Branch, Edison, New Jersey. 
QA/QC SUMMARY

PROGRAM: $\quad$ New York/ New Jersey Red Hook/Bay Ridge Projects

PARAMETER: Metals

LABORATORY: Battelle/Marine Sciences Laboratory, Sequim, Washington

MATRIX: $\quad$ Sediment

QA/QC DATA QUALITY OBJECTIVES

\begin{tabular}{|c|c|c|c|c|c|c|}
\hline & Method & $\begin{array}{c}\begin{array}{c}\text { Range } \\
\text { of } \\
\text { Recovery }\end{array} \\
\end{array}$ & $\begin{array}{c}\text { SRM } \\
\text { Accuracy }\end{array}$ & $\begin{array}{c}\text { Relative } \\
\text { Precision } \\
\end{array}$ & $\begin{array}{c}\text { Target } \\
\text { Detection Limit } \\
\text { (mg/kg dry wt) }\end{array}$ & \\
\hline Arsenic & ICP/MS & $75-125 \%$ & $\leq 20 \%$ & $\leq 20 \%$ & 0.1 & \\
\hline Cadmium & ICP/MS & $75-125 \%$ & $\leq 20 \%$ & $\leq 20 \%$ & 0.01 & \\
\hline Chromium & ICP/MS & $75-125 \%$ & $\leq 20 \%$ & $\leq 20 \%$ & 0.02 & \\
\hline Copper & ICP/MS & $75-125 \%$ & $-\leq 20 \%$ & $\leq 20 \%$ & 0.1 & \\
\hline Lead & ICP/MS & $75-125 \%$ & $\leq 20 \%$ & $\leq 20 \%$ & 0.1 & \\
\hline Mercury & CVAA: = & $75-125 \%$ & $\leq 20 \%$ & $\leq 20 \%$ & 0.02 & - \\
\hline Nickel & ICP/MS & $75-125 \%$ & $\leq 20 \%$ & $\leq 20 \%$ & 0.1 & $\therefore$ \\
\hline Silver & ICP/MS & $75-125 \%$ & $\leq 20 \%$ & $\leq 20 \%$ & 0.1 & \\
\hline Zinc & ICP/MS & $75-125 \%$ & $\leq 20 \%$ & $\leq 20 \%$ & 0.1 & \\
\hline
\end{tabular}

SAMPLE CUSTODY - Eight-samples were received on 4/11/95, logged into the Battelle system and stored frozen until extraction.

METHOD

Nine metals were analyzed: silver (Ag), arsenic (As), cadmium (Cd), chromium $(\mathrm{Cr})$, copper $(\mathrm{Cu})$, mercury $(\mathrm{Hg})$, nickel $(\mathrm{Ni})$, lead $(\mathrm{Pb})$ and żinc $(\mathrm{Zn})$. $\mathrm{Hg}$ was analyzed using cold-vapor atomic absorption spectroscopy (CVAA) according to the method of Bloom and Crecelius (1983). The remaining metals were analyzed by inductively coupled plasma mass spectrometry (ICP/MS) following EPA Method 200.8 (EPA 1991).

To prepare sediment samples for analysis, they were freeze-dried and blended in a Spex mixer-mill. Approximately $5 \mathrm{~g}$ of mixed sample was ground in a ceramic ball mill. For ICP/MS and CVAA analyses, 0.2- to 0.5-g aliquots of dried homogenous sample were digested using two different methods. One method used hot nitric acid following a modified version of EPA method 200.2 (EPA 1991). The modification involved precluding the addition of hydrochloric acid during digestion. This was to avoid interferences caused by the formation of argon chloride in the ICP-MS which interferes with the quantitation of arsenic which has the same mass. The second digestion was an Aqua Regia method. This digestate was analyzed only for Ag because it precludes precipitation of $\mathrm{AgCl}$, which occurs in samples that are from marine environments.

A. vi 


\section{QA/QC SUMMARY METALS (contd)}

HOLDING TIMES Samples were frozen to $-80^{\circ} \mathrm{C}$ and subsequently freeze-dried. Samples were all analyzed within 180 days of collection. The following list summarizes all analysis dates:

Task
Aqua Regia Digestion
Nitric Digestion
ICP-MS
CVAA-Hg

\begin{tabular}{l} 
Date Performed \\
\hline $4 / 26 / 95$ \\
$5 / 1 / 95$ \\
$5 / 9-10 / 95$ \\
$5 / 9 / 95$.
\end{tabular}

DETECTION LIMITS Target detection limits were exceeded for some metals; however, metals were detected above the MDLs in all samples. MDLs were determined by multiplying the standard deviation of the results of a minimum of seven replicate low level sediment spikes by the student $t$ value at the 99th percentile (3.142).

METHOD BLANKS One method blank was analyzed. No metals were detected above the MDL in the blank with the exception of $\mathrm{Cr}$ and $\mathrm{Hg}$. The $\mathrm{Cr}$ blank value was less than three ... times the MDL and all sample values were detected at levels greater than five times the blank concentration so no data were flagged. All data were blank corrected.

MATRIX SPIKES One-sample was spiked with all nine metals. Recoveries of all metals were within

REPLICATES - - - One sample was digested and analyzed in triplicate. Precision for-triplicate analy.ses is reported by calculating the relative standard deviation:(RSD) between -the replicate results. RSD values ranged from 1 to $5 \%$, within the QC limits of $= \pm 20 \%$, with the exception of $\mathrm{Pb}$, which had an RSD of $59 \%$. Two of the three -replicate values for this sample were similar with the third replicate high. No -. apparent analytical cause was evident, and since other $Q C$ for lead was acceptable, no further action was taken.

SRM

SRM 1646a (estuarine sediment from the National Institute of Standards and Technology [NIST]), was analyzed for all metals. Only results for $\mathrm{Cd}, \mathrm{Pb}$ and $\mathrm{Hg}$ were within $\pm 20 \%$ of the certified value ( $\mathrm{Ag}$ is not certified). Values for the remaining metals were low, because the digestion method used is not as strong as the method (perchloric and hydrofluoric acids) used to certify the SRM; thus the results for this analysis should not be expected to match the SRM certified values. Therefore, no corrective actions were taken.

\section{REFERENCES}

Bloom, N.S., and E.A. Crecelius. 1983. Determination of Mercury in Seawater at Sub-Nanogram per Liter Levels. Mar. Chem. 14:49-59.

EPA (U.S. Environmental Protection Agency). 1991. Methods for the Determination of Metals in Environmental Samples. EPA-600/4-91-010. Environmental Services Division, Monitoring Management Branch, Washington D.C. 
PROGRAM: New York/New Jersey Red Hook/Bay Ridge Projects

PARAMETER: $\quad$ PCB Congeners/Chlorinated Pesticides

LABORATORY: Battelle/Marine Sciences Laboratory, Sequim, Washington

MATRIX: $\quad$ Sediment

QA/QC DATA QUALITY OBJECTIVES

\begin{tabular}{cccccc}
$\begin{array}{c}\text { Reference } \\
\text { Method }\end{array}$ & $\begin{array}{c}\text { Surrogate } \\
\text { Recovery }\end{array}$ & $\begin{array}{c}\text { Spike } \\
\text { Recovery }\end{array}$ & $\begin{array}{l}\text { Relative } \\
\text { Precision }\end{array}$ & $\begin{array}{c}\text { Target } \\
\text { Detection Limit } \\
\text { fug/kg dry wt. }\end{array}$ \\
\cline { 1 - 1 } GCIECD & & $30-150 \%$ & $50-120 \%$ & $530 \%$ & 1.0
\end{tabular}

SAMPLE CUSTODY Eight samples were received on 4/11/95, logged into the-Battelle system and stored frozen at $-20^{\circ} \mathrm{C}$ until extraction.

$=$ METHOD

HOLDING TIMES

DETECTION LIMITS
A 20 gram (wet wt) aliquot of sediment was extracted-with methylene chloride ....... using the roller technique under ambient conditions following a procedure based :- on methods used by the National Oceanic and Atmosphèric Adiministrátiōn-for its :- - Status and Trends Program (NOAA 1993). Samples were then cleaned using = : silica/alumina ( $5 \%$ deactivated) chromatography-followed by HPLC cleanup (NOAA 1993). Extracts were analyzed for 15 chlorinated-pesticides and-22individual $\mathrm{PCB}$ congeners using gas chromatography/electron capture detection (GC/ECD) following a procedure based on EPA Method:8080 (EPA 1986). The -column used was a J\&W DB-17, and.the confirmatory column was a-DB=1701, both capillary columns $(30 \mathrm{~m} \times 0.25 \mathrm{~mm}$ I.D.).

Samples were extracted on 5/3/95. Extracts were analyzed by GC/ECD from $5 / 18-19 / 95$, within the established holding time of 40 days.

Target detection limits were met for all PCBs and pesticides. MDLs were determined from multiplying the standard deviation of seven spiked replicates of a representative clean marine sediment by the student $t$ value(3.142). A MDL verification was performed consisting of four spiked replicate samples of a representative clean sediment. MDL verification values were determined by multiplying the standard deviation of the four replicate spike results by 4.54 . All MDL verification results were below the target detection limit. 


\section{QA/QC SUMMARY PCB CONGENERS/PESTICIDES (contd)}

METHOD BLANKS One method blank was extracted. No PCB congeners or pesticides were detected above the MDL in the method blank.

SURROGATES Two compounds, PCB congeners 103 and 198, were added to all samples prior to extraction to assess the efficiency of the analysis. Sample surrogate recoveries were all within the QC guidelines of $30 \%$ to $150 \%$.

MATRIX SPIKES Five out of the twenty two congeners and eleven of the fifteen pesticides were spiked into one sample. Matrix spike recoveries ranged from $90 \%$ to $174 \%$. Three pesticides and three congeners exceeded the QC range of $5 \%$ to $120 \%$. However, all recoveries, except Endosulfan II, that were outside of the control limits were for compounds that were spiked from one to eight times below the native levels; therefore, no corrective action was taken.

REPLICATES

One sample was analyzed in triplicate. Precision was measured by calculating the relative standard deviation (RSD) between the replicate results. RSDs for all detectable values were below the target precision goal of $\leq 30 \%$ indicating acceptable precision.

SRMs

One SRM, 1941a, a marine sediment obtained by the National Institute for Science and Technology (NIST), was analyzed with the samples. Thirteen of the twenty two PCB congeners and five of the fifteen pesticide compounds analyzed are certified. Four pesticides and 10 congeners-were detected within $30 \%$ of the certified mean. Two of the pesticides are certified at levels less than 10 times the MDL. Only one PCB congener was detected at greater than $50 \%$ difference from the certified value and this congener exhibited chromatographic interferences. The average percent difference from mean certified values was $-22.4 \%$, and only $26.7 \%$ of the compounds exceeded $35 \%$ difference.

\section{MISCELLANEOUS}

All congener and pesticide results are confirmed using a second dissimilar column. Results for each column must be within a factor of two of each other to be considered a confirmed value.

\section{REFERENCES}

NOAA (National Oceanic and Atmospheric Administration). 1993. Sampling and Analytical Methods for the National Status and Trends Program, National Benthic Surveillance and Mussel Watch Projects 19841992. Volume IV. Comprehensive Descriptions of Trace Organic Analytical Methods. G.G. Lauenstein and A.Y. Cantillo, eds. NOAA Technical Memorandum NOS ORCA 71. National Oceanic and Atmospheric Administration, Coastal Monitoring and Bioeffects Assessment Division, Office of Ocean Resources Conservation and Assessment, Silver Spring, Maryland.

U.S. Environmental Protection Agency (EPA). . 1986. Test Methods for Evaluating Solid Waste:

Physical/Chemical Methods. SW-846. U.S. Document No. 955-001-00000, U.S. EPA, Washington, D. C. 
PROGRAM: $\quad$ New York/New Jersey Red Hook/Bay Ridge Projects

PARAMETER: $\quad$ Polynuclear Aromatic Hydrocarbons (PAH) and 1,4-Dichlorobenzene

LABORATORY: $\quad$ Battelle/Marine Sciences Laboratory, Sequim, Washington

MATRIX: $\quad$ Sediment

QAIQC DATA QUALITY OBJECTIVES

\begin{tabular}{lllll}
$\begin{array}{c}\text { Reference } \\
\text { Method }\end{array}$ & $\begin{array}{l}\text { Surrogate } \\
\text { Recovery }\end{array}$ & $\begin{array}{c}\text { Spike } \\
\text { Recovery }\end{array}$ & $\begin{array}{l}\text { Relative } \\
\text { Precision }\end{array}$ & $\begin{array}{l}\text { Target } \\
\text { Detection Limit } \\
\text { (ug/kgdry wt.) }\end{array}$ \\
\hline
\end{tabular}

GC/MS/SIM $-50-120 \% \quad 30-150 \% \quad \leq 30 \% \quad 10$

SAMPLE CUSTODY Eight samples were received on 4/11/95, logged-into the Battelle system, and stored frozen until extraction.

METHOD

Sediment samples were extracted with methylene chloride using a roller under" : : ambient conditions following a procedure which is based on methods used by the National Oceanic and Atmospheric Administration for its Status and Trends Program (NOAA 1993). Samples were then cleaned using silica/alumina (5\% deactivated) chromatography followed by HPLC cleanup.

Extracts were quantified using gas chromatography/mass spectrometry (GC/MS) in the selected ion mode (SIM) following a procedure based on EPA Method 8270 (EPA 1986).

HOLDING TIMES Samples were extracted on 5/3/95. All extracts were analyzed by GC/MS/SIM on 5/15-5/16/95.

DETECTION LIMITS Target detection limits of $10 \mathrm{ng} / \mathrm{g}$ dry wt were met for all PAH compounds. Method detection limits (MDLs) were determined by multiplying the standard deviation of seven spiked replicates of a background clam sample by the student $t$ value (3.142). A MDL verification was performed consisting of four spiked replicate samples of a representative clean sediment. MDL verification values were determined by multiplying the standard deviation of the four replicate spike results by 4.54. All MDL verification results were below the target detection limit.

METHOD BLANKS One method blank was extracted with the extraction batch. Flouranthene and benzo[a]anthracene were detected in the blank. All blank levels were less than the target MDL of $10 \mathrm{ng} / \mathrm{g}$ dry wt and all sample concentrations were well above five times the blank concentration; therefore, no data were flagged. No data were blank corrected. 


\section{QA/QC SUMMARYIPAHS (contd)}

SURROGATES Five isotopically labeled compounds were added to the samples prior to extraction, to assess the efficiency of the method. These were d8-naphthalene, d10-acenaphthene, d12-chrysene, d14-dibenzo[a, h] anthracene and d4-1,4 dichlorobenzene. All surrogate recoveries were within the quality control limits of $30 \%$ to $150 \%$. All sample results are surrogate corrected.

MATRIX SPIKES One sample was spiked with all PAH compounds. Matrix spike recoveries were outside of the QC limits of $50 \%$ to $120 \%$ due to high native levels, relative to the levels spiked. Spike concentrations were from 10-200 times lower than native concentrations.

REPLICATES

One sample was extracted and analyzed in triplicate. Precision was measured by calculating the relative standard deviation (RSD) between the replicate results. RSDs ranged from $1 \%$ to $29 \%$, indicating acceptable precision.

SRMs

One SRM, 1941a, a marine sediment obtained by the National Institute for Science and Technology (NIST), was analyzed with the samples. Fourteen of the 16 PAH compounds analyzed are certified. -Ten of the 14 PAHs were detected within $30 \%$ of the certified mean. Three compounds; chrysene, benzo[b]fluoranthene and dibenzo[a,h]anthracene were recovered above the certified range at recoveries ranging from $148 \%$ to $197 \%$. These three compounds all coelute with other specific compounds present at significant levels in the SRM, which accounts for the high recoveries.

MISCELLANEOUS Some of the compounds are flagged to indicate that the ion ratio for that compound was outside of the QC range. This is due primarily to low levels.of.the compound of interest. Because the confirmation ion is present at only a fraction of the level of the parent ion, when the native level of the compound is low, the amount of error in the concentration measurement of the confirmation ion increases. The compound is actually quantified from the parent ion only, so it is unlikely that this would affect the quality of the data: For sample values that are relatively high ( $>5$ times the $M D L$ ) it may be an indication of some sort of interference.

\section{REFERENCES}

NOAA (National Oceanic and Atmospheric Administration). 1993. Sampling and Analytical Methods for the National Status and Trends Program, National Benthic Surveillance and Mussel Watch Projects 19841992. Volume IV. Comprehensive Descriptions of Trace Organic Analytical Methods. G.G. Lauenstein and A.Y. Cantillo, eds. NOAA Technical Memorandum NOS ORCA 71. National Oceanic and Atmospheric Administration, Coastal Monitoring and Bioeffects Assessment Division, Office of Ocean Resources Conservation and Assessment, Silver Spring, Maryland.

U.S. Environmental Protection Agency (EPA). 1986. Test Methods for Evaluating Solid Waste: Physical/Chemical Methods. SW-846. U.S. Document No. 955-001-00000, U.S. Environmental Protection Agency, Washington, D.C.

A. $x i$ 
Table A.1. Grain Size of Sediment Samples, Red Hook and Bay Ridge Channels

\begin{tabular}{|c|c|c|c|c|c|c|}
\hline \multirow[b]{2}{*}{ Sediment Treatment } & \multirow[b]{2}{*}{ Replicate } & \multirow[b]{2}{*}{$\begin{array}{c}\text { Analytical } \\
\text { Batch }\end{array}$} & \multicolumn{4}{|c|}{ Total Percent (dry wt) } \\
\hline & & & $\begin{array}{c}\text { Gravel } \\
>2000 \mu \mathrm{m} \\
\end{array}$ & $\begin{array}{c}\text { Sand } \\
62.5- \\
2000 \mu \mathrm{m} \\
\end{array}$ & $\begin{array}{c}\text { Silt } \\
3.9- \\
62.5 \mu \mathrm{m} \\
\end{array}$ & $\begin{array}{c}\text { Clay } \\
<3.9 \mu \mathrm{m} \\
\end{array}$ \\
\hline \multicolumn{7}{|l|}{ Red Hook } \\
\hline $\mathrm{RH}-1$ & 1 & 1 & 2 & 29 & 35 & 34 \\
\hline $\mathrm{RH}-2$ & 1 & 1 & 7 & 63 & 16 & 14 \\
\hline $\mathrm{RH}-3$ & 1 & 1 & 7 & 54 & 22 & 17 \\
\hline $\mathrm{RH}-4$ & 1 & 1 & 6 & 67 & 15 & 12 \\
\hline $\mathrm{RH}-5$ & 1 & 1 & 36 & 47 & 10 & 7 \\
\hline $\mathrm{RH}-6$ & 1 & 1 & 3 & 75 & 16 & 6 \\
\hline \multicolumn{7}{|l|}{ Bay Ridge Reach A } \\
\hline BR-A-1 & 1 & 1 & 0 & 21 & 43 & 36 \\
\hline BR-A-2 & 1 & 1 & 1 & 24 & 43 & 32 \\
\hline BR-A-3 & 1 & 1 & 2 & 18 & 45 & 35 \\
\hline BR-A-4 & 1 & 1 & 0 & 16 & 52 & 32 \\
\hline BR-A-5 & 1 & 1 & 0 & 15 & 42 & 43 \\
\hline BR-A-6 & 1 & 1 & 0 & 10 & 43 & 47 \\
\hline BR-A-7 & 1 & 1. & 0 & 10 & 41 & 49 \\
\hline BR-A-8 & 1 & 1 & 0 & 18 & 44 & 38 \\
\hline BR-A-9 & 1 & 1 & 0 & 16 & 47 & 37 \\
\hline BR-A-10 & 1 & 1 & 0 & 11 & 47 & 42 \\
\hline BR-A-11 & 1 & 1 & 1 & 13 & 44 & 42 \\
\hline$B R-A-12$ & 1 & 1 & 2 & 19 & 47 & 32 \\
\hline \multicolumn{7}{|l|}{ Bay Ridge Reach B } \\
\hline$\overline{B R-B-13}$ & 1 & 1 & 0 & 29 & 43 & 28 \\
\hline BR-B-14 & 1 & 1 & 0 & 29 & 40 & 31 \\
\hline BR-B-15 & 1 & 1 & 1 & 69 & 17 & 13 \\
\hline BR-B-16 & 1 & 1 & 5 & 55 & 22 & 18 \\
\hline BR-B-17 & 1 & 1 & 9 & 84 & 5 & 2 \\
\hline BR-B-18 & 1 & 1 & 0 & 27 & 42 & 31 \\
\hline BR-B-18 & 2 & 1 & 0 & 28 & 42 & 30 \\
\hline BR-B-18 & 3 & 1 & 0 & 27 & 42 & 31 \\
\hline MDRS $^{(a)}$ & 1 & 1 & 3 & 96 & 0 & 1 \\
\hline Mysidopsis/Macoma Control & 1 & 1 & 0 & 21 & 52 & 27 \\
\hline Nereis Control & 1 & 1 & 0 & 13 & 60 & 27 \\
\hline Ampelisca Control & 1 & 1 & 0 & 11 & 67 & 22 \\
\hline
\end{tabular}

(a) MDRS Mud Dump Reference Site. 
Table A.2. Quality Control Data for Sediment Grain Size Analysis

\begin{tabular}{|c|c|c|c|c|c|c|}
\hline \multirow[b]{2}{*}{$\begin{array}{l}\text { Sediment } \\
\text { Treatment }\end{array}$} & \multirow[b]{2}{*}{ Replicate } & \multirow[b]{2}{*}{ Batch } & \multicolumn{4}{|c|}{ Total Percent (dry wt) } \\
\hline & & & $\begin{array}{c}\text { Gravel } \\
>2000 \mu \mathrm{m}\end{array}$ & $\begin{array}{c}\text { Sand } \\
62.5- \\
2000 \mu \mathrm{m}\end{array}$ & $\begin{array}{c}\text { Silt } \\
3.9- \\
62.5 \mu \mathrm{m} \\
\end{array}$ & $\begin{array}{c}\text { Clay } \\
<3.9 \mu \mathrm{m} \\
\end{array}$ \\
\hline \multicolumn{7}{|c|}{ Analytical Replicates } \\
\hline BR-B-18 ${ }^{(a)}$ & 1 & 1 & 0 & 27 & 42 & 31 \\
\hline BR-B-18 & 2 & 1 & 0 & 28 & 42 & 30 \\
\hline BR-B-18 & 3 & 1 & 0 & 27 & 42 & 31 \\
\hline RSD (\%) & & & $N A^{(b)}$ & 2 & 0 & 2 \\
\hline$C L-A-5^{(a)}$ & 1 & 2 & 1 & 6 & 53 & 40 \\
\hline CL-A-5 & 2 & 2 & 0 & 6 & 52 & 42 \\
\hline CL-A-5 & 3 & 2 & 1 & 7 & 51 & 41 \\
\hline RSD (\%) & & & NA & 9 & 2 & 2 \\
\hline$C L-C-21^{(a)}$ & 1 & 3 & 1 & 33 & 40 & 26 \\
\hline CL-C-21 & 2 & 3 & 1 & 34 & 40 & 25 \\
\hline CL-C-21 & 3 & 3 & 1 & 34 & 40 & 25 \\
\hline RSD (\%) & & & NA & 2 & 0 & 2 \\
\hline PJ-B-21 (a) & 1 & 4 & 1 & 15 & 44 & 40 \\
\hline PJ-B-21 & 2 & 4 & 0 & 13 & 45 & 42 \\
\hline PJ-B-21 & 3 & 4 & 0 & 13 & 45 & 42 \\
\hline RSD (\%) & & & NA & 8 & 1 . & 3 \\
\hline
\end{tabular}

(a) Sample randomly selected for use as a quality control sample in analytical batch.

(b) NA Not applicable; grain size fractions $<5 \%$. 
Table A.3. Specific Gravity and Bulk Density of Sediment Samples and Quality Control Data, Red Hook and Bay Ridge Channels

\begin{tabular}{|c|c|c|c|c|c|}
\hline \multirow[b]{3}{*}{ Sediment Treatment } & \multirow{3}{*}{ Replicate } & \multirow[b]{2}{*}{ Analytical } & \multicolumn{2}{|c|}{ Bulk Density } & \multirow{3}{*}{$\begin{array}{l}\text { Specific } \\
\text { Gravity }\end{array}$} \\
\hline & & & Wet & Dry & \\
\hline & & Batch & $\mathrm{lbs} / \mathrm{ft3}$ & Ibs/ft3 & \\
\hline \multicolumn{6}{|l|}{ Red Hook } \\
\hline RH COMP & 1 & 1 & 104 & 64 & 2.68 \\
\hline \multicolumn{6}{|l|}{ Bay Ridge Reach A } \\
\hline BR-A COMP & 1 & 1 & 85 & 35 & 2.63 \\
\hline \multicolumn{6}{|l|}{ Bay Ridge Reach B } \\
\hline BR-B COMP & 1 & 1 & 106 & 69 & 2.66 \\
\hline MDRS $^{(a)}$ & 1 & 1 & 110 & 96 & 2.68 \\
\hline
\end{tabular}

Quality Control Data

Analytical Replicates

$\begin{array}{lrrrrr}\text { CL-C COMP(b) }^{(b)} & 1 & 1 & -97 & 53 & 2.66 \\ \text { CL-C COMP } & 2 & 1 & 96 & 52 & 2.65 \\ \text { CL-C COMP } & 3 & 1 & -9.96 & 53 & 2.64\end{array}$

$\operatorname{RSD}(\%)$

11

0

(a) MDRS Mud Dump Reference Site.

(b) Sample run concurrently with this study and used as a quality control sample. 
Table A.4. Total Organic Carbon (TOC) and Percentage of Moisture in Sediment Samples, Red Hook and Bay Ridge Channels

\begin{tabular}{lccccc} 
Sediment Treatment & Replicate & $\begin{array}{c}\text { Analytical } \\
\text { Batch }\end{array}$ & $\begin{array}{c}\text { TOC } \\
\text { (\% dry wt) }\end{array}$ & $\begin{array}{c}\text { Solids } \\
\%\end{array}$ & $\begin{array}{c}\text { Moisture } \\
\%\end{array}$ \\
\hline Red Hook & & & & & \\
RH-1 & 1 & 1 & 3.59 & 49 & 51 \\
RH-2 & 1 & 1 & 1.57 & 63 & 37 \\
RH-2 & 2 & 1 & 1.62 & NA $^{(a)}$ & NA \\
RH-2 & 3 & 1 & 1.50 & NA & NA \\
RH-3 & 1 & 2 & 1.93 & 59 & 41 \\
RH-4 & 1 & 2 & 0.74 & 66 & 34 \\
RH-5 & 1 & 2 & 2.99 & 77 & 23 \\
RH-6 & 1 & 2 & 0.28 & 82 & 18
\end{tabular}

\section{Bay Ridge Reach $\mathrm{A}$}

BR-A-1
BR-A-2
BR-A-3
BR-A-4
BR-A-5
BR-A-6
BR-A-7
BR-A-8
BR-A-9
BR-A-10
BR-A-11
BR-A-12

1

1

1

1

1.

$1-\frac{1}{1}-1$

Bay Ridge Reach B

BR-B-14

BR-B-15

BR-B-16

BR-B-17

BR-B-18

BR-B-18

BR-B-18

MDRS $^{(\text {b) }}$

Mysidopsis/Macoma Control

Nereis Control

Ampelisca Control

Ampelisca Control

Ampelisca Control

2.70

12.66

42

58

2.80

2.82

41

57

1

3.19

42

59

1

3.19

3.02

3.17

2.80

2.77

2.95

3.02

2.82

58

61

58

59

63

57

60

62

1

38

41

59

(a) NA Not applicable.

(b) MDRS Mud Dump Reference Site.

3.56

3.39

0.66

1.02

0.36

2.90

NA

NA

0.02

2.00

2.11

3.05

2.86

2.94
52

49

67

57

$$
84
$$

49

49

49

48

51

33

43

16

51

51

51

2

2

2

2

2

$\begin{array}{ll}87 & 13 \\ 25 & 75 \\ 46 & 54 \\ 31 & 69 \\ \text { NA } & \text { NA } \\ \text { NA } & \text { NA }\end{array}$


Table A.5. Quality Control Data for Total Organic Carbon (TOC) Analysis of Sediment Samples

\begin{tabular}{|c|c|c|c|}
\hline Sediment Treatment & Replicate. & $\begin{array}{c}\text { Analytical } \\
\text { Batch }\end{array}$ & $\begin{array}{c}\text { TOC } \\
\text { (\% dry wt) }\end{array}$ \\
\hline \multicolumn{4}{|c|}{ Standard Reference Material } \\
\hline SRM 1941a & 1 & 1 & 4.90 \\
\hline SRM 1941a & 1 & 2 & 4.82 \\
\hline SRM 1941a & 1 & 3 & 4.83 \\
\hline SRM 1941a & 1 & 4 & 4.84 \\
\hline SRM 1941a & 1 & 5 & 4.97 \\
\hline $\begin{array}{r}\text { Non-Certified Value } \\
\text { Range }\end{array}$ & & & 4.80 \\
\hline Percent Difference & & 1 & 2 \\
\hline Percent Difference & & 2 & 0 \\
\hline Percent Difference & & 3 & 1 \\
\hline Percent Difference & & 4 & 1 \\
\hline Percent Difference & & 5 & 4 \\
\hline \multicolumn{4}{|l|}{ Anialytical Replicates } \\
\hline $\mathrm{RH}-2^{(2)}$ & 1 & 1 & 1.57 \\
\hline $\mathrm{RH}-2$ & 2 & 1 & 1.62 \\
\hline $\mathrm{RH}-2$ & 3 & 1 & 1.50 \\
\hline RSD (\%) & & & 4 \\
\hline Ampelisca Control & 1 & 2 & 3.05 \\
\hline Ampelisca Control & 2 & 2 & 2.86 \\
\hline Ampelisca Control & 3 & 2 & 2.94 \\
\hline RSD (\%) & & & 3 \\
\hline$C L-C-17^{(a)}$ & 1 & 3 & 3.36 \\
\hline CL-C-17 & 2 & 3 & 3.18 \\
\hline CL-C-17 & 3 & 3 & 3.19 \\
\hline RSD (\%) & & & 3 \\
\hline PJ-B-14 ${ }^{(\mathrm{a})}$ & 1 & 4 & 2.31 \\
\hline PJ-B-14 & 2 & 4 & 2.15 \\
\hline PJ-B-14 & 3 & 4 & 2.23 \\
\hline RSD (\%) & & & 4 \\
\hline PJ-B-24(a) & 1 & 5 & 2.79 \\
\hline PJ-B-24 & 2 & 5 & 2.79 \\
\hline PJ-B-24 & 3 & 5 & 2.85 \\
\hline RSD (\%) & & & 1 \\
\hline
\end{tabular}

(a) Sample randomly selected for use as a quality control sample in analytical batch. 
Table A.6. Quality Control Data for Percentage of Moisture Analysis of Sediment Samples

\begin{tabular}{|c|c|c|c|c|}
\hline & & $\begin{array}{c}\text { Analytical } \\
\text { Batch }\end{array}$ & $\begin{array}{l}\text { Percentage } \\
\text { Solids }\end{array}$ & Perc \\
\hline
\end{tabular}

Analytical Replicates

\begin{tabular}{lcccc}
\hline BR-B-18 & & & \\
BR-B-18 & 1 & 1 & 49 & 51 \\
BR-B-18 & 2 & 1 & 49 & 51 \\
RSD (\%) & 3 & 1 & 49 & 51 \\
& & & 0 & 0 \\
CL-A-5 & & & & \\
CL-A-5 & 1 & 3 & 46 & 54 \\
CL-A-5 & 2 & 3 & 44 & 56 \\
RSD (\%) & 3 & 3 & 46 & 54 \\
& & & 2 & 2 \\
CL-C-21 & & & & \\
CL-C-21 & 1 & 4 & 63 & 37 \\
CL-C-21 & 2 & 4 & 63 & 37 \\
RSD (\%) & 3 & 4 & 63 & 37 \\
PJ-B-21 (a) & & & 0 & 0 \\
PJ-B-21 & & & & \\
PJ-B-21 & 1 & 5 & 45 & 55 \\
RSD (\%) & 2 & 5 & 45 & 55 \\
& 3 & 5 & 45 & 55 \\
& & & 0 & 0
\end{tabular}

(a) Sample randomly selected for use as a quality control sample in analytical batch. 
Table A.7. Metals in Sediment Samples, Red Hook and Bay Ridge Channels

\begin{tabular}{|c|c|c|c|c|c|c|c|c|c|c|c|}
\hline \multirow{2}{*}{ Sediment Treatment } & \multirow{2}{*}{\multicolumn{2}{|c|}{$\begin{array}{cc}\text { Analytica } \\
\text { Replicate } & \text { Batch } \\
\end{array}$}} & \multicolumn{9}{|c|}{ Metals ( $\mu \mathrm{g} / \mathrm{g}$ dry wt) } \\
\hline & & & $\mathrm{Ag}$ & As & $\mathrm{Cd}$ & $\mathrm{Cr}$ & $\mathrm{Cu}$ & $\mathrm{Hg}$ & $\mathrm{Ni}$ & $\overline{\mathrm{Pb}}$ & $\mathrm{Zn}$ \\
\hline Target Detection Limit & & & 0.1 & 0.1 & 0.01 & 0.02 & 0.1 & 0.02 & 0.1 & 0.1 & 0.1 \\
\hline Method Detection Limit & & & 0.20 & 0.426 & 0.025 & 0.235 & 0.485 & 0.001 & 0.217 & 0.238 & 1.25 \\
\hline Red Hook & & & & & & & & & & & \\
\hline RH-COMP & 1 & 1 & 3.58 & 14.1 & 1.71 & 61.8 & 79.5 & 1.69 & 41.5 & 118 & 132 \\
\hline RH-COMP & 2 & 1 & 3.38 & 15.4 & 1.64 & 66.7 & 81.5 & 1.95 & 43.3 & 117 & 135 \\
\hline RH-COMP & 3 & 1 & 3.45 & 15.1 & 1.57 & 65.8 & 86.1 & 1.96 & 46.6 & 298 & 129 \\
\hline Bay Ridge Reach A & & & & & & & & & & & \\
\hline BR-A COMP & 1 & 1 & 7.06 & 12.0 & '2.43 & 110 & 122 & 1.95 & 31.5 & 172 & 177 \\
\hline Bay Ridge Reach B & & & & & & & & & & & \\
\hline BR-B COMP & 1 & 1 & 4.32 & 10.3 & 2.02 & 78.2 & 89.2 & 1.42 & 21.7 & 113 & 131 \\
\hline
\end{tabular}


Table A.8. Quality Control Data for Metals Analysis of Sediment Samples

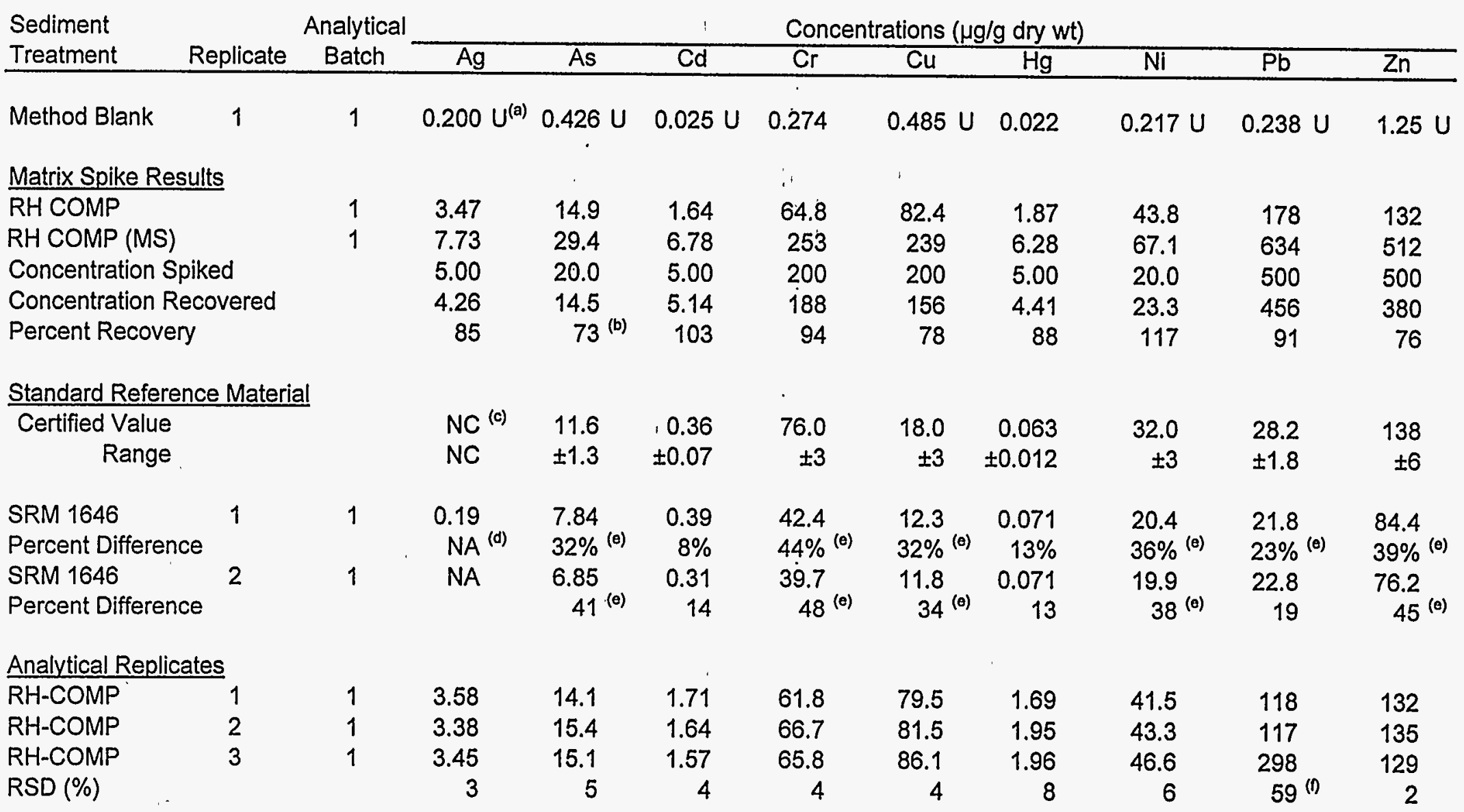

(a) U Undetected at or above given concentration.

(b) Outside quality control criteria (75-125\%) for spike recovery.

(c) NC Not certified.

(d) NA Not applicable.

(e) Outside SRM quality control criteria ( $\leq 20 \%)$.

(f) Outside quality control criteria $(\leq 20 \%)$ for replicate analysis. 
Table A.9. Pesticides and Polychlorinated Biphenyls (PCBs) in Sediment Samples, Red Hook and Bay Ridge Channels

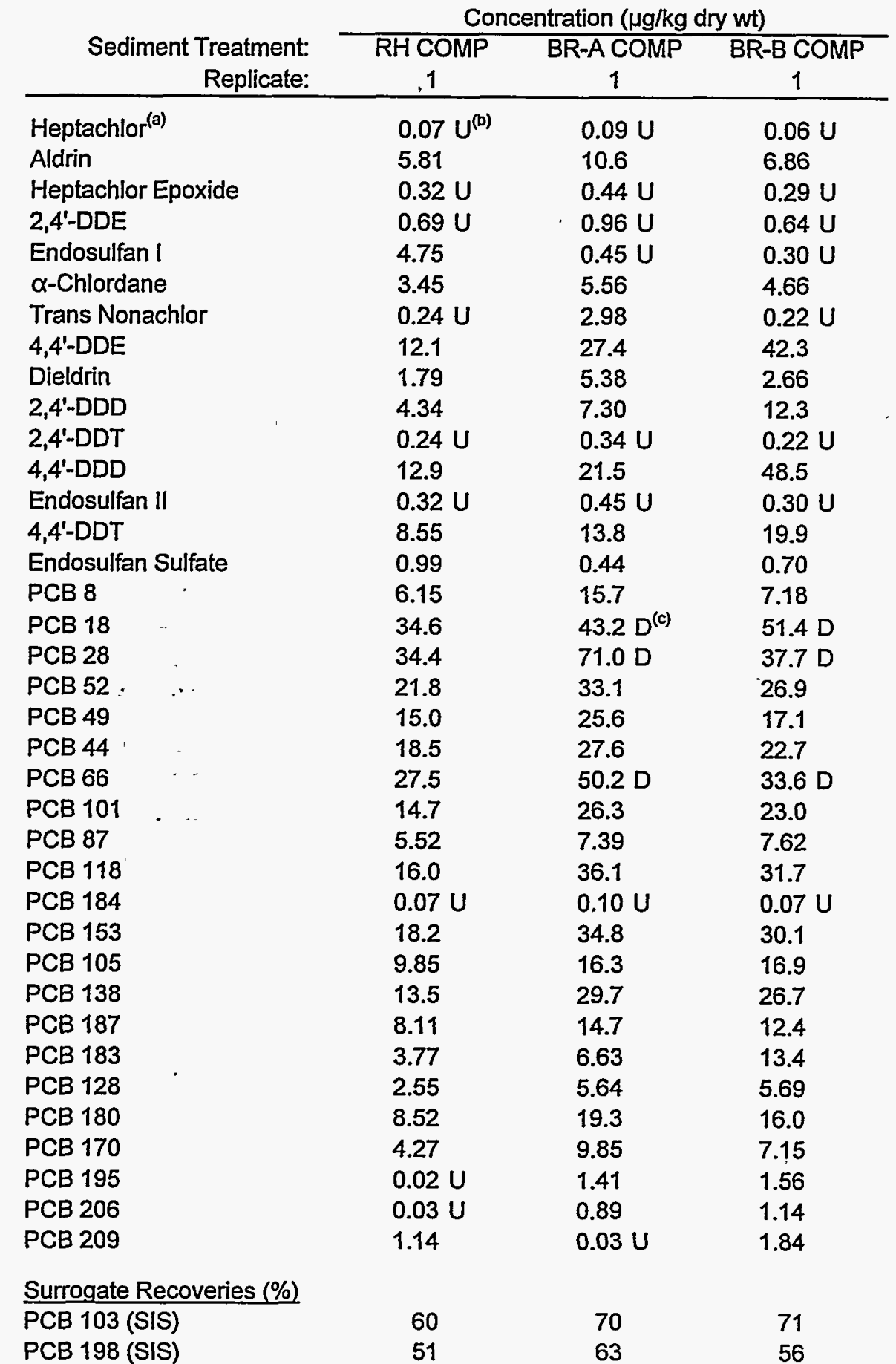

(a) Target detection limits are $1.0 \mu \mathrm{g} / \mathrm{kg}$ for all analytes.

(b) U Undetected at or above given concentration.

(c) D Determined from diluted sample (1:5). 
Table A.10. Quality Control Data for Pesticide and Polychlorinated Biphenyl (PCB) Analysis of Sediment Samples

\begin{tabular}{|c|c|c|c|c|c|c|}
\hline $\begin{array}{r}\text { Sediment Treatment: } \\
\text { Replicate: }\end{array}$ & $\begin{array}{c}\text { Method Blank } \\
1 \\
\end{array}$ & $\begin{array}{c}\mathrm{RHCOMP}^{(\mathrm{d})} \\
1\end{array}$ & $\underset{1}{\mathrm{RH} C O M P(M S}$ & $\begin{array}{l}\text { Concentration } \\
\text { Spiked }\end{array}$ & $\begin{array}{c}\text { Concentration } \\
\text { Recovered }\end{array}$ & $\begin{array}{c}\text { Percent } \\
\text { Recovery }\end{array}$ \\
\hline Heptachlor & $0.06 U^{(b)}$ & $0.07 U$ & 4.16 & 4.20 & 4.16 & 99 \\
\hline Aldrin & $0.19 \mathrm{U}$ & 5.81 & 11.4 & 4.20 & 5.59 & $133^{(c)}$ \\
\hline Heptachlor Epoxide & $0.28 \mathrm{U}$ & $0.32 \mathrm{U}$ & 5.01 & 4.20 & 5.01 & 119 \\
\hline 2,4'-DDE & $0.61 \mathrm{U}$ & $0.69 \mathrm{U}$ & $N A^{(d)}$ & $N S^{(e)}$ & NA & NA \\
\hline Endosulfan I & $0.28 \mathrm{U}$ & 4.75 & 9.49 & 4.20 & 4.74 & 113 \\
\hline$\alpha$-Chlordane & $0.46 \mathrm{U}$ & 3.45 & 7.21 & 4.20 & 3.76 & 90 \\
\hline Trans Nonachlor & $0.21 \mathrm{U}$ & $0.24 \mathrm{U}$ & NA & NS & NA & NA \\
\hline $4,4^{\prime}-\mathrm{DDE}$ & $0.13 \mathrm{U}$ & 12.1 & 16.5 & 4.20 & 4.40 & 105 \\
\hline Dieldrin & $0.19 \mathrm{U}$ & 1.79 & 6.33 & 4.20 & 4.54 & 108 \\
\hline 2,4'-DDD & $0.18 \mathrm{U}$ & 4.34 & NA & NS & NA & NA \\
\hline 2,4'-DDT & $0.21 \mathrm{U}$ & $0.24 \mathrm{U}$ & NA & NS & NA & NA \\
\hline 4,4'-DDD & $0.24 U$ & 12.9 & 17.2 & 4.20 & 4.30 & 102 \\
\hline Endosulfan II & $0.28 U$ & $0.32 U$ & 6.15 & 4.20 & 6.15 & $146^{(c)}$ \\
\hline $4,4^{2}-\mathrm{DDT}$ & $0.67 \mathrm{U}$ & 8.55 & 15.8 & 4.20 & 7.25 & $173^{\text {(c) }}$ \\
\hline Endosulfan Sulfate & $0.20 \mathrm{U}$ & 0.99 & 5.19 & 4.20 & 4.20 & 100 \\
\hline PCB 8 & $0.53 U$ & 6.15 & NA & NS & NA & NA \\
\hline РCB 18 & $0.18 U$ & 34.6 & NA & NS & NA & NA \\
\hline РСВ 28 & $0.05 \mathrm{U}$ & 34.4 & 43.7 & 5.36 & 9.30 & $174^{(c)}$ \\
\hline РСВ 52 & $0.03 \mathrm{U}$ & 21.8 & 33.7 & 11.17 & 11.90 & 107 \\
\hline РСВ 49 & $0.06 \mathrm{U}$ & 15.0 & NA & NS & NA & NA \\
\hline РСВ 44 & $0.02 \mathrm{U}$ & 18.5 & NA & NS & NA & NA \\
\hline РCB 66 & $0.03 \mathrm{U}$ & 27.5 & NA & NS & NA & NA \\
\hline PCB 101 & $0.04 \mathrm{U}$ & 14.7 & 22.6 & $7.58^{\circ}$ & 7.90 & 104 \\
\hline PCB 87 & $0.03 \mathrm{U}$ & 5.52 & NA & NS & NA & NA \\
\hline PCB 118 & $0.04 \mathrm{U}$ & 16.0 & NA & NS & NA & NA \\
\hline PCB 184 & $0.06 \mathrm{U}$ & $0.07 \mathrm{U}$ & NA & NS & NA & NA \\
\hline PCB 153 & $0.03 \mathrm{U}$ & 18.2 & 24.2 & 4.43 & 6.00 & $135^{(c)}$ \\
\hline PCB 105 & $0.02 \mathrm{U}$ & 9.85 & NA & NS & NA & NA \\
\hline РCB 138 & $0.03 \mathrm{U}$ & 13.5 & 19.2 & 3.42 & 5.70 & $167^{(c)}$ \\
\hline PCB 187 & $0.03 \mathrm{U}$ & 8.11 & NA & NS & NA & NA \\
\hline PCB 183 & $0.06 \mathrm{U}$ & 3.77 & NA & NS & NA & NA \\
\hline PCB 128 & $0.02 \mathrm{U}$ & 2.55 & NA & NS & NA & NA \\
\hline PCB 180 & $0.02 U$ & 8.52 & NA & NS & NA & NA \\
\hline PCB 170 & $0.01 \mathrm{U}$ & 4.27 & NA & NS & NA & NA \\
\hline PCB 195 & $0.02 \mathrm{U}$ & $0.02 \mathrm{U}$ & NA & NS & NA & NA \\
\hline PCB 206 & $0.03 \mathrm{U}$ & $0.03 \mathrm{U}$ & NA & NS & NA & NA \\
\hline PCB 209 & $0.02 U$ & 1.14 & NA & NS & NA & NA \\
\hline \multicolumn{7}{|c|}{ Surrogate Recoveries (\%) } \\
\hline PCB 103 (SIS) & 83 & 60 & 61 & NA & NA & NA \\
\hline PCB 198 (SIS) & 88 & 51 & 49 & NA & NA & NA \\
\hline
\end{tabular}


Table A.10. (contd)

Standard Reference Material

Concentration $(\mu \mathrm{g} / \mathrm{kg}$ dry $w t)$ Sediment Treatment: SRM 1941a Certified Percent Replicate:

SRM

\section{Aldrin}

Heptachlor

Heptachlor Epoxide

2,4'-DDE

Endosulfan I

$\alpha$-Chlordane

Trans Nonachlor

4,4'-DDE

Dieldrin

2,4'-DDD

2,4'-DDT

4,4'-DDD

Endosulfan II

4,4'-DDT

Endosulfan Sulfate

PCB 8

PCB 18

PCB 28

PCB. 52

PCB 49

PCB 44

PCB 66

PCB 101

PCB 87

PCB 118

PCB 184

PCB 153

PCB 105

PCB 138

PCB 187

PCB 183

PCB 128

PCB 180

PCB 170

PCB 195

PCB 206

PCB 209

\section{1} Value

$0.06 \mathrm{U} \quad \mathrm{NC}{ }^{(1)} \quad \mathrm{NA}$

4.18 NC NA

$0.27 \mathrm{U}$ NC NA

$0.58 \mathrm{U} \quad 0.73$

$0.27 \mathrm{U} \quad \mathrm{NC}$

$2.56 \quad 2.33$

0.635

6.61

3.04

$0.17 \mathrm{U}$

$0.20 \mathrm{U}$

6.16

$0.27 \mathrm{U}$

5.83

$0.19 \mathrm{U}$

3.73

8.13

$0.05 \mathrm{U}$

9.98

5.15

6.18

7.60

10.8

5.26

10.9

$0.06 \mathrm{U}$

13.9

4.80

11.6

6.04

2.59

1.86

9.76

4.24

0.91

3.74

8.74

1.26

6.59

$1.26^{(9)}$

NA

NA

10

$50^{\text {(h) }}$

NA

NA

NA

NC

5.06

NC

$1.25^{\text {(g) }}$

NC

$1.39^{(9)}$

$1.15^{(9)}$

$9.80^{(9)}$

6.89

9.50

4.80

6.80

11.0

6.70

10.0

NC

17.6

3.65

13.38

$7.00^{(9)}$

22

NA

NA

NA

NA

NA $\quad 71.6 \mathrm{D}$

$45^{\text {(h) }}$

$46^{(h)}$

29

12

2

21

9

NA

$212^{\text {(h) }}$

13

13

59

1.87

5.83

3.00

NC

3.67

8.34

$0.71 \mathrm{U}$

Analytical Replicates

Concentration ( $\mu \mathrm{g} / \mathrm{kg}$ dry wt)

PJ-A COMP ${ }^{(a)}$ PJ-A COMP PJ-A COMP RSD

\begin{tabular}{cccc}
1 & \multicolumn{1}{c}{2} & \multicolumn{1}{c}{3} & $(\%)$ \\
\hline $0.07 \mathrm{U}$ & $0.06 \mathrm{U}$ & $0.07 \mathrm{U}$ & $\mathrm{NA}$ \\
9.98 & 9.93 & 9.84 & 1
\end{tabular}

$0.30 \mathrm{U}$

$0.32 \mathrm{U}$

$0.65 \mathrm{U}$

$0.30 \mathrm{U}$

3.99

2.53

23.0

5.17

6.42

$0.23 \mathrm{U}$

14.9

$0.30 \mathrm{U}$

11.8

0.50

17.0

$59.6 \mathrm{D}$

$70.7 \mathrm{D}$

39.9

26.8

33.9

$50.8 \mathrm{D}$

27.4

8.66

30.5

$0.07 \mathrm{U}$

27.3

13.5

24.3

9.88

5.09

4.83

15.7

7.28

0.93

0.96

1.11

$0.70 \mathrm{U}$

$0.33 \mathrm{U}$

4.21

2.75

21.2

4.99

6.58

$0.33 \cup \quad$ NA

$10.4 \quad 8$

0.54 - 19

17.2

$59.1 \mathrm{D}$

$70.4 \mathrm{D}$

38.1

$27: 1$

33.1

$48.9 \mathrm{D}$

24.6

7.23

26.0

$0.07 \mathrm{U}$

23.8

11.7

20.0

9.26

4.24

3.75

14.7

6.76

0.91

1.16

1.21

NA

Surrogate Recoveries (\%)

PCB 103 (SIS)

PCB 198 (SIS)

$\begin{array}{lll}\text { NA } & \text { NA } & \text { NA } \\ \text { NA } & \text { NA } & \text { NA }\end{array}$

60
63

62

63

66

NA

(a) Sample randomly selected for use as a quality control sample in analytical batch.

(b) U Undetected at or above given concentration.

(c) Outside quality control criteria (50-120\%) for spike recovery.

(d) NA Not applicable.

(e) NS Not spiked.

(f) NC Not certified.

(g) Non-certified value.

(h) Outside SRM quality control criteria ( $<30 \%)$.

(i) D Determined from diluted sample (1:5). 
Table A.11 Polynuclear Aromatic Hydrocarbons (PAH) in Sediment Samples, Red Hook and Bay Ridge Channels

\begin{tabular}{|c|c|c|c|}
\hline \multirow[b]{2}{*}{ Sediment Treatment: } & \multicolumn{3}{|c|}{ Concentration ( $\mu \mathrm{g} / \mathrm{kg}$ dry $w t)$} \\
\hline & \multirow{2}{*}{$\begin{array}{c}\text { RH-COMP } \\
1\end{array}$} & \multirow{2}{*}{$\begin{array}{c}\text { BR-A COMP } \\
1\end{array}$} & \multirow{2}{*}{$\begin{array}{c}\text { BR-B COMP } \\
1 \\
\end{array}$} \\
\hline Replicate: & & & \\
\hline 1,4-Dichlorobenzene ${ }^{(a)}$ & 74.5 & 145 & 120 \\
\hline Naphthalene & 3360 & 517 & 11100 \\
\hline Acenaphthylene & 416 & 231 & 437 \\
\hline Acenaphthene & 2530 & 172 & 4370 \\
\hline Fluorene & 2020 & 226 & 2280 \\
\hline Phenanthrene & 8470 & 1060 & 6330 \\
\hline Anthracene & 3400 & 656 & 2450 \\
\hline Fluoranthene & 4670 & 1970 & 3110 \\
\hline Pyrene & 6420 & 2280 & 4130 \\
\hline Benzo[a]anthracene & 3230 & 1370 & 1920 \\
\hline Chrysene & 3680 & 1300 & 1960 \\
\hline Benzo[b]fluoranthene & 2520 & 1700 & . 1810 \\
\hline Benzo[k]fluoranthene & 885 & 579 & 651 \\
\hline Benzo[a]pyrene & 2720 & 1460 & 1820 \\
\hline Indeno[123-cd]pyrene & 1290 & 948 & 982 \\
\hline Dibenzo[a,h]anthracene & 417 & $277 \div$ & 308 \\
\hline Benzo[g,h,i]perylene & 1340 & 958 & 1000 \\
\hline \multicolumn{4}{|l|}{ Surrogate Recoveries (\%) } \\
\hline d4 1,4-Dichlorobenzene & 56 & 72 & 67 \\
\hline d8 Naphthalene & 61 & 71 & 70 \\
\hline d10 Acenaphthene & 63 & 67 & 68 \\
\hline d12 Chrysene & 59 & 59 & 64 \\
\hline d14 Dibenzo[a,h,i]anthracene & 87 & 86 & 93 \\
\hline
\end{tabular}

(a) Target detection limits are $10 \mu \mathrm{g} / \mathrm{kg}$ for all analytes. 
Table A.12. Quality Control Data for Polynuclear Aromatic Hydrocarbons (PAH) Analysis of Sediment Samples

Matrix Spike Results

\begin{tabular}{|c|c|c|c|c|c|c|}
\hline \multirow{3}{*}{$\begin{array}{r}\text { Sediment Treatment: } \\
\text { Replicate: }\end{array}$} & \multirow{3}{*}{$\begin{array}{l}\text { Method } \\
\text { Blank }\end{array}$} & \multicolumn{4}{|c|}{ Concentration ( $\mu \mathrm{g} / \mathrm{kg}$ dry $w t)$} & \multirow{3}{*}{$\begin{array}{l}\text { Percent } \\
\text { Recovery }\end{array}$} \\
\hline & & \multirow{2}{*}{$\begin{array}{c}\mathrm{RH} \operatorname{COMP}^{\mathrm{a}} \\
1 \\
\end{array}$} & $\begin{array}{c}\text { Matrix Spike } \\
\text { RH COMP(MS) }\end{array}$ & \multirow[t]{2}{*}{$\begin{array}{l}\text { Conc. } \\
\text { Spiked }\end{array}$} & \multirow[t]{2}{*}{$\begin{array}{c}\text { Conc. } \\
\text { Recovered }\end{array}$} & \\
\hline & & & 1 & & & \\
\hline 1,4-Dichlorobenzene & $2.01 U^{(b)}$ & 74.5 & $N A^{(c)}$ & NA & NA & NA \\
\hline Naphthalene & $2.01 \mathrm{U}$ & 3360 & 3710 & 42 & 350 & $833^{(d)}$ \\
\hline Acenaphthylene & $2.13 U$ & 416 & 506 & 42 & 90.0 & $214^{(d)}$ \\
\hline Acenaphthene & $1.91 \mathrm{U}$ & 2530 & 3000 & 42 & 470 & $1119^{(d)}$ \\
\hline Fluorene & $3.80 \mathrm{U}$ & 2020 & 2370 & 42 & 350 & $833^{(d)}$ \\
\hline Phenanthrene & $4.49 \mathrm{U}$ & 8470 & 9670 & 42 & 1200 & $2857^{\text {(d) }}$ \\
\hline Anthracene & $5.46 \mathrm{U}$ & 3400 & 3820 & 42 & 420 & $1000^{(d)}$ \\
\hline Fluoranthene & $4.43^{(e)}$ & 4670 & 5260 & 42 & 590 & $1405^{(d)}$ \\
\hline Pyrene & $1.54 \mathrm{U}$ & 6420 & 7390 & 42 & 970 & $2310^{\text {(d) }}$ \\
\hline Benzo[a]anthracene & $4.53^{(e)}$ & 3230 & 3600 & 42 & 370 & $881^{\text {(d) }}$ \\
\hline Chrysene & $0.83 \mathrm{U}$ & 3680 & 4260 & 42 & 580 & $1381^{(d)}$ \\
\hline Benzo[b]fluorarithene & $1.58 \mathrm{U}$ & 2520 & 2660 & 42 & 140 & $333^{(d)}$ \\
\hline Benzo[k]fluoranthene & $2.67 \mathrm{U}$ & 885 & 939 & 42. & 54.0 & $129^{\text {(d) }}$ \\
\hline Benzo[a]pyrene & $2.08 \mathrm{U}$ & 2720 & 2970 & 42 & 250 & $595^{(d)}$ \\
\hline Indeno[123-cd]pyrene & $0.95 \mathrm{U}$ & 1290 & 1410 & 42 & 120 & $286^{(d)}$ \\
\hline Dibenzo[a,h]anthracene & $1.21 \mathrm{U}$ & 417 & 521 & 42 & 104 & $248^{(d)}$ \\
\hline Benzo[g,h,i]perylene & $0.87 \mathrm{U}$ & 1340 & 1470 & 42 & 130 & $310^{(d)}$ \\
\hline \multicolumn{7}{|l|}{ Surrogate Recoveries (\%) } \\
\hline d4 1,4-Dichlorobenzene & 67 & 56 & 59 & NA & NA & NA \\
\hline d8 Naphthalene & 68 & 61 & 66 & NA & NA & NA \\
\hline d10 Acenaphthene & 69 & 63 & 67 & NA & NA & NA \\
\hline d12 Chrysene & 70 & 59 & 63 & NA & NA & NA \\
\hline d14 Dibenzo[a,h,i]anthracene & 60 & 87 & 93 & NA & NA & NA \\
\hline
\end{tabular}


Table A.12. (contd)

Standard Reference Material

\begin{tabular}{|c|c|c|c|}
\hline \multirow[b]{2}{*}{$\begin{array}{r}\text { Sediment Treatment: } \\
\text { Replicate: }\end{array}$} & \multicolumn{2}{|c|}{ Concentration ( $\mu \mathrm{g} / \mathrm{kg}$ dry wt) } & \multirow[b]{2}{*}{$\begin{array}{c}\text { Percent } \\
\text { Difference } \\
\text { NA } \\
\end{array}$} \\
\hline & $\begin{array}{c}1941 \text { a SRM } \\
1 \\
\end{array}$ & $\begin{array}{c}\text { Certified } \\
\text { Value } \\
\text { NA }\end{array}$ & \\
\hline 1,4-Dichlorobenzene & 132 & NC ${ }^{(1)}$ & NA \\
\hline Naphthalene & 1100 & 1010 & 9 \\
\hline Acenaphthylene & 62.5 & $37.0^{(\mathrm{g})}$ & NA \\
\hline Acenaphthene & 49.1 & $41.0^{(9)}$ & NA \\
\hline Fluorene & 94.6 & 97.3 & 3 \\
\hline Phenanthrene & 567 & 489 & 16 \\
\hline Anthracene & 226 & 184 & 23 \\
\hline Fluoranthene & 1020 & 981 & 4 \\
\hline Pyrene & 831 & 811 & 2 \\
\hline Benzo[a]anthracene & 456 & 427 & 7 \\
\hline Chrysene & 561 & 380 & $48^{(h)}$ \\
\hline Benzo[b]fluoranthene & 1330 & 740 & $80^{(h)}$ \\
\hline Benzo[k]fluoranthene & 431 & $\cdots \quad 361$ & 19 \\
\hline Benzo[a]pyrene & 636 & 628 & 1 \\
\hline Indeno[123-cd]pyrene & 587 & 501 & 17 \\
\hline Dibenzo[a,h]anthracene & 145 & 73.9 & $96^{(h)}$ \\
\hline Benzo[g,h,i]perylene & 548 & 525 & 4 \\
\hline \multicolumn{4}{|l|}{ Surrogate Recoveries (\%) } \\
\hline d4 1,4-Dichlorobenzene & 62 & NA & NA \\
\hline d8 Naphthalene & 64 & NA & NA \\
\hline d10 Acenaphthene & 63 & NA & NA \\
\hline d12 Chrysene & 55 & NA & NA \\
\hline d14 Dibenzo[a,h,i]anthracene & 60 & NA & NA \\
\hline
\end{tabular}


Table A.12. (contd)

Analytical Replicates

\begin{tabular}{|c|c|c|c|c|}
\hline \multirow[b]{2}{*}{$\begin{array}{r}\text { Sediment Treatment: } \\
\text { Replicate: }\end{array}$} & \multicolumn{3}{|c|}{ Concentration $(\mu \mathrm{g} / \mathrm{kg}$ dry wt) } & \multirow[b]{2}{*}{$\begin{array}{l}\text { RSD } \\
(\%) \\
\end{array}$} \\
\hline & $\begin{array}{c}\text { PJ-A-COMP(a) } \\
1 \\
\end{array}$ & $\begin{array}{c}\text { PJ-A-COMP } \\
2 \\
\end{array}$ & $\begin{array}{c}\text { PJ-A-COMP } \\
3 \\
\end{array}$ & \\
\hline 1,4-Dichlorobenzene & 148 & 149 & 147 & 1 \\
\hline Naphthalene & 215 & 186 & 182 & 9 \\
\hline Acenaphthylene & 38.0 & 40.3 & 41.4 & 4 \\
\hline Acenaphthene & 126 & 74.3 & 99.6 & 26 \\
\hline Fluorene & 145 & 94.4 & 124 & 21 \\
\hline Phenanthrene & 686 & 374 & 564 & 29 \\
\hline Anthracene & 316 & 226 & 278 & 17 \\
\hline Fluoranthene & 995 & 686 & 848 & 18 \\
\hline Pyrene & 976 & 725 & 852 & 15 \\
\hline Benzo[a]anthracene & 494 & 351 & 412 & 17 \\
\hline Chrysene & 480 & 347 & 395 & 17 \\
\hline Benzo[b]fluoranthene & 597 & 519 & 640 & 10 \\
\hline Benzo[k]fluoranthene & 199 & 170 & 211 & 11 \\
\hline Benzo[a]pyrene & 430 & 375 & 452 & 9 \\
\hline Indeno[123-cd]pyrene & 334 & 279 & 331 & 10 \\
\hline Dibenzo[a, h]anthracene & 85.7 & 71.6 & 82.9 & 9 \\
\hline Benzo[g,h,i]perylene & 326 & 274 & 330 & 10 \\
\hline \multicolumn{5}{|l|}{ Surrogate Recoveries (\%) } \\
\hline d4 1,4-Dichlorobenzene & 58 & 60 & 57 & NA \\
\hline d8 Naphthalene & 65 & 65 & 66 & NA \\
\hline d10 Acenaphthene & 67 & 70 & 69 & NA \\
\hline d12 Chrysene & 63 & 61 & 63 & NA \\
\hline d14 Dibenzo[a,h,j]anthracene & 89 & 87 & 87 & NA \\
\hline
\end{tabular}

(a) Sample randomly selected for use as a quality control sample in analytical batch.

(b) U Undetected at or above given concentration.

(c) NA Not applicable.

(d) Outside quality control criteria (50-120\%) for spike recovery.

(e) Ion ratio out or confirmation ion not detected.

(f) NC Not certified.

(g) Non-certified value.

(h) Outside SRM quality control criteria ( $\leq 30 \%)$. 
Appendix B.

Quality Assurance/Quality Control Data for Water and Elutriate Analyses, . Red Hook and Bay Ridge Channels 

PROGRAM: $\quad$ New York/New Jersey Red Hook/Bay Ridge Projects

PARAMETER: Metals

LABORATORY: Battelle/Marine Sciences Laboratory, Sequim, Washington

MATRIX: $\quad$ Site Water

QA/QC DATA QUALITY OBJECTIVES

\begin{tabular}{|c|c|c|c|c|c|}
\hline & $\begin{array}{c}\text { Reference } \\
\text { Method }\end{array}$ & $\begin{array}{l}\text { Range of } \\
\text { Recovery }\end{array}$ & $\begin{array}{l}\text { SRM } \\
\text { Accuracy }\end{array}$ & $\begin{array}{l}\text { Relative } \\
\text { Precision }\end{array}$ & $\begin{array}{l}\text { Target } \\
\text { Detection } \\
\text { Limit }(\mu \mathrm{g} / \mathrm{L})\end{array}$ \\
\hline Cadmium & ICP/MS & $75-125 \%$ & $\leq 20 \%$ & $\leq 20 \%$ & 0.025 \\
\hline Chromium & GFAA & $75-125 \%$ & $\leq 20 \%$ & $\leq 20 \%$ & 1.0 \\
\hline Copper & ICP/MS & $75-125 \%$ & $\leq 20 \%$ & $\leq 20 \%$ & 0.30 \\
\hline Lead & ICP/MS & $75-125 \%$ & $\leq 20 \%$ & $\leq 20 \%$ & 0.30 \\
\hline Mercury & CVAA & $75-125 \%$ & $\leq 20 \%$ & $\leq 20 \%$ & 0.002 \\
\hline Nickel & ICP/MS & $75-125 \%$ & $\leq 20 \%$ & $\leq 20 \%$ & 0.30 \\
\hline Silver & ICP/MS & $75-125 \%$ & $=-\leq 20 \%$ & $\leq 20 \%$ & 0.10 \\
\hline Zinc & GFAA & $75-125 \%$ & $\leq 20 \%$ & $\leq 20 \%$ & 0.15 \\
\hline
\end{tabular}

SAMPLE CUSTODY -Samples were-received:on 3/31 through 4/3/95 in good condition. These samples were logged into the Battelle system and stored cold $\left(4^{\circ} \mathrm{C}\right)$ until extraction.

METHOD Eight metals were analyżed in water and elutriate samples: silver (Ag), cadmium $\cdot(\mathrm{Cd})$, chromium $(\mathrm{Cr})$; copper $(\mathrm{Cu})$, mercury $(\mathrm{Hg})$, nickel. $(\mathrm{Ni})$, lead $(\mathrm{Pb})$ and zinc $(\mathrm{Zn})$. Hg was analyzed using cold-vapor atomic absorption spectroscopy (CVAA) - . according to the method of Bloom and Crecelius (1983). Cr and $\mathrm{Zn}$ were analyzed by graphite furnace atomic absorption (GFAA) spectrometry following the EPA Method 200.9 (EPA 1991). The remaining metals were analyzed by inductively coupled plasma mass spectrometry (ICP/MS) following a procedure based on EPA Method 200.8 (EPA 1991).

All water and elutriate samples were acidified to $\mathrm{pH}<2$ upon receipt in the laboratory. Five metals, $\mathrm{Cd}, \mathrm{Cu}, \mathrm{Pb}, \mathrm{Ni}$ and $\mathrm{Ag}$, were extracted from the water according to a procedure based on EPA Method 218.3 (EPA 1979). This preconcentration involves addition of a chelating agent which results in precipitation of the metals from solution, followed by filtration, and digestion of the filter in concentrated acid in order to achieve low detection limits. The digestates were then analyzed by ICP/MS as described above.

HOLDING TIMES Mercury in water has a holding time of 28 days from collection to analysis. All samples were analyzed within this holding time. Samples were all analyzed for the remaining metals within 180 days of collection. The following table summarizes all analysis: 
QA/QC - METALS - SITE WATER (contd)

\begin{tabular}{ll} 
Task & Date \\
\hline APDC Extraction & $7 / 13 / 95$ \\
ICP-MS & $7 / 19 / 95$ \\
CVAA-Hg & $4 / 11 / 95$ \\
GFAA-Cr & $5 / 12 / 95$ \\
GFAA-Zn & $5 / 15 / 95$ \\
APDC Re-extract & $8 / 24 / 95$ \\
ICP-MS Re-analysis & $8 / 24 / 95$.
\end{tabular}

Some samples had high levels of $\mathrm{Cd}$; these samples were reprocessed and reanalyzed.

DETECTION LIMITS Target detection limits were met for all metals except $\mathrm{Zn}$. Detection limits for $\mathrm{Zn}$ exceeded the target limits; however, all sample values were well above the achieved detection limits. MDLs for $\mathrm{Ag}, \mathrm{Cd}, \mathrm{Cu}, \mathrm{Hg}, \mathrm{Ni}$ and $\mathrm{Pb}$ were determined by spiking eight replicates of laboratory deionized water and multiplying the standard.deviation of the resulting analysis by the student $t$ value for $n=8$. MDLs reported for $\mathrm{Cr}$ and $\mathrm{Zn}$ were determined by calculating the standard deviation of three-replicate analyses of the method blank and multiplying by three.

An MDL verification study was performed for ICP-MS metals by spiking four replicates of Sequim Bay seawater and multiplying the standard deviation of the resulting analysis by 4.54 .

METHOD BLANKS

Procedural blanks. were generated during the APDC extraction step and only analyzed for the metals that were preconcentrated $(\mathrm{Ag}, \mathrm{Cd}, \mathrm{Cu}, \mathrm{Ni}$ and $\mathrm{Pb}$.). Two types of blanks were generated: 1) the reagent blank, which consists of the APDC reagents only, and 2) the procedural blank, which consists of the reagents and DI water. Ni was the only metal detected in one of the reagent blanks.

The blanks reported for $\mathrm{Hg}, \mathrm{Cr}$ and $\mathrm{Zn}$ (the metals analyzed directly on waters) consist of solutions (including modifiers for the GFAA analyses), which are used to dilute all samples for analysis. $\mathrm{Zn}$ and $\mathrm{Cr}$ were detected in the blank. Both are present at less than three times the MDL. In addition, all zinc values are greater than five times the blank zinc concentration. All data are corrected for the blank concentrations.

MATRIX SPIKES One sample was spiked with all metals. An additional sample was spiked for the APDC procedure. The APDC metals were spiked prior to sample processing and the other metals were spiked just prior to analysis. All recoveries were within the QC limits of $75 \%$ to $125 \%$ with the exception of $\mathrm{Cu}$ in one APDC spike. Since the $\mathrm{Cu}$ recovery was acceptable for the other spike, no further action was taken.

B. iv 
REPLICATES Each sample was analyzed in triplicate. Precision for triplicate analyses is reported by calculating the relative standard deviation (RSD) among the replicate results. RSD values were all within the $Q C$ limits of $\pm 20 \%$ with the exception of $\mathrm{Ni}$ in one sample and $\mathrm{Hg}$ in another sample.

SRMs

SRM, SLRS-3, a certified riverine water sample from the National Research Council of Canada (NRCC), was analyzed for all metals with the exception of $\mathrm{Ag}$ and $\mathrm{Hg}$, which are not certified in this SRM. Results for all metals were within $\pm 20 \%$ of mean certified value.

A second SRM, 1643c, a freshwater sample from NIST, was analyzed only for $\mathrm{Cr}$ and $\mathrm{Zn}$. They were recovered within the control limits of $\pm 20 \%$ of mean certified value.

A third SRM, CASS-3, a seawater ample from NRCC was analyzed for $\mathrm{Cd}$. The result was within $\pm 20 \%$ of the mean certified value.

In addition, 1641b, a freshwater sample from NIST, was analyzed twice for $\mathrm{Hg}$. Results were within $\pm 20 \%$ of mean certified value.

\section{REFERENCES}

Bloom, N.S., and E.A. Crecelius. 1983. "Determination of Mercury in Seawater at Sub-Nanogram per Liter Levels." Mar. Chem. 14:49-59.

$$
\therefore=-
$$

EPA (U.S. Environmental Protection Agency). 1979. Revised (1983). Methods for the Chemical Analysis of Water and Wastes. EPA-600/4-79-020. Environmental Monitoring Systems Laboratory, Cincinnati, Ohio.

EPA. (U.S. Environmental Protection Agency). 1991 Methods for the Determination of Metals in Environmental Samples. EPA-600/4-91-010. Environmental Services Division, Monitoring Management Branch, Cincinnati, Ohio. 
QA/QC SUMMARY

PROGRAM: $\quad$ New York/New Jersey Red Hook/Bay Ridge Projects

PARAMETER: Metals

LABORATORY: Battelle/Marine Sciences Laboratory, Sequim, Washington

MATRIX: $\quad$ Elutriate

QA/QC DATA QUALITY OBJECTIVES

\begin{tabular}{|c|c|c|c|c|c|c|}
\hline & $\begin{array}{c}\text { Reference } \\
\text { Method }\end{array}$ & $\begin{array}{l}\text { Range of } \\
\text { Recovery }\end{array}$ & $\begin{array}{l}\text { SRM } \\
\text { Accuracy }\end{array}$ & $\begin{array}{l}\text { Relative } \\
\text { Precision }\end{array}$ & & $\begin{array}{l}\text { Target } \\
\text { Detection } \\
\text { Limit }(\mu \mathrm{g} / \mathrm{L})\end{array}$ \\
\hline Cadmium & ICP/MS & $75-125 \%$ & $\leq 20 \%$ & $\leq 20 \%$ & & 0.025 \\
\hline Chromium & GFAA & $75-125 \%$ & $\leq 20 \%$ & $\leq 20 \%$ & & 1.0 \\
\hline Copper & ICP/MS & $75-125 \%$ & $\leq 20 \%$ & $\leq 20 \%$ & & 0.35 \\
\hline Lead & ICP/MS & $75-125 \%$ & $\leq 20 \%$ & $\leq 20 \%$ & & 0.35 \\
\hline Mercury & CVAA & $75-125 \%$ & $\leq 20 \%$ & $\leq 20 \%$ & & 0.002 \\
\hline Nickel & ICP/MS & $75-125 \%$ & $\leq 20 \%$ & $\leq 20 \%$ & - & 0.3 \\
\hline Silver & ICP/MS & $75-125 \%$ & $\leq 20 \%$ & $\leq 20 \%$ & - & $0.25 \ldots$ \\
\hline Zinc & GFAA $\ldots$ & $75-125 \%$ & $\leq 20 \%$ & $\leq 20 \%$ & $\cdots$ & 0.15 \\
\hline
\end{tabular}

SAMPLE CUSTODY -Samples were received on 4/25/95 in good condition, logged into the Battelle ... $\quad \therefore . . .=$ system, acidified to $\mathrm{pH}<2$ and held at ambient temperature until analysis.

METHOD - Eight metals were analyzed in water and elutriate samples: silver $(\mathrm{Ag})$, cadmium (Ed); chromium (Cr), copper (Cu), mercury ( $\mathrm{Hg})$, nickel $(\mathrm{Ni})$, lead $(\mathrm{Pb})$ and zinc $(\mathrm{Zn})$. Hg was analyzed using cold-vapor atomic absorption spectroscopy (CVAA) according to the method of Bloom and Crecelius (1983): "Crand- $\mathrm{Zn}$ 'were " analyzed by graphite furnace atomic absorption (GFAA) spectrometry following the EPA Method 200.9 (EPA 1991). The remaining metals were analyzed by inductively coupled plasma mass spectrometry (ICP/MS) following a procedure based on EPA Method 200.8 (EPA 1991).

All water and elutriate samples were acidified to $\mathrm{pH}<2$ upon receipt in the laboratory. Five metals, $\mathrm{Cd}, \mathrm{Cu}, \mathrm{Pb}, \mathrm{Ni}$ and $\mathrm{Ag}$, were extracted from the water according to a procedure based on EPA Method 218.3 (EPA 1979). This preconcentration involves addition of a chelating agent which results in precipitation of the metals from solution, followed by filtration, and digestion of the filter in concentrated acid in order to achieve low detection limits. The digestates were then analyzed by ICP/MS as described above.

HOLDING TIMES Mercury in water has a holding time of 28 days from collection to analysis. All samples were analyzed within this holding time. Samples were all analyzed for the remaining metals within 180 days of collection. The following table summarizes all analysis: 
QA/QC SUMMARY-METALS-ELUTRIATE (contd)

Task

APDC Extraction

ICP-MS

CVAA-Hg

GFAA-Cr

GFAA-Zn

APDC Re-extract
Date

$7 / 10 / 95$

$7 / 21 / 95$

$5 / 11 / 95$

$5 / 12 / 95$

$5 / 16 / 95$

$8 / 24$ and $9 / 1 / 95$.

Some samples had high levels of $\mathrm{Cd}$ ( two replicates of one sample) and were reprocessed and re-analyzed.

DETECTION LIMITS Target detection limits were met for all metals except $\mathrm{Zn}$. Detection limits for $\mathrm{Zn}$ exceeded the target limits; however, all sample values were well above the detection limits achieved. MDLs for $\mathrm{Ag}, \mathrm{Cd}, \mathrm{Cu}, \mathrm{Hg}, \mathrm{Ni}$ and $\mathrm{Pb}$ were determined by spiking eight replicates of laboratory deionized water and multiplying the standard deviation of the resulting analysis by the student $t$ value for $n=8$. MDLs reported for $\mathrm{Cr}$ and $\mathrm{Zn}$ were determined by taking the standard deviation of three replicate analyses of the method blank and multiplying the standard deviation by three.

$\therefore \quad-\quad$-METHOD-BLANKS - - Procedural blanks were generated during the APDC extraction step and only. $=\ldots-\ldots$ APDC reagents only, and 2) the procedural blank which consists of the reagents
The-blanks reported for $\mathrm{Hg}, \mathrm{Cr}$ and $\mathrm{Zn}$ ( the metals analyzed directly on waters)
consist of a solution (including modifiers for the GFAA analyses) which is used to
dilute all samples for analysis. The compounds $\mathrm{Zn}$ and $\mathrm{Cr}$ were detected in the
blank. Both are present at less than three times the MDL. All data is corrected
for the blank concentrations.

MATRIX SPIKES

REPLICATES
Two samples were spiked with APDC metals ( $\mathrm{Ag}, \mathrm{Cd}, \mathrm{Cu}, \mathrm{Ni}, \mathrm{Pb})$. A different sample was spiked with the GFAA metals ( $\mathrm{Cr}$ and $\mathrm{Zn}$ ) and $\mathrm{Hg}$. The APDC metals were spiked prior to sample processing and the other metals were spiked just prior to analysis. All recoveries were within the QC limits of $75 \%$ to $125 \%$ with the exception of $\mathrm{Cd}$ and $\mathrm{Pb}$ in both APDC spikes and $\mathrm{Ni}$ in one of the spikes. An additional $\mathrm{Cd}$ matrix spike was performed with the reprocessed samples. $\mathrm{Cd}$ recovery in this spike was below the lower $\mathrm{QC}$ limit.

Each sample was analyzed in triplicate. Precision for triplicate analyses is reported by calculating the relative standard deviation (RSD) between the replicate results. RSD values were all within the QC limits of $\pm 20 \%$ with the exception of $\mathrm{Cd}$ in two samples and $\mathrm{Cu}, \mathrm{Ni}$ and $\mathrm{Pb}$ in another sample. Except for one Cd RSD of $158 \%$, all other out of control RSDs were between 20 and $40 \%$. 


\section{QA/QC SUMMARY-METALS-ELUTRIATE (contd)}

SRMs

SRM, SLRS-3, a certified riverine water sample from the National Research Council of Canada (NRCC), was analyzed twice for all APDC metals and once for GFAA metals. $\mathrm{Ag}$ and $\mathrm{Hg}$ are not certified in this SRM. Results for all metals were within $\pm 20 \%$ of mean certified value with the exception of $\mathrm{Cd}, \mathrm{Ni}$ and $\mathrm{Pb}$ in the first SRM.

A second SRM, 1643c, a freshwater sample from NIST, was analyzed in triplicate for APDC metals and once for $\mathrm{Cr}$ and $\mathrm{Zn}$. $\mathrm{Cd}$ and $\mathrm{Pb}$ were recovered within 30 to $40 \%$ of the certified value, which was outside of the control limits of $\pm 20 \%$ of mean certified value. All other metals were recovered within the control limit.

In addition, $1641 \mathrm{~b}$, a freshwater sample from NIST, was analyzed twice for $\mathrm{Hg}$. Results were within $\pm 20 \%$ of mean certified value.

\section{REFERENCES}

Bloom, N.S., and E.A. Crecelius. 1983. "Determination of Mercury in Seawater at Sub-Nanogram per Liter Levels." Mar. Chem. 14:49-59.

- ERA (U.S. Environmental.Protection:Agency). 1979. Revised (1983). Methods for the Chemical Analysis - of Water and-Wastes. EPA-600/4-79-020. Environmental Monitoring Systems Laboratory, CincinnatiOhio.

EPA (U:S.-Environmental Protection=Agency).- 1991. Methods for the Determination of Metals in-Environmental Samples. EPA-600/4-91-010: Environmental Services Division, Monitoring.Management Branch, Cincinnati, Ohio. 
PROGRAM: $\quad$ New York/New Jersey Red Hook/Bay Ridge Projects

PARAMETER: $\quad$ PCB Congeners/Chlorinated Pesticides

LABORATORY: Battelle/Marine Sciences Laboratory, Sequim, Washington

MATRIX: $\quad$ Site Water

QA/QC DATA QUALITY OBJECTIVES

\begin{tabular}{|c|c|c|c|c|}
\hline $\begin{array}{c}\text { Reference } \\
\text { Method }\end{array}$ & $\begin{array}{l}\text { Surrogate } \\
\text { Recovery }\end{array}$ & $\begin{array}{l}\text { Spike } \\
\text { Recovery }\end{array}$ & $\begin{array}{l}\text { Relative } \\
\text { Precision }\end{array}$ & $\begin{array}{l}\text { Target } \\
\text { Detection } \\
\text { Limit (ng/L) }\end{array}$ \\
\hline GC/ECD & $30-150 \%$ & $50-120 \%$ & $\leq 30 \%$ & 1.0 \\
\hline
\end{tabular}

SAMPLE CUSTODY Samples were received on 3/31 through 4/3/95 in good condition, .logged.into the...

Battelle system and stored cold $\left(4^{\circ} \mathrm{C}\right)$ until extraction.

METHOD One-liter of water was extracted with methylene chloride in a separatory funnel

=following atprocedure based on methods used by the National Oceanic and

$\therefore$ Atmospheric-Administration for its Status and Trends Program.(NOAA-1993).

Sample extracts were then cleaned using silica/alumina ( $5 \%$ deactivated)

chromatography followed by HPLC cleanup (NOAA 1993). Extracts were

analyzed for: 15 chlorinated pesticides and 22 individual PCB congeners using -

gas chromatography/electron capture detection (GC/ECD) following a procedure

based on EPA Method 8080 (EPA 1986). The column used was a J\&W DB-17

and the confirmatory column was a DB-1701, both capillary columns $(30 \mathrm{~m} x$

$0.25 \mathrm{~mm}$ I.D.).

HOLDING TIMES

Samples were extracted on $3 / 29$ and $4 / 3 / 95$. Extracts were analyzed by $\mathrm{GC} / \mathrm{ECD}$ from $4 / 20$ through $4 / 24 / 95$, within the established holding time of 40 days.

DETECTION LIMITS Target detection limits were met for all PCBs and pesticides. MDLs were determined from multiplying the standard deviation of seven spiked replicates of a representative clean Sequim Bay water by the student $t$ value(3.142). A MDL verification was performed by spiking a representative clean sediment replicate samples four times. MDL verification values were determined by multiplying the standard deviation of the four replicate spike results by 4.54. All MDL verification results were below the target detection limit.

METHOD BLANKS Two method blanks were extracted. No PCB congeners or pesticides were detected above the MDL in the blank.

SURROGATES Two compounds, PCB congeners 103 and 198, were added to all samples prior to extraction to assess the efficiency of the analysis. Sample surrogate recoveries were all within the QC guidelines of $30 \%$ to $150 \%$.

B. ix 


\section{QA/QC SUMMARYIPCB CONGENERS/PESTICIDES - SITE WATER (contd)}

MATRIX SPIKES Five out of the 22 congeners and 12 of the 15 pesticides were spiked into one sample. Matrix spike recoveries ranged from $81 \%$ to $111 \%$, all within the quality control range of $50 \%$ to $120 \%$.

REPLICATES All samples were analyzed in triplicate. Precision was measured by calculating the relative standard deviation (RSD) between the replicate results. No PCBs were detected above the MDL in all three replicates of any of the samples and only a limited number of pesticides were detected. RSDs for all detectable values were below the target precision goal of $\leq 30 \%$ indicating acceptable precision with the exception of $4,4-' D D E(R S D=32 \%)$ in one replicate.

SRMs Not available.

\section{MISCELLANEOUS}

All congener and pesticide results are confirmed using a second dissimilar column. Results for each column must be within a factor of 2 of each other to be considered a confirmed value."

\section{REFERENCES}

........... NOAA (Natioñal Oceanic and Atmospheric Administration)...1993. Sampling and Analytical.Methods: for .-. the-National-Status and Trends Program, National Benthic Surveillance-äñd-Mussël:Watēh Projects-19841992. Volume:IV. Comprehensive Descriptions of Trace Organic Analytical.Methods. G.G. Lauenstein and A.Y. Ganitillo, eds.- NOAA Technical Memorandum NOS ORCA 71. National Oceanic and and A.Y. Gantillo, eds. NOAA Technical Memorandum NOS ORCA 71. National Oceanic and Resources Conservation and Assessment; Silver Spring, Maryland.

U.S. Environmental Protection Agency (EPA). 1986. Test Methods for Evaluating Solid Waste: Physical/Chemical Methods. SW-846. U.S. Document No. 955-001-00000, U.S. Environmental Protection Agency, Washington, D.C. 
QA/QC SUMMARY

PROGRAM: $\quad$ New York/New Jersey Red Hook/Bay Ridge Projects

PARAMETER: $\quad$ PCB Congeners/Chlorinated Pesticides

LABORATORY: Battelle/Marine Sciences Laboratory, Sequim, Washington

MATRIX: $\quad$ Elutriate

QA/QC DATA QUALITY OBJECTIVES

\begin{tabular}{|c|c|c|c|c|}
\hline $\begin{array}{c}\text { Reference } \\
\text { Method }\end{array}$ & $\begin{array}{l}\text { Surrogate } \\
\text { Recovery }\end{array}$ & $\begin{array}{c}\text { Spike } \\
\text { Recovery }\end{array}$ & $\begin{array}{l}\text { Relative } \\
\text { Precision }\end{array}$ & $\begin{array}{l}\text { Target } \\
\text { Detection } \\
\text { Limit (ng/L) }\end{array}$ \\
\hline GC/ECD & $30-150 \%$ & $50-120 \%$ & $\leq 30 \%$ & 1.0 \\
\hline
\end{tabular}

- SAMPLE CUSTODY Samples were received on 4/25/95 in good condition, logged into the Battelle system, and stored cold at $\left(4^{\circ} \mathrm{C}\right)$.

METHOD - . One liter of water was extracted with methylene chloride in:a separatory funnel

- following a procedure based on methods used by the National Oceanic and .

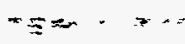

Stmospheric Administration for its Status and-Trends:Program (NOAA:1993)
Sample extracts were then cleaned using silica/alumina (5\% deactivated)

$\therefore \quad: \quad . \quad$ chromatography followed by HPLC cleanup (NOAA 1993). Extracts were

- analyzed for 15 chlorinated pesticides and 22 individual-PCB congeners using gas chromatography/electron capture detection (GC/ECD) following a procedure based on EPA Method 8080 (EPA 1986). The column used was a J\&W'DB-17 and the confirmatory column was a DB-1701, both capillary columns $(30 \mathrm{~m} x$ $0.25 \mathrm{~mm}$ l.D.).

HOLDING TIMES Samples were extracted on 5/2 and 5/3/95. Extracts were analyzed by GC/ECD from $5 / 9$ through $5 / 11 / 95$, within the established holding time of 40 days.

DETECTION LIMITS Target detection limits were met for all PCBs and pesticides. MDLs were determined from multiplying the standard deviation of seven spiked replicates of a representative clean Sequim Bay water by the student $t$ value(3.142). A MDL verification was performed consisting of four spiked replicate samples of a representative clean sediment. MDL verification values were determined by multiplying the standard deviation of the four replicate spike results by 4.54 . All MDL verification results were below the target detection limit.

B. $x i$ 


\section{QA/QC SUMMARYIPCB CONGENERS/PESTICIDES - ELUTRIATE (contd)}

METHOD BLANKS One method blank was extracted. No PCB congeners or pesticides were detected above the MDL in the method blank.

SURROGATES Two compounds, PCB congeners 103 and 198, were added to all samples prior to extraction to assess the efficiency of the analysis. Sample surrogate recoveries were all within the QC guidelines of $30 \%$ to $50 \%$.

MATRIX SPIKES Five out of the 22 congeners and 12 of the 15 pesticides were spiked into a sample of Sequim Bay seawater. Matrix spike recoveries ranged from 69 $129 \%$, all within the control limit range of $50 \%$ to $120 \%$ with the exception of PCB $101(129 \%)$.

REPLICATES All samples were analyzed in triplicate. Precision was measured by calculating the relative standard deviation (RSD) between the replicate results. RSDs for all detectable values were below the target precision goal of $\leq 30 \%$ in five of the eight samples. Three of the samples had a number of replicate RSD values between 30 and $100 \%$, primarily involving PCB congeners. Since these samples had relatively high particulate loads, the low precision is most likely due.to nonhomogeneity of samples extracted.

SRMs $\quad \cdot$ Not available.

\section{MISCELLANEOUS}

All congener and pesticide results are confirmed using a second dissimilar column. Results for each column must be within a factor of two of each other to be considered a confirmed value.

\section{REFERENCES}

NOAA (National Oceanic and Atmospheric Administration). 1993. Sampling and Analytical Methods for the National Status and Trends Program, National Benthic Surveillance and Mussel Watch Projects.19841992. Volume IV. Comprehensive Descriptions of Trace Organic Analytical Methods. G.G. Lauenstein . and A.Y. Cantillo, eds. NOAA Technical Memorandum NOS ORCA 71. National Oceanic and Atmospheric Administration, Coastal Monitoring and Bioeffects Assessment Division, Office of Ocean Resources Conservation and Assessment, Silver Spring, Maryland.

U.S. Environmental Protection Agency (EPA). 1986. Test Methods for Evaluating Solid Waste: Physical/Chemical Methods. SW-846. U.S. Document No. 955-001-00000, U.S. Environmental Protection Agency, Washington, D.C.

B. xii 
Table B.1. Metals in Site Water Samples, Red Hook and Bay Ridge Channels




Table B.2. Quality Control Data for Metals Analysis of Site Water Samples




Table B.2. (contd)

\begin{tabular}{|c|c|c|c|c|c|c|c|c|c|c|}
\hline & & & & & & Concent & ation $(\mu \mathrm{g} / \mathrm{L})$ & & & \\
\hline Sediment & & & $\mathrm{Ag}$ & $\mathrm{Cd}$ & $\mathrm{Cr}$ & $\mathrm{Cu}$ & $\mathrm{Hg}$ & $\mathrm{Ni}$ & $\mathrm{Pb}$ & $\overline{\mathrm{Zn}}$ \\
\hline Treatment & Replicate & Batch & ICPMS & ICP/MS & GFAA & ICPIMS & CVAF & ICP/MS & ICPMS & GFAA \\
\hline Standard Reference Mat & terial & & & & & & & & & \\
\hline $1641 \mathrm{~b}$ & 1 & 1 & NA & NA & NA & NA & 1583712 & NA & NA & NA \\
\hline Certified Value & & & NA & NA & NA & NA & 1520000 & NA & NA & NA \\
\hline Range & & & NA & NA & NA & NA & \pm 40000 & NA & NA & NA \\
\hline Percent Difference & 1 & 1 & NA & NA & NA & NA & 4 & NA & NA & NA \\
\hline $1643 c$ & 1 & 1 & NA & NA & 20.9 & NA & NA & NA & NA & 84.6 \\
\hline Certified Value & & & NA & NA & 19.0 & NA & NA & NA & NA & 73.9 \\
\hline Range & & & NA & NA & \pm 0.6 & NA & NA & NA & NA & \pm 0.9 \\
\hline Percent Difference & & & NA & NA & 10 & NA & NA & NA & NA & $14 \%$ \\
\hline SLRS - 3 & 1 & 1 & $0.018 U$ & 0.017 & 0.24 & 1.54 & NA & 0.887 & 0.0887 & 1.63 \\
\hline SLRS - 3 & 2 & 1 & $0.018 \mathrm{U}$ & 0.015 & NA & 1.55 & NA & 0.846 & 0.0718 & NA \\
\hline Certified Value & & & $\mathrm{NC}$ & 0.013 & 0.30 & 1.35 & NA & 0.830 & 0.0680 & 1.04 \\
\hline Range & & & NC & \pm 0.002 & \pm 0.04 & \pm 0.07 & NA & \pm 0.080 & \pm 0.0070 & \pm 0.09 \\
\hline Percent Difference & 1 & 1 & NA & $32^{(g)}$ & 20 & 14 & NA & 7 & $30^{(9)}$ & $57^{(g)}$ \\
\hline Percent Difference & 2 & 1 & NA & 15 & NA & 15 & NA & 2 & 6 & NA \\
\hline CASS - 3 & 1 & 2 & NA & 0.032 & NA & NA & NA & NA & NA & NA \\
\hline Certified Value & & & NA & 0.030 & NA & NA & NA & NA & NA & NA \\
\hline Range & & & NA & \pm 0.005 & NA & NA & NA & NA & NA & NA \\
\hline Percent Difference & 1 & 2 & NA & 7 & NA & NA & NA & NA & NA & NA \\
\hline
\end{tabular}


Table B.2. (contd)




Table B.2. (contd)

,

Concentration $(\mu \mathrm{g} / \mathrm{L})$ - blank corrected

\begin{tabular}{|c|c|c|c|c|c|c|c|c|c|}
\hline \multirow{3}{*}{$\begin{array}{l}\text { Sediment } \\
\text { Treatment }\end{array}$} & & \multicolumn{8}{|c|}{ Concentration $(\mu \mathrm{g} / \mathrm{L})$ - blank corrected } \\
\hline & & $\overline{\mathrm{Ag}}$ & $\mathrm{Cd}$ & $\mathrm{Cr}$ & $\mathrm{Cu}$ & $\mathrm{Hg}$ & $\mathrm{Ni}$ & $\mathrm{Pb}$ & $\overline{Z n}$ \\
\hline & Replicate Batch & ICPIMS & ICPIMS & GFAA & ICP/MS & CVAF & ICPIMS & ICPIMS & GFAA \\
\hline
\end{tabular}

Analytical Replicates (contd)

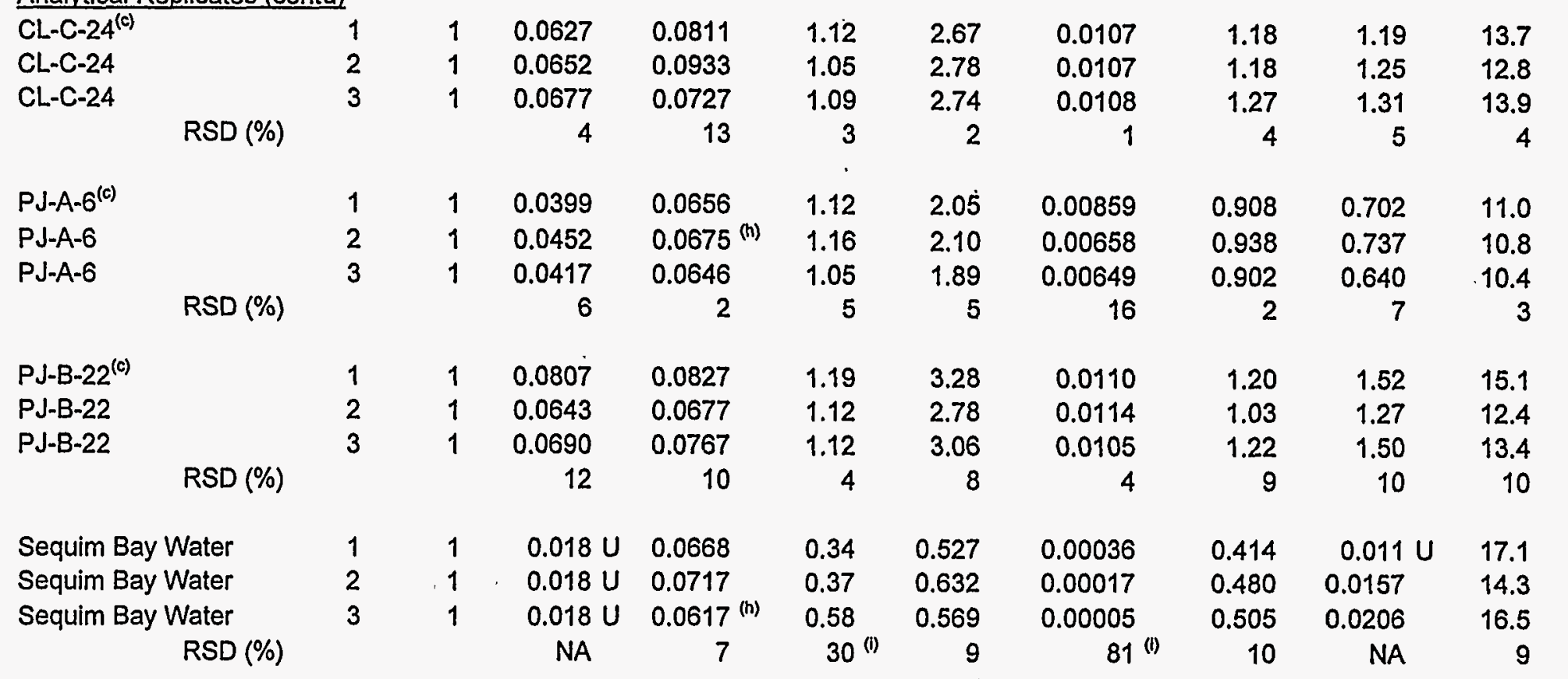

(a) U Undetected at or above given concentration.

(b) NA Not applicable.

(c) Sample randomly selected for use as a quality control sample in analytical batch.

(d) NS Not spiked.

(e) Outside quality control criteria (75-125\%) for spike recovery.

(f) MDS Mud Dump Site.

(g) Outside SRM quality control criteria ( $\pm 20 \%$ ).

(h) Value obtained from re-processing and re-analysis of different batch.

(i) Outside quality control criteria $<20 \%$ ) for replicate analysis. 
Table B.3. Method Detection Limit Verification Study for Metals in Site Water

\begin{tabular}{|c|c|c|c|c|c|c|c|c|c|}
\hline & \multirow[b]{2}{*}{ Replicate } & \multicolumn{8}{|c|}{ Concentration $(\mu \mathrm{g} / \mathrm{L})$ - blank corrected } \\
\hline & & $\begin{array}{c}\mathrm{Ag} \\
\mathrm{ICP} / \mathrm{MS}\end{array}$ & $\begin{array}{c}\text { Cd } \\
\text { ICP/MS }\end{array}$ & $\begin{array}{c}\mathrm{Cr} \\
\text { GFAA }\end{array}$ & $\begin{array}{c}\mathrm{Cu} \\
\text { ICPMS }\end{array}$ & $\begin{array}{c}\mathrm{Hg} \\
\text { CVAF }\end{array}$ & $\begin{array}{c}\mathrm{Ni} \\
\text { ICP/MS }\end{array}$ & $\begin{array}{c}\mathrm{Pb} \\
\text { ICPMS }\end{array}$ & $\begin{array}{c}\mathrm{Zn} \\
\text { GFAA }\end{array}$ \\
\hline Sequim Bay Water + Spike & 1 & 0.978 & 0.952 & 0.410 & 1.55 & 0.00209 & 1.35 & 0.788 & 2.41 \\
\hline Sequim Bay Water + Spike & 2 & 0.948 & 0.899 & 0.370 & 1.45 & 0.00203 & 1.28 & 0.759 & 1.86 \\
\hline Sequim Bay Water + Spike & 3 & 0.932 & 0.922 & 0.440 & 1.46 & 0.00296 & 1.30 & 0.757 & 2.78 \\
\hline Sequim Bay Water + Spike & 4 & 0.934 & 0.913 & 0.410 & 1.43 & 0.00312 & 1.36 & 0.773 & 2.23 \\
\hline Detection Limit ${ }^{(a)}$ & & 0.096 & 0.102 & 0.130 & 0.241 & 0.00259 & 0.175 & 0.065 & 1.74 \\
\hline
\end{tabular}

(a) Detection limit determined by multiplying the standard deviation of the four replicates by Students-t (4.54). 
Table B.4. Metals in Elutriate Samples, Red Hook and Bay Ridge Channels

\begin{tabular}{|c|c|c|c|c|c|c|c|c|c|c|}
\hline & & & & & Cono & ration $(\mu \mathrm{g}$ & ) - blank & ected & & \\
\hline $\begin{array}{l}\text { Sediment } \\
\text { Treatment }\end{array}$ & Replicate & Batch & $\begin{array}{c}\mathrm{Ag} \\
\text { APDC } \\
\text { ICP-MS }\end{array}$ & $\begin{array}{c}\text { Cd } \\
\text { APDC } \\
\text { ICP-MS }\end{array}$ & $\begin{array}{c}\mathrm{Cr} \\
\mathrm{GFAA}\end{array}$ & $\begin{array}{c}\mathrm{Cu} \\
\text { APDC } \\
\text { ICP-MS }\end{array}$ & $\begin{array}{l}\mathrm{Hg} \\
\text { CVAF }\end{array}$ & $\begin{array}{c}\mathrm{Ni} \\
\text { APDC } \\
\text { ICP-MS }\end{array}$ & $\begin{array}{c}\mathrm{Pb} \\
\text { APDC } \\
\text { ICP-MS }\end{array}$ & $\begin{array}{c}\mathrm{Zn} \\
\text { GFAA }\end{array}$ \\
\hline $\begin{array}{l}\text { Target Detection Limit: } \\
\text { Method Detection Limit: }\end{array}$ & & & $\begin{array}{r}0.10 \\
0.018\end{array}$ & $\begin{array}{l}0.025 \\
0.003\end{array}$ & $\begin{array}{r}1.0 \\
0.07\end{array}$ & $\begin{array}{r}0.30 \\
0.021\end{array}$ & $\begin{array}{r}0.002 \\
0.0001\end{array}$ & $\begin{array}{r}0.30 \\
0.028\end{array}$ & $\begin{array}{r}0.30 \\
0.011\end{array}$ & $\begin{array}{l}0.15 \\
0.24\end{array}$ \\
\hline $\begin{array}{l}\text { Red Hook } \\
\text { COMP RH } \\
\text { COMP RH } \\
\text { COMP RH }\end{array}$ & $\begin{array}{l}1 \\
2 \\
3\end{array}$ & $\begin{array}{l}1 \\
1 \\
1\end{array}$ & $\begin{array}{l}0.0236 \\
0.0245 \\
0.0256\end{array}$ & $\begin{array}{l}0.0158 \\
0.0219 \\
0.596\end{array}$ & $\begin{array}{l}0.880 \\
0.850 \\
0.830\end{array}$ & $\begin{array}{l}0.862 \\
0.840 \\
1.01 \text { (a) }\end{array}$ & $\begin{array}{l}0.0186 \\
0.0175 \\
0.0160\end{array}$ & $\begin{array}{l}1.63 \\
1.84 \\
2.22^{(\mathrm{a})}\end{array}$ & $\begin{array}{l}0.586 \\
0.685 \\
1.20^{(a)}\end{array}$ & $\begin{array}{l}2.14 \\
2.46 \\
2.46\end{array}$ \\
\hline $\begin{array}{l}\text { Bay Ridge Reach A } \\
\text { COMP BR-A } \\
\text { COMP BR-A } \\
\text { COMP BR-A }\end{array}$ & $\begin{array}{l}1 \\
2 \\
3\end{array}$ & $\begin{array}{l}1 \\
1 \\
1\end{array}$ & $\begin{array}{l}0.0442 \\
0.0443 \\
0.0437\end{array}$ & $\begin{array}{r}0.0150 \\
0.013 \\
0.016\end{array}$ & $\begin{array}{l}1.62 \\
1.64 \\
1.80\end{array}$ & $\begin{array}{l}0.973 \\
0.933 \\
0.985\end{array}$ & $\begin{array}{l}0.0112 \\
0.0101 \\
0.0108\end{array}$ & $\begin{array}{l}1.49 \\
1.32 \\
1.49\end{array}$ & $\begin{array}{l}0.236 \\
0.246 \\
0.253\end{array}$ & $\begin{array}{l}2.30 \\
2.06 \\
2.38\end{array}$ \\
\hline Bay Ridge Reach B & & & & I & & & & & & \\
\hline $\begin{array}{l}\text { COMP BR-B } \\
\text { COMP BR-B } \\
\text { COMP BR-B }\end{array}$ & $\begin{array}{l}1 \\
2 \\
3\end{array}$ & $\begin{array}{l}1 \\
1 \\
1\end{array}$ & $\begin{array}{l}0.0348 \\
0.0391 \\
0.0377\end{array}$ & $\begin{array}{r}0.028 \\
0.02 \\
0.018\end{array}$ & $\begin{array}{l}1.91 \\
1.75 \\
1.78\end{array}$ & $\begin{array}{l}1.25 \\
1.36 \\
1.17\end{array}$ & $\begin{array}{l}0.0231 \\
0.0237 \\
0.0231\end{array}$ & $\begin{array}{l}0.878 \\
0.972 \\
0.850\end{array}$ & $\begin{array}{l}0.558 \\
0.546 \\
0.497\end{array}$ & $\begin{array}{l}2.78 \\
3.34 \\
3.18\end{array}$ \\
\hline
\end{tabular}

(a) Value obtained from re-processing and re-analysis of different sample. 
Table B.5. Quality Control Data for Metals Analysis of Elutriate Samples

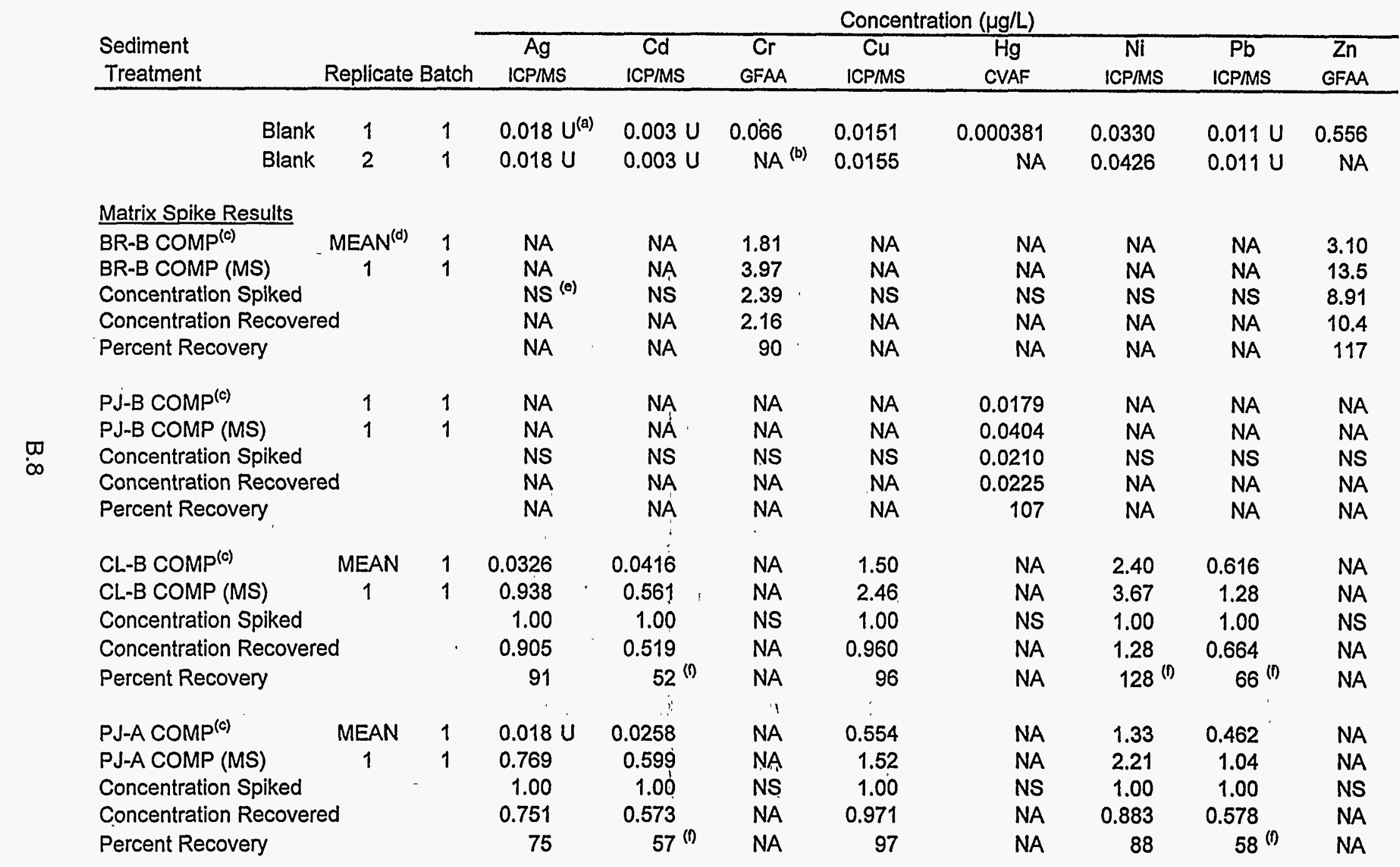


Table B.5. (contd)

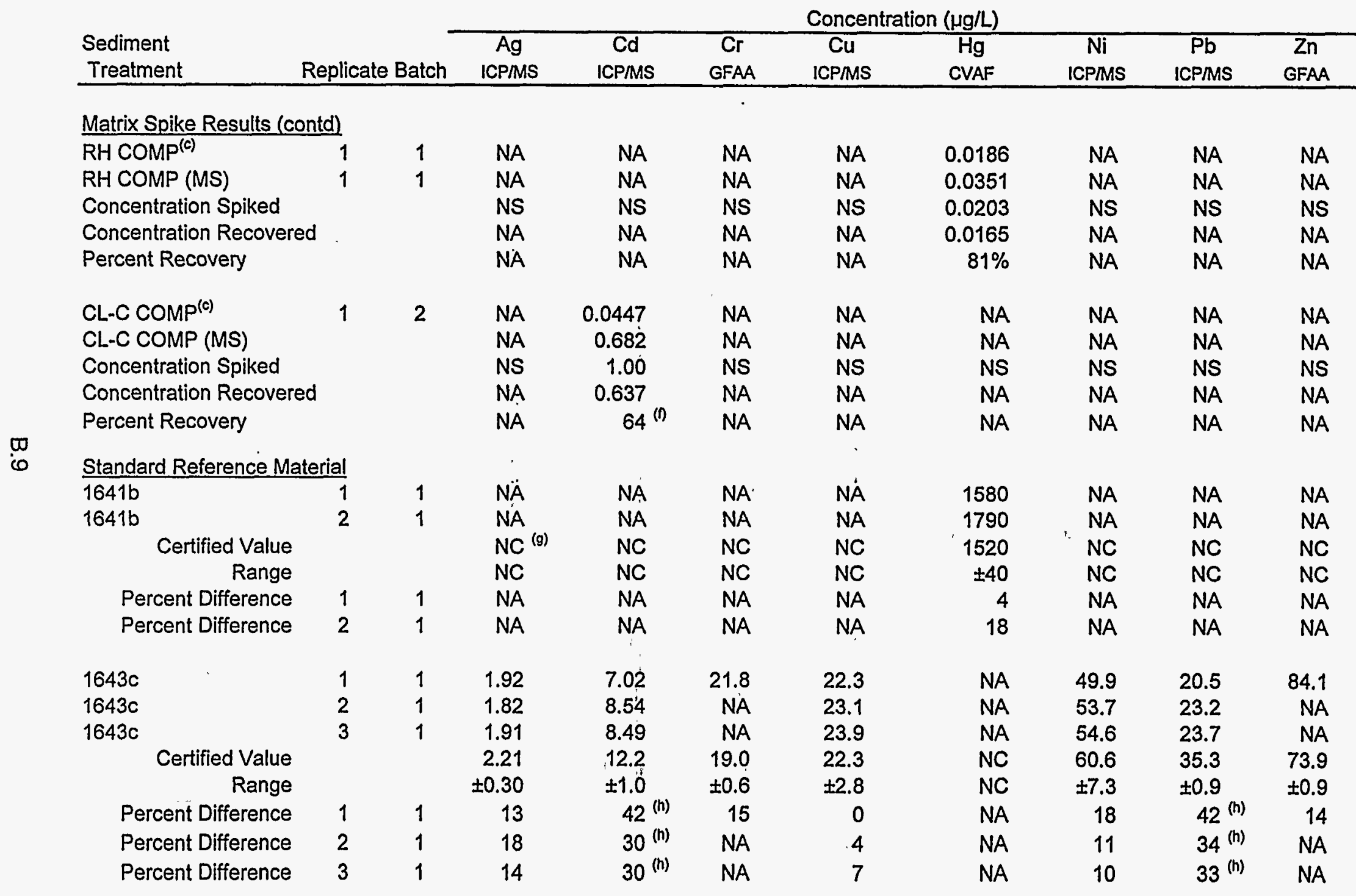


Table B.5. (contd)

\begin{tabular}{|c|c|c|c|c|c|c|c|c|c|c|}
\hline \multirow[b]{2}{*}{$\begin{array}{l}\text { Sediment } \\
\text { Treatment }\end{array}$} & \multirow{2}{*}{\multicolumn{2}{|c|}{ Replicate Batch }} & \multicolumn{8}{|c|}{ Concentration $(\mu \mathrm{g} / \mathrm{L})$} \\
\hline & & & $\begin{array}{c}\mathrm{Ag} \\
\text { ICPMS }\end{array}$ & $\begin{array}{c}\text { Cd } \\
\text { ICPIMS }\end{array}$ & $\begin{array}{c}\mathrm{Cr} \\
\text { GFAA }\end{array}$ & $\begin{array}{c}\mathrm{Cu} \\
\text { ICPMS }\end{array}$ & $\begin{array}{c}\mathrm{Hg} \\
\text { CVAF }\end{array}$ & $\begin{array}{c}\mathrm{Ni} \\
\text { ICPMS } \\
\end{array}$ & $\begin{array}{c}\mathrm{Pb} \\
\text { ICPMS }\end{array}$ & $\begin{array}{c}\mathrm{Zn} \\
\text { GFAA } \\
\end{array}$ \\
\hline \multicolumn{11}{|c|}{ Standard Reference Material } \\
\hline SLRS-3 & 1 & 1 & 0.0113 & 0.007 & 0.35 & 1.19 & NA & 0.605 & 0.048 & 1.24 \\
\hline SLRS-3 & 2 & 1 & 0.0114 & 0.0112 & NA & 1.34 & NA & 0.706 & 0.053 & NA \\
\hline Certified Value & & & NC & 0.013 & 0.30 & 1.35 & NC & 0.83 & 0.068 & 1.04 \\
\hline Range & & & NC & \pm 0.002 & \pm 0.04 & \pm 0.07 & NC & \pm 0.08 & \pm 0.007 & \pm 0.09 \\
\hline Percent Difference & 1 & 1 & NA & $46^{(h)}$ & 17 & 12 & NA & $27^{(h)}$ & $29^{(h)}$ & 19 \\
\hline Percent Difference & 2 & 1 & NA & 14 & NA & 0 & NA & 15 & $23^{(h)}$ & NA \\
\hline \multicolumn{11}{|l|}{ Analytical Replicates } \\
\hline BR-B COMP(c) & 1 & 1 & 0.0348 & 0.0281 & 1.91 & 1.25 & 0.0231 & 0.878 & 0.558 & 2.78 \\
\hline BR-B COMP & 2 & 1 & 0.0391 & 0.0197 & 1.75 & 1.36 & 0.0237 & 0.972 & 0.546 & 3.34 \\
\hline BR-B COMP & 3 & 1 & 0.0377 & 0.0184 & 1.78 & 1.17 & 0.0231 & 0.850 & 0.497 & 3.18 \\
\hline \multicolumn{3}{|l|}{ RSD (\%) } & 6 & $24^{(1)}$ & 5 & 8 & 1 & 7 & 6 & 9 \\
\hline BR-A COMP(c) & 1 & 1 & 0.0442 & 0.0150 & 1.62 & 0.973 & 0.0112 & 1.49 & 0.236 & 2.30 \\
\hline BR-A COMP & 2 & 1 & 0.0443 & 0.0129 & 1.64 & 0.933 & 0.0101 & 1.32 & 0.246 & 2.06 \\
\hline BR-A COMP & 3 & 1 & 0.0437 & 0.0163 & 1.80 & 0.985 & 0.0108 & 1.49 & 0.253 & 2.38 \\
\hline \multicolumn{3}{|l|}{ RSD (\%) } & 1 & 12 & 6 & 3 & 5 & 7 & 3 & 7 \\
\hline PJ-B COMP(c) & 1 & 1 & 0.0329 & 0.0225 & 1.78 & 1.33 & 0.0179 & 1.50 & 0.423 & 2.78 \\
\hline PJ-B COMP & 2 & 1 & 0.0300 & 0.0232 & 1.73 & 1.19 & 0.0167 & 1.38 & 0.501 & 2.94 \\
\hline PJ-B COMP & 3 & 1 & 0.0276 & 0.0242 & 1.82 & 1.21 & 0.0164 & 1.46 & 0.476 & 4 \\
\hline \multicolumn{3}{|l|}{ RSD (\%) } & 9 & 4 & 3 & 6 & 5 & 4 & 9 & 20 \\
\hline CL-B COMP(c) & 1 & 1 & 0.0304 & 0.0434 & 1.69 & 1.59 & 0.0148 & 2.46 & 0.641 & 5.48 \\
\hline CL-B COMP & 2 & 1 & 0.0321 & 0.0422 & 1.56 & 1.52 & 0.0146 & 2.33 & 0.599 & 5.08 \\
\hline CL-B COMP & 3 & 1 & 0.0352 & 0.0391 & 1.60 & 1.39 & 0.0153 & 2.39 & 0.607 & 5.64 \\
\hline \multicolumn{3}{|l|}{ RSD (\%) } & 7 & 5 & 4 & 7 & 2 & 3 & 4 & 5 \\
\hline
\end{tabular}


Table B.5. (contd)




Table B.6. Pesticides and Polychlorinated Biphenyls (PCBs) in Site Water Samples, Red Hook and Bay Ridge Channels

\begin{tabular}{|c|c|c|c|c|c|c|}
\hline \multirow[b]{2}{*}{$\begin{array}{r}\text { Sediment Treatment } \\
\text { Replicate }\end{array}$} & \multicolumn{6}{|c|}{ Concentration (ng/L) } \\
\hline & $\begin{array}{c}\mathrm{RH}-3 \\
1\end{array}$ & $\begin{array}{c}\mathrm{RH}-3 \\
2\end{array}$ & $\begin{array}{c}\mathrm{RH}-3 \\
3\end{array}$ & $\begin{array}{c}\text { BR-A-6 } \\
1\end{array}$ & $\begin{array}{c}\text { BR-A-6 } \\
2\end{array}$ & $\begin{array}{c}\text { BR-A-6 } \\
3\end{array}$ \\
\hline Heptachlor $^{(a)}$ & $0.47 \mathrm{U}^{(\mathrm{b})}$ & $0.47 \mathrm{U}$ & $0.47 \mathrm{U}$ & $0.47 U$ & $0.47 \mathrm{U}$ & $0.47 \mathrm{U}$ \\
\hline Aldrin & $0.39 \mathrm{U}$ & 1.48 & 0.79 & 0.94 & 0.91 & 1.14 \\
\hline Heptachlor Epoxide & $0.11 \mathrm{U}$ & $0.11 \mathrm{U}$ & $0.11 \mathrm{U}$ & $0.11 \mathrm{U}$ & $0.11 U$ & $0.11 \mathrm{U}$ \\
\hline 2,4-DDE & $0.23 \mathrm{U}$ & $0.23 \mathrm{U}$ & $0.23 U$ & $0.23 U$ & $0.23 U$ & $0.23 \mathrm{U}$ \\
\hline Endosulfan I & $0.46 \mathrm{U}$ & $0.46 \mathrm{U}$ & 1.61 & $0.46 U$ & $0.46 \mathrm{U}$ & $0.46 \mathrm{U}$ \\
\hline$\alpha$-Chlordane & 1.16 & $0.83 U$ & $0.83 U$ & $0.83 \mathrm{U}$ & $0.83 U$ & $0.83 \mathrm{U}$ \\
\hline Trans Nonachlor & $1.11 \mathrm{U}$ & $1.11 \mathrm{U}$ & $1.11 \mathrm{U}$ & $1.11 \mathrm{U}$ & $1.11 \mathrm{U}$ & $1.11 \mathrm{U}$ \\
\hline $4,4^{\prime}-D D E$ & 4.42 & 5.73 & 2.96 & $0.28 U$ & $0.28 \mathrm{U}$ & $0.28 \mathrm{U}$ \\
\hline Dieldrin & $0.12 \mathrm{U}$ & $0.12 \mathrm{U}$ & $0.12 \mathrm{U}$ & $0.12 \mathrm{U}$ & $0.12 U$ & $0.12 \mathrm{U}$ \\
\hline $2,4^{\prime}-\mathrm{DDD}$ & $0.94 \mathrm{U}$ & $0.94 U$ & $0.94 \mathrm{U}$ & $0.94 \mathrm{U}$ & $0.94 \mathrm{U}$ & $0.94 \mathrm{U}$ \\
\hline 2,4'-DDT & $0.44 \mathrm{U}$ & $0.44 \mathrm{U}$ & 2.20 & $0.44 U$ & $0.44 U$ & $0.44 \mathrm{U}$ \\
\hline 4,4'-DDD & $0.45 \mathrm{U}$ & $0.45 \mathrm{U}$ & $0.45 \mathrm{U}$ & $0.45 \mathrm{U}$ & $0.45 \mathrm{U}$ & $0.45 \mathrm{U}$ \\
\hline Endosulfan II & $0.46 U$ & $.0 .46 \cdot U$ & $0.46 \mathrm{U}$ & $0.46 U$ & $0.46 \mathrm{U}$ & $0.46 U$ \\
\hline 4,4'-DDT & $-0.40 \mathrm{U}$ & $0.40 \mathrm{U}$ & $0.40 \mathrm{U}$ & $0.40 U$ & $0.40 \mathrm{U}$ & $0.40 \mathrm{U}$ \\
\hline Endosulfan Sulfate & $0.46 \mathrm{U}$ & $0.46 \mathrm{U}$ & $0.46 \mathrm{U}$ & $0.46 \mathrm{U}$ & $0.46 U$ & $0.46 U$ \\
\hline PCB 8 & $1.00 \mathrm{U}$ & $1.00 \mathrm{U}$ & $1.00 \mathrm{U}$ & $1.00 \mathrm{U}$ & $1.00 \mathrm{U}$ & $1.00 \mathrm{U}$ \\
\hline PCB 18 & $1.05 \mathrm{U}$ & $1.05 \mathrm{U}$ & $1.05 \mathrm{U}$ & $1.05 U$ & $1.05 \mathrm{U}$ & $1.05 \mathrm{U}$ \\
\hline PCB 28 & $0: 71 \mathrm{U}$ & $0.71 \mathrm{U}$ & $0.71 \mathrm{U}$ & $0.71 \mathrm{U}$ & $0.71 \mathrm{U}$ & $0.71 \mathrm{U}$ \\
\hline РСB 52 & $0.35 \mathrm{U}$ & $0.35 \mathrm{U}$ & $0: 35 \mathrm{U}$ & $0.35 U$ & $0.35 \mathrm{U}$ & $0.35 \mathrm{U}$ \\
\hline РСB 49 & $0.53 \mathrm{U}$ & $0.53 \mathrm{U}$ & $\cdots \quad 0.82$ & $0.53 \mathrm{U}$ & $0.53 \mathrm{U}$ & $0.53 U$ \\
\hline PCB 44 & $0.31 \mathrm{U}$ & $0.31 \mathrm{U}$ & $0.31 \mathrm{U}$ & $0.31 \mathrm{U}$ & $0.31 \mathrm{U}$ & $0.31 \mathrm{U}$ \\
\hline PCB 66 & $0.38 \mathrm{U}$ & $0.38 \mathrm{U}$ & $0.38 \mathrm{U}$ & $0.38 \mathrm{U}$ & $0.38 \mathrm{U}$ & $0.38 \mathrm{U}$ \\
\hline PCB 101 & $0.48 \mathrm{U}$ & $0.48 \mathrm{U}$ & $0.48 \mathrm{U}$ & $0.48 \mathrm{U}$ & $0.48 \mathrm{U}$ & $0.48 U$ \\
\hline PCB 87 & $0.35 \mathrm{U}$ & $0.35 \mathrm{U}$ & $0.35 \mathrm{U}$ & 0.38 & $0.35 U$ & $0.35 \mathrm{U}$ \\
\hline PCB 118 & $0.47 \mathrm{U}$ & $0.47 \mathrm{U}$ & $0.47 \mathrm{U}$ & $0.47 \mathrm{U}$ & $0.47 \mathrm{U}$ & $0.47 U$ \\
\hline PCB 184 & $0.53 \mathrm{U}$ & $0.53 \mathrm{U}$ & $0.53 U$ & $0.53 \mathrm{U}$ & $0.53 \mathrm{U}$ & $0.53 U$ \\
\hline PCB 153 & $0.39 \mathrm{U}$ & $0.39 \mathrm{U}$ & $0.39 \mathrm{U}$ & $0.39 \mathrm{U}$ & $0.39 \mathrm{U}$ & $0.39 \mathrm{U}$ \\
\hline PCB 105 & $0.30 \mathrm{U}$ & $0.30 \mathrm{U}$ & $0.30 \mathrm{U}$ & $0.30 \mathrm{U}$ & $0.30 \mathrm{U}$ & $0.30 \mathrm{U}$ \\
\hline PCB 138 & $0.34 \mathrm{U}$ & $0.34 \mathrm{U}$ & $0.34 \mathrm{U}$ & $0.34 \mathrm{U}$ & $0.34 \mathrm{U}$ & $0.34 \mathrm{U}$ \\
\hline PCB 187 & $0.39 \mathrm{U}$ & $0.39 \mathrm{U}$ & $0.39 \mathrm{U}$ & $0.39 \mathrm{U}$ & $0.39 \mathrm{U}$ & $0.39 \mathrm{U}$ \\
\hline PCB 183 & $0.53 \mathrm{U}$ & $0.53 \mathrm{U}$ & $0.53 U$ & $0.53 \mathrm{U}$ & $0.53 \mathrm{U}$ & $0.53 \mathrm{U}$ \\
\hline PCB 128 & $0.24 \mathrm{U}$ & $0.24 \mathrm{U}$ & $0.24 U$ & $0.24 \mathrm{U}$ & $0.24 \mathrm{U}$ & $0.24 \mathrm{U}$ \\
\hline PCB 180 & $0.27 \mathrm{U}$ & $0.27 \mathrm{U}$ & $0.27 \mathrm{U}$ & $0.27 \mathrm{U}$ & $0.27 \mathrm{U}$ & $0.27 \mathrm{U}$ \\
\hline PCB 170 & $0.20 \mathrm{U}$ & $0.20 \mathrm{U}$ & $0.20 \mathrm{U}$ & $0.20 \mathrm{U}$ & $0.20 \mathrm{U}$ & $0.20 \mathrm{U}$ \\
\hline PCB 195 & $0.27 \mathrm{U}$ & $0.27 \mathrm{U}$ & $0.27 U$ & $0.27 \mathrm{U}$ & $0.27 \mathrm{U}$ & $0.27 U$ \\
\hline PCB 206 & $0.39 \mathrm{U}$ & $0.39 \mathrm{U}$ & $0.39 \mathrm{U}$ & $0.39 \mathrm{U}$ & $0.39 \mathrm{U}$ & $0.39 \mathrm{U}$ \\
\hline PCB 209. & $0.27 \mathrm{U}$ & $0.27 \mathrm{U}$ & $0.27 U$ & $0.27 \mathrm{U}$ & $0.27 \mathrm{U}$ & $0.27 \mathrm{U}$ \\
\hline \multicolumn{7}{|c|}{ Surrogate Recoveries (\%) } \\
\hline PCB 103 (SIS) & 66 & 73 & 68 & 65 & 58 & 64 \\
\hline PCB 198 (SIS) & 85 & 87 & 91 & 81 & 73 & 75 \\
\hline
\end{tabular}


Table B.6. (contd)

\begin{tabular}{|c|c|c|c|c|c|c|c|}
\hline \multirow{2}{*}{\multicolumn{2}{|c|}{$\begin{array}{r}\text { Sediment Treatment } \\
\text { Replicate }\end{array}$}} & \multicolumn{6}{|c|}{ Concentration (ng/L) } \\
\hline & & $\begin{array}{c}\text { BR-B-15 } \\
1 \\
\end{array}$ & $\begin{array}{c}\text { BR-B-15 } \\
2 \\
\end{array}$ & $\begin{array}{c}\text { BR-B-15 } \\
3 \\
\end{array}$ & $\begin{array}{c}\mathrm{MDS}^{(\mathrm{c})} \\
1 \\
\end{array}$ & $\begin{array}{c}\text { MDS } \\
2 \\
\end{array}$ & $\begin{array}{c}\text { MDS } \\
3 \\
\end{array}$ \\
\hline Heptachlor & & $0.47 \mathrm{U}$ & $0.47 \mathrm{U}$ & $0.47 \mathrm{U}$ & $=0.47 \mathrm{U}$ & $0.47 \mathrm{U}$ & $0.47 \mathrm{U}$ \\
\hline Aldrin & & $0.39 \mathrm{U}$ & $0.39 \mathrm{U}$ & $0.39 \mathrm{U}$ & $0.39 \mathrm{U}$ & $0.39 \mathrm{U}$ & $0.39 \mathrm{U}$ \\
\hline Heptachlor Epoxide & & $0.11 \mathrm{U}$ & $0.11 \mathrm{U}$ & $0.11 \mathrm{U}$ & $0.11 \mathrm{U}$ & $0.11 \mathrm{U}$ & $0.11 \mathrm{U}$ \\
\hline $2,4^{\prime}-\mathrm{DDE}$ & & $0.23 \mathrm{U}$ & $0.23 \mathrm{U}$ & $0.23 \mathrm{U}$ & $0.23 U$ & $0.23 \mathrm{U}$ & $0.23 \mathrm{U}$ \\
\hline Endosulfan I & & $0.46 \mathrm{U}$ & $0.46 \mathrm{U}$ & $0.46 U$ & $0.46 U$ & $0.46 U$ & $0.46 \mathrm{U}$ \\
\hline$\alpha$-Chlordane & & $0.83 \mathrm{U}$ & $0.83 \mathrm{U}$ & $0.83 \mathrm{U}$ & $0.83 \mathrm{U}$ & $0.83 \mathrm{U}$ & $0.83 U$ \\
\hline Trans Nonachlor & & $1.11 \mathrm{U}$ & $1.11 \mathrm{U}$ & $1.11 \mathrm{U}$ & $1.11 \mathrm{U}$ & $1.11 \mathrm{U}$ & $1.11 \mathrm{U}$ \\
\hline 4,4'-DDE & & $0.28 \mathrm{U}$ & $0.28 \mathrm{U}$ & $0.28 U$ & $0.28 U$ & $0.28 \mathrm{U}$ & $0.28 \mathrm{U}$ \\
\hline Dieldrin & & $0.12 \mathrm{U}$ & $0.12 \mathrm{U}$ & $0.12 \mathrm{U}$ & $0.12 \mathrm{U}$ & $0.12 \mathrm{U}$ & $0.12 U$ \\
\hline 2,4'-DDD & & $0.94 \mathrm{U}$ & $0.94 U$ & $0.94 \mathrm{U}$ & $0.94 \mathrm{U}$ & $0.94 U$ & $0.94 \mathrm{U}$ \\
\hline 2,4'-DDT & & $0.44 \mathrm{U}$ & $0.44 U$ & $0.44 U$ & $0.44 U$ & $0.44 U$ & $0.44 \mathrm{U}$ \\
\hline 4,4'-DDD & & $0.45 \mathrm{U}$ & $0.45 U$ & $0.45 \mathrm{U}$ & $0.45 \mathrm{U}$ & $0.45 \mathrm{U}$ & $0.45 \mathrm{U}$ \\
\hline Endosulfan II & & $0.46 \mathrm{U}$ & $0.46 U$ & $0.46 U$ & $0.46 \mathrm{U}$ & $0.46 \mathrm{U}$ & $0.46 \mathrm{U}$ \\
\hline 4,4'-DDT & & $0.40: \mathrm{U}$ & $0.40 \mathrm{U}$ & $0.40 \mathrm{U}$ & $0.40 \mathrm{U}$ & $0.40 \mathrm{U}$ & $0.40 \mathrm{U}$ \\
\hline Endosulfan Sulfate & & $0.46 \mathrm{U}$ & $0.46 \mathrm{U}=$ & $0.46 U$ & $0.46 \mathrm{U}$ & $0.46 \mathrm{U}$ & $0.46 \mathrm{U}$ \\
\hline PCB 8 & & $1.00 \mathrm{U}$ & $1.00 \mathrm{U}$ & $1.00 \mathrm{U}$ & $1.00 \mathrm{U}$ & $1.00 \mathrm{U}$ & $1.00 \mathrm{U}$ \\
\hline PCB 18 & & $1.05 \mathrm{U}$ & $1.05 \mathrm{U}$ & $1.05 \mathrm{U}$ & $1.05 \mathrm{U}$ & $1.05 \mathrm{U}$ & $1.05 \mathrm{U}$ \\
\hline PCB 28 & ' & $0.71 \mathrm{U}$ & $0.71 \mathrm{U}$ & $0.71 \mathrm{U}$ & $0.71 \mathrm{U}$ & $=0.71 \mathrm{U}$ & $0.71 \mathrm{U}$ \\
\hline PCB 52 & & $0: 35 \mathrm{U}$ & $0.35 \mathrm{U}$ & $=0.35 \mathrm{U}$ & $0.35 \mathrm{U}$ & $0.35 \mathrm{U}$ & $0.35 \mathrm{U}$ \\
\hline PCB 49 & & $0.53 \mathrm{U}$ & $0.53 \mathrm{U}$ & $0.53 \mathrm{U}$ & $0.53 U$ & $=0.53 \mathrm{U}$ & $0.53 \mathrm{U}$ \\
\hline РCB 44 & · & $0.31 \mathrm{U}$ & $0.31 \mathrm{U}$ & $0.31 \mathrm{U}$ & $0.31 \mathrm{U}$ & $0.31 \mathrm{U}$ & $0.31 \mathrm{U}$ \\
\hline РСВ 66 & - & $-0.38 U$ & $=0.38 \mathrm{U}$ & $0.38 \mathrm{U}$ & $0.38 \mathrm{U}$ & $-0.38 U$ & $0.38 \mathrm{U}$ \\
\hline PCB 101 & & $0.48 \mathrm{U}$ & $0.48 \mathrm{U}$ & $0.48 \mathrm{U}$ & $0.48 U$ & $0.48 \mathrm{U}$ & $0.48 U$ \\
\hline РСВ 87 & & $0.35 \mathrm{U}$ & $0.35 \mathrm{U}$ & $0.35 \mathrm{U}$ & $0.35 \mathrm{U}$ & $0.35 \dot{U}$ & $0.35 U$ \\
\hline PCB 118 & & $0.47 \mathrm{U}$ & $0.47 \mathrm{U}$ & $0.47 \mathrm{U}$ & $0.47 \mathrm{U}$ & $0.47 \mathrm{U}$ & $0.47 \mathrm{U}$ \\
\hline PCB 184 & & $0.53 \mathrm{U}$ & $0.53 \mathrm{U}$ & $0.53 U$ & $0.53 \mathrm{U}$ & $0.53 \mathrm{U}$ & $0.53 \mathrm{U}$ \\
\hline PCB 153 & & $0.39 \mathrm{U}$ & $0.39 \mathrm{U}$ & $0.39 \mathrm{U}$ & $0.39 \mathrm{U}$ & $0.39 \mathrm{U}$ & $0.39 \mathrm{U}$ \\
\hline PCB 105 & & $0.30 \mathrm{U}$ & $0.30 \mathrm{U}$ & $0.30 \mathrm{U}$ & $0.30 \mathrm{U}$ & $0.30 \mathrm{U}$ & $0.30 \mathrm{U}$ \\
\hline PCB 138 & & $0.34 \mathrm{U}$ & $0.34 \mathrm{U}$ & $0.34 \mathrm{U}$ & $0.34 \mathrm{U}$ & $0.34 \mathrm{U}$ & $0.34 \mathrm{U}$ \\
\hline PCB 187 & & $0.39 \mathrm{U}$ & $0.39 \mathrm{U}$ & $0.39 \mathrm{U}$ & $0.39 \mathrm{U}$ & $0.39 \mathrm{U}$ & $0.39 \mathrm{U}$ \\
\hline PCB 183 & & $0.53 U$ & $0.53 U$ & $0.53 \mathrm{U}$ & $0.53 \mathrm{U}$ & $0.53 \mathrm{U}$ & $0.53 U$ \\
\hline PCB 128 & & $0.24 \mathrm{U}$ & $0.24 \mathrm{U}$ & $0.24 U$ & $0.24 U$ & $0.24 \mathrm{U}$ & $0.24 \mathrm{U}$ \\
\hline PCB 180 & & $0.27 \mathrm{U}$ & $0.27 U$ & $0.27 \mathrm{U}$ & $0.27 \mathrm{U}$ & $0.27 \mathrm{U}$ & $0.27 \mathrm{U}$ \\
\hline PCB 170 & & $0.20 \mathrm{U}$ & $0.20 \mathrm{U}$ & $0.20 \mathrm{U}$ & $0.20 \mathrm{U}$ & $0.20 \mathrm{U}$ & $0.20 \mathrm{U}$ \\
\hline РСВ 195 & & $0.27 \mathrm{U}$ & $0.27 \mathrm{U}$ & $0.27 \mathrm{U}$ & $0.27 \mathrm{U}$ & $0.27 \mathrm{U}$ & $0.27 \mathrm{U}$ \\
\hline PCB 206 & & $0.39 \mathrm{U}$ & $0.39 \mathrm{U}$ & $0.39 \mathrm{U}$ & $0.39 \mathrm{U}$ & $0.39 \mathrm{U}$ & $0.39 \mathrm{U}$ \\
\hline PCB 209 & & $0.27 \mathrm{U}$ & $0.27 \cup$ & $0.27 \mathrm{U}$ & $0.27 \mathrm{U}$ & $0.27 \mathrm{U}$ & $0.27 \mathrm{U}$ \\
\hline \multicolumn{8}{|c|}{ Surrogate Recoveries (\%) } \\
\hline PCB 103 (SIS) & & 69 & 66 & 61 & 69 & 69 & 71 \\
\hline PCB 198 (SIS) & & 78 & 76 & 91 & 72 & 74 & 73 \\
\hline
\end{tabular}


Table B.6. (contd)

\begin{tabular}{|c|c|c|c|}
\hline \multirow[b]{2}{*}{$\begin{array}{r}\text { Sediment Treatment } \\
\text { Replicate } \\
\end{array}$} & \multicolumn{3}{|c|}{ Concentration (ng/L) } \\
\hline & $\begin{array}{c}\text { Sequim Bay Water } \\
1 \\
\end{array}$ & $\begin{array}{c}\text { Sequim Bay Water } \\
2\end{array}$ & $\begin{array}{c}\text { Sequim Bay Water } \\
3 \\
\end{array}$ \\
\hline Heptachlor & $0.47 \mathrm{U}$ & $0.47 \mathrm{U}$ & $0.47 \mathrm{U}$ \\
\hline Aldrin & $0.39 \mathrm{U}$ & $0.39 \mathrm{U}$ & $0.39 \mathrm{U}$ \\
\hline Heptachlor Epoxide & $0.11 U$ & $0.11 \mathrm{U}$ & $0.11 \mathrm{U}$ \\
\hline 2,4'-DDE & $0.23 U$ & $0.23 U$ & $0.23 \mathrm{U}$ \\
\hline Endosulfan 1 & $0.46 \mathrm{U}$ & $0.46 \mathrm{U}$ & $0.46 \mathrm{U}$ \\
\hline$\alpha$-Chlordane & $0.83 U$ & $0.83 U$ & $0.83 \mathrm{U}$ \\
\hline Trans Nonachlor & $1.11 \mathrm{U}$ & $1.11 \mathrm{U}$ & $1.11 \mathrm{U}$ \\
\hline $4,4^{\prime}-\mathrm{DDE}$ & $0.28 U$ & $0.28 \mathrm{U}$ & $0.28 \mathrm{U}$ \\
\hline Dieldrin & $0.12 \mathrm{U}$ & $0.12 U$ & $0.12 \mathrm{U}$ \\
\hline 2,4'-DDD & $0.94 \mathrm{U}$ & $0.94 \mathrm{U}$ & $0.94 \mathrm{U}$ \\
\hline 2,4'-DDT & $0.44 \mathrm{U}$ & $0.44 U$ & $0.44 \mathrm{U}$ \\
\hline 4,4'-DDD & $0.45 \mathrm{U}$ & $0.45 \mathrm{U}$ & $0.45 U$ \\
\hline Endosulfan II & $0.46 \mathrm{U}$ & $0.46 \mathrm{U}$ & $0.46 \mathrm{U}$ \\
\hline 4,4'-DDT & $0.40 \mathrm{U}$ & $0.40 \mathrm{U}$ & $0.40 \mathrm{U}$ \\
\hline Endosulfan Sulfate & $0.46 \mathrm{U}$ & $0.46 \mathrm{U}$ & $0.46 \mathrm{U}$ \\
\hline PCB 8 & $1.00 \mathrm{U}$ & $1.00 \mathrm{U}$ & $1.00 \mathrm{U}$ \\
\hline PCB 18 & $1.05 \mathrm{U}$ & $1.05 \mathrm{U}$ & $1.05 \mathrm{U}$ \\
\hline PCB 28 & $0.71 \mathrm{U}$ & $\cdots 0.71 \mathrm{U}$ & $0.71 \mathrm{U}$ \\
\hline РСB 52 & $\ldots \quad 0.35 \mathrm{U}$ & $0.35 \mathrm{U}$ & $0.35 U$ \\
\hline РСВ 49 & $0.53 U$ & $0.53 \mathrm{U}$ & $0.53 U$ \\
\hline PCB 44 & $0.31 \mathrm{U}$ & $0.31 \mathrm{U}$ & $0.31 \mathrm{U}$ \\
\hline PCB 66 & $0.38 \mathrm{U}$ & $0.38 \mathrm{U}$ & . $\quad 0.38 \mathrm{U}$ \\
\hline PCB 101 & $0.48 U$ & $-0.48 \mathrm{U}$ & $0.48 U$ \\
\hline РCB 87 & $0.35 U$ & $0.35 U$ & $0.35 \mathrm{U}$ \\
\hline РCB 118 & $0.47 \mathrm{U}$ & $0.47 \mathrm{U}$ & $0.47 \mathrm{U}$ \\
\hline PCB 184 & $0.53 \mathrm{U}$ & $0.53 \mathrm{U}$ & $0.53 \mathrm{U}$ \\
\hline PCB 153. & $0.39 \mathrm{U}$ & $0.39 \mathrm{U}$ & $0.39 U$ \\
\hline PCB 105 & $0.30 \mathrm{U}$ & $0.30 \mathrm{U}$ & $0.30 \mathrm{U}$ \\
\hline PCB 138 & $0.34 U$ & $0.34 \mathrm{U}$ & $0.34 \mathrm{U}$ \\
\hline PCB 187 & $0.39 U$ & $0.39 \mathrm{U}$ & $0.39 \mathrm{U}$ \\
\hline PCB 183 & $0.53 \mathrm{U}$ & $0.53 U$ & $0.53 \mathrm{U}$ \\
\hline PCB 128 & $0.24 \mathrm{U}$ & $0.24 U$ & $0.24 \mathrm{U}$ \\
\hline PCB 180 & $0.27 U$ & $0.27 \mathrm{U}$ & $0.27 \mathrm{U}$ \\
\hline PCB 170 & $0.20 \mathrm{U}$ & $0.20 \mathrm{U}$ & $0.20 \mathrm{U}$ \\
\hline PCB 195 & $0.27 \mathrm{U}$ & $0.27 \mathrm{U}$ & $0.27 \mathrm{U}$ \\
\hline РCB 206 & $0.39 \mathrm{U}$ & $0.39 \mathrm{U}$ & $0.39 \mathrm{U}$ \\
\hline PCB 209 & $0.27 \mathrm{U}$ & $0.27 \mathrm{U}$ & $0.27 U$ \\
\hline Surrogate Recoveries (\%) & 78 & 78 & 78 \\
\hline PCB 103 (SIS) & 81 & 81 & 81 \\
\hline PCB 198 (SIS) & & & \\
\hline
\end{tabular}


Table B.7. Quality Control Data for Pesticide and Polychlorinated Biphenyl (PCB) Analysis of Site Water Samples, Blank and Spike Recovery Results

\begin{tabular}{|c|c|c|c|c|c|c|c|}
\hline \multirow[b]{3}{*}{$\begin{array}{r}\text { ediment Treatment } \\
\text { Replicate }\end{array}$} & \multicolumn{2}{|c|}{ Concentration (ng/L) } & \multicolumn{4}{|c|}{ Concentration (ng/L) } & \multirow{3}{*}{$\begin{array}{l}\text { Percent } \\
\text { Recovery }\end{array}$} \\
\hline & \multirow{3}{*}{$\begin{array}{c}\begin{array}{c}\text { Method } \\
\text { Blank } \\
1\end{array} \\
0.50 \mathrm{U}^{(b)}\end{array}$} & \multirow{2}{*}{$\begin{array}{c}\text { Method } \\
\text { Blank } \\
2 \\
\end{array}$} & \multirow{2}{*}{$\begin{array}{c}\text { Sequim } \\
\text { Bay Water } \\
\text { Mean }^{(a)}\end{array}$} & \multirow{2}{*}{$\begin{array}{c}\text { Sequim Bay } \\
\text { Water (MS) } \\
1 \\
\end{array}$} & \multicolumn{2}{|c|}{ Concentration } & \\
\hline & & & & & Spiked & Recovered & \\
\hline Heptachlor & & $0.50 \mathrm{U}$ & $0.47 \mathrm{U}$ & 43.0 & 47.0 & 43.0 & 92 \\
\hline Aldrin & $0.41 \mathrm{U}$ & $0.41 \mathrm{U}$ & $0.39 \mathrm{U}$ & 38.1 & 47.0 & 38.1 & 81 \\
\hline Heptachlor Epoxide & $0.12 U$ & $0.12 \mathrm{U}$ & $0.11 \mathrm{U}$ & 44.3 & 47.0 & 44.3 & 94 \\
\hline 2,4'-DDE & $0.24 \mathrm{U}$ & $0.24 \mathrm{U}$ & $0.23 \mathrm{U}$ & 47.6 & 47.0 & 47.6 & 101 \\
\hline Endosulfan I & $0.49 \mathrm{U}$ & $0.49 \mathrm{U}$ & $0.46 \mathrm{U}$ & $N S^{(c)}$ & NS & NS & $N A^{(d)}$ \\
\hline$\alpha$-Chlordane & $0.88 \mathrm{U}$ & $0.88 \mathrm{U}$ & $0.83 \mathrm{U}$ & 41.1 & 47.0 & 41.1 & 87 \\
\hline Trans Nonachlor & $1.18 \mathrm{U}$ & $1.18 \mathrm{U}$ & $1.11 \mathrm{U}$ & 39.4 & 47.0 & 39.4 & 84 \\
\hline 4,4'-DDE & $0.29 \mathrm{U}$ & $0.29 \mathrm{U}$ & $0.28 U$ & 40.6 & 47.0 & 40.6 & 86 \\
\hline Dieldrin & $0.13 \mathrm{U}$ & $0.13 \mathrm{U}$ & $0.12 U$ & 40.5 & 47.0 & 40.5 & 86 \\
\hline 2,4'-DDD & $1.00 \mathrm{U}$ & $1.00 \mathrm{U}$ & $0.94 \mathrm{U}$ & 45.2 & 47.0 & 45.2 & 96 \\
\hline 2,4'-DDT & $0.46 \mathrm{U}$ & $0.46 \mathrm{U}$ & $0.44 U$ & 46.6 & 47.0 & 46.6 & 99 \\
\hline 4,4'-DDD & $0.48 \mathrm{U}$ & $0.48 \mathrm{U}$ & $0.45 \mathrm{U}$ & 41.2 & 47.0 & 41.2 & 88 \\
\hline Endosulfan II & $\because-0.49 \mathrm{U}$ & $-0.49 \mathrm{U}$ & $0.46 \mathrm{U}$ & NS & NS & NS & NA \\
\hline 4,4'-DDT & $0.43 \mathrm{U}$ & $0.43 \mathrm{U}$ & $0.40 \mathrm{U}$ & 41.4 & 47.0 & 41.4 & 88 \\
\hline Endosulfan Sulfate & $0.49 \mathrm{U}$ & $0.49 \mathrm{U}$ & $0.46 \mathrm{U}$ & NS & NS & NS & NA \\
\hline PCB 8 & $=1.06 \mathrm{U} \cdot$ & $1.06 \mathrm{U}$ & $1.00 \mathrm{U}$ & NS & NS & NS & NA \\
\hline РСВ 18 & $1.12 U$ & $1.12 U$ & $1.05 \mathrm{U}$ & NS & NS & NS & NA \\
\hline РСB 28 & $0.75 U$ & $0.75 \mathrm{U}$ & $0.71 \mathrm{U}$ & 16.6 & 15.0 & 16.6 & 111 \\
\hline РСВ 52 & $0.38 \mathrm{U}$ & $0.38 \mathrm{U}$ & $0: 35 \mathrm{U}$ & 30.9 & 31.3 & 30.9 & 99 \\
\hline РСВ 49 & $0.57 \cup$ & $0.57 \mathrm{U}$ & $0.53 \mathrm{U}$ & NS & NS & NS & NA \\
\hline РСB 44 & $0.33 \mathrm{U}$ & $0.33 \mathrm{U}$ & $0: 31 \cdot U$ & NS & NS & NS & NA \\
\hline РCB 66 & $0.41 U$ & $0.41 \mathrm{U}$ & $0.38 U$ & NS & NS & NS & NA \\
\hline РCB 101 & $0.52 \mathrm{U}$ & $0.52 \mathrm{U}$ & $0.48 U$ & 22.4 & 21.2 & 22.4 & 105 \\
\hline РСВ 87 & $0.38 \mathrm{U}$ & $0.38 \mathrm{U}$ & $0.35 U$ & NS & NS & NS & NA \\
\hline РCB 118 & $0.50 \mathrm{U}$ & $0.50 \mathrm{U}$ & $0.47 \mathrm{U}$ & NS & NS & NS & NA \\
\hline РСB 184 & $0.57 \mathrm{U}$ & $0.57 \mathrm{U}$ & $0.53 U$ & NS & NS & NS & NA \\
\hline РСВ 153 & $0.42 \mathrm{U}$ & $0.42 \mathrm{U}$ & $0.39 \mathrm{U}$ & 12.6 & 12.4 & 12.6 & 101 \\
\hline PCB 105 & $0.32 U$ & $0.32 \mathrm{U}$ & $0.30 \mathrm{U}$ & NS & NS & NS & NA \\
\hline РCB 138 & $0.36 \mathrm{U}$ & $0.36 \mathrm{U}$ & $0.34 U$ & 9.56 & 9.57 & 9.6 & 100 \\
\hline PCB 187 & $0.41 \mathrm{U}$ & $0.41 \mathrm{U}$ & $0.39 \mathrm{U}$ & NS & NS & NS & NA \\
\hline РCB 183 & $0.57 \cup$ & $0.57 \mathrm{U}$ & $0.53 \mathrm{U}$ & NS & NS & NS & NA \\
\hline PCB 128 & $0.26 U$ & $0.26 \mathrm{U}$ & $0.24 \mathrm{U}$ & NS & NS & NS & NA \\
\hline PCB 180 & $0.29 \mathrm{U}$ & $0.29 \mathrm{U}$ & $0.27 \mathrm{U}$ & NS & NS & NS & NA \\
\hline PCB 170 & $0.21 U$ & $0.21 \mathrm{U}$ & $0.20 \mathrm{U}$ & NS & NS & NS & NA \\
\hline PCB 195 & $0.29 \mathrm{U}$ & $0.29 \mathrm{U}$ & $0.27 \mathrm{U}$ & NS & NS & NS & NA \\
\hline РCB 206 & $0.42 \mathrm{U}$ & $0.42 \mathrm{U}$ & $0.39 \mathrm{U}$ & NS & NS & NS & NA \\
\hline PCB 209 & $0.29 \mathrm{U}$ & $0.29 \mathrm{U}$ & $0.27 \mathrm{U}$ & NS & NS & NS & NA \\
\hline \multicolumn{8}{|l|}{ Sur } \\
\hline РCB 103 (SIS) & 60 & 60 & NA & 61 & NA & NA & NA \\
\hline PCB 198 (SIS) & 70 & 70 & NA & 93 & NA & NA & NA \\
\hline
\end{tabular}

(a) Mean of three replicates used for matrix spike analysis.

(b) U Undetected at or above given concentration.

(c) NS Not spiked.

(d) NA Not applicable. 
Table B.8 Quality Control Data for Pesticide and Polychlorinated Biphenyl (PCB) Analysis of Site Water Samples, Analytical Replicates




Table B.8. (contd)

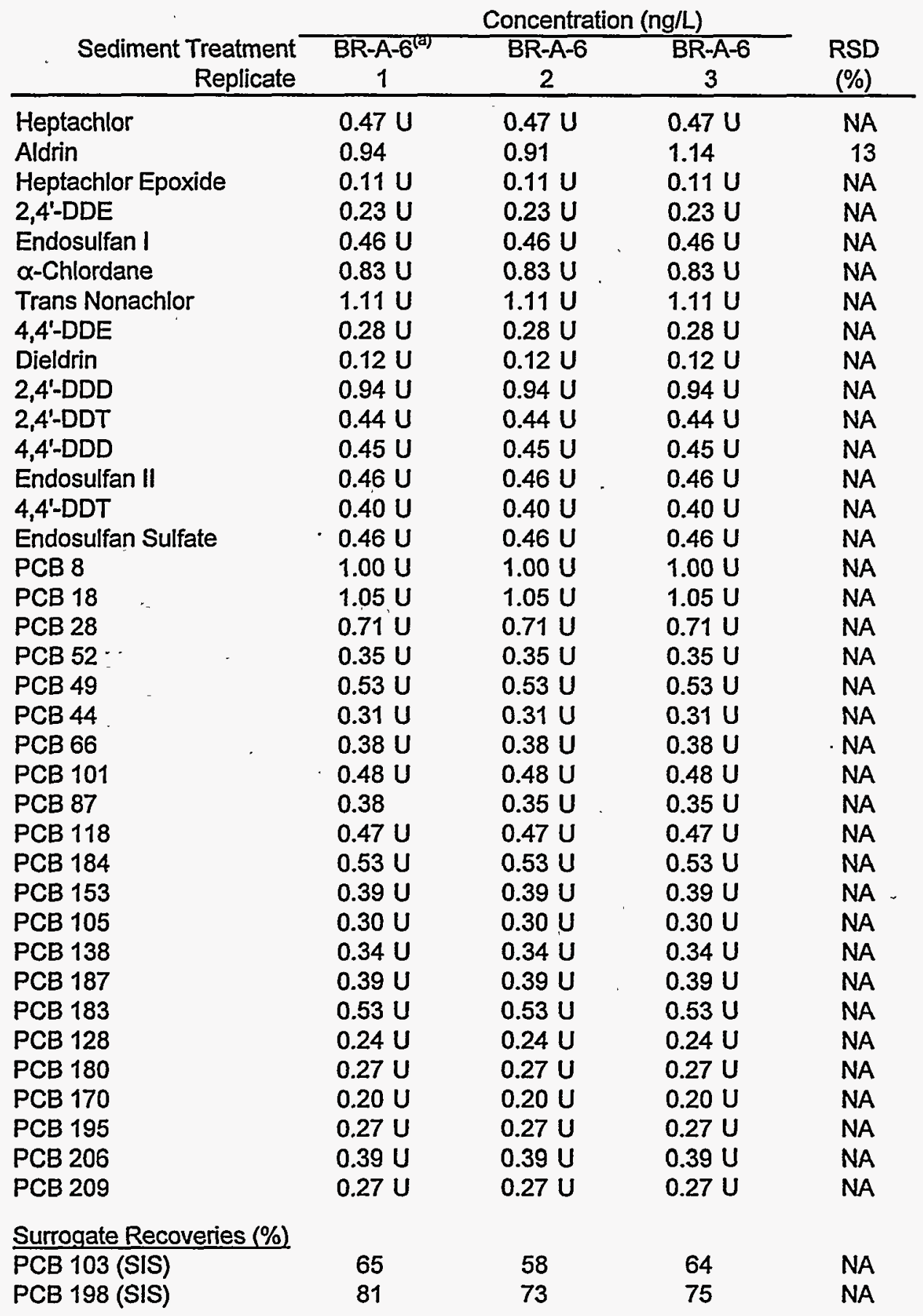


Table B.8. (contd)




Table B.8. (contd)

\begin{tabular}{|c|c|c|c|}
\hline \multirow[b]{2}{*}{$\begin{array}{r}\text { Sediment Treatment } \\
\text { Replicate }\end{array}$} & \multicolumn{2}{|c|}{ Concentration (ng/L) } & \multirow[b]{2}{*}{$\begin{array}{l}\text { RPD } \\
(\%)\end{array}$} \\
\hline & $\begin{array}{c}\mathrm{CL}^{-A-7^{(j)}} \\
1\end{array}$ & $\begin{array}{c}C L-A-7 \\
2\end{array}$ & \\
\hline Heptachlor & $0.47 \mathrm{U}$ & $0.47 \mathrm{U}$ & NA \\
\hline Aldrin & $0.39 U$ & $0.39 \mathrm{U}$ & NA \\
\hline Heptachlor Epoxide & $0.11 \mathrm{U}$ & $0.11 \mathrm{U}$ & NA \\
\hline 2,4'-DDE & $0.23 \mathrm{U}$ & $0.23 \mathrm{U}$ & NA \\
\hline Endosulfan I & $0.46 \mathrm{U}$ & $0.46 \mathrm{U}$ & NA \\
\hline$\alpha$-Chlordane & $0.83 \mathrm{U}$ & $0.83 \mathrm{U}$ & NA \\
\hline Trans Nonachlor & $1.11 \mathrm{U}$ & $1.11 \mathrm{U}$ & NA \\
\hline 4, $4^{\prime}-\mathrm{DDE}$ & 2.51 & 3.19 & 24 \\
\hline Dieldrin & $0.12 \mathrm{U}$ & $0.12 \mathrm{U}$ & NA \\
\hline 2,4'-DDD. & $0.94 \mathrm{U}$ & $0.94 \mathrm{U}$ & NA \\
\hline 2,4'-DDT & $0.44 \mathrm{U}$ & $0.44 \mathrm{U}$ & NA \\
\hline 4,4'-DDD & $0.45 \mathrm{U}$ & $0.45 \mathrm{U}$ & NA \\
\hline Endosulfan II & $0.46 \mathrm{U}$ & $0.46 \mathrm{U}$ & NA \\
\hline 4,4'-DDT & $0.40 \mathrm{U}$ & $0.40 \mathrm{U}$ & NA \\
\hline Endosulfan Sulfate & $0.46 \mathrm{U}$ & $0.46 \mathrm{U}$ & NA \\
\hline РCB 8 & $1.00 \mathrm{U}$ & $1.00 \mathrm{U}$ & NA \\
\hline PCB 18 & $1.05 \mathrm{U}$ & $1.05 \mathrm{U}$ & NA \\
\hline PCB 28 & $0.71 \cup$ & $0.71 \mathrm{U}$ & NA \\
\hline PCB 52 & $0.35 \mathrm{U}$ & $0.35 \mathrm{U}$ & NA \\
\hline РСB 49 & 1.23 & $0.53 \mathrm{U}$ & NA \\
\hline PCB 44 & $0.31 \mathrm{U}$ & $0.31 \mathrm{U}$ & NA \\
\hline PCB 66 & $0.38 \mathrm{U}$ & $0.38 \mathrm{U}$ & NA \\
\hline PCB 101 & $0.48 \mathrm{U}$ & $0.48 \mathrm{U}$ & NA \\
\hline РCB 87 & 0.36 & $0.35 \mathrm{U}$ & NA \\
\hline PCB 118 & $0.47 \mathrm{U}$ & $0.47 \mathrm{U}$ & NA \\
\hline PCB 184 & $0.53 \mathrm{U}$ & $0.53 \mathrm{U}$ & NA \\
\hline РCB 153 & $0.39 \mathrm{U}$ & $0.39 \mathrm{U}$ & NA \\
\hline PCB 105 & $0.30 \mathrm{U}$ & $0.30 \mathrm{U}$ & NA \\
\hline PCB 138 & 0.38 & $0.34 \mathrm{U}$ & NA \\
\hline PCB 187 & $0.39 \mathrm{U}$ & $0.39 \mathrm{U}$ & NA \\
\hline PCB 183 & $0.53 \mathrm{U}$ & $0.53 \mathrm{U}$ & NA \\
\hline PCB 128 & $0.24 \mathrm{U}$ & $0.24 \mathrm{U}$ & NA \\
\hline PCB 180 & 0.32 & $0.27 \mathrm{U}$ & NA \\
\hline PCB 170 & $0.20 \mathrm{U}$ & $0.20 \mathrm{U}$ & NA \\
\hline PCB 195 & $0.27 \mathrm{U}$ & $0.27 \mathrm{U}$ & NA \\
\hline PCB 206 & $0.39 \mathrm{U}$ & $0.39 \mathrm{U}$ & NA \\
\hline PCB 209 & $0.27 \mathrm{U}$ & $0.27 \mathrm{U}$ & NA \\
\hline \multicolumn{4}{|l|}{ ecoveries } \\
\hline$\overline{\text { PCB } 103 \text { (SIS) }}$ & 60 & 62 & NA \\
\hline PCB 198 (SIS) & 100 & .101 & NA \\
\hline
\end{tabular}


Table B.8. (contd)




Table B.8. (contd)

\begin{tabular}{|c|c|c|c|c|}
\hline \multirow[b]{2}{*}{$\begin{array}{r}\text { Sediment Treatment } \\
\text { Replicate }\end{array}$} & \multicolumn{3}{|c|}{ Concentration (ng/L) } & \multirow[b]{2}{*}{$\begin{array}{r}\text { RSD } \\
(\%) \\
\end{array}$} \\
\hline & $\begin{array}{c}\text { CL-C-24(a) } \\
1\end{array}$ & $\begin{array}{c}\mathrm{CL}-\mathrm{C}-24 \\
2\end{array}$ & $\begin{array}{c}\text { CL-C-24 } \\
3\end{array}$ & \\
\hline Heptachlor & $0.47 \mathrm{U}$ & $0.47 \mathrm{U}$ & $0.47 \mathrm{U}$ & NA \\
\hline Aldrin & 1.38 & $0.39 \mathrm{U}$ & $0.39 \mathrm{U}$ & NA \\
\hline Heptachlor Epoxide & $0.11 \mathrm{U}$ & $0.11 \mathrm{U}$ & $0.11 \mathrm{U}$ & NA \\
\hline $2,4^{\prime}-\mathrm{DDE}$ & $0.23 \mathrm{U}$ & $0.23 \mathrm{U}$ & $0.23 \mathrm{U}$ & NA \\
\hline Endosulfan I & 0.94 & 1.12 & 0.88 & 13 \\
\hline$\alpha$-Chlordane & $0.83 \mathrm{U}$ & $0.83 \mathrm{U}$ & $0.83 \mathrm{U}$ & NA \\
\hline Trans Nonachlor & $1.11 \mathrm{U}$ & $1.11 \mathrm{U}$ & $1.11 \mathrm{U}$ & NA \\
\hline 4,4'-DDE & $0.28 \mathrm{U}$ & $0.28 \mathrm{U}$ & $0.28 U$ & NA \\
\hline Dieldrin & $0.12 \mathrm{U}$ & $0.12 \mathrm{U}$ & $0.12 \mathrm{U}$ & NA \\
\hline 2,4'-DDD & $0.94 \mathrm{U}$ & $0.94 \mathrm{U}$ & $0.94 \mathrm{U}$ & NA \\
\hline 2,4'-DDT & $0.44 \mathrm{U}$ & $0.44 \mathrm{U}$ & $0.44 \mathrm{U}$ & NA \\
\hline 4,4'-DDD & $0.45 \mathrm{U}$ & $0.45 \mathrm{U}$ & $0.45 \mathrm{U}$ & NA \\
\hline Endosulfan II & $0.46 \mathrm{U}$ & $0.46 \mathrm{U}$ & $0.46 \mathrm{U}$ & NA \\
\hline 4,4'-DDT & $0.40 \mathrm{U}$ & $0.40 \mathrm{U}$ & $0.40 \mathrm{U}$ & NA \\
\hline Endosulfan Sulfate & $0.46 \mathrm{U}$ & $0.46 \mathrm{U}$ & $0.46 \mathrm{U}$ & NA \\
\hline PCB 8 & $1.00 \mathrm{U}$ & $1.00 \mathrm{U}$ & $1.00 \mathrm{U}$ & NA \\
\hline PCB 18 & $1.05 \mathrm{U}$ & $1.05 \mathrm{U}$ & $1.05 \mathrm{U}$ & NA \\
\hline PCB 28 & $0.71 \mathrm{U}$ & $0.71 \mathrm{U}$ & $0.71 \mathrm{U}$ & NA \\
\hline PCB 52 & 0.85 & 0.66 & $0.35 \mathrm{U}$ & NA \\
\hline РСВ 49 & $0.53 \mathrm{U}$ & $0.53 \mathrm{U}$ & 0.88 & NA \\
\hline PCB 44. & $0.31 \mathrm{U}$ & $0.31 \mathrm{U}$ & $0.31 \mathrm{U}$ & - NA \\
\hline PCB 66 & $0.38 U$ & $0.38 \mathrm{U}$ & $0.38 \mathrm{U}$ & $\ldots N A$ \\
\hline РCB 101 & $0.48 \mathrm{U}$ & $0.48 \mathrm{U}$ & $0.48 \mathrm{U}$ & NA \\
\hline PCB 87 & $0.35 \mathrm{U}$ & 0.39 & 0.38 & NA \\
\hline PCB 118 & $0.47 \mathrm{U}$ & $0.47 \mathrm{U}$ & $0.47 \mathrm{U}$ & NA \\
\hline PCB 184 & $0.53 \mathrm{U}$ & $0.53 \mathrm{U}$ & $0.53 U$ & NA \\
\hline РCB 153 & $0.39 \mathrm{U}$ & $0.39 \mathrm{U}$ & $0.39 \mathrm{U}$ & NA \\
\hline PCB 105 & $0.30 \mathrm{U}$ & $0.30 \mathrm{U}$ & $0.30 \mathrm{U}$ & NA \\
\hline РCB 138 & $0.34 \mathrm{U}$ & $0.34 \mathrm{U}$ & $0.34 \mathrm{U}$ & NA \\
\hline PCB 187 & $0.39 \mathrm{U}$ & $0.39 \mathrm{U}$ & $0 . \dot{39} \mathrm{U}$ & NA \\
\hline PCB 183 & $0.53 \mathrm{U}$ & $0.53 \mathrm{U}$ & $0.53 \mathrm{U}$ & NA \\
\hline PCB 128 & $0.24 \mathrm{U}$ & $0.24 \mathrm{U}$ & $0.24 \mathrm{U}$ & NA \\
\hline PCB 180 & $0.27 \mathrm{U}$ & $0.27 \mathrm{U}$ & $0.27 \mathrm{U}$ & NA \\
\hline PCB 170 & $0.20 \mathrm{U}$ & $0.20 \mathrm{U}$ & $0.20 \mathrm{U}$ & NA \\
\hline PCB 195 & $0.27 \mathrm{U}$ & $0.27 \mathrm{U}$ & $0.27 \mathrm{U}$ & NA \\
\hline PCB 206 & $0.39 \mathrm{U}$ & $0.39 \mathrm{U}$ & $0.39 \mathrm{U}$ & NA \\
\hline PCB 209 & $0.27 \mathrm{U}$ & $0.27 \mathrm{U}$ & $0.27 \mathrm{U}$ & NA \\
\hline \multicolumn{5}{|l|}{ Surrogate Recoveries (\%) } \\
\hline PCB 103 (SIS) & 69 & 64 & 64 & NA \\
\hline PCB 198 (SIS) & 73 & 74 & 72 & NA \\
\hline
\end{tabular}


Table B.8. (contd)

\begin{tabular}{|c|c|c|c|c|}
\hline \multirow[b]{2}{*}{ Replicate } & \multicolumn{3}{|c|}{ Concentration (ng/L) } & \multirow[b]{2}{*}{$\begin{array}{r}\text { RSD } \\
(\%) \\
\end{array}$} \\
\hline & $\begin{array}{c}\text { PJ-A-6 }^{(a)} \\
1\end{array}$ & $\begin{array}{c}\text { PJ-A-6 } \\
2\end{array}$ & $\begin{array}{c}\text { PJ-A-6 } \\
3\end{array}$ & \\
\hline Heptachlor & $0.47 \mathrm{U}$ & $0.47 \mathrm{U}$ & $0.47 \mathrm{U}$ & NA \\
\hline Aldrin & $0.39 \mathrm{U}$ & $0.39 \mathrm{U}$ & 0.84 & NA \\
\hline Heptachlor Epoxide & $0.11 \mathrm{U}$ & $0.11 \mathrm{U}$ & $0.11 \mathrm{U}$ & NA \\
\hline 2,4'-DDE & $0.23 \mathrm{U}$ & $0.23 \mathrm{U}$ & $0.23 \mathrm{U}$ & NA \\
\hline Endosulfan I & $0.46 \mathrm{U}$ & $0.46 \mathrm{U}$ & $0.46 \mathrm{U}$ & NA \\
\hline$\alpha$-Chlordane & $0.83 \mathrm{U}$ & $0.83 \mathrm{U}$ & $0.83 \mathrm{U}$ & NA \\
\hline Trans Nonachlor & $1.11 \mathrm{U}$ & $1.11 \mathrm{U}$ & $1.11 \mathrm{U}$ & NA \\
\hline 4,4'-DDE & $0.28 \mathrm{U}$ & $0.28 \mathrm{U}$ & $0.28 \mathrm{U}$ & NA \\
\hline Dieldrin & $0.12 \mathrm{U}$ & $0.12 U$ & $0.12 \mathrm{U}$ & NA \\
\hline 2,4'-DDD & $0.94 \mathrm{U}$ & $0.94 U$ & $0.94 \mathrm{U}$ & NA \\
\hline 2,4'-DDT & $0.44 \mathrm{U}$ & $0.44 \mathrm{U}$ & $0.44 \mathrm{U}$ & NA \\
\hline 4,4'-DDD & $0.45 \mathrm{U}$ & $0.45 \mathrm{U}$ & $0.45 \mathrm{U}$ & NA \\
\hline Endosulfan II & $0.46 \mathrm{U}$ & $0.46 \mathrm{U}$ & $0.46 \mathrm{U}$ & NA \\
\hline 4,4'-DDT & $0.40 \mathrm{U}$ & $0.40 \mathrm{U}$ & $0.40 \mathrm{U}$ & NA \\
\hline Endosulfan Sulfate & $0.46 \mathrm{U}$ & $0.46 \mathrm{U}$ & $-0.46 \mathrm{U}$ & $\because N A$ \\
\hline PCB 8 & $1.00 \mathrm{U}$ & $1.00 \mathrm{U}$ & $1.00 \mathrm{U}$ & NA \\
\hline PCB 18 & $1.05 \mathrm{U}$ & $1.05 \mathrm{U}$ & $1.05 \mathrm{U}$ & NA \\
\hline PCB 28 & $0.71 \mathrm{U}$ & $0.71 \mathrm{U}$ & $0.71 \mathrm{U}$ & NA \\
\hline PCB 52 & 0.43 & 0.56 & $0.35 \mathrm{U}$ & $=N A$ \\
\hline PCB 49 & $0.53 \mathrm{U}$ & $0.53 \mathrm{U}$ & $0.53 U$ & NA \\
\hline PCB 44 & $0.31 \mathrm{U}$ & $0.31 \mathrm{U}$ & $0.31 \mathrm{U}$ & - NA \\
\hline PCB 66 & $0.38 \mathrm{U}$ & $0.38 \mathrm{U}$ & $0.38 \mathrm{U}$ & $=N A$ \\
\hline РСВ 101 & $0.48 \mathrm{U}$ & $0.48 \mathrm{U}$ & $0.48 U$ & NA \\
\hline PCB 87 & $0.35 \mathrm{U}$ & $0.35 \mathrm{U}$ & 0.38 & -NA \\
\hline РCB 118 & $0.47 \mathrm{U}$ & $0.47 \mathrm{U}$ & $0.47 \mathrm{U}$ & NA \\
\hline PCB 184 & $0.53 \mathrm{U}$ & $0.53 \mathrm{U}$ & $0.53 \mathrm{U}$ & NA \\
\hline PCB 153 & $0.39 \mathrm{U}$ & $0.39 \mathrm{U}$ & $0.39 \mathrm{U}$ & NA \\
\hline PCB 105 & $0.30 \mathrm{U}$ & $0.30 \mathrm{U}$ & $0.30 \mathrm{U}$ & NA \\
\hline PCB 138 & $0.34 \mathrm{U}$ & $0.34 U$ & $0.34 \mathrm{U}$ & NA \\
\hline PCB 187 & $0.39 \mathrm{U}$ & $0.39 \mathrm{U}$ & $0.39 \mathrm{U}$ & NA \\
\hline PCB 183 & $0.53 \mathrm{U}$ & $0.53 \mathrm{U}$ & $0.53 \mathrm{U}$ & NA \\
\hline PCB 128 & $0.24 \mathrm{U}$ & $0.24 \mathrm{U}$ & $0.24 U$ & NA \\
\hline PCB 180 & $0.27 \mathrm{U}$ & $0.27 \mathrm{U}$ & $0.27 \mathrm{U}$ & NA \\
\hline РCB 170 & $0.20 \mathrm{U}$ & $0.20 \mathrm{U}$ & $0.20 \mathrm{U}$ & NA \\
\hline РCB 195 & $0.27 \mathrm{U}$ & $0.27 \mathrm{U}$ & $0.27 \mathrm{U}$ & NA \\
\hline PCB 206 & $0.39 \mathrm{U}$ & $0.39 \mathrm{U}$ & $0.39 \mathrm{U}$ & NA \\
\hline РCB 209 & $0.27 \mathrm{U}$ & $0.27 \mathrm{U}$ & $0.27 \mathrm{U}$ & NA \\
\hline \multicolumn{5}{|l|}{ Surrogate Recoveries (\%) } \\
\hline PCB 103 (SIS) & 74 & 71 & 66 & NA \\
\hline PCB 198 (SIS) & 80 & 75 & 70 & NA \\
\hline
\end{tabular}


Table B.8. (contd)

\begin{tabular}{|c|c|c|c|c|}
\hline \multirow[b]{2}{*}{ Sedim } & \multicolumn{3}{|c|}{ Concentration (ng/L) } & \multirow[b]{2}{*}{$\begin{array}{r}\text { RSD } \\
(\%) \\
\end{array}$} \\
\hline & $\begin{array}{c}\text { PJ-B-22(a) } \\
1 \\
\end{array}$ & $\begin{array}{c}\text { PJ-B-22 } \\
2 \\
\end{array}$ & $\begin{array}{c}\text { PJ-B-22 } \\
3 \\
\end{array}$ & \\
\hline Heptachlor & $0.47 \mathrm{U}$ & $0.47 \mathrm{U}$ & $0.47 \mathrm{U}$ & NA \\
\hline Aldrin & 1.15 & $0.39 \mathrm{U}$ & 2.54 & NA \\
\hline Heptachlor Epoxide & $0.11 \mathrm{U}$ & $0.11 \mathrm{U}$ & $0.11 \mathrm{U}$ & NA \\
\hline $2,4^{\prime}-\mathrm{DDE}$ & $0.23 \mathrm{U}$ & $0.23 \mathrm{U}$ & $0.23 \mathrm{U}$ & NA \\
\hline Endosulfan I & $0.46 \mathrm{U}$ & $0.46 \mathrm{U}$ & $0.46 \mathrm{U}$ & NA \\
\hline$\alpha$-Chlordane & $0.83 \mathrm{U}$ & $0.83 \mathrm{U}$ & $0.83 \mathrm{U}$ & NA \\
\hline Trans Nonachlor & $1.11 \mathrm{U}$ & $1.11 \mathrm{U}$ & $1.11 \mathrm{U}$ & NA \\
\hline 4,4'-DDE & $0.28 \mathrm{U}$ & $0.28 \mathrm{U}$ & $0.28 \mathrm{U}$ & NA \\
\hline Dieldrin & $0.12 \mathrm{U}$ & $0.12 \mathrm{U}$ & $0.12 \mathrm{U}$ & NA \\
\hline 2,4'-DDD & $0.94 \mathrm{U}$ & $0.94 \mathrm{U}$ & $0.94 \mathrm{U}$ & NA \\
\hline 2,4'-DDT & $0.44 \mathrm{U}$ & $0.44 \mathrm{U}$ & $0.44 U$ & NA \\
\hline 4,4'-DDD & $0.45 \mathrm{U}$ & $0.45 \mathrm{U}$ & $0.45 \mathrm{U}$ & NA \\
\hline Endosulfan II & $0.46 \mathrm{U}$ & $0.46 U$ & $0.46 \mathrm{U}$ & NA \\
\hline 4,4'-DDT & $0.40 \mathrm{U}$ & $0.40 \mathrm{U}$ & $0.40 \mathrm{U}$ & NA \\
\hline Endosulfan Sulfate & $0.46 \mathrm{U}$ & $0.46 \mathrm{U}$ & $0.46 \mathrm{U}$ & $\therefore N A$ \\
\hline РCB 8 & $1.00 \mathrm{U}$ & $1.00 \mathrm{U}$ & $1.00 \mathrm{U}$ & NA \\
\hline РCB 18 & $1.05 \mathrm{U}$ & $1.05 U$ & $1.05 \mathrm{U}$ & NA \\
\hline PCB 28 & $0.71 \mathrm{U}$ & $0.71 \mathrm{U}$ & $0.71 \mathrm{U}$ & NA \\
\hline PCB 52 & $0.35 \mathrm{U}$ & $0.35 U$ & $0.35 \mathrm{U}$ & NA \\
\hline PCB 49 & $0.53 \mathrm{U}$ & $0.53 U$ & 0.81 & NA \\
\hline РСВ 44 & $0.31 \mathrm{U}$ & $0.31 \mathrm{U}$ & $0.31 \mathrm{U}$ & NA \\
\hline РCB 66 & $0.38 \mathrm{U}$ & 0.74 & $0.38 \mathrm{U}$ & NA \\
\hline РCB 101 & $0.48 \mathrm{U}$ & $0.48 \mathrm{U}$ & $0.48 \mathrm{U}$ & NA \\
\hline РСВ 87 & $0.35 \mathrm{U}$ & 0.61 & 0.46 & NA \\
\hline РСВ 118 & $0.47 U$ & $0.47 \mathrm{U}$ & $0.47 \mathrm{U}$ & NA \\
\hline PCB 184 & $0.53 \mathrm{U}$ & $0.53 \mathrm{U}$ & $0.53 \mathrm{U}$ & NA \\
\hline РСB 153 & $0.39 \mathrm{U}$ & $0.39 \mathrm{U}$ & $0.39 \mathrm{U}$ & NA \\
\hline PCB 105 & $0.30 \mathrm{U}$ & $0.30 \mathrm{U}$ & $0.30 \mathrm{U}$ & NA \\
\hline PCB 138 & $0.34 \mathrm{U}$ & $0.34 \mathrm{U}$ & $0.34 \mathrm{U}$ & NA \\
\hline РCB 187 & $0.39 \mathrm{U}$ & $0.39 \mathrm{U}$ & $0.39 \mathrm{U}$ & NA \\
\hline РCB 183 & $0.53 \mathrm{U}$ & $0.53 \mathrm{U}$ & $0.53 \mathrm{U}$ & NA \\
\hline PCB 128 & $0.24 \mathrm{U}$ & $0.24 \mathrm{U}$ & $0.24 \mathrm{U}$ & NA \\
\hline PCB 180 & $0.27 \mathrm{U}$ & $0.27 \mathrm{U}$ & $0.27 \mathrm{U}$ & NA \\
\hline PCB 170 & $0.20 \mathrm{U}$ & $0.20 \mathrm{U}$ & $0.20 \mathrm{U}$ & NA \\
\hline PCB 195 & $0.27 \mathrm{U}$ & $0.27 \mathrm{U}$ & $0.27 \mathrm{U}$ & NA \\
\hline PCB 206 & $0.39 \mathrm{U}$ & $0.39 \mathrm{U}$ & $0.39 \mathrm{U}$ & NA \\
\hline PCB 209 & $0.27 \mathrm{U}$ & $0.27 \mathrm{U}$ & $0.27 \mathrm{U}$ & NA \\
\hline \multicolumn{5}{|l|}{ Surrogate Recoveries (\%) } \\
\hline PCB 103 (SIS) & 67 & 66 & 70 & NA \\
\hline PCB 198 (SIS) & 75 & 76 & 77 & NA \\
\hline
\end{tabular}


Table B.8. (contd)

\begin{tabular}{|c|c|c|c|c|}
\hline \multirow[b]{2}{*}{$\begin{array}{r}\text { Sediment Treatment } \\
\text { Replicate }\end{array}$} & \multicolumn{3}{|c|}{ Concentration (ng/L) } & \multirow[b]{2}{*}{$\begin{array}{l}\text { RSD } \\
(\%)\end{array}$} \\
\hline & $\begin{array}{c}\mathrm{MDS}^{(e)} \\
1 \\
\end{array}$ & $\begin{array}{c}\text { MDS } \\
2\end{array}$ & $\begin{array}{c}\text { MDS } \\
3 \\
\end{array}$ & \\
\hline Heptachlor & $0.47 \mathrm{U}$ & $0.47 \mathrm{U}$ & $0.47 \mathrm{U}$ & NA \\
\hline Aldrin & $0.39 U$ & $0.39 \mathrm{U}$ & $0.39 \mathrm{U}$ & NA \\
\hline Heptachlor Epoxide & $0.11 \mathrm{U}$ & $0.11 U$ & $0.11 \mathrm{U}$ & NA \\
\hline $2,4^{\prime}-\mathrm{DDE}$ & $0.23 \mathrm{U}$ & $0.23 \mathrm{U}$ & $0.23 \mathrm{U}$ & NA \\
\hline Endosulfan I & $0.46 \mathrm{U}$ & $0.46 \mathrm{U}$ & $0.46 \mathrm{U}$ & NA \\
\hline$\alpha$-Chlordane & $0.83 \mathrm{U}$ & $0.83 \mathrm{U}$ & $0.83 \mathrm{U}$ & NA \\
\hline Trans Nonachlor & $1.11 U$ & $1.11 \mathrm{U}$ & $1.11 \mathrm{U}$ & NA \\
\hline 4,4'-DDE & $0.28 \mathrm{U}$ & $0.28 \mathrm{U}$ & $0.28 \mathrm{U}$ & NA \\
\hline Dieldrin & $0.12 U$ & $0.12 \mathrm{U}$ & $0.12 \mathrm{U}$ & NA \\
\hline 2,4'-DDD & $0.94 \mathrm{U}$ & $0.94 \mathrm{U}$ & $0.94 \mathrm{U}$ & NA \\
\hline 2,4'-DDT & $0.44 \mathrm{U}$ & $0.44 \mathrm{U}$ & $0.44 \mathrm{U}$ & NA \\
\hline 4,4'-DDD & $0.45 \mathrm{U}$ & $0.45 \mathrm{U}$ & $0.45 \mathrm{U}$ & NA \\
\hline Endosulfan II & $0.46 \mathrm{U}$ & $0.46 \mathrm{U}$ & $0.46 \mathrm{U}$ & NA \\
\hline 4,4'-DDT & $0.40 \mathrm{U}$ & $0.40 \mathrm{U}$ & $0.40 \mathrm{U}$ & NA \\
\hline Endosulfan Sulfate & $0.46 U$ & $0.46 \mathrm{U}$ & $0.46 \mathrm{U}$ & NA \\
\hline РСВ 8 & $1.00 \mathrm{U}$ & $1.00 \mathrm{U}$ & $1.00 \mathrm{U}$ & NA \\
\hline PCB 18 & $1.05 \mathrm{U}$ & $1.05 U$ & $1.05 \mathrm{U}$ & NA. \\
\hline РCB 28 & $0.71 \mathrm{U}$ & $0.71 \mathrm{U}$ & $0.71 \mathrm{U}$ & NA \\
\hline PCB 52 & $0.35 \mathrm{U}$ & $0.35 \mathrm{U}$ & $0.35 \mathrm{U}$ & NA: - \\
\hline PCB 49 & $0.53 \mathrm{U}$ & $0.53 \mathrm{U}$ & $0.53 \mathrm{U}$ & NA: \\
\hline РCB 44 & $0.31 \mathrm{U}$ & $0.31 \mathrm{U}$ & $0.31 \mathrm{U}$ & NA \\
\hline PCB 66 & $0.38 U$ & $0.38 \cdot U$. & $0.38 \mathrm{U}$ & $N A^{-}$ \\
\hline PCB 101 & $0.48 U$ & $0.48 \mathrm{U}$ & $0.48 \mathrm{U}$ & NA \\
\hline PCB 87 & $0.35 \mathrm{U}$ & $0.35 \mathrm{U}$ & $0.35 \mathrm{U}$ & NA \\
\hline PCB 118 & $0.47 \mathrm{U}$ & $0.47 \mathrm{U}$ & $0.47 \mathrm{U}$ & NA \\
\hline PCB 184 & $0.53 \mathrm{U}$ & $0.53 U$ & $0.53 U$ & NA \\
\hline PCB 153 & $0.39 \mathrm{U}$ & $0.39 \mathrm{U}$ & $0.39 \mathrm{U}$ & NA \\
\hline РСВ 105 & $0.30 \mathrm{U}$ & $0.30 \mathrm{U}$ & $0.30 \mathrm{U}$ & NA \\
\hline PCB 138 & $0.34 \mathrm{U}$ & $0.34 \mathrm{U}$ & $0.34 \mathrm{U}$ & NA \\
\hline PCB 187 & $0.39 \mathrm{U}$ & $0.39 \mathrm{U}$ & $0.39 \mathrm{U}$ & NA \\
\hline PCB 183 & $0.53 \mathrm{U}$ & $0.53 \mathrm{U}$ & $0.53 \mathrm{U}$ & NA \\
\hline PCB 128 & $0.24 \mathrm{U}$ & $0.24 \mathrm{U}$ & $0.24 \mathrm{U}$ & NA \\
\hline PCB 180 & $0.27 \mathrm{U}$ & $0.27 \mathrm{U}$ & $0.27 \mathrm{U}$ & NA \\
\hline PCB 170 & $0.20 \mathrm{U}$ & $0.20 \mathrm{U}$ & $0.20 \mathrm{U}$ & NA \\
\hline PCB 195 & $0.27 \mathrm{U}$ & $0.27 \mathrm{U}$ & $0.27 \mathrm{U}$ & NA \\
\hline PCB 206 & $0.39 \mathrm{U}$ & $0.39 \mathrm{U}$ & $0.39 \mathrm{U}$ & NA \\
\hline PCB 209 & $0.27 \mathrm{U}$ & $0.27 \mathrm{U}$ & $0.27 \mathrm{U}$ & NA \\
\hline \multicolumn{5}{|l|}{ Surrogate Recoveries (\%) } \\
\hline PCB 103 (SIS) & 69 & 69 & 71 & NA \\
\hline PCB 198 (SIS) & 72 & 74 & 73 & NA \\
\hline
\end{tabular}

(a) Sample randomly selected for use as quality control sample in analytical batch.

(b) $U$ Undetected at or above given concentration.

(c) NA Not applicable.

(d) Outside QC criteria ( $\leq 30 \%)$ for replicate analysis.

(e) MDS Mud Dump Site. 
Table B.9. Pesticides and Polychlorinated Biphenyls (PCBs) in Elutriate Samples, Red Hook and Bay Ridge Channels

\begin{tabular}{|c|c|c|c|c|c|}
\hline \multirow[b]{2}{*}{$\begin{array}{l}\text { Sediment Treatment } \\
\text { Replicate } \\
\end{array}$} & \multicolumn{5}{|c|}{ Concentration (ng/L) } \\
\hline & $\begin{array}{c}\text { RH COMP } \\
1 \\
\end{array}$ & $\begin{array}{l}\text { RHCOMP } \\
2 \\
\end{array}$ & $\begin{array}{c}\text { RHCOMP } \\
3 \\
\end{array}$ & $\begin{array}{c}\text { BR-A COMP } \\
1 \\
\end{array}$ & $\begin{array}{c}\text { BR-A COMP } \\
2 \\
2\end{array}$ \\
\hline Heptachlor ${ }^{(a)}$ & $0.49 u^{(b)}$ & $0.47 \mathrm{U}$ & $0.47 \mathrm{U}$ & 0.56 & $0.47 \mathrm{U}$ \\
\hline Aldrin & 3.27 & 2.78 & 5.50 & $0.39 \mathrm{U}$ & $0.39 \mathrm{U}$ \\
\hline Heptachlor Epoxide & $0.12 \mathrm{U}$ & $0.11 \mathrm{U}$ & $0.11 \mathrm{U}$ & $0.11 \mathrm{U}$ & $0.11 \mathrm{U}$ \\
\hline 2,4'-DDE & $0.24 \mathrm{U}$ & $0.23 \mathrm{U}$ & $0.23 \mathrm{U}$ & $0.23 \mathrm{U}$ & $0.23 \mathrm{U}$ \\
\hline Endosulfan I & $0.49 \mathrm{U}$ & $0.46 \mathrm{U}$ & $0.47 \mathrm{U}$ & $0.46 \mathrm{U}$ & $0.47 \mathrm{U}$ \\
\hline$\alpha$-Chlordane & $0.87 \mathrm{U}$ & $0.83 \mathrm{U}$ & $0.83 \mathrm{U}$ & $0.83 \mathrm{U}$ & $0.83 U$ \\
\hline Trans Nonachlor & $1.17 \mathrm{U}$ & $1.11 \mathrm{U}$ & $1.12 \mathrm{U}$ & $1.11 \mathrm{U}$ & $1.12 \mathrm{U}$ \\
\hline 4,4'-DDE & 6.65 & 7.14 & 8.19 & 6.55 & 6.64 \\
\hline Dieldrin & 2.36 & 4.87 & 5.10 & $0.12 \mathrm{U}$ & $0.13 \mathrm{U}$ \\
\hline 2,4'-DDD & $0.99 \mathrm{U}$ & $0.94 \mathrm{U}$ & $0.95 \mathrm{U}$ & $0.94 \mathrm{U}$ & $0.95 \mathrm{U}$ \\
\hline 2,4'-DDT & $0.46 \mathrm{U}$ & $0.44 \mathrm{U}$ & $0.44 \mathrm{U}$ & $0.44 \mathrm{U}$ & $0.44 \mathrm{U}$ \\
\hline 4,4'-DDD & $0.47 \mathrm{U}$ & $0.45 \mathrm{U}$ & $0.45 \mathrm{U}$ & $0.45 \mathrm{U}$ & $0.45 \mathrm{U}$ \\
\hline Endosulfan II & $0.49 \mathrm{U}$ & 0.88 & $0.47 \mathrm{U}$ & $0.46 \mathrm{U}$ & $0.47 \mathrm{U}$ \\
\hline 4,4'-DDT & 7.95 & 7.72 & 8.21 & 8.35 & 7.74 \\
\hline Endosulfan Sulfate & $0.49 \mathrm{U}$ & $0.46 \mathrm{U}$ & $0.47 \mathrm{U}$ & $0.46 \mathrm{U}$ & $0.47 \mathrm{U}$ \\
\hline РСВ 8 & $1.05 \mathrm{U}$ & $1.00 \mathrm{U}$ & $1.01 \mathrm{U}$ & $1.00 \mathrm{U}^{-}$ & $1.01 \mathrm{U}$ \\
\hline РСВ 18 & 8.53 & 8.56 & 11.8 & $1.05 \mathrm{U}$ & $1.06 \mathrm{U}$ \\
\hline РСВ 28 & 5.10 & 4.99 & 8.85 & $0.71 \mathrm{U}$ & $0.71 \mathrm{U}$ \\
\hline PCB 52 & 3.65 & $0.35 \mathrm{U}$ & $0.36 \mathrm{U}$ & $0.35 \mathrm{U}$ & $0.36 \mathrm{U}$ \\
\hline РСВ 49 & 2.37 & 2.30 & 6.74 & 1.30 & 1.49 \\
\hline РСВ 44 & $0.32 \mathrm{U}$ & $0.31 \mathrm{U}$ & $0.31 \mathrm{U}$ & $0.31 \mathrm{U}$ & $0.31 \mathrm{U}$ \\
\hline РСB 66 & $0.40 \mathrm{U}$ & $0.38 \mathrm{U}$ & $0.39 \mathrm{U}$ & $0.38 \mathrm{U}$ & $0.39 \mathrm{U}$ \\
\hline РCB 101 & 1.54 & 1.82 & $0.49 \mathrm{U}$ & 1.23 & 1.40 \\
\hline РСВ 87 & $0.37 \cup$ & $0.35 U$ & 1.63 & $0.35 U$ & $0.36 \mathrm{U}$ \\
\hline PCB 118 & 1.44 & 1.52 & 4.73 & 1.00 & 1.16 \\
\hline PCB 184 & $0.56 U$ & $0.53 \mathrm{U}$ & $0.54 \mathrm{U}$ & $0.53 U$ & $0.54 \mathrm{U}$ \\
\hline PCB 153 & 1.16 & 1.33 & $0.40 \mathrm{U}$ & 1.15 & 1.34 \\
\hline PCB 105 & $0.31 \mathrm{U}$ & $0.30 \mathrm{U}$ & $0.30 \mathrm{U}$ & $0.30 \mathrm{U}$ & $0.30 \mathrm{U}$ \\
\hline PCB 138 & 1.23 & 1.42 & 1.78 & 1.30 & 1.47 \\
\hline PCB 187 & $0.41 \mathrm{U}$ & $0.39 \mathrm{U}$ & $0.39 \mathrm{U}$ & $0.39 \mathrm{U}$ & 0.61 \\
\hline PCB 183 & $0.56 \mathrm{U}$ & $0.53 \mathrm{U}$ & $0.54 \mathrm{U}$ & $0.53 \mathrm{U}$ & $0.54 \mathrm{U}$ \\
\hline PCB 128 & $0.25 \mathrm{U}$ & $0.24 \mathrm{U}$ & $0.24 \mathrm{U}$ & $0.24 \mathrm{U}$ & $0.24 \mathrm{U}$ \\
\hline PCB 180 & 0.92 & 1.04 & 1.23 & 1.00 & 1.14 \\
\hline PCB 170 & $0.21 \mathrm{U}$ & $0.20 \mathrm{U}$ & $0.20 \mathrm{U}$ & $0.20 \mathrm{U}$ & $0.20 \mathrm{U}$ \\
\hline РCB 195 & $0.29 \mathrm{U}$ & $0.27 U$ & $0.28 \mathrm{U}$ & $0.27 \mathrm{U}$ & $0.28 \mathrm{U}$ \\
\hline РСВ 206 & 0.40 & $0.39 \mathrm{U}$ & $0.39 \mathrm{U}$ & $0.39 \mathrm{U}$ & $0.39 \mathrm{U}$ \\
\hline PCB 209 & $0.29 \mathrm{U}$ & $0.27 \mathrm{U}$ & $0.28 \mathrm{U}$ & $0.27 \mathrm{U}$ & $0.28 \mathrm{U}$ \\
\hline \multicolumn{6}{|c|}{ Surrogate Recoveries (\%) } \\
\hline PCB 103 (SIS) & 67 & 68 & 69 & 68 & 70 \\
\hline PCB 198 (SIS) & 61 & 61 & 61 & 60 & 63 \\
\hline
\end{tabular}


Table B.9. (contd)

\begin{tabular}{|c|c|c|c|c|}
\hline \multirow[b]{2}{*}{$\begin{array}{r}\text { Sediment Treatment } \\
\text { Replicate } \\
\end{array}$} & \multicolumn{4}{|c|}{ Concentration (ng/L) } \\
\hline & $\begin{array}{c}\text { BR-A COMP } \\
3 \\
\end{array}$ & $\begin{array}{c}\text { BR-B COMP } \\
1 \\
\end{array}$ & $\begin{array}{c}\text { BR-B COMP } \\
2 \\
\end{array}$ & $\begin{array}{c}\text { BR-B COMP } \\
3 \\
\end{array}$ \\
\hline Heptachlor & $0.47 \mathrm{U}$ & $0.48 \mathrm{U}$ & $0.46 \mathrm{U}$ & $0.48 \mathrm{U}$ \\
\hline Aldrin & $0.39 \mathrm{U}$ & 7.49 & 8.27 & 8.25 \\
\hline Heptachlor Epoxide & $0.11 U$ & $0.11 \mathrm{U}$ & $0.11 U$ & $0.11 \mathrm{U}$ \\
\hline 2,4'-DDE & $0.23 \mathrm{U}$ & $0.24 \mathrm{U}$ & $0.23 \mathrm{U}$ & $0.24 \mathrm{U}$ \\
\hline Endosulfan I & $0.47 \mathrm{U}$ & $0.47 \mathrm{U}$ & $0.46 \mathrm{U}$ & $0.47 \mathrm{U}$ \\
\hline$\alpha$-Chlordane & $0.83 U$ & $0.84 U$ & $0.82 \mathrm{U}$ & $0.84 \mathrm{U}$ \\
\hline Trans Nonachlor & $1.12 \mathrm{U}$ & $1.13 \mathrm{U}$ & $1.10 \mathrm{U}$ & $1.13 \mathrm{U}$ \\
\hline 4,4'-DDE & 7.28 & 26.8 & 31.6 & 29.8 \\
\hline Dieldrin & $0.13 \mathrm{U}$ & 6.50 & 6.84 & 6.39 \\
\hline 2,4'-DDD & $0.95 \mathrm{U}$ & 6.25 & 7.84 & 5.92 \\
\hline 2,4'-DDT & $0.44 \mathrm{U}$ & $0.44 \mathrm{U}$ & $0.43 \mathrm{U}$ & $0.44 \mathrm{U}$ \\
\hline 4,4'-DDD & $0.45 \mathrm{U}$ & 13.1 & 14.0 & 13.9 \\
\hline Endosulfan II & $0.47 U$ & $0.47 \mathrm{U}$ & $0.46 \mathrm{U}$ & 1.12 \\
\hline 4,4'-DDT & 7.84 & 14.0 & $=16.8$ & 15.9 \\
\hline Endosulfan Sulfate & $0.47 \mathrm{U}$ & $0.47 \mathrm{U}$ & $.0 .46 \mathrm{U}$ & $0.47 \mathrm{U}$ \\
\hline PCB 8 & $1.01 \mathrm{U}$ & $1.02 U$ & $0.98 \mathrm{U}$ & $1.02 \mathrm{U}$ \\
\hline PCB 18 & $1.06 \mathrm{U}$ & 47.0 & 56.3 & 54.0 \\
\hline РCB 28 & $0.71 \mathrm{U}$ & 15.0 & .20 .4 & 19.3 \\
\hline РСВ 52 & $0.36 \mathrm{U}$ & 21.5 & 27.8 & 26.6 \\
\hline РСB 49 & $0.54 \mathrm{U}$ & 12.2 & 15.7 & 14.7 \\
\hline РСB 44 & $0.31 \mathrm{U}$ & 27.6 & 35.6 & 31.8 \\
\hline РСB 66 & $0.39 \mathrm{U}$ & 24.1 & 30.3 & 29.3 \\
\hline PCB 101 & 1.47 & 18.9 & -23.9 & 22.3 \\
\hline РСB 87 & 0.46 & 4.22 & 5.76 & 4.84 \\
\hline PCB 118 & 1.12 & 13.1 & 17.7 & 17.1 \\
\hline PCB 184 & $0.54 \mathrm{U}$ & $0.55 \mathrm{U}$ & $0.53 U$ & $0.55 U$ \\
\hline PCB 153 & 1.43 & 15.9 & 21.3 & 20.5 \\
\hline PCB 105 & $0.30 \mathrm{U}$ & $0.30 \mathrm{U}$ & $0.29 \mathrm{U}$ & $0.30 \mathrm{U}$ \\
\hline PCB 138 & 1.53 & 12.3 & 16.0 & 15.4 \\
\hline PCB 187 & 0.64 & 4.13 & 6.76 & 6.16 \\
\hline РСB 183 & $0.54 \mathrm{U}$ & 1.98 & 2.91 & 2.47 \\
\hline PCB 128 & $0.24 \mathrm{U}$ & 1.48 & 1.78 & 1.71 \\
\hline РCB 180 & 1.43 & 8.34 & 11.2 & 10.8 \\
\hline PCB 170 & $0.20 \mathrm{U}$ & 2.64 & 3.73 & 3.52 \\
\hline PCB 195 & $0.28 \mathrm{U}$ & 0.66 & 0.82 & 0.76 \\
\hline PCB 206 & $0.39 \mathrm{U}$ & 2.29 & 3.53 & 3.57 \\
\hline PCB 209 & $0.28 \mathrm{U}$ & 1.99 & 2.81 & 2.68 \\
\hline \multicolumn{5}{|c|}{ Surrogate Recoveries (\%) } \\
\hline PCB 103 (SIS) & 74 & 72 & 65 & 68 \\
\hline PCB 198 (SIS) & 68 & 70 & 66 & 68 \\
\hline
\end{tabular}

(a) Target detection limits range from $0.5 \mathrm{ng} / \mathrm{L}$ to $100 \mathrm{ng} / \mathrm{L}$ for all analytes.

(b) $U$ Undetected at or above given concentration. 
Table B.10. Quality Control Data for Pesticide and Polychlorinated Biphenyl (PCB) Analysis of Elutriate Samples, Spike Recovery Results

\begin{tabular}{|c|c|c|c|c|c|c|}
\hline \multirow[b]{3}{*}{$\begin{array}{r}\text { Sediment Treatment } \\
\text { Replicate }\end{array}$} & \multirow[b]{3}{*}{$\begin{array}{c}\text { Method Blank } \\
1 \\
\end{array}$} & \multicolumn{4}{|c|}{ Concentration (ng/L) } & \multirow{3}{*}{$\begin{array}{l}\text { Percent } \\
\text { Recovery }\end{array}$} \\
\hline & & \multirow{2}{*}{$\begin{array}{c}\text { Sequim Bay } \\
\text { Water } \\
1\end{array}$} & \multirow{2}{*}{$\begin{array}{c}\text { Sequim Bay } \\
\text { Water (MS) } \\
1\end{array}$} & \multicolumn{2}{|c|}{ Concentration } & \\
\hline & & & & Spiked & Recovered & \\
\hline Heptachlor & $0.50 U^{(a)}$ & $0.50 \mathrm{U}$ & 17.7 & 25.0 & 17.7 & 71 \\
\hline Aldrin & $0.41 \mathrm{U}$ & $0.41 \mathrm{U}$ & 17.3 & 25.0 & 17.3 & 69 \\
\hline Heptachlor Epoxide & $0.12 U$ & $0.12 U$ & 23.2 & 25.0 & 23.2 & 93 \\
\hline 2,4'-DDE & $0.24 \mathrm{U}$ & $0.24 \mathrm{U}$ & $N S^{(b)}$ & NS & NS & $N A^{(c)}$ \\
\hline Endosulfan I & $0.49 \mathrm{U}$ & $0.49 \mathrm{U}$ & 23.0 & 25.0 & 23.0 & 92 \\
\hline$\alpha$-Chlordane & $0.88 U$ & $0.88 U$ & 21.1 & 25.0 & 21.1 & 84 \\
\hline Trans Nonachlor & $1.18 \mathrm{U}$ & $1.18 \mathrm{U}$ & NS & NS & NS & NA \\
\hline 4,4'-DDE & $0.29 \mathrm{U}$ & $0.29 \mathrm{U}$ & 24.8 & 25.0 & 24.8 & 99 \\
\hline Dieldrin & $0.13 U$ & $0.13 U$ & 25.6 & 25.0 & 25.6 & 102 \\
\hline 2,4'-DDD & $1.00 \mathrm{U}$ & $1.00 \mathrm{U}$ & NS & NS & NS & NA \\
\hline 2,4'-DDT & $0.46 \mathrm{U}$ & $0.46 U$ & NS & NS & NS & NA \\
\hline 4,4'-DDD & $0.48 \mathrm{U}$ & $0.48 \mathrm{U}$ & 28.6 & 25.0 & 28.6 & 114 \\
\hline Endosulfan II & $0.49 \mathrm{U}$ & $0.49 \mathrm{U}$ & 29.0 & 25.0 & 29.0 & 116 \\
\hline 4,4'-DDT & $0.43 U$ & $0.43 \mathrm{U}$ & 29.2 & 25.0 & 29.2 & $117^{(d)}$ \\
\hline Endosulfan Sulfate & $0.49 \mathrm{U}$ & $0.49 \mathrm{U}$ & 22.2 & 25.0 & 22.2 & 89 \\
\hline РСВ 8 & $1.06 \mathrm{U}$ & $1.06 \mathrm{U}$ & NS & NS & NS & NA - \\
\hline PCB 18 & $1.12 \mathrm{U}$ & $1.12 \mathrm{U}$ & NS & NS & NS & NA \\
\hline РCB 28 & $0.75 \mathrm{U}$ & $0.75 \mathrm{U}$ & 31.5 & 31.9 & 31.5 & 99 \\
\hline PCB 52 & $0.38 \mathrm{U}$ & $0.38 \mathrm{U}$ & 70.6 & 66.5 & 70.6 & 106 \\
\hline РСВ 49 & $0.57 \mathrm{U}$ & $0.57 \mathrm{U}$ & NS & NS & NS & NA \\
\hline РСв 44 & $0.33 \mathrm{U}$ & $0.33 \mathrm{U}$ & NS & NS & NS & NA \\
\hline РCB 66 & $0.41 \mathrm{U}$ & $0.41 \mathrm{U}$ & NS & NS & NS & NA \\
\hline PCB 101 & $0.52 \mathrm{U}$ & $0.52 \mathrm{U}$ & 58.3 & 45.1 & 58.3 & 129 \\
\hline РCB 87 & $0.38 \mathrm{U}$ & $0.38 \mathrm{U}$ & NS & NS & NS & NA \\
\hline PCB 118 & $0.50 \mathrm{U}$ & $0.50 \mathrm{U}$ & NS & NS & NS & NA \\
\hline РCB 184 & $0.57 \mathrm{U}$ & $0.57 \mathrm{U}$ & NS & NS & NS & NA \\
\hline РCB 153 & $0.42 \mathrm{U}$ & $0.42 \mathrm{U}$ & 29.6 & 26.4 & 29.6 & 112 \\
\hline PCB 105 & $0.32 U$ & $0.32 \mathrm{U}$ & NS & NS & NS & NA \\
\hline PCB 138 & $0.36 U$ & $0.36 U$ & 21.8 & 20.4 & 21.8 & 107 \\
\hline РCB 187 & $0.41 \mathrm{U}$ & $0.41 \mathrm{U}$ & NS & NS & NS & NA \\
\hline PCB 183 & $0.57 U$ & $0.57 \mathrm{U}$ & NS & NS & NS & NA \\
\hline PCB 128 & $0.26 \mathrm{U}$ & $0.26 U$ & NS & NS & NS & NA \\
\hline PCB 180 & $0.29 U$ & $0.29 \mathrm{U}$ & NS & NS & NS & NA \\
\hline РСВ 170 & $0.21 U$ & $0.21 U$ & NS & NS & NS & NA \\
\hline PCB 195 & $0.29 \mathrm{U}$ & $0.29 \mathrm{U}$ & NS & NS & NS & NA \\
\hline PCB 206 & $0.42 U$ & $0.42 U$ & NS & NS & NS & NA \\
\hline PCB 209 & $0.29 \mathrm{U}$ & $0.29 \mathrm{U}$ & NS & NS & NS & NA \\
\hline \multicolumn{7}{|c|}{ Surrogate Recoveries (\%) } \\
\hline PCB 103 (SIS) & 44 & 61 & 57 & NA & NA & NA \\
\hline PCB 198 (SIS) & 65 & 64 & 61 & NA & NA & NA \\
\hline
\end{tabular}

(a) Undetected at or above given concentration.

(b) NS Not spiked.

(c) NA Not applicable.

(d) Outside quality control criteria (50-120\%) for spike recovery. 
Table B.11. Quality Control Data for Pesticide and Polychlorinated Biphenyl (PCB) Analysis of Elutriate Samples, Analytical Replicates

\begin{tabular}{|c|c|c|c|c|}
\hline \multirow[b]{2}{*}{$\begin{array}{r}\text { Sediment Treatment } \\
\text { Replicate } \\
\end{array}$} & \multicolumn{3}{|c|}{ Concentration (ng/L) } & \multirow[b]{2}{*}{$\begin{array}{l}\text { RSD } \\
(\%) \\
\end{array}$} \\
\hline & $\begin{array}{c}\mathrm{BR}-\mathrm{B} \mathrm{COMP}^{(\mathrm{a})} \\
1 \\
\end{array}$ & $\begin{array}{c}\text { BR-B COMP } \\
2 \\
\end{array}$ & $\begin{array}{c}\text { BR-B COMP } \\
3 \\
\end{array}$ & \\
\hline Heptachlor & $0.48 U^{(b)}$ & $0.46 \mathrm{U}$ & $0.48 U$ & $N A^{(c)}$ \\
\hline Aldrin & 7.49 & 8.27 & 8.25 & 6 \\
\hline Heptachlor Epoxide & $0.11 \mathrm{U}$ & $0.11 \mathrm{U}$ & $0.11 \mathrm{U}$ & NA \\
\hline $2,4^{\circ}-\mathrm{DDE}$ & $0.24 U$ & $0.23 \mathrm{U}$ & $0.24 \mathrm{U}$ & NA \\
\hline Endosulfan I & $0.47 \mathrm{U}$ & $0.46 \mathrm{U}$ & $0.47 \mathrm{U}$ & NA \\
\hline$\alpha$-Chlordane & $0.84 U$ & $0.82 U$ & $0.84 \mathrm{U}$ & NA \\
\hline Trans Nonachlor & $1.13 \mathrm{U}$ & $1.10 \mathrm{U}$ & $1.13 U$ & NA \\
\hline 4,4'-DDE & 26.8 & 31.6 & 29.8 & 8 \\
\hline Dieldrin & 6.50 & 6.84 & 6.39 & 4 \\
\hline 2,4'-DDD & 6.25 & 7.84 & 5.92 & 15 \\
\hline 2,4'-DDT & $0.44 \mathrm{U}$ & $0.43 \mathrm{U}$ & $0.44 \mathrm{U}$ & NA \\
\hline 4,4'-DDD & 13.1 & 14.0 & 13.9 & 4 \\
\hline Endosulfan II & $0.47 U$ & $0.46 \mathrm{U}$ & 1.12 & NA \\
\hline 4,4'-DDT & 14.0 & 16.8 & 15.9 & 9 \\
\hline Endosulfan Sulfate & $0.47 \mathrm{U}$ & $0.46 \mathrm{U}$ & $0.47 \mathrm{U}$ & NA \\
\hline PCB 8 & $1.02 U$ & $0.98 \mathrm{U}$ & $1.02 \mathrm{U}$ & NA \\
\hline РCB 18 & 47.0 & 56.3 & 54.0 & 9 \\
\hline РCB 28 & 15.0 & 20.4 & 19.3 & 16 \\
\hline РCB 52 & 21.5 & 27.8 & 26.6 & 13 \\
\hline РСB 49 & 12.2 & 15.7 & 14.7 & 13 \\
\hline РСB 44 & 27.6 & 35.6 & 31.8 & 13 \\
\hline РСB 66 & 24.1 & 30.3 & 29.3 & 12 \\
\hline РCB 101 & 18.9 & 23.9 & 22.3 & 12 \\
\hline PCB 87 & .4 .22 & 5.76 & 4.84 & 16 \\
\hline PCB 118 & 13.1 & 17.7 & 17.1 & 16 \\
\hline РСВ 184 & $0.55 \mathrm{U}$ & $0.53 U$ & $0.55 \mathrm{U}$ & NA \\
\hline PCB 153 & 15.9 & 21.3 & 20.5 & 15 \\
\hline PCB 105 & $0.30 \mathrm{U}$ & $0.29 \mathrm{U}$ & $0.30 U$ & NA \\
\hline PCB 138 & 12.3 & 16.0 & 15.4 & 14 \\
\hline PCB 187 & 4.13 & 6.7 .6 & 6.16 & 24 \\
\hline PCB 183 & 1.98 & 2.91 & 2.47 & 19 \\
\hline РСВ 128 & 1.48 & $1.78^{-}$ & 1.71 & 9 \\
\hline PCB 180 & 8.34 & 11.2. & 10.8 & 15 \\
\hline PCB 170 & 2.64 & 3.73 & 3.52 & 18 \\
\hline PCB 195 & 0.66 & 0.82 & 0.76 & 11 \\
\hline РCB 206 & 2.29 & 3.53 & 3.57 & 23 \\
\hline PCB 209 & 1.99 & 2.81 & 2.68 & 18 \\
\hline \multicolumn{5}{|l|}{ Surrogate Recoveries (\%) } \\
\hline PCB 103 (SIS) & 72 & 65 & 68 & NA \\
\hline PCB 198 (SIS) & 70 & 66 & 68 & NA \\
\hline
\end{tabular}


Table B.11. (contd)

\begin{tabular}{|c|c|c|c|c|}
\hline \multirow[b]{2}{*}{$\begin{array}{r}\text { Sediment Treatment } \\
\text { Replicate }\end{array}$} & \multicolumn{3}{|c|}{ Concentration (ng/L) } & \multirow[b]{2}{*}{$\begin{array}{c}\text { RSD } \\
(\%) \\
\end{array}$} \\
\hline & $\begin{array}{c}\text { BR-A COMP(a) } \\
1\end{array}$ & $\begin{array}{c}\text { BR-A COMP } \\
2\end{array}$ & $\begin{array}{c}\text { BR-A COMP } \\
3\end{array}$ & \\
\hline Heptachlor & 0.56 & $0.47 \mathrm{U}$ & $0.47 \mathrm{U}$ & NA \\
\hline Aldrin & $0.39 \mathrm{U}$ & $0.39 \mathrm{U}$ & $0.39 \mathrm{U}$ & NA \\
\hline Heptachlor Epoxide & $0.11 \mathrm{U}$ & $0.11 \mathrm{U}$ & $0.11 \mathrm{U}$ & NA \\
\hline $2,4^{\prime}-\mathrm{DDE}$ & $0.23 \mathrm{U}$ & $0.23 \mathrm{U}$ & $0.23 \mathrm{U}$ & NA \\
\hline Endosulfan I & $0.46 \mathrm{U}$ & $0.47 \mathrm{U}$ & $0.47 U$ & NA \\
\hline$\alpha$-Chlordane & $0.83 \mathrm{U}$ & $0.83 \mathrm{U}$ & $0.83 \mathrm{U}$ & NA \\
\hline Trans Nonachlor & $1.11 \mathrm{U}$ & $1.12 U$ & $1.12 U$ & NA \\
\hline 4,4'-DDE & 6.55 & 6.64 & 7.28 & 6 \\
\hline Dieldrin & $0.12 \mathrm{U}$ & $0.13 \mathrm{U}$ & $0.13 U$ & NA \\
\hline 2,4'-DDD & $0.94 \mathrm{U}$ & $0.95 U$ & $0.95 \mathrm{U}$ & NA \\
\hline 2,4'-DDT & $0.44 \mathrm{U}$ & $0.44 \mathrm{U}$ & $0.44 \mathrm{U}$ & NA \\
\hline 4,4'-DDD & $0.45 \mathrm{U}$ & $0.45 \mathrm{U}$ & $0.45 \mathrm{U}$ & NA \\
\hline Endosulfan II & $0.46 \mathrm{U}$ & $0.47 \mathrm{U}$ & $0.47 U$ & NA \\
\hline 4,4'-DDT & 8.35 & 7.74 & 7.84 & 4 \\
\hline Endosulfan Sulfate & $0.46 \mathrm{U}$ & $0.47 \mathrm{U}$ & $0.47 \mathrm{U}$ & NA \\
\hline РСВ 8 & $1.00 \mathrm{U}$ & $1.01 \mathrm{U}$ & $1.01 \mathrm{U}$ & NA \\
\hline РСВ 18 & $1.05 \mathrm{U}$ & $1.06 \mathrm{U}$ & $1.06 \mathrm{U}$ & NA \\
\hline PCB 28 & $0.71 \mathrm{U}$ & $0.71 \mathrm{U}$ & $0.71 \mathrm{U}$ & NA \\
\hline РСB 52 & $0.35 \mathrm{U}$ & $0.36 \mathrm{U}$ & $0.36 \mathrm{U}$ & NA \\
\hline РСB 49 & 1.30 & $1.49^{\circ}$ & $0.54 \mathrm{U}$ & NA \\
\hline РСВ 44 & $0.31 \mathrm{U}$ & $0.31 \mathrm{U}$ & $0.31 \cup$ & NA \\
\hline РСВ 66 & $0.38 \mathrm{U}$ & $0.39 \mathrm{U}$ & $0.39 \mathrm{U}$ & NA \\
\hline PCB 101 & 1.23 & 1.40 & 1.47 & 9 \\
\hline PCB 87 & $0.35 \mathrm{U}$ & $0.36 \mathrm{U}$ & 0.46 & NA \\
\hline PCB 118 & 1.00 & 1.16 & 1.12 & 8 \\
\hline PCB 184 & $0.53 \mathrm{U}$ & $0.54 \mathrm{U}$ & $0.54 \mathrm{U}$ & NA \\
\hline PCB 153 & 1.15 & 1.34 & 1.43 & 11 \\
\hline PCB 105 & $0.30 \mathrm{U}$ & $0.30 \mathrm{U}$ & $0.30 \mathrm{U}$ & NA \\
\hline PCB 138 & 1.30 & 1.47 & 1.53 & 8 \\
\hline PCB 187 & $0.39 \mathrm{U}$ & 0.61 & 0.64 & NA \\
\hline PCB 183 & $0.53 \mathrm{U}$ & $0.54 \mathrm{U}$ & $0.54 \mathrm{U}$ & NA \\
\hline PCB 128 & $0.24 \mathrm{U}$ & $0.24 \mathrm{U}$ & $0.24 \mathrm{U}$ & NA \\
\hline PCB 180 & 1.00 & 1.14 & 1.43 & 18 \\
\hline PCB 170 & $0.20 \mathrm{U}$ & $0.20 \mathrm{U}$ & $0.20 \mathrm{U}$ & NA \\
\hline PCB 195 & $0.27 \mathrm{U}$ & $0.28 \mathrm{U}$ & $0.28 U$ & NA \\
\hline PCB 206 & $0.39 \mathrm{U}$ & $0.39 \mathrm{U}$ & $0.39 \mathrm{U}$ & NA \\
\hline PCB 209 & $0.27 \mathrm{U}$ & $0.28 \mathrm{U}$ & $0.28 \mathrm{U}$ & NA \\
\hline \multicolumn{5}{|c|}{ Surrogate Recoveries (\%) } \\
\hline PCB 103 (SIS) & 68 & 70 & 74 & NA \\
\hline PCB 198 (SIS) & 60 & 63 & 68 & NA \\
\hline
\end{tabular}


Table B.11. (contd)

\begin{tabular}{|c|c|c|c|c|}
\hline \multirow[b]{2}{*}{$\begin{array}{r}\text { Sediment Treatment } \\
\text { Replicate } \\
\end{array}$} & \multicolumn{3}{|c|}{ Concentration (ng/L) } & \multirow[b]{2}{*}{$\begin{array}{l}\text { RSD } \\
(\%)\end{array}$} \\
\hline & $\begin{array}{c}\text { PJ-B COMP(a) }^{(a)} \\
1\end{array}$ & $\begin{array}{c}\text { PJ-B COMP } \\
2 \\
\end{array}$ & $\begin{array}{c}\text { PJ-B COMP } \\
3 \\
\end{array}$ & \\
\hline Heptachlor & 2.26 & 2.31 & $0.47 \mathrm{U}$ & NA \\
\hline Aldrin & 6.25 & 6.21 & 6.33 & 1 \\
\hline Heptachlor Epoxide & $0.12 \mathrm{U}$ & $0.11 \mathrm{U}$ & $0.11 \mathrm{U}$ & NA \\
\hline 2,4'-DDE & $0.24 \mathrm{U}$ & $0.23 \mathrm{U}$ & $0.23 \mathrm{U}$ & $\mathrm{NA}$ \\
\hline Endosulfan I & $0.48 \mathrm{U}$ & $0.46 \mathrm{U}$ & $0.46 \mathrm{U}$ & NA \\
\hline$\alpha$-Chlordane & $0.86 U$ & $0.82 U$ & $0.83 \mathrm{U}$ & NA \\
\hline Trans Nonachlor & $1.16 \mathrm{U}$ & $1.10 \mathrm{U}$ & $1.11 \mathrm{U}$ & NA \\
\hline 4,4'-DDE & 21.6 & 21.2 & 23.4 & 5 \\
\hline Dieldrin & 5.69 & 5.66 & 7.45 & 16 \\
\hline $2,4^{\prime}-\mathrm{DDD}$ & $0.98 \mathrm{U}$ & $0.93 \mathrm{U}$ & 6.50 & NA \\
\hline 2,4'-DDT & $0.45 \mathrm{U}$ & $0.43 \mathrm{U}$ & $0.44 \mathrm{U}$ & NA \\
\hline $4,4^{\prime}-D D D$ & 7.84 & 10.0 & 11.2 & 18 \\
\hline Endosulfan II & $0.48 \mathrm{U}$ & 1.31 & 1.13 & NA \\
\hline 4,4'-DDT & 9.61 & 12.6 & 12.8 & 15 \\
\hline Endosulfan Sulfate & $0.48 \mathrm{U}$ & $0.46 \mathrm{U}$ & $0.46 \mathrm{U}$ & NA \\
\hline РCB 8 & $1.04 \mathrm{U}$ & $0.98 \mathrm{U}$ & $1.00 \mathrm{U}$ & NA \\
\hline PCB 18 & 31.6 & 28.5 & 30.3 & 5 \\
\hline PCB 28 & 16.1 & 15.5 & 16.7 & 4 \\
\hline PCB 52 & 14.6 & 13.2 & $14: 2$ & 5 \\
\hline РСB 49 & 8.72 & 7.55 & 7.87 & 8 \\
\hline РCB 44 & $0.32 \mathrm{U}$ & $0.30 \mathrm{U}$ & $0.31 \mathrm{U}$ & NA \\
\hline PCB 66 & $0.40 \mathrm{U}$ & 16.9 & 17.7 & NA \\
\hline PCB 101 & 11.0 & 11.8 & 12.4 & 6 \\
\hline PCB 87 & 2.34 & $2: 39$ & 2.45 & 2 \\
\hline PCB 118 & 7.53 & 8.69 & 8.45 & $\overline{7}$ \\
\hline PCB 184 & $0.56 \mathrm{U}$ & $0.53 \mathrm{U}$ & $0.53 \mathrm{U}$ & NA \\
\hline PCB 153 & 7.85 & 9.48 & 9.05 & 10 \\
\hline PCB 105 & $0.31 \mathrm{U}$ & $0.29 \mathrm{U}$ & $0.30 \mathrm{U}$ & NA \\
\hline PCB 138 & 6.85 & 8.04 & 7.72 & 8 \\
\hline PCB 187 & 1.95 & 2.20 & 2.14 & 6 \\
\hline PCB 183 & 1.33 & 1.63 & 1.55 & 10 \\
\hline PCB 128 & 1.27 & 1.40 & 1.15 & 10 \\
\hline PCB 180 & 4.85 & 6.08 & 6.28 & 13 \\
\hline PCB 170 & 1.96 & 2.26 & 2.12 & 7 \\
\hline PCB 195 & $0.28 U$ & $0.27 \mathrm{U}$ & 0.39 & NA \\
\hline PCB 206 & 1.34 . & 1.43 & 1.43 & 4 \\
\hline PCB 209 & 1.14 & 1.20 & 1.06 & 6 \\
\hline \multicolumn{5}{|c|}{ Surrogate Recoveries (\%) } \\
\hline PCB 103 (SIS) & 69 & 72 & 72 & NA \\
\hline PCB 198 (SIS) & 62 & 64 & 67 & NA \\
\hline
\end{tabular}


Table B.11. (contd)

\begin{tabular}{|c|c|c|c|c|}
\hline \multirow[b]{2}{*}{$\begin{array}{r}\text { Sediment Treatment } \\
\text { Replicate } \\
\end{array}$} & \multicolumn{3}{|c|}{ Concentration (ng/L) } & \multirow[b]{2}{*}{$\begin{array}{l}\text { RSD } \\
(\%)\end{array}$} \\
\hline & $\begin{array}{c}\mathrm{CL}^{-B} \mathrm{COMP}^{(\mathrm{a})} \\
1 \\
\end{array}$ & $\begin{array}{c}\text { CL-B COMP } \\
2 \\
\end{array}$ & $\begin{array}{c}\text { CL-B COMP } \\
3 \\
\end{array}$ & \\
\hline Heptachlor & $0.46 \mathrm{U}$ & $0.46 U$ & $0.49 \mathrm{U}$ & NA \\
\hline Aldrin & 9.58 & 9.61 & 10.6 & 6 \\
\hline Heptachlor Epoxide & $0.11 \mathrm{U}$ & $0.11 \mathrm{U}$ & $0.12 \mathrm{U}$ & NA \\
\hline 2,4'-DDE & $0.23 U$ & $0.23 \mathrm{U}$ & $0.24 \mathrm{U}$ & NA \\
\hline Endosulfan I & $0.46 \mathrm{U}$ & $0.46 \mathrm{U}$ & $0.48 \mathrm{U}$ & NA \\
\hline$\alpha$-Chlordane & $0.82 U$ & $0.82 U$ & 3.24 & NA \\
\hline Trans Nonachlor & $1.10 \mathrm{U}$ & $1.10 \mathrm{U}$ & $1.16 \mathrm{U}$ & NA \\
\hline 4,4'-DDE & 32.0 & 30.9 & 35.7 & 8 \\
\hline Dieldrin & 9.06 & 7.69 & 10.2 & 14 \\
\hline 2,4'-DDD & 5.97 & 7.03 & 7.78 & 13 \\
\hline 2,4'-DDT & $0.43 \mathrm{U}$ & $0.43 \mathrm{U}$ & $0.45 \mathrm{U}$ & NA \\
\hline 4,4'-DDD & 13.1 & 13.3 & 13.8 & 3 \\
\hline Endosulfan II & $0.46 \mathrm{U}$ & $0.46 \mathrm{U}$ & $0.48 U$ & NA \\
\hline 4,4'-DDT & 16.7 & 16.6 & 17.3 & 2 \\
\hline Endosulfan Sulfate & $0.46 \mathrm{U}$ & $0.46 \mathrm{U}$ & $0.48 \mathrm{U}$ & NA \\
\hline PCB 8 & 7.13 & 5.78 & 7.87 & 15 \\
\hline РСВ 18 & 62.3 & 54.5 & 67.8 & -11 \\
\hline PCB 28 & 37.7 & 37.0 & 42.6 & 8 \\
\hline РСВ 52 & 36.0 & 34.4 & 37.2 & 4 \\
\hline РСB 49 & 20.9 & 20.3 & 22.4 & 5 \\
\hline РCB 44 & 44.9 & 36.6 & 34.6 & 14 \\
\hline РСВ 66 & 37.6 & 36.5 & 41.0 & 6 \\
\hline PCB 101 & 27.2 & 24.7 & 27.0 & 5 \\
\hline PCB 87 & 7.65 & 6.54 & 6.74 & 8 \\
\hline PCB 118 & 20.6 & 17.9 & 19.3 & 7 \\
\hline PCB 184 & $0.53 \mathrm{U}$ & $0.53 \mathrm{U}$ & $0.56 \mathrm{U}$ & NA \\
\hline PCB 153 & 20.6 & 18.8 & 19.9 & 5 \\
\hline PCB 105 & $0.29 \mathrm{U}$ & $0.29 \mathrm{U}$ & $0.31 \mathrm{U}$ & NA \\
\hline PCB 138 & 17.2 & 15.5 & 16.8 & 5 \\
\hline PCB 187 & 6.15 & 5.81 & 6.30 & 4 \\
\hline PCB 183 & 2.80 & 2.52 & 2.63 & 5 \\
\hline PCB 128 & 2.24 & 2.02 & 2.23 & 6 \\
\hline PCB 180 & 10.8 & 11.3 & 11.4 & 3 \\
\hline PCB 170 & 4.12 & 4.18 & 4.39 & 3 \\
\hline PCB 195 & 0.81 & $0.27 \mathrm{U}$ & 0.94 & NA \\
\hline PCB 206 & 2.23 & 2.22 & 2.40 & 4 \\
\hline РСВ 209 & 1.78 & 1.71 & 1.88 & 5 \\
\hline \multicolumn{5}{|l|}{ Surrogate Recoveries (\%) } \\
\hline PCB 103 (SIS) & 75 & 74 & 69 & NA \\
\hline PCB 198 (SIS) & 75 & 70 & 73 & NA \\
\hline
\end{tabular}


Table B.11. (contd)

\begin{tabular}{|c|c|c|c|c|}
\hline \multirow[b]{2}{*}{$\begin{array}{r}\text { Sediment Treatment } \\
\text { Replicate }\end{array}$} & \multicolumn{3}{|c|}{ Concentration (ng/L) } & \multirow[b]{2}{*}{$\begin{array}{l}\text { RSD } \\
(\%)\end{array}$} \\
\hline & $\begin{array}{c}\text { CL-A COMP } \\
1 \\
\end{array}$ & $\begin{array}{l}\text { CL-A COMP } \\
\quad 2 \\
\end{array}$ & $\begin{array}{c}\text { CL-A COMP } \\
3 \\
\end{array}$ & \\
\hline Heptachlor & $0.48 U$ & $0.46 \mathrm{U}$ & $0.47 \mathrm{U}$ & NA \\
\hline Aldrin & 8.05 & 10.9 & 11.9 & 19 \\
\hline Heptachlor Epoxide & $0.11 \mathrm{U}$ & $0.11 \mathrm{U}$ & $0.11 \mathrm{U}$ & NA \\
\hline $2,4^{\prime}-\mathrm{DDE}$ & $0.24 U$ & $0.23 \mathrm{U}$ & $0.23 \mathrm{U}$ & NA \\
\hline Endosulfan I & $0.48 \mathrm{U}$ & $0.46 \mathrm{U}$ & $0.46 \mathrm{U}$ & NA \\
\hline$\alpha$-Chlordane & 1.21 & $0.82 \mathrm{U}$ & $0.83 \mathrm{U}$ & NA \\
\hline Trans Nonachlor & $1.15 \mathrm{U}$ & $1.10 \mathrm{U}$ & $1.11 \mathrm{U}$ & NA \\
\hline $4,4^{\prime}-\mathrm{DDE}$ & 19.4 & 27.9 & 31.2 & 23 \\
\hline Dieldrin & 5.49 & 5.70 & 5.52 & 2 \\
\hline 2,4'-DDD & 4.62 & 5.99 & 5.42 & 13 \\
\hline $2,4^{\prime}-\mathrm{DDT}$ & $0.45 \mathrm{U}$ & $0.43 U$ & $0.44 \mathrm{U}$ & NA \\
\hline $4,4^{\prime}-\mathrm{DDD}$ & 9.28 & 11.7 & 10.4 & 12 \\
\hline Endosulfan II & $0.48 \mathrm{U}$ & $0.46 \mathrm{U}$ & $0.46 \mathrm{U}$ & NA \\
\hline 4,4'-DDT & 13.4 & 15.9 & 14.3 & $9 \%$ \\
\hline Endosulfan Sulfate & $0.48 \mathrm{U}$ & $0.46 \mathrm{U}$ & $0.46 \mathrm{U}$ & NA \\
\hline РCB 8 & $1.03 U$ & $0.98 \mathrm{U}$ & $1.00 \mathrm{U}$ & NA \\
\hline PCB 18 & 42.2 & $60.7^{-}$ & 70.2 & 25 \\
\hline РСВ 28 & 29.7 & 44.1 & 51.1 & 26 \\
\hline РСB 52 & 26.4 & 39.1 & 43.5 & 24 \\
\hline РСB 49 & 15.8 & 23.9 & 26.7 & 26 \\
\hline PCB 44 & 29.4 & 38.1 & 41.3 & 17 \\
\hline РCB 66 & 26.5 & 39.8 & 46.1 & 27 \\
\hline PCB 101 & 16.2 & 25.3 & 28.9 & 28 \\
\hline PCB 87 & 3.57 & $6.78:$ & 7.48 & $35^{\text {(d) }}$ \\
\hline PCB 118 & 11.4 & 19.7 & 21.3 & 30 \\
\hline PCB 184 & $0.55 \mathrm{U}$ & $0.53 \mathrm{U}$ & $0.53 \mathrm{U}$ & NA \\
\hline PCB 153 & 10.3 & 19.4 & 20.4 & $33^{(0)}$ \\
\hline PCB 105 & $0.31 \mathrm{U}$ & $0.29 \mathrm{U}$ & $0.30 \mathrm{U}$ & NA \\
\hline PCB 138 & 8.83 & 15.5 & 16.1 & 30 \\
\hline PCB 187 & 2.40 & 6.46 & 6.92 & $47^{\text {(d) }}$ \\
\hline PCB 183 & 1.57 & 2.63 & 2.72 & 28 \\
\hline PCB 128 & 1.40 & 2.27 & 2.12 & 24 \\
\hline PCB 180 & 5.84 & 11.1 & 12.2 & $35^{\text {(d) }}$ \\
\hline PCB 170 & 2.14 & 4.46 & 4.32 & $36^{\text {(d) }}$ \\
\hline PCB 195 & $0.28 \mathrm{U}$ & 1.03 & 0.80 & NA \\
\hline PCB 206 & 2.46 & 4.83 & 5.42 & $37^{(d)}$ \\
\hline PCB 209 & 2.10 & 3.21 & 3.99 & $31^{(d)}$ \\
\hline \multicolumn{5}{|c|}{ Surrogate Recoveries (\%) } \\
\hline PCB 103 (SIS) & 69 & 70 & 69 & NA \\
\hline PCB 198 (SIS) & 65 & 68 & 77 & NA \\
\hline
\end{tabular}


Table B.11. (contd)

\begin{tabular}{|c|c|c|c|c|}
\hline \multirow[b]{2}{*}{$\begin{array}{r}\text { Sediment Treatment } \\
\text { Replicate } \\
\end{array}$} & \multicolumn{3}{|c|}{ Concentration (ng/L) } & \multirow[b]{2}{*}{$\begin{array}{r}\text { RSD } \\
(\%) \\
\end{array}$} \\
\hline & $\begin{array}{c}\text { PJ-A COMP(a) }^{(a)} \\
1 \\
\end{array}$ & $\begin{array}{c}\text { PJ-A COMP } \\
2 \\
\end{array}$ & $\begin{array}{c}\text { PJ-A COMP } \\
3 \\
\end{array}$ & \\
\hline Heptachlor & $0.48 \mathrm{U}$ & 0.88 & $0.48 \mathrm{U}$ & NA \\
\hline Aldrin & 5.39 & 5.64 & 5.52 & 2 \\
\hline Heptachlor Epoxide & $0.11 \mathrm{U}$ & $0.11 \mathrm{U}$ & $0.11 \mathrm{U}$ & NA \\
\hline 2,4'-DDE & $0.24 \mathrm{U}$ & $0.24 \mathrm{U}$ & $0.24 \mathrm{U}$ & NA \\
\hline Endosulfan I & $0.47 \mathrm{U}$ & $0.47 \mathrm{U}$ & $0.47 \mathrm{U}$ & NA \\
\hline$\alpha$-Chlordane & $0.84 \mathrm{U}$ & $0.84 \mathrm{U}$ & 0.95 & NA \\
\hline Trans Nonachlor & $1.13 U$ & $1.13 \mathrm{U}$ & $1.13 \mathrm{U}$ & NA \\
\hline 4,4'-DDE & 8.51 & 9.24 & 9.21 & 5 \\
\hline Dieldrin & 5.28 & 4.95 & 5.02 & 3 \\
\hline 2,4'-DDD & $0.96 \mathrm{U}$ & $0.96 U$ & $0.96 \mathrm{U}$ & NA \\
\hline 2,4'-DDT & $0.44 \mathrm{U}$ & $0.44 \mathrm{U}$ & $0.44 \mathrm{U}$ & NA \\
\hline 4,4'-DDD & $0.46 \mathrm{U}$ & $0.46 \mathrm{U}$ & $0.46 \mathrm{U}$ & NA \\
\hline Endosulfan II & $0.47 \mathrm{U}$ & $0.47 \mathrm{U}$ & $0.47 \mathrm{U}$ & NA \\
\hline 4,4'-DDT & 9.19 & 9.09 & 9.47 & 2 \\
\hline Endosulfan Sulfate & $0.47 \cup$ & $0.47 \mathrm{U}$ & $0.47 \mathrm{U}$ & NA \\
\hline РСВ 8 & $1.02 U$ & $1.02 U$ & $1.02 U$ & NA \\
\hline РCB 18 & 17.6 & 19.6 & 19.7 & 6 \\
\hline РСB 28 & 10.8 & 12.4 & 13.1 & 10 \\
\hline PCB 52 & 6.81 & $8.95^{\circ}$ & 8.95 & 15 \\
\hline РСВ 49 & 5.04 & 6.24 & 6.37 & 12 \\
\hline РСB 44 & $0.31 \mathrm{U}$ & $0.31 \mathrm{U}$ & $0.31 \mathrm{U}$ & NA \\
\hline РСB 66 & $0.39 \mathrm{U}$ & $0.39 \mathrm{U}$ & $0.39 \mathrm{U}$ & NA \\
\hline PCB 101 & 3.32 & 4.75 & 5.19 & 22 \\
\hline PCB 87 & 1.02 & 1.15 & 1.17 & 7 \\
\hline PCB 118 & 2.39 & 3.40 & 3.77 & 22 \\
\hline PCB 184 & $0.55 U$ & $0.55 \mathrm{U}$ & $0.55 \mathrm{U}$ & NA \\
\hline PCB 153 & 2.51 & 3.47 & 3.59 & 19 \\
\hline PCB 105 & $0.30 \mathrm{U}$ & $0.30 \mathrm{U}$ & $0.30 \mathrm{U}$ & NA \\
\hline PCB 138 & 2.94 & 3.58 & 3.56 & 11 \\
\hline PCB 187 & 1.00 & 1.12 & 1.17 & 8 \\
\hline PCB 183 & 0.74 & 0.76 & 0.83 & 6 \\
\hline PCB 128 & 0.50 & 0.56 & 0.60 & 9 \\
\hline PCB 180 & 2.15 & 2.57 & 2.65 & 11 \\
\hline РСB 170 & 1.56 & 1.62 & 1.56 & 2 \\
\hline РСВ 195 & $0.28 \mathrm{U}$ & $0.28 \mathrm{U}$ & $0.28 \mathrm{U}$ & NA \\
\hline PCB 206 & $0.40 \mathrm{U}$ & $0.40 U$ & $0.40 \mathrm{U}$ & NA \\
\hline РCB 209 & $0.28 \mathrm{U}$ & $0.28 \mathrm{U}$ & $0.28 \mathrm{U}$ & NA \\
\hline \multicolumn{5}{|c|}{ Surrogate Recoveries (\%) } \\
\hline PCB 103 (SIS) & 70 & 71 & 76 & NA \\
\hline PCB 198 (SIS) & 61 & 64 & 66 & NA \\
\hline
\end{tabular}


Table B.11. (contd)

\begin{tabular}{|c|c|c|c|c|}
\hline \multirow[b]{2}{*}{$\begin{array}{r}\text { Sediment Treatment } \\
\text { Replicate } \\
\end{array}$} & \multicolumn{3}{|c|}{ Concentration (ng/L) } & \multirow[b]{2}{*}{$\begin{array}{l}\text { RSD } \\
(\%)\end{array}$} \\
\hline & $\begin{array}{c}\mathrm{RHCOMP}^{(\mathrm{a})} \\
1 \\
\end{array}$ & $\begin{array}{c}\text { RH COMP } \\
2 \\
\end{array}$ & $\begin{array}{c}\mathrm{RHCOMP} \\
3 \\
\end{array}$ & \\
\hline Heptachlor & $0.49 \mathrm{U}$ & $0.47 \mathrm{U}$ & $0.47 \mathrm{U}$ & NA \\
\hline Aldrin & 3.27 & 2.78 & 5.50 & $38^{(d)}$ \\
\hline Heptachlor Epoxide & $0.12 \mathrm{U}$ & $0.11 \mathrm{U}$ & $0.11 \mathrm{U}$ & NA \\
\hline $2,4^{\prime}-D D E$ & $0.24 \mathrm{U}$ & $0.23 \mathrm{U}$ & $0.23 U$ & NA \\
\hline Endosulfan I & $0.49 \mathrm{U}$ & $0.46 \mathrm{U}$ & $0.47 \mathrm{U}$ & NA \\
\hline$\alpha$-Chlordane & $0.87 \cup$ & $0.83 \mathrm{U}$ & $0.83 \mathrm{U}$ & NA \\
\hline Trans Nonachlor & $1.17 \mathrm{U}$ & $1.11 \mathrm{U}$ & $1.12 \mathrm{U}$ & NA \\
\hline 4,4'-DDE & 6.65 & 7.14 & 8.19 & 11 \\
\hline Dieldrin & 2.36 & 4.87 & 5.10 & $37^{\text {(d) }}$ \\
\hline 2,4'-DDD & $0.99 \mathrm{U}$ & $0.94 U$ & $0.95 \mathrm{U}$ & NA \\
\hline $2,4^{\prime}-D D T$ & $0.46 \mathrm{U}$ & $0.44 \mathrm{U}$ & $0.44 \mathrm{U}$ & NA \\
\hline 4,4'-DDD & $0.47 \mathrm{U}$ & $0.45 \mathrm{U}$ & $0.45 \mathrm{U}$ & NA \\
\hline Endosulfan II & $0.49 \mathrm{U}$ & 0.88 & $0.47 \mathrm{U}$ & NA \\
\hline 4,4'-DDT & 7.95 & 7.72 & 8.21 & 3 \\
\hline Endosulfan Sulfate & $0.49 \mathrm{U}$ & $0.46 \mathrm{U}$ & $0.47 \mathrm{U}$ & NA \\
\hline PCB 8 & $1.05 \mathrm{U}$ & $1.00 \mathrm{U}$ & $1.01 \mathrm{U}$ & NA \\
\hline РСВ 18 & 8.53 & 8.56 & 11.8 & 19 \\
\hline РCB 28 & 5.10 & 4.99 & 8.85 & $35^{\text {(d) }}$ \\
\hline РСВ 52 & 3.65 & $0.35 \mathrm{U}$ & $0.36 \mathrm{U}$ & NA \\
\hline РСВ 49 & 2.37 & 2.30 & 6.74 & $67^{\text {(d) }}$ \\
\hline РСВ 44 & $0.32 \mathrm{U}$ & $0.31 \mathrm{U}$ & $0.31 \mathrm{U}$ & NA \\
\hline PCB 66 & $0.40 \mathrm{U}$ & $0.38 \mathrm{U}$ & $0.39 \mathrm{U}$ & NA \\
\hline PCB 101 & 1.54 & 1.82 & $0.49 \mathrm{U}$ & NA \\
\hline РСВ 87 & $0.37 \mathrm{U}$ & $0.35 \mathrm{U}$ & 1.63 & NA \\
\hline PCB 118 & 1.44 & 1.52 & 4.73 & $73^{\text {(d) }}$ \\
\hline PCB 184 & $0.56 \mathrm{U}$ & $0.53 \mathrm{U}$ & $0.54 \mathrm{U}$ & $\mathrm{NA}$ \\
\hline PCB 153 & 1.16 & 1.33 & $0.40 \mathrm{U}$ & NA \\
\hline PCB 105 & $0.31 \mathrm{U}$ & $0.30 \mathrm{U}$ & $0.30 \mathrm{U}$ & NA \\
\hline PCB 138 & 1.23 & 1.42 & 1.78 & 19 \\
\hline PCB 187 & $0.41 \mathrm{U}$ & $0.39 \mathrm{U}$ & $0.39 \mathrm{U}$ & NA \\
\hline PCB 183 & $0.56 \mathrm{U}$ & $0.53 \mathrm{U}$ & $0.54 \mathrm{U}$ & NA \\
\hline PCB 128 & $0.25 \mathrm{U}$ & $0.24 \mathrm{U}$ & $0.24 \mathrm{U}$ & NA \\
\hline PCB 180 & 0.92 & 1.04 & 1.23 & 15 \\
\hline PCB 170 & $0.21 \mathrm{U}$ & $0.20 \mathrm{U}$ & $0.20 \mathrm{U}$ & NA \\
\hline PCB 195 & $0.29 \mathrm{U}$ & $0.27 \mathrm{U}$ & $0.28 \mathrm{U}$ & NA \\
\hline PCB 206 & 0.40 & $0.39 \mathrm{U}$ & $0.39 \mathrm{U}$ & NA \\
\hline PCB 209 & $0.29 \mathrm{U}$ & $0.27 \mathrm{U}$ & $0.28 \mathrm{U}$ & NA \\
\hline \multicolumn{5}{|l|}{ Surrogate Recoveries (\%) } \\
\hline PCB 103 (SIS) & 67 & 68 & 69 & NA \\
\hline PCB 198 (SIS) & 61 & 61 & 61 & NA \\
\hline
\end{tabular}


Table B.11. (contd)

\begin{tabular}{|c|c|c|c|c|}
\hline \multirow[b]{2}{*}{$\begin{array}{r}\text { Sediment Treatment } \\
\text { Replicate }\end{array}$} & \multicolumn{3}{|c|}{ Concentration (ng/L) } & \multirow[b]{2}{*}{$\begin{array}{l}\text { RSD } \\
(\%) \\
\end{array}$} \\
\hline & $\begin{array}{c}C L-C \text { COMP } \\
1 \\
\end{array}$ & $\begin{array}{c}\text { CL-C COMP } \\
2 \\
\end{array}$ & $\begin{array}{c}\text { CL-C COMP } \\
3 \\
\end{array}$ & \\
\hline Heptachlor & 1.08 & 6.57 & 1.26 & $105^{(d)}$ \\
\hline Aldrin & 5.26 & 7.34 & 6.38 & 16 \\
\hline Heptachlor Epoxide & $0.11 \mathrm{U}$ & $0.11 \mathrm{U}$ & $0.11 \mathrm{U}$ & NA \\
\hline 2,4'-DDE & $0.23 \mathrm{U}$ & $0.24 U$ & $0.23 \mathrm{U}$ & NA \\
\hline Endosulfan I & $0.46 \mathrm{U}$ & $0.47 \mathrm{U}$ & $0.46 \mathrm{U}$ & NA \\
\hline$\alpha$-Chlordane & $0.83 \mathrm{U}$ & 1.53 & $0.82 U$ & NA \\
\hline Trans Nonachlor & $1.11 \mathrm{U}$ & $1.13 \mathrm{U}$ & $1.10 \mathrm{U}$ & NA \\
\hline 4,4'-DDE & 8.59 & 14.7 & 11.9 & 26 \\
\hline Dieldrin & 5.37 & 7.25 & 5.86 & 16 \\
\hline 2,4'-DDD & $0.94 \mathrm{U}$ & 3.83 & $0.93 \mathrm{U}$ & NA \\
\hline 2,4'-DDT & $0.44 \mathrm{U}$ & $0.44 \mathrm{U}$ & $0.43 \mathrm{U}$ & NA \\
\hline 4,4'-DDD & 7.13 & 8.79 & 7.70 & 11 \\
\hline Endosulfan II & $0.46 U$ & $0.47 \mathrm{U}$ & $0.46 \mathrm{U}$ & NA \\
\hline 4,4'-DDT & 9.65 & 12.2 & 9.83 & 13 \\
\hline Endosulfan Sulfate & $0.46 \mathrm{U}$ & $0.47 \mathrm{U}$ & $0.46 U$ & NA \\
\hline РСВ 8 & $1.00 \mathrm{U}$ & $1.02 \mathrm{U}$ & $0.98 \mathrm{U}$ & NA \\
\hline РСВ 18 & 20.0 & 32.7 & 29.1 & 24 \\
\hline РСВ 28 & 12.1 & 22.0 & 19.2 & 29 \\
\hline РСВ 52 & $0.35 \mathrm{U}$ & $0.36 U$ & 14.8 & NA \\
\hline РСВ 49 & 5.94 & 18.3 & 9.26 & $57^{\text {(d) }}$ \\
\hline РСВ 44 & $0.31 \mathrm{U}$ & $0.31 \mathrm{U}$ & $0.30 \mathrm{U}$ & NA \\
\hline РСB 66 & $0.38 \mathrm{U}$ & $0.39 \mathrm{U}$ & $0.38 \mathrm{U}$ & NA \\
\hline PCB 101 & 4.63 & 12.8 & 9.26 & $46^{(d)}$ \\
\hline РСВ 87 & 1.25 & 2.01 & $0.35 \mathrm{U}$ & NA \\
\hline PCB 118 & 3.62 & 7.87 & 6.75 & $36^{(d)}$ \\
\hline PCB 184 & $0.53 \mathrm{U}$ & $0.55 \mathrm{U}$ & $0.53 U$ & NA \\
\hline РСВ 153 & 2.41 & 7.26 & 6.56 & $48^{\text {(d) }}$ \\
\hline PCB 105 & $0.30 \mathrm{U}$ & $0.30 \mathrm{U}$ & $0.29 \mathrm{U}$ & NA \\
\hline PCB 138 & 3.28 & 7.11 & 5.95 & $36^{(d)}$ \\
\hline PCB 187 & 1.01 & 1.75 & 1.67 & 28 \\
\hline PCB 183 & $0.53 \mathrm{U}$ & 1.10 & 1.07 & NA \\
\hline PCB 128 & $0.24 \mathrm{U}$ & $0.25 \mathrm{U}$ & 0.98 & NA \\
\hline PCB 180 & 2.07 & 5.66 & 4.31 & $45^{(d)}$ \\
\hline PCB 170 & $0.20 \mathrm{U}$ & 2.20 & 1.89 & NA \\
\hline PCB 195 & $0.27 \mathrm{U}$ & $0.28 \mathrm{U}$ & $0.27 \mathrm{U}$ & NA \\
\hline PCB 206 & $0.39 \mathrm{U}$ & $0.40 \mathrm{U}$ & 0.87 & NA \\
\hline PCB 209 & $0.27 \mathrm{U}$ & $0.28 \mathrm{U}$ & $0.27 \mathrm{U}$ & NA \\
\hline \multicolumn{5}{|c|}{ Surrogate Recoveries (\%) } \\
\hline PCB 103 (SIS) & 82 & 75 & 69 & NA \\
\hline РCB 198 (SIS) & 72 & 63 & 64 & NA \\
\hline
\end{tabular}

(a) Sample randomly selected for use as a quality control sample in analytical batch.

(b) $U$ Undetected at or above given concentration.

(c) NA Not applicable.

(d) Outside quality control criteria $(\leq 30 \%)$ for replicate analysis. 


\section{Appendix C.}

Benthic Acute Toxicity Test Data, Red Hook and Bay Ridge Channels 
Table C.1. Results of 10-Day, Static-Renewal, Benthic Acute Toxicity Test with $A$. abdita, Red Hook and Bay Ridge Channels

\begin{tabular}{|c|c|c|c|c|c|c|}
\hline $\begin{array}{l}\text { Sediment } \\
\text { Treatment }\end{array}$ & Replicate & Live $^{(a)}$ & $\begin{array}{l}\text { Dead or } \\
\text { Missing }\end{array}$ & $\begin{array}{c}\text { Proportion } \\
\text { Surviving } \\
\end{array}$ & $\begin{array}{c}\text { Mean } \\
\text { Proportion } \\
\text { Surviving } \\
\end{array}$ & $\begin{array}{l}\text { Standard } \\
\text { Deviation } \\
\end{array}$ \\
\hline Red Hook & & & & - & & \\
\hline RH COMP & 1 & 13 & 7 & 0.65 & & \\
\hline RH COMP & 2 & 14 & 6 & 0.70 & & \\
\hline RH COMP & 3 & 13 & 7 & 0.65 & & \\
\hline RH COMP & 4 & 10 & 10 & 0.50 & & \\
\hline RH COMP & 5 & 15 & 5 & 0.75 & 0.65 & 0.09 \\
\hline \multicolumn{7}{|l|}{ Bay Ridge Reach A } \\
\hline BR-A COMP & 1 & 20 & 0 & 1.00 & & \\
\hline BR-A COMP & 2 & 18 & 2 & 0.90 & & \\
\hline BR-A COMP & 3 & 18 & 2 & 0.90 & & \\
\hline BR-A COMP & 4 & 16 & 4 & 0.80 & & \\
\hline BR-A COMP & 5 & 19 & 1 & 0.95 & 0.91 & 0.07 \\
\hline \multicolumn{7}{|l|}{ Bay Ridge Reach B } \\
\hline BR-B COMP & 1 & 8 & 12 & 0.40 & & \\
\hline BR-B COMP & 2 & 4 & 16 & 0.20 & & \\
\hline BR-B COMP & 3 & 5 & 15 & 0.25 & & \\
\hline BR-B COMP & 4 & 12 & 8 & 0.60 & & \\
\hline BR-B COMP & 5 & 6 & 14 & 0.30 & 0.35 & 0.16 \\
\hline MDRS $^{(b)}$ & 1 & 19 & 1 & 0.95 & & \\
\hline MDRS & 2 & 19 & 1 & 0.95 & & \\
\hline MDRS & 3 & 19 & 1 & 0.95 & & \\
\hline MDRS & 4 & 20 & 0 & 1.00 & & \\
\hline MDRS & 5 & 17 & 3 & 0.85 & 0.94 & 0.05 \\
\hline Ampelisca Control & 1 & 20 & 0 & 1.00 & & \\
\hline Ampelisca Control & 2 & 20 & 0 & 1.00 & & \\
\hline Ampelisca Control & 3 & 20 & 0 & 1.00 & & \\
\hline Ampelisca Control & 4 & 20 & 0 & 1.00 & & \\
\hline Ampelisca Control & 5 & 20 & 0 & 1.00 & 1.00 & 0.00 \\
\hline
\end{tabular}

(a) Survival based on initial exposure of 20 organisms per replicate.

(b) MDRS Mud Dump Reference Site.

C.1 
Table C.2. Water Quality Data for 10-Day, Static-Renewal, Benthic Acute Toxicity Test with $A$. abdita, Red Hook and Bay Ridge Channels

\begin{tabular}{|c|c|c|c|c|c|c|c|c|c|c|}
\hline \multirow[b]{2}{*}{ Sediment Treatment } & \multicolumn{2}{|c|}{$\begin{array}{c}\text { Temperature } \\
\left({ }^{\circ} \mathrm{C}\right)\end{array}$} & \multicolumn{2}{|c|}{$\mathrm{pH}$} & \multicolumn{2}{|c|}{$\begin{array}{c}\text { Dissolved } \\
\text { Oxygen } \\
\text { (mg/L) }\end{array}$} & \multicolumn{2}{|c|}{$\begin{array}{c}\text { Salinity } \\
(\%)\end{array}$} & \multicolumn{2}{|c|}{$\begin{array}{c}\text { Total } \\
\text { Ammonia }^{(a)} \\
(\mathrm{mg} / \mathrm{L})\end{array}$} \\
\hline & Min & Max & Min & Max & Min & Max & Min & Max & Min & Max \\
\hline Acceptable Range: & 18.0 & 22.0 & 7.30 & 8.30 & 4.6 & $N A^{(b)}$ & 28.0 & 32.0 & NA & 30.0 \\
\hline Red Hook & & & & & & & & & & \\
\hline RH COMP & 19.4 & 20.5 & 7.79 & 8.08 & 6.5 & 7.2 & 30.0 & 32.0 & $<1.0$ & $<1.0$ \\
\hline Bay Ridge Reach A & & & & & & & & & & \\
\hline BR-A COMP & 19.3 & 20.4 & 8.02 & $8.59^{(c)}$ & 6.3 & 7.5 & 30.0 & $\begin{array}{r}31.0 \\
\quad \therefore .\end{array}$ & $<1.0$ & $<1.0$ \\
\hline Bay Ridge Re & & & & & & & & & & \\
\hline BR-B COMP & 19.4 & 20.3 & 7.75 & 8.10 & 6.6 & 7.3 & 30.0 & 30.5 & $<1.0$ & $<1.0$ \\
\hline MDRS $^{(d)}$ & 19.3 & 20.4 & 7.81 & 8.13 & 6.8 & 7.4 & 30.0 & 32.0 & $<1.0$ & $<1.0$ \\
\hline Ampelisca Control & 19.5 & 20.3 & 7.76 & $8.50^{(c)}$ & 6.3 & 7.4 & 30.0 & 31.5 & $<1.0$ & $<1.0$ \\
\hline
\end{tabular}
(a) Ammonia measured in overlying water.
(b) NA Not applicable.
(c) Data point out of range.
(d) MDRS Mud Dump Reference Site. 
Table C.3. Results of 96-Hour, Cadmium Reference Toxicant Test with $A$. abdita

\begin{tabular}{|c|c|c|c|c|c|c|}
\hline $\begin{array}{c}\text { Cadmium } \\
\text { Concentration }(\mathrm{mg} / \mathrm{L}) \\
\end{array}$ & Replicate & $\operatorname{Live}^{(a)}$ & $\begin{array}{l}\text { Dead or } \\
\text { Missing }\end{array}$ & $\begin{array}{l}\text { Proportion } \\
\text { Surviving }\end{array}$ & $\begin{array}{c}\text { Mean } \\
\text { Proportion } \\
\text { Surviving }\end{array}$ & $\begin{array}{l}\text { Standard } \\
\text { Deviation }\end{array}$ \\
\hline 0.0 & 1 & 20 & 0 & 1.00 & & \\
\hline 0.0 & 2 & 20 & 0 & 1.00 & 1.00 & 0.00 \\
\hline 0.0 & 3 & 20 & 0 & 1.00 & & \\
\hline 0.19 & 1 & 13 & 7 & 0.65 & & \\
\hline 0.19 & 2 & 17 & 3 & 0.85 & 0.80 & 0.13 \\
\hline 0.19 & 3 & 18 & 2 & 0.90 & & \\
\hline 0.38 & 1 & 15 & 5 & 0.75 & & \\
\hline 0.38 & 2 & 13 & 7 & 0.65 & 0.68 & 0.06 \\
\hline 0.38 & 3 & 13 & 7 & 0.65 & & \\
\hline 0.75 & 1 & 8 & 12 & 0.40 & & \\
\hline 0.75 & 2 & 7 & 13 & 0.35 & 0.38 & 0.03 \\
\hline 0.75 & 3 & 8 & 12 & 0.40 & & \\
\hline 1.5 & 1 & 2 & 18 & 0.10 & & \\
\hline 1.5 & 2 & 1 & 19 & .0 .05 & 0.07 & 0.03 \\
\hline 1.5 & 3 & 1 & 19 & 0.05 & & \\
\hline
\end{tabular}

(a) Survival based on initial exposure of 20 organisms per replicate.

C.3 . 
Table C.4. Water Quality Data for 96-Hour, Cadmium Reference Toxicant Test with $A$. abdita

\begin{tabular}{|c|c|c|c|c|c|c|c|c|}
\hline \multirow{2}{*}{$\begin{array}{c}\text { Cadmium } \\
\text { Concentration } \\
\text { (mg/L) }\end{array}$} & \multicolumn{2}{|c|}{$\begin{array}{c}\text { Temperature } \\
\left({ }^{\circ} \mathrm{C}\right) \\
\end{array}$} & \multicolumn{2}{|c|}{$\mathrm{pH}$} & \multicolumn{2}{|c|}{$\begin{array}{c}\text { Dissolved } \\
\text { Oxygen } \\
\text { (mg/L) }\end{array}$} & \multicolumn{2}{|c|}{$\begin{array}{l}\text { Salinity } \\
(\%)\end{array}$} \\
\hline & Min & $\operatorname{Max}$ & Min & Max & Min & $\operatorname{Max}$ & Min & $\operatorname{Max}$ \\
\hline Acceptable Range: & 18.0 & 22.0 & 7.30 & 8.30 & 4.6 & $N A^{(a)}$ & 28.0 & 32.0 \\
\hline 0 & 19.5 & 20.0 & 8.12 & 8.18 & 7.0 & 7.2 & 30.5 & 31.0 \\
\hline 0.19 & 19.5 & 20.0 & 8.09 & 8.17 & 7.0 & 7.3 & 30.5 & 31.5 \\
\hline .0 .38 & 19.5 & 20.0 & 8.10 & 8.16 & 6.9 & 7.3 & 30.5 & 31.5 \\
\hline 0.75 & 19.5 & 20.0 & 8.10 & 8.15 & 6.8 & 7.2 & 31.0 & 32.0 \\
\hline 1.5 & 19.4 & 19.9 & 8.07 & 8.12 & 7.0 & 7.3 & 31.0 & 31.5 \\
\hline
\end{tabular}


Table C.5. Results of 10-day, Static-Renewal, Benthic Acute Toxicity Test with $M$. bahia, Red Hook and Bay Ridge Channels

\begin{tabular}{|c|c|c|c|c|c|c|}
\hline $\begin{array}{l}\text { Sediment } \\
\text { Treatment } \\
\end{array}$ & Replicate & Live $^{(a)}$ & $\begin{array}{l}\text { Dead or } \\
\text { Missing }\end{array}$ & $\begin{array}{c}\text { Proportion } \\
\text { Surviving } \\
\end{array}$ & $\begin{array}{c}\text { Mean } \\
\text { Proportion } \\
\text { Surviving }\end{array}$ & $\begin{array}{l}\text { Standard } \\
\text { Deviation }\end{array}$ \\
\hline \multicolumn{7}{|l|}{ Red Hook } \\
\hline$\overline{\mathrm{RH} \text { COMP }}$ & 1 & 13 & 7 & 0.65 & & \\
\hline RH COMP & 2 & 16 & 4 & 0.80 & & \\
\hline RH COMP & 3 & 16 & 4 & 0.80 & & \\
\hline RH COMP & 4 & 15 & 5 & 0.75 & & \\
\hline RH COMP & 5 & 17 & 3 & 0.85 & 0.77 & 0.08 \\
\hline \multicolumn{7}{|c|}{ Bay Ridge Reach A } \\
\hline BR-A COMP & 1 & 14 & 6 & 0.70 & & \\
\hline BR-A COMP & 2 & 16 & 4 & 0.80 & & \\
\hline BR-A COMP & 3 & 13 & 7 & 0.65 & & \\
\hline BR-A COMP & 4 & 16 & 4 & 0.80 & & \\
\hline BR-A COMP & 5 & 17 & 3 & 0.85 & 0.76 & 0.08 \\
\hline
\end{tabular}

Bay Ridge Reach B

\begin{tabular}{lllllll}
\hline BR-B COMP & 1 & 16 & 4 & 0.80 & & \\
BR-B COMP & 2 & 10 & 10 & 0.50 & $\cdots$ & \\
BR-B COMP & 3 & 17 & 3 & 0.85 & & \\
BR-B COMP & 4 & 16 & 4 & 0.80 & & \\
BR-B COMP & 5 & 15 & 5 & 0.75 & 0.74 & 0.14 \\
& & & & & & \\
MDRS(b) & 1 & 20 & 0 & 1.00 & & \\
MDRS & 2 & 20 & 0 & 1.00 & & \\
MDRS & 3 & 19 & 1 & 0.95 & & \\
MDRS & 4 & 19 & 1 & 0.95 & & \\
MDRS & 5 & 17 & 3 & 0.85 & 0.95 & \\
& & & & & & \\
Mysidopsis Control & 1 & 19 & 1 & 0.95 &. & \\
Mysidopsis Control & 2 & 20 & 0 & 1.00 & & \\
Mysidopsis Control & 3 & 20 & 0 & 1.00 & & \\
Mysidopsis Control & 4 & 19 & 1 & 0.95 & & \\
Mysidopsis Control & 5 & 19 & 1 & 0.95 & 0.97 &
\end{tabular}

(a) Survival based on initial exposure of 20 organisms per replicate.

(b) MDRS Mud Dump Reference Site. 
Table C.6. Water Quality Summary for 10-Day, Static-Renewal, Benthic Acute Toxicity Test with M. bahia, Red Hook and Bay Ridge Channels

\begin{tabular}{|c|c|c|c|c|c|c|c|c|c|c|}
\hline \multirow[b]{2}{*}{ Sediment Treatment } & \multicolumn{2}{|c|}{$\begin{array}{c}\text { Temperature } \\
\left({ }^{\circ} \mathrm{C}\right)\end{array}$} & \multicolumn{2}{|c|}{$\mathrm{pH}$} & \multicolumn{2}{|c|}{$\begin{array}{c}\text { Dissolved } \\
\text { Oxygen } \\
\text { (mg/L) }\end{array}$} & \multicolumn{2}{|c|}{$\begin{array}{c}\text { Salinity } \\
(\% 0)\end{array}$} & \multicolumn{2}{|c|}{$\begin{array}{c}\text { Total } \\
\text { Ammonia } \\
(\mathrm{mg} / \mathrm{L})\end{array}$} \\
\hline & Min & $\operatorname{Max}$ & Min & Max & Min & Max & Min & $\operatorname{Max}$ & Min & Max \\
\hline Acceptable Range: & 18.0 & 22.0 & 7.30 & 8.30 & 3.0 & $N A^{(b)}$ & 28.0 & 32.0 & NA & 15.0 \\
\hline \multicolumn{11}{|l|}{ Red Hook } \\
\hline RH COMP & 19.4 & 20.3 & 7.50 & 8.07 & 5.4 & 6.9 & 30.0 & 31.0 & $<1.0$ & $<1.0$ \\
\hline \multicolumn{11}{|l|}{ Bay Ridge Reach A } \\
\hline BR-A COMP & 19.5 & 20.4 & 7.98 & $8.61^{(c)}$ & 4.1 & 6.8 & 30.5 & 31.5 & $<1.0$ & $<1.0$ \\
\hline \multicolumn{11}{|l|}{ Bay Ridge Reach B } \\
\hline BR-B COMP & 19.4 & 20.3 & 7.44 & 8.10 & 5.3 & 7.0 & 30.0 & 32.0 & $<1.0$ & $<1.0$ \\
\hline $\operatorname{MDRS}^{(d)}$ & 19.3 & 20.3 & 7.48 & 8.12 & 5.5 & 7.1 & 30.0 & 31.5 & $<1.0$ & 1.71 \\
\hline Mysidopsis Control & 19.3 & 20.4 & 7.53 & $8.51^{(c)}$ & 5.0 & 6.9 & 30.0 & 32.0 & $<1.0$ & $<1.0$ \\
\hline
\end{tabular}
(a) Ammonia measured in overlying water.
(b) NA Not applicable.
(c) Data point out of range.
(d) MDRS Mud Dump Reference Site. 
Table C.7. Results of 96-Hour, Copper Reference Toxicant Test with M. bahia

\begin{tabular}{ccccccc}
$\begin{array}{c}\text { Copper } \\
\text { Concentration }(\mu \mathrm{g} / \mathrm{L})\end{array}$ & Replicate & Live $\mathrm{a}^{(\mathrm{a})}$ & $\begin{array}{c}\text { Dead or } \\
\text { Missing }\end{array}$ & $\begin{array}{c}\text { Mean } \\
\text { Proportion } \\
\text { Surviving }\end{array}$ & $\begin{array}{c}\text { Proportion } \\
\text { Surviving }\end{array}$ & $\begin{array}{c}\text { Standard } \\
\text { Deviation }\end{array}$ \\
\hline 0.0 & 1 & 10 & 0 & 1.00 & & \\
0.0 & 2 & 10 & 0 & 1.00 & & \\
0.0 & 3 & 10 & 0 & 1.00 & 1.00 & 0.00 \\
100 & 1 & 10 & 0 & 1.00 & & \\
100 & 2 & 10 & 0 & 1.00 & & \\
100 & 3 & 9 & 1 & 0.90 & 0.97 & 0.06 \\
150 & 1 & 10 & 0 & 1.00 & & \\
150 & 2 & 7 & 3 & 0.70 & & \\
150 & 3 & 8 & 2 & 0.80 & 0.83 & 0.15 \\
& & & & & & \\
200 & 1 & 7 & 3 & 0.70 & & \\
200 & 2 & 8 & 2 & 0.80 & & \\
200 & 3 & 5 & 5 & 0.50 & 0.67 & 0.15 \\
300 & 1 & 1 & 9 & 0.10 & & \\
300 & 2 & 3 & 7 & 0.30 & & \\
300 & 3 & 1 & 9 & 0.10 & 0.17 & 0.12
\end{tabular}

(a) Survival based on initial exposure of 10 organisms per replicate. 
Table C.8. Water Quality Data for 96-hour, Copper Reference Toxicant Test with M. bahia

\begin{tabular}{|c|c|c|c|c|c|c|c|c|}
\hline \multirow{2}{*}{$\begin{array}{c}\text { Copper } \\
\text { Concentration }(\mu \mathrm{g} / \mathrm{L})\end{array}$} & \multicolumn{2}{|c|}{$\begin{array}{c}\text { Temperature } \\
\left({ }^{\circ} \mathrm{C}\right) \\
\end{array}$} & \multicolumn{2}{|c|}{$\mathrm{pH}$} & \multicolumn{2}{|c|}{$\begin{array}{c}\text { Dissolved } \\
\text { Oxygen (mg/L) }\end{array}$} & \multicolumn{2}{|c|}{ Salinity (\%०) } \\
\hline & Min. & Max. & Min. & Max. & Min. & Max. & Min. & Max. \\
\hline Acceptable Range: & 18.0 & 22.0 & 7.30 & 8.30 & 3.0 & $N A^{(a)}$ & 28.0 & 32.0 \\
\hline 0 & 18.6 & 19.1 & 7.55 & 8.21 & 4.5 & 7.7 & 29.5 & 32.0 \\
\hline 100 & 18.6 & 19.1 & 7.65 & 8.19 & 5.0 & 7.4 & 29.5 & 32.0 \\
\hline 150 & 18.6 & 19.1 & 7.81 & 8.19 & 5.4 & 8.2 & 29.5 & 32.0 \\
\hline 200 & 18.6 & 19.1 & 7.92 & 8.21 & 7.0 & 7.9 & 29.5 & 32.0 \\
\hline 300 & 18.6 & 19.1 & 7.95 & 8.18 & 6.6 & 8.2 & 29.5 & 32.0 \\
\hline
\end{tabular}

(a) NA Not applicable. 
Appendix D.

Water-Column Toxicity Test Data, Red Hook and Bay Ridge Channels 
Table D.1. Results of 96-Hour, Water-Column Toxicity Test with M. beryllina, Red Hook and Bay Ridge Channels

\begin{tabular}{|c|c|c|c|c|c|c|c|}
\hline $\begin{array}{l}\text { Sediment } \\
\text { Treatment } \\
\end{array}$ & $\begin{array}{c}\text { Concentration } \\
(\% \text { SPP })\end{array}$ & Replicate & $\operatorname{Live}^{(a)}$ & $\begin{array}{l}\text { Dead or } \\
\text { Missing }\end{array}$ & $\begin{array}{c}\text { Proportion } \\
\text { Surviving } \\
\end{array}$ & $\begin{array}{c}\text { Mean } \\
\text { Proportion } \\
\text { Surviving }\end{array}$ & $\begin{array}{l}\text { Standard } \\
\text { Deviation }\end{array}$ \\
\hline \multicolumn{8}{|l|}{ Red Hook } \\
\hline RH COMP & 0 & 1 & 10 & 0 & 1.00 & & \\
\hline RH COMP & 0 & 2 & 10 & 0 & 1.00 & & \\
\hline RH COMP & 0 & 3 & 9 & 1 & 0.90 & & \\
\hline RH COMP & 0 & 4 & 9 & 1 & 0.90 & - & \\
\hline RH COMP & 0 & 5 & 9 & 1 & 0.90 & 0.94 & 0.05 \\
\hline RH COMP & 10 & 1 & 10 & 0 & 1.00 & & \\
\hline RH COMP & 10 & 2 & 10 & 0 & 1.00 & & \\
\hline RH COMP & 10 & 3 & 9 & 1 & 0.90 & & \\
\hline RH COMP & 10 & 4 & 9 & 1 & 0.90 & & \\
\hline RH COMP & 10 & 5 & 7 & 3 & 0.70 & 0.90 & 0.12 \\
\hline RH COMP & 50 . & 1 & 5 & 5 & 0.50 & $\cdot$ & \\
\hline RH COMP & 50 & 2 & 7 & 3 & 0.70 & & \\
\hline RH COMP & 50 & 3 & 7 & 3 & 0.70 & & \\
\hline RH COMP & 50 & 4 & 8 & 2 & 0.80 & 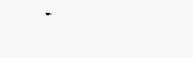 & \\
\hline RH COMP & 50 & 5 & 7 & 3 & 0.70 & 0.68 & 0.11 \\
\hline RH COMP & 100 & 1 & 0 & 10 & 0.00 & & \\
\hline RH COMP & 100 & 2 & 0 & 10 & 0.00 & & \\
\hline RH COMP & 100 & 3 & 1 & 9 & 0.10 & & \\
\hline RH COMP & 100 & 4 & 1 & 9 & 0.10 & & \\
\hline RH COMP & 100 & 5 & 1 & 9 & 0.10 & 0.06 & 0.05 \\
\hline \multicolumn{8}{|c|}{ Bay Ridge Reach A } \\
\hline BR-A COMP & 0 & 1 & 9 & 1 & 0.90 & & \\
\hline BR-A COMP & 0 & 2 & 9 & 1 & 0.90 & & . \\
\hline BR-A COMP & 0 & 3 & 7 & 3 & 0.70 & & \\
\hline BR-A COMP & 0 & 4 & 9 & 1 & 0.90 & & \\
\hline BR-A COMP & 0 & 5 & 7 & 3 & 0.70 & 0.82 & 0.11 \\
\hline BR-A COMP & 10 & 1 & 8 & 2 & 0.80 & & \\
\hline BR-A COMP & 10 & 2 & 6 & 4 & 0.60 & & \\
\hline BR-A COMP & 10 & 3 & 6 & 4 & 0.60 & & \\
\hline BR-A COMP & 10 & 4 & 7 & 3 & 0.70 & & \\
\hline BR-A COMP & 10 & 5 & 7 & 3 & 0.70 & 0.68 & 0.08 \\
\hline
\end{tabular}

D.1 
Table D.1. (contd)

\begin{tabular}{|c|c|c|c|c|c|c|c|}
\hline $\begin{array}{l}\text { Sediment } \\
\text { Treatment } \\
\end{array}$ & $\begin{array}{c}\text { Concentration } \\
(\% \text { SPP })\end{array}$ & Replicate & Live $^{(2)}$ & $\begin{array}{l}\text { Dead or } \\
\text { Missing }\end{array}$ & $\begin{array}{c}\text { Proportion } \\
\text { Surviving } \\
\end{array}$ & $\begin{array}{c}\text { Mean } \\
\text { Proportion } \\
\text { Surviving } \\
\end{array}$ & $\begin{array}{l}\text { Standard } \\
\text { Deviation }\end{array}$ \\
\hline BR-A COMP & 50 & 1 & 0 & 10 & 0.00 & & \\
\hline BR-A COMP & 50 & 2 & 0 & 10 & 0.00 & & \\
\hline BR-A COMP & 50 & 3 & 0 & 10 & 0.00 & & \\
\hline BR-A COMP & 50 & 4 & 0 & 10 & 0.00 & & \\
\hline BR-A COMP & 50 & 5 & 0 & 10 & 0.00 & 0.00 & 0.00 \\
\hline BR-A COMP & 100 & 1 & 0 & 10 & 0.00 & & \\
\hline BR-A COMP & 100 & 2 & 0 & 10 & 0.00 & & \\
\hline BR-A COMP & 100 & 3 & 0 & 10 & 0.00 & & \\
\hline BR-A COMP & 100 & 4 & 0 & 10 & 0.00 & & \\
\hline BR-A COMP & 100 & 5 & 0 & 10 & 0.00 & 0.00 & 0.00 \\
\hline \multicolumn{2}{|c|}{ Bay Ridge Reach B } & & . & & & & \\
\hline BR-B COMP & 0 & 1 & $10 \ldots$ & 0 & 1.00 & & \\
\hline BR-B COMP & 0 & 2 & $9=$ & 1 & 0.90 & & \\
\hline BR-B COMP & 0 & 3 & $9^{-}$ & 1 & 0.90 & & \\
\hline BR-B COMP & 0 & 4 & 8 & 2 & 0.80 & & \\
\hline BR-B COMP & 0 & 5 & 8 & 2 & 0.80 & $\cdot 0.88$ & 0.08 \\
\hline BR-B COMP & 10 & 1 & 9 & 1 & 0.90 & & \\
\hline BR-B COMP & 10 & 2 & 7 & 3 & 0.70 & & \\
\hline BR-B COMP & 10 & 3 & 9 & 1 & 0.90 & & \\
\hline BR-B COMP & 10 & 4 & 7 & 3 & 0.70 & & \\
\hline BR-B COMP & 10 & 5 & 6 & 4 & 0.60 & 0.76 & 0.13 \\
\hline BR-B COMP & 50 & 1 & 3 & 7 & 0.30 & & \\
\hline BR-B COMP & 50 & .2 & 2 & 8 & 0.20 & & \\
\hline BR:B COMP & 50 & 3 & 4 & 6 & 0.40 & & \\
\hline BR-B COMP & 50 & 4 & 4 & 6 & 0.40 & & \\
\hline BR-B COMP & 50 & 5 & 2 & 8 & 0.20 & 0.30 & 0.10 \\
\hline BR-B COMP & 100 & 1 & 0 & 10 & 0.00 & & . \\
\hline BR-B COMP & 100 & 2 & 0 & 10 & 0.00 & & \\
\hline BR-B COMP & 100 & 3 & 0 & 10 & 0.00 & & \\
\hline BR-B COMP & 100 & 4 & 0 & 10 & 0.00 & & \\
\hline BR-B COMP & 100 & 5 & 0 & 10 & 0.00 & 0.00 & 0.00 \\
\hline
\end{tabular}

(a) Survival based on initial exposure of 10 organisms per replicate. 
Table D.2. Water Quality Data for 96-Hour, Water-Column Toxicity Test with M. beryllina, Red Hook and Bay Ridge Channels

\begin{tabular}{|c|c|c|c|c|c|c|c|c|c|c|}
\hline \multirow{2}{*}{$\begin{array}{l}\text { Sediment } \\
\text { Treatment }\end{array}$} & \multirow{2}{*}{$\begin{array}{c}\text { Concentration } \\
(\% \text { SPP })\end{array}$} & \multicolumn{2}{|c|}{$\begin{array}{c}\text { Temperature } \\
\left({ }^{\circ} \mathrm{C}\right) \\
\end{array}$} & \multicolumn{3}{|c|}{$\mathrm{pH}$} & \multicolumn{2}{|c|}{$\begin{array}{c}\text { Dissolved } \\
\text { Oxygen } \\
\text { (mg/L) }\end{array}$} & \multicolumn{2}{|c|}{$\begin{array}{l}\text { Salinity } \\
(\%)\end{array}$} \\
\hline & & Min & $\operatorname{Max}$ & Min & $\operatorname{Max}$ & & Min & Max & Min & Max \\
\hline \multicolumn{2}{|c|}{ Acceptable Range: } & 18.0 & 22.0 & 7.30 & 8.30 & & 3.0 & $N A^{(2)}$ & 28.0 & 32.0 \\
\hline \multicolumn{11}{|l|}{ Red Hook } \\
\hline RH COMP & 0 & 19.0 & 20.1 & 7.98 & 8.14 & & 6.8 & 9.4 & 32.0 & 32.0 \\
\hline RH.COMP & 10 & 18.8 & 20.1 & 7.95 & 8.16 & & 6.5 & 8.2 & 32.0 & 32.0 \\
\hline RH COMP & 50 & $18.9^{\circ}$ & 20.1 & 7.86 & 8.28 & & 6.8 & 7.2 & 31.0 & 32.0 \\
\hline RH COMP & 100 & 19.1 & 20.2 & 7.86 & 8.44 & (s) & 6.8 & 7.2 & 30.0 & 30.5 \\
\hline \multicolumn{11}{|c|}{ Bay Ridge Reach A } \\
\hline BR-A COMP & 0 & 19.3 & 20.2 & 7.99 & 8.15 & & 6.9 & 7.5 & 31.0 & 32.0 \\
\hline BR-A COMP & 10 & · 19.4 & 20.3 & 7.78 & 8.23 & & 3.6 & 7.3 & 31.0 & 32.0 \\
\hline BR-A COMP & 50 & 19.3 & 20.2 & 7.63 & 8.44 & (b) & 6.1 & 7.1 & 30.0 & 31.5 \\
\hline BR-A COMP & 100 & 19.6 & 19.6 & 7.70 & 7.88 & & 6.2 & 6.9 & 29.5 & 29.5 \\
\hline \multicolumn{4}{|c|}{ Bay Ridge Reach B } & 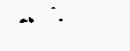 & & & & & & \\
\hline BR-B COMP & 0 & 19.3 & 20.2 & -7.99 & 8.26 & & 6.7 & 7.5 & 31.0 & 32.0 \\
\hline BR-B COMP & 10 & 19.3 & 20,2 & $\quad 7.95$ & 8.18 & & 6.7 & 7.4 & 31.0 & 32.0 \\
\hline BR-B COMP & 50 & 19.4 & 20.2 & $\because 7.82$ & 8.38 & (b) & 6.2 & 7.1 & 29.5 & 31.5 \\
\hline BR-B COMP & 100 & 19.4 & 19.6 & $=7.83$ & 8.42 & (b) & 6.0 & 7.4 & 29.0 & 30.5 \\
\hline
\end{tabular}

D.3 
Table D.3. Results of 96-Hour, Copper Reference Toxicant Test with M. beryllina

\begin{tabular}{ccccccc}
$\begin{array}{c}\text { Copper } \\
\text { Concentration }(\mu \mathrm{g} / \mathrm{L})\end{array}$ & Replicate & Live ${ }^{\text {(a) }}$ & $\begin{array}{c}\text { Mead or } \\
\text { Missing }\end{array}$ & $\begin{array}{c}\text { Mean } \\
\text { Proportion } \\
\text { Surviving }\end{array}$ & $\begin{array}{c}\text { Proportion } \\
\text { Surviving }\end{array}$ & $\begin{array}{c}\text { Standard } \\
\text { Deviation }\end{array}$ \\
\hline 0 & 1 & 9 & 1 & 0.90 & & \\
0 & 2 & 8 & 2 & 0.80 & & \\
0 & 3 & 10 & 0 & 1.00 & 0.90 & 0.10 \\
16 & 1 & 9 & 1 & 0.90 & & \\
16 & 2 & 8 & 2 & 0.80 & & \\
16 & 3 & 8 & 2 & 0.80 & 0.83 & 0.06 \\
64 & 1 & 7 & 3 & 0.70 & & \\
64 & 2 & 7 & 3 & 0.70 & & \\
64 & 3 & 5 & 5 & 0.50 & 0.63 & 0.12 \\
160 & 1 & 1 & 9 & 0.10 & & \\
160 & 2 & 1 & 9 & 0.10 & & \\
160 & 3 & 1 & 9 & 0.10 & 0.10 & 0.00 \\
400 & 1 & 0 & 10 & 0.00 & & \\
400 & 2 & 0 & 10 & 0.00 & & \\
400 & 3 & 0 & 10 & 0.00 & 0.00 & 0.00
\end{tabular}

(a) Survival based on initial exposure of 10 organisms per replicate. 
Table D.4. Water Quality Data for 96-Hour, Copper Reference Toxicant Test with $M$. beryllina

\begin{tabular}{|c|c|c|c|c|c|c|c|c|}
\hline \multirow{2}{*}{$\begin{array}{c}\text { Copper } \\
\text { Concentration } \\
(\mu \mathrm{g} / \mathrm{L}) \\
\end{array}$} & \multicolumn{2}{|c|}{$\begin{array}{c}\text { Temperature } \\
\left({ }^{\circ} \mathrm{C}\right)\end{array}$} & \multicolumn{4}{|c|}{$\begin{array}{c}\text { Dissolved } \\
\text { Oxygen } \\
\text { (mg/L) }\end{array}$} & \multicolumn{2}{|c|}{$\begin{array}{c}\text { Salinity } \\
(\% \circ)\end{array}$} \\
\hline & Min & $\operatorname{Max}$ & Min & Max & Min & Max & $\operatorname{Min}$ & $\operatorname{Max}$ \\
\hline Acceptable Range: & 18.0 & 22.0 & 7.30 & 8.30 & 3.0 & NA & 28.0 & 32.0 \\
\hline 0 & 18.4 & 18.9 & 7.92 & 8.16 & 7.0 & 8.0 & 30.5 & 31.5 \\
\hline 16 & 18.2 & 18.9 & 7.92 & 8.18 & 7.2 & 7.8 & 30.5 & 31.0 \\
\hline 64 & 18.3 & 18.9 & 7.82 & 8.19 & 7.2 & 7.9 & 30.0 & 31.0 \\
\hline 160 & 18.3 & 19.0 & 7.87 & 8.19 & 7.0 & 8.0 & 30.5 & 31.0 \\
\hline 400 & 18.2 & 18.7 & 7.81 & 8.10 & 7.2 & 8.1 & 30.5 & 30.5 \\
\hline
\end{tabular}

(a) NA Not applicable. 
Table D.5. Results of 96-Hour, Water-Column Toxicity Test, with M. bahia, Red Hook and Bay Ridge Channels

\begin{tabular}{|c|c|c|c|c|c|c|c|}
\hline $\begin{array}{l}\text { Sediment } \\
\text { Treatment } \\
\end{array}$ & $\begin{array}{c}\text { Concentration } \\
(\% \text { SPP }) \\
\end{array}$ & Replicate & Live $^{(\mathrm{a})}$ & $\begin{array}{l}\text { Dead or } \\
\text { Missing }\end{array}$ & $\begin{array}{c}\text { Proportion } \\
\text { Surviving } \\
\end{array}$ & $\begin{array}{c}\text { Mean } \\
\text { Proportion } \\
\text { Surviving } \\
\end{array}$ & $\begin{array}{l}\text { Standard } \\
\text { Deviation }\end{array}$ \\
\hline \multicolumn{8}{|l|}{ Red Hook } \\
\hline RH COMP & 0 & 1 & 10 & 0 & 1.00 & & \\
\hline RH COMP & 0 & 2 & 10 & 0 & 1.00 & & \\
\hline RH COMP & 0 & 3 & 9 & 1 & 0.90 & & \\
\hline RH COMP & 0 & 4 & 10 & 0 & 1.00 & & \\
\hline RH COMP & 0 & 5 & 10 & 0 & 1.00 & 0.98 & 0.04 \\
\hline RH COMP & 10 & 1 & 10 & 0 & 1.00 & & \\
\hline RH COMP & 10 & 2 & 9 & 1 & 0.90 & & \\
\hline RH COMP & 10 & 3 & 9 & 1 & 0.90 & & \\
\hline RH COMP & 10 & 4 & 10 & 0 & 1.00 & & \\
\hline RH COMP & 10 & 5 & 10 & 0 & 1.00 & 0.96 & 0.05 \\
\hline $\mathrm{RH}$ COMP & 50 & 1 & 9 & 1 & 0.90 & & \\
\hline RH COMP & 50 & 2 & 9 & 1 & 0.90 & & \\
\hline RH COMP & 50 & 3 & 10 & 0 & 1.00 & & \\
\hline RH COMP & 50 & 4 & 10 & 0 & 1.00 & & \\
\hline RH COMP & 50 & 5 & 9 & 1 & 0.90 & 0.94 & 0.05 \\
\hline RH COMP & 100 & 1 & 7 & 3 & 0.70 & & \\
\hline RH COMP & 100 & 2 & 8 & 2 & .0 .80 & & \\
\hline RH COMP & 100 & 3 & 8 & 2 & 0.80 & & \\
\hline RH COMP & 100 & 4 & 9 & 1 & 0.90 & & \\
\hline RH COMP & 100 & 5 & 6 & 4 & 0.60 & 0.76 & 0.11 \\
\hline \multicolumn{8}{|c|}{ Bay Ridge Reach A } \\
\hline BR-A COMP & 0 & 1 & 10 & 0 & 1.00 & & \\
\hline BR-A COMP & 0 & 2 & 10 & 0 & 1.00 & & \\
\hline BR-A COMP & 0 & 3 & 10 & 0 & 1.00 & & \\
\hline BR-A COMP & 0 & 4 & 10 & 0 & 1.00 & & \\
\hline BR-A COMP & 0 & 5 & 10 & 0 & 1.00 & 1.00 & 0.00 \\
\hline BR-A COMP & 10 & 1 & 9 & 1 & 0.90 & & \\
\hline BR-A COMP & 10 & 2 & 10 & 0 & 1.00 & & \\
\hline BR-A COMP & 10 & 3 & 10 & 0 & 1.00 & & \\
\hline BR-A COMP & 10 & 4 & 10 & 0 & 1.00 & & \\
\hline BR-A COMP & 10 & 5 & 9 & 1 & 0.90 & 0.96 & 0.05 \\
\hline
\end{tabular}


Table D.5. (contd)



(a) Survival based on initial exposure of 10 organism per replicate. 
Table D.6. Water Quality Data for 96-Hour, Water-Column Toxicity Test with M. bahia, Red Hook and Bay Ridge Channels

\begin{tabular}{|c|c|c|c|c|c|c|c|c|c|}
\hline \multirow{2}{*}{$\begin{array}{l}\text { Sediment } \\
\text { Treatment }\end{array}$} & \multirow{2}{*}{$\begin{array}{c}\text { Concentration } \\
(\% \text { SPP })\end{array}$} & \multicolumn{2}{|c|}{$\begin{array}{c}\text { Temperature } \\
\left({ }^{\circ} \mathrm{C}\right)\end{array}$} & \multicolumn{2}{|c|}{$\mathrm{pH}$} & \multicolumn{2}{|c|}{$\begin{array}{c}\text { Dissolved } \\
\text { Oxygen } \\
\text { (mg/L) }\end{array}$} & \multicolumn{2}{|c|}{$\begin{array}{l}\text { Salinity } \\
(\% \circ)\end{array}$} \\
\hline & & $\operatorname{Min}$ & Max & Min & $\operatorname{Max}$ & Min & $\operatorname{Max}$ & Min & $\operatorname{Max}$ \\
\hline \multicolumn{2}{|c|}{ Acceptable Range: } & 18.0 & 22.0 & 7.30 & 8.30 & 3.0 & $N A^{(a)}$ & 28.0 & 32.0 \\
\hline \multicolumn{10}{|l|}{ Red Hook } \\
\hline RH COMP & 0 & 18.0 & 19.1 & 7.98 & 8.15 & 6.7 & 8.4 & 32.0 & $32.5^{(0)}$ \\
\hline RH COMP & 10 & 18.0 & 19.0 & 7.95 & 8.19 & 6.9 & 8.4 & 32.0 & $32.5^{(b)} \cdot$ \\
\hline RH COMP & 50 & 18.1 & 19.0 & 7.86 & $8.33^{(0)}$ & 6.2 & 7.3 & 31.0 & 32.0 \\
\hline RH COMP &. .100 & 18.3 & 19.0 & 7.89 & $8.40^{(\mathrm{b})}$ & 6.5 & 7.6 & 30.0 & 31.5 \\
\hline \multicolumn{10}{|c|}{ Bay Ridge Reach A } \\
\hline BR-A COMP & 0 & 18.6 & 19.1 & 8.01 & 8.20 & 6.9 & 7.8 & 30.0 & $32.5^{(0)}$ \\
\hline BR-A COMP & 10 & 18.6 & 19.0 & 7.91 & 8.29 & 7.1 & 7.5 & 30.0 & 32.0 \\
\hline BR-A COMP & 50 & 18.6 & 19.0 & 7.68 & $8.50^{\text {(a) }}$ & 6.4 & 7.6 & 29.0 & 32.0 \\
\hline BR-A COMP & 100 & 18.7 & 19.0 & 7.84 & $8.65^{(0)}$ & 7.1 & 7.4 & 28.0 & 32.0 \\
\hline \multicolumn{10}{|c|}{ Bay Ridge Reach B } \\
\hline BR-B COMP & 0 & 18.6 & 19.0 & 7.92 & 8.14 & 6.5 & 7.7 & 30.0 & $32.5^{(b)}$ \\
\hline BR-B COMP & 10 & 18.6 & 19.0 & 7.97 & 8.22 & 7.0 & 7.6 & 30.0 & 32.0 \\
\hline BR-B COMP & 50 & 18.6 & 18.9 & 7.86 & $8.35^{(0)}$ & 6.8 & 7.4 & 29.0 & 32.0 \\
\hline BR-B COMP & 100 & 18.6 & 19.0 & 7.95 & $8.53^{(b)}$ & 7.0 & 7.4 & 28.0 & 30.5 \\
\hline
\end{tabular}

(a) NA Not applicable.

(b) Data point out of range. 
Table D.7. Results of 96-Hour, Copper Reference Toxicant Test with M. bahia,

\begin{tabular}{|c|c|c|c|c|c|c|}
\hline $\begin{array}{c}\text { Copper } \\
\text { Concentration }(\mu \mathrm{g} / \mathrm{L}) \\
\end{array}$ & Replicate & $\operatorname{Live}^{(a)}$ & $\begin{array}{l}\text { Dead or } \\
\text { Missing }\end{array}$ & $\begin{array}{l}\text { Proportion } \\
\text { Surviving }\end{array}$ & $\begin{array}{c}\text { Mean } \\
\text { Proportion } \\
\text { Surviving }\end{array}$ & $\begin{array}{l}\text { Standard } \\
\text { Deviation }\end{array}$ \\
\hline 0 & 1 & 10 & 0 & 1.00 & & \\
\hline 0 & 2 & 10 & 0 & 1.00 & & \\
\hline 0 & 3 & 10 & 0 & 1.00 & 1.00 & 0.00 \\
\hline 100 & 1 & 9 & 1 & 0.90 & & \\
\hline 100 & 2 & 10 & 0 & 1.00 & & \\
\hline 100 & 3 & 10 & 0 & 1.00 & 0.97 & 0.06 \\
\hline 150 & 1 & 8 & 2 & 0.80 & & \\
\hline 150 & 2 & 9 & 1 & 0.90 & . & \\
\hline 150 & 3 & 10 & 0 & 1.00 & 0.90 & 0.10 \\
\hline 200 & 1 & 8 & 2 & 0.80 & & \\
\hline 200 & 2 & 7 & 3 & 0.70 & & \\
\hline 200 & $\begin{array}{r}3 \\
-\end{array}$ & 7 & 3 & 0.70 & 0.73 & 0.06 \\
\hline 300 & 1 & 3 & 7 & 0.30 & & \\
\hline 300 & 2 & 2 & 8 & 0.20 & & \\
\hline 300 & 3 & 1 & 9 & 0.10 & 0.20 & 0.10 \\
\hline
\end{tabular}

D.9 
Table D.8. Water Quality Data for 96-Hour, Copper Reference Toxicant Test with M. bahia

\begin{tabular}{|c|c|c|c|c|c|c|c|c|}
\hline \multirow{2}{*}{$\begin{array}{c}\text { Copper } \\
\text { Concentration } \\
(\mu \mathrm{g} / \mathrm{L}) \\
\end{array}$} & \multicolumn{2}{|c|}{$\begin{array}{c}\text { Temperature } \\
\left({ }^{\circ} \mathrm{C}\right) \\
\end{array}$} & \multicolumn{2}{|c|}{$\mathrm{pH}$} & \multicolumn{2}{|c|}{$\begin{array}{c}\text { Dissolved } \\
\text { Oxygen } \\
(\mathrm{mg} / \mathrm{L}) \\
\end{array}$} & \multicolumn{2}{|c|}{$\begin{array}{c}\text { Salinity } \\
(\% \circ)\end{array}$} \\
\hline & Min & Max & Min & Max & Min & $\operatorname{Max}$ & Min & $\operatorname{Max}$ \\
\hline Acceptable Range: & 18.0 & 22.0 & 7.30 & 8.30 & 3.0 & $N A^{(a)}$ & 28.0 & 32.0 \\
\hline 0 & 18.3 & 19.0 & 7.96 & 8.19 & 6.7 & 8.2 & 30.5 & 32.0 \\
\hline 100 & 18.1 & 19.1 & 7.94 & 8.19 & 6.9 & 8.1 & 30.5 & 32.0 \\
\hline 150 & 18.1 & 19.1 & 7.92 & 8.18 & 6.9 & 8.2 & 30.0 & 32.0 \\
\hline 200 & 18.1 & 19.1 & 7.90 & 8.18 & 7.0 & 8.1 & 30.5 & 32.0 \\
\hline 300 & 18.0 & 19.1 & 7.85 & 8.21 & 7.0 & 8.3 & 30.0 & 32.0 \\
\hline
\end{tabular}

D.10 
Table D.9. Results of 48-Hour, Water-Column Toxicity Test with M. galloprovincialis, Red Hook and Bay Ridge Channels

\begin{tabular}{|c|c|c|c|c|c|c|c|c|c|c|c|c|}
\hline $\begin{array}{l}\text { Sediment } \\
\text { Treatment } \\
\end{array}$ & $\begin{array}{c}\text { Conc. } \\
(\% \text { SPP }) \\
\end{array}$ & Replicate & $\begin{array}{c}\text { Mean } \\
\text { Stocking } \\
\text { Density }\end{array}$ & $\begin{array}{l}\text { Number } \\
\text { Normal } \\
\end{array}$ & $\begin{array}{c}\text { Number } \\
\text { Abnormal }\end{array}$ & $\begin{array}{c}\text { Number } \\
\text { Other }\end{array}$ & $\begin{array}{l}\text { Number } \\
\text { Surviving }\end{array}$ & $\begin{array}{l}\text { Proportion } \\
\text { Normal }^{(\mathrm{a})}\end{array}$ & $\begin{array}{c}\text { Mean } \\
\text { Proportion } \\
\text { Normal } \\
\end{array}$ & $\begin{array}{l}\text { Proportion } \\
\text { Surviving }\end{array}$ & $\begin{array}{c}\text { Mean } \\
\text { Proportion } \\
\text { Surviving } \\
\end{array}$ & $\begin{array}{l}\text { Standard } \\
\text { Deviation }{ }^{(c)}\end{array}$ \\
\hline \multicolumn{13}{|l|}{ Red Hook } \\
\hline RH COMP & 0 & 1 & 280 & 211 & 0 & 9 & 220 & 0.75 & & 0.79 & & \\
\hline RH COMP & 0 & 2 & 280 & 221 & 0 & 18 & 239 & 0.79 & & 0.85 & & \\
\hline RH COMP & 0 & 3 & 280 & 206 & 0 & 19 & 225 & 0.74 & & 0.80 & & \\
\hline RH COMP & 0 & 4 & 280 & 259 & 0 & 5 & 264 & 0.93 & & 0.94 & & \\
\hline RH COMP & 0 & 5 & 280 & 223 & 0 & 15 & 238 & 0.80 & 0.80 & 0.85 & 0.85 & 0.06 \\
\hline RH COMP & 10 & 1 & 280 & 266 & 0 & 13 & 279 & 0.95 & & 1.00 & & \\
\hline RH COMP & 10 & 2 & 280 & 204 & 0 & 14 & 218 & 0.73 & & 0.78 & & \\
\hline RH COMP & 10 & 3 & 280 & 274 & 0 & 14 & 288 & 0.98 & & $1.00^{(d)}$ & & \\
\hline RH COMP & 10 & 4 & 280 & 220 & 0 & 10 & 230 & 0.79 & & 0.82 & & \\
\hline RH COMP & 10 & 5 & 280 & 210 & 0 & 10 & 220 & 0.75 & 0.84 & 0.79 & 0.88 & 0.11 \\
\hline RH COMP & 50 & 1 & 280 & 1 & 0 & 265 & 266 & 0.00 & & 0.95 & & \\
\hline RH COMP & 50 & 2 & 280 & 2 & 0 & 262 & 264 & 0.01 & & 0.94 & & \\
\hline RH COMP & 50 & 3 & 280 & 0 & 0 & 285 & 285 & 0.00 & & $1.00^{(d)}$ & & \\
\hline RH COMP & 50 & 4 & 280 & 1 & 0 & 224 & 225 & 0.00 & & 0.80 & & \\
\hline RH COMP & 50 & 5 & 280 & 0 & 0 & 248 & 248 & 0.00 & 0.00 & 0.89 & 0.92 & 0.08 \\
\hline RH COMP & 100 & 1 & 280 & 0 & 0 & 102 & 102 & 0.00 & & 0.36 & & \\
\hline RH COMP & 100 & 2 & 280 & 0 & 0 & 127 & 127 & 0.00 & & 0.45 & & \\
\hline RH COMP & 100 & 3 & 280 & 0 & 0 & 115 & 115 & 0.00 & & 0.41 & & \\
\hline RH COMP & 100 & 4 & 280. & 0 & 0 & 106 & 106 & 0.00 & & 0.38 & & \\
\hline RH COMP & 100 & 5 & 280 & 0 & 0 & 132 & 132 & 0.00 & 0.00 & 0.47 & 0.41 & 0.05 \\
\hline
\end{tabular}


Table D.9. (contd)




Table D.9. (contd)

\begin{tabular}{lccccc} 
& Mean & & Mean & Mean \\
Sediment & Conc. & Stocking Number Number Number Number & Proportion & Proportion Proportion Proportion Standard \\
Treatment & $(\%$ SPP) Replicate Density Normal Abnormal Other Surviving Normal & Normal Surviving & Surviving Deviation & (a) \\
\hline
\end{tabular}

Bay Ridge Reach B

$\begin{array}{cccccccc}\text { BR-B COMP } & 0 & 1 & 280 & 303 & 0 & 11 & 314 \\ \text { BR-B COMP } & 0 & 2 & 280 & 243 & 0 & 10 & 253 \\ \text { BR-B COMP } & 0 & 3 & 280 & 302 & 0 & 10 & 312 \\ \text { BR-B COMP } & 0 & 4 & 280 & 293 & 0 & 8 & 301 \\ \text { BR-B COMP } & 0 & 5 & 280 & 239 & 0 & 6 & 245 \\ \text { BR-B COMP } & 10 & 1 & 280 & 251 & 0 & 18 & 269 \\ \text { BR-B COMP } & 10 & 2 & 280 & 215 & 1 & 7 & 223 \\ \text { BR-B COMP } & 10 & 3 & 280 & 290 & 0 & 13 & 303 \\ \text { BR-B COMP } & 10 & 4 & 280 & 227 & 0 & 12 & 239 \\ \text { BR-B COMP } & 10 & 5 & 280 & 269 & 0 & 17 & 286 \\ \text { BR-B COMP } & 50 & 1 & 280 & 0 & 0 & 248 & 248 \\ \text { BR-B COMP } & 50 & 2 & 280 & 0 & 0 & 226 & 226 \\ \text { BR-B COMP } & 50 & 3 & 280 & 0 & 0 & 249 & 249 \\ \text { BR-B COMP } & 50 & 4 & 280 & 0 & 0 & 234 & 234 \\ \text { BR-B COMP } & 50 & 5 & 280 & 0 & 0 & 270 & 270 \\ \text { BR-B COMP } & 100 & 1 & 280 & 0 & 0 & 35 & 35 \\ \text { BR-B COMP } & 100 & 2 & 280 & 0 & 0 & 28 & 28 \\ \text { BR-B COMP } & 100 & 3 & 280 & 0 & 0 & 45 & 45 \\ \text { BR-B COMP } & 100 & 4 & 280 & 1 & 4 & 66 & 71 \\ \text { BR-B COMP } & 100 & 5 & 280 & 0 & 0 & 13 & 13\end{array}$

(a) Proportion normal = number normal / mean stocking density.

(b) Proportion surviving $=$ number surviving / mean stocking density.

(c) Standard deviation is based on proportion surviving.

(d) When number normal or number surviving exceeded the mean stocking density, a proportion normal and/or proportion surviving of 1.00 was used for mean calculations and statistical analysis. 
Table D.10. Water Quality Data for 48-Hour, Water-Column Toxicity Test with M. galloprovincialis, Red Hook and Bay Ridge Channels

\begin{tabular}{|c|c|c|c|c|c|c|c|c|c|c|}
\hline \multirow{2}{*}{$\begin{array}{l}\text { Sediment } \\
\text { Treatment }\end{array}$} & \multirow{2}{*}{$\begin{array}{c}\text { Concentration } \\
\text { (\% SPP) }\end{array}$} & \multicolumn{2}{|c|}{$\begin{array}{l}\text { Temperature } \\
\left({ }^{\circ} \mathrm{C}\right)\end{array}$} & \multicolumn{2}{|c|}{$\mathrm{pH}$} & \multicolumn{2}{|c|}{$\begin{array}{c}\text { Dissolved } \\
\text { Oxygen } \\
\text { (mg/L) }\end{array}$} & & \multicolumn{2}{|c|}{$\begin{array}{c}\text { Salinity } \\
(\% \circ)\end{array}$} \\
\hline & & Min & $\operatorname{Max}$ & Min & $\operatorname{Max}$ & Min & $\operatorname{Max}$ & & Min & Max \\
\hline \multicolumn{2}{|c|}{ Acceptable Range: } & 14.0 & 18.0 & 7.30 & 8.30 & 4.9 & $N A^{(a)}$ & & 28.0 & 32.0 \\
\hline \multicolumn{11}{|l|}{ Red Hook } \\
\hline RH COMP & 0 & 15.8 & 16.5 & 7.96 & 8.13 & 7.5 & 8.5 & & 31.5 & 33.0 \\
\hline RH COMP & 10 & 15.8 & 16.5 & 7.82 & 8.18 & 7.5 & 9.5 & & 31.5 & 32.5 \\
\hline RH COMP & 50 & 15.8 & 16.6 & 7.82 & $8.33^{(b)}$ & 7.4 & 8.0 & & 30.5 & 32.0 \\
\hline RH COMP & 100 & 15.8 & 16.6 & 7.60 & $8.43^{(b)}$ & 4.9 & 7.9 & & 30.0 & 32.0 \\
\hline \multicolumn{11}{|c|}{ Bay Ridge Reach A } \\
\hline BR-A COMP & 0 & 15.8 & 16.6 & 7.95 & 8.14 & 7.3 & 9.4 & & 32.0 & 32.5 \\
\hline BR-A COMP & 10 & 15.8 & 16.6 & 7.85 & 8.24 & 7.2 & 9.0 & & 30.0 & 32.5 \\
\hline BR-A COMP & 50 & 15.8 & 16.6 & 7.55 & $8.45^{(B)}$ & 7.5 & 7.9 & 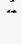 & 31.0 & 32.5 \\
\hline BR-A COMP & 100 & 15.8 & 16.7 & 7.35 & $8.61^{(0)}$ & 5.6 & 7.8 & & 30.0 & 32.0 \\
\hline \multicolumn{6}{|c|}{ Bay Ridge Reach B } & & & & & \\
\hline BR-B COMP & 0 & 15.8 & 16.6 & 7.98 & 8.14 & 7.4 & 9.2 & & 30.5 & 32.0 \\
\hline BR-B COMP & .10 & 15.8 & 16.7. & 7.93 & 8.20 & 7.6 & 9.0 & & 31.0 & 32.0 \\
\hline BR-B COMP & 50 & 15.9 & 16.7 & 7.79 & $8.39^{(b)}$ & 7.5 & 7.8 & & 30.5 & 32.0 \\
\hline BR-B COMP & 100 & 15.8 & 16.8 & 7.68 & $8.49^{(b)}$ & 5.3 & 7.8 & & $30.0^{-}$ & 30.5 \\
\hline
\end{tabular}

(a) NA- Not applicable.

(b) Data point out of range. 
Table D.11. Results of 48-Hour, Copper Reference Toxicant Test with M. galloprovincialis

\begin{tabular}{|c|c|c|c|c|c|c|c|c|c|c|c|c|}
\hline & $\begin{array}{c}\text { Copper } \\
\text { Concentratio } \\
(\mu \mathrm{g} / \mathrm{L})\end{array}$ & Replicate & $\begin{array}{c}\text { Mean } \\
\text { Stocking } \\
\text { Density }\end{array}$ & $\begin{array}{l}\text { Number } \\
\text { Normal }\end{array}$ & $\begin{array}{l}\text { Number } \\
\text { Abnormal }\end{array}$ & $\begin{array}{c}\text { Number } \\
\text { Other }\end{array}$ & $\begin{array}{l}\text { Number } \\
\text { Surviving }\end{array}$ & $\begin{array}{c}\text { Proportion } \\
\text { Normal }^{(n)} \\
\end{array}$ & $\begin{array}{c}\text { Mean } \\
\text { Proportion } \\
\text { Normal } \\
\end{array}$ & $\begin{array}{l}\text { Proportion } \\
\text { Surviving }^{(0)}\end{array}$ & $\begin{array}{c}\text { Mean } \\
\text { Proportion } \\
\text { Surviving }\end{array}$ & $\begin{array}{l}\text { Standard } \\
\text { Deviation }^{(c)}\end{array}$ \\
\hline & 0 & 1 & 280 & 250 & 0 & 11 & 261 & 0.89 & & 0.93 & & \\
\hline & 0 & 2 & 280 & 293 & 0 & 7 & 300 & $1.00^{(n)}$ & & $1.00^{(0)}$ & & \\
\hline & 0 & 3 & 280 & 286 & 0 & 9 & 295 & 1.00 (d) & 0.96 & $1.00^{(0)}$ & 0.98 & 0.04 \\
\hline & 1 & 1 & 280 & 203 & 0 & 10 & 213 & 0.73 & & 0.76 & & \\
\hline & 1 & 2 & 280 & 280 & 0 & 0 & 280 & 1.00 & & 1.00 & & \\
\hline & 1 & 3 & 280 & 214 & 0 & 9 & 223 & 0.76 & 0.83 & 0.80 & 0.85 & 0.13 \\
\hline & 4 & 1 & 280 & 243 & 0 & 10 & 253 & 0.87 & & 0.90 & & \\
\hline & 4 & 2 & 280 & 274 & 0 & 8 & 282 & 0.98 & & $1.00^{(0)}$ & & \\
\hline \multirow{7}{*}{$\frac{0}{\sigma}$} & 4 & 3 & 280 & 264 & 0 & 8 & 272 & 0.94 & 0.93 & 0.97 & 0.96 & 0.05 \\
\hline & 16 & 1 & 280 & 9 & 93. & 123 & 225 & 0.03 & & 0.80 & & \\
\hline & 16 & 2 & 280 & 3 & 0 & 202 & 205 & 0.01 & & 0.73 & & \\
\hline & 16 & 3 & 280 & 5 & 105 & 110 & 220 & 0.02 & 0.02 & 0.79 & 0.77 & 0.04 \\
\hline & 64 & 1 & 280 & 0 & 0 & 22 & .22 & 0.00 & & 0.08 & & . \\
\hline & 64 & 2 & 280 & 0 & 0 & 70 & 70 & 0.00 & & 0.25 & & \\
\hline & 64 & 3 & 280 & 0 & 0 & 46 & 46 & 0.00 & 0.00 & 0.16 & 0.16 & 0.09 \\
\hline
\end{tabular}

(a) Proportion normal = number normal / mean stocking density.

(b) Proportion surviving = number surviving / mean stocking density.

(c) Standard deviation is based on proportion surviving.

(d) When number normal or number surviving exceeded the mean stocking density, a proportion normal and/or proportion surviving of 1.00 was used for mean calculations and statistical analysis. 
Table D.12. Water Quality Data for 48-Hour, Copper Reference Toxicant Test with M. galloprovincialis

\begin{tabular}{|c|c|c|c|c|c|c|c|c|}
\hline \multirow{2}{*}{$\begin{array}{c}\text { Copper } \\
\text { Concentration } \\
(\mu \mathrm{g} / \mathrm{L})\end{array}$} & \multicolumn{2}{|c|}{$\begin{array}{c}\text { Temperature } \\
\left({ }^{\circ} \mathrm{C}\right) \\
\end{array}$} & \multicolumn{4}{|c|}{$\begin{array}{c}\text { Dissolved } \\
\text { Oxygen } \\
(\mathrm{mg} / \mathrm{L})\end{array}$} & \multicolumn{2}{|c|}{$\begin{array}{c}\text { Salinity } \\
(\% \circ)\end{array}$} \\
\hline & Min & $\operatorname{Max}$ & Min & $\operatorname{Max}$ & Min & Max & Min & $\operatorname{Max}$ \\
\hline Acceptable Range: & 14.0 & 18.0 & 7.30 & 8.30 & 4.9 & $N A^{(a)}$ & 28.0 & 32.0 \\
\hline 0 & 15.8 & 16.8 & 7.99 & 8.13 & 7.5 & 8.7 & 30.0 & 31.5 \\
\hline 1 & 15.8 & 16.8 & 8.01 & 8.12 & 7.5 & 8.6 & 30.0 & 30.5 \\
\hline 4 & 15.9 & 16.8 & 8.02 & 8.14 & 7.5 & 8.6 & 30.0 & 30.5 \\
\hline 16 & 15.8 & 16.8 & 8.00 & 8.14 & 7.6 & 8.6 & 30.0 & 30.5 \\
\hline 64 & 15.9 & 16.8 & 8.00 & 8.14 & 7.5 & 8.9 & 30.0 & 31.0 \\
\hline
\end{tabular}

(a) NA Not applicable. 


\section{Appendix E.}

Bioaccumulation Test Data, Red Hook and Bay Ridge Channels 
Table E.1. Results of 28-Day Bioaccumulation Test with M. nasuta, Red Hook and Bay Ridge Channels

\begin{tabular}{|c|c|c|c|c|c|c|}
\hline $\begin{array}{l}\text { Sediment } \\
\text { Treatment }\end{array}$ & Replicate & $\operatorname{Live}^{(\mathrm{a})}$ & $\begin{array}{l}\text { Dead or } \\
\text { Missing }\end{array}$ & $\begin{array}{l}\text { Proportion } \\
\text { Surviving }\end{array}$ & $\begin{array}{c}\text { Mean } \\
\text { Proportion } \\
\text { Surviving } \\
\end{array}$ & $\begin{array}{l}\text { Standard } \\
\text { Deviation }\end{array}$ \\
\hline Red Hook & & & & . & & \\
\hline RH COMP & 1 & 19 & 6 & 0.76 & & \\
\hline RH COMP & 2 & 21 & 4 & 0.84 & & \\
\hline RH COMP & 3 & 21 & 4 & 0.84 & & \\
\hline RH COMP & 4 & 23 & 2 & 0.92 & & \\
\hline RH COMP & 5 & 22 & 3 & 0.88 & 0.85 & 0.06 \\
\hline \multicolumn{7}{|c|}{ Bay Ridge Reach A } \\
\hline BR-A COMP & 1 & 25 & 0 & 1.00 & & \\
\hline BR-A COMP & 2 & 24 & 1 & 0.96 & & \\
\hline BR-A COMP & 3 & 24 & 1 & 0.96 & & \\
\hline BR-A COMP & 4 & 24 & 1 & 0.96 & & \\
\hline BR-A COMP & 5 & 22 & 3 & 0.88 & 0.95 & 0.04 \\
\hline \multicolumn{7}{|c|}{ Bay Ridge Reach B } \\
\hline BR-B COMP & 1 & 20 & 5 & 0.80 & & \\
\hline BR-B COMP & 2 & 21 & 4 & 0.84 & & \\
\hline BR-B COMP & 3 & 20 & 5 & 0.80 & & \\
\hline BR-B COMP & 4 & 20 & 5 & 0.80 & & \\
\hline BR-B COMP & 5 & 24 & 1 & 0.96 & 0.84 & 0.07 \\
\hline MDRS $^{(b)}$ & 1 & 22 & 3 & 0.88 & & \\
\hline MDRS & 2 & 22 & 3 & 0.88 & & \\
\hline MDRS & 3 & 18 & 7 & 0.72 & & \\
\hline MDRS & 4 & 21 & 4 & 0.84 & & \\
\hline MDRS & 5 & 19 & 6 . & 0.76 & 0.82 & 0.07 \\
\hline Macoma Control & 1 & 23 & 2 & 0.92 & & \\
\hline Macoma Control & 2 & 22 & 3 & 0.88 & & \\
\hline Macoma Control & 3 & 22 & 3 & 0.88 & & \\
\hline Macoma Control & 4 & 22 & 3 & 0.88 & & \\
\hline Macoma Control & 5 & 24 & 1 & 0.96 & 0.90 & 0.04 \\
\hline
\end{tabular}

(a) Survival based on initial exposure of 25 organisms per replicate.

(b) MDRS Mud Dump Reference Site.

E.1 
Table E.2. Water Quality Data for 28-Day Bioaccumulation Test with M. nasuta, Red Hook and Bay Ridge Channels

\begin{tabular}{|c|c|c|c|c|c|c|c|c|}
\hline \multirow{2}{*}{$\begin{array}{l}\text { Sediment } \\
\text { Treatment }\end{array}$} & \multicolumn{2}{|c|}{$\begin{array}{c}\text { Temperature } \\
\left({ }^{\circ} \mathrm{C}\right)\end{array}$} & \multicolumn{2}{|c|}{$\mathrm{pH}$} & \multicolumn{2}{|c|}{$\begin{array}{c}\text { Dissolved } \\
\text { Oxygen } \\
\text { (mg/L) }\end{array}$} & \multicolumn{2}{|c|}{$\begin{array}{l}\text { Salinity } \\
(\% \circ)\end{array}$} \\
\hline & Min & Max & Min & Max & Min & $\operatorname{Max}$ & Min & Max \\
\hline Acceptable Range: & 13.0 & 17.0 & 7.30 & 8.30 & 5.0 & $N A^{(a)}$ & 28.0 & 32.0 \\
\hline \multicolumn{9}{|l|}{ Red Hook } \\
\hline RH COMP & 15.6 & 17.0 & 7.57 & 8.11 & 6.6 & 7.8 & 30.0 & 31.0 \\
\hline \multicolumn{9}{|l|}{ Bay Ridge Reach A } \\
\hline BR-A COMP & 15.7 & 16.9 & 7.60 & 8.12 & 6.5 & 7.8 & 30.0 & 31.0 \\
\hline \multicolumn{9}{|l|}{ Bay Ridge Reach B } \\
\hline BR-B COMP & 15.7 & $17.1^{(8)}$ & 7.64 & 8.14 & 6.5 & 7.8 & 30.0 & 31.0 \\
\hline MDRS $^{(c)}$ & 15.7 & $17.1^{(0)}$ & 7.66 & 8.14 & 7.3 & 7.9 & 30.0 & 31.0 \\
\hline Macoma Control & 15.7 & 17.0 & 7.61 & 8.12 & 6.5 & 7.7 & 30.0 & 31.0 \\
\hline
\end{tabular}


Table E.3. Results of 96-Hour, Copper Reference Toxicant Test with $M$. nasuta

\begin{tabular}{cccc}
$\begin{array}{c}\text { Copper } \\
\text { Concentration }(\mu / L)\end{array}$ & Live $^{(a)}$ & $\begin{array}{c}\text { Dead or } \\
\text { Missing }\end{array}$ & $\begin{array}{c}\text { Proportion } \\
\text { Surviving }\end{array}$ \\
\hline 0 & 10 & 0 & 1.00 \\
250 & 10 & 0 & 1.00 \\
500 & 9 & 1 & 0.90 \\
750 & 9 & 1 & 0.90 \\
1000 & 8 & 2 & 0.80 \\
1500 & 10 & 0 & 1.00 \\
2500 & 7 & 3 & 0.70
\end{tabular}

(a) Survival based on initial exposure of 10 organisms per replicate. 
Table E.4. Water Quality Data for 96-Hour, Copper Reference Toxicant Test with $M$. nasuta

\begin{tabular}{|c|c|c|c|c|c|c|c|c|}
\hline \multirow{2}{*}{$\begin{array}{c}\text { Copper } \\
\text { Concentration } \\
(\mu g / L)\end{array}$} & \multicolumn{2}{|c|}{$\begin{array}{c}\text { Temperature } \\
\left({ }^{\circ} \mathrm{C}\right)\end{array}$} & \multicolumn{2}{|c|}{$\mathrm{pH}$} & \multicolumn{2}{|c|}{$\begin{array}{c}\text { Dissolved } \\
\text { Oxygen } \\
\text { (mg/L) }\end{array}$} & \multicolumn{2}{|c|}{$\begin{array}{c}\text { Salinity } \\
(\% \circ)\end{array}$} \\
\hline & Min & $\operatorname{Max}$ & Min & Max & Min & Max & Min & $\operatorname{Max}$ \\
\hline Acceptable Range: & 13.0 & 17.0 & 7.30 & 8.30 & 5.0 & $N A^{(a)}$ & 28.0 & $32.0^{\circ}$ \\
\hline 0 & 15.6 & 16.7 & 7.71 & 8.04 & 7.3 & 7.8 & 30.0 & 31.5 \\
\hline 250 & 15.6 & 16.7 & 7.69 & 8.05 & 7.3 & 8.0 & 30.0 & 31.0 \\
\hline 500 & 15.6 & 16.7 & 7.66 & 8.07 & 7.0 & 8.5 & 30.0 & 31.0 \\
\hline 750 & 15.6 & 16.6 & 7.67 & 8.07 & 6.0 & 8.2 & 30.0 & 31.5 \\
\hline 1000 & 15.6 & 16.6 & 7.56 & 8.05 & 5.2 & 8.3 & 30.0 & 31.5 \\
\hline 1500 & 15.7 & 16.6 & 7.67 & 8.05 & 5.7 & 8.2 & 30.5 & 31.5 \\
\hline 2500 & 15.6 & 16.6 & $7.21^{(0)}$ & 7.94 & $4.3^{(0)}$ & 8.0 & 30.5 & 31.0 \\
\hline
\end{tabular}

(a) NA Not applicable.

(b) Data point out of range. 
Table E.5. Results of 28-Day Bioaccumulation Test with N. virens, Red Hook and Bay Ridge Channels

\begin{tabular}{lllll} 
& Mean & & Mean \\
Sediment & Replicate Live ${ }^{(a)}$ & Missing & Proportion & Proportion Standard \\
Treatment & Surving Surviving Deviation \\
\hline
\end{tabular}

Red Hook

RH COMP

RH COMP

$\mathrm{RH}$ COMP

RH COMP

RH COMP

$\begin{array}{cccc}6 & 16 & 4 & 0.80 \\ 7 & 14 & 6 & 0.70 \\ 8 & 19 & 1 & 0.95 \\ 9 & 19 & 1 & 0.95 \\ 10 & 16 & 4 & 0.80\end{array}$

0.84

0.11

Bay Ridge Reach A

BR-A COMP
BR-A COMP
BR-A COMP
BR-A COMP
BR-A COMP

$\begin{array}{ccccc}6 & 13 & 7 & & 0.65 \\ 7 & 13 & 7 & & 0.65 \\ 8 & 12 & 8 & & 0.60 \\ 9 & 19 & 1 & & 0.95 \\ 10 & 16 & 4 & \cdots & 0.80\end{array}$

$0.73 \quad 0.14$

Bay Ridge Reach B

BR-B COMP
BR-B COM
BR-B COM
BR-B COMP
BR-B COMP
MDRS $^{(0)}$
MDRS
MDRS
MDRS
MDRS

Nereis Control

Nereis Control

Nereis Control

Nereis Control

Nereis Control

$\begin{array}{cc}6 & 13 \\ 7 & 20 \\ 8 & 18 \\ 9 & 17 \\ 10 & 16\end{array}$

$\begin{array}{rr}7 & 0.65 \\ 0 & 1.00 \\ 2 & - \\ 3 & 0.90 \\ 4 & 0.85 \\ & 0.80\end{array}$

0.84

0.13

$6 \quad 12$

$7 \quad 16$

$8 \quad 0.60$

$4 \cdot 0.80$

819

$9 \quad 17$

$10 \quad 18$

0.95

0.85

0.90

0.82

0.14

$\begin{array}{cccc}6 & 14 & 6 & 0.70 \\ 7 & 15 & 5 & 0.75 \\ 8 & 10 & 10 & 0.50 \\ 9 & 9 & 11 & 0.45 \\ 10 & 14 & 6 & 0.70\end{array}$

0.70

0.75

0.50

0.70

0.62

0.14 .

(a) Survival based on initial exposure of 20 organisms per replicate.

(b) MDRS Mud Dump Reference Site. 
Table E.6. Water Quality Data for 28-Day Bioaccumulation Test with N. virens, Red Hook and Bay Ridge Channels

\begin{tabular}{|c|c|c|c|c|c|c|c|c|}
\hline \multirow{2}{*}{$\begin{array}{l}\text { Sediment } \\
\text { Treatment }\end{array}$} & \multicolumn{2}{|c|}{$\begin{array}{c}\text { Temperature } \\
\left({ }^{\circ} \mathrm{C}\right)\end{array}$} & \multicolumn{2}{|c|}{$\mathrm{pH}$} & \multicolumn{2}{|c|}{$\begin{array}{c}\text { Dissolved } \\
\text { Oxygen } \\
\text { (mg/L) }\end{array}$} & \multicolumn{2}{|c|}{$\begin{array}{l}\text { Salinity } \\
(\%)\end{array}$} \\
\hline & Min & Max & Min & Max & Min & Max & $\operatorname{Min}$ & Max \\
\hline Acceptable Range: & 18.0 & 22.0 & 7.30 & 8.30 & 4.6 & $N^{(a)}$ & 28.0 & 32.0 \\
\hline \multicolumn{9}{|l|}{ Red Hook } \\
\hline RH COMP & 18.8 & 20.1 & $5.60^{(b)}$ & 8.13 & 5.8 & 7.1 & 30.0 & 31.0 \\
\hline \multicolumn{9}{|l|}{ Bay Ridge Reach A } \\
\hline BR-A COMP & 19.3 & 20.2 & 7.51 & 8.13 & 6.0 & 7.1 & 30.0 & 30.5 \\
\hline \multicolumn{9}{|l|}{ Bay Ridge Reach B } \\
\hline BR-B COMP & 19.2 & 20.1 & 7.55 & 8.14 & 5.6 & 7.1 & 30.0 & 30.5 \\
\hline MDRS $^{(c)}$ & 19.3 & 20.2 & 7.57 & 8.13 & 5.6 & 7.6 & 30.0 & 30.5 \\
\hline Nereis Control & 19.3 & 20.3 & 7.54 & 8.11 & 5.8 & 7.1 & 30.0 & 31.0 \\
\hline $\begin{array}{l}\text { (a) NA Not applical } \\
\text { (b) Data point out o } \\
\text { (c) MDRS Mud Du }\end{array}$ & eren & e. & & & & & & \\
\hline
\end{tabular}


Table E.7. Results of 96-Hour, Copper Reference Toxicant Test with $N$. virens

\begin{tabular}{cccc}
$\begin{array}{c}\text { Copper } \\
\text { Concentration }(\mu \mathrm{g} / \mathrm{L})\end{array}$ & Live $^{(\mathrm{a})}$ & $\begin{array}{c}\text { Dead or } \\
\text { Missing }\end{array}$ & $\begin{array}{c}\text { Proportion } \\
\text { Surviving }\end{array}$ \\
\hline 0 & 10 & 0 & 1.00 \\
50 & 10 & 0 & 1.00 \\
75 & 10 & 0 & 1.00 \\
150 & 0 & 10 & 0.00 \\
200 & 0 & 10 & 0.00 \\
250 & 0 & 10 & 0.00 \\
300 & 0 & 10 & 0.00
\end{tabular}

(a) Survival based on initial exposure of 10 organisms per replicate. 
Table E.8. Water Quality Data for 96-Hour, Copper Reference Toxicant Test with $N$. virens

\begin{tabular}{|c|c|c|c|c|c|c|c|c|}
\hline \multirow{2}{*}{$\begin{array}{c}\text { Copper } \\
\text { Concentration } \\
(\mu g / L) \\
\end{array}$} & \multicolumn{2}{|c|}{$\begin{array}{c}\text { Temperature } \\
\left({ }^{\circ} \mathrm{C}\right) \\
\end{array}$} & \multicolumn{2}{|c|}{$\mathrm{pH}$} & \multicolumn{2}{|c|}{$\begin{array}{c}\text { Dissolved } \\
\text { Oxygen } \\
(\mathrm{mg} / \mathrm{L})\end{array}$} & \multicolumn{2}{|c|}{$\begin{array}{c}\text { Salinity } \\
(\%)\end{array}$} \\
\hline & Min & Max & Min & Max & Min & Max & Min & Max \\
\hline Acceptable Range: & 18.0 & 22.0 & 7.30 & 8.30 & 4.6 & $N A^{(a)}$ & 28.0 & 32.0 \\
\hline 0 & 18.7 & 20.0 & 7.81 & 8.08 & 5.6 & 8.0 & 30.0 & 31.0 \\
\hline 50 & 18.6 & 20.0 & 7.81 & 8.11 & 5.9 & 8.5 & 30.0 & 31.0 \\
\hline 75 & 18.7 & 20.1 & 7.80 & 8.12 & 5.8 & 8.2 & 30.0 & 31.0 \\
\hline 150 & 18.5 & 20.1 & 7.31 & 8.10 & $0.7^{(6)}$ & 8.6 & 30.0 & 31.0 \\
\hline 200 & 18.9 & 20.0 & $7.28^{(0)}$ & 7.96 & $0.9^{(\mathfrak{b})}$ & 7.6 & 30.0 & 31.0 \\
\hline 250 & 18.5 & 20.1 & $7.25^{(0)}$ & 8.04 & $0.6^{(b)}$ & 8.5 & 30.0 & 31.0 \\
\hline 300 & 18.3 & 20.1 & 7.68 & 8.05 & 5.7 & 8.6 & 30.0 & 31.0 \\
\hline
\end{tabular}




\section{Appendix F.}

Quality Assurance/Quality Control Data for Chemical Analyses of Macoma nasuta Tissues, Red Hook and Bay Ridge Channels 

PROGRAM: New York/New Jersey Red Hook/Bay Ridge Projects

PARAMETER: Metals

LABORATORY: Battelle/Marine Sciences Laboratory, Sequim, Washington

MATRIX: Macoma nasuta Tissue

QA/QC DATA QUALITY OBJECTIVES

\begin{tabular}{|c|c|c|c|c|c|}
\hline & $\begin{array}{l}\text { Reference } \\
\text { Method }\end{array}$ & $\begin{array}{l}\text { Range of } \\
\text { Recovery }\end{array}$ & $\begin{array}{c}\text { SRM } \\
\text { Accuracy }\end{array}$ & $\begin{array}{r}\text { Relative } \\
\text { Precision } \\
\end{array}$ & $\begin{array}{c}\text { Target } \\
\text { Detection Limit } \\
\text { (mg/kg dry wt) }\end{array}$ \\
\hline Arsenic & ICP/MS & $75-125 \%$ & $\leq 20 \%$ & $\leq 20 \%$ & 1.0 \\
\hline Cadmium & ICP/MS & $75-125 \%$ & $\leq 20 \%$ & $\leq 20 \%$ & 0.1 \\
\hline Chromium & ICP/MS & $75-125 \%$ & $\leq 20 \%$ & $\leq 20 \%$ & 0.2 \\
\hline Copper & ICP/MS & $75-125 \%$ & $\leq 20 \%$ & $\leq 20 \%$ & 1.0 \\
\hline Lead & ICP/MS & $75-125 \%$ & $\leq 20 \%$ & $\leq 20 \%$ & 0.1 \\
\hline Mercury & CVAA. & $-75-125 \%$ & $\leq 20 \%$ & $-\leq 20 \%=$ & 0.02 \\
\hline Nickel & ICP/MS & $75-125 \%$ & $\leq 20 \%$ & $\leq 20 \%$. & 0.1 \\
\hline Silver & ICP/MS & $75-125 \%$ & $\leq 20 \%$ & $\leq 20 \%$ & 0.1 \\
\hline Zinc & ICP/MS & $75-125 \%$ & $\leq 20 \%$ & $\leq 20 \%$ & 1.0 \\
\hline
\end{tabular}

SAMPLE CUSTODY

METHOD
Twenty-one Macoma nasuta tissue samples were received on 5/30/95 in good condition, logged.into the Battelle system; frozen to $-20^{\circ} \mathrm{C} \pm 10^{\circ} \mathrm{C}$ and subsequently freeze dried within approximately seven days of sample receipt.

Nine (9) metals were analyzed for the New York 4 Program: silver (Ag), arsenic (As), cadmium (Cd), chromium (Cr), copper (Cu), mercury ( $\mathrm{Hg})$, nickel (Ni), lead $(\mathrm{Pb})$ and zinc $(\mathrm{Zn})$. $\mathrm{Hg}$ was analyzed using cold-vapor atomic absorption spectroscopy (CVAA) according to the method of Bloom and Crecelius (1983). The remaining metals were analyzed by inductively coupled plasma mass spectrometry (ICP/MS) following a procedure based on EPA method 200.8 (EPA 1991)

To prepare tissue for analysis, samples were freeze-dried and blended in a Spex mixer-mill. Approximately $5 \mathrm{~g}$ of mixed sample was ground in a ceramic ball mill. For ICP/MS and CVAA analyses, $0.2-$ to $0.5-\mathrm{g}$ aliquots of dried homogenous sample were digested using a mixture of nitric acid and hydrogen peroxide following a modified version of EPA Method 200.3 (EPA 1991). 
QA/QC SUMMARY METALS (contd)

HOLDING TIMES

Samples were analyzed within 180 days of collection. Tissue samples were digested in a single batch. The following table summarizes the analysis dates:

Task

$$
\begin{aligned}
& \text { Sample Digestion } \\
& \text { ICP-MS } \\
& \text { CVAA-Hg }
\end{aligned}
$$

Macoma nasutas

$6 / 14 / 95$

$7 / 26 / 95$

$6 / 22 / 95$

DETECTION LIMITS Target Detection limits were met for all metals except $\mathrm{As}, \mathrm{Cu}, \mathrm{Ni}$ and $\mathrm{Zn}$; however, all sample values for $\mathrm{Cu}, \mathrm{Ni}$ and $\mathrm{Zn}$ were above the achieved method detection limit (MDL). MDLs were determined by spiking seven replicates of the reagent blank and multiplying standard deviation of the resulting analyses by the student $t$ value at the 99th percentile( 3.142).

An MDL verification study.was performed by spiking four aliqouts of a background Macoma nasuta sample with all metals and analyzing them as four separate replicates. The standard deviation of these results were multiplied-by 4.54-to determine the method verification detection limit- Target detection limits were exceeded for all metals.

METHOD BLANKS . - :- One procedural blank was analyzed per 20 samples: No metals were detected in the blanks above the MDLs.

MATRIX SPIKES

One sample was:spiked withall metals at a frequency of 1 per 20 samples. All recoveries were within the QC limits of $75 \%$ to $125 \%$.

REPLICATES

One sample was analyzed in triplicate. In addition, the background sample - was analyzed in triplicate. Precision for triplicate analyses is reported by calculating the relative standard deviation (RSD) between the replicate results. RSDs were within the QC limits of $\pm 20 \%$ for all metals.

SRMs

SRM, 1566a (Oyster tissue from the National Institute of Standards and Technology, NIST), was analyzed twice for all metals. Results for all metals were within $\pm 20 \%$ of mean certified value with the exception of $\mathrm{Hg}$ in one replicate and $\mathrm{Ni}$ in two replicates. This may have happened because a total digestion method was not used.

\section{REFERENCES}

Bloom, N.S., and E.A. Crecelius. 1983. "Determination of Mercury in Seawater at Sub-Nanogram per Liter Levels." Mar. Chem. 14:49-59.

U.S. Environmental Protection Agency (EPA). 1991. Methods for the Determination of Metals in Environmental Samples. EPA-600/4-91-010. Environmental Services Division, Monitoring Management Branch, Washington D.C. 
PROGRAM: $\quad$ New York/New Jersey Red Hook/Bay Ridge Projectś

PARAMETER: Chlorinated Pesticides/PCB Congeners

LABORATORY: Battelle/Marine Sciences Laboratory, Sequim, Washington

MATRIX: $\quad$ Macoma nasuta Tissue

\section{QA/QC DATA QUALITY OBJECTIVES}

\begin{tabular}{lccccc}
$\begin{array}{c}\text { Reference } \\
\text { Method }\end{array}$ & $\begin{array}{c}\text { Surrogate } \\
\text { Recovery }\end{array}$ & $\begin{array}{c}\text { MS } \\
\text { Recovery }\end{array}$ & $\begin{array}{c}\text { SRM } \\
\text { Accuracy }\end{array}$ & $\begin{array}{c}\text { Relative } \\
\text { Precision }\end{array}$ & $\begin{array}{c}\text { Target } \\
\text { Detection Limit } \\
\text { (ug/kg wet wt) }\end{array}$ \\
\cline { 1 - 2 } GC/MS/SIM & 30 to $150 \%$ & $30-120 \%$ & $\leq 30 \%$ & $\leq 30 \%$ & 0.4
\end{tabular}

SAMPLE CUSTODY .Twenty=one samples were received on 5/30/95 in good condition, logged into the Battelle system, and stored frozen at $-20^{\circ} \mathrm{C} \pm 10^{\circ} \mathrm{C}$ until extraction.

METHOD

Tissues were homogenized wet using a stainless steel blade. An aliquot of tissue sample-was extracted with methylene chloride using the roller-technique under ambient:conditions following a procedure which is based on methods used by the National.Oceanic and Atmospheric Administration for their Status and Trends. Program (NOAA 1993). Samples were then cleaned using Silica/Alumina (5\% deactivated) chromatography followed by HPLC cleanup (NOAA 1993). Extracts: were-analyzed for 15 chlorinated pesticides and 22 PCB congeners using Gas Chromatography/Electron Capture Detection (GC/ECD) following a procedure based on EPA method 8080 (EPA 1986). The column used was a J\&W DB-17 and the confirmatory column was a DB-1701, both capillary columns $(30 \mathrm{~m} x$ $0.25 \mathrm{~mm}$ I.D.). All detections were quantitatively confirmed on the second column.

HOLDING TIMES Samples were initially extracted in one batch. Due to low surrogate recoveries, three samples were re-extracted in a separate batch. All extracts were analyzed by $G C / E C D$. The following summarizes the extraction and analysis dates:

\begin{tabular}{clll} 
Batch & Species & Extraction & Analysis \\
\hline 1 & M. nasuta & $6 / 5 / 95$ & $6 / 9$ through $6 / 11 / 95$ \\
2 & 3 samples + MDL study & $6 / 19 / 95$ & $7 / 5 / 95$
\end{tabular}

DETECTION LIMITS Target detection limits of $0.4 \mathrm{ng} / \mathrm{g}$ wet weight were met for most pesticides and PCB congeners. Three samples that were re-extracted due to low initial surrogate recoveries, have higher detection limits for all analytes. These elevated detection limits are due to the limited amount of tissue that was available for re-extraction. Method detection limits (MDLs) reported were determined from multiplying the standard deviation of seven spiked replicates of Macoma nasuta tissue by the Student $t$ value (99 percentile)(3.142). MDLs were reported corrected for individual sample wet weight extracted. 
QA/QC SUMMARYIPCBS and PESTICIDES (contd)

Method detection limit verification was performed by analyzing four replicate spike Macoma nasuta samples and multiplying the standard deviation of the result by 4.54 . All detection limits calculated in this manner were below the target detection limit except for five pesticides and five PCB congeners which were below $1.7 \mathrm{ng} / \mathrm{g}$ wet weight.

METHOD BLANKS One method blank was extracted with each extraction batch. No pesticides or PCBs were detected in any of the method blanks.

SURROGATES Two compounds, PCB congeners 103 and 198, were added to all samples prior to extraction to assess the efficiency of the analysis. Sample surrogate recoveries were all within the QC guidelines of $30 \%$ to $150 \%$ with the exception of one sample in Batch 1 involving a high recovery of PCB 198 (162\%). This was probably due to matrix interferences with the Internal Standard octachloronaphthalene (OCN), which is used to quantify the recovery of surrogate PCB 198. Since no sample data are corrected for OCN, sample results should not be affected. Sample results were quantified using the surrogate internal standard method.

MATRIX SPIKES Eleven Eleven (11) out of the 15 pesticides and 5 of the 22 PCB congeners analyzed $\cdots$. were spiked into one sample. Matrix spike recoveries in batch 1 were within the control limit-range of $50 \%$ to $120 \%$ for all Pesticides and PCBs: with the exception of $-4,4^{\prime}=$ DDE $(121 \%)$ and P.CB $28(134 \%)$. The samples in batch 2 were analyzed in the same batch as the spiked sample used to determine the MDL verification. This . sample was spiked at a concentration near the detection limit. Because of this low spiking:concentration, matrix spike recoveries were poor but do not necessarily compromise data accuracy.

REPLICATES

One sample was analyzed in triplicate. Precision was measured by calculating the relative standard deviation (RSD) among the replicate results. RSDs for all detectable values were below the target precision goal of $\leq 30 \%$.

SRMs

Not available.

MISCELLANEOUS

All pesticide and PCB congener results are confirmed using a second dissimilar column. RPDs between the primary and confirmation values must be less than $75 \%$ to be considered a confirmed value.

\section{REFERENCES}

NOAA (National Oceanic and Atmospheric Administration). 1993. Sampling and Analytical Methods for the National Status and Trends Program, National Benthic Surveillance and Mussel Watch Projects 1984-1992. Volume IV. Comprehensive Descriptions of Trace Organic Analytical Methods. G.G. Lauenstein and A.Y. Cantillo, eds. NOAA Technical Memorandum NOS ORCA 71. National Oceanic and Atmospheric Administration, Coastal Monitoring and Bioeffects Assessment Division, Office of Ocean Resources Conservation and Assessment, Silver Spring, Maryland.

U.S. Environmental Protection Agency (EPA). 1986. Test Methods for Evaluating Solid Waste:

Physical/Chemical Methods. SW-846. U.S. Document No. 955-001-00000, U.S. EPA, Washington D. C. 
PROGRAM: $\quad$ New York/New Jersey Red Hook/Bay Ridge Projeçts

PARAMETER: $\quad$ Polynuclear Aromatic Hydrocarbons (PAH) and 1,4-Dichlorobenzene

LABORATORY: Battelle/Marine Sciences Laboratory, Sequim, Washington

MATRIX: $\quad$ Macoma nasuta Tissue

QA/QC DATA QUALITY OBJECTIVES

\begin{tabular}{lllccc}
$\begin{array}{c}\text { Reference } \\
\text { Method }\end{array}$ & $\begin{array}{c}\text { Surrogate } \\
\text { Recovery }\end{array}$ & $\begin{array}{c}\text { MS } \\
\text { Recovery }\end{array}$ & $\begin{array}{c}\text { SRM } \\
\text { Accuracy }\end{array}$ & $\begin{array}{c}\text { Relative } \\
\text { Precision }\end{array}$ & $\begin{array}{c}\text { Target } \\
\text { Detection Limit } \\
\text { (ug/kg wet wt) }\end{array}$ \\
\cline { 1 - 2 } & $50-120 \%$ & $30-150 \%$ & $530 \%$ & $530 \%$ & 4.0
\end{tabular}

SAMPLE CUSTODY Twenty-one samples were received on 5/30/95 in good condition, logged into the Battelle system, and stored frozen at $-20^{\circ} \mathrm{C} \pm 10^{\circ} \mathrm{C}$ until extraction.

METHOD Tissue samples were extracted with methylene chloride using a roller under ambient conditions following a procedure which is based on methods used by the National . Oceanic and:Atmospheric Administration for their Status and Trends Program - (NOAA 1993). Samples were then cleaned using Silica/Alumina (5\% deactivated) chromatography followed by HPLC cleanup.

Extracts were quantified using gas chromatography/mass spectrometry (GC/MS) in the selected ion mode (SIM) following a procedure based on EPA method 8270 (EPA 1986).

HOLDING TIMES - . Samples were initially extracted in one batch. Due to low surrogate recoveries, three samples were re-extracted in a separate batch. All extracts were analyzed by GC/ECD: The following summarizes the extraction and analysis dates:

\begin{tabular}{|c|c|c|c|}
\hline Batch & Species & Extraction & Analysis: \\
\hline 1 & M. nasuta & $6 / 5 / 95$ & $6 / 9$ through $6 / 11 / 95$ \\
\hline 2 & 3 samples + MDL study & $6 / 19 / 95$ & $7 / 5 / 95$ \\
\hline
\end{tabular}

DETECTION LIMITS Target detection limits of $4 \mathrm{ng} / \mathrm{g}$ wet weight were met for all PAH compounds except for fluoranthene and pyrene, which had method detection limits (MDL) between 4 and 6 ng/g wet weight. MDLs were determined by multiplying the standard deviation of seven spiked replicates of a background Macoma nasuta sample by the student's $t$ value (99 percentile, 3.142). These MDLs were based on a wet weight of $20 \mathrm{~g}$ of tissue sample. Aliquots of samples that were analyzed in triplicate, used for spiking, or were re-extracted, were generally less than $20 \mathrm{~g}$ due to limited quantities of tissue available. Because MDLs reported are corrected for sample weight, the MDLs reported for these samples appear elevated and in some cases may exceed the target detection limit.

In addition, a method detection limit verification study was performed, which consisted of analyzing four spiked aliquots of a background Macoma nasuta sample. The standard deviation of the result of the replicate analysis was multiplied by the student $t$

F. vii 
QA/QC SUMMARYIPAHs (contd)

value (4.54). Detection limits calculated in this way were all less than the target detection limit of $4 \mathrm{ng} / \mathrm{g}$ wet weight.

METHOD BLANKS

SURROGATES

MATRIX SPIKES

REPLICATES

$\cdots=\cdots$

SRMs

MISCELLANEOUS
One method blank was extracted with each extraction batch. No PAHs were detected in the blanks.

Five isotopically labeled compounds were added prior to extraction to assess the efficiency of the method. These were d8-naphthalene, d10-acenaphthene, d12chrysene, d14-dibenz[a,h]anthracene and d4-1,4 dichlorobenzene. Recoveries of all surrogates were within the quality control limits of $30 \%$ to $150 \%$ with the exception of d14-dibenz[a,h]anthracene in six samples and d4-1,4-dichlorobenzene recovery in two samples.

One sample was spiked with all PAH compounds. Matrix spike recoveries were within QC limits of $50 \%$ to $120 \%$, with some exceptions. Spike recoveries for a number of $\mathrm{PAH}$ compounds were not calculated due to high native levels, relative to the levels spiked. Spike concentrations were from two to thirty times lower than native concentrations.

One sample from each batch was extracted and analyzed in triplicate:- Precision was measured by calculating the relative standard deviation (RSD) between the replicate : . . $=$ results. All RSDs were within $\pm 30 \%$.

Not available.

Some of the compounds are flagged to indicate that the ion ratio for that compound was outside of the QC.range: This is due primarily to low levels of the compound of interest. Because the confirmation ion is present at only a fraction of the level of the parent ion, when the native level of the compound is low, the amount of error in the concentration measurement of the confirmation ion goes up. The compound is actually quantified from the parent ion only so most likely this will not affect the quality of the data. For sample values that are relatively high ( $>5$ times.the MDL) it may be an indication of some sort of interference.

Benzo[b]- and benzo[k]fluoranthene values were reported in some samples as the sum of the two compounds and in some as individual values. Due to the poor resolution of these two compounds, the ability to separate them for quantitation was variable.

\section{REFERENCES}

NOAA (National Oceanic and Atmospheric Administration). 1993. Sampling and Analytical Methods for the National Status and Trends Program, National Benthic Surveillance and Mussel Watch Projects 1984-1992. Volume IV. Comprehensive Descriptions of Trace Organic Analytical Methods. G.G. Lauenstein and A.Y. Cantillo, eds. NOAA Technical Memorandum NOS ORCA 71. National Oceanic and Atmospheric Administration, Coastal Monitoring and Bioeffects Assessment Division, Office of Ocean Resources Conservation and Assessment, Silver Spring, Maryland.

U.S. Environmental Protection Agency (EPA). 1986. Test Methods for Evaluating Solid Waste: Physical/Chemical Methods. SW-846. U.S. Document No. 955-001-00000, EPA, Washington D.C.

$$
\text { F. viii }
$$


Table F.1. Metals in Tissue of M. nasuta (Wet Weight), Red Hook and Bay Ridge Channels

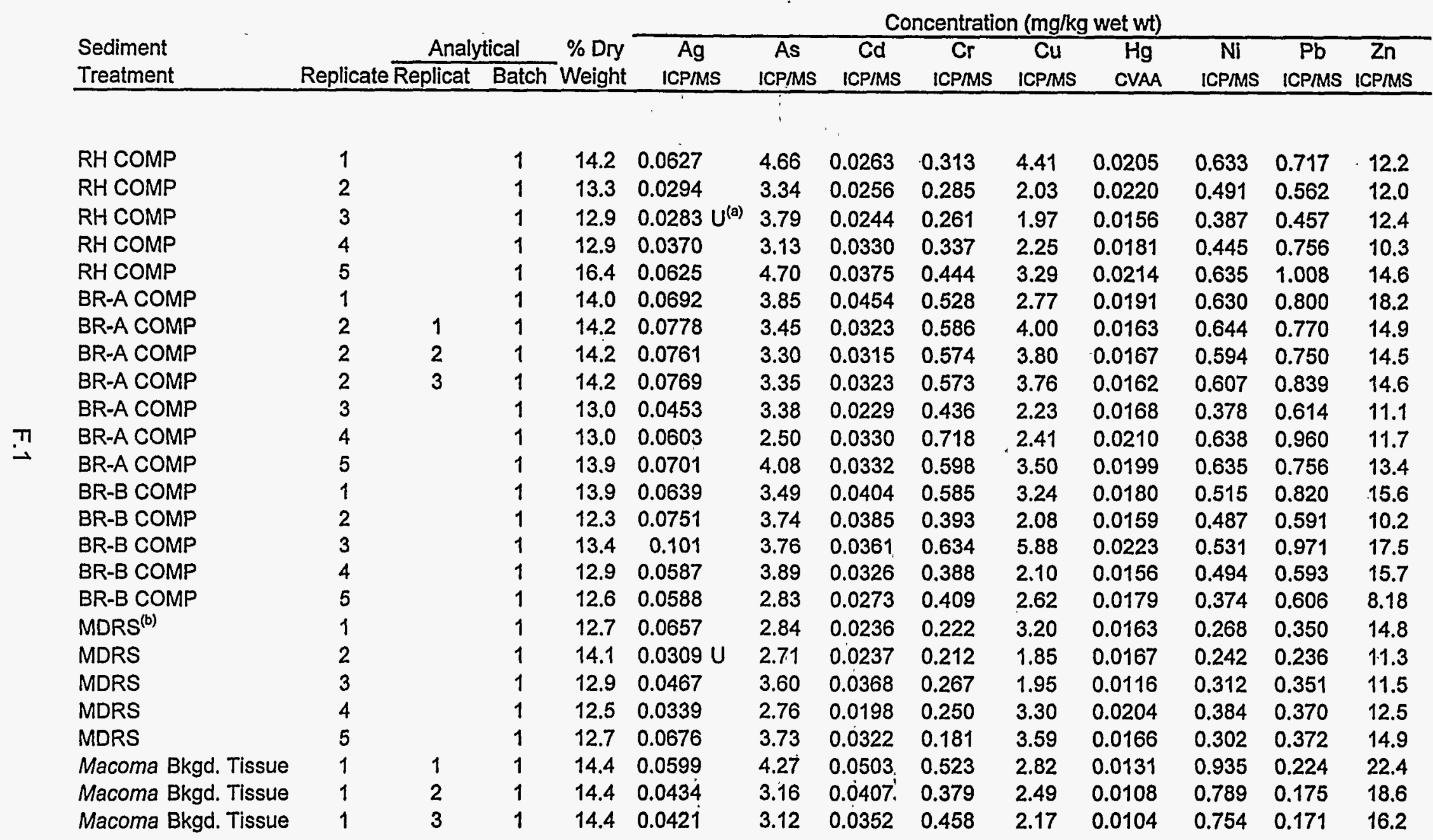

(a) U Undetected at or above given concentration.

(b) MDRS Mud Dump Reference Site. 
Table F.2. Metals in Tissue of M. nasuta (Dry Weight), Red Hook and Bay Ridge Channels

\begin{tabular}{|c|c|c|c|c|c|c|c|c|c|c|c|c|c|}
\hline \multirow{3}{*}{$\begin{array}{l}\text { Sediment } \\
\text { Treatment }\end{array}$} & \multirow{2}{*}{\multicolumn{3}{|c|}{ Analytical }} & \multicolumn{10}{|c|}{ Concentration (mg/kg dry wt) } \\
\hline & & & & \multirow{2}{*}{$\begin{array}{l}\% \text { Dry } \\
\text { Weight }\end{array}$} & \multirow{2}{*}{$\begin{array}{c}\mathrm{Ag} \\
\mathrm{ICP} / \mathrm{MS} \\
\end{array}$} & \multirow{2}{*}{$\begin{array}{c}\text { As } \\
\text { ICP/MS }\end{array}$} & \multirow{2}{*}{$\begin{array}{c}\text { Cd } \\
\text { ICPMS }\end{array}$} & \multirow{2}{*}{$\begin{array}{c}\mathrm{Cr} \\
\text { ICPMS }\end{array}$} & \multirow{2}{*}{$\begin{array}{c}\mathrm{Cu} \\
\text { ICPIMS }\end{array}$} & \multirow{2}{*}{$\begin{array}{c}\mathrm{Hg} \\
\text { CVAA } \\
\end{array}$} & \multirow{2}{*}{$\begin{array}{c}\mathrm{Ni} \\
\text { ICPMS } \\
\end{array}$} & \multirow{2}{*}{$\begin{array}{l}\mathrm{Pb} \\
\text { ICP/MS }\end{array}$} & \multirow{2}{*}{$\begin{array}{c}\mathrm{Zn} \\
\text { ICP/MS } \\
\end{array}$} \\
\hline & \multirow{3}{*}{\multicolumn{3}{|c|}{$\begin{array}{l}\text { Target Detection Limit: } \\
\text { Method Detection Limit: }\end{array}$}} & & & & & & & & & & \\
\hline & & & & & 0.1 & 1.0 & 0.1 & 0.2 & 1.0 & 0.02 & 0.1 & 0.1 & 1.0 \\
\hline & & & & & 0.22 & 0.83 & 0.081 & 0.08 & 1.20 & 0.0011 & 0.25 & 0.08 & 1.37 \\
\hline RH COMP & 1 & & 1 & 14.2 & 0.441 & 32.8 & 0.185 & 2.20 & 31.0 & 0.144 & 4.45 & 5.04 & 85.5 \\
\hline RH COMP & 2 & & 1 & 13.3 & 0.222 & 25.2 & 0.193 & 2.15 & 15.3 & 0.166 & 3.70 & 4.24 & 90.4 \\
\hline RH COMP & 3 & & 1 & 12.9 & $0.220 U^{(a)}$ & 29.5 & 0.190 & 2.03 & 15.3 & 0.121 & 3.01 & 3.56 & 96.4 \\
\hline RH COMP & 4 & & 1 & 12.9 & 0.286 & 24.2 & 0.255 & 2.61 & 17.4 & 0.140 & 3.44 & 5.85 & 79.9 \\
\hline RH COMP & 5 & & 1 & 16.4 & 0.380 & 28.6 & 0.228 & 2.70 & 20.0 & 0.130 & 3.86 & 6.13 & 89.0 \\
\hline BR-A COMP & 1 & & 1 & 14.0 & 0.494 & 27.5 & 0.324 & 3.77 & 19.8 & 0.136 & 4.50 & 5.71 & 130 \\
\hline BR-A COMP & 2 & 1 & 1 & 14.2 & 0.549 & 24.3 & 0.228 & 4.13 & 28.2 & 0.115 & 4.54 & 5.43 & 105 \\
\hline BR-A COMP & 2 & 2 & 1 & 14.2 & 0.537 & 23.3 & 0.222 & 4.05 & 26.8 & 0.118 & 4.19 & 5.29 & 102 \\
\hline BR-A COMP & 2 & 3 & 1 & 14.2 & 0.542 & 23.6 & 0.228 & 4.04 & 26.5 & 0.114 & 4.28 & 5.92 & 103 \\
\hline BR-A COMP & 3 & & 1 & 13.0 & 0.350 & 26.1 & 0.177 & 3.37 & 17.2 & 0.130 & 2.92 & 4.74 & 85.6 \\
\hline BR-A COMP & 4 & . & 1 & 13.0 & 0.463 & 19.2 & 0.253 & 5.51 & 18.5 & 0.161 & 4.90 & 7.37 & 89.9 \\
\hline BR-A COMP & 5 & & 1 & 13.9 & 0.503 & 29.3 & 0.238 & 4.29 & 25.1 & 0.143 & 4.56 & 5.43 & 96.3 \\
\hline BR-B COMP & 1 & & 1 & 13.9 & 0.459 & 25.1 & 0.290 & 4.20 & 23.3 & 0.129 & 3.70 & 5.89 & 112 \\
\hline BR-B COMP & 2 & & 1 & 12.3 & 0.610 & 30.4 & 0.313 & 3.19 & 16.9 & 0.129 & 3.96 & 4.80 & 82.7 \\
\hline BR-B COMP & 3 & & 1 & 13.4 & 0.754 & 28.1 & 0.270 & 4.74 & 44.0 & 0.167 & 3.97 & 7.26 & 131 \\
\hline BR-B COMP & 4 & & 1 & 12.9 & 0.454 & 30.1 & 0.252 & 3.00 & 16.2 & 0.121 & 3.82 & 4.58 & 121 \\
\hline BR-B COMP & 5 & & 1 & 12.6 & 0.467 & 22.5 & 0.217 & 3.25 & 20.8 & 0.142 & 2.97 & 4.81 & 65.0 \\
\hline MDRS $^{(b)}$ & 1 & & 1 & 12.7 & 0.516 & 22.3 & 0.185 & 1.74 & 25.1 & 0.128 & 2.10 & 2.75 & 116 \\
\hline MDRS & 2 & & 1 & 14.1 & $0.220 \mathrm{U}$ & 19.3 & 0.169 & 1.51 & 13.2 & 0.119 & 1.72 & 1.68 & 80.7 \\
\hline MDRS & 3 & & 1 & 12.9 & 0.363 & 28.0 & 0.286 & 2.08 & 15.2 & 0.0902 & 2.43 & 2.73 & 89.1 \\
\hline MDRS & 4 & & 1 & 12.5 & 0.270 & 22.0 & 0.158 & 1.99 & 26.3 & 0.162 & 3.06 & 2.95 & 99.5 \\
\hline MDRS & 5 & & 1 & 12.7 & 0.531 & 29.3 & 0.253 & 1.42 & 28.2 & 0.131 & 2.37 & 2.92 & 117 \\
\hline Macoma Bkgd. Tissue & 1 & 1 & 1 & 14.4 & 0.417 & 29.7 & 0.350 & 3.64 & 19.6 & 0.0913 & 6.51 & 1.56 & 156 \\
\hline Macoma Bkgd. Tissue & 1 & 2 & 1 & 14.4 & 0.302 & 22.0 & 0.283 & 2.64 & 17.3 & 0.0749 & 5.49 & 1.22 & 130 \\
\hline Macoma Bkgd. Tissue & 1 & 3 & 1 & 14.4 & 0.293 & $21: 7$ & 0.245 & 3.19 & 15.1 & 0.0727 & 5.25 & 1.19 & 113 \\
\hline
\end{tabular}

(a) $U$ Undetected at or above given concentration.

(b) MDRS Mud Dump Reference Site. 
Table F.3. Quality Control Data for Metals Analysis of M. nasuta Tissue (Dry Weight)




Table F.3. (contd)

\begin{tabular}{|c|c|c|c|c|c|c|c|c|c|c|c|}
\hline \multirow[b]{2}{*}{$\begin{array}{l}\text { Sediment } \\
\text { Treatment }\end{array}$} & \multirow[b]{2}{*}{ Replicate } & \multirow[b]{2}{*}{$\begin{array}{c}\text { Analytical } \\
\text { Batch }\end{array}$} & \multicolumn{9}{|c|}{ Concentration (mg/kg dry wt) } \\
\hline & & & $\begin{array}{c}\mathrm{Ag} \\
\mathrm{ICP} / \mathrm{MS}\end{array}$ & $\begin{array}{c}\text { As } \\
\text { ICP/MS }\end{array}$ & $\begin{array}{c}\text { Cd } \\
\text { ICP/MS }\end{array}$ & $\begin{array}{c}\mathrm{Cr} \\
\text { ICP/MS }\end{array}$ & $\begin{array}{c}\mathrm{Cu} \\
\text { ICP/MS }\end{array}$ & $\begin{array}{c}\mathrm{Hg} \\
\text { CVAA }\end{array}$ & $\begin{array}{c}\mathrm{Ni} \\
\text { ICP/MS }\end{array}$ & $\begin{array}{c}\mathrm{Pb} \\
\mathrm{ICP} / \mathrm{MS}\end{array}$ & $\begin{array}{c}\mathrm{Zn} \\
\text { ICP/MS }\end{array}$ \\
\hline \multicolumn{12}{|l|}{ Analytical Replicates } \\
\hline BR-A COMP(I) & 1 & 1 & 0.549 & 24.3 & 0.228 & 4.13 & 28.2 & 0.115 & 4.54 & 5.43 & 105 \\
\hline BR-A COMP & 2 & 1 & 0.537 & 23.3 & 0.222 & 4.05 & 26.8 & 0.118 & 4.19 & 5.29 & 102 \\
\hline BR-A COMP & 3 & 1 & 0.542 & 23.6 & 0.228 & 4.04 & 26.5 & 0.114 & 4.28 & 5.92 & 103 \\
\hline \multicolumn{2}{|c|}{ RSD (\%) } & & 1 & 2 & 2 & 1 & 3 & 1 & 4 & 6 & 1 \\
\hline Macoma Bkgd. Tissue & 1 & 1 & 0.417 & 29.7 & 0.350 & 3.64 & 19.6 & 0.0913 & 6.51 & 1.56 & 156 \\
\hline Macoma Bkgd. Tissue & 2 & 1 & 0.302 & 22.0 & 0.283 & 2.64 & 17.3 & 0.0749 & 5.49 & 1.22 & 130 \\
\hline Macoma Bkgd. Tissue & 3 & 1 & 0.293 & 21.7 & 0.245 & 3.19 & 15.1 & 0.0727 & 5.25 & 1.19 & 113 \\
\hline \multicolumn{2}{|c|}{ RSD (\%) } & & 20 & 19 & 18 & 16 & 13 & 13 & 12 & 16 & 16 \\
\hline
\end{tabular}

(a) U Undetected at or above given concentration.

$\pi \quad$ (b) NA Not applicable.

i (c) NS Not spiked.

(d) Outside quality control criteria (75-125\%) for spike recovery.

(e) Outside SRM quality control criteria $(\leq 20 \%)$.

(f) Sample randomly selected for use as a quality control sample in analytical batch. 
Table F.4. Method Detection Limit Verification Study for Metals in M. nasuta Tissue

\begin{tabular}{|c|c|c|c|c|c|c|c|c|c|c|c|}
\hline \multirow{3}{*}{ Sediment Treatment } & \multirow{2}{*}{\multicolumn{2}{|c|}{ Analytical }} & \multicolumn{9}{|c|}{ Concentration (mg/kg dry wt) } \\
\hline & & & $\mathrm{Ag}$ & As & $\mathrm{Cd}$ & $\mathrm{Cr}$ & $\mathrm{Cu}$ & $\mathrm{Hg}$ & $\overline{\mathrm{Ni}}$ & $\overline{\mathrm{Pb}}$ & $\overline{Z n}$ \\
\hline & Replicate & Batch & ICPIMS & ICP/MS & ICPIMS & ICPMS & ICP/MS & CVAA & ICPMS & ICPMS & ICPMS \\
\hline Macoma Bkgd. Tissue + Spike & 1 & 1 & 1.11 & 21.5 & 1.20 & 2.95 & 14.8 & 1.07 & 5.30 & 2.08 & 109 \\
\hline Macoma Bkgd. Tissue + Spike & 2 & 1 & 1.13 & 22.8 & 1.24 & 3.72 & 16.4 & 1.06 & 6.52 & 2.17 & 120 \\
\hline Macoma Bkgd. Tissue + Spike & 3 & 1 & 1.14 & 22.4 & 1.25 & 3.31 & 15.7. & 1.07 & 6.97 & 2.08 & 114 \\
\hline Macoma Bkgd. Tissue + Spike & 4 & 1 & 1.10 & 21.8 & 1.19 & $4.22^{\circ}$ & 15.5 & 1.04 & 5.79 & 2.13 & 107 \\
\hline Detection Limit ${ }^{(a)}$ & & & 0.0829 & 2.66 & 0.134 & 2.48 & 2.99 & 0.0642 & 3.38 & 0.198 & 26.3 \\
\hline
\end{tabular}

(a) Detection limit determined by multiplying the standard deviation of the four replicates by Students-t (4.54). 
Table F.5. Pesticides and Polychlorinated Biphenyls (PCBs) in Tissue of M. nasuta (Wet Weight), Red Hook and Bay Ridge Channels

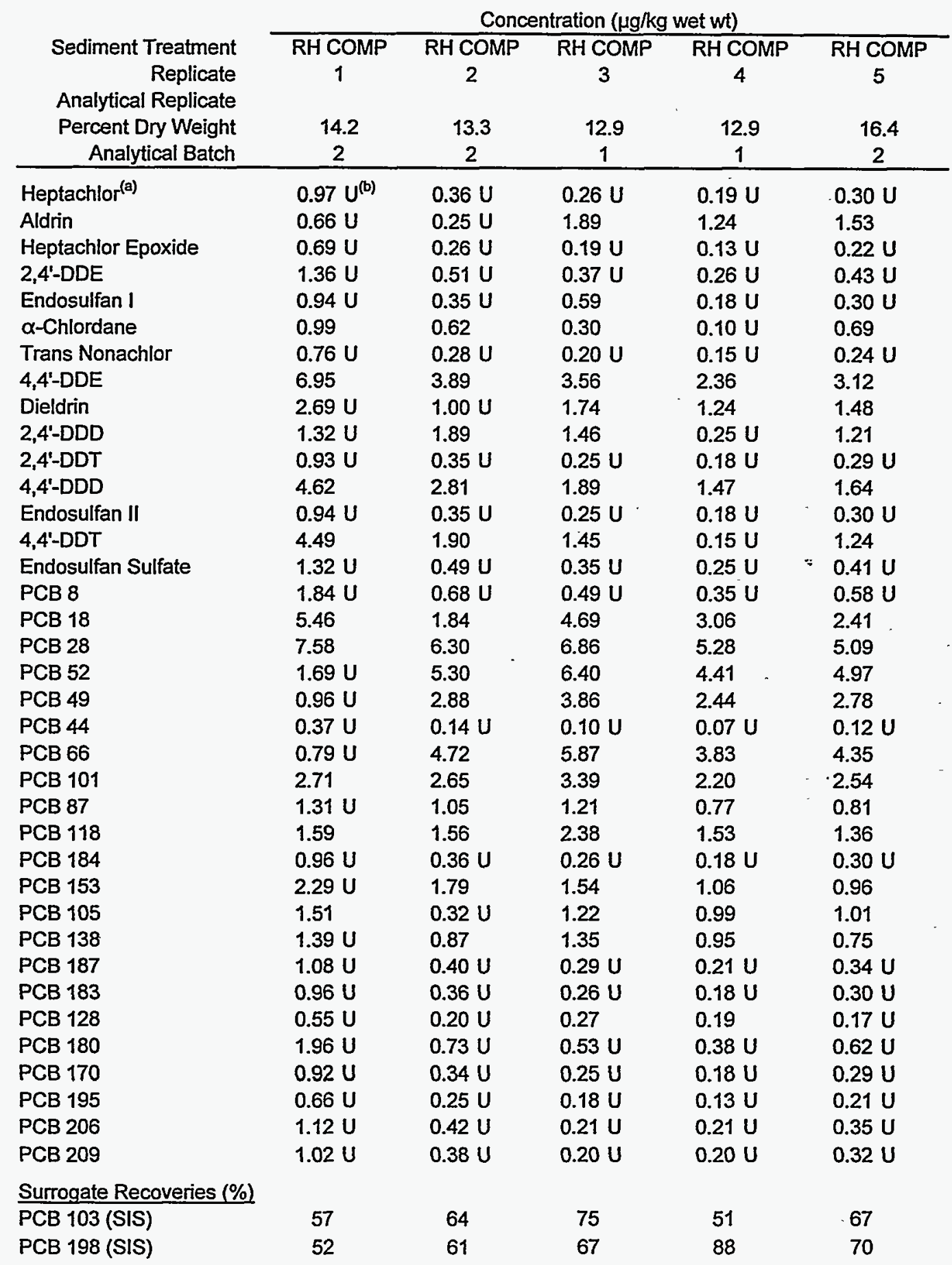


Table F.5. (contd)

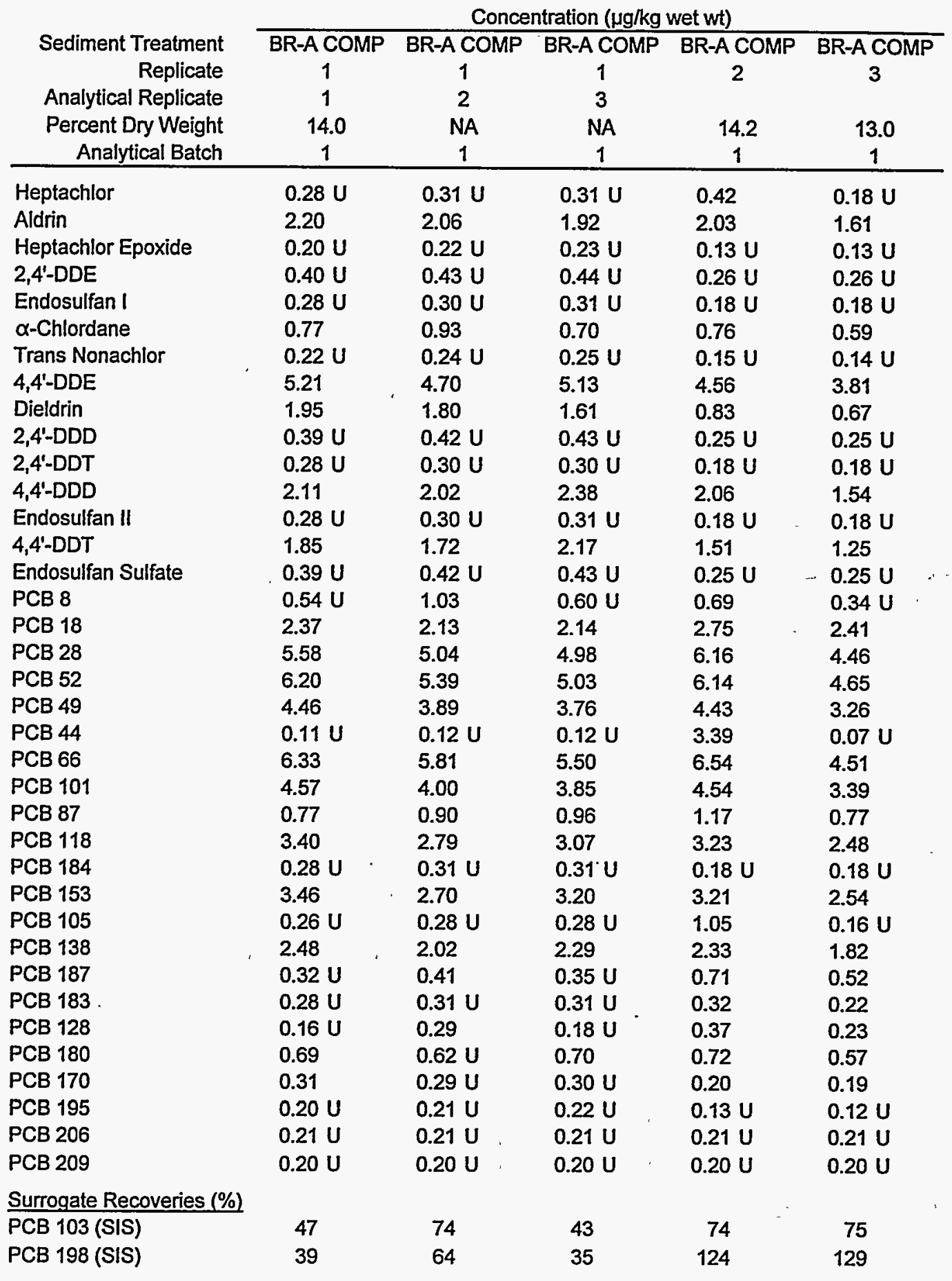


Table F.5. (contd)

Concentration $(\mu \mathrm{g} / \mathrm{kg}$ wet $\mathrm{wt})$

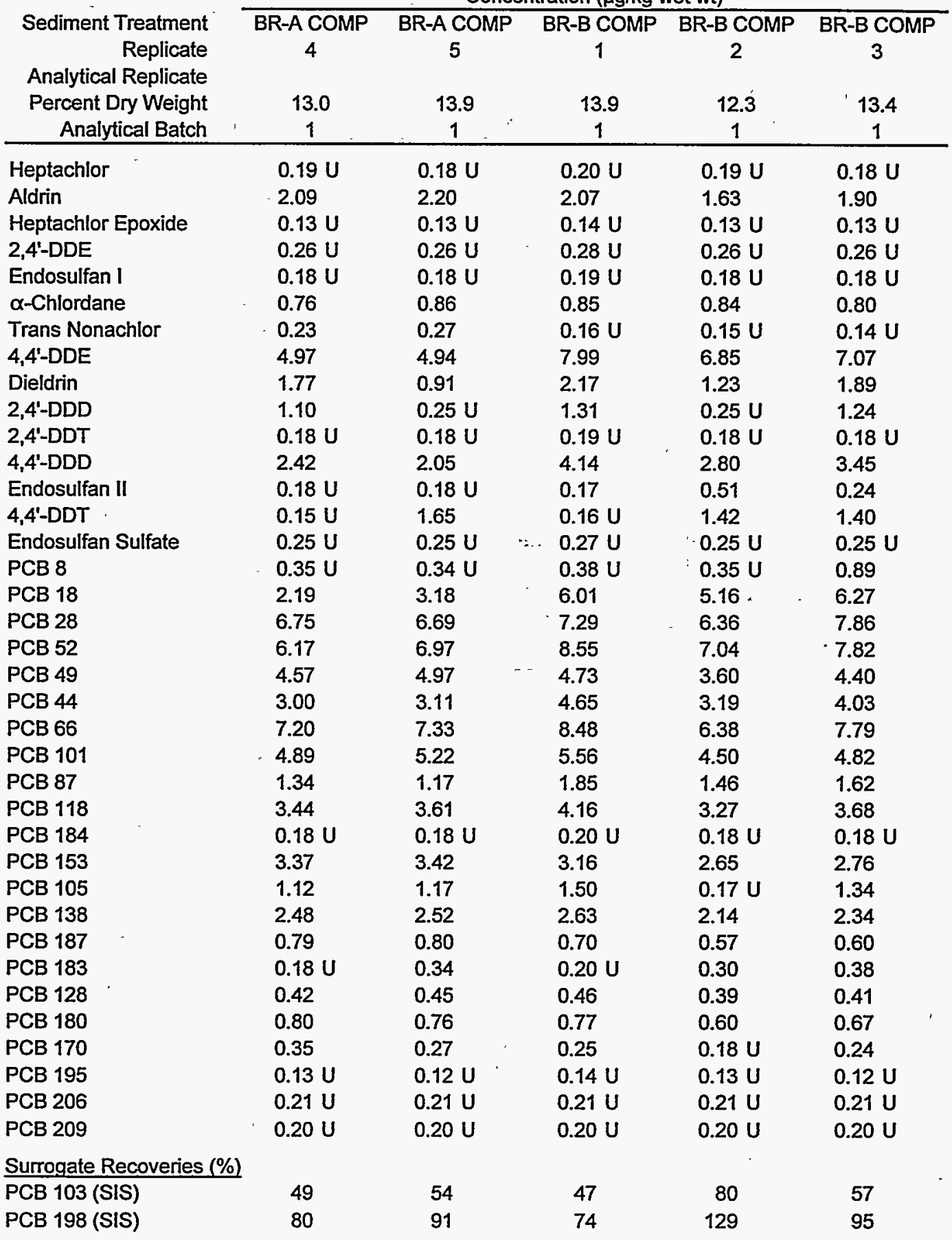


Table F.5. (contd)

\begin{tabular}{|c|c|c|c|c|c|}
\hline \multirow[b]{2}{*}{$\begin{array}{l}\text { Sediment Treatment } \\
\text { Replicate }\end{array}$} & \multicolumn{5}{|c|}{ Concentration $(\mu \mathrm{g} / \mathrm{kg}$ wet $w t)$} \\
\hline & $\begin{array}{c}\text { BR-B COMP } \\
4\end{array}$ & $\begin{array}{c}\text { BR-B COMP } \\
5\end{array}$ & $\begin{array}{c}\mathrm{MDRS}^{(0)} \\
1\end{array}$ & $\begin{array}{c}\text { MDRS } \\
2\end{array}$ & $\begin{array}{c}\text { MDRS } \\
3\end{array}$ \\
\hline \multicolumn{6}{|l|}{ Analytical Replicate } \\
\hline $\begin{array}{l}\text { Percent Dry Weight } \\
\text { Analytical Batch }\end{array}$ & $\begin{array}{c}12.9 \\
1 \\
\end{array}$ & $\begin{array}{c}12.6 \\
1\end{array}$ & $\begin{array}{c}12.7 \\
1\end{array}$ & $\begin{array}{c}14.1 \\
1 \\
\end{array}$ & $\begin{array}{c}12.9 \\
1 \\
\end{array}$ \\
\hline Heptachlor & $0.18 \mathrm{U}$ & $0.18 \mathrm{U}$ & $0.19 u$ & $0.18 U$ & 0.20 \\
\hline Aldrin & 1.91 & 1.90 & 0.53 & $0.12 U$ & 0.44 \\
\hline Heptachlor Epoxide & $0.13 U$ & $0.13 U$ & $0.13 \mathrm{U}$ & $0.13 \mathrm{U}$ & $0.13 U$ \\
\hline 2,4'-DDE & $0.26 \mathrm{U}$ & $0.26 U$ & 0.55 & 0.66 & 0.60 \\
\hline Endosulfan I & $0.18 U$ & $0.18 \mathrm{U}$ & $0.18 \mathrm{U}$ & $0.18 \mathrm{U}$ & $0.18 U$ \\
\hline$\alpha$-Chlordane & 0.93 & 1.04 & $0.10 \mathrm{U}$ & $0.09 \mathrm{U}$ & 0.36 \\
\hline Trans Nonachlor & $0.14 U$ & $0.14 \mathrm{U}$ & $0.15 \mathrm{U}$ & $0.14 \mathrm{U}$ & $0.15 \mathrm{U}$ \\
\hline 4,4'-DDE & 7.32 & 7.39 & $0.19 \mathrm{U}$ & 1.32 & 0.78 \\
\hline Dieldrin & 2.19 & 1.35 & $0.52 \mathrm{U}$ & 0.70 & 1.29 \\
\hline 2,4'-DDD & 1.63 & 1.05 & $0.25 \mathrm{U}$ & $0.25 U$ & $0.25 \mathrm{U}$ \\
\hline 2,4'-DDT & $0.18 U$ & $0.18 U$ & $0.18 U$ & $0.18 \mathrm{U}$ & $0.18 U$ \\
\hline 4,4'-DDD & 2.98 & 4.27 & $0.26 U$ & $0.26 \mathrm{U}$ & $0.26 \mathrm{U}$ \\
\hline Endosulfan II & $0.18 \mathrm{U}$ & $0.18 \mathrm{U}$ & $0.18 \mathrm{U}$ & $0.18 U$ & $0.18 \mathrm{U}$ \\
\hline 4,4'-DDT & $0.15 U$ & 1.93 & $0.15 \mathrm{U}$ & $0.15 U$ & $0.15 U$ \\
\hline Endosulfan Sulfate & $0.25 U$ & $0.25 U$ & $0.25 U$ & $0.25 U$ & $0.25 \mathrm{U}$ \\
\hline РСВ 8 & $0.34 \mathrm{U}$ & $0.34 \mathrm{U}$ & 0.45 & 0.46 & $0.35 \mathrm{U}$ \\
\hline РCB 18 & 6.29 & 5.92 & $0.10 U$ & $0.10 \mathrm{U}$ & $0.10 \mathrm{U}$ \\
\hline РCB 28 & 7.97 & 7.90 & 0.31 & 0.39 & 0.27 \\
\hline РСB 52 & 7.95 & 8.29 & 0.71 & $0.32 \mathrm{U}$ & 0.38 \\
\hline РСВ 49 & 4.52 & 4.61 & $0.18 \mathrm{U}$ & $0.18 U$ & $0.18 \mathrm{U}$ \\
\hline РСВ 44 & 3.66 & 4.22 & $0.07 \mathrm{U}$ & $0.07 \mathrm{U}$ & $0.07 \mathrm{U}$ \\
\hline РCB 66 & 7.73 & 7.68 & $0.15 \mathrm{U}$ & $0.15 U$ & $0.15 U$ \\
\hline PCB 101 & 5.12 & 5.00 & $0.13 U$ & 0.24 & 0.23 \\
\hline РСВ 87 & 1.72 & 1.60 & $0.25 \mathrm{U}$ & $0.25 \mathrm{U}$ & $0.25 \mathrm{U}$ \\
\hline PCB 118 & 3.61 & 3.42 & $0.19 \mathrm{U}$ & $0.19 U$ & 0.21 \\
\hline PCB 184 & $0.18 \mathrm{U}$ & $0.18 \mathrm{U}$ & $0.18 \mathrm{U}$ & $0.18 \mathrm{U}$ & $0.18 U$ \\
\hline PCB 153 & 2.65 & 2.60 & $0.44 \mathrm{U}$ & $0.43 \mathrm{U}$ & $0.44 \mathrm{U}$ \\
\hline PCB 105 & 1.30 & 1.22 & $0.17 \mathrm{U}$ & $0.16 \mathrm{U}$ & $0.17 \mathrm{U}$ \\
\hline PCB 138 & 2.24 & 2.16 & $0.27 \mathrm{U}$ & $0.26 \mathrm{U}$ & $0.27 \mathrm{U}$ \\
\hline PCB 187 & 0.57 & $0.20 \mathrm{U}$ & $0.21 \mathrm{U}$ & $0.20 \mathrm{U}$ & $0.21 \mathrm{U}$ \\
\hline PCB 183 & $0.18 \mathrm{U}$ & $0.18 \mathrm{U}$ & $0.18 \mathrm{U}$ & $0.18 \mathrm{U}$ & $0.18 \mathrm{U}$ \\
\hline PCB 128 & 0.43 & 0.60 & $0.11 \mathrm{U}$ & $0.10 \mathrm{U}$ & $0.11 \mathrm{U}$ \\
\hline PCB 180 & 0.66 & $0.37 \mathrm{U}$ & $0.38 \mathrm{U}$ & $0.37 \mathrm{U}$ & $0.38 \mathrm{U}$ \\
\hline PCB 170 & 0.20 & 0.19 & $0.18 \mathrm{U}$ & $0.17 \mathrm{U}$ & $0.18 U$ \\
\hline PCB 195 & $0.12 U$ & $0.12 U$ & $0.13 \mathrm{U}$ & $0.12 \mathrm{U}$ & $0.13 \mathrm{U}$ \\
\hline PCB 206 & $0.21 \mathrm{U}$ & $0.21 U$ & $0.21 \mathrm{U}$ & $0.21 \mathrm{U}$ & $0.21 \mathrm{U}$ \\
\hline PCB 209 & $0.20 \mathrm{U}$ & $0.20 \mathrm{U}$ & $0.20 \mathrm{U}$ & $0.20 \mathrm{U}$ & $0.20 \mathrm{U}$ \\
\hline \multicolumn{6}{|c|}{ Surrogate Recoveries (\%) } \\
\hline PCB 103 (SIS) & 51 & 76 & 94 & 58 & 51 \\
\hline РСВ 198 (SIS) & 85 & 121 & $162^{(d)}$ & 101 & 86 \\
\hline
\end{tabular}


Table F.5. (contd)

\begin{tabular}{|c|c|c|c|}
\hline \multirow{3}{*}{$\begin{array}{r}\text { Sediment Treatment } \\
\text { Replicate } \\
\text { Analytical Replicate }\end{array}$} & \multicolumn{3}{|c|}{ Concentration ( $\mu \mathrm{g} / \mathrm{kg}$ wet $\omega t)$} \\
\hline & $\begin{array}{c}\text { MDRS } \\
4\end{array}$ & $\begin{array}{l}\text { MDRS } \\
5\end{array}$ & Macoma Bkgd. Tissue \\
\hline & & & \\
\hline Percent Dry Weight & 12.5 & 12.7 & 14.4 \\
\hline Analytical Batch & 1 & 1 & 1 \\
\hline Heptachlor & $0.19 \mathrm{U}$ & $0.20 \mathrm{U}$ & $0.18 \mathrm{U}$ \\
\hline Aldrin & $0.13 \mathrm{U}$ & 0.57 & $0.12 U$ \\
\hline Heptachlor Epoxide & $0.13 U$ & $0.14 \mathrm{U}$ & $0.13 U$ \\
\hline 2,4'-DDE & $0.26 \mathrm{U}$ & $0.28 \mathrm{U}$ & $0.26 \mathrm{U}$ \\
\hline Endosulfan I & $0.18 \mathrm{U}$ & $0.19 \mathrm{U}$ & $0.18 U$ \\
\hline$\alpha$-Chlordane & $0.10 \mathrm{U}$ & 0.49 & $0.09 \mathrm{U}$ \\
\hline Trans Nonachlor & $0.15 \mathrm{U}$ & $0.15 U$ & $0.14 U$ \\
\hline 4,4'-DDE & 0.85 & 0.90 & $0.18 U$ \\
\hline Dieldrin & $0.52 \mathrm{U}$ & 0.72 & 0.97 \\
\hline 2,4'-DDD & $0.25 \mathrm{U}$ & $0.27 \mathrm{U}$ & $0.25 \mathrm{U}$ \\
\hline 2,4'-DDT & $0.18 \mathrm{U}$ & $0.19 U$ & $0.18 U$ \\
\hline 4,4'-DDD & $0.26 \mathrm{U}$ & $0.28 \mathrm{U}$ & $0.26 U$ \\
\hline Endosulfan II & $0.18 \mathrm{U}$ & $0.19 \mathrm{U}$ & $0.18 \mathrm{U}$ \\
\hline 4,4'-DDT & $0.15 U$ & $0.16 \mathrm{U}$ & $0.15 \mathrm{U}$ \\
\hline Endosulfan Sulfate & $0.25 \mathrm{U}$ & $0.27 U$ & $0.25-U$ \\
\hline РСВ 8 & $0.35 \mathrm{U}$ & 0.67 & $0.34 U$ \\
\hline PCB 18 & $0.10 \mathrm{U}$ & $0.11 \mathrm{U}$ & $0.10 \mathrm{U}$ \\
\hline РCB 28 & $0.11 \mathrm{U}$ & $0.12 \mathrm{U}$ & $0.11 \mathrm{U}$ \\
\hline РCB 52 & $0.32 \mathrm{U}$ & 0.52 & $0.32 \mathrm{U}$ \\
\hline PCB 49 & $0.18 \mathrm{U}$ & $0.19 U$ & $0.18 U$ \\
\hline РCB 44 & $0.07 \mathrm{U}$ & $0.07 \mathrm{U}$ & $0.07 \mathrm{U}$ \\
\hline PCB 66 & $0.15 \mathrm{U}$ & $0.16 U$ & $0.15 \mathrm{U}$ \\
\hline PCB 101 & $0.13 \mathrm{U}$ & 0.24 & $0.13 \mathrm{U}$ \\
\hline PCB 87 & $0.25 U$ & $0.27 \mathrm{U}$ & $0.25 \mathrm{U}$ \\
\hline PCB 118 & $0.19 U$ & $0.20 \mathrm{U}$ & $0.19 \mathrm{U}$ \\
\hline PCB 184 & $0.18 U$ & $0.19 \mathrm{U}$ & $0.18 \mathrm{U}$ \\
\hline PCB 153 & $0.44 \mathrm{U}$ & $0.46 \mathrm{U}$ & $0.43 \mathrm{U}$ \\
\hline PCB 105 & $0.17 \mathrm{U}$ & $0.18 U$ & $0.16 U$ \\
\hline PCB 138 & $0.27 \mathrm{U}$ & 0.29 & $0.26 \mathrm{U}$ \\
\hline PCB 187 & $0.21 \mathrm{U}$ & $0.22 \mathrm{U}$ & $0.20 \mathrm{U}$ \\
\hline PCB 183 & $0.18 \mathrm{U}$ & $0.19 \mathrm{U}$ & $0.18 \mathrm{U}$ \\
\hline PCB 128 & $0.11 U$ & $0.11 \mathrm{U}$ & $0.10 \mathrm{U}$ \\
\hline PCB 180 & $0.38 \mathrm{U}$ & $0.40 \mathrm{U}$ & $0.37 \mathrm{U}$ \\
\hline PCB 170 & $0.18 \mathrm{U}$ & $0.19 \mathrm{U}$ & $0.17 U$ \\
\hline PCB 195 & $0.13 \mathrm{U}$ & $0.13 \mathrm{U}$ & $0.12 U$ \\
\hline PCB 206 & $0.21 \mathrm{U}$ & $0.21 \mathrm{U}$ & $0.21 \mathrm{U}$ \\
\hline PCB 209 & $0.20 \mathrm{U}$ & $0.20 \mathrm{U}$ & $0.20 \mathrm{U}$ \\
\hline Surrogate Recoveries & & & \\
\hline PCB 103 (SIS) & 61 & 47 & 47 \\
\hline PCB 198 (SIS) & 108 & 74 & 74 \\
\hline
\end{tabular}

(a) Target detection limits are $0.4 \mu \mathrm{g} / \mathrm{kg}$ for all analytes.

(b) $U$ Undetected at or above given concentration.

(c) MDRS Mud Dump Reference Site.

(d) Outside quality control criteria (30-150\%) for surrogate recovery. 
Table F.6. Pesticides and Polychlorinated Biphenyls (PCBs) in Tissue of $M$. nasuta (Dry Weight), Red Hook and Bay Ridge Channels

\begin{tabular}{|c|c|c|c|c|c|}
\hline \multirow[b]{2}{*}{$\begin{array}{r}\text { Sediment Treatment } \\
\text { Replicate } \\
\text { Analytical Replicate }\end{array}$} & \multicolumn{5}{|c|}{ Concentration ( $\mu \mathrm{g} / \mathrm{kg}$ dry wt) } \\
\hline & $\begin{array}{c}\text { RH COMP } \\
1\end{array}$ & $\begin{array}{c}\text { RH COMP } \\
2\end{array}$ & $\begin{array}{c}\text { RH COMP } \\
3\end{array}$ & $\begin{array}{c}\mathrm{RH} \text { COMP } \\
4\end{array}$ & $\begin{array}{c}\mathrm{RH} \text { COMP } \\
5\end{array}$ \\
\hline Percent Dry Weight & 14.2 & 13.3 & 12.9 & 12.9 & 16.4 \\
\hline Analytical Batch & 2 & 2 & 1 & 1 & 2 \\
\hline Heptachlor & $6.8 U^{(a)}$ & $2.7 \mathrm{U}$ & $2.0 \mathrm{U}$ & $1.5 \mathrm{U}$ & $1.8 \mathrm{U}$ \\
\hline Aldrin & $4.6 \mathrm{U}$ & $1.9 \mathrm{U}$ & 14.7 & 9.61 & 9.33 \\
\hline Heptachlor Epoxide & $4.9 \mathrm{U}$ & $2.0 \mathrm{U}$ & $1.5 \mathrm{U}$ & $1.0 \mathrm{U}$ & $1.3 \mathrm{U}$ \\
\hline 2,4'-DDE & $9.58 \mathrm{U}$ & $3.8 \mathrm{U}$ & $2.9 \mathrm{U}$ & $2.0 \mathrm{U}$ & $2.6 \mathrm{U}$ \\
\hline Endosulfan I & $6.6 \mathrm{U}$ & $2.6 \mathrm{U}$ & 4.6 & $1.4 \mathrm{U}$ & $1.8 \mathrm{U}$ \\
\hline$\alpha$-Chlordane & 7.0 & 4.7 & 2.3 & $0.78 \mathrm{U}$ & 4.2 \\
\hline Trans Nonachlor & $5.4 \mathrm{U}$ & $2.1 \mathrm{U}$ & $1.6 \mathrm{U}$ & $1.2 \mathrm{U}$ & $1.5 \mathrm{U}$ \\
\hline 4,4'-DDE & 48.9 & 29.2 & 27.6 & 18.3 & 19.0 \\
\hline Dieldrin & $18.9 \mathrm{U}$ & $7.52 \mathrm{U}$ & 13.5 & 9.61 & 9.02 \\
\hline 2,4'-DDD & $9.30 \mathrm{U}$ & 14.2 & 11.3 & $1.9 \mathrm{U}$ & 7.38 \\
\hline 2,4'-DDT & $6.5 \mathrm{U}$ & $2.6 \mathrm{U}$ & $1.9 \mathrm{U}$ & $1.4 \mathrm{U}$ & $1.8 \mathrm{U}$ \\
\hline 4,4'-DDD & 32.5 & 21.1 & 14.7 & 11.4 & 10.0 \\
\hline Endosulfan II & $6.6 \mathrm{U}$ & $2.6 \mathrm{U}$ & $1.9 \mathrm{U}$ & $1.4 \mathrm{U}$ & $1.8 \mathrm{U}$ \\
\hline 4,4'-DDT & 31.6 & 14.3 & 11.2 & $1.2 \mathrm{U}$ & 7.56 \\
\hline Endosulfan Sulfate & $9.30 \mathrm{U}$ & $3.7 \mathrm{U}$ & $2.7 \mathrm{U}$ & $1.9 \mathrm{U}$ & $2.5 \mathrm{U}$ \\
\hline PCB 8 & $13.0 \mathrm{U}$ & $5.1 \mathrm{U}$ & $3.8 \mathrm{U}$ & $2.7 \mathrm{U}$ & $3.5 \mathrm{U}$ \\
\hline РСB 18 & 38.5 & 13.8 & 36.4 & 23.7 & 14.7 \\
\hline РСВ 28 & 53.4 & 47.4 & 53.2 & 40.9 & 31.0 \\
\hline РСВ 52 & $11.9 \mathrm{U}$ & $39.8 \mathrm{U}$ & 49.6 & 34.2 & 30.3 \\
\hline РСВ 49 & $6.8 \mathrm{U}$ & 21.7 & 29.9 & 18.9 & 17.0 \\
\hline PCB 44 & $2.6 \mathrm{U}$ & $1.1 \mathrm{U}$ & $0.78 \mathrm{U}$ & $0.5 \mathrm{U}$ & $0.73 \mathrm{U}$ \\
\hline РСB 66 & $5.6 \mathrm{U}$ & 35.5 & 45.5 & 29.7 & 26.5 \\
\hline PCB 101 & 19.1 & 19.9 & 26.3 & 17.1 & 15.5 \\
\hline РСB 87 & $9.23 \mathrm{U}$ & 7.89 & 9.38 & 6.0 & 4.9 \\
\hline РСB 118 & 11.2 & 11.7 & 18.4 & 11.9 & 8.29 \\
\hline PCB 184 & $6.8 \mathrm{U}$ & $2.7 \mathrm{U}$ & $2.0 \mathrm{U}$ & $1.4 \mathrm{U}$ & $1.8 \mathrm{U}$ \\
\hline PCB 153 & $16.1 \mathrm{U}$ & 13.5 & 11.9 & 8.22 & 5.9 \\
\hline РCB 105 & 10.6 & $2.4 \mathrm{U}$ & 9.46 & 7.7 & 6.16 \\
\hline PCB 138 & $9.79 \mathrm{U}$ & 6.5 & 10.5 & 7.4 & 4.6 \\
\hline PCB 187 & $7.61 \mathrm{U}$ & $3.0 \mathrm{U}$ & $2.2 \mathrm{U}$ & $1.6 \mathrm{U}$ & $2.1 \mathrm{U}$ \\
\hline РСВ 183 & $6.8 \mathrm{U}$ & $2.7 \mathrm{U}$ & $2.0 \mathrm{U}$ & $1.4 \mathrm{U}$ & $1.8 \mathrm{U}$ \\
\hline PCB 128 & $3.9 \mathrm{U}$ & $1.5 \mathrm{U}$ & 2.1 & 1.5 & $1.0 \mathrm{U}$ \\
\hline PCB 180 & $13.8 U$ & $5.5 \mathrm{U}$ & $4.1 \mathrm{U}$ & $2.9 \mathrm{U}$ & $3.8 \mathrm{U}$ \\
\hline PCB 170 & $6.5 \mathrm{U}$ & $2.6 \mathrm{U}$ & $1.9 \mathrm{U}$ & $1.4 \mathrm{U}$ & $1.8 \mathrm{U}$ \\
\hline PCB 195 & $4.6 \mathrm{U}$ & $1.9 U$ & $1.4 \mathrm{U}$ & $1.0 \mathrm{U}$ & $1.3 \mathrm{U}$ \\
\hline PCB 206 & $7.89 \mathrm{U}$ & $3.2 \mathrm{U}$ & $1.6 U$ & $1.6 \mathrm{U}$ & $2.1 \mathrm{U}$ \\
\hline PCB 209 & $7.18 \mathrm{U}$ & $2.9 \mathrm{U}$ & $1.6 \mathrm{U}$ & $1.6 \mathrm{U}$ & $2.0 \mathrm{U}$ \\
\hline
\end{tabular}


Table F.6. (contd)

\begin{tabular}{|c|c|c|c|c|c|}
\hline \multirow{3}{*}{$\begin{array}{r}\text { ediment Treatment } \\
\text { Replicate }\end{array}$} & \multicolumn{5}{|c|}{ Concentration ( $\mu \mathrm{g} / \mathrm{kg}$ dry wt) } \\
\hline & BR-A COMP & BR-A COMP & BR-A COMP & BR-A COMP & $\overline{B R-A ~ C O M P}$ \\
\hline & 1 & 1 & 1 & 2 & 3 \\
\hline Analytical Replicate & 1 & 2 & 3 & & \\
\hline Percent Dry Weight & 14.0 & NA & NA & 14.2 & 13.0 \\
\hline Analytical Batch & 1 & 1 & & 1 & 1 \\
\hline Heptachlor & $2.0 \mathrm{U}$ & $2.2 \mathrm{U}$ & $2.2 \mathrm{U}$ & 3.0 & $1.4 \mathrm{U}$ \\
\hline Aldrin & 15.7 & 14.7 & 13.7 & 14.3 & 12.4 \\
\hline Heptachlor Epoxide & $1.4 \mathrm{U}$ & $1.6 \mathrm{U}$ & $1.6 \mathrm{U}$ & $0.92 \mathrm{U}$ & $1.0 \mathrm{U}$ \\
\hline 2,4'-DDE & $2.9 \mathrm{U}$ & $3.1 \mathrm{U}$ & $3.1 \mathrm{U}$ & $1.8 \mathrm{U}$ & $2.0 \mathrm{U}$ \\
\hline Endosulfan I & $2.0 \mathrm{U}$ & $2.1 \mathrm{U}$ & $2.2 \mathrm{U}$ & $1.3 \mathrm{U}$ & $1.4 \mathrm{U}$ \\
\hline$\alpha$-Chlordane & 5.5 & 6.6 & 5.0 & 5.35 & 4.5 \\
\hline Trans Nonachlor & $1.6 \mathrm{U}$ & $1.7 \mathrm{U}$ & $1.8 \mathrm{U}$ & $1.1 \mathrm{U}$ & $1.1 \mathrm{U}$ \\
\hline 4,4'-DDE & 37.2 & 33.6 & 36.6 & 32.1 & 29.3 \\
\hline Dieldrin & 13.9 & 12.9 & 11.5 & 5.8 & 5.2 \\
\hline 2,4'-DDD & $2.8 \mathrm{U}$ & $3.0 \mathrm{U}$ & $3.1 \mathrm{U}$ & $1.8 \mathrm{U}$ & $1.9 \mathrm{U}$ \\
\hline 2,4'-DDT & $2.0 \mathrm{U}$ & $2.1 \mathrm{U}$ & $2.1 \mathrm{U}$ & $1.3 \mathrm{U}$ & $1.4 \mathrm{U}$ \\
\hline 4,4'-DDD & 15.1 & 14.4 & 17.0 & 14.5 & 11.8 \\
\hline Endosulfan II & $2.0 \mathrm{U}$ & $2.1 \mathrm{U}$ & $\cdots \cdot 2.2 \mathrm{U}$ & $1.3 \mathrm{U}$ & $1.4 \mathrm{U}$ \\
\hline 4,4'-DDT & 13.2 & 12.3 & 15.5 & 10.6 & 9.62 \\
\hline Endosulfan Sulfate & $2.8 \mathrm{U}$ & $3.0 \mathrm{U}$ & $3.1 \mathrm{U}$ & $1.8 \mathrm{U}$ & $1.9 U$ \\
\hline РСB 8 & $3.9 \mathrm{U}$ & 7.36 & $4.3 U$ & 4.9 & $2.6 \mathrm{U}$ \\
\hline РСB 18 & 16.9 & 15.2 & 15.3 & 19.4 & 18.5 \\
\hline PCB 28 & 39.9 & 36.0 & 35.6 & 43.4 & 34.3 \\
\hline PCB 52 & 44.3 & 38.5 & 35.9 & 43.2 & 35.8 \\
\hline РСB 49 & 31.9 & 27.8 & 26.9 & 31.2 & 25.1 \\
\hline PCB 44 & $0.79 \mathrm{U}$ & $0.86 \mathrm{U}$ & $0.86 \mathrm{U}$ & 23.9 & $0.5 \mathrm{U}$ \\
\hline РСВ 66 & 45.2 & 41.5 & 39.3 & 46.1 & 34.7 \\
\hline PCB 101 & 32.6 & 28.6 & 27.5 & 32.0 & 26.1 \\
\hline РСВ 87 & 5.5 & 6.4 & 6.9 & 8.24 & 5.9 \\
\hline PCB 118 & 24.3 & 19.9 & 21.9 & 22.7 & 19.1 \\
\hline PCB 184 & $2.0 \mathrm{U}$ & $2.2 \mathrm{U}$ & $2.2 \mathrm{U}$ & $1.3 \mathrm{U}$ & $1.4 \mathrm{U}$ \\
\hline PCB 153 & 24.7 & 19.3 & 22.9 & 22.6 & 19.5 \\
\hline PCB 105 & $1.86 \mathrm{U}$ & $2.0 \mathrm{U}$ & $2.0 \mathrm{U}$ & 7.39 & $1.2 \mathrm{U}$ \\
\hline PCB 138 & 17.7 & 14.4 & 16.4 & 16.4 & 14.0 \\
\hline PCB 187 & $2.3 \mathrm{U}$ & 2.9 & $2.5 \mathrm{U}$ & 5.0 & 4.0 \\
\hline PCB 183 & $2.0 \mathrm{U}$ & $2.2 \mathrm{U}$ & $2.2 \mathrm{U}$ & 2.3 & 1.7 \\
\hline PCB 128 & $1.1 \mathrm{U}$ & 2.1 & $1.29 \mathrm{U}$ & 2.6 & 1.8 \\
\hline PCB 180 & 4.9 & $4.4 U$ & 5.0 & 5.1 & 4.4 \\
\hline РCB 170 & 2.2 & $2.1 \mathrm{U}$ & $2.1 \mathrm{U}$ & 1.4 & 1.5 \\
\hline PCB 195 & $1.4 \mathrm{U}$ & $1.5 \mathrm{U}$ & $1.6 \mathrm{U}$ & $0.92 \mathrm{U}$ & $0.92 U$ \\
\hline PCB 206 & $1.5 \mathrm{U}$ & $1.5 \mathrm{U}$ & $1.5 \mathrm{U}$ & $1.5 \mathrm{U}$ & $1.6 \mathrm{U}$ \\
\hline PCB 209 & $1.4 \mathrm{U}$ & $1.4 \mathrm{U}$ & $1.4 \mathrm{U}$ & $1.4 \mathrm{U}$ & $1.5 \mathrm{U}$ \\
\hline
\end{tabular}


Table F.6. (contd)

Sediment Treatment

Replicate

Analytical Replicate

Percent Dry Weight

Analytical Batch

Concentration ( $\mu \mathrm{g} / \mathrm{kg}$ dry $w t)$

\begin{tabular}{|c|c|c|c|c|c|}
\hline Heptachlor & $1.5 \mathrm{U}$ & $1.3 \mathrm{U}$ & $1.4 \mathrm{U}$ & $1.5 \mathrm{U}$ & $1.3 \mathrm{U}$ \\
\hline Aldrin & 16.1 & 15.8 & 14.9 & 13.3 & 14.2 \\
\hline Heptachlor Epoxide & $1.0 \mathrm{U}$ & $0.94 \mathrm{U}$ & $1.0 \mathrm{U}$ & $1.1 \mathrm{U}$ & $0.97 \mathrm{U}$ \\
\hline 2,4'-DDE & $2.0 \mathrm{U}$ & $1.87 \mathrm{U}$ & $2.0 \mathrm{U}$ & $2.1 \mathrm{U}$ & $1.9 \mathrm{U}$ \\
\hline Endosulfan I & $1.4 U$ & $1.3 U$ & $1.4 U$ & $1.5 \mathrm{U}$ & $1.3 \mathrm{U}$ \\
\hline$\alpha$-Chlordane & 5.8 & 6.2 & 6.1 & 6.8 & 6.0 \\
\hline Trans Nonachlor & 1.8 & 1.9 & $1.2 U$ & $1.2 \mathrm{U}$ & $1.0 \mathrm{U}$ \\
\hline 4,4'-DDE & 38.2 & 35.5 & 57.5 & 55.7 & 52.8 \\
\hline Dieldrin & 13.6 & 6.5 & 15.6 & 10.0 & 14.1 \\
\hline 2,4'-DDD & 8.46 & $1.8 \mathrm{U}$ & 9.42 & $2.0 \mathrm{U}$ & 9.25 \\
\hline 2,4'-DDT & $1.4 \mathrm{U}$ & $1.3 \mathrm{U}$ & $1.4 U$ & $1.5 \mathrm{U}$ & $1.3 \mathrm{U}$ \\
\hline 4,4'-DDD & 18.6 & 14.7 & 29.8 & 22.8 & 25.7 \\
\hline Endosulfan II & $1.4 U$ & $1.3 U$ & .1 .2 & 4.1 & 1.8 \\
\hline 4,4'-DDT & $1.2 U$ & 11.9 & $1.2 \mathrm{U}$ & 11.5 & 10.4 \\
\hline Endosulfan Sulfate & $1.9 U$ & $1.8 \mathrm{U}$ & $.1 .9 \mathrm{U}$ & $2.0 \mathrm{U}$ & $1.9 \mathrm{U}$ \\
\hline PCB 8 & $2.7 \mathrm{U}$ & $2.5 \mathrm{U}$ & $-2.7 U$ & $2.8 \mathrm{U}$ & 6.6 \\
\hline PCB 18 & 16.8 & 22.9 & 43.2 & 42.0 & 46.8 \\
\hline РСВ 28 & 51.9 & 48.1 & 52.4 & 51.7 & 58.7 \\
\hline PCB 52 & 47.5 & 50.1 & 61.5 & 57.2 & 58.4 \\
\hline РCB 49 & 35.2 & 35.8 & 34.0 & 29.3 & 32.8 \\
\hline РСB 44 & 23.1 & 22.4 & 33.5 & 25.9 & 30.1 \\
\hline PCB 66 & 55.4 & 52.7 & 61.0 & 51.9 & 58.1 \\
\hline PCB 101 & 37.6 & 37.6 & 40.0 & 36.6 & 36.0 \\
\hline РCB 87 & 10.3 & 8.42 & 13.3 & 11.9 & 12.1 \\
\hline PCB 118 & 26.5 & 26.0 & 29.9 & 26.6 & 27.5 \\
\hline PCB 184 & $1.4 \mathrm{U}$ & $1.3 U$ & $1.4 \mathrm{U}$ & $1.5 \mathrm{U}$ & $1.3 \mathrm{U}$ \\
\hline РCB 153 & 25.9 & 24.6 & 22.7 & 21.5 & 20.6 \\
\hline РСВ 105 & 8.62 & 8.42 & 10.8 & $1.4 \mathrm{U}$ & 10.0 \\
\hline РCB 138 & 19.1 & 18.1 & 18.9 & 17.4 & 17.5 \\
\hline РCB 187 & 6.1 & 5.8 & 5.0 & 4.6 & 4.5 \\
\hline РCB 183 & $1.4 \mathrm{U}$ & 2.4 & $1.44 \mathrm{U}$ & 2.4 & 2.8 \\
\hline РCB 128 & 3.2 & 3.2 & 3.3 & 3.2 & 3.1 \\
\hline РCB 180 & 6.2 & 5.5 & 5.5 & 4.9 & 5.0 \\
\hline РСВ 170 & 2.7 & 1.9 & 1.8 & $1.5 \mathrm{U}$ & 1.8 \\
\hline РCB 195 & $1.0 \mathrm{U}$ & $0.86 \mathrm{U}$ & $1.0 \mathrm{U}$ & $1.1 \mathrm{U}$ & $0.90 \mathrm{U}$ \\
\hline РCВ 206 & $1.6 \mathrm{U}$ & $1.5 \mathrm{U}$ & $1.5 \mathrm{U}$ & $1.7 \mathrm{U}$ & $1.6 \mathrm{U}$ \\
\hline PCB 209 & $1.5 \mathrm{U}$ & $1.4 \mathrm{U}$ & $1.4 \mathrm{U}$ & $1.6 \mathrm{U}$ & $1.5 \mathrm{U}$ \\
\hline
\end{tabular}


Table F.6. (contd)

Concentration ( $\mu \mathrm{g} / \mathrm{kg}$ dry $w t)$

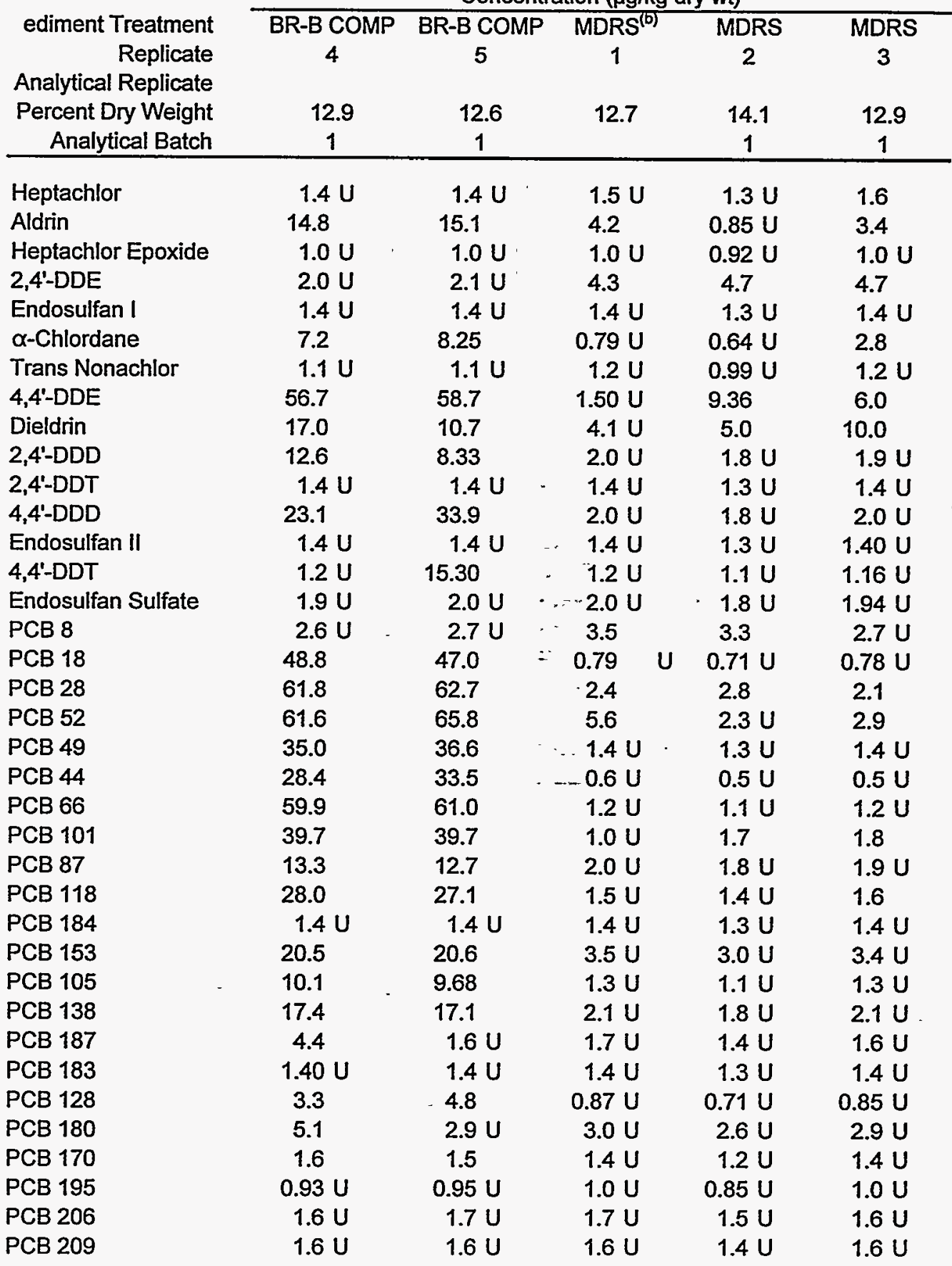


Table F.6. (contd)

\begin{tabular}{|c|c|c|c|}
\hline \multirow{4}{*}{$\begin{array}{r}\text { Sediment Treatment } \\
\text { Replicate } \\
\text { Analytical Replicate }\end{array}$} & \multicolumn{3}{|c|}{ Concentration $(\mu \mathrm{g} / \mathrm{kg}$ dry $w t)$} \\
\hline & MDRS & MDRS & Macoma Bkgd. Tissue \\
\hline & 4 & 5 & 1 \\
\hline & & & \\
\hline Percent Dry Weight & 12.5 & 12.7 & 14.4 \\
\hline Analytical Batch & 1 & 1 & 1 \\
\hline Heptachlor & $1.5 \mathrm{U}$ & $1.6 \mathrm{U}$ & $1.3 U$ \\
\hline Aldrin & $1.0 \mathrm{U}$ & 4.5 & $0.83 \mathrm{U}$ \\
\hline Heptachlor Epoxide & $1.0 \mathrm{U}$ & $1.1 \mathrm{U}$ & $0.90 \mathrm{U}$ \\
\hline 2,4'-DDE & $2.1 \mathrm{U}$ & $2.2 \mathrm{U}$ & $1.81 \mathrm{U}$ \\
\hline Endosulfan I & $1.4 \mathrm{U}$ & $1.5 \mathrm{U}$ & $1.3 \mathrm{U}$ \\
\hline$\alpha$-Chlordane & $0.80 \mathrm{U}$ & 3.9 & $0.63 \mathrm{U}$ \\
\hline Trans Nonachlor & $1.2 U$ & $1.2 \mathrm{U}$ & $0.97 \mathrm{U}$ \\
\hline 4,4'-DDE & 6.8 & 7.1 & $1.3 \mathrm{U}$ \\
\hline Dieldrin & $4.2 U$ & 5.7 & 6.7 \\
\hline 2,4'-DDD & $2.0 \mathrm{U}$ & $2.1 \mathrm{U}$ & $1.7 \mathrm{U}$ \\
\hline $2,4^{\prime}-\mathrm{DDT}$ & $1.4 \mathrm{U}$ & $1.5 \mathrm{U}$ & $1.3 U$ \\
\hline 4,4'-DDD & $2.1 \mathrm{U}$ & $2.2 \mathrm{U}$ & $1.8 \mathrm{U}$ \\
\hline Endosulfan II & $1.4 \mathrm{U}$ & $1.5 \mathrm{U}$ & $1.3 U$ \\
\hline 4,4'-DDT & $1.2 \mathrm{U}$ & $1.3 \mathrm{U}$ & $1.0 \mathrm{U}$ \\
\hline Endosulfan Sulfate & $2.0 \mathrm{U}$ & $2.1 \mathrm{U}$ & $1.7 \mathrm{U}$ \\
\hline PCB 8 & $2.8 \mathrm{U}$ & 5.3 & $2.4 U$ \\
\hline РCB 18 & $0.80 \mathrm{U}$ & $0.87 U$ & $0.69 \mathrm{U}$ \\
\hline РCB 28 & $0.88 \mathrm{U}$ & $0.94 \mathrm{U}$ & $0.76 \mathrm{U}$ \\
\hline РCB 52 & $2.6 \mathrm{U}$ & 4.1 & $2.2 \mathrm{U}$ \\
\hline РCB 49 & $1.4 \mathrm{U}$ & $1.5 \mathrm{U}$ & $1.3 \mathrm{U}$ \\
\hline PCB 44 & $0.6 \mathrm{U}$ & $0.6 U$ & $0.5 U$ \\
\hline PCB 66 & $1.2 U$ & $1.3 \mathrm{U}$ & $1.0 \mathrm{U}$ \\
\hline РСВ 101 & $1.0 \mathrm{U}$ & 1.9 & $0.90 \mathrm{U}$ \\
\hline PCB 87 & $2.0 \mathrm{U}$ & $2.1 U$ & $1.7 \mathrm{U}$ \\
\hline РСВ 118 & $1.5 \mathrm{U}$ & $1.6 \mathrm{U}$ & $1.3 \mathrm{U}$ \\
\hline РCB 184 & $1.4 \mathrm{U}$ & $1.5 \mathrm{U}$ & $1.3 \mathrm{U}$ \\
\hline РСВ 153 & $3.5 \mathrm{U}$ & $3.6 \mathrm{U}$ & $3.0 \mathrm{U}$ \\
\hline PCB 105 & $1.4 \mathrm{U}$ & $1.4 \mathrm{U}$ & $1.1 \mathrm{U}$ \\
\hline PCB 138 & $2.2 \mathrm{U}$ & 2.3 & $1.8 \mathrm{U}$ \\
\hline PCB 187 & $1.7 \mathrm{U}$ & $1.7 U$ & $1.4 \mathrm{U}$ \\
\hline PCB 183 & $1.4 \mathrm{U}$ & $1.5 \mathrm{U}$ & $1.3 \mathrm{U}$ \\
\hline PCB 128 & $0.88 \mathrm{U}$ & $0.87 \mathrm{U}$ & $0.69 \mathrm{U}$ \\
\hline PCB 180 & $3.0 \mathrm{U}$ & $3.1 \mathrm{U}$ & $2.6 \mathrm{U}$ \\
\hline PCB 170 & $1.4 \mathrm{U}$ & $1.5 U$ & $1.2 \mathrm{U}$ \\
\hline PCB 195 & $1.0 \mathrm{U}$ & $1.0 \mathrm{U}$ & $0.83 U$ \\
\hline PCB 206 & $1.7 \mathrm{U}$ & $1.7 \mathrm{U}$ & $1.5 \mathrm{U}$ \\
\hline РСВ 209 & $1.6 \mathrm{U}$ & $1.6 \mathrm{U}$ & $1.4 \mathrm{U}$ \\
\hline
\end{tabular}

(a) U Undetected at or above given concentration.

(b) MDRS Mud Dump Reference Site. 
Table F.7. Quality Control Data for Pesticide and Polychlorinated Biphenyl (PCB) Analysis of $M$. nasuta Tissue (Wet Weight)

\begin{tabular}{|c|c|c|c|c|c|}
\hline \multirow{2}{*}{$\frac{\text { Matrix Spike Results }}{\text { Sediment Treatment }}$} & \multicolumn{4}{|c|}{ Concentration ( $\mu \mathrm{g} / \mathrm{kg}$ wet wt) } & \multirow{5}{*}{$\begin{array}{l}\text { Percent } \\
\text { Recovery }\end{array}$} \\
\hline & \multirow{3}{*}{$\begin{array}{c}\mathrm{RH} \mathrm{COMP}^{(\mathrm{a})} \\
3 \\
1\end{array}$} & \multirow{3}{*}{$\begin{array}{c}\text { RH COMP (MS) } \\
3 \\
1\end{array}$} & \multicolumn{2}{|c|}{ Concentration } & \\
\hline Replicate & & & Spiked & Recovered & \\
\hline Analytical Replicate & & & & & \\
\hline Analytical Batch & 1 & 1 & 1 & & \\
\hline Heptachlor & $0.26 U^{(b)}$ & 3.45 & 3.30 & 3.45 & 105 \\
\hline Aldrin & 1.89 & 4.53 & -3.30 & 2.64 & 80 \\
\hline Heptachlor Epoxide & $0.19 U$ & 2.90 & 3.30 & 2.90 & 88 \\
\hline $2,4^{\prime}-D D E$ & $0.37 \mathrm{U}$ & $N A^{(c)}$ & $N S^{(d)}$ & NA & NA \\
\hline Endosulfan I & 0.59 & 3.28 & 3.30 & 2.69 & 82 \\
\hline$\alpha$-Chlordane & 0.30 & 2.94 & NS & NA & NA \\
\hline Trans Nonachlor & $0.20 \mathrm{U}$ & NA & NS & NA & NA \\
\hline 4,4'-DDE & 3.56 & 5.20 & 3.30 & 1.64 & 50 \\
\hline Dieldrin & 1.74 & 4.48 & 3.30 & 2.74 & 83 \\
\hline 2,4'-DDD & 1.46 & NA & NS & NA & NA \\
\hline 2,4'-DDT & $0.25 \mathrm{U}$ & NA & NS & NA & NA \\
\hline 4,4-DDD & 1.89 & 5.89 & 3.30 & 4.00 & $121^{(e)}$ \\
\hline Endosulfan II & $0.25 \mathrm{U}$ & 3.21 & 3.30 & 3.21 & 97 \\
\hline 4,4'-DDT & 1.45 & 3.49 & 3.30 & 2.04 & 62 \\
\hline Endosulfan Sulfate & $0.35 \mathrm{U}$ & 3.25 & 3.30 & 3.25 & 98 \\
\hline PCB 8 & $0.49 \mathrm{U}$ & NA & NS & NA & NA \\
\hline РCB 18 & 4.69 & 3.81 & NS & NA & NA \\
\hline РCB 28 & 6.86 & 12.5 & 4.21 & 5.64 & $134^{(e)}$ \\
\hline РСВ 52 & 6.40 & 15.1 & 8.78 & 8.70 & 99 \\
\hline РСВ 49 & 3.86 & 3.21 & NS & NA & NA \\
\hline РCB 44 & $0.10 U$ & NA & NS & NA & NA \\
\hline РСВ 66 & 5.87 & 4.89 & NS & NA & NA \\
\hline PCB 101 & 3.39 & 9.03 & 5.96 & 5.64 & 95 \\
\hline РСВ 87 & 1.21 & 0.95 & NS & NA & NA \\
\hline PCB 118 & 2.38 & 2.08 & NS & NA & NA \\
\hline PCB 184 & $0.26 \mathrm{U}$ & NS & NS & NA & NA \\
\hline PCB 153 & 1.54 & 5.41 & 3.48 & 3.87 & 111 \\
\hline РCB 105 & 1.22 & 1.12 & NS & NA & NA \\
\hline PCB 138 & 1.35 & 4.45 & 2.69 & 3.10 & 115 \\
\hline РCB 187 & $0.29 \mathrm{U}$ & NS & NS & NA & NA \\
\hline РCB 183 & $0.26 \mathrm{U}$ & NS & NS & NA & NA \\
\hline РCB 128 & 0.27 & 0.26 . & NS & NA & NA \\
\hline PCB 180 & $0.53 \mathrm{U}$ & NS & NS & NA & NA \\
\hline PCB 170 & $0.25 \mathrm{U}$ & NS & NS & NA & NA \\
\hline РCB 195 & $0.18 U$ & NS & NS & NA & NA \\
\hline PCB 206 & $0.21 \mathrm{U}$ & NS & NS & NA & NA \\
\hline РCB 209 & $0.20 \mathrm{U}$ & NS & NS & NA & NA \\
\hline \multicolumn{6}{|l|}{ Surrogate Recoveries (\%) } \\
\hline PCB 103 (SIS) & 75 & 81 & NA & NA & NA \\
\hline РСВ 198 (SIS) & 67 & 69 & NA & NA & NA \\
\hline
\end{tabular}


Table F.7. (contd)

\begin{tabular}{|c|c|c|c|c|c|}
\hline \multirow{3}{*}{$\begin{array}{r}\text { Matrix Spike Results } \\
\text { Sediment Treatment } \\
\text { Replicate }\end{array}$} & \multicolumn{4}{|c|}{ Concentration ( $\mu \mathrm{g} / \mathrm{kg}$ wet $w t)$} & \multirow{5}{*}{$\begin{array}{l}\text { Percent } \\
\text { Recovery }\end{array}$} \\
\hline & \multirow{3}{*}{$\begin{array}{c}\text { Macoma Bkgd. } \\
1 \\
1\end{array}$} & \multirow{3}{*}{$\begin{array}{c}\text { Macoma Bkgd.(MS) } \\
1 \\
1\end{array}$} & \multicolumn{2}{|c|}{ Concentration } & \\
\hline & & & Spiked & Recovered & \\
\hline Analytical Replicate & & & & & \\
\hline Analytical Batch & 2 & 2 & 2 & & \\
\hline Heptachlor & $0.19 \mathrm{U}$ & 0.50 & 0.472 & 0.50 & 106 \\
\hline Aldrin & $0.13 U$ & 0.78 & 0.472 & 0.78 & $165^{(\theta)}$ \\
\hline Heptachlor Epoxide & $0.13 \mathrm{U}$ & 0.52 & 0.472 & 0.52 & 110 \\
\hline 2,4'-DDE & $0.26 \mathrm{U}$ & 0.63 & 0.472 & 0.63 & $133^{(\theta)}$ \\
\hline Endosulfan I & $0.18 \mathrm{U}$ & $0.18 U$ & NS & NA & NA \\
\hline$\alpha$-Chlordane & $0.10 \mathrm{U}$ & 0.71 & 0.472 & 0.71 & $150^{(e)}$ \\
\hline Trans Nonachlor & $0.15 \mathrm{U}$ & 0.30 & 0.472 & 0.30 & 64 \\
\hline $4,4^{\prime}-\mathrm{DDE}$ & 0.75 & 1.12 & 0.472 & 0.37 & 78 \\
\hline Dieldrin & 0.67 & 0.91 & 0.472 & 0.24 & 51 \\
\hline 2,4'-DDD & $0.25 \mathrm{U}$ & 0.73 & 0.472 & 0.73 & $155^{(\mathrm{e})}$ \\
\hline 2,4'-DDT & $0.18 \mathrm{U}$ & 0.62 & 0.472 & 0.62 & $131^{(e)}$ \\
\hline 4,4'-DDD & 0.79 & 0.87 & 0.472 & 0.08 & $17^{(e)}$ \\
\hline Endosulfan II & $0.18 U$ & $0.18 \mathrm{U}$ & NS & 0.18 & NA \\
\hline 4,4'-DDT & $0.15 \mathrm{U}$ & 0.94 & 0.472 & 0.94 & $199^{(\theta)}$ \\
\hline Endosulfan Sulfate & $0.25 U$ & $0.25 U$ & NS & NA & NA \\
\hline PCB 8 & 0.86 & 1.05 & 0.816 & 0.19 & 23 \\
\hline РСВ 18 & $0.10 \mathrm{U}$ & 1.02 & 0.816 & 1.02 & $125^{(\theta)}$ \\
\hline PCB 28 & $0.11 U$ & 1.38 & 0.816 & 1.38 & $169^{(\theta)}$ \\
\hline PCB 52 & $0.32 U$ & 1.09 & 0.816 & 1.09 & $134^{(\mathrm{e})}$ \\
\hline РСВ 49 & $0.18 \mathrm{U}$ & $0.18 \mathrm{U}$ & NS & NA & NA \\
\hline РСВ 44 & $0.07 \mathrm{U}$ & 2.28 & 0.816 & 2.28 & $279^{(e)}$ \\
\hline РCB 66 & $0.15 \mathrm{U}$ & 1.17 & 0.816 & 1.17 & $143^{(e)}$ \\
\hline PCB 101 & $0.13 U$ & 0.88 & 0.816 & 0.88 & 108 \\
\hline РCB 87 & $0.25 \mathrm{U}$ & 1.10 & 0.816 & 1.10 & $135^{\text {(e) }}$ \\
\hline PCB 118 & $0.19 \mathrm{U}$ & 0.93 & 0.816 & 0.93 & 114 \\
\hline PCB 184 & $0.18 \mathrm{U}$ & $0.18 \mathrm{U}$ & NS & NA & NA \\
\hline PCB 153 & $0.43 \mathrm{U}$ & 0.73 & 0.816 & 0.73 & 89 \\
\hline PCB 105 & $0.16 \mathrm{U}$ & 0.79 & 0.816 & 0.79 & 97 \\
\hline PCB 138 & $0.26 \mathrm{U}$ & 0.81 & 0.816 & 0.81 & 99 \\
\hline РCB 187 & $0.20 \mathrm{U}$ & 0.76 & 0.816 & 0.76 & 93 \\
\hline PCB 183 & $0.18 \mathrm{U}$ & $0.18 U$ & NS & NA & NA \\
\hline PCB 128 & $0.10 \mathrm{U}$ & 0.72 & 0.816 & 0.72 & 88 \\
\hline PCB 180 & $0.37 \mathrm{U}$ & 0.76 & 0.816 & 0.76 & 93 \\
\hline РСB 170 & $0.17 \mathrm{U}$ & 0.70 & 0.816 & 0.70 & 86 \\
\hline PCB 195 & $0.12 \mathrm{U}$ & 0.73 & 0.816 & 0.73 & 89 \\
\hline PCB 206 & $0.21 \mathrm{U}$ & 0.62 & 0.816 & 0.62 & 76 \\
\hline РCB 209 & $0.19 U$ & 0.59 & 0.816 & 0.59 & 72 \\
\hline \multicolumn{6}{|l|}{ Surrogate Recoveries (\%) } \\
\hline PCB 103 (SIS) & 75 & 89 & NA & NA & NA \\
\hline PCB 198 (SIS) & 62 & 73 & NA & NA & NA \\
\hline
\end{tabular}


Table F.7. (contd)

\begin{tabular}{|c|c|c|c|c|}
\hline Analytical Replicates & Cona & ntration $(\mu \mathrm{g} / \mathrm{k}$ & wet wt) & \\
\hline Sediment Treatment & BR-A COMP(a) & BR-A COMI & BR-A COMP & RSD \\
\hline Replicate & 1 & 1 & 1 & $(\%)$ \\
\hline Analytical Replicate & 1 & 2 & 3 & \\
\hline Analytical Batch & 1 & 1 & 1 & \\
\hline Heptachlor & $0.28 \mathrm{U}$ & $0.31 \mathrm{U}$ & $0.31 \mathrm{U}$ & NA \\
\hline Aldrin & 2.20 & 2.06 & 1.92 & 7 \\
\hline Heptachlor Epoxide & $0.20 \mathrm{U}$ & $0.22 \mathrm{U}$ & $0.23 U$ & NA \\
\hline 2,4'-DDE & $0.40 \mathrm{U}$ & $0.43 \mathrm{U}$ & $0.44 \mathrm{U}$ & NA \\
\hline Endosulfan I & $0.28 \mathrm{U}$ & $0.30 \mathrm{U}$ & $0.31 \mathrm{U}$ & NA \\
\hline$\alpha$-Chlordane & 0.77 & 0.93 & 0.70 & 15 \\
\hline Trans Nonachlor & $0.22 U$ & $0.24 U$ & $0.25 U$ & NA \\
\hline 4,4'-DDE & 5.21 & 4.70 & 5.13 & 5 \\
\hline Dieldrin & 1.95 & 1.80 & 1.61 & 10 \\
\hline 2,4'-DDD & $0.39 \mathrm{U}$ & $0.42 \mathrm{U}$ & $0.43 \mathrm{U}$ & NA \\
\hline 2,4'-DDT & $0.28 \mathrm{U}$ & $0.30 \mathrm{U}$ & $0.30 \mathrm{U}$ & NA \\
\hline 4,4'-DDD & 2.11 & 2.02 & 2.38 & 9 \\
\hline Endosulfan î & $0.28 \mathrm{U}$ & $0.30 \mathrm{U}$ & $0.31 \mathrm{U}$ & NA \\
\hline 4,4'-DDT & 1.85 & 1.72 & 2.17 & 12 \\
\hline Endosulfan Sulfate & $0.39 \mathrm{U}$ & $0.42 \mathrm{U}$ & $0.43 \mathrm{U}$ & NA \\
\hline PCB 8 & $0.54 \mathrm{U}$ & 1.03 & $0.60 \mathrm{U}$ & NA \\
\hline РСB 18 & 2.37 & 2.13 & 2.14 & 6 \\
\hline PCB 28 & 5.58 & 5.04 & 4.98 & 6 \\
\hline PCB 52 & 6.20 & 5.39 & 5.03 & 11 \\
\hline PCB 49 & 4.46 & 3.89 & 3.76 & 9 \\
\hline РCB 44 & $0.11 \mathrm{U}$ & $0.12 \mathrm{U}$ & $0.12 \mathrm{U}$ & NA \\
\hline РCB 66 & 6.33 & 5.81 & 5.50 & 7 \\
\hline РCB 101 & 4.57 & 4.00 & 3.85 & 9 \\
\hline РСВ 87 & 0.77 & 0.90 & 0.96 & 11 \\
\hline РСB 118 & 3.40 & 2.79 & 3.07 & 10 \\
\hline РСВ 184 & $0.28 \mathrm{U}$ & $0.31 \mathrm{U}$ & $0.31 \mathrm{U}$ & $\mathrm{NA}$ \\
\hline РСB 153 & 3.46 & 2.70 & 3.20 & 12 \\
\hline РСВ 105 & $0.26 \mathrm{U}$ & $0.28 \mathrm{U}$ & $0.28 \mathrm{U}$ & NA \\
\hline РСВ 138 & 2.48 & 2.02 & 2.29 & 10 \\
\hline РСВ 187 & $0.32 \mathrm{U}$ & 0.41 & $0.35 \mathrm{U}$ & NA \\
\hline РСВ 183 & $0.28 \mathrm{U}$ & $0.31 \mathrm{U}$ & $0.31 \mathrm{U}$ & NA \\
\hline РСВ 128 & $0.16 \mathrm{U}$ & 0.29 & $0.18 \mathrm{U}$ & NA \\
\hline РСВ 180 & 0.69 & $0.62 U$ & 0.70 & NA \\
\hline PCB 170 & 0.31 & $0.29 \mathrm{U}$ & $0.30 U$ & NA \\
\hline PCB 195 & $0.20 \mathrm{U}$ & $0.21 \mathrm{U}$ & $0.22 U$ & NA \\
\hline PCB 206 & $0.21 \mathrm{U}$ & $0.21 \mathrm{U}$ & $0.21 \mathrm{U}$ & NA \\
\hline РСB 209 & $0.20 \mathrm{U}$ & $0.20 \mathrm{U}$ & $0.20 \mathrm{U}$ & NA \\
\hline Surrogate Recoveries (\% & & & & \\
\hline PCB 103 (SIS) & 47 & 74 & 43 & NA \\
\hline PCB 198 (SIS) & 39 & 64 & 35 & NA \\
\hline
\end{tabular}

(a) Sample randomly selected for use as a quality control sample in analytical batch.

(b) U Undetected at or above given concentration.

(c) NA Not applicable.

(d) NS Not spiked.

(e) Outside quality control criteria (50-120\%) for spike recovery. 
Table F.8. Method Detection Limit Verification Study for Pesticides and

Polychlorinated Biphenyls (PCBs) in M. nasuta Tissue

\begin{tabular}{|c|c|c|c|c|c|c|c|}
\hline \multirow[b]{2}{*}{ Sediment Treatment } & \multicolumn{4}{|c|}{ Concentration ( $\mu \mathrm{g} / \mathrm{kg}$ wet wt) } & \multirow{2}{*}{\multicolumn{2}{|c|}{ Standard }} & \multirow[b]{3}{*}{$\mathrm{MDL}^{(\mathrm{a})}$} \\
\hline & $\begin{array}{c}\text { Macoma } \\
\text { Bkgd + Spike }\end{array}$ & $\begin{array}{c}\text { Macoma } \\
\text { Bkgd + Spike }\end{array}$ & $\begin{array}{c}\text { Macoma } \\
\text { Bkgd + Spike }\end{array}$ & $\begin{array}{c}\text { Macoma } \\
\text { Bkgd + Spike }\end{array}$ & & & \\
\hline $\begin{array}{c}\text { Analytical Replicate } \\
\text { Analytical Batch }\end{array}$ & $\begin{array}{l}1 \\
2 \\
\end{array}$ & $\begin{array}{l}2 \\
2 \\
\end{array}$ & $\begin{array}{l}3 \\
2 \\
\end{array}$ & $\begin{array}{r}4 \\
2 \\
\end{array}$ & Mean & Deviation & \\
\hline Heptachlor & 0.38 & 0.50 & 0.52 & 0.53 & 0.48 & 0.07 & 0.32 \\
\hline Aldrin & 0.81 & 0.78 & 0.61 & 0.79 & 0.75 & 0.09 & 0.41 \\
\hline Heptachlor Epoxide & 0.59 & 0.52 & 0.56 & 0.56 & 0.56 & 0.03 & 0.14 \\
\hline $2,4^{\prime}-\mathrm{DDE}$ & 0.87 & 0.63 & 0.83 & 0.83 & 0.79 & 0.11 & 0.50 \\
\hline Endosulfan I & $N D^{(b)}$ & ND & ND & ND & $N A^{(c)}$ & NA & NA \\
\hline a-Chlordane & 0.56 & 0.71 & 0.43 & 0.56 & 0.57 & 0.11 & 0.50 \\
\hline Trans Nonachlor & 0.28 & 0.30 & 0.31 & 0.31 & 0.30 & 0.01 & 0.05 \\
\hline 4,4'-DDE & 1.02 & 1.12 & 1.25 & 1.13 & 1.13 & 0.09 & 0.41 \\
\hline Dieldrin & 0.97 & 0.91 & 1.67 & 1.44 & 1.25 & 0.37 & 1.68 \\
\hline 2,4'-DDD & 0.68 & 0.73 & 0.55 & 0.57 & 0.63 & 0.09 & 0.41 \\
\hline 2,4'-DDT & 0.61 & 0.62 & 0.69 & 0.64 & 0.64 & 0.04 & 0.18 \\
\hline 4,4'-DDD & 0.93 & 0.87 & 0.94 & 1.00 & 0.94 & 0.05 & 0.23 \\
\hline Endsulfan II & ND & ND & ND & ND & NA & NA & NA \\
\hline 4,4'-DDT & 1.01 & 0.94 & 0.90 & 0.95 & 0.95 & 0.05 & 0.23 \\
\hline Endosulfan Sulfate & ND & ND & ND & ND & NA & NA & NA \\
\hline PCB 8 & 1.11 & 1.05 & 1.56 & 1.08 & 1.20 & 0.24 & 1.09 \\
\hline РСВ 18 & 1.05 & 1.02 & 1.04 & 1.06 & 1.04 & 0.02 & 0.09 \\
\hline РСB 28 & 1.13 & 1.38 & 1.37 & 1.53 & 1.35 & 0.17 & 0.77 \\
\hline РСB 52 & 1.07 & 1.09 & 0.84 & 0.95 & 0.99 & 0.12 & 0.54 \\
\hline РСВ 49 & ND & ND & 0.19 & ND & NA & NA & NA \\
\hline РСВ 44 & 1.90 & 2.28 & 2.31 & 2.04 & 2.13 & 0.20 & 0.91 \\
\hline РСВ 66 & 1.19 & 1.17 & 1.24 & 1.20 & 1.20 & 0.03 & 0.14 \\
\hline РСB 101 & 0.99 & 0.88 & 0.93 & 0.96 & 0.94 & 0.05 & 0.23 \\
\hline РСВ 87 & 0.84 & 1.10 & 1.19 & 1.09 & 1.06 & 0.15 & 0.68 \\
\hline РСB 118 & 0.99 & 0.93 & 0.94 & 0.91 & 0.94 & 0.03 & 0.14 \\
\hline PCB 184 & ND & ND & ND & ND & NA & NA & NA \\
\hline PCB 153 & 0.78 & 0.73 & 0.77 & 0.69 & 0.74 & 0.04 & 0.18 \\
\hline PCB 105 & 0.85 & 0.79 & 0.84 & 0.81 & 0.82 & 0.03 & 0.14 \\
\hline PCB 138 & 0.88 & 0.81 & 0.83 & 0.80 & 0.83 & 0.04 & 0.18 \\
\hline PCB 187 & 0.87 & 0.76 & 0.77 & 0.75 & 0.79 & 0.06 & 0.27 \\
\hline PCB 183 & ND & ND & ND & ND & NA & NA & NA \\
\hline PCB 128 & 0.68 & 0.72 & 0.65 & 0.64 & 0.67 & 0.04 & 0.18 \\
\hline PCB 180 & 0.81 & 0.76 & 0.76 & 0.78 & 0.78 & 0.02 & 0.09 \\
\hline PCB 170 & 0.76 & 0.70 & 0.73 & 0.69 & 0.72 & 0.03 & 0.14 \\
\hline PCB 195 & 0.73 & 0.73 & 0.77 & 0.74 & 0.74 & 0.02 & 0.09 \\
\hline PCB 206 & 0.69 & 0.62 & 0.67 & 0.64 & 0.66 & 0.03 & 0.14 \\
\hline РСВ 209 & 0.62 & 0.59 & 0.64 & 0.60 & 0.61 & 0.02 & 0.09 \\
\hline
\end{tabular}

(a) Method detection limit calculated by multiplying the standard deviation of the four replicates by Students-t (4.54).

(b) ND Not detected.

(c) NA Not applicable. 
Table F.9. Polynuclear Aromatic Hydrocarbons (PAHs) in Tissue of $M$. nasuta (Wet Weight), Red Hook and Bay Ridge Channels

\begin{tabular}{|c|c|c|c|c|c|}
\hline \multirow{3}{*}{$\begin{array}{r}\text { Sediment Treatment } \\
\text { Replicate }\end{array}$} & \multicolumn{5}{|c|}{ Concentration ( $\mu \mathrm{g} / \mathrm{kg}$ wet wt) } \\
\hline & RH COMP & RH COMP & RH COMP & RH COMP & RH COMP \\
\hline & 1 & 2 & 3 & 4 & 5 \\
\hline \multicolumn{6}{|l|}{ Analytical Replicate } \\
\hline Percent Dry Weight & 14.2 & 13.3 & 12.9 & 12.9 & 16.4 \\
\hline Analytical Batch & 2 & 2 & 1 & 1 & 2 \\
\hline 1,4-Dichlorobenzene $\mathrm{a}^{(\mathrm{a})}$ & $9.73 U^{(b)}$ & $3.62 \mathrm{U}$ & 2.61 & $1.86 U$ & $3.06 \mathrm{U}$ \\
\hline Naphthalene & 14.8 & 9.92 & 7.80 & 4.78 & 6.19 \\
\hline Acenaphthylene & $6.20^{(c)}$ & $3.99^{(c)}$ & 4.00 & $2.77^{(c)}$ & $3.05^{(c)}$ \\
\hline Acenaphthene & 18.9 & 28.3 & 39.5 & 11.5 & 26.0 \\
\hline Fluorene & 31.5 & 31.3 & 48.4 & 18.0 & 35.3 \\
\hline Dibenzothiophene & 35.0 & 28.3 & 41.3 & 20.2 & 32.6 \\
\hline Phenanthrene & 489 & 365 & 601 & 305 & 440 \\
\hline Anthracene & 244 & 182 & 287 & 164 & 217 \\
\hline Fluoranthene & 801 & 609 & 930 & 604 & 637 \\
\hline Pyrene & 1060 & 752 & 1170 & 791 & 806 \\
\hline Benzo[a]anthracene & 711 & 508 & $\ldots 693 \ldots$ & 455 & 518 \\
\hline Chrysene & 757 & 593 & 788 & 524 & 492 \\
\hline Benzo[b]fluoranthene & 271 & 230 & $398^{(d)}$ & $254^{(d)}$ & 194 \\
\hline Benzo[k]fluoranthene & $.81 .4^{(c)}$ & $56.8^{(c)}$ & - (d) & $-^{(d)}$ & $44.8^{(c)}$ \\
\hline Benzo[e]pyrene & 191 & 172 & 227 . & 146 & 140 \\
\hline Benzo[a]pyrene & 269 & 232 & 317 & 202 & 188 \\
\hline Perylene & 33.0 & 29.2 & 35.9 & 22.8 & 24.7 \\
\hline Indeno[123-cd]pyrene & 66.2 & 47.7 & 39.3 & 25.3 & 37.2 \\
\hline Dibenzo[a,h]anthracene & 21.6 & 14.0 & 12.4 & 7.73 & 12.5 \\
\hline Benzo[g,h,i]perylene & 74.0 & 59.7 & 51.3 & 34.2 & 49.0 \\
\hline \multicolumn{6}{|l|}{ Surrogate Recoveries (\%) } \\
\hline d4 1,4-Dichlorobenzene & 95 & 102 & 62 & 45 & 95 \\
\hline d8 Naphthalene & 103 & 119 & 72 & 54 & 112 \\
\hline d10 Acenaphthene & 107 & 132 & 74 & 57 & 121 \\
\hline ḋ12 Chrysene & 122 & $151^{(e)}$ & 73 & 62 & 134 \\
\hline d14 Dibenzo(a,h)anthracene & $168^{(\mathrm{e})}$ & $194^{(\mathrm{e})}$ & 48 & 46 & $181^{(e)}$ \\
\hline
\end{tabular}


Table F.9. (contd)

\begin{tabular}{|c|c|c|c|c|c|}
\hline \multirow[b]{2}{*}{ Sediment Treatment } & \multicolumn{5}{|c|}{ Concentration ( $\mu \mathrm{g} / \mathrm{kg}$ wet wt) } \\
\hline & BR-A COMP & BR-A COMP & BR-A COMP & BR-A COM & BR-A COMP \\
\hline Replicate & 1 & 1 & 1 & 2 & 3 \\
\hline Analytical Replicate & 1 & 2 & 3 & & \\
\hline Percent Dry Weight & 14.0 & 14.0 & 14.0 & 14.2 & 13.0 \\
\hline Analytical Batch & 1 & 1 & 1 & 1 & 1 \\
\hline 1,4-Dichlorobenzene & $2.87 \mathrm{U}$ & $3.09 \mathrm{U}$ & $3.17 \mathrm{U}$ & $1.86 \mathrm{U}$ & $1.83 \mathrm{U}$ \\
\hline Naphthalene & $5.14^{\text {(c) }}$ & $5.82^{(c)}$ & $7.49^{\text {(c) }}$ & 3.23 & $2.98^{(c)}$ \\
\hline Acenaphthylene & $2.35^{(c)}$ & $2.61^{(c)}$ & $2.47^{\text {(c) }}$ & $1.83^{\text {(c) }}$ & $1.67^{\text {(c) }}$ \\
\hline Acenaphthene & $2.01 \mathrm{U}$ & 3.11 & $2.22 \mathrm{U}$ & 2.45 & 2.31 \\
\hline Fluorene & $3.49^{(c)}$ & 3.39 & $2.10 \mathrm{U}$ & $2.64^{(c)}$ & $1.21 \mathrm{U}$ \\
\hline Dibenzothiophene & $2.58^{(\mathrm{c})}$ & $2.41^{\text {(c) }}$ & $2.22^{(c)}$ & 2.27 & $1.96^{(c)}$ \\
\hline Phenanthrene & 14.5 & 13.1 & 14.6 & 11.2 & 10.5 \\
\hline Anthracene & 10.2 & 8.66 & 9.10 & 8.49 & 8.09 \\
\hline Fluoranthene & 72.0 & 62.9 & 64.4 & 67.5 & 55.7 \\
\hline Pyrene & 112 & 99.0 & 104 & 102 & 85.8 \\
\hline Benzo[a]anthracene & 54.6 & 48.5 & 49.1 & 53.7 & 43.2 \\
\hline Chrysene & 72.6 & 62.3 & 65.1 & 65.2 & 52.6 \\
\hline Benzo[b]fluoranthene & $84.0^{(d)}$ & $77.5^{(d)}$ & $78.9^{(d)}$ & $74.3^{(d)}$ & $58.9^{\text {(d) }}$ \\
\hline Benzo[k]fluoranthene & - (d) & - (d) & - (d) & - (d) & - (d) \\
\hline Benzo[e]pyrene & 46.0 & 42.2 & 44.8 & 41.0 & 32.6 \\
\hline Benzo[a]pyrene & 45.7 & 43.0 & 44.1 & 42.5 & 33.8 \\
\hline Perylene & 14.4 & 12.8 & 12.6 & 12.8 & 10.1 \\
\hline Indeno[123-cd]pyrene & 14.0 & 13.8 & 17.4 & 9.53 & 9.44 \\
\hline Dibenzo[a,h]anthracene & $5.25^{(b)}$ & 5.52 & $6.08^{(c)}$ & 3.53 & $3.30^{(c)}$ \\
\hline Benzo[g,h,i]perylene & 16.5 & 17.2 & 19.4 & 12.6 & 11.1 \\
\hline \multicolumn{6}{|l|}{ Surrogate Recoveries (\%) } \\
\hline d4 1,4-Dichlorobenzene & $28^{(e)}$ & 47 & $21^{\text {(e) }}$ & 54 & 32 \\
\hline d8 Naphthalene & 33 & 87 & $26^{(e)}$ & 68 & 37 \\
\hline d10 Acenaphthene & 37 & 61 & 32 & 74 & 41 \\
\hline d12 Chrysene & 39 & 63 & 34 & 74 & 42 \\
\hline d14 Dibenzo(a,h)anthracene & $26^{(e)}$ & 52 & 38 & 38 & $26^{(e)}$ \\
\hline
\end{tabular}


Table F.9. (contd)

\begin{tabular}{|c|c|c|c|c|c|}
\hline \multirow[b]{2}{*}{ Sediment Treatment } & \multicolumn{5}{|c|}{ Concentration ( $\mu \mathrm{g} / \mathrm{kg}$ wet $w t)$} \\
\hline & \multirow{3}{*}{$\begin{array}{c}\text { BR-A COMP } \\
4\end{array}$} & BR-A COMP & BR-B COMP & \multicolumn{2}{|c|}{ BR-B COMP BR-B COMP } \\
\hline Replicate & & 5 & 1 & 2 & 3 \\
\hline \multicolumn{5}{|l|}{ Analytical Replicate } & \\
\hline Percent Dry Weight & 13.0 & 13.9 & 13.9 & 12.3 & 13.4 \\
\hline Analytical Batch & 1 & 1 & 1 & 1 & 1 \\
\hline 1,4-Dichlorobenzene & $1.86 \mathrm{U}$ & $1.83 \mathrm{U}$ & $2.01 \mathrm{U}$ & $1.86 U$ & $1.83 \mathrm{U}$ \\
\hline Naphthalene & 4.81 & $4.05^{(c)}$ & 9.91 & 6.62 & 6.47 \\
\hline Acenaphthylene & $1.96^{(c)}$ & $2.14^{(c)}$ & 5.24 & $3.27^{(c)}$ & $3.53^{(c)}$ \\
\hline Acenaphthene & 2.51 & 2.27 & 59.9 & 30.5 & 49.8 \\
\hline Fluorene & $2.91^{(c)}$ & 3.14 & 50.0 & 30.3 & 43.8 \\
\hline Dibenzothiophene & $2.28^{\text {(c) }}$ & 2.82 & 42.6 & 31.1 & 39.8 \\
\hline Phenanthrene & 12.3 & 15.0 & 376 & 280 & 366 \\
\hline Anthracene & 9.41 & 11.0 & 156 & 124 & 156 \\
\hline Fluoranthene & 71.0 & 81.9 & 438 & 333 & 416 \\
\hline Pyrene & 109 & 126 & 577 & 443 & 550 \\
\hline Benzo[a]anthracene & 55.7 & 62.0 & 257 & 216 & 242 \\
\hline Chrysene & 68.4 & 75.1 & 307 & 247 & 272 \\
\hline Benzo[b]fluoranthene & $58.0-$ & $86.6^{(d)}$ & $176^{(d)}$ & 107 & $149^{(d)}$ \\
\hline Benzo[k]fluoranthene & 20.4 & - (d) & $-(d)$ & 30.1 & .. (d) \\
\hline Benzo[e]pyrene & 43.4 & 47.0 & 100 & 74.4 & 78.2 \\
\hline Benzo[a]pyrene & 44.2 & 47.0 & 135 & 103 & 108 \\
\hline Perylene & 14.7 & 15.3 & 23.2 & 16.5 & 17.8 \\
\hline Indeno[123-cd]pyrene & 10.2 & 12.2 & 17.8 & 16.4 & 12.8 \\
\hline Dibenzo[a,h]anthracene & 3.73 & 4.39 & 5.17 & 4.91 & 4.36 \\
\hline Benzo[g,h,i]perylene & 13.6 & 16.1 & 21.3 & 18.8 & 16.1 \\
\hline \multicolumn{6}{|l|}{ Surrogate Recoveries (\%) } \\
\hline d4 1,4-Dichlorobenzene & 35 & 36 & 52 & 35 & 38 \\
\hline d8 Naphthalene & 42 & 44 & 64 & 41 & 46 \\
\hline d10 Acenaphthene & 46 & 53 & 67 & 45 & 50 \\
\hline d12 Chrysene & 46 & 63 & 66 & 46 & 49 \\
\hline d14 Dibenzo(a,h)anthracene & $25^{(e)}$ & 43 & 31 & $26^{(\mathrm{e})}$ & $23^{(e)}$ \\
\hline
\end{tabular}


Table F.9. (contd)

\begin{tabular}{|c|c|c|c|c|c|}
\hline \multirow[b]{2}{*}{ Sediment Treatment } & \multicolumn{5}{|c|}{ Concentration ( $\mu \mathrm{g} / \mathrm{kg}$ wet $\omega t)$} \\
\hline & BR-B COMP & BR-B COMP & MDRS $^{(i)}$ & MDRS & MDRS \\
\hline Replicate & 4 & 5 & 1 & 2 & 3 \\
\hline \multicolumn{6}{|l|}{ Analytical Replicate } \\
\hline Percent Dry Weight & 12.9 & 12.6 & 12.7 & 14.1 & 12.9 \\
\hline Analytical Batch & 1 & 1 & 1 & 1 & 1 \\
\hline 1,4-Dichlorobenzene & $1.83 U$ & $1.86 \mathrm{U}$ & $1.86 \mathrm{U}$ & $1.83 \mathrm{U}$ & $1.86 \mathrm{U}$ \\
\hline Naphthalene & 10.9 & 5.40 & $2.12^{(c)}$ & $2.63^{(c)}$ & $2.44^{(c)}$ \\
\hline Acenaphthylene & 4.37 & 4.21 & $0.73 \mathrm{U}$ & $0.71 \mathrm{U}$ & $0.73 U$ \\
\hline Acenaphthene & 89.2 & 48.2 & $1.30 \mathrm{U}$ & $1.28 \mathrm{U}$ & $1.30 \mathrm{U}$ \\
\hline Fluorene & 67.0 & 41.3 & $1.24 \mathrm{U}$ & $1.21 \mathrm{U}$ & $1.24 \mathrm{U}$ \\
\hline Dibenzothiophene & 52.9 & 34.2 & $0.50 \mathrm{U}$ & $0.49 \mathrm{U}$ & $0.50 \mathrm{U}$ \\
\hline Phenanthrene & 485 & 335 & $2.56 \mathrm{U}$ & 3.23 & $2.56 U$ \\
\hline Anthracene & 192 & 143 & $2.24 \mathrm{U}$ & $2.19 \mathrm{U}$ & $2.80^{\text {(c) }}$ \\
\hline Fluoranthene & 458 & 377 & $5.36 \mathrm{U}$ & $5.26 \mathrm{U}$ & $5.36 \mathrm{U}$ \\
\hline Pyrene & 603 & 497 & $4.57 \mathrm{U}$ & $4.48 \mathrm{U}$ & $4.57 \mathrm{U}$ \\
\hline Benzo[a]anthracene & 246 & 230 & $1.15^{(c)}$ & 1.91 & $1.26^{(c)}$ \\
\hline Chrysene & 277 & 264 & $2.27 \mathrm{U}$ & 2.29 & $2.27 U$ \\
\hline Benzo[b]fluoranthene & $148^{(d)}$ & 110 & $2.63^{(c)}$ & $3.99^{\text {(d) }}$ & $3.60^{(d)}$ \\
\hline Benzo[k]fluoranthene & $-(d)$ & 25.7 & $1.67 \mathrm{U}$ & - (d) $^{(1)}$ & $-^{\text {(d) }}$ \\
\hline Benzo[e]pyrene & 82.4 & 78.8 & $1.56^{(c)}$ & $2.31^{(c)}$ & $1.87^{(c)}$ \\
\hline Benzo[a]pyrene & 106 & 103 & $1.49 \mathrm{U}$ & $1.56^{(c)}$ & $1.49 \mathrm{U}$ \\
\hline Perylene & 18.3 & 17.6 & $1.40 \mathrm{U}$ & $1.38 \mathrm{U}$ & $1.40 \mathrm{U}$ \\
\hline Indeno[123-cd]pyrene & 17.9 & 14.3 & $1.76 \mathrm{U}$ & $1.73 \mathrm{U}$ & $1.96^{(b)}$ \\
\hline Dibenzo[a,h]anthracene & 5.77 & 4.62 & $1.26 \mathrm{U}$ & $1.24 \mathrm{U}$ & $1.26 U$ \\
\hline Benzo[g,h,i]perylene & 23.8 & 17.3 & $1.40 \mathrm{U}$ & $1.37 \mathrm{U}$ & $1.40 \mathrm{U}$ \\
\hline \multicolumn{6}{|l|}{ Surrogate Recoveries (\%) } \\
\hline d4 1,4-Dichlorobenzene & 57 & 52 & 45 & 47 & 53 \\
\hline d8 Naphthalene & 65 & 67 & 56 & 56 & 67 \\
\hline d10 Acenaphthene & 69 & 79 & 60 & 59 & 70 \\
\hline d12 Chrysene & 67 & 77 & 62 & 58 & 72 \\
\hline d14 Dibenzo(a,h)anthracene & 75 & 41 & 50 & $25^{(\mathrm{e})}$ & 78 \\
\hline
\end{tabular}


Table F.9. (contd)



(a) Target detection limits are $4.0 \mu \mathrm{g} / \mathrm{kg}$ for all analytes.

(b) $U$ Undetected at or above given concentration.

(c) Ion ratio out or confirmation ion not detected.

(d) Benzo(b)fluoranthene is the sum of benzo(b)fluoranthene and benzo(k)fluoranthene.

Benzo(k)fluoranthene is present but could not be quantified due to co-eluting peak.

(e) Outside quality control criteria (30-150\%) for surrogate recovery.

(f) MDRS Mud Dump Reference Site. 
Table F.10. Polynuclear Aromatic Hydrocarbons (PAHs) in Tissue of M. nasuta (Dry Weight), Red Hook and Bay Ridge Channels




Table F.10. (contd)

\begin{tabular}{|c|c|c|c|c|c|}
\hline \multirow[b]{2}{*}{ Sediment Treatment } & \multicolumn{5}{|c|}{ Concentration ( $\mu \mathrm{g} / \mathrm{kg}$ dry $w t)$} \\
\hline & BR-A COMP & BR-A COMP & BR-A COMP & BR-A COMP & BR-A COMP \\
\hline Replicate & 1 & 1 & 1 & 2 & 3 \\
\hline Analytical Replicate & 1 & 2 & 3 & & \\
\hline Percent Dry Weight & 14.0 & 14.0 & 14.0 & 14.2 & 13.0 \\
\hline Analytical Batch & 1 & 1 & 1 & 1 & 1 \\
\hline 1,4-Dichlorobenzene & $20.5 \mathrm{U}$ & $22.1 \mathrm{U}$ & $22.6 \mathrm{U}$ & $13.1 \mathrm{U}$ & $14.1 U$ \\
\hline Naphthalene & $36.7^{(b)}$ & $41.5^{(b)}$ & $53.5^{(b)}$ & 22.8 & $23.0^{(b)}$ \\
\hline Acenaphthylene & $16.8^{(b)}$ & $18.6^{(b)}$ & $17.6^{(\text {b) }}$ & $12.9^{(b)}$ & $12.9^{(b)}$ \\
\hline Acenaphthene & $14.3 \mathrm{U}$ & 22.2 & $15.8 U$ & 17.3 & 17.8 \\
\hline Fluorene & $24.9^{(b)}$ & 24.2 & $15.0 \mathrm{U}$ & $18.6^{(b)}$ & $9.34 \mathrm{U}$ \\
\hline Dibenzothiophene & $18.4^{(b)}$ & $17.2^{\text {(b) }}$ & $15.8^{(b)}$ & 16.0 & $15.1^{(b)}$ \\
\hline Phenanthrene & 104 & 93.2 & 104 & 79.0 & 81.2 \\
\hline Anthracene & 72.9 & 61.8 & 65.0 & 59.9 & 62.5 \\
\hline Fluoranthene & 514 & 449 & 459 & 476 & 430 \\
\hline Pyrene & 802 & 707 & 744 & 717 & 662 \\
\hline Benzo[a]anthracene & 389 & 346 & 350 & 379 & 333 \\
\hline Chrysene & 518 & 444 & 465 & 460 & 406 \\
\hline Benzo[b]fluoranthene & $600^{(c)}$ & $553^{(c)}$ & $563^{(c)}$ & $524^{(c)}$ & $455^{(c)}$ \\
\hline Benzo[k]fluoranthene & $-($ c) & $-(c)$ & $-(c)$ & $-(c)$ & $-(c)$ \\
\hline Benzo[e]pyrene & 328 & 301 & 319 & 289 & 252 \\
\hline Benzo[a]pyrene & 326 & 307 & 315 & 300 & 261 \\
\hline Perylene & 103 & 91.6 & 89.7 & 89.9 & 77.6 \\
\hline Indeno[123-cd]pyrene & 100 & 98.2 & 124 & 67.2 & 72.9 \\
\hline Dibenzo[a,h]anthracene & $37.5^{(b)}$ & 39.4 & $43.4^{(b)}$ & 24.9 & $25.5^{(b)}$ \\
\hline Benzo[g,h,i]perylene & 117 & 123 & 139 & 89.1 & 85.9 \\
\hline
\end{tabular}


Table F.10. (contd)

\begin{tabular}{|c|c|c|c|c|c|}
\hline \multirow{2}{*}{ Sediment Treatment } & \multicolumn{5}{|c|}{ Concentration ( $\mu \mathrm{g} / \mathrm{kg}$ dry wt) } \\
\hline & BR-A COMP & BR-A COMP & BR-B COMP & BR-B COMP & BR-B COMP \\
\hline Replicate & 4 & 5 & 1 & 2 & 3 \\
\hline \multicolumn{6}{|l|}{ Analytical Replicate } \\
\hline Percent Dry Weight & 13.0 & 13.9 & 13.9 & 12.3 & 13.4 \\
\hline Analytical Batch & 1 & 1 & 1 & 1 & 1 \\
\hline 1,4-Dichlorobenzene & $14.3 \mathrm{U}$ & $13.1 \mathrm{U}$ & $14.4 U$ & $15.1 U$ & $13.7 \mathrm{U}$ \\
\hline Naphthalene & 36.9 & $29.1^{\text {(b) }}$ & 71.2 & 53.8 & 48.4 \\
\hline Acenaphthylene & $15.0^{(b)}$ & $15.4^{\text {(b) }}$ & 37.6 & $26.6^{(b)}$ & $26.4^{\text {(b) }}$ \\
\hline Acenaphthene & 19.3 & 16.3 & 430 & 248 & 372 \\
\hline Fluorene & $22.3^{\text {(b) }}$ & 22.5 & 359 & 246 & 328 \\
\hline Dibenzothiophene & $17.5^{(b)}$ & 20.2 & 306 & 253 & 298 \\
\hline Phenanthrene & 94.2 & 108 & 2700 & 2270 & 2740 \\
\hline Anthracene & 72.2 & 78.9 & 1120 & 1010 & 1170 \\
\hline Fluoranthene & 545 & 588 & 3150 & 2700 & 3110 \\
\hline Pyrene & 838 & 904 & 4140 & 3500 & 4110 \\
\hline Benzo[a]anthracene & 428 & 445 & 1840 & 1760 & 1810 \\
\hline Chrysene & 525 & 539 & 2210 & 2000 & 2030 \\
\hline Benzo[b]fluoranthene & 445 & $622^{(c)}$ & $1260^{(c)}$ & 866 & $1110^{(c)}$ \\
\hline Benzo[k]fluoranthene & 157 & $-(c)$ & $-(c)$ & 244 & - (c) \\
\hline Benzo[e]pyrene & 333 & 338 & 721 & 604 & 585 \\
\hline Benzo[a]pyrene & 339 & 337 & 971 & 835 & 804 \\
\hline Perylene & 113 & 110 & 167 & 134 & 133 \\
\hline Indeno[123-cd]pyrene & 78.4 & 87.4 & 128 & 133 & 95.8 \\
\hline Dibenzo[a,h]anthracene & 28.6 & 31.5 & 37.1 & 39.9 & 32.6 \\
\hline Benzo[g,h,i]perylene & 105 & 116 & 153 & 152 & 121 \\
\hline
\end{tabular}


Table F.10. (contd)

\begin{tabular}{|c|c|c|c|c|c|}
\hline \multirow[b]{2}{*}{ Sediment Treatment } & \multicolumn{5}{|c|}{ Concentration ( $\mu \mathrm{g} / \mathrm{kg}$ dry $w t)$} \\
\hline & BR-B COMP & BR-B COMP & MDRS $^{(0)}$ & MDRS & MDRS \\
\hline Replicate & 4 & 5 & 1 & 2 & 3 \\
\hline \multicolumn{6}{|l|}{ Analytical Replicate } \\
\hline Percent Dry Weight & 12.9 & 12.6 & 12.7 & 14.1 & 12.9 \\
\hline Analytical Batch & 1 & 1 & 1 & 1 & 1 \\
\hline 1,4-Dichlorobenzene & $14.1 \mathrm{U}$ & $14.8 \mathrm{U}$ & $14.6 \mathrm{U}$ & $13.0 \mathrm{U}$ & $14.5 \mathrm{U}$ \\
\hline Naphthalene & 84.2 & 42.9 & $16.6^{(\mathrm{b})}$ & $18.7^{(\mathrm{b})}$ & $19.0^{(b)}$ \\
\hline Acenaphthylene & 33.8 & 33.4 & $5.7 \mathrm{U}$ & $5.1 \mathrm{U}$ & $5.7 \mathrm{U}$ \\
\hline Acenaphthene & 689 & 383 & $10.2 \mathrm{U}$ & $9.11 \mathrm{U}$ & $10.1 \mathrm{U}$ \\
\hline Fluorene & 518 & 328 & $9.73 \mathrm{U}$ & $8.61 \mathrm{U}$ & $9.64 \mathrm{U}$ \\
\hline Dibenzothiophene & 409 & 272 & $3.9 \mathrm{U}$ & $3.5 \mathrm{U}$ & $3.9 \mathrm{U}$ \\
\hline Phenanthrene & 3750 & 2660 & $20.1 \mathrm{U}$ & 23.0 & $19.9 \mathrm{U}$ \\
\hline Anthracene & 1480 & 1140 & $17.6 \mathrm{U}$ & $15.6 U$ & $21.8^{(b)}$ \\
\hline Fluoranthene & 3540 & 2990 & $42.1 \mathrm{U}$ & $37.4 \mathrm{U}$ & $41.7 \mathrm{U}$ \\
\hline Pyrene & 4660 & 3950 & $35.9 \mathrm{U}$ & $31.9 \mathrm{U}$ & $35.5 \mathrm{U}$ \\
\hline Benzo[a]anthracene & 1900 & 1820 & $9.03^{\text {(b) }}$ & 13.6 & $9.80^{(b)}$ \\
\hline Chrysene & 2140 & 2090 & $17.8 \mathrm{U}$ & 16.3 & $17.7 \mathrm{U}$ \\
\hline Benzo[b]fluoranthene & $1140^{(c)}$ & 877 & $20.6^{(b)}$ & $28.4^{\text {(c) }}$ & $28.0^{\text {(c) }}$ \\
\hline Benzo[k]fluoranthene & $-^{(c)}$ & 204 & $13.11 \mathrm{U}$ & $-(c)$ & - (c) \\
\hline Benzo[e]pyrene & 637 & 626 & $12.2^{\text {(b) }}$ & $16.4^{(b)}$ & $14.5^{(b)}$ \\
\hline Benzo[a]pyrene & 819 & 819 & $11.7 \mathrm{U}$ & $11.1^{\text {(b) }}$ & $11.6 \mathrm{U}$ \\
\hline Perylene & 141 & 140 & $11.0 \mathrm{U}$ & $9.82 \mathrm{U}$ & $10.9 \mathrm{U}$ \\
\hline Indeno[123-cd]pyrene & 138 & 114 & $13.8 U$ & $12.3 \mathrm{U}$ & $15.2^{(b)}$ \\
\hline Dibenzo[a,h]anthracene & 44.6 & 36.7 & $9.89 \mathrm{U}$ & $8.83 \mathrm{U}$ & $9.80 \mathrm{U}$ \\
\hline Benzo[g,h,i]perylene & 184 & 138 & $11.0 \mathrm{U}$ & $9.75 \mathrm{U}$ & $10.9 U$ \\
\hline
\end{tabular}


Table F.10. (contd)

\begin{tabular}{|c|c|c|c|}
\hline \multirow{3}{*}{$\begin{array}{r}\text { Sediment Treatment } \\
\text { Replicate }\end{array}$} & \multicolumn{3}{|c|}{ Concentration ( $\mu \mathrm{g} / \mathrm{kg} \mathrm{dry} w \mathrm{w})$} \\
\hline & MDRS & MDRS & Macoma Bkgrd. Tissue \\
\hline & 4 & 5 & \\
\hline \multicolumn{4}{|l|}{ Analytical Replicate } \\
\hline Percent Dry Weight & 12.5 & 12.7 & 14.4 \\
\hline Analytical Batch & 1 & 1 & 1 \\
\hline 1,4-Dichlorobenzene & $14.8 \mathrm{U}$ & $15.6 \mathrm{U}$ & $12.7 \mathrm{U}$ \\
\hline Naphthalene & $17.8^{(b)}$ & $21.8^{(b)}$ & $14.6^{(\mathrm{b})}$ \\
\hline Acenaphthylene & $5.8 \mathrm{U}$ & $6.0 \mathrm{U}$ & $4.9 \mathrm{U}$ \\
\hline Acenaphthene & $10.4 \mathrm{U}$ & $10.8 U$ & $8.91 \mathrm{U}$ \\
\hline Fluorene & $9.89 \mathrm{U}$ & $10.3 U$ & $8.42 \mathrm{U}$ \\
\hline Dibenzothiophene & $4.0 \mathrm{U}$ & $4.2 \mathrm{U}$ & $3.4 \mathrm{U}$ \\
\hline Phenanthrene & $20.4 \mathrm{U}$ & $21.3 U$ & $17.5 U$ \\
\hline Anthracene & $17.9 \mathrm{U}$ & $18.6 U$ & $15.2 U$ \\
\hline Fluoranthene & $42.7 \mathrm{U}$ & $44.7 \mathrm{U}$ & 37.4 \\
\hline Pyrene & $36.4 \mathrm{U}$ & $38.0 \mathrm{U}$ & $31.2 \mathrm{U}$ \\
\hline Benzo[a]anthracene & $13.2^{\text {(b) }}$ & 14.8 & 10.9 \\
\hline Chrysene & 24.3 & $18.9 \mathrm{U}$ & $15.4 U$ \\
\hline Benzo[b]fluoranthene & $33.0^{(c)}$ & $41.6^{(c)}$ & $21.4^{(c)}$ \\
\hline Benzo[k]fluoranthene & $-(c)$ & $-^{(c)}$ & - (c) \\
\hline Benzo[e]pyrene & $17.9^{(b)}$ & $21.8^{(b)}$ & $10.6 \mathrm{U}$ \\
\hline Benzo[a]pyrene & $15.1^{\text {(b) }}$ & 16.6 & $10.2 U$ \\
\hline Perylene & $11.2 U$ & $11.7 \mathrm{U}$ & $9.60 \mathrm{U}$ \\
\hline Indeno[123-cd]pyrene & $16.3^{(b)}$ & $17.4^{\text {(b) }}$ & $12.9^{\text {(b) }}$ \\
\hline Dibenzo[a,h]anthracene & $10.0 \mathrm{U}$ & $10.5 \mathrm{U}$ & $8.63 \mathrm{U}$ \\
\hline Benzo[g,h,i]perylene & $11.2 \mathrm{U}$ & $22.3^{(b)}$ & $9.53 \mathrm{U}$ \\
\hline
\end{tabular}

(a) U Undetected at or above given concentration.

(b) Ion ratio out or confirmation ion not detected.

(c) Benzo(b)fluoranthene is the sum of benzo(b)fluoranthene and benzo(k)fluoranthene. Benzo(k)fluoranthene is present but could not be quantified due to co-eluting peak.

(d) MDRS Mud Dump Reference Site. 
Table F.11. Quality Control Data for Polynuclear Aromatic Hydrocarbon (PAH) Analysis of $M$. nasuta Tissue (Wet Weight)

\begin{tabular}{|c|c|c|c|c|c|}
\hline \multirow{3}{*}{$\begin{array}{r}\text { Matrix Spike Results } \\
\text { Sediment Treatment } \\
\text { Replicate } \\
\text { Analytical Replicate }\end{array}$} & \multicolumn{4}{|c|}{ Concentration ( $\mu \mathrm{g} / \mathrm{kg}$ wet $w \mathrm{t})$} & \multirow{3}{*}{$\begin{array}{l}\text { Percent } \\
\text { Recovery }\end{array}$} \\
\hline & \multirow{2}{*}{$\begin{array}{c}\mathrm{RH} \mathrm{COMP}^{(\mathrm{a})} \\
3\end{array}$} & \multirow[t]{2}{*}{ RH COMP (MS } & \multicolumn{2}{|c|}{ Concentration } & \\
\hline & & & Spiked & Recovered & \\
\hline Percent Moisture & 74.3 & NA & NA & NA & NA \\
\hline Analytical Batch & 1 & 1 & & & \\
\hline 1,4-Dichlorobenzene & 2.61 & $2.46 U^{(b)}$ & $N S^{(c)}$ & $-N A^{(d)}$ & NA \\
\hline Naphthalene & 7.80 & 42.9 & 33.0 & 35.1 & 106 \\
\hline Acenaphthylene & 4.00 & 38.6 & 33.0 & 34.6 & 105 \\
\hline Acenaphthene & 39.5 & 70.4 & 33.0 & 30.8 & 93 \\
\hline Fluorene & 48.4 & 79.9 & 33.0 & 31.5 & 95 \\
\hline Dibenzothiophene & 41.3 & 35.0 & NS & NA & NA \\
\hline Phenanthrene & 601 & 551 & 33.0 & US $^{(e)}$ & NC ${ }^{(0)}$ \\
\hline Anthracene & 287 & 281 & 33.0 & US & NC \\
\hline Fluoranthene & 930 & 828 & 33.0 & US & NC \\
\hline Pyrene & 1170 & 1030 & 33.0 & US & NC \\
\hline Benzo[a]anthracene & 693 & 622 & 33.0 & US & NC \\
\hline Chrysene & 788 & 717 & 33.0 & US & NC \\
\hline Benzo[b]fluoranthene & $398^{(9)}$ & 308 & $66^{(9)}$ & US & NC \\
\hline Benzo[k]fluoranthene & $-(9)$ & 109 & - $(\mathrm{g})$ & $-(9)$ & - \\
\hline Benzo[e]pyrene & 227 & 197 & NS & NA & NA \\
\hline Benzo[a]pyrene & 317 & 309 & 33.0 & US & NA \\
\hline Perylene & 35.9 & 31.2 & NS & NA & NA \\
\hline Indeno[123-cd]pyrene & 39.3 & 69.1 & 33.0 & 29.8 & 90 \\
\hline Dibenzo[a,h]anthracene & 12.4 & 42.6 & 33.0 & 30.3 & 92 \\
\hline Benzo[g,h,i]perylene & 51.3 & 78.5 & 33.0 & 27.2 & 82 \\
\hline \multicolumn{6}{|l|}{ Surrogate Recoveries (\%) } \\
\hline d4 1,4-Dichlorobenzene & 62 & 54 & NA & NA & NA \\
\hline d8 Naphthalene & 72 & 60 & NA & NA & NA \\
\hline d10 Acenaphthene & 74 & 69 & NA & NA & NA \\
\hline d10 Phenanthene & NA & NA & NA & NA & NA \\
\hline d12 Chrysene & 73 & 72 & NA & NA & NA \\
\hline d12 Perylene & NA & NA & NA & NA & NA \\
\hline d14 Dibenzo(a,h)anthracene & 48 & 48 & NA & NA & NA \\
\hline
\end{tabular}


Table F.11. (contd)

\begin{tabular}{|c|c|c|c|c|c|}
\hline \multirow{3}{*}{$\begin{array}{r}\text { Matrix Spike Results } \\
\text { Sediment Treatment } \\
\text { Replicate } \\
\text { Analytical Replicate }\end{array}$} & \multicolumn{4}{|c|}{ Concentration ( $\mu \mathrm{g} / \mathrm{kg}$ wet wt) } & \multirow{3}{*}{$\begin{array}{l}\text { Percent } \\
\text { Recovery }\end{array}$} \\
\hline & \multirow{3}{*}{$\begin{array}{c}\text { Macoma Bkgd. } \\
1\end{array}$} & \multirow{2}{*}{$\begin{array}{c}\text { Macoma Bkgd. (MS) } \\
1\end{array}$} & \multicolumn{2}{|c|}{ Concentration } & \\
\hline & & & Spiked & Recovered & \\
\hline $\begin{array}{r}\text { Percent Moisture } \\
\text { Analytical Batch }\end{array}$ & & $\begin{array}{c}\text { NA } \\
2\end{array}$ & NA & NA & NA \\
\hline 1,4-Dichlorobenzene & $1.83 \mathrm{U}$ & $1.83 \mathrm{U}$ & NS & NA & NA \\
\hline Naphthalene & 2.32 & 17.8 & 15.6 & 15.5 & 99 \\
\hline Acenaphthylene & $0.71 \mathrm{U}$ & 15.7 & 15.0 & 15.7 & 105 \\
\hline Acenaphthene & $1.28 U$ & 16.8 & 16.2 & 16.8 & 104 \\
\hline Fluorene & $1.21 \mathrm{U}$ & 16.8 & 15.5 & 16.8 & 108 \\
\hline Dibenzothiophene & $0.49 \mathrm{U}$ & $0.49 \mathrm{U}$ & NS & NA & NA \\
\hline Phenanthrene & $2.51 \mathrm{U}$ & 17.4 & 15.6 & 17.4 & 112 \\
\hline Anthracene & $2.19 \mathrm{U}$ & 11.1 & 11.8 & 11.1 & 94 \\
\hline Fluoranthene & $5.26 \mathrm{U}$ & 16.9 & 15.6 & 16.9 & 108 \\
\hline Pyrene & $4.48 \mathrm{U}$ & 15.5 & 15.6 & 15.5 & 99 \\
\hline Benzo[a]anthracene & $1.07 \mathrm{U}$ & 13.4 & 13.5 & 13.4 & 99 \\
\hline Chrysene & $2.22 \mathrm{U}$ & 17.0 & 15.7 & 17.0 & 108 \\
\hline Benzo[b]fluoranthene & 2.19 & 16.6 & 15.6 & 14.4 & 92 \\
\hline Benzo[k]fluoranthene & $1.64 \mathrm{U}$ & 15.2 & 15.5 & 15.2 & 98 \\
\hline Benzo[e]pyrene & $1.52 \mathrm{U}$ & 16.6 & NS & 16.6 & NA \\
\hline Benzo[a]pyrene & 1.61 & 13.8 & 14.0 & 12.2 & 87 \\
\hline Perylene & $1.38 \mathrm{U}$ & 11.5 & NS & 11.5 & NA \\
\hline Indeno[123-cd]pyrene & $1.73 \mathrm{U}$ & 18.9 & 13.8 & 18.9 & $137^{(\mathrm{h})}$ \\
\hline Dibenzo[a,h]anthracene & $1.24 U$ & 15.9 & 11.7 & 15.9 & $136^{(h)}$ \\
\hline Benzo[g,h,i]perylene & $1.37 \mathrm{U}$ & 19.1 & 13.9 & 19.1 & $137^{(h)}$ \\
\hline \multicolumn{6}{|l|}{ Surrogate Recoveries (\%) } \\
\hline d4 1,4-Dichlorobenzene & NA & NA & NA & NA & NA \\
\hline d8 Naphthalene & 54 & 62 & NA & NA & NA \\
\hline d10 Acenaphthene & 58 & 66 & NA & NA & NA \\
\hline d10 Phenanthene & 54 & 63 & NA & NA & NA \\
\hline d12 Chrysene & 64 & 76 & NA & NA & NA \\
\hline d12 Perylene & 56 & 65 & NA & NA & NA \\
\hline d14 Dibenzo(a,h)anthracene & 79 & 97 & NA & NA & NA \\
\hline
\end{tabular}


Table F.11. (contd)

\begin{tabular}{|c|c|c|c|c|}
\hline Analytical Replicates & Cone & ation $(\mu \mathrm{g} / \mathrm{kg}$ & & \\
\hline Sediment Treatment & $B R-A^{(a)}$ & BR-A & BR-A & RSD \\
\hline Replicate & 1 & 1 & 1 & $(\%)$ \\
\hline Analytical Replicate & 1 & 2 & 3 & \\
\hline Percent Moisture & 72.0 & NA & NA & NA \\
\hline Analytical Batch & 1 & 1 & 1 & \\
\hline 1,4-Dichlorobenzene & $2.87 \mathrm{U}$ & $3.09 \mathrm{U}$ & $3.17 \mathrm{U}$ & NA \\
\hline Naphthalene & $5.14^{(i)}$ & $5.82^{(i)}$ & $7.49^{(i)}$ & 20 \\
\hline Acenaphthylene & $2.35^{(0)}$ & $2.61^{(i)}$ & $2.47^{(i)}$ & 5 \\
\hline Acenaphthene & $2.01 \mathrm{U}$ & 3.11 & $2.22 U$ & NA \\
\hline Fluorene & $3.49^{(i)}$ & 3.39 & $2.10 \mathrm{U}$ & NA \\
\hline Dibenzothiophene & $2.58^{(i)}$ & $2.41^{(i)}$ & $2.22^{(i)}$ & 7 \\
\hline Phenanthrene & 14.5 & 13.1 & 14.6 & 6 \\
\hline Anthracene & 10.2 & 8.66 & 9.10 & 9 \\
\hline Fluoranthene & 72.0 & 62.9 & 64.4 & 7 \\
\hline Pyrene & 112 & 99.0 & 104 & 6 \\
\hline Benzo[a]anthracene & 54.6 & .. 48.5 . & 49.1 & 7 \\
\hline Chrysene & 72.6 & 62.3 & $65.1^{\circ}$ & 8 \\
\hline Benzo[b]fluoranthene & $84.0^{(9)}$ & $77.5^{(\mathrm{g})}$ & $78.9^{(9)}$ & 4 \\
\hline Benzo[k]fluoranthene & $-(9)$ & - (g) & - (g) & - \\
\hline Benzo[e]pyrene & 46.0 & 42.2 & 44.8 & 4 \\
\hline Benzo[a]pyrene & 45.7 & 43.0 & 44.1 & 3 \\
\hline Perylene & 14.4 & 12.8 & 12.6 & 7 \\
\hline Indeno[123-cd]pyrene & 14.0 & 13.8 & 17.4 & 13 \\
\hline Dibenzo[a,h]anthracene & $5.25^{(i)}$ & 5.52 & $6.08^{(i)}$ & 8 \\
\hline Benzo[g,h,i]perylene & 16.5 & 17.2 & 19.4 & 9 \\
\hline Surrogate Recoveries (\%) & & & & \\
\hline d4 1,4-Dichlorobenzene & $28^{0)}$ & 47 & $21^{(0)}$ & NA \\
\hline d8 Naphthalene & 33 & 87 & $26^{\circ}$ & NA \\
\hline d10 Acenaphthene & 37 & 61 & 32 & NA \\
\hline d10 Phenanthene & NA & NA & NA & NA \\
\hline d12 Chrysene & 39 & 63 & 34 & NA \\
\hline d12 Perylene & NA & NA & NA & NA. \\
\hline d14 Dibenzo(a,h)anthracene & $26^{(0)}$ & 52 & 38 & NA \\
\hline
\end{tabular}

\footnotetext{
(a) Sample randomly selected for use as a quality control sample in analytical batch.

(b) U Undetected at or above given concentration.

(c) NS Not spiked.

(d) NA Not applicable.

(e) US. Under spiked.

(f) NC Not calculated.

(g) Benzo(b)fluoranthene is the sum of benzo(b)fluoranthene and benzo(k)fluoranthene. Benzo(k)fluoranthene is present but could not be quantified due to co-eluting peak.

(h) Outside quality control criteria (50-120\%) for spike recovery.

(i) Ion ratio out or confirmation ion not detected.

(i) Outside quality control criteria (30-150\%) for surrogate recovery.
} 
Table F.12. Method Detection Limit Verification Study for Polynuclear Aromatic Hydrocarbons (PAHs) in $M$. nasuta Tissue

\begin{tabular}{|c|c|c|c|c|c|c|c|}
\hline \multirow{5}{*}{$\begin{array}{r}\text { Sediment Treatment } \\
\text { Analytical Replicate } \\
\text { Analytical Batch }\end{array}$} & \multicolumn{4}{|c|}{ Concentration ( $\mu \mathrm{g} / \mathrm{kg}$ wet $w t)$} & \multirow{5}{*}{ Mean } & & \multirow{5}{*}{$M D L^{(a)}$} \\
\hline & Macoma Bks & Macoma Bk & coma Bks & coma Bkgd. & & & \\
\hline & + Spike & + Spike & + Spike & + Spike & & & \\
\hline & 1 & 2 & 3 & 4 & & \multirow{2}{*}{$\begin{array}{l}\text { Standard } \\
\text { Deviation }\end{array}$} & \\
\hline & 2 & 2 & 2 & 2 & & & \\
\hline 1,4-Dichlorobenzene & $N D^{(b)}$ & ND & ND & ND & $N A^{(c)}$ & NA & NA \\
\hline Naphthalene & 18.8 & 17.8 & 17.9 & 17.9 & 18.1 & 0.47 & 2.13 \\
\hline Acenaphthylene & 14.4 & 15.7 & 15.4 & 15.1 & 15.2 & 0.56 & 2.54 \\
\hline Acenaphthene & 17.6 & 16.8 & 17.4 & 16.8 & 17.2 & 0.41 & 1.86 \\
\hline Fluorene & 16.6 & 16.8 & 16.9 & 16.6 & 16.7 & 0.15 & 0.68 \\
\hline Dibenzothiophene & ND & ND & ND & ND & NA & NA & NA \\
\hline Phenanthrene & 17.7 & 17.4 & 17.6 & 17.3 & 17.5 & 0.18 & 0.82 \\
\hline Anthracene & 11.0 & 11.1 & 11.2 & 11.1 & 11.1 & 0.08 & 0.36 \\
\hline Fluoranthene & 17.4 & 16.9 & 17.4 & 17.9 & 17.4 & 0.41 & 1.86 \\
\hline Pyrene & 16.2 & 15.5 & 15.9 & 16.0 & 15.9 & 0.29 & 1.32 \\
\hline Benzo(a)anthracene & 13.4 & 13.4 & 13.9 & 13.7 & 13.6 & 0.24 & 1.09 \\
\hline Chrysene & 17.4 & 17.0 & 17.0 & 17.0 & 17.1 & 0.20 & 0.91 \\
\hline Benzo(b)fluoranthene & 16.1 & 16.6 & 17.8 & 16.9 & 16.9 & 0.71 & 3.22 \\
\hline Benzo(k)fluoranthene & 14.9 & 15.2 & 16.6 & 15.5 & 15.6 & 0.74 & 3.36 \\
\hline Benzo(e)pyrene & 16.8 & 16.6 & 17.6 & 16.9 & 17.0 & 0.43 & 1.95 \\
\hline Benzo(a)pyrene & 14.0 & 13.8 & 14.3 & 13.8 & 14.0 & 0.24 & 1.09 \\
\hline Perylene & 11.5 & 11.5 & 11.2 & 11.0 & 11.3 & 0.24 & 1.09 \\
\hline Indeno(123-cd)pyrene & 18.6 & 18.9 & 19.8 & 19.4 & 19.2 & 0.53 & 2.41 \\
\hline Dibenzo(a,h)anthracene & 16.3 & 15.9 & 17.0 & 16.3 & 16.4 & 0.46 & 2.09 \\
\hline Benzo(g,h,i)perylene & 18.5 & 19.1 & 20.1 & 19.6 & 19.3 & 0.68 & 3.09 \\
\hline
\end{tabular}

(a) Method detection limit calculated by multiplying the standard deviation of the four replicates by Students-t (4.54).

(b) ND Not detected.

(c) NA Not applicable. 
Table F.13. Lipids in Tissue of M. nasuta

\begin{tabular}{lccc} 
Sample ID & $\begin{array}{c}\text { \% Dry } \\
\text { Weight }\end{array}$ & $\begin{array}{c}\text { \% Lipid } \\
\text { (wet wt) }\end{array}$ & $\begin{array}{c}\text { \% Lipid } \\
\text { (dry wt) }\end{array}$ \\
\hline Macoma Bkgd. Tissue & 15.12 & 0.64 & 4.23 \\
Macoma Bkgd. Tissue & 15.12 & 0.85 & 5.62 \\
Macoma Bkgd. Tissue & 15.12 & 0.63 & 4.17
\end{tabular}


Appendix G.

Quality Assurance/Quality Control Data for Chemical Analyses of Nereis virens Tissues, Red Hook and Bay Ridge Channels 


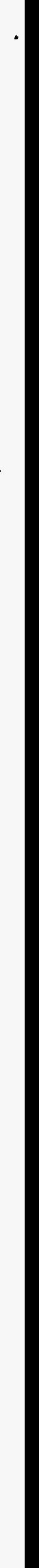


PROGRAM: New.York/New Jersey Red Hook/Bay Ridge Projects

PARAMETER: Metals

LABORATORY: Battelle/Marine Sciences Laboratory, Sequim, Washington

MATRIX: Nereis virens Tissue

\section{QA/QC DATA QUALITY OBJECTIVES}

\begin{tabular}{|c|c|c|c|c|c|}
\hline . & $\begin{array}{c}\text { Reference } \\
\text { Method }\end{array}$ & $\begin{array}{l}\text { Range of } \\
\text { Recovery }\end{array}$ & $\begin{array}{c}\text { SRM } \\
\text { Accuracy }\end{array}$ & $\begin{array}{c}\text { Relative } \\
\text { Precision }\end{array}$ & $\begin{array}{l}\text { Target } \\
\text { Detection Limi } \\
\text { (mg/kg dry wt) }\end{array}$ \\
\hline Arsenic & ICP/MS & $75-125 \%$ & $\leq 20 \%$ & $\leq 20 \%$ & 1.0 \\
\hline Cadmium & ICP/MS & $75-125 \%$ & $\leq 20 \%$ & $\leq 20 \%$ & 0.1 \\
\hline Chromium & ICP/MS & $75-125 \%$ & $\leq 20 \%$ & $\leq 20 \%$ & 0.2 \\
\hline Copper & ICP/MS & $75-125 \%$ & $\leq 20 \%$ & $\leq 20 \%$ & 1.0 \\
\hline Lead & ICP/MS & $75-125 \%$ & $\leq 20 \%$ & $\leq 20 \%$ & 0.1 \\
\hline Mercury & CVAA & $75-125 \%$ & $\leq 20 \%$ & $\leq 20 \%$ & 0.02 \\
\hline Nickel & ICP/MS & $75-125 \%$ & $\leq 20 \%$ & $\leq 20 \%$ & 0.1 \\
\hline Silver & ICP/MS & $75-125 \%$ & $\leq 20 \%$ & $\leq 20 \%$ & 0.1 \\
\hline Zinc & ICP/MS & $75-125 \%$ & $\leq 20 \%$ & $\leq 20 \%$ & 1.0 \\
\hline
\end{tabular}

SAMPLE CUSTODY Twenty-one Nereis virens tissue samples were received on 5/30/95 in good condition, logged into the Battelle system, frozen to $-20^{\circ} \mathrm{C} \pm 10^{\circ} \mathrm{C}$ and subsequently freeze dried within approximately seven days of sample receipt.

METHOD.

Nine (9) metals were analyzed for the New York 4 Program: silver $(\mathrm{Ag})$, arsenic (As), cadmium (Cd), chromium ( $\mathrm{Cr})$, copper $(\mathrm{Cu})$, mercury $(\mathrm{Hg})$, nickel $(\mathrm{Ni})$, lead $(\mathrm{Pb})$ and zinc $(\mathrm{Zn})$. Hg was analyzed using cold-vapor atomic absorption spectroscopy (CVAA) according to the method of Bloom and Crecelius (1983). The remaining metals were analyzed by inductively coupled plasma mass spectrometry (ICP/MS) following a procedure based on EPA method 200.8 (EPA 1991)

To prepare tissue for analysis, samples were freeze-dried and blended in a Spex mixer-mill. Approximately $5 \mathrm{~g}$ of mixed sample was ground in a ceramic ball mill. For ICP/MS and CVAA analyses, $0.2-$ to $0.5-\mathrm{g}$ aliquots of dried homogenous sample were digested using a mixture of nitric acid and hydrogen peroxide following a modified version of EPA Method 200.3 (EPA 1991). 


\section{QA/QC SUMMARY METALS (contd)}

HOLDING TIMES Samples were analyzed within 180 days of collection. Tissue samples were digested in a single batch. The following table summarizes the analysis dates:

\begin{tabular}{ll} 
Task & Worms \\
\hline Sample Digestion & $6 / 14 / 95$ \\
ICP-MS & $7 / 26 / 95$ \\
CVAA-Hg & $6 / 21 / 95$
\end{tabular}

DETECTION LIMITS Target Detection limits were met for all metals except $\mathrm{As}, \mathrm{Cu}, \mathrm{Ni}$ and $\mathrm{Zn}$, however, all sample values for $\mathrm{Cu}, \mathrm{Ni}$ and $\mathrm{Zn}$ were above the achieved method detection limit (MDL). MDLs were determined by spiking seven replicates of the reagent blank and multiplying standard deviation of the resulting analyses by the student $t$ value at the 99th percentile( 3.142).

An MDL verification study was performed by spiking four aliqouts of a background Nereis virens sample with all metals and analyzing them as four

.. separate replicates. The standard deviation of these results were multiplied by 4.54 to determine the method verification detection limit. Target detection limits were exceeded for all metals.

METHOD BLANKS - One procedural blank.was analyzed per 20 samples. No metals were detected in the blanks above the MDLs.

MATRIX SPIKES . . . One sample was spiked with-all metals at a frequency of 1 per 20 samples. All recoveries were within the QC limits of $75 \%$ to $125 \%$.

REPLICATES

SRMs

\section{REFERENCES}

Bloom, N.S., and E.A. Crecelius. 1983. "Determination of Mercury in Seawater at Sub-Nanogram per Liter Levels." Mar. Chem. 14:49-59.

U.S. Environmental Protection Agency (EPA). 1991 Methods for the Determination of Metals in Environmental Samples. EPA-600/4-91-010. Environmental Services Division, Monitoring Management

Branch, Washington D.C. also analyzed in triplicate. Precision for triplicate analyses is reported by calculating the relative standard deviation (RSD) between the replicate results. RSDs were within the QC limits of $\pm 20 \%$ for all metals.

SRM, 1566a (Oyster tissue from the National Institute of Standards and Technology, NIST), was analyzed twice for all metals. Results for all metals were within $\pm 20 \%$ of mean certified value with the exception of $\mathrm{Hg}$ in one replicate and $\mathrm{Ni}$ in two replicates. This may have happened because a total digestion method was not used. 
PROGRAM: $\quad$ New York/New Jersey Red Hook/Bay Ridge Projects

PARAMETER: Chlorinated Pesticides/PCB Congeners

LABORATORY: Battelle/Marine Sciences Laboratory, Sequim, Washington

MATRIX: $\quad$ Nereis virens Tissue

QA/QC DATA QUALITY OBJECTIVES

\begin{tabular}{lccccc}
$\begin{array}{c}\text { Reference } \\
\text { Method }\end{array}$ & $\begin{array}{c}\text { Surrogate } \\
\text { Recovery }\end{array}$ & $\begin{array}{c}\text { MS } \\
\text { Recovery }\end{array}$ & $\begin{array}{c}\text { SRM } \\
\text { Accuracy }\end{array}$ & $\begin{array}{c}\text { Relative } \\
\text { Precision }\end{array}$ & $\begin{array}{c}\text { Target } \\
\text { Detection Limit } \\
\text { (ug/kg wet wt) }\end{array}$ \\
\cline { 1 - 2 } & 30 to $150 \%$ & $30-120 \%$ & $530 \%$ & $530 \%$ & 0.4
\end{tabular}

SAMPLE CUSTODY Twenty-one samples were received on 5/30/95 in good condition, logged into the Battelle system, and stored frozen at $-20^{\circ} \mathrm{C} \pm 10^{\circ} \mathrm{C}$ until extraction.

METHOD Tissues were homogenized-wet using a stainless steel blade. An aliquot of tissue sample was extracted with methylene chloride using the roller technique under ambient conditions following a procedure which is based on methods used by the National Oceanic and Atmospheric Administration for their Status and Trends Program (NOAA 1993). Samples were then cleaned using silica/alumina (5\% deactivated) chromatography followed by HPLC cleanup (NOAA 1993). Extracts were analyzed for 15 chlorinated pesticides and 22 PCB congeners using gas chromatography/electron capture detection (GC/ECD) following a procedure based on EPA method 8080 (EPA 1986). The column used was a J\&W DB-17 and the confirmatory column was a DB1701 , both capillary columns $(30 \mathrm{~m} \times 0.25 \mathrm{~mm}$ l.D.). All detections were quantitatively confirmed on the second column.

HOLDING TIMES Samples were initially extracted in one batch. Due to low surrogate recoveries, three samples were re-extracted in a separate batch. All extracts were analyzed by GC/ECD. The following summarizes the extraction and analysis dates:

\begin{tabular}{|c|c|c|c|}
\hline Batch & Species & Extraction & Analysis \\
\hline 1 & $\vec{N}$. virens & $6 / 5 / 95$ & $6 / 9$ through $6 / 11 / 95$ \\
\hline
\end{tabular}

DETECTION LIMITS Target detection limits of $0.4 \mathrm{ng} / \mathrm{g}$ wet weight were met for most pesticides and PCB congeners. Three samples that were re-extracted due to low initial surrogate recoveries, have higher detection limits for all analytes. These elevated detection limits are due to the limited amount of tissue that was available for re-extraction. Method detection limits (MDLs) reported were determined from multiplying the standard deviation of seven spiked replicates of Nereis virens tissue by the student $t$ value (99 percentile, 3.142). MDLs were reported corrected for individual sample wet weight extracted.

G. $v$ 
QA/QC SUMMARYIPCBS and PESTICIDES (contd)

METHOD BLANKS One method blank was extracted with each extraction batch. No pesticides or PCBs were detected in any of the method blanks.

SURROGATES Two compounds, PCB congeners 103 and 198, were added to all samples prior to extraction to assess the efficiency of the analysis. Sample surrogate recoveries were all within the QC guidelines of $30 \%$ to $150 \%$ with the exception of one sample in Batch 1 involving a high recovery of PCB $198(162 \%)$. This was probably due to matrix interferences with the Internal Standard octachloronaphthalene (OCN), which is used to quantify the recovery of surrogate PCB 198. Since no sample data are corrected for OCN, sample results should not be affected. Sample results were quantified using the surrogate internal standard method.

MATRIX SPIKES Eleven out of the 1.5 pesticides and 5 of the 22 PCB congeners analyzed were spiked into one sample: Matrix spike recoveries were within the quality control range of $50 \%$ to $120 \%$ for all Pesticides and PCBs with the exception of $4,4^{\prime}-\mathrm{DDD}(121 \%)$ and PCB 28 (134\%).

REPLICATES - One sample was analyzed in triplicate. Precision was measured by calculating the relative standard deviation (RSD) among the replicate results. RSDs for all detectable values were below the target precision goal of $\leq 30 \%$.

SRMs

Not available.

MISCELLANEOUS

All pesticide and $\mathrm{PCB}$ congener results are confirmed using a second dissimilar column. RPDs between the primary and confirmation values must be less than $75 \%$ to be considered a confirmed value.

\section{REFERENCES}

NOAA (National Oceanic and Atmospheric Administration). 1993. Sampling and Analytical Methods for the National Status and Trends Program, National Benthic Surveillance and Mussel Watch Projects 1984-1992. Volume IV. Comprehensive Descriptions of Trace Organic Analytical Methods. G.G. Lauenstein and A.Y. Cantillo, eds. NOAA Technical Memorandum NOS ORCA 71. National Oceanic and Atmospheric Administration, Coastal Monitoring and Bioeffects Assessment Division, Office of Ocean Resources Conservation and Assessment, Silver Spring, Maryland.

U.S. Environmental Protection Agency (EPA). 1986. Test Methods for Evaluating Solid Waste:

Physical/Chemical Methods. SW-846. U.S. Document No. 955-001-00000, U.S. EPA, Washington D. C. 
PROGRAM:

PARAMETER:

LABORATORY:

MATRIX:
New York /New Jersey Red Hook/Bay Ridge Projects

Polynuclear Aromatic Hydrocarbons (PAH) and 1,4-Dichlorobenzene

Battelle/Marine Sciences Laboratory, Sequim, Washington

Nereis virens Tissue

\section{QA/QC DATA QUALITY OBJECTIVES}

\begin{tabular}{lccccc}
$\begin{array}{l}\text { Reference } \\
\text { Method }\end{array}$ & $\begin{array}{c}\text { Surrogate } \\
\text { Recovery }\end{array}$ & $\begin{array}{c}\text { MS } \\
\text { Recovery }\end{array}$ & $\begin{array}{c}\text { SRM } \\
\text { Accuracy }\end{array}$ & $\begin{array}{c}\text { Relative } \\
\text { Precision }\end{array}$ & $\begin{array}{c}\text { Target } \\
\text { Detection Limit } \\
\text { (ug/kg wet wt) }\end{array}$ \\
\cline { 1 - 2 } & $50-120 \%$ & $30-150 \%$ & $530 \%$ & $530 \%$ & 4.0
\end{tabular}

SAMPLE CUSTODY Twenty-one samples were received on 5/30/95 in good condition, logged into the Battelle system, and stored frozen at $-20^{\circ} \mathrm{C} \pm 10^{\circ} \mathrm{C}$ until extraction.

METHOD . Tissue samples were extracted with methylene chloride using a roller under ambient - conditions following a procedure which is based on methods used by the National Oceanic and Atmospheric-Administration for their Status and Trends Program (NOAA 1993). Samples were then cleaned using silica/alumina ( $5 \%$ deactivated) chromatography followed by HPLC cleanup.

Extracts were quantified using gas chromatography/mass spectrometry (GC/MS) in the selected ion mode (SIM) following a procedure based on EPA method 8270 (EPA 1986).

HOLDING TIMES

Samples were initially extracted in one batch. Due to low surrogate recoveries, three . samples were re-extracted in a separate batch. All extracts were analyzed by GC/ECD. The following summarizes the extraction and analysis dates:

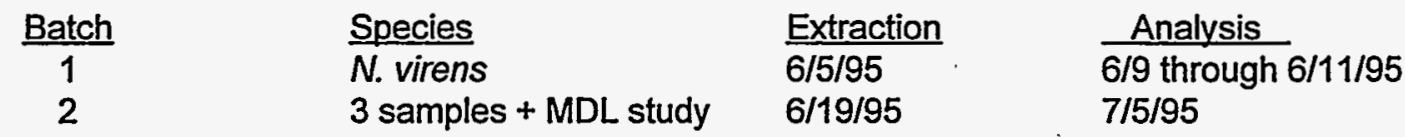

DETECTION LIMITS Target detection limits of $4 \mathrm{ng} / \mathrm{g}$ wet weight were met for all PAH compounds except for fluoranthene and pyrene, which had method detection limits (MDL) between 4 and $6 \mathrm{ng} / \mathrm{g}$ wet weight. MDLs were determined by multiplying the standard deviation of seven spiked replicates of a background Nereis virens sample by the student's t value (99 percentile, 3.142). These MDLs were based on a wet weight of $20 \mathrm{~g}$ of tissue sample. Aliquots of samples that were analyzed in triplicate, used for spiking, or were re-extracted, were generally less than $20 \mathrm{~g}$ due to limited quantities of tissue available. Because MDLs reported are corrected for sample weight, they appear elevated and in some cases may exceed the target detection limit.

In addition, an MDL verification study was performed which consisted of analyzing four spiked aliquots of a background Macoma nasuta sample. The standard deviation of the result of the replicate analysis was multiplied by the student $t$ value (4.54). Detection limits calculated in this way were all less than the target detection limit of $4 \mathrm{ng} / \mathrm{g}$ wet weight.
G. vii 
METHOD BLANKS

SURROGATES

MATRIX SPIKES

REPLICATES -

SRMs

MISCELLANEOUS

\section{REFERENCES}

NOAA (National Oceanic and Atmospheric Administration). 1993. Sampling and Analytical Methods for the National Status and Trends Program, National Benthic Surveillance and Mussel Watch Projects 1984-1992. Volume IV. Comprehensive Descriptions of Trace Organic Analytical Methods. G.G. Lauenstein and A.Y. Cantillo, eds. NOAA Technical Memorandum NOS ORCA 71. National Oceanic and Atmospheric Administration, Coastal Monitoring and Bioeffects Assessment Division, Office of Ocean Resources Conservation and Assessment, Silver Spring, Maryland.

U.S. Environmental Protection Agency (EPA). 1986. Test Methods for Evaluating Solid Waste: Physical/Chemical Methods. SW-846. U.S. Document No. 955-001-00000, EPA, Washington D.C.
One method blank was extracted with each extraction batch. No PAHs were detected in the blanks.

Five isotopically labeled compounds were added prior to extraction to assess the efficiency of the method. These were d8-naphthalene, d10-acenaphthene, d12-chrysene, d14-dibenz[a,h]anthracene and d4-1,4 dichlorobenzene. Recoveries of all surrogates were within the quality control limits of $30 \%$ to $150 \%$ with the exception of $d 4-1,4-$ dichlorobenzene and d8-naphthalene which were recovered below $30 \%$ in the majority of the samples. No additional sample was available for re-extraction, however, since sample results were quantified using the surrogate internal standard method, these low recoveries should not affect the actual results.

One sample was spiked with all PAH compounds. Matrix spike recoveries were within QC limits of $50 \%$ to $120 \%$, with some exceptions. Spike recoveries for a number of $\mathrm{PAH}$ compounds were not calculated due to high native levels, relative to the levels spiked. Spike concentrations were from two to ten times lower than native concentrations. results. All RSDs were within. $\pm 30 \%$ with the exception of naphthalene.

Not available.

Some of the compounds are flagged to indicate that the ion ratio for that compound was outside of the QC range. This is due primarily to low levels of the compound of interest. Because the confirmation ion is present at only a fraction of the level of the parent ion, when-the native levelof the compound is low, the amount of error in the concentration measurement of the confirmation ion goes up. The compound is actually quantified from the parent ion only so most likely this will not affect the quality of the data. For sample values that are relatively high ( $>5$ times the MDL) it may be an indication of some sort of interference.
One sample from each batch was extracted and analyzed in triplicate. Precision was 
Table G.1. Metals in Tissue of N. virens (Wet Weight), Red Hook and Bay Ridge Channels

\begin{tabular}{|c|c|c|c|c|c|c|c|c|c|c|c|c|c|}
\hline \multirow[b]{2}{*}{$\begin{array}{l}\text { Sediment } \\
\text { Treatment }\end{array}$} & \multirow[b]{2}{*}{ Replicate } & \multirow{2}{*}{\multicolumn{2}{|c|}{ Analytical }} & \multirow[b]{2}{*}{$\begin{array}{l}\text { \% Dry } \\
\text { Weight }\end{array}$} & \multicolumn{9}{|c|}{ Concentration ( $\mu \mathrm{g} / \mathrm{g}$ wet wt) } \\
\hline & & & & & $\begin{array}{c}\mathrm{Ag} \\
\text { ICPIMS }\end{array}$ & $\begin{array}{c}\text { As } \\
\text { ICP/MS }\end{array}$ & $\begin{array}{c}\text { Cd } \\
\text { ICPIMS }\end{array}$ & $\begin{array}{c}\mathrm{Cr} \\
\mathrm{ICP} / \mathrm{MS}\end{array}$ & $\begin{array}{c}\mathrm{Cu} \\
\text { ICPMS }\end{array}$ & $\begin{array}{c}\mathrm{Hg} \\
\text { CVAA }\end{array}$ & $\begin{array}{c}\mathrm{Ni} \\
\text { ICPMS }\end{array}$ & $\begin{array}{c}\mathrm{Pb} \\
\text { ICPMS }\end{array}$ & $\begin{array}{c}\mathrm{Zn} \\
\text { ICPMMS }\end{array}$ \\
\hline RH COMP & 1 & & 1 & 14.7 & $0.0323 U^{(a)}$ & 1.92 & 0.0404 & 0.170 & 1.38 & 0.0204 & 0.225 & 0.189 & 13.1 \\
\hline RH COMP & 2 & & 1 & 13.9 & $0.0307 \mathrm{U}$ & 2.33 & 0.0411 & 0.184 & 1.29 & 0.0152 & 0.188 & 0.215 & 26.8 \\
\hline RH COMP & 3 & & 1 & 15.5 & $0.0340 \mathrm{U}$ & 1.99 & 0.0442 & 0.229 & 1.48 & 0.0319 & 0.235 & 0.192 & 20.3 \\
\hline RH COMP & 4 & & 1 & 14.9 & $0.0328 \mathrm{U}$ & 2.52 & 0.0346 & 0.158 & 1.40 & 0.00866 & 0.090 & 0.243 & 64.6 \\
\hline RH COMP & 5 & & 1 & 14.2 & $0.0312 \mathrm{U}$ & 2.02 & 0.0329 & $0.169^{\circ}$ & 1.64 & 0.0209 & 0.232 & 0.197 & 21.7 \\
\hline BR-A COMP & 1 & & 1 & 14.3 & 0.0402 & 2.09 & 0.0317 & 0.146 & 1.27 & 0.00709 & 0.177 & 0.217 & 20.9 \\
\hline BR-A COMP & 2 & & 1 & 14.9 & $0.0327 \mathrm{U}$ & 2.06 & 0.0303 & 0.15 & 1.29 & 0.0157 & 0.159 & 0.160 & 17.5 \\
\hline BR-A COMP & 3 & & 1 & 14.5 & $0.0318 \mathrm{U}$ & 1.82 & 0.0392 & $0.233^{\prime}$ & 1.39 & 0.0140 & 0.214 & 0.205 & 13.9 \\
\hline BR-A COMP & 4 & & 1 & 15.7 & $0.0346 U$ & 2.11 & 0.0344 & 0.175 & 1.37 & 0.0191 & 0.175 & 0.159 & 19.3 \\
\hline BR-A COMP & 5 & 1 & 1 & 15.7 & 0.0352 & 2.39 & 0.0407 & 0.160 & 1.31 & 0.00723 & 0.148 & 0.244 & 13.9 \\
\hline BR-A COMP & 5 & 2 & 1 & 15.7 & $0.0346 \mathrm{U}$ & 2.42 & 0.0533 & 0.159 & 1.34 & 0.00786 & 0.146 & 0.286 & 35.5 \\
\hline BR-A COMP & 5 & 3 & 1 & 15.7 & $0.0346 U$ & 2.33 & 0.0344 & 0.145 & 1.23 & 0.00772 & 0.139 & 0.250 & 19.5 \\
\hline BR-B COMP & 1 & & 1 & 14.3 & $0.0315 \mathrm{U}$ & 1.65 & 0.0402 & 0.179 & 1.41 & 0.0210 & 0.165 & 0.162 & 8.49 \\
\hline BR-B COMP & 2 & & 1 & 13.6 & $0.0300 \mathrm{U}$ & 1.94 & 0.0372 & 0.151 & 1.26 & 0.0167 & 0.210 & 0.211 & 33.6 \\
\hline BR-B COMP & 3 & & 1 & 14.2 & $0.0311 \mathrm{U}$ & 2.12 & 0.0372 & 0.198 & 1.49 & 0.0146 & 0.226 & 0.214 & 25.0 \\
\hline BR-B COMP & 4 & & 1 & 14.6 & $0.0321 \mathrm{U}$ & 1.96 & 0.0406 & 0.175 & 1.33 & 0.0190 & 0.188 & 0.164 & 10.2 \\
\hline BR-B COMP & 5 & & 1 & 15.7 & 0.0392 & 1.97 & 0.0312 & 0.197 & 1.74 & 0.00836 & 0.194 & 0.186 & 23.3 \\
\hline$M^{\prime} S^{(b)}$ & 1 & & 1 & 14.4 & $0.0317 \mathrm{U}$ & 2.24 & 0.0296 & 0.205 & 1.56 & 0.0185 & 0.102 & 0.160 & 16.0 \\
\hline MDRS & 2 & & 1 & 13.5 & $0.0297 \mathrm{U}$ & 2.26 & 0.0366 & 0.180 & 1.29 & 0.0312 & 0.098 & 0.142 & 22.6 \\
\hline MDRS & 3 & & 1 & 15.3 & 0.0370 & 2.03 & 0.0588 & 0.166 & 1.33 & 0.0160 & 0.162 & 0.140 & 12.2 \\
\hline MDRS & 4 & & 1 & 14.1 & $0.0311 \mathrm{U}$ & 2.90 & 0.0297 & 0.157 & 1.33 & 0.0179 & 0.0967 & 0.181 & 19.4 \\
\hline MDRS & 5 & & 1 & 16.2 & $0.0357 \mathrm{U}$ & 3.40 & 0.0438 & 0.172 & 1.52 & 0.0144 & 0.0859 & 0.160 & 8.70 \\
\hline Nereis Bkgd. Tissue & 1 & 1 & 1 & 15.6 & $0.0343 \mathrm{U}$ & 2.65 & 0.0429 & 0.141 & 1.65 & 0.0144 & 0.0833 & 0.112 & 13.0 \\
\hline Nereis Bkgd. Tissue & 1 & 2 & 1 & 15.6 & $0.0343 \mathrm{U}$ & 2.65 & 0.0424 & 0.165 & 1.62 & 0.0145 & 0.0775 & 0.129 & 11.7 \\
\hline Nereis Bkgd. Tissue & 1 & 3 & 1 & 15.6 & $0.0343 \mathrm{U}$ & 2.64 & 0.0495 & 0.175 & 1.62 & 0.0143 & 0.0850 & 0.144 & 9.81 \\
\hline
\end{tabular}

(a) U Undetected at or above given concentration.

(b) MDRS Mud Dump Reference Site. 
Table G.2. Metals in Tissue of N. virens (Dry Weight), Red Hook and Bay Ridge Channels

\begin{tabular}{|c|c|c|c|c|c|c|c|c|c|c|c|c|}
\hline \multirow[b]{2}{*}{$\begin{array}{l}\text { Sediment } \\
\text { Treatment }\end{array}$} & \multirow[b]{2}{*}{ Replicate } & \multirow[b]{2}{*}{ Analytical } & \multirow[b]{2}{*}{$\begin{array}{l}\% \text { Dry } \\
\text { Weight }\end{array}$} & \multicolumn{9}{|c|}{ Concentration $(\mu \mathrm{g} / \mathrm{g}$ dry $w t)$} \\
\hline & & & & $\begin{array}{c}\mathrm{Ag} \\
\text { ICP/MS }\end{array}$ & $\begin{array}{c}\text { As } \\
\text { ICP/MS }\end{array}$ & $\begin{array}{c}C d \\
\text { ICP/MS }\end{array}$ & $\begin{array}{c}\mathrm{Cr} \\
\text { ICP/MS }\end{array}$ & $\begin{array}{c}\mathrm{Cu} \\
\text { ICPIMS }\end{array}$ & $\begin{array}{l}\mathrm{Hg} \\
\text { CVAA } \\
\end{array}$ & $\begin{array}{c}\mathrm{Ni} \\
\text { ICP/MS } \\
\end{array}$ & $\begin{array}{c}\mathrm{Pb} \\
\text { ICP/MS }\end{array}$ & $\begin{array}{c}\mathrm{Zn} \\
\text { ICPIMS }\end{array}$ \\
\hline & & $\begin{array}{l}\text { Target Detectic } \\
\text { Method Detectic }\end{array}$ & $\begin{array}{l}\text { on Limit: } \\
\text { on Limit: }\end{array}$ & $\begin{array}{r}0.1 \\
0.22\end{array}$ & $\begin{array}{r}1.0 \\
0.83\end{array}$ & $\begin{array}{r}0.1 \\
0.081\end{array}$ & $\begin{array}{r}0.2 \\
0.08\end{array}$ & $\begin{array}{r}1.0 \\
1.20\end{array}$ & $\begin{array}{r}0.02 \\
0.0011\end{array}$ & $\begin{array}{r}0.1 \\
0.25\end{array}$ & $\begin{array}{r}0.1 \\
0.08\end{array}$ & $\begin{array}{r}1.0 \\
1.37\end{array}$ \\
\hline RH COMP & 1 & 1 & 14.7 & $0.220 U^{(a)}$ & 13.1 & 0.275 & 1.16 & 9.42 & 0.139 & 1.53 & 1.29 & 89.1 \\
\hline RH COMP & 2 & 1 & 13.9 & $0.220 \mathrm{U}$ & 16.7 & 0.295 & 1.32 & 9.27 & 0.109 & 1.35 & 1.54 & 192 \\
\hline RH COMP & 3 & 1 & 15.5 & $0.220 \mathrm{U}$ & 12.9 & $0: 286$ & 1.48 & 9.58 & 0.206 & 1.52 & 1.24 & 131 \\
\hline RH COMP & 4 & 1 & 14.9 & $0.220 \mathrm{U}$ & 16.9 & 0.232 & 1.06 & 9.39 & 0.0580 & 0.603 & 1.63 & 433 \\
\hline RH COMP & 5 & 1 & 14.2 & $0.220 \mathrm{U}$ & 14.3 & 0.232 & 1:19 & 11.6 & 0.147 & 1.64 & 1.39 & 153 \\
\hline BR-A COMP & 1 & 1 & 14.3 & 0.281 & 14.6 & 0.222 & 1.02 & 8.85 & 0.0496 & 1.24 & 1.52 & 146 \\
\hline BR-A COMP & 2 & 1 & 14.9 & $0.220 \mathrm{U}$ & 13.9 & 0.204 & 0.98 & 8.67 & 0.106 & 1.07 & 1.08 & 118 \\
\hline BR-A COMP & 3 & 1. & 14.5 & $0.220 \mathrm{U}$ & 12.6 & 0.271 & 1.61 & 9.63 & 0.0970 & 1.48 & 1.42 & 96.0 \\
\hline BR-A COMP & 4 & 1 & 15.7 & $0.220 \mathrm{U}$ & 13.4 & 0.219 & 1.11 & 8.74 & 0.121 & 1.11 & 1.01 & 123 \\
\hline BR-A COMP & 5 & 1 & 15.7 & 0.224 & 15.2 & 0.259 & 1.02 & 8.33 & 0.0460 & 0.943 & 1.55 & 89 \\
\hline BR-A COMP & 5 & 1 & 15.7 & $0.220 \mathrm{U}$ & 15.4 & 0.339 & 1.01 & 8.54 & 0.0500 & 0.928 & 1.82 & 226 \\
\hline BR-A COMP & 5 & 1 & 15.7 & $0.220 \mathrm{U}$ & 14.8 & 0.219 & 0.924 & 7.80 & 0.0491 & 0.885 & 1.59 & 124 \\
\hline BR-B COMP & 1 & 1 & 14.3 & $0.220 \mathrm{U}$ & 11.5 & 0.281 & 1.25 & 9.88 & 0.147 & 1.15 & 1.13 & 59.3 \\
\hline BR-B COMP & 2 & 1 & 13.6 & $0.220 \mathrm{U}$ & 14.2 & 0.273 & 1.11 & 9.21 & 0.122 & 1.54 & 1.55 & 246 \\
\hline BR-B COMP & 3 & 1 & 14.2 & $0.220 \mathrm{U}$ & 15.0 & 0.263 & 1.40 & 10.5 & 0.103 & 1.60 & 1.51 & 177 \\
\hline BR-B COMP & 4 & 1 & 14.6 & $0.220 \mathrm{U}$ & 13.4 & 0.278 & 1.20 & 9.11 & 0.130 & 1.29 & 1.12 & 70.1 \\
\hline BR-B COMP & 5 & 1 & 15.7 & 0.250 & 12.6 & 0.199 & 1.26 & 11.1 & 0.0534 & 1.24 & 1.19 & 149 \\
\hline MDRS $S^{(b)}$ & 1 & 1 & 14.4 & $0.220 \mathrm{U}$ & 15.5 & 0.205 & 1.42 & 10.8 & 0.128 & 0.704 & 1.11 & 111 \\
\hline MDRS & 2 & 1 & 13.5 & $0.220 \mathrm{U}$ & 16.7 & 0.271 & 1.33 & 9.57 & 0.231 & 0.723 & 1.05 & 167 \\
\hline MDRS & 3 & 1 & 15.3 & 0.242 & 13.3 & 0.385 & 1.09 & 8.72 & 0.105 & 1.06 & 0.918 & 79.8 \\
\hline MDRS & 4 & 1 & 14.1 & $0.220 \mathrm{U}$ & 20.5 & 0.210 & 1.11 & 9.40 & 0.127 & 0.684 & 1.28 & 137 \\
\hline MDRS & 5 & 1 & 16.2 & $0.220 \mathrm{U}$ & 21.0 & 0.270 & 1.06 & 9.36 & 0.0886 & 0.530 & 0.985 & 53.7 \\
\hline Nereis Bkgd. Tissue & 1 & 1 & 15.6 & $0.220 \mathrm{U}$ & 17.0 & 0.275 & 0.903 & 10.6 & 0.0924 & 0.534 & 0.719 & 83.2 \\
\hline Nereis Bkgd. Tissue & 1 & 2 & 15.6 & $0.220 \mathrm{U}$ & 17.0 & 0.272 & 1.06 & 10.4 & 0.0930 & 0.497 & 0.825 & 75.2 \\
\hline Nereis Bkgd. Tissue & 1 & 3 & 15.6 & $0.220 \mathrm{U}$ & 16.9 & 0.317 & 1.12 & 10.4 & 0.0915 & 0.545 & 0.925 & 62.9 \\
\hline
\end{tabular}

(a) U Undetected at or above given concentration.

(b) MDRS Mud Dump Reference Site. 
Table G.3. Quality Control Summary for Metals in Tissue of N. virens

\begin{tabular}{|c|c|c|c|c|c|c|c|c|c|c|c|}
\hline \multirow[b]{2}{*}{$\begin{array}{l}\text { Sediment } \\
\text { Treatment }\end{array}$} & \multirow[b]{2}{*}{ Replicat } & \multirow[b]{2}{*}{$\begin{array}{c}\text { Analytical } \\
\text { Batch }\end{array}$} & \multicolumn{9}{|c|}{ Concentration ( $\mu \mathrm{g} / \mathrm{g}$ dry $w t)$} \\
\hline & & & $\begin{array}{c}\mathrm{Ag} \\
\text { ICPMS }\end{array}$ & $\begin{array}{c}\text { As } \\
\text { ICP/MS }\end{array}$ & $\begin{array}{c}\text { Cd } \\
\text { ICP/MS }\end{array}$ & $\begin{array}{c}\mathrm{Cr} \\
\text { ICPIMS }\end{array}$ & $\begin{array}{c}\mathrm{Cu} \\
\text { ICPMS }\end{array}$ & $\begin{array}{c}\mathrm{Hg} \\
\text { CVAA } \\
\end{array}$ & $\begin{array}{c}\mathrm{Ni} \\
\text { ICP/MS }\end{array}$ & $\begin{array}{c}\mathrm{Pb} \\
\text { ICP/MS }\end{array}$ & $\begin{array}{c}\mathrm{Zn} \\
\text { ICP/MS }\end{array}$ \\
\hline Blank & 1 & 1 & $0.220 U^{(a)}$ & $0.83 U$ & $0.081 \mathrm{U}$ & $0.08 \mathrm{U}$ & $N A^{(b)}$ & $0.0011 \mathrm{U}$ & $0.25 \mathrm{U}$ & $0.08 U$ & NA \\
\hline Blank & 2 & 1 & $0.220 \mathrm{U}$ & $0.83 \mathrm{U}$ & $0.081 \mathrm{U}$ & $0.08 \mathrm{U}$ & $1.20 \mathrm{U}$ & NA & $0.25 \mathrm{U}$ & $0.08 U$ & $1.37 U$ \\
\hline
\end{tabular}

Matrix Spike Results

\begin{tabular}{|c|c|c|c|c|c|c|c|c|c|c|c|}
\hline Nereis Bkgd. Tiss. & $\operatorname{Mean}^{(c)}$ & 1 & $0.220 \mathrm{U}$ & 17.0 & 0.288 & 1.03 & 10.5 & 0.0923 & 0.525 & 0.823 & 73.8 \\
\hline Nereis Bkgd. Tiss.(MS) & & & 0.95 & 42.8 & 1.19 & 2.07 & 35.6 & 1.02 & 26.8 & 23.9 & 75.6 \\
\hline Concentration Spiked & & & 1.00 & 25.0 & 1.00 & 1.00 & 25.0 & 1.00 & 25.0 & 25.0 & 25.0 \\
\hline Concentration Recovered & & & 0.95 & 25.8 & 0.902 & 1.04 & 25.1 & 0.933 & 26.3 & 23.1 & US ${ }^{(d)}$ \\
\hline Percent Recovery & & & 95 & 103 & 90 & 104 & 100 & 93 & 105 & 92 & NA \\
\hline
\end{tabular}

$\stackrel{9}{\omega}$ Standard Reference Material

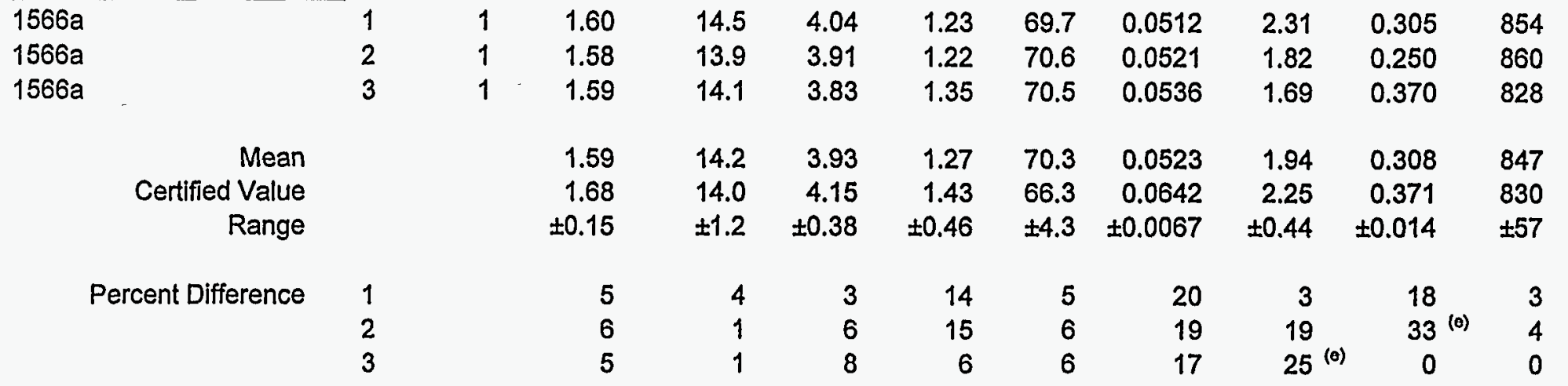


Table G.3. (contd)

\begin{tabular}{|c|c|c|c|c|c|c|c|c|c|c|c|}
\hline \multirow[b]{2}{*}{$\begin{array}{l}\text { Sediment } \\
\text { Treatment }\end{array}$} & \multirow[b]{2}{*}{ Replicat } & \multirow[b]{2}{*}{$\begin{array}{c}\text { Analytical } \\
\text { Batch }\end{array}$} & \multicolumn{9}{|c|}{ Concentration ( $\mu \mathrm{g} / \mathrm{g} \mathrm{dry} w t)$} \\
\hline & & & $\begin{array}{c}\mathrm{Ag} \\
\mathrm{ICP} / \mathrm{MS} \\
\end{array}$ & $\begin{array}{c}\text { As } \\
\text { ICP/MS }\end{array}$ & $\begin{array}{c}\mathrm{Cd} \\
\text { ICPMS } \\
\end{array}$ & $\begin{array}{c}\mathrm{Cr} \\
\text { ICP/MS } \\
\end{array}$ & $\begin{array}{c}\mathrm{Cu} \\
\text { ICP/MS }\end{array}$ & $\begin{array}{c}\mathrm{Hg} \\
\text { CVAA }\end{array}$ & $\begin{array}{c}\mathrm{Ni} \\
\text { ICP/MS }\end{array}$ & $\begin{array}{c}\mathrm{Pb} \\
\text { ICP/MS }\end{array}$ & $\begin{array}{c}\mathrm{Zn} \\
\text { ICP/MS }\end{array}$ \\
\hline \multicolumn{12}{|l|}{ Analytical Replicates } \\
\hline$B R-A^{(1)}$ & 1 & 1 & 0.224 & 15.2 & 0.259 & 1.02 & 8.3 & 0.046 & 0.94 & 1.55 & 89 \\
\hline BR-A & 2 & 1 & $0.220 \mathrm{U}$ & 15.4 & 0.339 & 1.01 & 8.5 & 0.050 & 0.93 & 1.82 & 226 \\
\hline$B R-A$ & 3 & 1 & $0.220 \mathrm{U}$ & 14.8 & 0.219 & 0.924 & 7.8 & 0.049 & 0.89 & 1.59 & 124 \\
\hline RSD (\%) & & & 1 & 2 & $22^{(9)}$ & 5 & 5 & 4 & 3 & 9 & $49^{(g)}$ \\
\hline Nereis Bkgd. Tissue & 1 & 1 & $0.220 \mathrm{U}$ & 17.0 & 0.275 & 0.903 & 10.6 & 0.0924 & 0.534 & 0.719 & 83.2 \\
\hline Nereis Bkgd. Tissue & 2 & 1 & $0.220 \mathrm{U}$ & 17.0 & 0.272 & 1.06 & 10.4 & 0.0930 & 0.497 & 0.825 & 75.2 \\
\hline Nereis Bkgd. Tissue & 3 & 1 & $0.220 \mathrm{U}$ & 16.9 & 0.317 & 1.12 & 10.4 & 0.0915 & 0.545 & 0.925 & 62.9 \\
\hline RSD (\%) & & & 0 & 0 & 9 & 11 & 1 & 1 & 5 & 13 & 14 \\
\hline
\end{tabular}

\footnotetext{
(a) $U$ Undetected at or above given concentration.

(b) NA Not applicable.

(c) Mean of analytical replicates.

(d) US Under spiked.

(e) Outside SRM quality control criteria $(\leq 20 \%)$.

(f) Sample randomly selected for use as a quality control sample in analytical batch

(g) Outside quality control criteria $(\leq 20 \%)$ for replicate analysis.
} 
Table G.4. Pesticides and Polychlorinated Biphenyls (PCBs), Wet Weight, in Tissue of $N$. virens, Red Hook and Bay Ridge Channels

Concentration ( $\mu \mathrm{g} / \mathrm{kg}$ wet $w \mathrm{t})$

\begin{tabular}{|c|c|c|c|c|c|}
\hline \multirow[b]{2}{*}{ Sediment Treatment } & \multicolumn{5}{|c|}{ Concentration ( $\mu \mathrm{g} / \mathrm{kg}$ wet wt) } \\
\hline & RH COMP & RH COMP & RH COMP & RH COMP & RH COMP \\
\hline $\begin{array}{l}\text { Replicate } \\
\text { Analytical Replicate }\end{array}$ & & 1 & 2 & 3 & \\
\hline Percent Dry Wt. (\%) & 14.7 & 13.9 & 13.9 & 13.9 & 15.5 \\
\hline Batch & 1 & 1 & 1 & 1 & 1 \\
\hline Heptachlor ${ }^{(\theta)}$ & $0.25 U^{(b)}$ & $0.28 \mathrm{U}$ & 1.06 & $0.26 U$ & $0.19 \mathrm{U}$ \\
\hline Aldrin & 2.79 & 3.07 & 2.83 & 3.19 & 2.16 \\
\hline Heptachlor Epoxide & $0.18 \mathrm{U}$ & $0.20 \mathrm{U}$ & $0.22 \mathrm{U}$ & $0.18 \mathrm{U}$ & $0.13 \mathrm{U}$ \\
\hline 2,4'-DDE & $0.35 \mathrm{U}$ & $0.40 \mathrm{U}$ & $0.42 \mathrm{U}$ & $0.36 \mathrm{U}$ & $0.26 \mathrm{U}$ \\
\hline Endosulfan I & $0.24 \mathrm{U}$ & $0.28 \mathrm{U}$ & $0.29 \mathrm{U}$ & $0.25 U$ & $0.18 \mathrm{U}$ \\
\hline$\alpha$-Chlordane & 0.90 & 1.01 & 0.97 & 1.00 & 0.72 \\
\hline Trans Nonachlor & $0.19 \mathrm{U}$ & 0.70 & $0.24 \mathrm{U}$ & 0.79 & 0.39 \\
\hline 4, $4^{\prime}-\mathrm{DDE}$ & 3.53 & 3.72 & 3.81 & 3.87 & 2.88 \\
\hline Dieldrin & 1.52 & 1.88 & 1.78 & 1.91 & 1.29 \\
\hline $2,4^{\prime}-\mathrm{DDD}$ & 1.29 & 1.60 & 1.53 & 1.87 & 1.10 \\
\hline 2,4'-DDT & $0.24 \mathrm{U}$ & $0.28 \mathrm{U}$ & $0.29 \mathrm{U}$ & $0.25 \mathrm{U}$ & $0.18 \mathrm{U}$ \\
\hline 4,4'-DDD & 3.01 & 3.58 & 3.33 & 3.58 & 2.77 \\
\hline Endosulfan II & $0.24 U$ & $0.28 U$ & $0.29 \mathrm{U}$ & $0.25 \mathrm{U}$ & $0.18 \mathrm{U}$ \\
\hline 4,4'-DDT & 2.76 & 3.20 & 3.05 & 3.10 & 2.15 \\
\hline Endosulfan Sulfate & $0.34 U$ & $0.39 \mathrm{U}$ & $0.41 \mathrm{U}$ & $0.35 U$ & $0.25 \mathrm{U}$ \\
\hline PCB 8 & $0.47 \mathrm{U}$ & $0.54 \mathrm{U}$ & $0.57 \mathrm{U}$ & $0.49 \mathrm{U}$ & $0.35 \mathrm{U}$ \\
\hline PCB 18 & 11.5 & 11.9 & 11.4 & 15.2 & 11.6 \\
\hline PCB 28 & 7.51 & 8.76 & 7.89 & 9.08 & 6.46 \\
\hline РCB 52 & 10.0 & 11.6 & 11.0 & 12.1 & 8.39 \\
\hline PCB 49 & 4.46 & 5.04 & 4.66 & 5.25 & 3.60 \\
\hline PCB 44 & 5.45 & 6.53 & 9.61 & 6.55 & 5.65 \\
\hline PCB 66 & 7.27 & 7.15 & 6.70 & 7.58 & 5.70 \\
\hline РCB 101 & 5.49 & 5.37 & 5.07 & 5.73 & 4.06 \\
\hline РCB 87 & 0.48 & 0.60 & 0.44 & 0.70 & 0.52 \\
\hline PCB 118 & 3.41 & 3.69 & 3.45 & 4.07 & 2.76 \\
\hline PCB 184 & $0.25 \mathrm{U}$ & $0.28 U$ & $0.30 \mathrm{U}$ & $0.25 \mathrm{U}$ & $0.18 \mathrm{U}$ \\
\hline PCB 153 & 5.86 & 6.02 & 5.67 & 6.69 & 4.13 \\
\hline PCB 105 & 1.36 & 1.40 & 1.33 & 1.68 & 1.13 \\
\hline PCB 138 & 3.65 & 4.30 & 4.00 & 4.64 & 2.91 \\
\hline PCB 187 & 1.97 & 2.09 & 2.20 & 2.43 & 1.48 \\
\hline PCB 183 & 0.69 & 0.71 & 0.66 & $\cdot 0.93$ & 0.58 \\
\hline PCB 128 & $0.14 \mathrm{U}$ & 0.37 & $0.17 \mathrm{U}$ & 0.58 & 0.35 \\
\hline PCB 180 & 1.97 & 2.11 & 2.04 & 2.37 & 1.57 \\
\hline PCB 170 & 0.75 & 0.80 & 0.83 & 1.00 & 0.60 \\
\hline PCB 195 & $0.17 \mathrm{U}$ & $0.20 \mathrm{U}$ & $0.21 \mathrm{U}$ & 0.21 & 0.14 \\
\hline PCB 206 & 0.57 & 0.66 & 0.58 & 0.74 & 0.48 \\
\hline PCB 209 & 0.34 & 0.31 & 0.32 & 0.35 & $0.20 \mathrm{U}$ \\
\hline \multicolumn{6}{|l|}{ Surrogate Recoveries (\%) } \\
\hline PCB 103 (SIS) & 75 & 65 & 48 & 63 & 82 \\
\hline PCB 198 (SIS) & 61 & 56 & 39 & 53 & 74 \\
\hline
\end{tabular}


Table G.4. (contd)

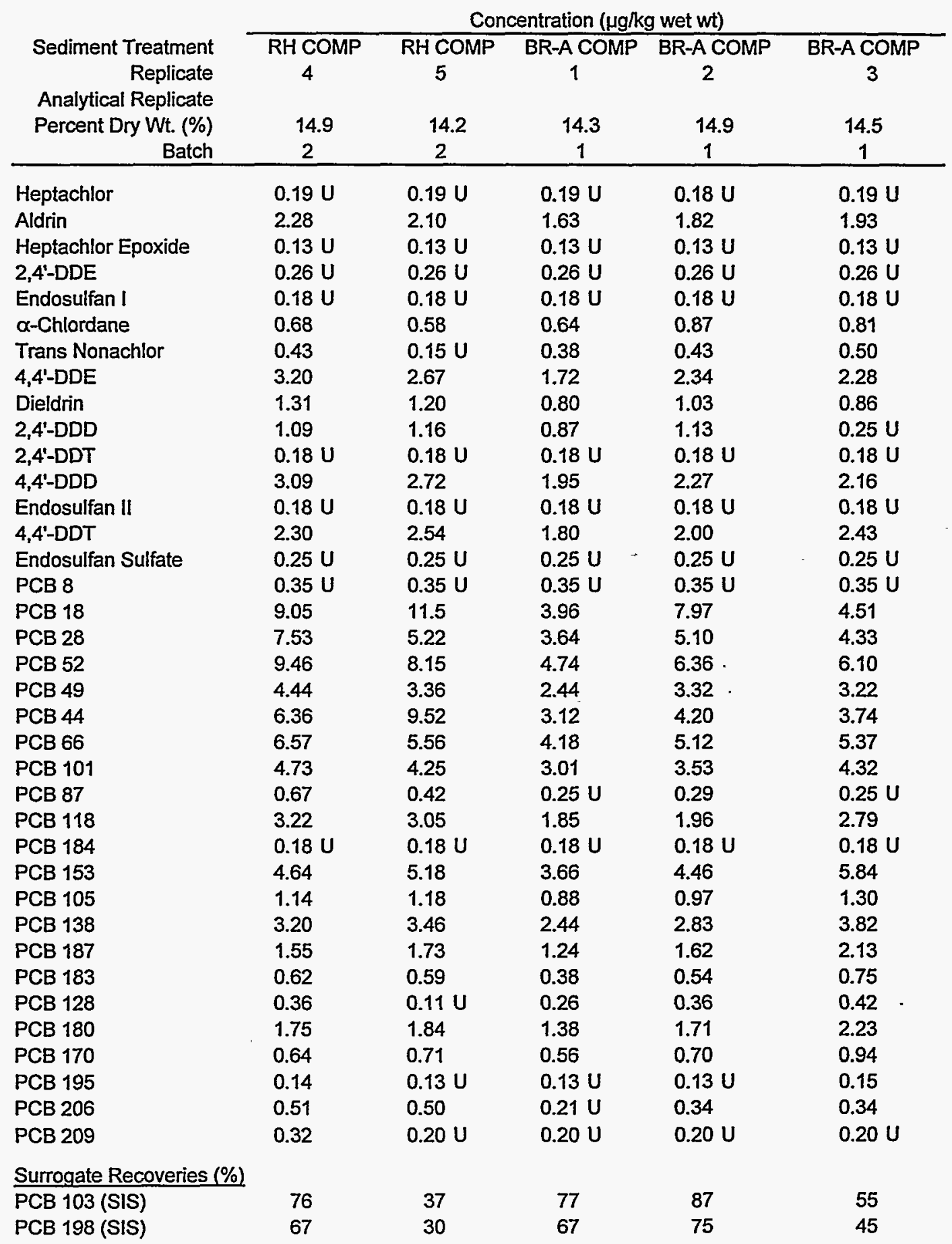


Table G.4. (contd)

Concentration ( $\mu \mathrm{g} / \mathrm{kg}$ wet $\mathrm{w}^{\mathrm{t}}$ )

\begin{tabular}{|c|c|c|c|c|c|}
\hline $\begin{array}{r}\text { Sediment Treatment } \\
\text { Replicate } \\
\text { Analytical Replicate }\end{array}$ & $\begin{array}{c}\text { BR-A COMP } \\
4\end{array}$ & $\begin{array}{c}\text { BR-A COMP } \\
5\end{array}$ & $\begin{array}{c}\text { BR-B COMP } \\
1\end{array}$ & $\begin{array}{c}\text { BR-B COMP } \\
2\end{array}$ & $\begin{array}{c}\text { BR-B COMP } \\
3\end{array}$ \\
\hline $\begin{array}{r}\text { Percent Dry Wt. (\%) } \\
\text { Batch }\end{array}$ & $\begin{array}{c}15.7 \\
1\end{array}$ & $\begin{array}{c}15.7 \\
1\end{array}$ & $\begin{array}{c}14.3 \\
1\end{array}$ & $\begin{array}{c}13.6 \\
1\end{array}$ & $\begin{array}{c}14.2 \\
1\end{array}$ \\
\hline Heptachlor & $0.18 \mathrm{U}$ & $0.19 \mathrm{U}$ & $0.19 \mathrm{U}$ & $0.18 \mathrm{U}$ & $0.19 \mathrm{U}$ \\
\hline Aldrin & 1.96 & 1.77 & 4.22 & 3.13 & 3.25 \\
\hline Heptachlor Epoxide & $0.13 U$ & $0.13 \mathrm{U}$ & $0.13 U$ & $0.13 U$ & $0.13 U$ \\
\hline 2,4'-DDE & $0.26 \mathrm{U}$ & $0.26 U$ & $0.26 \mathrm{U}$ & $0.26 \mathrm{U}$ & $0.26 \mathrm{U}$ \\
\hline Endosulfan I & $0.18 U$ & $0.18 \mathrm{U}$ & $0.18 \mathrm{U}$ & $0.18 \mathrm{U}$ & $0.18 \mathrm{U}$ \\
\hline$\alpha-$ Chlordane & 1.04 & 0.82 & 1.36 & 1.73 & 1.18 \\
\hline Trans Nonachlor & 1.03 & 0.57 & 1.06 & 0.91 & 1.05 \\
\hline 4,4'-DDE & 2.65 & 1.99 & 7.68 & 10.8 & 7.96 \\
\hline Dieldrin & 1.25 & 0.85 & 2.83 & 3.36 & 2.33 \\
\hline 2,4'-DDD & 1.41 & 1.09 & 2.85 & 2.53 & 2.20 \\
\hline 2,4'-DDT & $0.18 \mathrm{U}$ & $0.18 \mathrm{U}$ & $0.18 U$ & $0.18 \mathrm{U}$ & $0.18 \mathrm{U}$ \\
\hline 4,4'-DDD & 2.86 & 2.09 & 9.38 & 9.10 & 7.20 \\
\hline Endosulfan II & $0.18 \mathrm{U}$ & $0.18 U$ & $0.18 \mathrm{U}$ & $0.18 U$ & $0.18 \mathrm{U}$ \\
\hline 4,4'-DDT & 2.84 & 2.17 & 5.32 & 3.41 & 4.03 \\
\hline Endosulfan Sulfate & $0.25 \mathrm{U}$ & $0.25 \mathrm{U}$ & $0.25 \mathrm{U}$ & $0.25 U$ & $0.25 \mathrm{U}$ \\
\hline PCB 8 & $0.34 \mathrm{U}$ & $0.35 \mathrm{U}$ & $0.35 \mathrm{U}$ & $0.34 \mathrm{U}$ & $0.35 \mathrm{U}$ \\
\hline PCB 18 & 14.5 & 5.16 & 10.2 & 12.5 & 9.40 \\
\hline PCB 28 & 4.62 & 4.02 & 9.77 & 11.3 & 8.49 \\
\hline PCB 52 & 6.45 & 5.75 & 15.8 & 14.0 & 13.3 \\
\hline PCB 49 & $3.27 \mathrm{U}$ & 2.90 & 6.69 & 6.83 & 5.80 \\
\hline PCB 44 & 3.77 & 4.26 & 6.36 & 9.08 & 6.09 \\
\hline РCB 66 & 5.89 & 4.94 & 13.10 & 11.6 & 10.3 \\
\hline РСB 101 & 4.68 & 3.72 & 10.9 & 8.54 & 8.44 \\
\hline РСВ 87 & 0.31 & $0.25 \mathrm{U}$ & 0.99 & 1.43 & 0.99 \\
\hline PCB 118 & 2.78 & 2.16 & 7.05 & 5.96 & 5.43 \\
\hline РСB 184 & $0.18 U$ & $0.18 \mathrm{U}$ & $0.18 U$ & $0.18 U$ & $0.18 U$ \\
\hline РСВ 153 & 6.16 & 4.60 & 11.6 & 7.84 & 8.42 \\
\hline РCB 105 & 1.56 & 1.07 & 3.82 & 2.54 & 2.66 \\
\hline РСB 138 & 4.38 & 3.03 & 8.98 & 5.83 & 6.11 \\
\hline PCB 187 & 2.24 & 1.58 & 4.32 & 2.89 & 3.16 \\
\hline РCB 183 & 0.90 & 0.53 & 2.16 & 1.36 & 1.52 \\
\hline РСB 128 & 0.58 & 0.29 & 1.41 & 0.89 & 0.90 \\
\hline РCB 180 & 2.28 & 1.67 & 5.46 & 3.31 & 3.74 \\
\hline РСB 170 & 0.98 & 0.66 & 2.25 & 1.28 & 1.52 \\
\hline PCB 195 & $0.12 \mathrm{U}$ & $0.13 U$ & $0.13 \mathrm{U}$ & $0.12 \mathrm{U}$ & 0.27 \\
\hline РСВ 206 & 0.51 & 0.34 & 1.24 & 0.97 & 1.17 \\
\hline РCB 209 & $0.19 \mathrm{U}$ & $0.20 \mathrm{U}$ & 0.57 & 0.61 & 0.72 \\
\hline \multicolumn{6}{|l|}{ Surrogate Recoveries (\%) } \\
\hline PCB 103 (SIS) & 80 & 81 & 97 & 85 & 76 \\
\hline PCB 198 (SIS) & 71 & 69 & 63 & 73 & 66 \\
\hline
\end{tabular}


Table G.4. (contd)

\begin{tabular}{|c|c|c|c|c|c|}
\hline \multirow{3}{*}{$\begin{array}{r}\text { Sediment Treatment } \\
\text { Replicate }\end{array}$} & \multicolumn{5}{|c|}{ Concentration ( $\mu \mathrm{g} / \mathrm{kg}$ wet $w t)$} \\
\hline & $\overline{B R-B ~ C O M P}$ & BR-B COMP & MDRS $^{(c)}$ & MDRS & MDRS \\
\hline & 4 & 5 & 1 & 2 & 3 \\
\hline \multicolumn{6}{|l|}{$\begin{array}{l}\text { Analytical Replicate } \\
\text { Percent Dry Wt. (\%) }\end{array}$} \\
\hline Percent Dry Wt. (\%) & 14.6 & 15.7 & 14.4 & 13.5 & 15.3 \\
\hline Batch & 1 & 1 & 1 & 1 & 1 \\
\hline Heptachlor & $0.18 \mathrm{U}$ & $0.21 \mathrm{U}$ & $0.21 \mathrm{U}$ & $0.19 \mathrm{U}$ & $0.19 \mathrm{U}$ \\
\hline Aldrin & 2.63 & 3.01 & $0.14 \mathrm{U}$ & $0.13 U$ & $0.13 U$ \\
\hline Heptachlor Epoxide & $0.13 \mathrm{U}$ & $0.15 \mathrm{U}$ & $0.15 \mathrm{U}$ & $0.13 \mathrm{U}$ & 1.50 \\
\hline 2,4'-DDE & $0.26 \mathrm{U}$ & $0.30 \mathrm{U}$ & $0.29 \mathrm{U}$ & $0.26 \mathrm{U}$ & $0.26 \mathrm{U}$ \\
\hline $\begin{array}{l}\text { Endosulfan I } \\
\alpha \text {-Chlordane }\end{array}$ & $0.18 \mathrm{U}$ & $0.21 \mathrm{U}$ & $0.20 \mathrm{U}$ & $0.18 \mathrm{U}$ & 0.58 \\
\hline \multirow{2}{*}{$\begin{array}{l}\alpha \text {-Chlordane } \\
\text { Trans Nonachlor }\end{array}$} & 1.13 & 1.16 & 0.31 & 0.16 & $0.10 \mathrm{U}$ \\
\hline & 0.69 & 0.74 & $0.16 U$ & $0.15 \mathrm{U}$ & 0.54 \\
\hline 4,4'-DDE & 6.91 & 7.73 & $0.21 \mathrm{U}$ & $0.19 \mathrm{U}$ & 0.68 \\
\hline Dieldrin & 2.23 & 2.13 & 0.76 & 0.62 & 0.72 \\
\hline 2,4'-DDD & 2.08 & 2.39 & $0.28 \mathrm{U}$ & $0.25 \mathrm{U}$ & 0.77 \\
\hline 2,4'-DDT & $0.18 \mathrm{U}$ & $0.21 \mathrm{U}$ & $0.20 \mathrm{U}$ & $0.18 \mathrm{U}$ & $0.18 U$ \\
\hline 4,4'-DDD & 7.27 & 6.64 & 0.96 & 0.84 & 0.85 \\
\hline Endosulfan II & $0.18 U$ & $0.21 \mathrm{U}$ & $0.20 \mathrm{U}$ & $0.18 \mathrm{U}$ & $0.18 U$ \\
\hline 4,4'-DDT & 3.33 & 4.43 & 1.64 & 1.38 & 1.54 \\
\hline Endosulfan Sulfate & $0.25 \mathrm{U}$ & $0.29 \mathrm{U}$ & $0.28 U$ & $0.25 \mathrm{U}$ & $0.25 \mathrm{U}$ \\
\hline PCB 8 & $0.34 \mathrm{U}$ & $0.41 \mathrm{U}$ & $0.39 \mathrm{U}$ & $0.35 \mathrm{U}$ & $0.35 U$ \\
\hline РСB 18 & 9.35 & 12.0 & $0.11 \mathrm{U}$ & $0.10 \mathrm{U}$ & $0.10 \mathrm{U}$ \\
\hline PCB 28 & 8.87 & 8.42 & $0.12 \mathrm{U}$ & $0.11 \mathrm{U}$ & $0.11 \mathrm{U}$ \\
\hline PCB 52 & 11.4 & 13.5 & $0.36 \mathrm{U}$ & $0.32 \mathrm{U}$ & $0.32 \mathrm{U}$ \\
\hline РCB 49 & 5.21 & 5.95 & $0.21 U$ & $0.18 U$ & $0.18 U$ \\
\hline РСB 44 & 6.35 & 7.52 & $0.08 \mathrm{U}$ & $0.07 U$ & $0.07 \mathrm{U}$ \\
\hline РСВ 66 & 9.41 & 11.9 & $0.17 \mathrm{U}$ & $0.15 U$ & $0.15 U$ \\
\hline РCB 101 & 7.12 & 9.43 & 0.77 & 0.32 & 0.78 \\
\hline PCB 87 & 1.04 & 1.23 & $0.28 \mathrm{U}$ & $0.25 U$ & $0.25 \mathrm{U}$ \\
\hline PCB 118 & 4.88 & 6.69 & 0.39 & $0.19 \mathrm{U}$ & 0.36 \\
\hline PCB 184 & $0.18 \mathrm{U}$ & $0.21 \mathrm{U}$ & $0.21 U$ & $0.18 \mathrm{U}$ & $0.18 \mathrm{U}$ \\
\hline PCB 153 & 7.38 & 11.0 & 3.08 & 1.96 & 2.47 \\
\hline PCB 105 & 2.10 & 3.35 & $0.19 \mathrm{U}$ & $0.17 \mathrm{U}$ & 0.89 \\
\hline PCB 138 & 5.28 & 7.99 & 1.89 & 1.07 & 1.37 \\
\hline PCB 187 & 2.54 & 3.64 & 1.12 & 0.62 & 0.83 \\
\hline PCB 183 & 1.18 & 1.78 & 0.30 & 0.21 & 0.25 \\
\hline PCB 128 & 0.75 & 1.18 & $0.12 U$ & 0.12 & 0.16 \\
\hline РCB 180 & 3.00 & 4.54 & 0.86 & 0.63 & 0.66 \\
\hline PCB 170 & 1.23 & 1.88 & 0.34 & 0.25 & 0.24 \\
\hline РСВ 195 & 0.20 & 0.30 & $0.14 \mathrm{U}$ & $0.13 \mathrm{U}$ & $0.13 U$ \\
\hline PCB 206 & 0.66 & 1.03 & $0.25 \mathrm{U}$ & $0.21 U$ & $0.21 \mathrm{U}$ \\
\hline PCB 209 & 0.33 & 0.60 & $0.22 \mathrm{U}$ & $0.20 \mathrm{U}$ & $0.20 \mathrm{U}$ \\
\hline Surrogate Recoveries (\%) & & & & & \\
\hline PCB 103 (SIS) & 78 & 67 & 87 & 70 & 72 \\
\hline PCB 198 (SIS) & 67 & 57 & 70 & 57 & 59 \\
\hline
\end{tabular}


Table G.4. (contd)

\begin{tabular}{|c|c|c|c|}
\hline \multirow{4}{*}{$\begin{array}{r}\text { Sediment Treatment } \\
\text { Replicate } \\
\text { Analytical Replicate }\end{array}$} & \multicolumn{3}{|c|}{ Concentration ( $\mu \mathrm{g} / \mathrm{kg}$ wet $w \mathrm{t})$} \\
\hline & MDRS & MDRS & Nereis Bkgd. Tissue \\
\hline & 4 & 5 & 1 \\
\hline & & & \\
\hline Percent Dry Wt. (\%) & 14.1 & 16.2 & 15.6 \\
\hline Batch & 1 & 2 & 1 \\
\hline Heptachlor & $0.18 \mathrm{U}$ & $0.19 \mathrm{U}$ & $0.18 U$ \\
\hline Aldrin & $0.12 \mathrm{U}$ & $0.13 U$ & $0.12 \mathrm{U}$ \\
\hline Heptachlor Epoxide & $0.13 U$ & $0.13 \mathrm{U}$ & $0.13 \mathrm{U}$ \\
\hline 2,4'-DDE & $0.26 U$ & $0.26 \mathrm{U}$ & $0.26 \mathrm{U}$ \\
\hline Endosulfan I & $0.18 \mathrm{U}$ & $0.18 U$ & $0.18 \mathrm{U}$ \\
\hline$\alpha$-Chlordane & $0.09 \mathrm{U}$ & $0.10 \mathrm{U}$ & 0.18 \\
\hline Trans Nonachlor & $0.14 \mathrm{U}$ & $0.15 \mathrm{U}$ & 0.30 \\
\hline $4,4^{\prime}-\mathrm{DDE}$ & 0.60 & $0.19 \mathrm{U}$ & $0.18 \mathrm{U}$ \\
\hline Dieldrin & 0.81 & 0.64 & 0.75 \\
\hline 2,4'-DDD & $0.25 \mathrm{U}$ & $0.25 U$ & $0.25 \mathrm{U}$ \\
\hline $2,4^{3}-\mathrm{DDT}$ & $0.18 \mathrm{U}$ & $0.18 \mathrm{U}$ & $0.18 U$ \\
\hline 4,4'-DDD & 0.75 & $0.26 \mathrm{U}$ & 0.70 \\
\hline Endosulfan II & $0.18 \mathrm{U}$ & $0.18 \mathrm{U}$ & $0.18 U$ \\
\hline $4,4^{\prime}-$-DDT & 1.51 & 1.41 & 1.37 \\
\hline Endosulfan Sulfate & $0.25 \mathrm{U}$ & $0.25 \mathrm{U}$ & $0.25 \mathrm{U}$ \\
\hline РСB 8 & $0.34 U$ & $0.35 \mathrm{U}$ & $0.34 \mathrm{U}$ \\
\hline PCB 18 & $0.10 \mathrm{U}$ & $0.10 \mathrm{U}$ & $0.10 \mathrm{U}$ \\
\hline РCB 28 & $0.11 \mathrm{U}$ & $0.11 \mathrm{U}$ & $0.11 \mathrm{U}$ \\
\hline PCB 52 & $0.32 \mathrm{U}$ & $0.32 \mathrm{U}$ & $0.32 \mathrm{U}$ \\
\hline PCB 49 & $0.18 U$ & $0.18 U$ & $0.18 \mathrm{U}$ \\
\hline PCB 44 & $0.07 \cup$ & $0.07 \mathrm{U}$ & $0.07 \mathrm{U}$ \\
\hline РСB 66 & $0.15 \mathrm{U}$ & $0.15 \mathrm{U}$ & $0.15 \mathrm{U}$ \\
\hline PCB 101 & $0.13 \mathrm{U}$ & $0.13 U$ & 0.41 \\
\hline РCB 87 & $0.25 \mathrm{U}$ & $0.25 \mathrm{U}$ & $0.25 \mathrm{U}$ \\
\hline PCB 118 & 0.22 & $0.19 \mathrm{U}$ & 0.20 \\
\hline РCB 184 & $0.18 U$ & $0.18 U$ & $0.18 \mathrm{U}$ \\
\hline PCB 153 & 2.77 & 2.24 & 2.04 \\
\hline РСВ 105 & $0.16 \mathrm{U}$ & $0.17 \mathrm{U}$ & $0.16 U$ \\
\hline PCB 138 & 1.49 & 1.18 & 1.14 \\
\hline РСВ 187 & 0.94 & 0.74 & 0.66 \\
\hline РCB 183 & 0.28 & 0.22 & 0.22 \\
\hline PCB 128 & 0.16 & $0.11 \mathrm{U}$ & 0.14 \\
\hline РСВ 180 & 0.87 & 0.70 & 0.62 \\
\hline PCB 170 & 0.35 & 0.25 & 0.22 \\
\hline РCB 195 & $0.12 \mathrm{U}$ & $0.13 U$ & $0.12 U$ \\
\hline PCB 206 & 0.21 & $0.21 \mathrm{U}$ & $0.21 \mathrm{U}$ \\
\hline PCB 209 & $0.19 U$ & $0.20 \mathrm{U}$ & $0.19 \mathrm{U}$ \\
\hline Surrogate Recoveries (\%) & & & \\
\hline PCB 103 (SIS) & 67 & 77 & 90 \\
\hline PCB 198 (SIS) & 64 & 68 & 76 \\
\hline
\end{tabular}

(a) Target detection limits are $0.4 \mu \mathrm{g} / \mathrm{kg}$ for all analytes.

(b) U Undetected at or above given concentration.

(c) MDRS Mud Dump Reference Site. 
Table G.5. Pesticides and Polychlorinated Biphenyls (PCBs), Dry Weight, in Tissue of N. virens, Red Hook and Bay Ridge Channels

\begin{tabular}{|c|c|c|c|c|c|}
\hline \multirow[b]{2}{*}{$\begin{array}{l}\text { Sediment Treatment } \\
\text { Replicate }\end{array}$} & \multicolumn{5}{|c|}{ Concentration $(\mu \mathrm{g} / \mathrm{kg}$ dry $w t)$} \\
\hline & $\begin{array}{c}\text { RH COMP } \\
1\end{array}$ & $\begin{array}{c}\text { RH COMP } \\
2\end{array}$ & $\begin{array}{c}\mathrm{RH} \text { COMP } \\
2\end{array}$ & $\begin{array}{c}\mathrm{RH} \text { COMP } \\
2\end{array}$ & $\begin{array}{c}\text { RH COMP } \\
3\end{array}$ \\
\hline Analytical Replicate & & 1 & 2 & 3 & \\
\hline Percent Dry Wt. (\%) & 14.7 & 13.9 & 13.9 & 13.9 & 15.5 \\
\hline Batch & 1 & 1 & 1 & 1 & 1 \\
\hline Heptachlor & $1.7 U^{(a)}$ & $2.0 \mathrm{U}$ & 7.60 & $1.9 \mathrm{U}$ & $1.2 \mathrm{U}$ \\
\hline Aldrin & 19.0 & 22.0 & 20.3 & 22.9 & 14.0 \\
\hline Heptachlor Epoxide & $1.2 \mathrm{U}$ & $1.4 \mathrm{U}$ & $1.6 \mathrm{U}$ & $1.3 \mathrm{U}$ & $0.84 U$ \\
\hline 2,4'-DDE & $2.4 \mathrm{U}$ & $2.9 \mathrm{U}$ & $3.0 \mathrm{U}$ & $2.6 \mathrm{U}$ & $1.7 \mathrm{U}$ \\
\hline Endosulfan I & $1.6 \mathrm{U}$ & $2.0 \mathrm{U}$ & $2.1 \mathrm{U}$ & $1.8 \mathrm{U}$ & $1.2 U$ \\
\hline$\alpha$-Chlordane & 6.1 & 7.25 & 7.0 & 7.17 & 4.7 \\
\hline Trans Nonachlor & $1.3 \mathrm{U}$ & 5.0 & $1.7 \mathrm{U}$ & 5.7 & 2.5 \\
\hline 4,4'-DDE & 24.0 & 26.7 & 27.3 & 27.8 & 18.6 \\
\hline Dieldrin & 10.4 & 13.5 & 12.8 & 13.7 & 8.34 \\
\hline 2,4'-DDD & 8.79 & 11.5 & 11.0 & 13.4 & 7.12 \\
\hline 2,4'-DDT & $1.6 \mathrm{U}$ & $2.0 \mathrm{U}$ & $2.1 \mathrm{U}$ & $1.8 \mathrm{U}$ & $1.2 \mathrm{U}$ \\
\hline 4,4'-DDD & 20.5 & 25.7 & 23.9 & 25.7 & 17.9 \\
\hline Endosulfan II & $1.6 \mathrm{U}$ & $2.0 \mathrm{U}$ & $2.1 \mathrm{U}$ & $1.8 \mathrm{U}$ & $1.2 \mathrm{U}$ \\
\hline 4,4'-DDT & 18.8 & 23.0 & 21.9 & 22.2 & 13.9 \\
\hline Endosulfan Sulfate & $2.3 \mathrm{U}$ & $2.8 \mathrm{U}$ & $2.9 \mathrm{U}$ & $2.5 \mathrm{U}$ & $1.6 \mathrm{U}$ \\
\hline РCB 8 & $3.2 \mathrm{U}$ & $3.9 \mathrm{U}$ & $4.1 \mathrm{U}$ & $3.5 \mathrm{U}$ & $2.3 \mathrm{U}$ \\
\hline РCB 18 & 78.3 & 85.2 & 82.0 & 109 & 75.0 \\
\hline PCB 28 & 51.2 & 62.8 & 56.6 & 65.1 & 41.8 \\
\hline РСВ 52 & 68.3 & 83.1 & 78.7 & 86.9 & 54.3 \\
\hline РCB 49 & 30.4 & 36.2 & 33.4 & 37.7 & 23.3 \\
\hline РCB 44 & 37.1 & 46.8 & 68.9 & 47.0 & 36.5 \\
\hline PCB 66 & 49.5 & 51.3 & 48.1 & 54.4 & 36.9 \\
\hline PCB 101 & 37.4 & 38.5 & 36.4 & 41.1 & 26.3 \\
\hline РCB 87 & 3.3 & 4.3 & 3.2 & 5.0 & 3.4 \\
\hline PCB 118 & 23.2 & 26.5 & 24.7 & 29.2 & 17.9 \\
\hline РCB 184 & $1.7 \mathrm{U}$ & $2.0 \mathrm{U}$ & $2.2 \mathrm{U}$ & $1.8 \mathrm{U}$ & $1.2 \mathrm{U}$ \\
\hline PCB 153 & 39.9 & 43.2 & 40.7 & 48.0 & 26.7 \\
\hline PCB 105 & 9.26 & 10.0 & 9.54 & 12.1 & 7.31 \\
\hline РСВ 138 & 24.9 & 30.8 & 28.7 & 33.3 & 18.8 \\
\hline PCB 187 & 13.4 & 15.0 & 15.8 & 17.4 & 9.57 \\
\hline PCB 183 & 4.7 & 5.1 & 4.7 & 6.7 & 3.8 \\
\hline PCB 128 & $0.95 U$ & 2.7 & $1.22 \mathrm{U}$ & 4.2 & 2.3 \\
\hline PCB 180 & 13.4 & 15.1 & 14.6 & 17.0 & 10.2 \\
\hline PCB 170 & 5.1 & 5.7 & 6.0 & 7.17 & 3.9 \\
\hline РCB 195 & $1.2 \mathrm{U}$ & $1.4 \mathrm{U}$ & $1.5 \mathrm{U}$ & 1.5 & 0.91 \\
\hline PCB 206 & 3.9 & 4.7 & 4.2 & 5.3 & 3.1 \\
\hline PCB 209 & 2.3 & 2.2 & 2.3 & 2.5 & $1.3 \mathrm{U}$ \\
\hline
\end{tabular}


Table G.5. (contd)

\begin{tabular}{|c|c|c|c|c|c|}
\hline \multirow[b]{2}{*}{$\begin{array}{r}\text { Sediment Treatment } \\
\text { Replicate } \\
\text { Analytical Replicate }\end{array}$} & \multicolumn{5}{|c|}{ Concentration ( $\mu \mathrm{g} / \mathrm{kg}$ dry wt) } \\
\hline & $\begin{array}{c}\text { RH COMP } \\
4\end{array}$ & $\begin{array}{c}\text { RH COMP } \\
5\end{array}$ & $\begin{array}{c}\text { BR-A COMP } \\
1\end{array}$ & $\begin{array}{c}\text { BR-A COMP } \\
2\end{array}$ & $\begin{array}{c}\text { BR-A COMP } \\
3\end{array}$ \\
\hline Percent Dry Wt. (\%) & 14.9 & 14.2 & 14.3 & 14.9 & 14.5 \\
\hline Batch & 2 & 2 & 1 & 1 & 1 \\
\hline Heptachlor & $1.3 \mathrm{U}$ & $1.3 \mathrm{U}$ & $1.3 \mathrm{U}$ & $1.2 \mathrm{U}$ & $1.3 \mathrm{U}$ \\
\hline Aldrin & 15.3 & 14.8 & 11.4 & 12.3 & 13.3 \\
\hline Heptachlor Epoxide & $0.87 \mathrm{U}$ & $0.92 \mathrm{U}$ & $0.91 \mathrm{U}$ & $0.88 \mathrm{U}$ & $0.90 \mathrm{U}$ \\
\hline 2,4'-DDE & $1.7 \mathrm{U}$ & $1.8 \mathrm{U}$ & $1.8 \mathrm{U}$ & $1.8 \mathrm{U}$ & $1.8 \mathrm{U}$ \\
\hline Endosulfan I & $1.2 \mathrm{U}$ & $1.3 \mathrm{U}$ & $1.3 \mathrm{U}$ & $1.2 \mathrm{U}$ & $1.2 \mathrm{U}$ \\
\hline$\alpha$-Chlordane & 4.6 & 4.1 & 4.5 & 5.9 & 5.6 \\
\hline Trans Nonachlor & 2.9 & $1.1 \mathrm{U}$ & 2.7 & 2.9 & 3.5 \\
\hline 4,4'-DDE & 21.4 & 18.9 & 12.0 & 15.8 & 15.8 \\
\hline Dieldrin & 8.77 & 8.47 & 5.6 & 6.94 & 5.9 \\
\hline 2,4'-DDD & 7.30 & 8.19 & 6.1 & 7.61 & $1.7 \mathrm{U}$ \\
\hline $2,4^{\prime}-\mathrm{DDT}$ & $1.2 U$ & $1.3 \mathrm{U}$ & $1.3 \mathrm{U}$ & $1.2 \mathrm{U}$ & $1.2 \mathrm{U}$ \\
\hline 4,4'-DDD & 20.7 & 19.2 & 13.6 & 15.3 & 14.9 \\
\hline Endosulfan II & $1.2 \mathrm{U}$ & $1.3 \mathrm{U}$ & $1.3 \mathrm{U}$ & $1.2 \mathrm{U}$ & $1.2 \mathrm{U}$ \\
\hline 4,4'-DDT & 15.4 & 17.9 & 12.6 & 13.5 & 16.8 \\
\hline Endosulfan Sulfate & $1.7 \mathrm{U}$ & $1.8 \mathrm{U}$ & $1.7 \mathrm{U}$ & $1.7 \mathrm{U}$ & $1.7 \mathrm{U}$ \\
\hline РCB 8 & $2.3 \mathrm{U}$ & $2.5 \mathrm{U}$ & $2.4 \mathrm{U}$ & $2.4 \mathrm{U}$ & $2.4 \mathrm{U}$ \\
\hline РСВ 18 & 60.6 & 80.9 & 27.7 & 53.7 & 31.2 \\
\hline РCB 28 & 50.4 & 36.9 & 25.5 & 34.3 & 29.9 \\
\hline РCB 52 & 63.4 & 57.6 & 33.1 & 42.8 & 42.2 \\
\hline РCB 49 & 29.7 & 23.7 & 17.1 & 22.4 & 22.3 \\
\hline РСB 44 & 42.6 & 67.2 & 21.8 & 28.3 & 25.8 \\
\hline РСВ 66 & 44.0 & 39.3 & 29.2 & 34.5 & 37.1 \\
\hline РСВ 101 & 31.7 & 30.0 & 21.0 & 23.8 & 29.9 \\
\hline PCB 87 & 4.5 & 3.0 & $1.7 U$ & 2.0 & $1.7 \mathrm{U}$ \\
\hline РСВ 118 & 21.6 & 21.5 & 12.9 & 13.2 & 19.3 \\
\hline PCB 184 & $1.2 U$ & $1.3 \mathrm{U}$ & $1.3 \mathrm{U}$ & $1.2 \mathrm{U}$ & $1.2 \mathrm{U}$ \\
\hline PCB 153 & 31.1 & 36.6 & 25.6 & 30.0 & 40.4 \\
\hline PCB 105 & 7.64 & 8.33 & 6.2 & 6.5 & 8.98 \\
\hline PCB 138 & 21.4 & 24.4 & 17.1 & 19.1 & 26.4 \\
\hline РCB 187 & 10.4 & 12.2 & 8.67 & 10.9 & 14.7 \\
\hline PCB 183 & 4.2 & 4.2 & 2.7 & 3.6 & 5.2 \\
\hline PCB 128 & 2.4 & $0.78 \mathrm{U}$ & 1.8 & 2.4 & 2.9 \\
\hline PCB 180 & 11.7 & 13.0 & 9.65 & 11.5 & 15.4 \\
\hline РCB 170 & 4.3 & 5.0 & 3.9 & 4.7 & 6.5 \\
\hline РCB 195 & 0.94 & $0.92 \mathrm{U}$ & $0.91 \mathrm{U}$ & $0.88 \mathrm{U}$ & 1.0 \\
\hline PCB 206 & 3.4 & 3.5 & $1.5 \mathrm{U}$ & 2.3 & 2.3 \\
\hline PCB 209 & 2.1 & $1.4 \mathrm{U}$ & $1.4 \mathrm{U}$ & $1.3 \mathrm{U}$ & $1.4 \mathrm{U}$ \\
\hline
\end{tabular}


Table G.5. (contd)

Concentration ( $\mu \mathrm{g} / \mathrm{kg} \mathrm{dry} w \mathrm{t})$

\begin{tabular}{|c|c|c|c|c|c|}
\hline $\begin{array}{r}\text { Sediment Treatment } \\
\text { Replicate } \\
\text { Analytical Replicate } \\
\text { Percent Dry Wt. }(\%) \\
\text { Batch }\end{array}$ & $\begin{array}{c}\text { BR-A COMP } \\
4\end{array}$ & $\begin{array}{c}\text { BR-A COMP } \\
5\end{array}$ & $\begin{array}{c}\text { BR-B COMP } \\
1\end{array}$ & $\begin{array}{c}\text { BR-B COMP } \\
2\end{array}$ & $\begin{array}{c}\text { BR-B COMP } \\
\mathbf{3}\end{array}$ \\
\hline Heptachlor & $1.1 \mathrm{U}$ & $1.2 \mathrm{U}$ & $1.3 \mathrm{U}$ & $1.3 \mathrm{U}$ & $1.3 \mathrm{U}$ \\
\hline Aldrin & 12.5 & 11.3 & 29.5 & 22.9 & 23.0 \\
\hline Heptachlor Epoxide & $0.83 \mathrm{U}$ & $0.83 \mathrm{U}$ & $0.91 \mathrm{U}$ & $0.95 \mathrm{U}$ & $0.92 \mathrm{U}$ \\
\hline 2,4'-DDE & $1.7 U$ & $1.7 \mathrm{U}$ & $1.8 \mathrm{U}$ & $1.9 \mathrm{U}$ & $1.8 \mathrm{U}$ \\
\hline Endosulfan I & $1.1 \mathrm{U}$ & $1.1 \mathrm{U}$ & $1.3 \mathrm{U}$ & $1.3 \mathrm{U}$ & $1.3 \mathrm{U}$ \\
\hline$\alpha$-Chlordane & 6.61 & 5.2 & 9.50 & 12.7 & 8.34 \\
\hline Trans Nonachlor & 6.55 & 3.6 & 7.41 & 6.7 & 7.42 \\
\hline $4,4^{\prime}-\mathrm{DDE}$ & 16.8 & 12.7 & 53.7 & 79.3 & 56.3 \\
\hline Dieldrin & 7.95 & 5.4 & 19.8 & 24.6 & 16.5 \\
\hline 2,4'-DDD & 8.96 & 6.93 & 19.9 & 18.5 & 15.5 \\
\hline 2,4'-DDT & $1.1 \mathrm{U}$ & $1.1 \mathrm{U}$ & $1.3 \mathrm{U}$ & $1.3 \mathrm{U}$ & $1.3 \mathrm{U}$ \\
\hline 4,4'-DDD & 18.2 & 13.3 & 65.5 & 66.7 & 50.9 \\
\hline Endosulfan II & $1.1 \mathrm{U}$ & $1.1 \mathrm{U}$ & $-1.3 \mathrm{U}$ & $1.3 \mathrm{U}$ & $1.3 \mathrm{U}$ \\
\hline 4,4'-DDT & 18.1 & 13.8 & 37.2 & 25.0 & 28.5 \\
\hline Endosulfan Sulfate & $1.6 \mathrm{U}$ & $1.6 \mathrm{U}$ & $1.7 \mathrm{U}$. & $1.8 \mathrm{U}$ & $1.8 \mathrm{U}$ \\
\hline PCB 8 & $2.2 \mathrm{U}$ & $2.2 \mathrm{U}$ & $2.4 \mathrm{U}$ & $2.5 U$ & $2.5 \mathrm{U}$ \\
\hline PCB 18 & 92.1 & 32.8 & 71.1 & 91.6 & 66.4 \\
\hline PCB 28 & 29.4 & 25.6 & 68.3 & 82.5 & 60.0 \\
\hline РCB 52 & 41.0 & 36.6 & 111 & 103 & 93.7 \\
\hline PCB 49 & $20.8 U$ & 18.4 & 46.8 & 50.1 & 41.0 \\
\hline РСВ 44 & 24.0 & 27.1 & 44.4 & 66.6 & 43.0 \\
\hline PCB 66 & 37.4 & 31.4 & 91.5 & 85.0 & 72.5 \\
\hline РCB 101 & 29.8 & 23.7 & 76.5 & 62.6 & 59.6 \\
\hline РСB 87 & 2.0 & $1.6 \mathrm{U}$ & 6.9 & 10.5 & 7.0 \\
\hline PCB 118 & 17.7 & 13.7 & 49.3 & 43.7 & 38.4 \\
\hline РСB 184 & $1.1 U$ & $1.1 \mathrm{U}$ & $1.3 \mathrm{U}$ & $1.3 \mathrm{U}$ & $1.3 \mathrm{U}$ \\
\hline РCB 153 & 39.2 & 29.3 & 81.2 & 57.5 & 59.5 \\
\hline PCB 105 & 9.92 & 6.81 & 26.7 & 18.6 & 18.8 \\
\hline РCB 138 & 27.8 & 19.3 & 62.8 & 42.7 & 43.2 \\
\hline РCB 187 & 14.2 & 10.1 & 30.2 & 21.2 & 22.3 \\
\hline PCB 183 & 5.7 & 3.4 & 15.1 & 9.97 & 10.7 \\
\hline РCB 128 & 3.7 & 1.8 & 9.85 & 6.5 & 6.4 \\
\hline PCB 180 & 14.5 & 10.6 & 38.2 & 24.3 & 26.4 \\
\hline РСВ 170 & 6.2 & 4.2 & 15.7 & 9.38 & 10.7 \\
\hline PCB 195 & $0.76 \mathrm{U}$ & $0.83 \mathrm{U}$ & $0.91 U$ & $0.88 \mathrm{U}$ & 1.9 \\
\hline PCB 206 & 3.2 & 2.2 & 8.67 & 7.1 & 8.27 \\
\hline РСВ 209 & $1.2 \mathrm{U}$ & $1.3 \mathrm{U}$ & 4.0 & 4.5 & 5.1 \\
\hline
\end{tabular}


Table G.5. (contd)

Concentration ( $\mu \mathrm{g} / \mathrm{kg}$ dry $w t)$

\begin{tabular}{|c|c|c|c|c|c|}
\hline $\begin{array}{r}\text { Sediment Treatment } \\
\text { Replicate } \\
\text { Analytical Replicate }\end{array}$ & $\begin{array}{c}\text { BR-B COMP } \\
4\end{array}$ & $\begin{array}{c}\text { BR-B COMP } \\
5\end{array}$ & $\begin{array}{c}\text { MDRS }^{(D)} \\
1\end{array}$ & $\begin{array}{l}\text { MDRS } \\
2\end{array}$ & $\begin{array}{c}\text { MDRS } \\
3\end{array}$ \\
\hline $\begin{array}{r}\text { Percent Dry Wt. (\%) } \\
\text { Batch }\end{array}$ & $\begin{array}{c}14.6 \\
1\end{array}$ & $\begin{array}{c}15.7 \\
1\end{array}$ & $\begin{array}{c}14.4 \\
1\end{array}$ & $\begin{array}{c}13.5 \\
1\end{array}$ & $\begin{array}{c}15.3 \\
1\end{array}$ \\
\hline Heptachlor & $1.2 \mathrm{U}$ & $1.3 \mathrm{U}$ & $1.5 \mathrm{U}$ & $1.4 \mathrm{U}$ & $1.2 \mathrm{U}$ \\
\hline Aldrin & 18.0 & 19.2 & $0.97 U$ & $0.96 \mathrm{U}$ & $0.85 \mathrm{U}$ \\
\hline Heptachlor Epoxide & $0.89 \mathrm{U}$ & $0.96 \mathrm{U}$ & $1.0 \mathrm{U}$ & $0.96 \mathrm{U}$ & 9.82 \\
\hline 2,4'-DDE & $1.8 \mathrm{U}$ & $1.9 \mathrm{U}$ & $2.0 \mathrm{U}$ & $1.9 \mathrm{U}$ & $1.7 \mathrm{U}$ \\
\hline Endosulfan I & $1.2 U$ & $1.3 \mathrm{U}$ & $1.4 \mathrm{U}$ & $1.3 \mathrm{U}$ & 3.8 \\
\hline$\alpha$-Chlordane & 7.73 & 7.41 & 2.1 & 1.2 & $0.65 \mathrm{U}$ \\
\hline Trans Nonachlor & 4.7 & 4.7 & $1.1 \mathrm{U}$ & $1.1 \mathrm{U}$ & 3.5 \\
\hline 4,4'-DDE & 47.3 & 49.4 & $1.5 \mathrm{U}$ & $1.4 \mathrm{U}$ & 4.5 \\
\hline Dieldrin & 15.3 & 13.6 & 5.3 & 4.6 & 4.7 \\
\hline 2,4'-DDD & 14.2 & 15.3 & $1.9 \mathrm{U}$ & $1.9 \mathrm{U}$ & 5.0 \\
\hline 2,4'-DDT & $1.2 \mathrm{U}$ & $1.3 \mathrm{U}$ & $1.4 \mathrm{U}$ & $1.3 \mathrm{U}$ & $1.2 \mathrm{U}$ \\
\hline 4,4'-DDD & 49.8 & 42.4 & 6.7 & 6.2 & 5.6 \\
\hline Endosulfan II & $1.2 \mathrm{U}$ & $1.3 \mathrm{U}$ & $1.4 \mathrm{U}$ & $1.3 \mathrm{U}$ & $1.2 \mathrm{U}$ \\
\hline 4,4'-DDT & 22.8 & 28.3 & 11.4 & 10.2 & 10.1 \\
\hline Endosulfan Sulfate & $1.7 \mathrm{U}$ & $1.9 \mathrm{U}$ & $1.9 \mathrm{U}$ & $1.9 \mathrm{U}$ & $1.6 \mathrm{U}$ \\
\hline PCB 8 & $2.3 \mathrm{U}$ & $2.6 \mathrm{U}$ & $2.7 U$ & $2.6 \mathrm{U}$ & $2.3 \mathrm{U}$ \\
\hline PCB 18 & 64.0 & 76.4 & $0.76 \mathrm{U}$ & $0.74 \mathrm{U}$ & $0.65 \mathrm{U}$ \\
\hline PCB 28 & 60.7 & 53.8 & $0.83 U$ & $0.81 U$ & $0.72 U$ \\
\hline РСB 52 & 78.1 & 86.0 & $2.5 \mathrm{U}$ & $2.4 \mathrm{U}$ & $2.1 \mathrm{U}$ \\
\hline РСВ 49 & 35.7 & 38.0 & $1.5 \mathrm{U}$ & $1.3 \mathrm{U}$ & $1.2 \mathrm{U}$ \\
\hline РCB 44 & 43.5 & 48.0 & $0.55 \mathrm{U}$ & $0.52 \mathrm{U}$ & $0.46 \mathrm{U}$ \\
\hline PCB 66 & 64.4 & 76.1 & $1.2 \mathrm{U}$ & $1.1 \mathrm{U}$ & $0.98 \mathrm{U}$ \\
\hline РСВ 101 & 48.7 & 60.2 & 5.3 & 2.4 & 5.1 \\
\hline РСВ 87 & 7.12 & 7.85 & $1.9 \mathrm{U}$ & $1.9 \mathrm{U}$ & $1.6 \mathrm{U}$ \\
\hline PCB 118 & 33.4 & 42.7 & 2.7 & $1.4 \mathrm{U}$ & 2.4 \\
\hline РCB 184 & $1.2 \mathrm{U}$ & $1.3 \mathrm{U}$ & $1.5 \mathrm{U}$ & $1.3 \mathrm{U}$ & $1.2 U$ \\
\hline PCB 153 & 50.5 & 70.3 & 21.3 & 14.5 & 16.2 \\
\hline РСB 105 & 14.4 & 21.4 & $1.3 \mathrm{U}$ & $1.3 \mathrm{U}$ & 5.8 \\
\hline PCB 138 & 36.1 & 51.0 & 13.1 & 7.92 & 8.97 \\
\hline РСB 187 & 17.4 & 23.2 & 7.76 & 4.6 & 5.4 \\
\hline PCB 183 & 8.08 & 11.4 & 2.1 & 1.6 & 1.6 \\
\hline PCB 128 & 5.1 & 7.54 & $0.83 \mathrm{U}$ & 0.89 & 1.0 \\
\hline PCB 180 & 20.5 & 29.0 & 6.0 & 4.7 & 4.3 \\
\hline PCB 170 & 8.42 & 12.0 & 2.4 & 1.9 & 1.6 \\
\hline PCB 195 & 1.4 & 1.9 & $0.97 \mathrm{U}$ & $0.96 \mathrm{U}$ & $0.85 \mathrm{U}$ \\
\hline PCB 206 & 4.5 & 6.58 & $1.7 \mathrm{U}$ & $1.6 \mathrm{U}$ & $1.4 \mathrm{U}$ \\
\hline РCB 209 & 2.3 & 3.8 & $1.5 \mathrm{U}$ & $1.5 \mathrm{U}$ & $1.3 \mathrm{U}$ \\
\hline
\end{tabular}

G.13 
Table G.5. (contd)

\begin{tabular}{|c|c|c|c|}
\hline \multirow{4}{*}{$\begin{array}{r}\text { Sediment Treatment } \\
\text { Replicate } \\
\text { Analytical Replicate }\end{array}$} & \multicolumn{3}{|c|}{ Concentration ( $\mu \mathrm{g} / \mathrm{kg}$ dry $w t)$} \\
\hline & MDRS & MDRS & Nereis Bkgd. Tissue \\
\hline & 4 & 5 & 1 \\
\hline & & & \\
\hline Percent Dry Wt. (\%) & 14.1 & 16.2 & 15.6 \\
\hline Batch & 1 & 2 & 1 \\
\hline Heptachlor & $1.3 \mathrm{U}$ & $1.2 \mathrm{U}$ & $1.2 \mathrm{U}$ \\
\hline Aldrin & $0.85 \mathrm{U}$ & $0.80 \mathrm{U}$ & $0.77 \mathrm{U}$ \\
\hline Heptachlor Epoxide & $0.92 U$ & $0.80 \mathrm{U}$ & $0.83 \mathrm{U}$ \\
\hline 2,4'-DDE : & $1.8 \mathrm{U}$ & $1.6 \mathrm{U}$ & $1.7 \mathrm{U}$ \\
\hline Endosulfan! & $1.3 \mathrm{U}$ & $1.1 \mathrm{U}$ & $1.2 \mathrm{U}$ \\
\hline$\alpha$-Chlordane & $0.64 \mathrm{U}$ & $0.62 \mathrm{U}$ & 1.2 \\
\hline Trans Nonachlor & $0.99 \mathrm{U}$ & $0.93 \mathrm{U}$ & 1.9 \\
\hline 4,4'-DDE & 4.2 & $1.2 \mathrm{U}$ & $1.2 \mathrm{U}$ \\
\hline Dieldrin & 5.7 & 3.9 & 4.8 \\
\hline 2,4'-DDD & $1.8 \mathrm{U}$ & $1.5 \mathrm{U}$ & $1.6 \mathrm{U}$ \\
\hline 2,4'-DDT & $1.3 \mathrm{U}$ & $1.1 \mathrm{U}$ & $1.2 \mathrm{U}$ \\
\hline 4,4'-DDD & 5.3 & $1.6 \mathrm{U}$ & 4.5 \\
\hline Endosulfan II & $1.3 U$ & $1.1 \mathrm{U}$ & $1.2 \mathrm{U}$ \\
\hline $4,4^{\prime}-\mathrm{DDT}$ & 10.7 & 8.70 & 8.78 \\
\hline Endosulfan Sulfate & $1.8 \mathrm{U}$ & $1.5 \mathrm{U}$ & $1.6 \mathrm{U}$ \\
\hline PCB 8 & $2.4 \mathrm{U}$ & $2.2 U$ & $2.2 \mathrm{U}$ \\
\hline РСB 18 & $0.71 \mathrm{U}$ & $0.62 \mathrm{U}$ & $0.64 \mathrm{U}$ \\
\hline PCB 28 & $0.78 \mathrm{U}$ & $0.68 \mathrm{U}$ & $0.71 \mathrm{U}$ \\
\hline РСB 52 & $2.3 \mathrm{U}$ & $2.0 \mathrm{U}$ & $2.1 \mathrm{U}$ \\
\hline РСВ 49 & $1.3 \mathrm{U}$ & $1.1 \mathrm{U}$ & $1.2 \mathrm{U}$ \\
\hline РСВ 44 & $0.50 \mathrm{U}$ & $0.43 \mathrm{U}$ & $0.45 \mathrm{U}$ \\
\hline РСB 66 & $1.1 \mathrm{U}$ & $0.93 \mathrm{U}$ & $0.96 \mathrm{U}$ \\
\hline PCB 101 & $0.92 \mathrm{U}$ & $0.80 \mathrm{U}$ & 2.6 \\
\hline PCB 87 & $1.8 \mathrm{U}$ & $1.5 \mathrm{U}$ & $1.6 \mathrm{U}$ \\
\hline PCB 118 & 1.6 & $1.2 \mathrm{U}$ & 1.3 \\
\hline РCB 184 & $1.3 \mathrm{U}$ & $1.1 \mathrm{U}$ & $1.2 \mathrm{U}$ \\
\hline PCB 153 & 19.6 & 13.8 & 13.1 \\
\hline PCB 105 & $1.1 \mathrm{U}$ & $1.0 \mathrm{U}$ & $1.0 \mathrm{U}$ \\
\hline PCB 138 & 10.5 & 7.28 & 7.31 \\
\hline PCB 187 & 6.6 & 4.6 & 4.2 \\
\hline PCB 183 & 2.0 & 1.4 & 1.4 \\
\hline PCB 128 & 1.1 & $0.68 \mathrm{U}$ & 0.90 \\
\hline PCB 180 & 6.2 & 4.3 & 4.0 \\
\hline РCB 170 & 2.5 & 1.5 & 1.4 \\
\hline РCB 195 & $0.85 \mathrm{U}$ & $0.80 \mathrm{U}$ & $0.77 \mathrm{U}$ \\
\hline PCB 206 & 1.5 & $1.3 \mathrm{U}$ & $1.3 \mathrm{U}$ \\
\hline PCB 209 & $1.3 \mathrm{U}$ & $1.2 U$ & $1.2 \mathrm{U}$ \\
\hline
\end{tabular}

(a) U Undetected at or above given concentration.

(b) MDRS Mud Dump Reference Site. 
Table G.6. Quality Control Summary for Pesticide and Polychlorinated Byphenyl (PCB) Analysis in Tissue of $N$. virens (Wet Weight)

Matrix Spike Results

\begin{tabular}{|c|c|c|c|c|c|c|}
\hline \multirow{4}{*}{$\begin{array}{r}\text { Sediment Treatment } \\
\text { Replicate } \\
\text { Analytical Replicate } \\
\text { Batch } \\
\end{array}$} & \multirow{4}{*}{ Method Blank } & \multicolumn{4}{|c|}{ Concentration ( $\mu \mathrm{g} / \mathrm{kg}$ wet $w t)$} & \multirow{4}{*}{$\begin{array}{l}\text { Percent } \\
\text { Recovery }\end{array}$} \\
\hline & & \multirow{2}{*}{\multicolumn{4}{|c|}{$\begin{array}{cc}\mathrm{RH} \mathrm{COMP}^{(a)} & \mathrm{RH} \mathrm{COMP}(\mathrm{MS}) \\
1 & 1\end{array}$}} & \\
\hline & & & & & & \\
\hline & & & & Spiked & Recovered & \\
\hline Heptachlor & $0.19 U$ & $\frac{1}{0.25 U^{(b)}}$ & $\frac{1}{3.22}$ & $\frac{1}{3.30}$ & 3.22 & 98 \\
\hline Aldrin & $0.13 \mathrm{U}$ & 2.79 & 4.66 & 3.30 & 1.87 & 57 \\
\hline Heptachlor Epoxide & $0.13 \mathrm{U}$ & $0.18 U$ & 2.73 & 3.30 & 2.73 & 83 \\
\hline $2,4^{\prime}-\mathrm{DDE}$ & $0.26 \mathrm{U}$ & $0.35 \mathrm{U}$ & $N A^{(c)}$ & $N S^{(0)}$ & NA & NA \\
\hline Endosulfan I & $0.18 \mathrm{U}$ & $0.24 \mathrm{U}$ & 2.56 & 3.30 & 2.56 & 78 \\
\hline$\alpha$-Chlordane & $0.10 U$ & 0.90 & 3.27 & 3.30 & 2.37 & 72 \\
\hline Trans Nonachlor & $0.15 \mathrm{U}$ & $0.19 \mathrm{U}$ & NA & NS & $\mathrm{NA}$ & NA \\
\hline 4,4'-DDE & $0.19 \mathrm{U}$ & 3.53 & 5.49 & 3.30 & 1.96 & 59 \\
\hline Dieldrin & $0.52 U$ & 1.52 & 4.01 & 3.30 & 2.49 & 75 \\
\hline 2,4'-DDD & $0.25 \mathrm{U}$ & 1.29 & NA & NS & NA & NA \\
\hline 2,4'-DDT & $0.18 U$ & $0.24 \mathrm{U}$ & NA & NS & NA & NA \\
\hline 4,4'-DDD & $0.26 \mathrm{U}$ & 3.01 & 5.01 & 3.30 & 2.00 & 61 \\
\hline Endosulfan II & $0.18 \mathrm{U}$ & $0.24 \mathrm{U}$ & 3.63 & 3.30 & 3.63 & 110 \\
\hline 4,4'-DDT & $0.15 U$ & 2.76 & 4.80 & 3.30 & 2.04 & 62 \\
\hline Endosulfan Sulfate & $0.25 \mathrm{U}$ & $0.34 \mathrm{U}$ & 4.50 & 3.30 & 4.50 & $136^{(e)}$ \\
\hline РСB 8 & $0.35 \mathrm{U}$ & $0.47 \mathrm{U}$ & NA & NS & NA & NA \\
\hline РCB 18 & $0.10 \mathrm{U}$ & 11.5 & NA & NS & NA & NA \\
\hline PCB 28 & $0.11 \mathrm{U}$ & 7.51 & 11.4 & 4.21 & 3.85 & 91 \\
\hline РСВ 52 & $0.32 U$ & 10.0 & 16.7 & 8.78 & 6.68 & 76 \\
\hline РCB 49 & $0.18 \mathrm{U}$ & 4.46 & NA & NS & NA & NA \\
\hline PCB 44 & $0.07 \mathrm{U}$ & 5.45 & NA & NS & NA & NA \\
\hline РСB 66 & $0.15 U$ & $0.20 \mathrm{U}$ & NA & NS & NA & NA \\
\hline РСB 101 & $0.13 \mathrm{U}$ & 5.49 & 10.7 & 5.96 & 5.24 & 88 \\
\hline РСВ 87 & $0.25 \mathrm{U}$ & 0.48 & NA & NS & NA & NA \\
\hline РСВ 118 & $0.19 U$ & 3.41 & NA & NS & NA & NA \\
\hline РСB 184 & $0.18 \mathrm{U}$ & $0.25 \mathrm{U}$ & NA & NS & NA & NA \\
\hline РСВ 153 & $0.44 \mathrm{U}$ & 5.86 & 8.32 & 3.48 & 2.46 & 71 \\
\hline РСB 105 & $0.17 \mathrm{U}$ & 1.36 & NA & NS & NA & NA \\
\hline PCB 138 & $0.27 \mathrm{U}$ & 3.65 & 5.62 & 2.69 & 1.97 & 73 \\
\hline PCB 187 & $0.21 \mathrm{U}$ & 1.97 & NA & NS & NA & NA \\
\hline PCB 183 & $0.18 \mathrm{U}$ & 0.69 & NA & NS & NA & NA \\
\hline РСB 128 & $0.11 \mathrm{U}$ & $0.14 U$ & NA & NS & NA & NA \\
\hline PCB 180 & $0.38 \mathrm{U}$ & 1.97 & NA & NS & NA & NA \\
\hline PCB 170 & $0.18 \mathrm{U}$ & 0.75 & NA & NS & NA & NA \\
\hline PCB 195 & $0.13 \mathrm{U}$ & $0.17 \mathrm{U}$ & NA & NS & NA & NA \\
\hline PCB 206 & $0.21 U$ & 0.57 & NA & NS & NA & NA \\
\hline PCB 209 & $0.20 \mathrm{U}$ & 0.34 & NA & NS & NA & NA \\
\hline \multicolumn{7}{|l|}{ Surrogate Recoveries (\%) } \\
\hline PCB 103 (SIS) & 87 & 75 & 77 & NA & NA & NA \\
\hline PCB 198 (SIS) & 76 & 61 & 63 & NA & NA & NA \\
\hline
\end{tabular}


Table G.6. (contd)

Analytical Replicates

\begin{tabular}{|c|c|c|c|c|}
\hline \multirow[b]{2}{*}{ Sediment Treatment } & \multicolumn{3}{|c|}{ Concentration ( $\mu \mathrm{g} / \mathrm{kg}$ wet $w t)$} & \multirow{5}{*}{$\begin{array}{c}\text { RSD } \\
(\%)\end{array}$} \\
\hline & RH COMP & RH COMP & RH COMP & \\
\hline Replicate & 2 & 2 & 2 & \\
\hline Analytical Replicate & 1 & 2 & 3 & \\
\hline Batch & 1 & 1 & 1 & \\
\hline Heptachlor & $0.28 \mathrm{U}$ & 1.06 & $0.26 \mathrm{U}$ & NA \\
\hline Aldrin & 3.07 & 2.83 & 3.19 & 6 \\
\hline Heptachlor Epoxide & $0.20 \mathrm{U}$ & $0.22 \mathrm{U}$ & $0.18 \mathrm{U}$ & NA \\
\hline 2,4'-DDE & $0.40 \mathrm{U}$ & $0.42 \mathrm{U}$ & $0.36 \mathrm{U}$ & NA \\
\hline Endosulfan I & $0.28 \mathrm{U}$ & $0.29 \mathrm{U}$ & $0.25 \mathrm{U}$ & NA \\
\hline$\alpha$-Chlordane & 1.01 & 0.97 & 1.00 & 2 \\
\hline Trans Nonachlor & 0.70 & $0.24 U$ & 0.79 & NA \\
\hline 4,4'-DDE & 3.72 & 3.81 & 3.87 & 2 \\
\hline Dieldrin & 1.88 & 1.78 & 1.91 & 4 \\
\hline 2,4'-DDD & 1.60 & 1.53 & 1.87 & NA \\
\hline $2,4^{2}-D D T$ & $0.28 \mathrm{U}$ & $0.29 \mathrm{U}$ & $0.25 \mathrm{U}$ & NA \\
\hline 4,4-DDD & 3.58 & 3.33 & 3.58 & 4 \\
\hline & $0.28 \mathrm{U}$ & $0.29 \mathrm{U}$ & $0.25 \mathrm{U}$ & NA \\
\hline $\begin{array}{l}\text { Endosultan II } \\
\text { 4,4'-DDT }\end{array}$ & 3.20 & 3.05 & 3.10 & 2 \\
\hline Endosulfan Sulfate & $0.39 \mathrm{U}$ & $0.41 \mathrm{U}$ & $0.35 \mathrm{U}$ & NA \\
\hline PCB 8 & $0.54 \mathrm{U}$ & $0.57 \mathrm{U}$ & $0.49 \mathrm{U}$ & NA \\
\hline PCB 18 & 11.9 & 11.4 & 15.2 & 16 \\
\hline PCB 28 & 8.76 & 7.89 & 9.08 & 7 \\
\hline PCB 52 & 11.6 & 11.0 & 12.1 & 5 \\
\hline PCB 49 & 5.04 & 4.66 & 5.25 & 6 \\
\hline PCB 44 & 6.53 & 9.61 & 6.55 & 23 \\
\hline PCB 66 & 7.15 & 6.70 & 7.58 & 6 \\
\hline PCB 101 & 5.37 & 5.07 & 5.73 & 6 \\
\hline PCB 87 & 0.60 & 0.44 & 0.70 & 23 \\
\hline PCB 118 & 3.69 & 3.45 & 4.07 & 8 \\
\hline PCB 184 & $0.28 \mathrm{U}$ & $0.30 \mathrm{U}$ & $0.25 \mathrm{U}$ & NA \\
\hline PCB 153 & 6.02 & 5.67 & 6.69 & 8 \\
\hline PCB 105 & 1.40 & $0.27 \mathrm{U}$ & 1.68 & NA \\
\hline PCB 138 & 4.30 & 4.00 & 4.64 & 7 \\
\hline PCB 187 & 2.09 & 2.20 & 2.43 & 8 \\
\hline PCB 183 & 0.71 & 0.66 & 0.93 & 19 \\
\hline PCB 128 & 0.37 & $0.17 \mathrm{U}$ & 0.58 & NA \\
\hline PCB 180 & 2.11 & 2.04 & 2.37 & 8 \\
\hline PCB 170 & 0.80 & 0.83 & 1.00 & 12 \\
\hline PCB 195 & $0.20 \mathrm{U}$ & $0.21 \mathrm{U}$ & 0.21 & NA \\
\hline PCB 206 & 0.66 & 0.58 & 0.74 & 12 \\
\hline PCB 209 & 0.31 & 0.32 & 0.35 & 6 \\
\hline Surrogate Recoveries (\%) & & & & \\
\hline PCB 103 (SIS) & 65 & 48 & 63 & NA \\
\hline PCB 198 (SIS) & 56 & 39 & 53 & NA \\
\hline
\end{tabular}

(a) Sample randomly selected for use as a quality control sample in analytical batch.

(b) U Undetected at or above given concentration.

(c) NA Not applicable.

(d) NS Not spiked.

(e) Outside quality control criteria (50-120\%) for spike recovery. 
Table G.7. Polynuclear Aromatic Hydrocarbons (PAHs) in Tissue of N. virens (Wet Weight), Red Hook and Bay Ridge Channels

\begin{tabular}{|c|c|c|c|c|c|}
\hline \multirow[b]{2}{*}{ Sediment Treatment } & \multicolumn{5}{|c|}{ Concentration ( $\mu \mathrm{g} / \mathrm{kg}$ wet wt) } \\
\hline & RH COMP & RH COMP & RH COMP & RH COMP & RH COMP \\
\hline Replicate & 1 & 2 & 2 & 2 & 3 \\
\hline Analytical Replicate & & 1 & 2 & 3 & \\
\hline Percent Dry Wt. (\%) & 14.7 & 13.9 & 13.9 & 13.9 & 15.5 \\
\hline Batch & 1 & 1 & 1 & 1 & 1 \\
\hline 1,4-Dichlorobenzene ${ }^{(0)}$ & $2.61 U^{(b)}$ & $2.87 \mathrm{U}$ & $3.02 \mathrm{U}$ & $2.57 \mathrm{U}$ & $1.86 \mathrm{U}$ \\
\hline Naphthalene & 16.9 & 11.3 & 25.4 & 26.2 & $3.74^{(c)}$ \\
\hline Acenaphthylene & 12.7 & 8.63 & $10.8^{(c)}$ & 10.5 & 5.00 \\
\hline Acenaphthene & 118 & 95.7 & 120 & 120 & 48.1 \\
\hline Fluorene & 43.3 & 32.9 & 40.9 & 41.2 & 13.7 \\
\hline Dibenzothiophene & 17.0 & 13.0 & 12.0 & 13.8 & 8.17 \\
\hline Phenanthrene & 181 & 124 & 119 & 131 & 89.0 \\
\hline Anthracene & 69.2 & 42.3 & 41.3 & 44.8 & 27.8 \\
\hline Fluoranthene & 420 & 307 & 284 & 326 & 285 \\
\hline Pyrene & 388 & 267 & 252 & 281 & 272 \\
\hline Benzo[a]anthracene & 119 & 60.2 & 53.1 & 63.1 & 50.9 \\
\hline Chrysene & 256 & 181 & 171 & 193 & 160 \\
\hline Benzo[b]fluoranthene & 50.4 & 33.5 & 30.6 & 34.2 & 30.1 \\
\hline Benzo[k]fluoranthene & 28.7 & 14.0 & $14.6^{(c)}$ & 15.0 & 13.0 \\
\hline Benzo[e]pyrene. & 87.7 & 52.5 & 49.7 & 54.7 & 48.8 \\
\hline Benzo[a]pyrene & 84.5 & 40.8 & 39.1 & 42.8 & 38.9 \\
\hline Perylene & 6.93 & 5.07 & 4.97 & 5.34 & 4.45 \\
\hline Indeno[123-cd]pyrene & 11.2 & 7.23 & 7.52 & 6.78 & 6.02 \\
\hline Dibenzo[a,h]anthracene & 7.12 & 3.86 & $3.68^{(c)}$ & 3.93 & 3.33 \\
\hline Benzo[g,h,i]perylene & 20.7 & 14.5 & 12.8 & 13.0 & 11.7 \\
\hline \multicolumn{6}{|l|}{ Surrogate Recoveries (\%) } \\
\hline d4 1,4-Dichlorobenzene & $8^{(d)}$ & $17^{(\text {(d) }}$ & $6^{(d)}$ & $5^{(d)}$ & 50 \\
\hline d8 Naphthalene & $15^{(d)}$ & $27^{\text {(d) }}$ & $9^{(0)}$ & $12^{(d)}$ & 60 \\
\hline d10 Acenaphthene & 41 & 48 & $24^{\text {(d) }}$ & 38 & 72 \\
\hline d12 Chrysene & 75 & 64 & 44 & 62 & 85 \\
\hline d14 Dibenzo(a,h)anthracene & 63 & 85 & 52 & 67 & 66 \\
\hline
\end{tabular}


Table G.7. (contd)

\begin{tabular}{|c|c|c|c|c|c|}
\hline \multirow{3}{*}{$\begin{array}{r}\text { Sediment Treatment } \\
\text { Replicate }\end{array}$} & \multicolumn{5}{|c|}{ Concentration ( $\mu \mathrm{g} / \mathrm{kg}$ wet $w \mathrm{t})$} \\
\hline & RH COMP & RH COMP & BR-A COMP & BR-A COM & BR-A COMP \\
\hline & 4 & 5 & 1 & 2 & 3 \\
\hline \multicolumn{6}{|l|}{ Analytical Replicate } \\
\hline Percent Dry Wt. (\%) & 14.9 & 14.2 & 14.3 & 14.9 & 14.5 \\
\hline Batch & 1 & 1 & 1 & 1 & 1 \\
\hline 1,4-Dichlorobenzene & $1.86 \mathrm{U}$ & $1.86 \mathrm{U}$ & $1.86 U$ & $1.83 \mathrm{U}$ & $1.86 \mathrm{U}$ \\
\hline Naphthalene & 6.75 & 6.94 & $4.16^{(c)}$ & 3.30 & $2.87^{(c)}$ \\
\hline Acenaphthylene & 6.12 & $6.53^{(c)}$ & $1.11^{\text {(c) }}$ & $1.10^{(c)}$ & $1.61^{\text {(c) }}$ \\
\hline Acenaphthene & 66.5 & 57.8 & 2.73 & 3.34 & 2.53 \\
\hline Fluorene & 20.2 & 14.6 & $1.24 \mathrm{U}$ & $1.48^{(\mathrm{c})}$ & $1.24 U$ \\
\hline Dibenzothiophene & 9.92 & 8.68 & $0.50 \mathrm{U}$ & $0.84^{(c)}$ & $0.50 \mathrm{U}$ \\
\hline Phenanthrene & 103 & 65.2 & $2.56 \mathrm{U}$ & 2.97 & $2.56 \mathrm{U}$ \\
\hline Anthracene & 37.6 & 26.3 & $2.24 \mathrm{U}$ & $2.19 \mathrm{U}$ & $2.24 \mathrm{U}$ \\
\hline Fluoranthene & 277 & 169 & 9.65 & 21.3 & $9.80^{\circ}$ \\
\hline Pyrene & 271 & 152 & 15.6 & 33.8 & 17.4 \\
\hline Benzo[a]anthracene & 53.2 & 39.1 & 1.43 & 3.20 & 1.35 \\
\hline Chrysene & 174 & 145 & 6.62 & 12.2 & 6.72 \\
\hline Benzo[b]fluoranthene & 46.6 & 20.9 & 3.02 & 6.52 & 3.79 \\
\hline Benzo[k]fluoranthene & $1.67 \mathrm{U}$ & 13.8 & $1.79^{(c)}$ & $1.64 \mathrm{U}$ & $1.67 \mathrm{U}$ \\
\hline Benzo[e]pyrene & 56.9 & 37.7 & $2.44^{(c)}$ & $4.18^{(c)}$ & $2.54^{\text {(c) }}$ \\
\hline Benzo[a]pyrene & 44.5 & 38.9 & 1.97 & 3.28 & 1.85 \\
\hline Perylene & 5.09 & $3.06^{\text {(c) }}$ & $1.40 \mathrm{U}$ & $1.38 \mathrm{U}$ & $1.40 \mathrm{U}$ \\
\hline Indeno[123-cd]pyrene & 6.90 & 5.02 & $1.95^{(c)}$ & $2.10^{(c)}$ & $1.95^{(c)}$ \\
\hline Dibenzo[a,h]anthracene & 3.83 & 3.74 & $1.26 \mathrm{U}$ & $1.24 \mathrm{U}$ & $1.26 \mathrm{U}$ \\
\hline Benzo[g,h,i]perylene & 14.2 & 9.40 & $2.41^{(c)}$ & $2.53^{(c)}$ & $2.44^{(c)}$ \\
\hline \multicolumn{6}{|l|}{ Surrogate Recoveries (\%) } \\
\hline d4 1,4-Dichlorobenzene & $24^{(d)}$ & $18^{(d)}$ & $13^{(d)}$ & 52 & $25^{\text {(d) }}$ \\
\hline d8 Naphthalene & 38 & $22^{\text {(d) }}$ & $23^{(d)}$ & 67 & 34 \\
\hline d10 Acenaphthene & 63 & $29^{(d)}$ & 47 & 75 & 62 \\
\hline d12 Chrysene & 77 & 35 & 84 & 84 & 50 \\
\hline d14 Dibenzo(a,h)anthracene & 74 & $26^{(d)}$ & 70 & 60 & 45 \\
\hline
\end{tabular}

G.18 
Table G.7. (contd)

\begin{tabular}{|c|c|c|c|c|c|}
\hline & & & & & \\
\hline Sediment Treatment & BR-A COMP & BR-A COMP & BR-B COMP & BR-B COMP & $\overline{B R-B ~ C O M P}$ \\
\hline Replicate & 4 & 5 & 1 & 2 & 3 \\
\hline Analytical Replicate & & & & & \\
\hline Percent Dry Wt. (\%) & 15.7 & 15.7 & 14.3 & 13.6 & 14.2 \\
\hline Batch & 1 & 1 & 1 & 1 & 1 \\
\hline 1,4-Dichlorobenzene & $1.83 \mathrm{U}$ & $1.86 \mathrm{U}$ & $1.86 U$ & $1.86 \mathrm{U}$ & $1.86 \mathrm{U}$ \\
\hline Naphthalene & 3.52 & $3.96^{(c)}$ & 67.7 & 142 & 22.5 \\
\hline Acenaphthylene & $1.27^{(c)}$ & $1.17^{(c)}$ & 13.1 & 16.5 & 6.32 \\
\hline Acenaphthene & 4.22 & 2.88 & 200 & 386 & 101 \\
\hline Fluorene & 1.86 & $1.39^{(c)}$ & 22.9 & 97.2 & 16.7 \\
\hline Dibenzothiophene & $0.80^{(c)}$ & $0.50 \mathrm{U}$ & 7.29 & 25.0 & 5.85 \\
\hline Phenanthrene & 3.80 & $2.56 \mathrm{U}$ & 28.7 & 165 & 34.4 \\
\hline Anthracene & $2.29^{\text {(c) }}$ & $2.24 \mathrm{U}$ & 9.32 & 54.8 & 10.1 \\
\hline Fluoranthene & 21.3 & 10.9 & 58.3 & 219 & 62.6 \\
\hline Pyrene & 33.8 & 16.8 & 55.8 & 224 & 58.8 \\
\hline Benzo[a]anthracene & 4.81 & 1.80 & 10.6 & 30.5 & 8.43 \\
\hline Chrysene & 13.8 & 7.76 & 40.3 & 88.1 & 40.7 \\
\hline Benzo[b]fluoranthene & 7.75 & 4.53 & 7.30 & 22.8 & $6.52^{(c)}$ \\
\hline Benzo[k]fluoranthene & $1.64 U$ & $1.67 \mathrm{U}$ & 4.51 & $1.67 \mathrm{U}$ & $3.92^{\text {(c) }}$ \\
\hline Benzo[e]pyrene & $4.96^{(c)}$ & $3.07^{(c)}$ & 12.0 & 22.3 & $10.2^{(\mathrm{c})}$ \\
\hline Benzo[a]pyrene & 4.03 & 2.42 & 10.0 & 18.4 & 8.59 \\
\hline Perylene & $1.38 \mathrm{U}$ & $1.40 \mathrm{U}$ & $1.40 \mathrm{U}$ & 2.86 & $1.40 \mathrm{U}$ \\
\hline Indeno[123-cd]pyrene & $2.27^{(c)}$ & $2.10^{(c)}$ & 2.44 & 3.29 & $2.42^{\text {(c) }}$ \\
\hline Dibenzo[a,h]anthracene & $1.52^{(c)}$ & $1.26 U$ & $1.86^{(c)}$ & 2.15 & $1.74^{(c)}$ \\
\hline Benzo[g,h,i]perylene & $2.75^{(c)}$ & $2.67^{(c)}$ & 3.89 & 5.74 & 4.21 \\
\hline Surrogate Recoveries (\%) & & & & & \\
\hline d4 1,4-Dichlorobenzene & 49 & $25^{(d)}$ & $3^{(d)}$ & $3^{(d)}$ & $19^{(d)}$ \\
\hline d8 Naphthalene & 61 & 37 & $9^{(d)}$ & $10^{(d)}$ & 31 \\
\hline d10 Acenaphthene & 70 & 61 & 37 & 44 & 60 \\
\hline d12 Chrysene & 79 & 79 & 74 & 88 & 77 \\
\hline d14 Dibenzo(a,h)anthracene & 53 & 77 & 49 & 63 & 77 \\
\hline
\end{tabular}

G.19 
Table G.7. (contd)

\begin{tabular}{|c|c|c|c|c|c|}
\hline & & Concen & tration $(\mu \mathrm{g} / \mathrm{k}$ & t wt) & \\
\hline Sediment Treatment & BR-B COMP & BR-B COMP & MDRS $^{(e)}$ & MDRS & MDRS \\
\hline Replicate & 4 & 5 & 1 & 2 & 3 \\
\hline Analytical Replicate & & & & & \\
\hline Percent Dry Wt. (\%) & 14.6 & 15.7 & 14.4 & 13.5 & 15.3 \\
\hline Batch & 1 & 1 & 1 & 1 & 1 \\
\hline 1,4-Dichlorobenzene & $1.86 \mathrm{U}$ & $2.16 \mathrm{U}$ & $2.24 \mathrm{U}$ & $1.86 \mathrm{U}$ & $1.86 \mathrm{U}$ \\
\hline Naphthalene & 65.3 & 9.16 & $3.15^{(c)}$ & $3.17^{(c)}$ & $3.21^{(c)}$ \\
\hline Acenaphthylene & 10.6 & 5.08 & $0.87 \mathrm{U}$ & $0.73 \mathrm{U}$ & $0.73 \mathrm{U}$ \\
\hline Acenaphthene & 249 & 59.1 & 1.94 & $1.57^{\text {(c) }}$ & 1.84 \\
\hline Fluorene & 55.6 & 7.92 & $1.48 \mathrm{U}$ & $1.24 \mathrm{U}$ & $1.73^{(c)}$ \\
\hline Dibenzothiophene & 16.5 & 5.49 & $0.60 \mathrm{U}$ & $0.50 \mathrm{U}$ & 2.91 \\
\hline Phenanthrene & 108 & 24.5 & $3.07 \mathrm{U}$ & $2.56 \mathrm{U}$ & 14.0 \\
\hline Anthracene & 35.0 & 8.07 & $2.69 \mathrm{U}$ & $2.24 \mathrm{U}$ & 3.17 \\
\hline Fluoranthene & 131 & 71.9 & $\therefore 6.44 \mathrm{U}$ & $5.36 \mathrm{U}$ & $5.36 \mathrm{U}$ \\
\hline Pyrene & 138 & 79.2 & $5.48 \mathrm{U}$ & $4.57 \mathrm{U}$ & 8.58 \\
\hline Benzo[a]anthracene & 22.3 & 12.4 & $1.83^{(c)}$ & $1.31^{(c)}$ & 1.95 \\
\hline Chrysene & 62.6 & 54.7 & $2.72 \mathrm{U}$ & $2.27 \mathrm{U}$ & 4.92 \\
\hline Benzo[b]fluoranthene & 19.0 & $10.7^{(c)}$ & $2.41^{(c)}$ & $1.64 \mathrm{U}$ & $3.29^{(c)}$ \\
\hline Benzo[k]fluoranthene & $1.67 \mathrm{U}$ & 6.49 & $2.00 \mathrm{U}$ & $1.67 \mathrm{U}$ & $1.67 U$ \\
\hline Benzo[e]pyrene & 18.3 & .19 .8 & $1.86 \mathrm{U}$ & $1.55 \mathrm{U}$ & $2.68^{\text {(c) }}$ \\
\hline Benzo[a]pyrene & 15.2 & 16.0 & $1.79 \mathrm{U}$ & 1.56 & $1.49 \mathrm{U}$ \\
\hline Perylene & 2.59 & 2.12 & $1.68 \mathrm{U}$ & $1.40 \mathrm{U}$ & $1.40 \mathrm{U}$ \\
\hline Indeno[123-cd]pyrene & 3.38 & 4.25 & $2.11 \mathrm{U}$ & $1.76 \mathrm{U}$ & $1.87^{(c)}$ \\
\hline Dibenzo[a,h]anthracene & $2.11^{(c)}$ & 2.70 & $1.51 \mathrm{U}$ & $1.26 U$ & $1.26 U$ \\
\hline Benzo[g, $h, i] p e r y l e n e$ & 5.70 & 7.70 & $1.68 \mathrm{U}$ & $1.40 \mathrm{U}$ & 3.52 \\
\hline Surrogate Recoveries (\%) & & & & & \\
\hline d4 1,4-Dichlorobenzene & $8^{(d)}$ & $17^{\text {(d) }}$ & 53 & 31 & $29^{\text {(d) }}$ \\
\hline d8 Naphthalene & $16^{(\mathrm{d})}$ & $29^{(d)}$ & 64 & 41 & 42 \\
\hline d10 Acenaphthene & 44 & 52 & 70 & 52 & 63 \\
\hline d12 Chrysene & 78 & 65 & 80 & 65 & 69 \\
\hline d14 Dibenzo(a,h)anthracene & 66 & 63 & 70 & 61 & 64 \\
\hline
\end{tabular}


Table G.7. (contd)

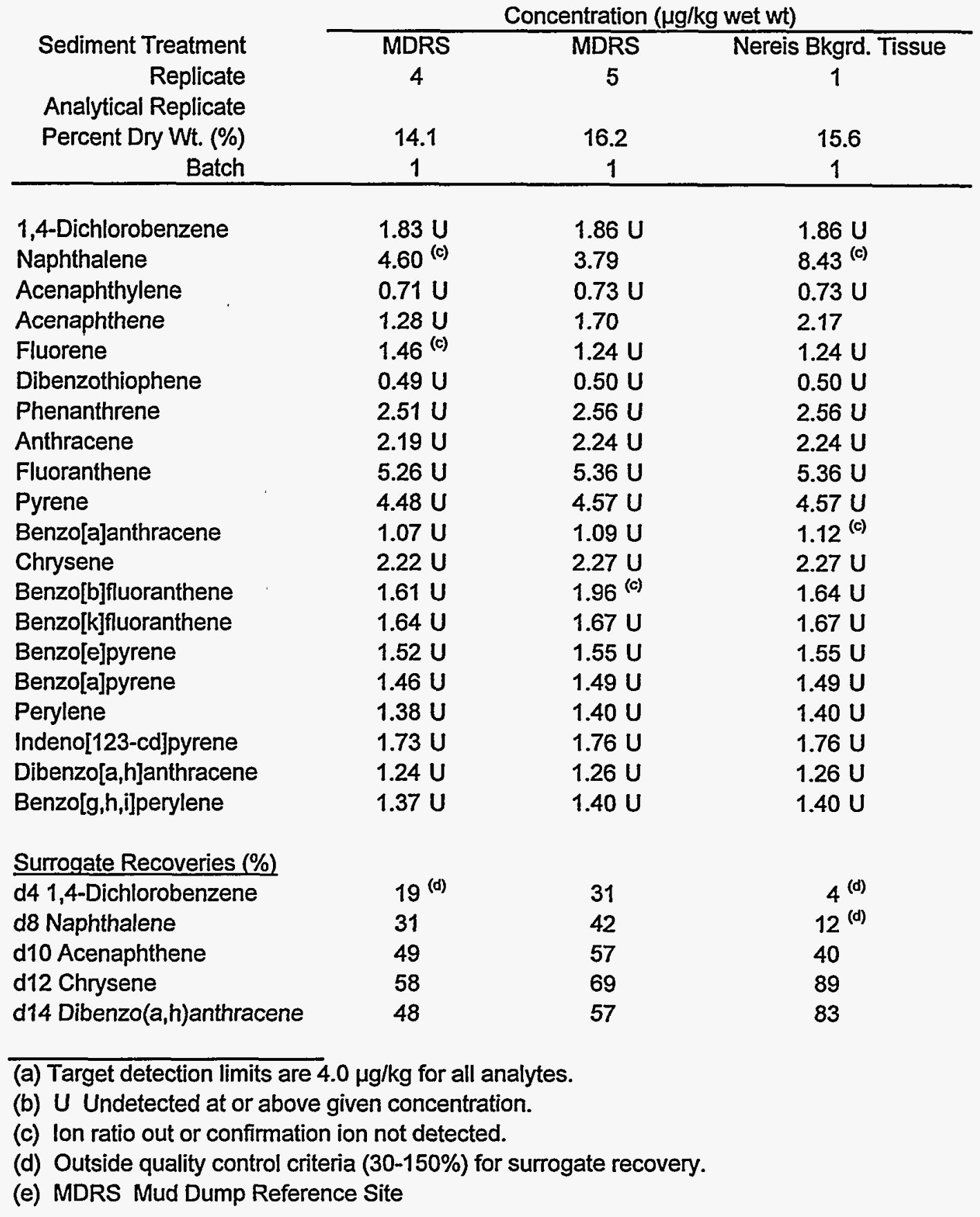


Table G.8. Polynuclear Aromatic Hydrocarbons (PAHs) in Tissue of N.virens (Dry Weight), Red Hook and Bay Ridge Channels

\begin{tabular}{|c|c|c|c|c|c|}
\hline \multirow[b]{2}{*}{$\begin{array}{r}\text { Sediment Treatment } \\
\text { Replicate }\end{array}$} & \multicolumn{5}{|c|}{ Concentration ( $\mu \mathrm{g} / \mathrm{kg}$ dry wt) } \\
\hline & $\begin{array}{c}\text { RH COMP } \\
1\end{array}$ & $\begin{array}{c}\text { RH COMP } \\
2\end{array}$ & $\begin{array}{l}\text { RH COMP } \\
2\end{array}$ & $\begin{array}{c}\text { RH COMP } \\
2\end{array}$ & $\begin{array}{c}\text { RH COMP } \\
3\end{array}$ \\
\hline Analytical Replicate & & 1 & 2 & 3 & \\
\hline Percent Dry Wt. (\%) & 14.7 & 13.9 & 13.9 & 13.9 & 15.5 \\
\hline Batch & 1 & 1 & 1 & 1 & 1 \\
\hline 1,4-Dichlorobenzene & $17.8 U^{(a)}$ & $20.6 U$ & $21.7 U$ & $18.4 U$ & $12.0 \mathrm{U}$ \\
\hline Naphthalene & 115 & 81.0 & 182 & 188 & $24.2^{\text {(b) }}$ \\
\hline Acenaphthylene & 86.6 & 61.9 & $77.3^{(b)}$ & 75.4 & 32.3 \\
\hline Acenaphthene & 803 & 687 & 861 & 862 & 311 \\
\hline Fluorene & 295 & 236 & 293 & 296 & 88.8 \\
\hline Dibenzothiophene & 116 & 93.1 & 85.8 & 99.1 & 52.8 \\
\hline Phenanthrene & 1230 & 886 & 851 & 943 & 575 \\
\hline Anthracene & 471 & 303 & 296 & 321 & 179 \\
\hline Fluoranthene & 2860 & 2200 & 2040 & 2340 & 1840 \\
\hline Pyrene & 2640 & 1910 & 1810 & 2010 & 1760 \\
\hline Benzo[a]anthracene & 810 & 432 & 381 & 453 & 329 \\
\hline Chrysene & 1750 & 1300 & 1220 & 1380 & 1030 \\
\hline Benzo[b]fluoranthene & 343 & 240 & 219 & 245 & 195 \\
\hline Benzo[k]fluoranthene & 195 & 101 & $105^{(b)}$ & 108 & 84.3 \\
\hline Benzo[e]pyrene & 598 & 377 & 357 & 392 & 315 \\
\hline Benzo[a]pyrene & 575 & 292 & 281 & 307 & 251 \\
\hline Perylene & 47.2 & 36.4 & 35.7 & 38.3 & 28.8 \\
\hline Indeno[123-cd]pyrene & 76.3 & 51.9 & 53.9 & 48.6 & 38.9 \\
\hline Dibenzo[a,h]anthracene & 48.5 & 27.7 & $26.4^{\text {(b) }}$ & 28.2 & 21.5 \\
\hline Benzo[g,h,i]perylene & 70.4 & 104 & 92.1 & 93.5 & 75.6 \\
\hline
\end{tabular}


Table G.8. (contd)

\begin{tabular}{|c|c|c|c|c|c|}
\hline \multirow[b]{2}{*}{ Sediment Treatment } & \multicolumn{5}{|c|}{ Concentration ( $\mu \mathrm{g} / \mathrm{kg}$ dry $w t)$} \\
\hline & RH COMP & RH COMP & BR-A COMP & BR-A COMP & BR-A COMP \\
\hline Replicate & 4 & 5 & 1 & 2 & 3 \\
\hline \multicolumn{6}{|l|}{ Analytical Replicate } \\
\hline Percent Dry Wt. (\%) & 14.9 & 14.2 & 14.3 & 14.9 & 14.5 \\
\hline Batch & 1 & 1 & 1 & 1 & 1 \\
\hline 1,4-Dichlorobenzene & $12.5 \mathrm{U}$ & $13.1 \mathrm{U}$ & $13.0 \mathrm{U}$ & $12.3 \mathrm{U}$ & $12.9 \mathrm{U}$ \\
\hline Naphthalene & 45.2 & 49.0 & $29.1^{(b)}$ & 22.2 & $19.8^{(b)}$ \\
\hline Acenaphthylene & 41.0 & $46.1^{\text {(b) }}$ & $7.76^{(b)}$ & $7.41^{\text {(b) }}$ & $11.1^{\text {(b) }}$ \\
\hline Acenaphthene & 445 & 408 & 19.1 & 22.5 & 17.5 \\
\hline Fluorene & 135 & 103 & $8.67 \mathrm{U}$ & $9.97^{\text {(b) }}$ & $8.57 \mathrm{U}$ \\
\hline Dibenzothiophene & 66.4 & 61.3 & $3.5 \mathrm{U}$ & $5.7^{(b)}$ & $3.5 \mathrm{U}$ \\
\hline Phenanthrene & 690 & 460 & $17.9 \mathrm{U}$ & 20.0 & $17.7 \cdot U$ \\
\hline Anthracene & 252 & 186 & $15.7 \mathrm{U}$ & $14.7 \mathrm{U}$ & $15.5 U$ \\
\hline Fluoranthene & 1860 & 1200 & 67.5 & 144 & 67.7 \\
\hline Pyrene & 1820 & 1080 & 109 & 228 & 120 \\
\hline Benzo[a]anthracene & 356 & 276 & 10.0 & 21.5 & 9.33 \\
\hline Chrysene & 1160 & 1020 & 46.3 & 82.4 & 46.4 \\
\hline Benzo[b]fluoranthene & 312 & 148 & 21.1 & 43.9 & 26.2 \\
\hline Benzo[k]fluoranthene & $11.2 \mathrm{U}$ & 97.1 & $12.5^{(b)}$ & $11.0 \mathrm{U}$ & $11.5 \mathrm{U}$ \\
\hline Benzo[e]pyrene & 381 & 266 & $17.1^{\text {(b) }}$ & $28.1^{(b)}$ & $17.6^{(\mathrm{b})}$ \\
\hline Benzo[a]pyrene & 298 & 274 & 13.8 & 22.1 & 12.8 \\
\hline Perylene & 34.1 & $21.6^{(b)}$ & $9.79 \mathrm{U}$ & $9.29 \mathrm{U}$ & $9.68 \mathrm{U}$ \\
\hline Indeno[123-cd]pyrene & 46.2 & 35.5 & $13.6^{(b)}$ & $14.1^{(b)}$ & $13.5^{(b)}$ \\
\hline Dibenzo[a,h]anthracene & 25.7 & 26.4 & $8.81 \mathrm{U}$ & $8.35 \mathrm{U}$ & $8.71 \mathrm{U}$ \\
\hline Benzo[g,h,i]perylene & 95.4 & 66.4 & $16.9^{\text {(b) }}$ & $17.0^{(\mathrm{b})}$ & $16.9^{(b)}$ \\
\hline
\end{tabular}


Table G.8. (contd)

\begin{tabular}{|c|c|c|c|c|c|}
\hline \multirow[b]{2}{*}{ Sediment Treatment } & \multicolumn{5}{|c|}{ Concentration ( $\mu \mathrm{g} / \mathrm{kg}$ dry $w t)$} \\
\hline & BR-A COMP & BR-A COMP & BR-B COMP & BR-B COMP & BR-B COMP \\
\hline Replicate & 4 & 5 & 1 & 2 & 3 \\
\hline \multicolumn{6}{|l|}{ Analytical Replicate } \\
\hline Percent Dry Wt. (\%) & 15.7 & 15.7 & 14.3 & 13.6 & 14.2 \\
\hline Batch & 1 & 1 & 1 & 1 & 1 \\
\hline 1,4-Dichlorobenzene & $11.6 \mathrm{U}$ & $11.8 \mathrm{U}$ & $13.0 \mathrm{U}$ & $13.6 \mathrm{U}$ & $13.1 \mathrm{U}$ \\
\hline Naphthalene & 22.4 & $25.2^{(b)}$ & 473 & 1040 & 159 \\
\hline Acenaphthylene & $8.07^{\text {(b) }}$ & $7.44^{(b)}$ & 91.7 & 121 & 44.7 \\
\hline Acenaphthene & 26.8 & 18.3 & 1400 & 2830 & 716 \\
\hline Fluorene & 11.8 & $8.84^{(b)}$ & 160 & 713 & 118 \\
\hline Dibenzothiophene & $5.1^{\text {(b) }}$ & $3.2 \mathrm{U}$ & 50.9 & 184 & 41.3 \\
\hline Phenanthrene & 24.2 & $16.3 \mathrm{U}$ & 201 & 1210 & 243 \\
\hline Anthracene & $14.6^{(b)}$ & $14.2 U$ & 65.1 & 402 & 71.7 \\
\hline Fluoranthene & 135 & 69.2 & 407 & 1610 & 443 \\
\hline Pyrene & 215 & 107 & 390 & 1640 & 415 \\
\hline Benzo[a]anthracene & 30.6 & 11.5 & 74.1 & 223 & 59.6 \\
\hline Chrysene & 87.7 & 49.4 & 282 & 646 & 288 \\
\hline Benzo[b]fluoranthene & 49.3 & 28.8 & 51.0 & 167 & $46.1^{(b)}$ \\
\hline Benzo[k]fluoranthene & $10.4 \mathrm{U}$ & $10.6 \mathrm{U}$ & 31.5 & $12.2 U$ & $27.7^{(b)}$ \\
\hline Benzo[e]pyrene & $31.5^{(b)}$ & $19.5^{\text {(b) }}$ & 83.6 & 164 & $72.2^{(b)}$ \\
\hline Benzo[a]pyrene & 25.6 & 15.4 & 70.0 & 135 & 60.7 \\
\hline Perylene & $8.77 \mathrm{U}$ & $8.91 \mathrm{U}$ & $9.78 \mathrm{U}$ & 21.0 & $9.89 \mathrm{U}$ \\
\hline Indeno[123-cd]pyrene & $14.4^{(b)}$ & $13.4^{(\mathrm{b})}$ & 17.1 & 24.1 & $17.1^{\text {(b) }}$ \\
\hline Dibenzo[a,h]anthracene & $9.66^{\text {(b) }}$ & $8.02 \mathrm{U}$ & $13.0^{(b)}$ & 15.8 & $12.3^{(b)}$ \\
\hline Benzo[g,h,i]perylene & $17.5^{(b)}$ & $17.0^{(b)}$ & 27.2 & 42.1 & 29.8 \\
\hline
\end{tabular}


Table G.8. (contd)

\begin{tabular}{|c|c|c|c|c|c|}
\hline \multirow[b]{2}{*}{$\begin{array}{r}\text { Sediment Treatment } \\
\text { Replicate } \\
\text { Analytical Replicate }\end{array}$} & \multicolumn{5}{|c|}{ Concentration ( $\mu \mathrm{g} / \mathrm{kg}$ dry $w t)$} \\
\hline & $\begin{array}{c}\text { BR-B COMP } \\
4\end{array}$ & $\begin{array}{c}\text { BR-B COMP } \\
5\end{array}$ & $\begin{array}{c}\mathrm{MDRS}^{(c)} \\
1\end{array}$ & $\begin{array}{l}\text { MDRS } \\
2\end{array}$ & $\begin{array}{c}\text { MDRS } \\
3\end{array}$ \\
\hline Percent Dry Wt. (\%) & 14.6 & 15.7 & 14.4 & 13.5 & 15.3 \\
\hline Batch & 1 & 1 & 1 & 1 & 1 \\
\hline 1,4-Dichlorobenzene & $12.7 \mathrm{U}$ & $13.8 \mathrm{U}$ & $15.5 \mathrm{U}$ & $13.8 \mathrm{U}$ & $12.2 \mathrm{U}$ \\
\hline Naphthalene & 447 & 58.5 & $21.8^{(b)}$ & $23.5^{(b)}$ & $21.0^{(b)}$ \\
\hline Acenaphthylene & 72.2 & 32.4 & $6.0 \mathrm{U}$ & $5.4 \mathrm{U}$ & $4.8 \mathrm{U}$ \\
\hline Acenaphthene & 1710 & 378 & 13.4 & $11.6^{(b)}$ & 12.0 \\
\hline Fluorene & 381 & 50.6 & $10.3 \mathrm{U}$ & $9.18 U$ & $11.3^{(b)}$ \\
\hline Dibenzothiophene & 113 & 35.1 & $4.2 \mathrm{U}$ & $3.7 \mathrm{U}$ & 19.1 \\
\hline Phenanthrene & 741 & 156 & $21.3 \mathrm{U}$ & $18.9 \mathrm{U}$ & 91.6 \\
\hline Anthracene & 240 & 51.5 & $18.6 \mathrm{U}$ & $16.6 \mathrm{U}$ & 20.8 \\
\hline Fluoranthene & 897 & 459 & $44.6 \mathrm{U}$ & $39.7 \mathrm{U}$ & $35.1 \mathrm{U}$ \\
\hline Pyrene & 947 & 506 & $38.0 \mathrm{U}$ & $33.8 \mathrm{U}$ & 56.2 \\
\hline Benzo[a]anthracene & 152 & 78.9 & $12.7^{(b)}$ & $9.70^{(b)}$ & 12.8 \\
\hline Chrysene & 429 & 349 & $18.8 \mathrm{U}$ & $16.8 \mathrm{U}$ & 32.2 \\
\hline Benzo[b]fluoranthene & 130 & $68.1^{\text {(b) }}$ & $16.7^{(b)}$ & $12.1 \mathrm{U}$ & $21.5^{(b)}$ \\
\hline Benzo[k]fluoranthene & $11.4 \mathrm{U}$ & 41.4 & $13.9 \mathrm{U}$ & $12.4 \mathrm{U}$ & $10.9 \mathrm{U}$ \\
\hline Benzo[e]pyrene & 125 & 127 & $12.9 \mathrm{U}$ & $11.5 \mathrm{U}$ & $17.6^{(b)}$ \\
\hline Benzo[a]pyrene & 104 & 102 & $12.4 \mathrm{U}$ & 11.5 & $9.76 \mathrm{U}$ \\
\hline Perylene & 17.7 & 13.5 & $11.6 \mathrm{U}$ & $10.4 \mathrm{U}$ & $9.17 \mathrm{U}$ \\
\hline Indeno[123-cd]pyrene & 23.1 & 27.1 & $14.6 \mathrm{U}$ & $13.0 \mathrm{U}$ & $12.2^{(b)}$ \\
\hline Dibenzo[a,h]anthracene & $14.4^{(b)}$ & 17.2 & $10.5 \mathrm{U}$ & $9.33 \mathrm{U}$ & $8.25 \mathrm{U}$ \\
\hline Benzo[g,h,i]perylene & 39.0 & 49.2 & $11.6 \mathrm{U}$ & $10.4 \mathrm{U}$ & 23.1 \\
\hline
\end{tabular}


Table G.8. (contd)

\begin{tabular}{|c|c|c|c|}
\hline \multirow[b]{2}{*}{ Sediment Treatment } & \multicolumn{3}{|c|}{ Concentration ( $\mu \mathrm{g} / \mathrm{kg}$ dry wt) } \\
\hline & MDRS & MDRS & Nereis Bkgrd. Tissue \\
\hline Replicate & 4 & 5 & 1 \\
\hline \multicolumn{4}{|l|}{ Analytical Replicate } \\
\hline Percent Dry Wt. (\%) & 14.1 & 16.2 & 15.6 \\
\hline Batch & 1 & 1 & 1 \\
\hline 1,4-Dichlorobenzene & $12.9 \mathrm{U}$ & $: 11.5 \mathrm{U}$ & $11.9 \mathrm{U}$ \\
\hline Naphthalene & $32.5^{(b)}$ & 23.4 & $54.0^{\text {(b) }}$ \\
\hline Acenaphthylene & $5.0 \mathrm{U}$ & $4.5 U$ & $4.7 U$ \\
\hline Acenaphthene & $9.05 \mathrm{U}$ & 10.5 & 13.9 \\
\hline Fluorene & $10.3^{(b)}$ & $7.65 \mathrm{U}$ & $7.95 \mathrm{U}$ \\
\hline Dibenzothiophene & $3.5 \mathrm{U}$ & $3.1 \mathrm{U}$ & $3.2 \mathrm{U}$ \\
\hline Phenanthrene & $17.8 \mathrm{U}$ & $15.8 U$ & $16.4 U$ \\
\hline Anthracene & $15.5 U$ & $13.8 \mathrm{U}$ & $14.4 \mathrm{U}$ \\
\hline Fluoranthene & $37.2 \mathrm{U}$ & $33.1 \mathrm{U}$ & $34.4 \mathrm{U}$ \\
\hline Pyrene & $31.7 \mathrm{U}$ & $28.2 \mathrm{U}$ & $29.3 \mathrm{U}$ \\
\hline Benzo[a]anthracene & $7.57 \mathrm{U}$ & $6.72 \mathrm{U}$ & $7.18^{\text {(b) }}$ \\
\hline Chrysene & $15.7 U$ & $14.0 \mathrm{U}$ & $14.6 \mathrm{U}$ \\
\hline Benzo[b]fluoranthene & $11.4 \mathrm{U}$ & $12.1^{\text {(b) }}$ & $10.5 \mathrm{U}$ \\
\hline Benzo[k]fluoranthene & $11.6 \mathrm{U}$ & $10.3 U$ & $10.7 \mathrm{U}$ \\
\hline Benzo[e]pyrene & $10.7 \mathrm{U}$ & $9.56 \mathrm{U}$ & $9.94 \mathrm{U}$ \\
\hline Benzo[a]pyrene & $10.3 \mathrm{U}$ & $9.19 \mathrm{U}$ & $9.55 \mathrm{U}$ \\
\hline Perylene & $9.76 \mathrm{U}$ & $8.64 \mathrm{U}$ & $8.97 \mathrm{U}$ \\
\hline Indeno[123-cd]pyrene & $12.2 \mathrm{U}$ & $10.9 \mathrm{U}$ & $11.3 U$ \\
\hline Dibenzo[a, h]anthracene & $8.77 \mathrm{U}$ & $7.77 \mathrm{U}$ & $8.08 \mathrm{U}$ \\
\hline Benzo[g,h,i]perylene & $9.69 \mathrm{U}$ & $8.64 U$ & $8.97 \mathrm{U}$ \\
\hline
\end{tabular}

(a) U Undetected at or above given concentration.

(b) Ion ratio out or confirmation ion not detected.

(c) MDRS Mud Dump Reference Site. 
Table G.9. Quality Control Data for Polynuclear Aromatic Hydrocarbon (PAH) Analysis of $N$. virens Tissue (Wet Weight)

Matrix Spike Results

\begin{tabular}{|c|c|c|c|c|c|c|}
\hline \multirow{4}{*}{$\begin{array}{r}\text { Sediment Treatment } \\
\text { Replicate } \\
\text { Analytical Replicate }\end{array}$} & & \multicolumn{4}{|c|}{ Concentration ( $\mu \mathrm{g} / \mathrm{kg}$ wet $w t)$} & \multirow{4}{*}{$\begin{array}{l}\text { Percent } \\
\text { Recovery }\end{array}$} \\
\hline & \multirow{4}{*}{$\begin{array}{r}\text { Blank } \\
1 \\
1 \\
\end{array}$} & \multicolumn{2}{|c|}{ RH COMP(a) RH COMP (MS) } & \multicolumn{2}{|c|}{ Concentration } & \\
\hline & & 1 & 1 & Spiked & Recovered & \\
\hline & & & & & & \\
\hline Batch & & 1 & 1 & 1 & & \\
\hline 1,4-Dichlorobenzene & $1.98 \mathrm{U}$ & $2.61 \mathrm{U}^{(\mathrm{b})}$ & $2.61 \mathrm{U}$ & NS ${ }^{(c)}$ & $N A^{(d)}$ & NA \\
\hline Naphthalene & $2.07^{(e)}$ & 16.9 & 38.9 & 35.0 & 22.0 & 63 \\
\hline Acenaphthylene & $0.77 \mathrm{U}$ & 12.7 & 40.0 & 35.0 & 27.3 & 78 \\
\hline Acenaphthene & $1.38 \mathrm{U}$ & 118 & 98.6 & 35.0 & US $^{(0)}$ & $N C^{(g)}$ \\
\hline Fluorene & 1.97 & 43.3 & 62.3 & 35.0 & 19.0 & 54 \\
\hline Dibenzothiophene & $0.53 \mathrm{U}$ & 17.0 & 13.4 & NS & NA & NA \\
\hline Phenanthrene & $2.71 \mathrm{U}$ & 181 & 177 & 35.0 & US & NC \\
\hline Anthracene & $2.37 \mathrm{U}$ & 69.2 & 89.5 & 35.0 & 20.3 & 58 \\
\hline Fluoranthene & $5.69 \mathrm{U}$ & 420 & 370 & 35.0 & US & NC \\
\hline Pyrene & $4.84 \mathrm{U}$ & 388 & 341 & 35.0 & US & NC \\
\hline Benzo[a]anthracene & $1.16 \mathrm{U}$ & 119 & 135 & 35.0 & 16.0 & $46^{(h)}$ \\
\hline Chrysene & $2.40 \mathrm{U}$ & 256 & 242 & 35.0 & US & NC \\
\hline Benzo[b]fluoranthene & $1.74 \mathrm{U}$ & 50.4 & 77.5 & 35.0 & 27.1 & 77 \\
\hline Benzo[k]fluoranthene & $1.77 \mathrm{U}$ & 28.7 & 57.9 & 35.0 & 29.2 & 83 \\
\hline Benzo[e]pyrene & $1.64 \mathrm{U}$ & 87.7 & 67.5 & NS & NA & NA \\
\hline Benzo[a]pyrene & $1.58 \mathrm{U}$ & 84.5 & 102 & 35.0 & 17.5 & $50^{(h)}$ \\
\hline Perylene & $1.49 \mathrm{U}$ & 6.93 & 5.98 & NS & NA & NA \\
\hline Indeno[123-cd]pyrene & $1.87 \mathrm{U}$ & 11.2 & 39.1 & 35.0 & 27.9 & 80 \\
\hline Dibenzo[a,h]anthracene & $1.34 \mathrm{U}$ & 7.12 & 33.6 & 35.0 & 26.5 & 76 \\
\hline Benzo[g,h,i]perylene & $1.49 \mathrm{U}$ & 20.7 & 42.8 & 35.0 & 22.1 & 63 \\
\hline \multicolumn{7}{|l|}{ Surrogate Recoveries (\%) } \\
\hline d4 1,4-Dichlorobenzene & 63 & $8^{(\text {(i) }}$ & 44 & NA & NA & NA \\
\hline d8 Naphthalene & 67 & $15^{(1)}$ & 54 & NA & NA & NA \\
\hline d10 Acenaphthene & 74 & 41 & 65 & NA & NA & NA \\
\hline d12 Chrysene & 82 & 75 & 74 & NA & NA & NA \\
\hline d14 Dibenzo(a,h)anthracene & 76 & 63 & 47 & NA & NA & NA \\
\hline
\end{tabular}


Table G.9. (contd)

Analytical Replicates

\begin{tabular}{|c|c|c|c|c|}
\hline & Conce & tration $(\mu \mathrm{g} / \mathrm{kg}$ & Net wt) & \\
\hline $\begin{array}{l}\text { Sediment Treatment. } \\
\text { Replicate }\end{array}$ & $\begin{array}{c}\text { RH COMP } \\
2\end{array}$ & $\begin{array}{l}\text { RH COMP } \\
2\end{array}$ & $\begin{array}{l}\text { RH COMP } \\
2\end{array}$ & $\begin{array}{l}\text { RSD } \\
(\%)\end{array}$ \\
\hline Analytical Replicate & 1 & 2 & 3 & \\
\hline Batch & 1 & 1 & 1 & \\
\hline 1,4-Dichlorobenzene & $2.87 \mathrm{U}$ & $3.02 \mathrm{U}$ & $2.57 \mathrm{U}$ & NA \\
\hline Naphthalene & 11.3 & 25.4 & 26.2 & $40^{\circ}$ \\
\hline Acenaphthylene & 8.63 & $10.8^{(e)}$ & 10.5 & 12 \\
\hline Acenaphthene & 95.7 & 120 & 120 & 13 \\
\hline Fluorene & 32.9 & 40.9 & 41.2 & 12 \\
\hline Dibenzothiophene & 13.0 & 12.0 & 13.8 & 7 \\
\hline Phenanthrene & 124 & 119 & 131 & 5 \\
\hline Anthracene & 42.3 & 41.3 & 44.8 & 4 \\
\hline Fluoranthene & 307 & 284 & 326 & 7 \\
\hline Pyrene & 267 & 252 & 281 & 5 \\
\hline Benzo[a]anthracene & 60.2 & 53.1 & 63.1 & 9 \\
\hline Chrysene & 181 & 171 & 193 & 6 \\
\hline Benzo[b]fluoranthene & 33.5 & 30.6 & 34.2 & 6 \\
\hline Benzo[k]fluoranthene & 14.0 & $14.6^{(\mathrm{e})}$ & 15.0 & 3 \\
\hline Benzo[e]pyrene & 52.5 & 49.7 & 54.7 & 5 \\
\hline Benzo[a]pyrene & 40.8 & 39.1 & 42.8 & 5 \\
\hline Perylene & 5.07 & 4.97 & 5.34 & 4 \\
\hline Indeno[123-cd]pyrene & 7.23 & 7.52 & 6.78 & 5 \\
\hline Dibenzo[a,h]anthracene & 3.86 & $3.68^{(e)}$ & 3.93 & 3 \\
\hline Benzo[g,h,i]perylene & 14.5 & 12.8 & 13.0 & 7 \\
\hline Surrogate Recoveries (\%) & & & & \\
\hline d4 1,4-Dichlorobenzene & $17^{\text {(i) }}$ & $6^{(1)}$ & $5^{(1)}$ & $N A$ \\
\hline d8 Naphthalene & $27^{(0)}$ & $9^{(3)}$ & $12^{(i)}$ & NA \\
\hline d10 Acenaphthene & 48 & $24^{\text {(1) }}$ & 38 & NA \\
\hline d12 Chrysene & 64 & 44 & 62 & NA \\
\hline d14 Dibenzo(a,h)anthracene & 85 & 52 & 67 & NA \\
\hline
\end{tabular}

(a) Sample randomly selected for use as a quality control sample in analytical batch.

(b) U Undetected at or above given concentration.

(c) NS Not spiked.

(d) NA Not applicable.

(e) Ion ratio out or confirmation ion not detected.

(f) US Under spiked.

(g) NC Not calculated.

(h) Outside quality control criteria (50-120\%) for spike recovery.

(i) Outside quality control criteria (30-150\%) for surrogate recovery.

(j) Outside quality control criteria ( $\leq 30 \%)$ for replicate analysis. 
Table G.10. Lipids in Tissue of $N$. virens

\begin{tabular}{lccc} 
Sample ID & $\begin{array}{c}\text { \% Dry } \\
\text { Weight }\end{array}$ & $\begin{array}{c}\text { \% Lipid } \\
\text { (wet wt) }\end{array}$ & $\begin{array}{c}\text { \% Lipid } \\
\text { (dry wt) }\end{array}$ \\
\hline Nereis Bkgd. Tissue & 14.00 & 1.72 & 12.29 \\
Nereis Bkgd. Tissue & 14.00 & 1.72 & 12.29 \\
Nereis Bkgd. Tissue & 14.00 & 1.94 & 13.86
\end{tabular}

